\title{
Air Emission Inventory for the Idaho National Engineering Laboratory- 1993 Emissions Report
}

\author{
Timothy S. Stirrup
}

\section{Published June 1994}

\author{
DISCLAIMER
}

This report was prepared as an account of work sponsored by an agency of the United States Government. Neither the United States Government nor any agency thereof, nor any of their employees, makes any warranty, express or implied, or assumes any legal liability or responsibility for the accuracy, completeness, or usefulness of any information, apparatus, product, or process disclosed, or represents that its use would not infringe privately owned rights. Reference herein to any specific commercial product, process, or service by trade name, trademark, manufacturer, or otherwise does not necessarily constitute or imply its endorsement, recommendation, or favoring by the United States Government or any agency thereof. The views and opinions of authors expressed herein do not necessarily state or reflect those of the United States Government or any agency thereof.

Prepared for the

Assistant Secretary for Environmental Restoration and Waste Management

U.S. Department of Energy

DOE Idaho Field Office. 


\section{DISCLAIMER}

Portions of this document may be illegible in electronic image products. Images are produced from the best available original document. 


\section{ABSTRACT}

This report presents the 1993 update of the Air Emission Inventory for the Idaho National Engineering Laboratory (INEL). The purpose of the Air Emission Inventory is to commence the preparation of the permit to operate application for the INEL, as required by the recently promulgated Title $V$ regulations of the Clean Air Act. The report describes the emission inventory process and all of the sources at the INEL and provides emissions estimates for both mobile and stationary sources. 


\section{EXECUTIVE SUMMARY}

During the fall of 1989, the Air Emission Inventory was initiated at the Idaho National Engineering Laboratory (INEL) as a result of the Environmental Oversight and Monitoring Agreement between the State of Idaho and the Department of Energy Idaho Field Office, and a request from the Idaho Air Quality Bureau. The current purpose of the Air Emission Inventory is to commence preparation of the INEL permit to operate application, as required by the recently promulgated Title $\mathrm{V}$ regulations of the Clean Air Act.

The Air Emission Inventory is updated annually to reflect the previous year's emissions, and the current update of Air Emission Inventory data reflects 1993 operations. The Air Emission Inventory System, an ORACLE-based database system, maintains the emissions inventory. The INEL contractors and their associated facilities provide information to the Air Emission Inventory System to reflect annual operations. The annual update of information is utilized to calculate air emissions for the INEL.

The inventory presently maintains approximately 10,500 vents, and of those vents, approximately 650 are possible emission sources. Emission source types range from the conventional fuel combustion and storage sources to nuclear reactor and research facility exhausts. The Air Emission Inventory System uses the U.S. Environmental Protection Agency's Compilation of Air Pollutant Emission Factors (AP-42) calculations to estimate emissions for many of the general sources. The air contaminants reported include nitrogen oxides, sulfur oxides, carbon monoxide, volatile organic compounds, lead, particulates, and radionuclides. The summary of emissions at the INEL for 1993 are presented in the table below.

Summary of emissions at the Idaho National Engineering Laboratory for 1993.

\begin{tabular}{lcccc}
\hline \multicolumn{1}{c}{ Pollutant } & $\begin{array}{c}\text { Actual } \\
\text { Hourly } \\
(\mathrm{lb} / \mathrm{hr})\end{array}$ & $\begin{array}{c}\text { Actual } \\
\text { Annual } \\
(\mathrm{tn} / \mathrm{yr})\end{array}$ & $\begin{array}{c}\text { Maximum } \\
\text { Hourly } \\
(\mathrm{lb} / \mathrm{hr})\end{array}$ & $\begin{array}{c}\text { Maximum } \\
\text { Annual } \\
(\mathrm{tn} / \mathrm{yr})\end{array}$ \\
\hline Carbon monoxide & $3.2 \mathrm{E}+02$ & $4.7 \mathrm{E}+02$ & $8.7 \mathrm{E}+02$ & $3.4 \mathrm{E}+03$ \\
Nitrogen oxides & $8.17+02$ & $7.0 \mathrm{E}+02$ & $2.7 \mathrm{E}+03$ & $1.1 \mathrm{E}+04$ \\
Particulates & $3.6 \mathrm{E}+02$ & $4.1 \mathrm{E}+02$ & $9.4 \mathrm{E}+02$ & $2.2 \mathrm{E}+03$ \\
Lead & $1.5 \mathrm{E}-02$ & $4.5 \mathrm{E}-03$ & $6.7 \mathrm{E}+01$ & $2.9 \mathrm{E}+02$ \\
Radionuclide & $2.2 \mathrm{E}+02$ & $2.6 \mathrm{E}+03$ & $1.6 \mathrm{E}+05$ & $2.4 \mathrm{E}+04$ \\
Sulfur oxides & $2.8 \mathrm{E}+02$ & $2.4 \mathrm{E}+02$ & $8.6 \mathrm{E}+02$ & $3.8 \mathrm{E}+03$ \\
VOC - nonmethane & $6.7 \mathrm{E}+02$ & $7.0 \mathrm{E}+01$ & $8.4 \mathrm{E}+02$ & $9.1 \mathrm{E}+02$ \\
\hline a. Units in Ci/mo and $\mathrm{Ci} / \mathrm{yr}$, respectively. & & & \\
\hline \multicolumn{7}{l}{}
\end{tabular}




\section{ACKNOWLEDGMENTS}

This year, the Air Emission Inventory Report was the result of the cumulative effort of various people, including Barbara Serna, of EG\&G Idaho, Inc., Environmental Support Group, who rewrote and compiled the report, and the contractors at the Idaho National Engineering Laboratory: Argonne National Laboratory West; Babcock \& Wilcox Company; EG\&G Idaho, Inc.; Westinghouse Electric Corporation; and Westinghouse Idaho Nuclear Company, Inc. 


\section{CONTENTS}

ABSTRACT $\ldots \ldots \ldots \ldots \ldots \ldots \ldots \ldots \ldots \ldots \ldots \ldots \ldots \ldots \ldots \ldots$

EXECUTIVE SUMMARY

ACKNOWLEDGMENTS ......................... vii

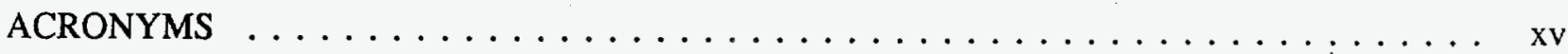

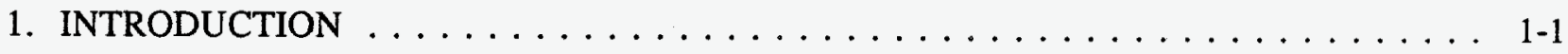

2. AIR EMISSION INVENTORY PROCESS . . . . . . . . . . . . . . 2-1

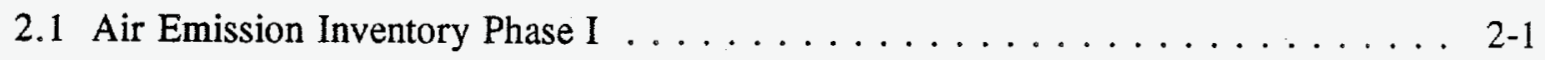

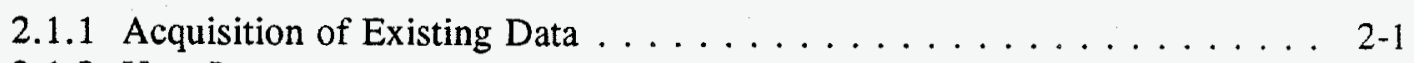

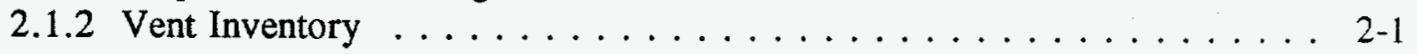

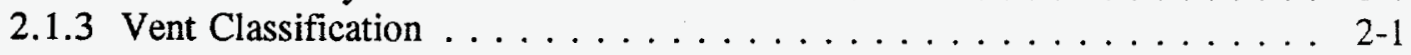

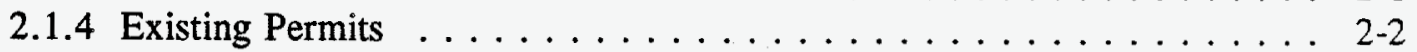

2.2 Air Emission Inventory Phase II . . . . . . . . . . . . . . 2-2

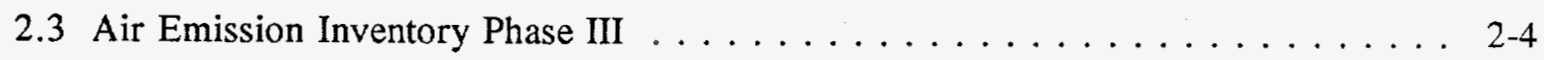

2.4 Air Emission Inventory Annual Update $\ldots \ldots \ldots \ldots \ldots \ldots \ldots \ldots$

3. 1993 AREA UPDATE .......................... $3-1$

3.1 Argonne National Laboratory-West . . . . . . . . . . . . . . . . 3-2

3.1 .1 Area Description . . . . . . . . . . . . . . . . . 3-2

3.1 .2 Primary Source Descriptions . . . . . . . . . . . . . . 3-2

3.1 .3 Secondary Sources . . . . . . . . . . . . . . . . . . . 3-4

3.1 .4 Summary of ANL-W Emissions $\ldots \ldots \ldots \ldots \ldots \ldots . \ldots \ldots$

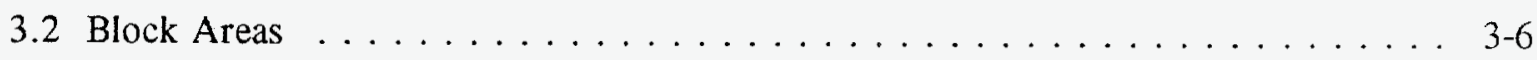

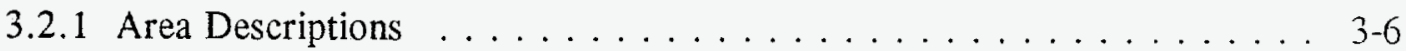

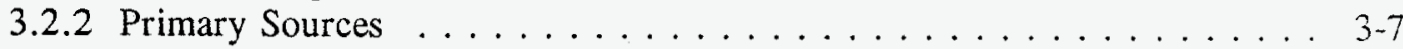

3.2 .3 Secondary Sources ... . . . . . . . . . . . . . . . . . 3-7

3.2.4 Summary of Block Area Emissions $\ldots \ldots \ldots \ldots \ldots$ 3-7

3.3 Central Facilities Area . . . . . . . . . . . . . . . . . . . 3-9

3.3 .1 Area Description $\ldots \ldots \ldots \ldots \ldots \ldots \ldots \ldots \ldots . \ldots \ldots$

3.3 .2 Primary Sources . . . . . . . . . . . . . . . . . . 3-9

3.3 .3 Secondary Sources . . . . . . . . . . . . . . . . . . . . . 3-10

3.3.4 Summary of CFA Emissions . . . . . . . . . . . . 3-11 
3.4 .1 Area Description . . . . . . . . . . . . . . . . 3-14

3.4 .2 Primary Source Description . . . . . . . . . . . . . 3-14

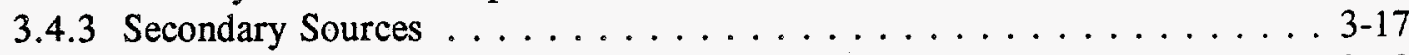

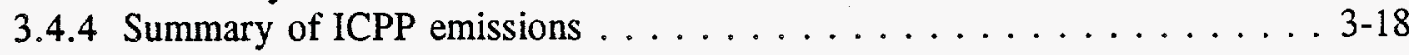

3.5 Naval Reactor Facility . . . . . . . . . . . . . . . . . . . . 3-20

3.5.1 Area Description . . . . . . . . . . . . . . . . . . 3-20

3.5 .2 Primary Sources . . . . . . . . . . . . . . . . 3-20

3.5 .3 Secondary Sources . . . . . . . . . . . . . . . . . . 3-22

3.5 .4 Summary of NRF Emissions . . . . . . . . . . . . . . 3-23

3.6 Power Burst Facility . . . . . . . . . . . . . . . . . . . . 3-25

3.6.1 Area Description . . . . . . . . . . . . . . . . . . 3-25

3.6.2 Primary Source Descriptions . . . . . . . . . . . . . . . 3-26

3.6 .3 Secondary Sources ... . . . . . . . . . . . . . . . . 3-26

3.6.4 Summary of PBF Emissions . . . . . . . . . . . . . 3-27

3.7 Radioactive Waste Management Complex . . . . . . . . . . . . . . 3-34

3.7.1 Area Description . . . . . . . . . . . . . . . . . . 3-34

3.7 .2 Primary Source Descriptions . . . . . . . . . . . . . . 3-34

3.7 .3 Secondary Sources . . . . . . . . . . . . . . . . . 3-34

3.7.4 Summary of RWMC Emissions . . . . . . . . . . . 3-35

3.8 Test Area North . . . . . . . . . . . . . . . . . . . . . .

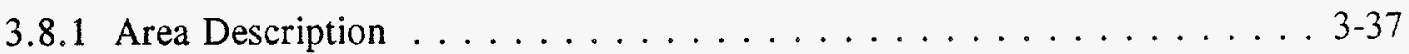

3.8 .2 Primary Sources ... . . . . . . . . . . . . . . . 3-37

3.8 .3 Secondary Sources . . . . . . . . . . . . . . . . . . 3-39

3.8.4 Summary of TAN Emissions $\ldots \ldots \ldots \ldots \ldots \ldots$. . . . . . . . . . . .

3.9 Test Reactor Area . . . . . . . . . . . . . . . . . . . . 3-43

3.9 .1 Area Description . . . . . . . . . . . . . . . . . 3-43

3.9 .2 Primary Source Descriptions . . . . . . . . . . . . . . 3-43

3.9 .3 Secondary Sources . . . . . . . . . . . . . . . . . . . 3-44

3.9 .4 Summary of TRA Emissions $\ldots \ldots \ldots \ldots \ldots \ldots .4 \ldots \ldots$

3.10 Auxiliary Reactor Area, Boiling Water Reactor Experiment, Experimental

Breeder Reactor $I$, and Initial Engine Test . . . . . . . . . . . . . 3-46

3.11 Paved and Unpaved Roads $\ldots \ldots \ldots \ldots \ldots \ldots \ldots \ldots \ldots \ldots$

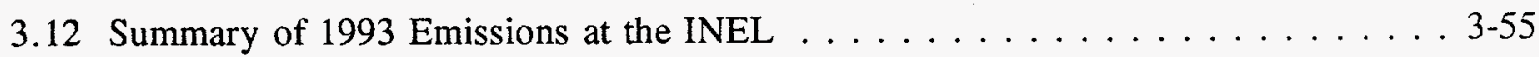


4.1 Emission Estimates for Buses and Heavy-Duty Diesel Vehicles . . . . . . . . . 4-1

4.2 Emission Estimates for Light-Duty Gasoline Vehicles . . . . . . . . . . . . 4-3

4.3 Emission Estimates for Construction Equipment . . . . . . . . . . . . . 4-4

4.4 Vehicle Emission Estimate Assumptions . . . . . . . . . . . . . . 4-5

4.5 Mobile Emissions Estimates for $1993 \ldots \ldots \ldots \ldots \ldots \ldots \ldots$. . . . . . . . . . . .

5. EMISSIONS ESTIMATES FOR STATIONARY SOURCES $\ldots \ldots \ldots \ldots \ldots$

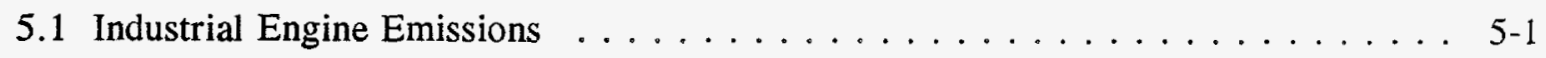

5.1 .1 Methodology and Assumptions $\ldots \ldots \ldots \ldots \ldots \ldots \ldots \ldots \ldots \ldots$ 5-1

5.1 .2 Maximum Emission Estimates ................. . . . 5-2

5.1.3 Calculations Performed by the Database ... . . . . . . . . 5-3

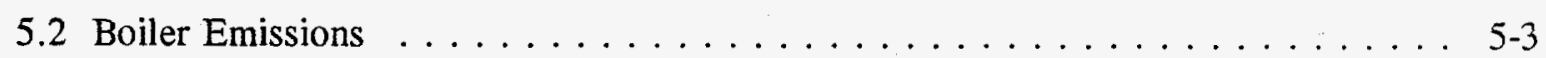

5.2 .1 Methodology and Assumptions . . . . . . . . . . . . . 5-3

5.2 .2 Maximum Emission Estimates . . . . . . . . . . . . . . 5-4

5.2.3 Calculations Performed by the Database ... . . . . . . . . 5-4

5.3 Radionuclide Sources $\ldots \ldots \ldots \ldots \ldots \ldots \ldots \ldots \ldots$. . . . . . . . . .

5.3.1 Methodology and Assumptions ................. . . 5-4

5.3.2 Maximum Emission Estimates . . . . . . . . . . . . . 5-5

5.4 Laboratory Fumehood Calculations $\ldots \ldots \ldots \ldots \ldots \ldots \ldots \ldots$

5.4.1 Methodology and Assumptions . . . . . . . . . . . . . . . 5-5

5.4 .2 Maximum Emission Estimates . . . . . . . . . . . . 5-6

5.5 Painting Operations Calculations $\ldots \ldots \ldots \ldots \ldots \ldots \ldots \ldots$

5.5 .1 Methodology and Assumptions ................. . . 5-6

5.5 .2 Maximum Emission Estimates . . . . . . . . . . . . . . . 5-7

5.6 Organic Storage Tank Calculations $\ldots \ldots \ldots \ldots \ldots \ldots \ldots \ldots \ldots$

5.6.1 Methodology and Assumptions . . . . . . . . . . . . . . 5-7

5.6 .2 Maximum Emission Estimates . . . . . . . . . . . . . . . . . 5-8

5.6 .3 Calculations Performed by the Database . . . . . . . . . . $5-8$

5.7 Emissions from Welding Operations $\ldots \ldots \ldots \ldots \ldots \ldots \ldots$

5.7.1 Methodology and Assumptions $\ldots \ldots \ldots \ldots \ldots \ldots$. . . . . . . 
5.8 Main Stacks $\ldots \ldots \ldots \ldots \ldots \ldots \ldots \ldots \ldots \ldots \ldots \ldots$

5.8 .1 Methodology and Assumptions . . . . . . . . . . . . . 5-9

5.8 .2 Maximum Emission Estimates . . . . . . . . . . . . 5-10

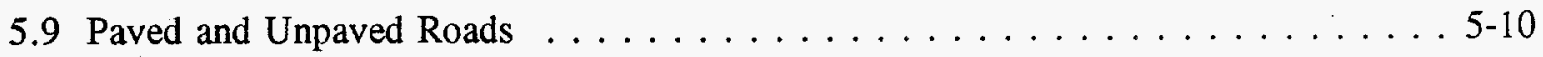

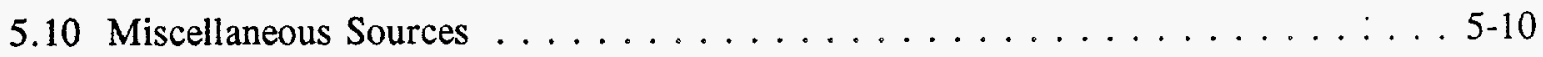

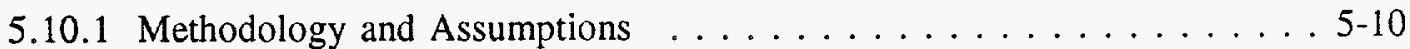

5.10 .2 Maximum Emission Estimates . . . . . . . . . . . . . 5-11

6. REFERENCES ............................ $6-1$

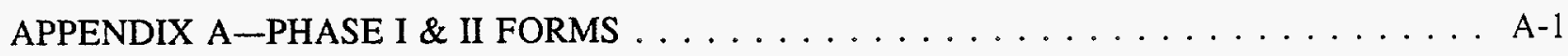

APPENDIX B-1993 AIR EMISSION INVENTORY EMISSIONS TABLES . . . . . . . . B-1

APPENDIX C-SUPPORTING DATA FOR THE 1993 AIR EMISSION INVENTORY FOR THE

INEL 


\section{FIGURES}

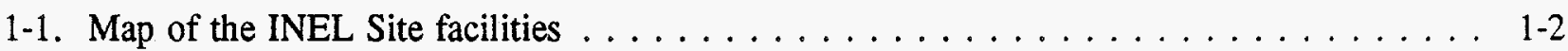

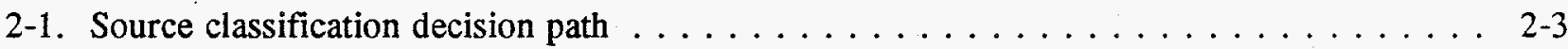

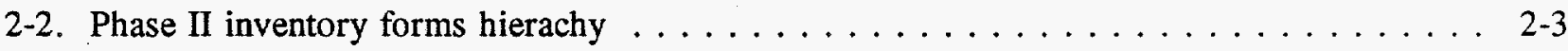

3-1. Area plot plan of Argonne National Laboratory-West $\ldots \ldots \ldots \ldots \ldots \ldots$. $\ldots \ldots$

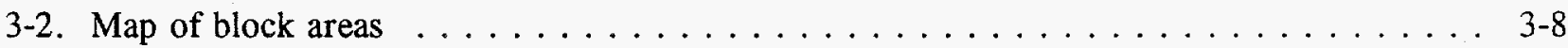

3-3. Area plot plan of the Central Facilities Area . . . . . . . . . . . . . 3-12

3-4. Detail of CFA area plot plan $\ldots \ldots \ldots \ldots \ldots \ldots \ldots \ldots \ldots \ldots \ldots \ldots \ldots \ldots \ldots \ldots .13$

3-5. Area plot plan of the Idaho Chemical Processing Plant $\ldots \ldots \ldots \ldots \ldots \ldots . .19$

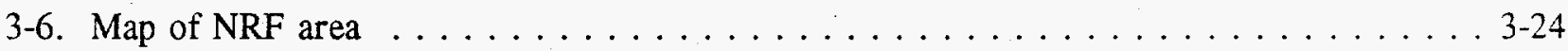

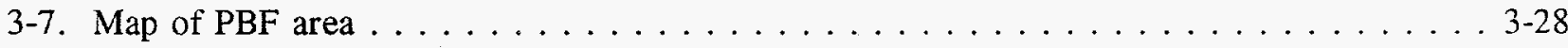

3-8. Area plot plan of PBF Control area . . . . . . . . . . . . . . . . . 3-29

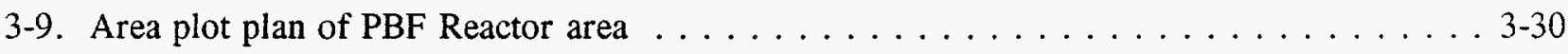

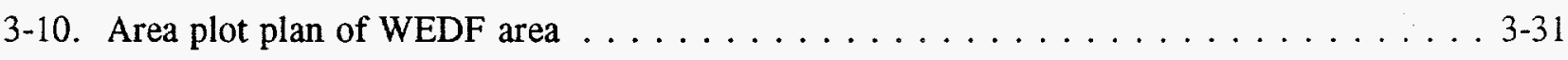

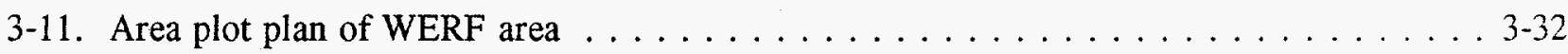

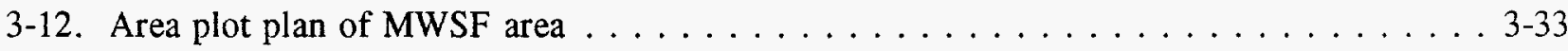

3-13. Area plot plan of the Radioactive Waste Management Complex . . . . . . . . . . 3-36

3-14. Area plot plan of Technical Support Facility . . . . . . . . . . . . . . . . . 3-40

3-15. Area plot plan of Loss of Fluid Test and Specific Manufacturing Capability area . . . . . 3-41

3-16. Area plot plan of Water Reactor Research Test Facility. . . . . . . . . . . . . 3-42

3-17. Area plot plan of the Test Reactor Area . . . . . . . . . . . . . . 35

3-18. Area map of the Auxiliary Reactor Area $\ldots \ldots \ldots \ldots \ldots \ldots \ldots \ldots \ldots \ldots \ldots .4 \ldots$

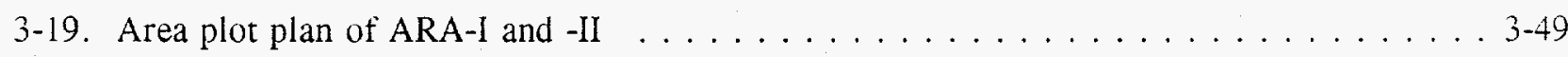

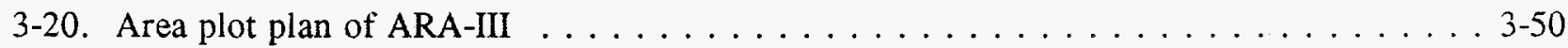

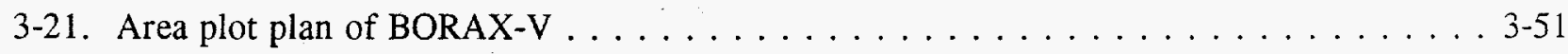


3-23. Area plot plan of IET

\section{TABLES}

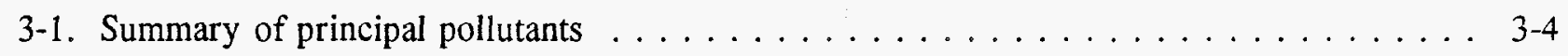

3-2. Summary of principal pollutants at block areas $\ldots \ldots \ldots \ldots \ldots \ldots \ldots$ 3-7

3-3. Summary of the totals for each of the principal pollutants at CFA $\ldots \ldots \ldots \ldots$ 3-11

3-4. Summary of the totals for each of the principal pollutants at ICPP $\ldots \ldots \ldots \ldots$ 3-18

3-5. Summary of principal pollutants at NRF $\ldots \ldots \ldots \ldots \ldots \ldots \ldots \ldots \ldots \ldots \ldots \ldots \ldots$

3-6. Summary of principal pollutants at $\mathrm{PBF} \ldots \ldots \ldots \ldots \ldots \ldots \ldots \ldots \ldots \ldots \ldots \ldots \ldots \ldots$

3-7. Summary of the totals for each of the principal pollutants at the RWMC . . . . . 3-35

3-8. Summary of the totals for each of the principal pollutants at TAN $\ldots \ldots \ldots \ldots .39$

3-9. Summary of principal pollutants at TRA $\ldots \ldots \ldots \ldots \ldots \ldots \ldots \ldots \ldots \ldots \ldots$

3-10. Summary of emissions at ARA-IV $\ldots \ldots \ldots \ldots \ldots \ldots \ldots \ldots \ldots \ldots \ldots \ldots \ldots \ldots$

3-11. Particulate emissions from roads $\ldots \ldots \ldots \ldots \ldots \ldots \ldots \ldots \ldots \ldots \ldots \ldots \ldots \ldots \ldots \ldots$

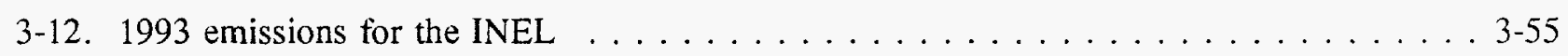

4-1. Vehicle fleet emissions for the INEL, $1993 \ldots \ldots \ldots \ldots \ldots \ldots$. . . . . . . . . .

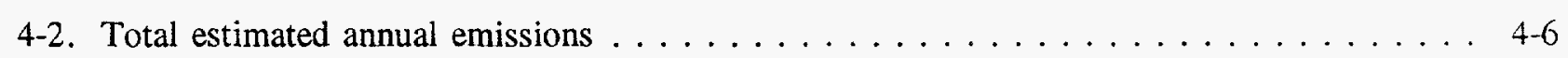




\section{ACRONYMS}

\begin{tabular}{|c|c|}
\hline $\mathrm{A} 1 \mathrm{~W}$ & NRF Large Ship Reactor \\
\hline AFSR & Argonne Fast Source Reactor \\
\hline ANL-W & Argonne National Laboratory - West \\
\hline AP-42 & EPA Compilation of Air Pollutant Emission Factors \\
\hline ARA & Auxiliary Reactor Area \\
\hline BER & basic emission rate \\
\hline BORAX & Boiling Water Reactor Experiment \\
\hline Btu & British thermal unit \\
\hline CFA & Central Facilities Area \\
\hline $\mathrm{cfm}$ & cubic feet per minute \\
\hline CFR & Code of Federal Regulations \\
\hline CFSGF & Coal-Fired Steam-Generating Facility \\
\hline $\mathrm{Ci}$ & Curie \\
\hline DOE & Department of Energy \\
\hline DOE-ID & Department of Energy Idaho Field Office \\
\hline EB & East Butte \\
\hline EBR-I & Experimental Breeder Reactor I \\
\hline EBR-II & Experimental Breeder Reactor II \\
\hline $\mathrm{ECF}$ & NRF Expended Core Facility \\
\hline EPA & Environmental Protection Agency \\
\hline ER & emission rate \\
\hline FAST & Fluorinel Dissolution Process and Fuel Storage \\
\hline FCF & Fuel Cycle Facility \\
\hline FMF & Fuel Manufacturing Facility \\
\hline HEPA & high-efficiency particulate air \\
\hline HFEF & Hot Fuel Examination Facility \\
\hline HPTF & Howe Peak Transformer Facility \\
\hline ICPP & Idaho Chemical Processing Plant \\
\hline IET & Initial Engine Test \\
\hline IFR & Integral Fast Reactor \\
\hline INEL & Idaho National Engineering Laboratory \\
\hline $\mathrm{kW}$ & kilowatt \\
\hline LOFT & Loss of Fluid Test \\
\hline MDF & Material Development Facility \\
\hline mph & miles per hour \\
\hline MW & megawatt \\
\hline MWSF & Mixed Waste Storage Facility \\
\hline NESHAPS & National Emission Standards for Hazardous Air Pollutants \\
\hline NOAA & National Oceanic and Atmospheric Administration \\
\hline NRF & Naval Reactor Facility \\
\hline NWCF & New Waste Calcining Facility \\
\hline PBF & Power Burst Facility \\
\hline PCB & polychlorinated biphenyl \\
\hline PER & Power Excursion Reactor \\
\hline PSD & prevention of significant deterioration (State of Idaho air quality permit) \\
\hline RCRA & Resource Conservation and Recovery Act \\
\hline RESL & Radiological and Environmental Sciences Laboratory \\
\hline RWMC & Radioactive Waste Management Complex \\
\hline
\end{tabular}


NRF Submarine Thermal Reactor NRF Natural Circulation Reactor

SCF speed correction factor

SDA Subsurface Disposal Area

SMC Specific Manufacturing Capability

SPERT Special Power Excursion Reactor Test

STF Security Training Facility

TAN Test Area North

TRA Test Reactor Area

TREAT Transient Reactor Test Facility

TSA Transuranic Storage Area

TSF Technical Support Facility

VOC volatile organic compound

WEDF Waste Engineering Development Facility

WERF Waste Experimental Reduction Facility

WMF Waste Management Facility

WMO Waste Management Office

WRRTF Water Reactor Research Test Facility

ZPPR Zero Power Physics Reactor 


\section{INTRODUCTION}

This report presents 1993 emissions data for operations at the Idaho National Engineering Laboratory (INEL). Emissions data are compiled into the Air Emission Inventory, which will provide the basis for the preparation of the INEL permit to operate (PTO) application as required by the recently promulgated Title $\mathrm{V}$ regulations of the Clean Air Act. The document describes the emission inventory process and all of the sources at the INEL and provides emissions estimates for both mobile and stationary sources.

The INEL is an $890-$ mile $^{2}$ research facility managed by the U.S. Department of Energy (DOE) and contains approximately 600 buildings and 500 other structures. The size and complexity of the INEL required the development of the Air Emission Inventory System, an ORACLE-based database system that maintains the emissions inventory. The 1993 Air Emission Inventory Report includes the following areas at the INEL (see Figure 1-1).

- $\quad$ Advanced Reactor Area (ARA)

- $\quad$ Argonne National Laboratory-West (ANL-W)

- Central Facilities Area (CFA)

- Idaho Chemical Processing Plant (ICPP)

- $\quad$ Naval Reactor Facility (NRF)

- Power Burst Facility (PBF)

- $\quad$ Radioactive Waste Management Complex (RWMC)

- $\quad$ Test Area North (TAN)

- Test Reactor Area (TRA)

- Block areas

- Miscellaneous areas (Howe Peak Transformer Facility and INEL roads)

- Mobile sources.

The inventory presently maintains approximately 10,500 vents, and of those vents, approximately 650 are possible emission sources. Emission sources range from conventional fuel combustion and storage sources to nuclear reactor and research facility exhausts. The air contaminants reported include nitrogen oxides, sulfur oxides, carbon monoxide, volatile organic compounds (VOCs), lead, particulates, and radionuclides. The Air Emission Inventory System utilizes the United States Environmental Protection Agency's (EPA's) Compilation of Air Pollutant Emission Factors (AP-42) calculations to estimate emissions for many of the general sources. 


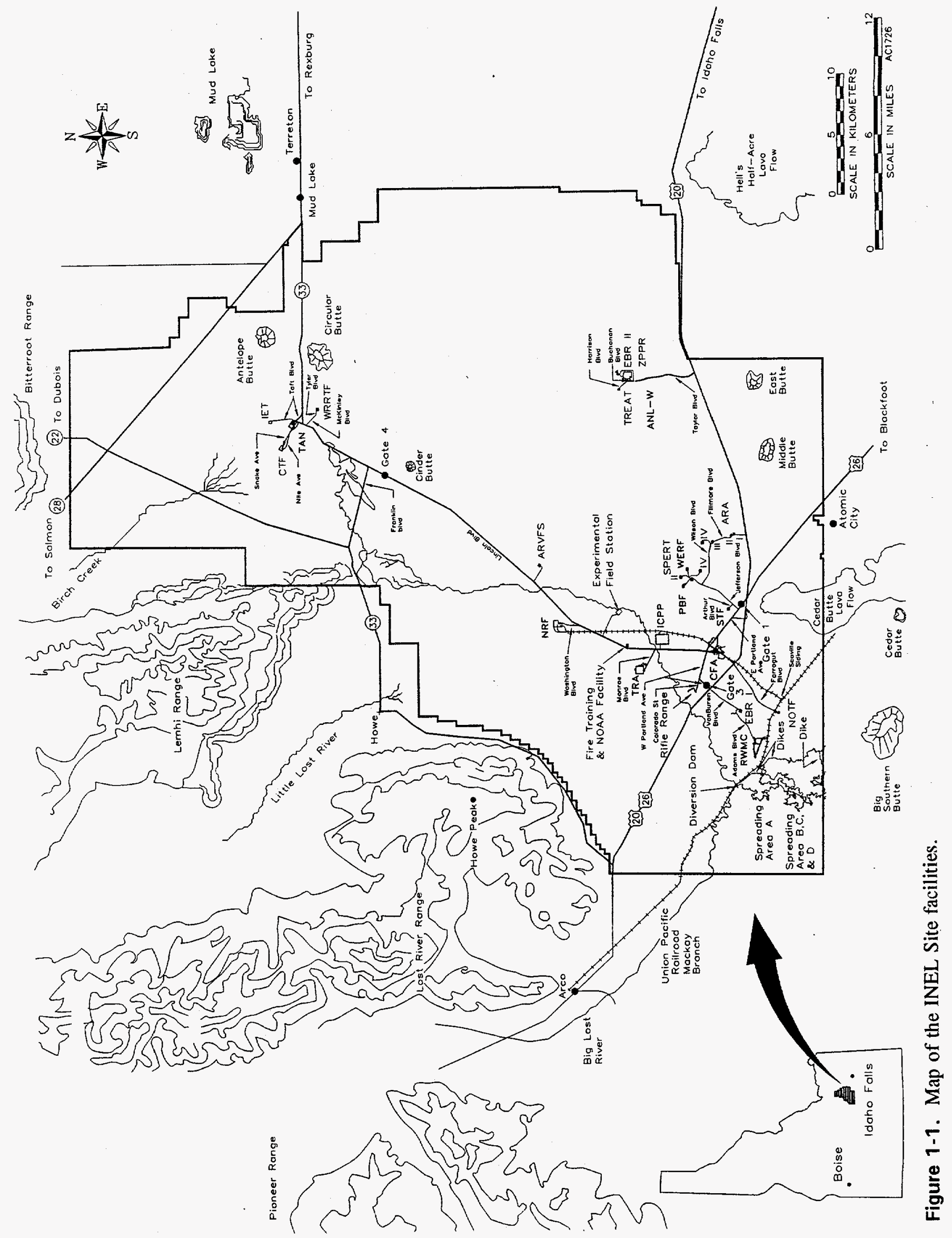




\section{AIR EMISSION INVENTORY PROCESS}

The first step in the development of the initial Air Emission Inventory was to determine the scope of the inventory and the procedures to be used. In order to evaluate all of the potential sources of air contamination at the INEL, every vent was inventoried. To proceed in an orderly manner and to ensure data comprehensiveness, the inventory process was divided into three phases: I, II, and III. Any new or upgraded structures, vents, and sources are inventoried.

The collected data from each phase of the inventory process were compiled and managed on an ORACLE-based data management system. Since the initial 1989 inventory process, the Air Emission Inventory System has been redesigned to reflect a production database system. The new Air Emission Inventory System has been incorporated into an INEL-wide effluent inventory: the INEL Effluent Inventory System.

\subsection{Air Emission Inventory Phase I}

Phase I determined potential emission points, and a preliminary classification eliminated those vents that were not potential air pollution sources.

\subsubsection{Acquisition of Existing Data}

For the initial Air Emission Inventory, all previous air emission inventories were evaluated to determine the usefulness of the compiled data. Data used from an existing inventory were checked for accuracy by comparing the data collected during the Phase I inventory.

\subsubsection{Vent Inventory}

Standardized forms were developed to collect and organize the data (see Phase I Forms, Appendix A). The building source form (Form 1) recorded survey team members' names, building contact's name, source number, description and location, and any other information available for the source. This form was filled out for any vent that was a potential air pollution source. The building summary form (Form 2) listed and briefly described all vents on a building, even those not listed as potential sources of air pollution.

\subsubsection{Vent Classification}

A vent was considered a source if the vent had the potential to exhaust any criteria pollutants (carbon monoxide, sulfur dioxide, nitrogen oxides, particulates, lead, and volatile organic compounds), noncriteria pollutants (asbestos, beryllium, mercury, vinyl chloride, radionuclides, fluorides, sulfuric acid mist, hydrogen sulfide, and reduced sulfur compounds), or toxic air pollutants listed in Tables V-A, V-B, and V-C of the draft State of Idaho Guidance Manual for Obtaining a Permit to Construct, Modify or Operate an Air Pollution Source.

Vents that were considered sources included those associated with combustion processes; radiological processes (or vents on radiologically contaminated equipment); chemical process exhausts; storage tank vents; fume hood exhausts; and area sources such as waste piles, evaporation

ponds, and lagoons. If a vent was considered a potential source of air pollutants, it became part of the Phase II inventory. 


\subsubsection{Existing Permits}

The final step in the Phase I inventory gathered all existing Idaho Air Quality Bureau permits and permit applications. Data from the existing permits were incorporated into the Phase II portion of the inventory.

\subsection{Air Emission Inventory Phase II}

Phase II of the inventory included collecting detailed data for those sources identified as potential sources of air contamination. Phase II resolved vents identified as unknown in Phase I. Data collected include operating and engineering parameters necessary for emission calculations, physical location, process descriptions with flow diagrams if necessary and available, and any previously permitted or otherwise documented information concerning potential emissions.

The first step of Phase II organized the preliminary information for a given area and corresponding structures. The material included available drawings, data forms, permit applications, and other existing data. Any additional information required to estimate emissions was also collected and included engineering drawings and safety analysis reports, contacting equipment manufacturers, and interviewing shift supervisors, operators, and area landlords.

After all of the pertainent information was collected, the status of any unknown and out-of-service vents was determined. All unknowns were identified during this phase and changed to either a vent with no emissions or a potential source. Many potential sources were not emitting anything at the time of the 1993 inventory, and many of these inactive vents were permanently out of service. Others were only temporarily inactive or only required a little service to bring them back online at any given time. Figure 2-1 is a flow diagram of the decision process used to determine the status of unknown vents and whether any estimates need to be made concerning their emissions or potential emissions.

The data were compiled on a set of inventory forms (see Phase II Forms, Appendix A). The Phase II inventory comprised 16 different data forms, but not all were needed for each source. The Phase II forms were organized into several levels, where each level was divided into increasingly more detailed degrees of data to be collected. Figure 2-2 is a flow chart diagramming the use of Phase II forms.

Level 1 forms were required for every potential source. These forms described the process stack and provided a gross evaluation of the source type. The source type section of the form identifies the appropriate Level 2 form. A Level 2 form is completed depending on the source type. Level 2 forms are supplied for chemical sources, fuel burning equipment, volatile organic liquid storage, and inorganic chemical storage. The Level 2 forms are used to gather source-specific information required for emission estimates. A check box is provided to indicate which Level 3 forms are required.

Level 3 forms compiled information on the chemicals, fuel, and materials used in specific sources. Level 4 is the final tier in the Phase II inventory form classification. This level was used to record information on pollution control equipment, pollution monitoring equipment, and additional information applicable to fume or laboratory hoods and paint booths. 


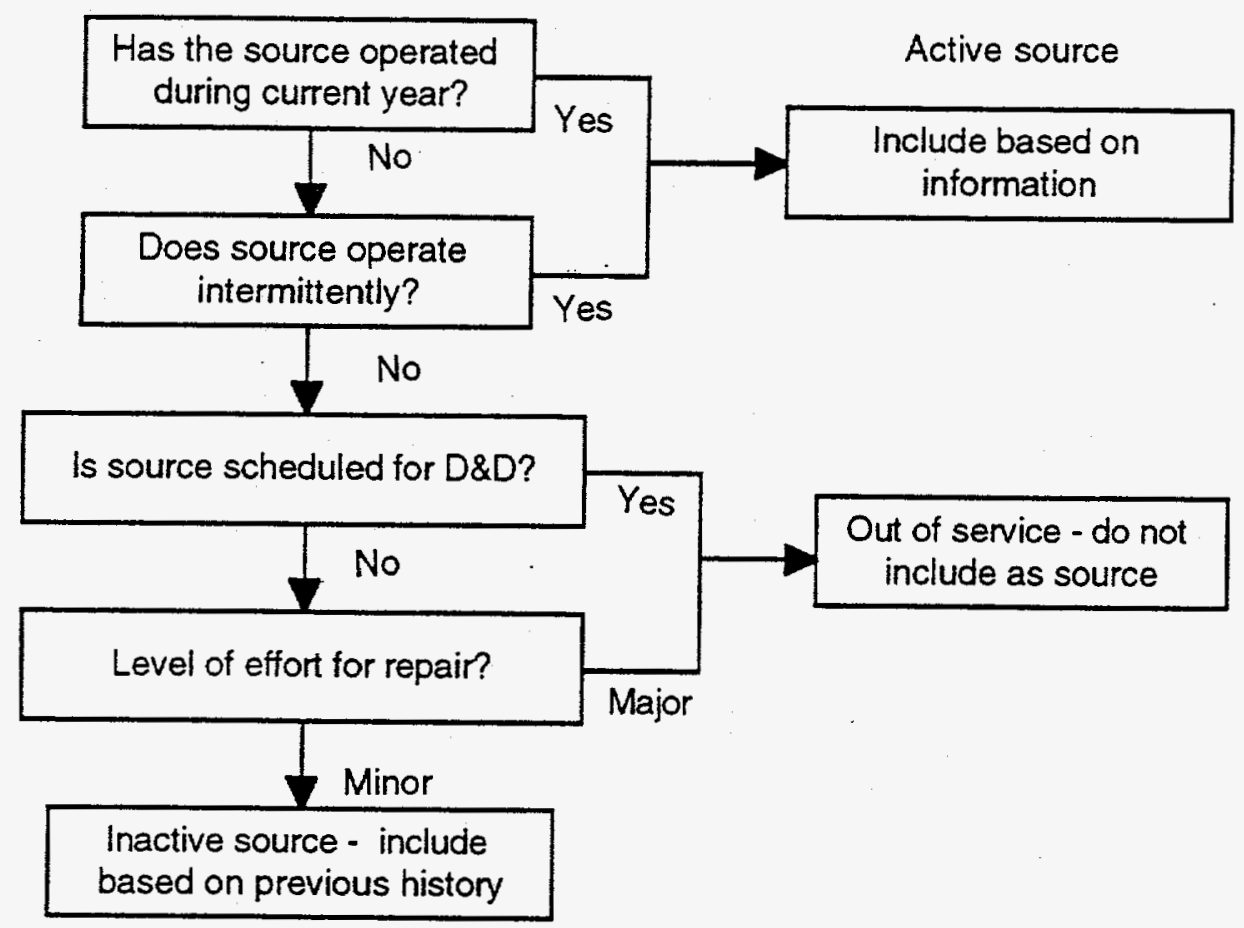

Figure 2-1. Source classification decision path.

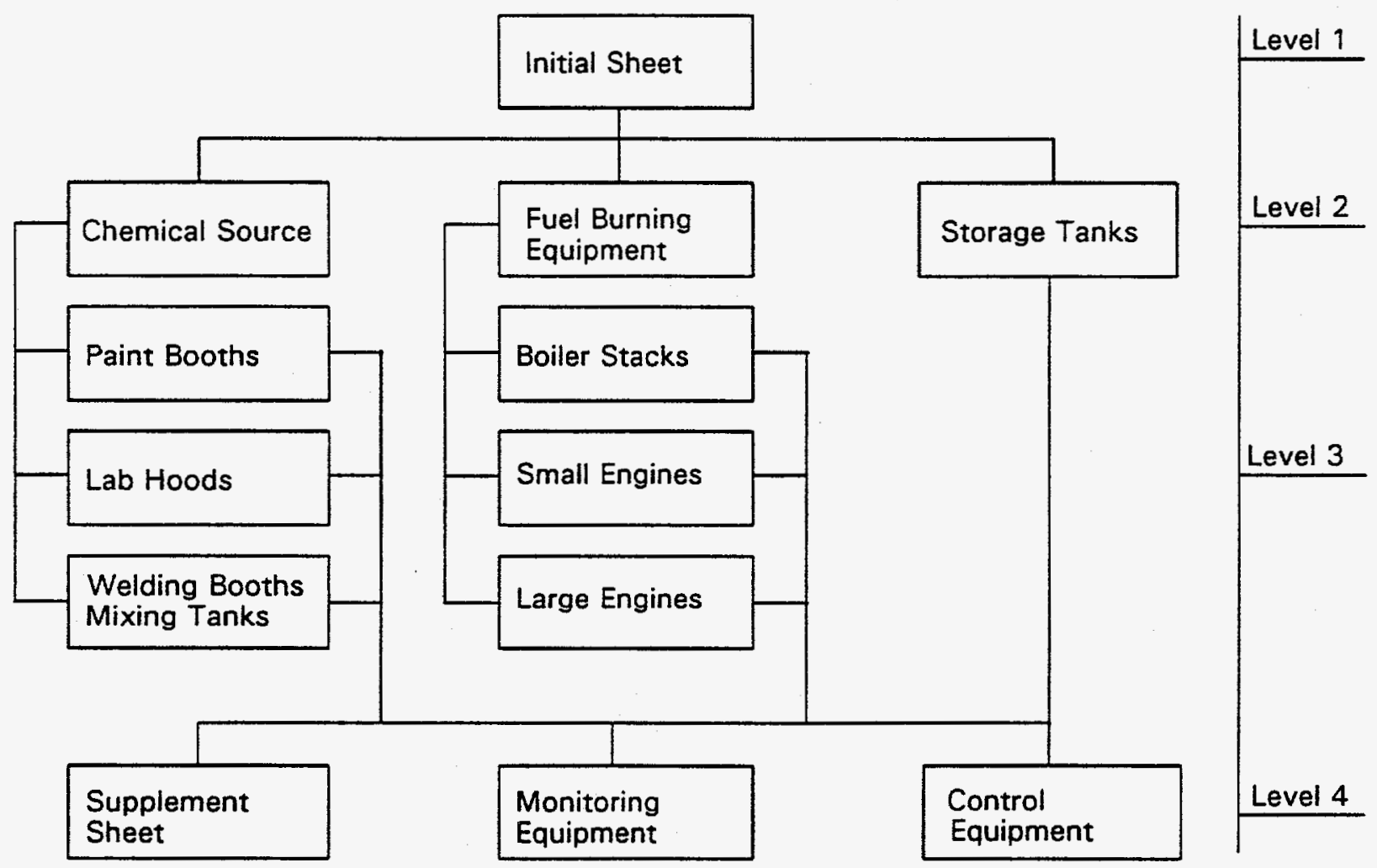

Figure 2-2. Phase II inventory forms hierachy. 
Not all sources could be standardized on these forms and were handled on a case-by-case basis using generic data forms. The generic forms recorded sources whose emissions had to be calculated by hand or were of such an unusual nature that the standardized forms are not applicable.

\subsection{Air Emission Inventory Phase III}

Phase III utilized the data gathered during Phases I and II to estimate the emissions of air pollutants from the INEL. The development of Phase III included calculating emissions from the following sources:

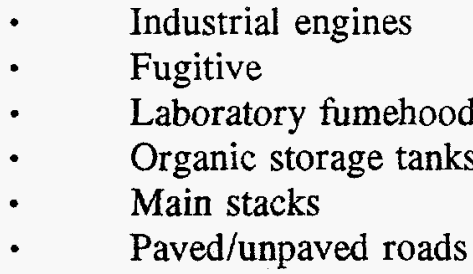

$\begin{array}{ll}\text { - } & \text { Boilers } \\ \text { - } & \text { Radionuclide } \\ \text { - } & \text { Painting operations } \\ \text { - } & \text { Velding operations } \\ \text { - } & \text { Miscellaneous/generic. }\end{array}$

The calculations for the above sources involve EPA acceptable methods per Volumes I and II of AP-42 and used several assumptions for each source. The calculations are presented in detail in the following chapter and sections. Section 5 provides descriptions of the various calculations used to estimate the emissions from the INEL sources.

\subsection{Air Emission Inventory Annual Update}

The INEL contractors and their associated facilities are required to provide information into the Air Emission Inventory System to reflect annual operations. The update process involves the updating of the inventory information to reflect 1993 operations and includes the emissions data and area descriptions. Each INEL contractor provides a coordinator for each operating area. The data to be updated is provided to each responsible coordinator and in turn provided by area coordinators to the appropriate personnel. The data are provided via update forms that are generated by the database. Each form details all the information pertinent to each source.

The contractors are encouraged to verify approximately $10 \%$ of the Air Emission Inventory data. Each area coordinator provides updated information to the Air Emission Inventory Coordinator. The Air Emission Inventory Coordinator compiles and reviews all data and provides the updated data to the Air Emission Inventory System Administrator for data entry. The purpose of the annual update is to esimate the emissions for the previous calender year. After the updated information is input, the applicable emission calculations are performed. All calculations performed during the update process follow the guidelines and assumptions as presented in the initial Air Emission Inventory report (DOEID 1991). Any additional assumptions or guidelines are provided.

The data update process includes deleting sources, adding sources, process changes for sources, recalculating emissions, and adding data to reflect actual operations. If a new vent, stack, source, or building has been added since the last survey, Phase I and Phase II forms are used to report the information. If a source appears in a phase but does not appear in any subsequent phase and now requires a subsequent phase analysis, the appropriate forms are used. 


\section{1993 AREA UPDATE}

The 1993 update incorporates 1993 operations to the Air Emission Inventory and comprises removing sources, adding sources, correcting source information, updating source information, and estimating emissions. The results of the update effort are presented for each INEL area.

The INEL has eight principal, functional areas where the bulk of all activities occur. These areas comprise

$\begin{array}{ll}\cdot & \text { ANL-W } \\ \cdot & \text { CFA } \\ \cdot & \text { ICPP } \\ \cdot & \text { NRF } \\ \cdot & \text { PBF } \\ \cdot & \text { RWMC } \\ \cdot & \text { TAN } \\ . & \text { TRA. }\end{array}$

In addition, various secondary emission sources are scattered around and near the INEL site, identified in the inventory as the block areas. Nonfunctioning areas at the INEL include ARA, the Boiling Water Reactor Experiment (BORAX), and the Experimental Breeder Reactor I/Waste Management Office (EBR-I/WMO).

Each of the areas are described in this report as follows:

- Area description: This section briefly describes the role and function of each area, discusses major programs, and includes an area plot plan. Information was obtained from facility personnel and DOE-ID (1993).

- Primary sources: Primary sources of emissions for each area include main stacks, operational reactors, and large boilers. The information presents a functional description of each source and a brief qualitative description of emission types.

- Secondary sources: Secondary sources of emissions include fumehoods, small fuel burning equipment, and miscellaneous sources not considered primary sources.

- Summary of area-wide emissions: A total for pollutant emissions for each individual area are presented in a table. The information includes the area, the pollutant, the actual hourly rates, and the actual annual quantities with their respective units.

Appendix B presents the emission summaries for each area and is organized by pollutant, showing area, calculational method, and the emissions for each source per each area.

- Area plot plans are provided for each area and for some facilities. 


\subsection{Argonne National Laboratory-West}

\subsubsection{Area Description}

ANL-W is a laboratory facility associated with the INEL and operated by the University of Chicago for the DOE Chicago Field Office. ANL-W is located near the south east corner of the INEL, about three miles north of U.S. Highway 20. ANL-W is devoted to addressing a broad range of issues in liquid metal reactor development as well as research in the fuel cycle for these reactors.

The present primary experimental facilities are

- $\quad$ Experimental Breeder Reactor II (EBR-II)

- Transient Reactor Test Facility (TREAT)

- $\quad$ Zero Power Physics Reactor (ZPPR)

- Hot Fuel Examination Facility (HFEF) (formerly HFEF North)

- $\quad$ Fuel Cycle Facility (FCF) (formerly HFEF South)

- $\quad$ Fuel Manufacturing Facility (FMF)

- Laboratory and Office Building

These facilities are well maintained and are projected to have useful lives of at least fifteen more years. Figure 3-1 presents an area plot plan of ANL-W.

\subsubsection{Primary Source Descriptions}

3.1.2.1 EBR-II. The EBR-II complex consists primarily of the EBR-II reactor building (ANL-767) and the power plant (ANL-768). EBR-II consists of an unmoderated, sodium-cooled reactor with a thermal power rating of 62.5-megawatt (MW), an intermediate closed loop of secondary sodium, and a steam plant that produces $19 \mathrm{MW}$ of electrical power through a conventional turbine generator. The reactor is primarily used at present for irradiation testing of potential fuels for larger breeder reactors.

The reactor building is vented to the main stack (ANL-764). Reactor offgases are highefficiency particulate air (HEPA) filtered and continuously monitored, the principal emissions being noble gases, bromine-82, and tritium (tritium is not continuously monitored.)

The power plant involves a number of support operations for the reactor, but the primary emission sources are the four industrial boilers. Boiler 1 is the primary boiler, and Boiler 2 is online approximately $20 \%$ of the time. Boilers 3 and 4 are 100\% backup to Boilers 1 and 2 and run less than $1 \%$ of the time. Other sources include emergency diesel generators, fuel tanks, mix tanks for water treatment, and health physics lab hoods for decontamination of small items such as hand tools.

3. 1.2.2 TREAT. The TREAT reactor (ANL-720) is a uranium-oxide-fueled, graphitemoderated, and air-cooled reactor designed to produce short, intense bursts of nuclear energy for the purpose of simulating accident conditions on test specimens in the reactor core. TREAT vents through the main stack, identified in the inventory as ANL-720-007. The offgas is HEPA filtered and continuously monitored. Present monitors are for gamma radiation only. Principal emissions include noble gases and $\mathrm{Ba}-\mathrm{La}-140$. Two diesel generators and associated fuel tanks are also located at ANL-720. 
3. 1.2.3 HFEF. HFEF, formerly HFEF North (ANL-785), is designed for examination of irradiated fuel specimens from experiments conducted in the liquid metal program and houses a semi-automated hot-cell facility with an argon-atmosphere cell designed to handle and examine large experiments containing sodium and plutonium. HFEF also houses a neutron-radiography facility, a diesel generator, and an associated fuel tank.

HFEF vents all the labs and the hot cells through a single stack: ANL-785-018. The gas stream from the lab area is HEPA filtered independently of the hot-cell gas stream, which also has a set of HEPA filters, and both streams combine at the stack. The emissions are continuously monitored for radionuclides, which are primarily noble gases. Some acids and some organics are also vented from the labs at this stack.

3.1.2.4 FCF. Formerly HFEF South and originally the fuel cycle facility for EBR-II, FCF (ANL-765) is the older of the two fuel examination facilities. At present, FCF is being modified and equipped to demonstrate the Integral Fast Reactor (IFR) fuel cycle technology.

FCF is vented out of the main stack (ANL-764) along with the EBR-II reactor building. Gas streams are HEPA filtered and continuously monitored. Emissions include noble gases and tritium. FCF also houses an emergency diesel generator and associated fuel tank.

3. 1.2.5 ZPPR. The ZPPR reactor complex includes the ZPPR reactor building (ANL-776), the ZPPR Support Wing (ANL-774), which houses the Argonne Fast Source Reactor (AFSR), the ZPPR Equipment Room (ANL-777), the ZPPR Vault/Workroom Equipment Room (ANL-775), the ZPPR Materials Control Building (ANL-784), and the ZPPR Mockup Building (ANL-792). The ZPPR reactor is designed for experiments that are most easily performed and studied under lowpower conditions. AFSR is a small reactor that serves as a neutron source for calibrating nuclear instruments and developing experimental equipment, primarily for ZPPR. AFSR is air cooled and has a maximum power level of $1 \mathrm{~kW}$. The Materials Control Building is for storage of nonfissile material plates for reactor mockups. The ZPPR equipment room houses the filters, ventilation, and air conditioning equipment for the ZPPR mound area. The ZPPR Mockup building is used for storage and mockup and testing of experimental equipment.

The primary point of emissions from the ZPPR reactor complex is the main stack, identified in the inventory as ANL-777-002. The air from the inactive reactor cell enters ANL-775, where it is HEPA filtered along with the ventilation air from ANL-775. This gas stream then vents to the main stack. This stack is continuously monitored, and emissions include noble gases and unidentified betagamma emitters.

The AFSR cooling air vents at source ANL-774-025 (which is presently inactive), and the AFSR room vents at ANL-774-008. ANL-774-025 is HEPA filtered and monitored for gamma radiation when operating. Under normal operations, these sources produce no emissions.

ANL-W maintains diesel generators, fuel tanks, and a few miscellaneous fumehoods associated with the ZPPR complex.

3.1.2.6 FMF. FMF (ANL-704) is located near the ZPPR complex. It is a high-security facility that fabricates fuel assemblies for the EBR-II reactor. EBR-II driver and experimental fuel pins, elements, and subassemblies are manufactured, inspected, and stored at FMF. The building is also equipped for the receipt and storage of fuel feedstock. 
All parts of the building are maintained at negative pressure, and air flows from areas of least likelihood of contamination to areas of the greatest likelihood. Hoods, gloveboxes, and room vents all discharge to a single stack, identified as ANL-704-008. Emissions include alpha, beta, and gamma radiation, as well as small amounts of ethanol and acetone. An emergency diesel generator and small fuel tank are also located at FMF.

\subsubsection{Secondary Sources}

Secondary sources comprise sources that are not considered primary sources and include potential sources with little or no emissions; sources with relatively insignificant emissions; and sources with emissions that may be comparable to some sources associated with primary sources/programs but function only in support of the primary activities at this facility (such as the main cooling tower for EBR-II). Secondary sources at ANL-W include lab fumehoods, paint spray booths, welding booths, cooling towers, a blueprint machine, several multi-source large stacks, miscellaneous small radioactive sources, diesel engines, small furnaces and heaters, inorganic storage tanks, and organic storage tanks.

The large stacks typically operate 24 hours per day, 7 days per week, 52 weeks per year. Fumehood blowers may only operate while hoods are in use. Furnaces and heaters generally only operate eight months out of the year. Diesel engines typically operate on a routine preventative maintenance schedule of 0.5 hours per week, 52 weeks per year.

\subsubsection{Summary of ANL-W Emissions}

Table 3-1 is a summary of the totals of each of the principal pollutants.

Table 3-1. Summary of principal pollutants at ANL-W.

\begin{tabular}{lcccc}
\hline \multicolumn{1}{c}{ Pollutant } & $\begin{array}{c}\text { Actual } \\
\text { Hourly } \\
(\mathrm{lb} / \mathrm{hr})\end{array}$ & $\begin{array}{c}\text { Actual } \\
\text { Annual } \\
(\mathrm{tn} / \mathrm{yr})\end{array}$ & $\begin{array}{c}\text { Maximum } \\
\text { Hourly } \\
(\mathrm{lb} / \mathrm{hr})\end{array}$ & $\begin{array}{c}\text { Maximum } \\
\text { Annual } \\
(\mathrm{tn} / \mathrm{yr})\end{array}$ \\
\hline Carbon monoxide & $1.482 \mathrm{E}+01$ & $1.400 \mathrm{E}+00$ & $3.2 \mathrm{E}+01$ & $1.4 \mathrm{E}+02$ \\
Nitrogen oxides & $6.467 \mathrm{E}+01$ & $5.673 \mathrm{E}+00$ & $1.4 \mathrm{E}+02$ & $6.1 \mathrm{E}+02$ \\
Particulate & $1.085 \mathrm{E}+01$ & $2.536 \mathrm{E}+01$ & $2.4 \mathrm{E}+01$ & $1.0 \mathrm{E}+02$ \\
Lead & $6.858 \mathrm{E}-04$ & $3.156 \mathrm{E}-04$ & $8.8 \mathrm{E}-04$ & $3.8 \mathrm{E}-03$ \\
Radionuclides & $9.150 \mathrm{E}+01$ & $1.101 \mathrm{E}+03$ & $2.5 \mathrm{E}+02$ & $1.8 \mathrm{E}+03$ \\
Sulfur oxides & $4.297 \mathrm{E}+01$ & $1.815 \mathrm{E}+01$ & $5.9 \mathrm{E}+01$ & $2.6 \mathrm{E}+02$ \\
VOC - nonmethane & $5.957 \mathrm{E}+01$ & $4.147 \mathrm{E}+01$ & $7.7 \mathrm{E}+01$ & $5.4 \mathrm{E}+01$ \\
\hline a. Units in Ci/mo and $\mathrm{Ci} / \mathrm{yr}$, respectively. & & & \\
\hline
\end{tabular}




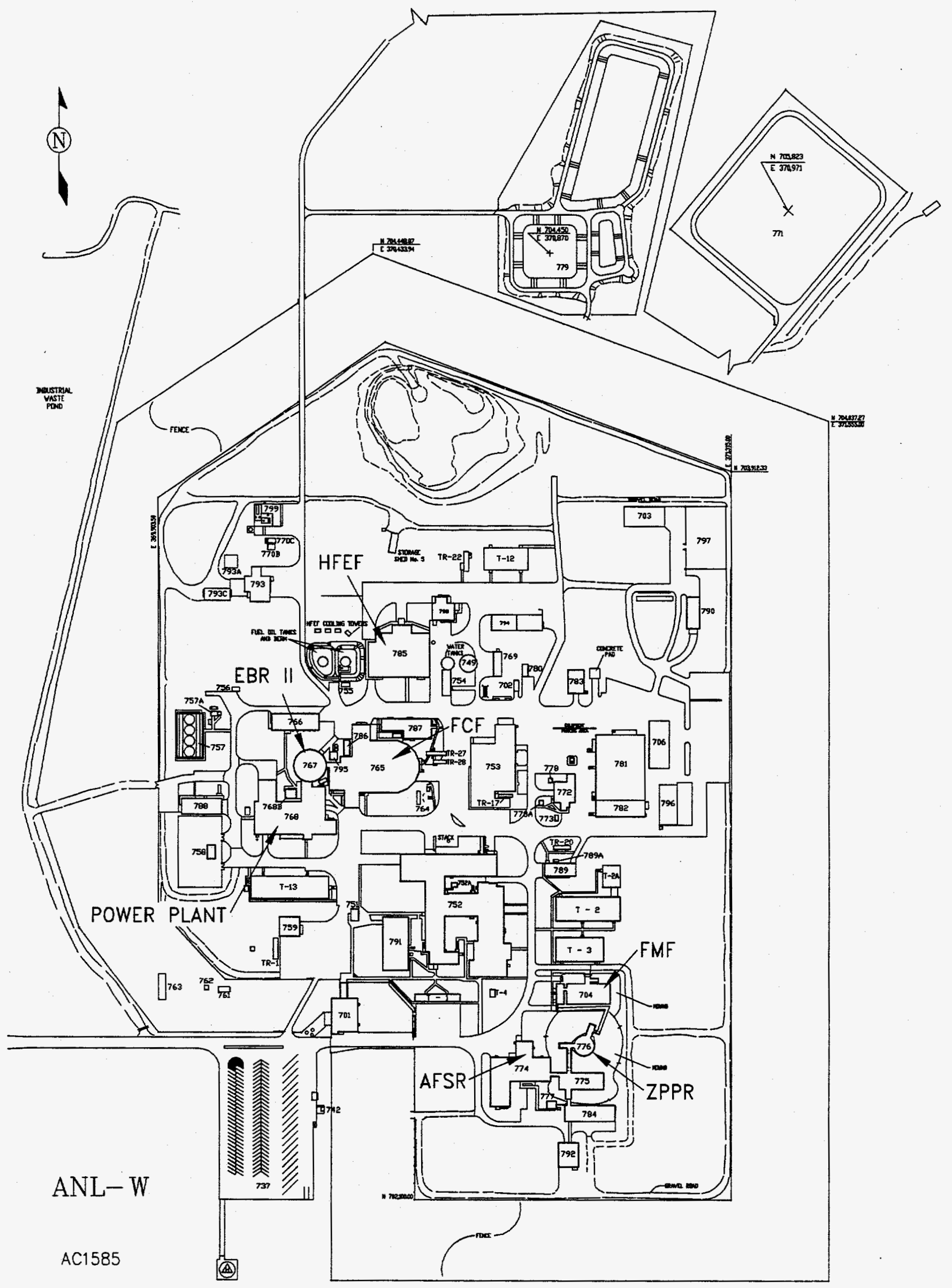

Figure 3-1. Area plot plan of Argonne National Laboratory-West. 


\subsection{Block Areas}

\subsubsection{Area Descriptions}

For administrative purposes, the INEL has been divided into a grid system, and each area is identified as a block and assigned a unique number. Many of these block areas have within them buildings or facilities that are not specifically assigned to one of the main INEL areas. These include the following:

- Howe Peak Transformer Station (HPTF)

- $\quad$ Security Firing Range, Block 21 (B21)

- $\quad$ Fire Station 2 and the Experimental Dairy Farm, Block 16 (B16)

- $\quad$ Main Guard Gate, Block 27 (B27)

- $\quad$ Security Training Facility (STF)

- $\quad$ North Guard Gate, Block 8 (B08)

- $\quad$ East Butte (EB)

Figure 3-2 presents a map of the INEL and surrounding area showing the location of the above facilities.

HPTF is part of the INEL radio network and is located near the summit of Howe Peak, due west of the INEL. The facility consists of a few small buildings, radio antennas, and an emergency propane generator. This generator is the only source of emissions. The facility is unoccupied, though maintenance personnel make regular trips for preventative maintenance.

The Security Firing Range consists of an outdoor firing range, an indoor firing range, and administrative and support buildings. Emission points include the exhaust system for the indoor range, and an exhaust hood over three solvent sinks used for cleaning guns. This facility is occupied regularly.

Fire Station 2 consists of a few buildings and an outdoor fire training facility, including a tower and several fire pits. The buildings are presently occupied on a part-time basis by the National Oceanic and Atmospheric Administration (NOAA). The only sources in the buildings are the two oil burning furnaces that vent from a single stack and the fuel oil tank that supplies these furnaces. The fire training facilities consist of several concrete pits where oil is poured in and ignited. After training activities, the water and residual oil drains to a small evaporation pond. Emission estimates for these facilities consider all of the fire training components as a single source. The dairy farm is presently unoccupied, and there are no known emissions from those buildings.

The Main Guard Gate is located on E. Portland Avenue between CFA and U.S. Highways 20 and 26. The only source is the emergency diesel generator that resides in the generator building. This facility is always occupied, and the generator runs primarily on a preventive maintenance schedule.

The STF, formerly Experimental Organic Cooled Reactor and Organic Moderated Reactor Experiment, is located west of Jefferson Avenue, which runs northeast from E. Portland Avenue just north of the main guard gate, to the PBF area. This area was a reactor facility at one time and has been turned over for security training and mock procedures. The only source at STF is a solvent sink used for gun cleaning purposes. STF is no longer occupied and is presently slated for decontamination and decomissioning. 
The North Guard Gate is on Lincoln Boulevard, just before it turns into U.S. Highway 33, between CFA and TAN. This is a small facility that consists of a single guard station in the middle of the road and a small emergency generator building, which houses the only source. This guard gate is typically only occupied by one or two security personnel.

East Butte is one of two natural volcanic buttes that are present in the southeast corner of the INEL, south of U.S. Highway 20. The top of the butte has been subdivided into several lots, most with a transmitter station. These stations include transmitters for local television and radio stations, Idaho State University, the Bureau of Land Management, Utah Power and Light, the State of Idaho, and others. The INEL has a small transmitter as well, consisting of a small trailer and a single tower. Many of the buildings house emergency diesel generators for their respective transmission towers, but the INEL transistor area does not. Consequently, these sources are not included in the inventory since they are not INEL property nor property of any INEL contractor. The only fully occupied operation on East Butte belongs to KIDK television station, based in Idaho Falls, who takes much of the responsibility for the maintenance of the East Butte facilities.

\subsubsection{Primary Sources}

All primary sources in any of the block areas are associated with one of the main areas and are discussed in the appropriate area discussion.

\subsubsection{Secondary Sources}

All sources in the block areas are considered to be secondary sources. Most are fuel burning equipment with associated fuel tanks, but there are a few chemical sources as well. There are no sources of radiation in any of the block areas. The secondary sources include two solvent sinks, lead and particulate from the firing range, a furnace/heater, an emergency generator, organic storage tanks, and an evaporation/fire pit.

\subsubsection{Summary of Block Area Emissions}

Table 3-2 is a summary of the totals for each of the principal pollutants.

Table 3-2. Summary of principal pollutants at block areas.

\begin{tabular}{llccc}
\hline \multicolumn{1}{c}{ Pollutant } & $\begin{array}{c}\text { Actual } \\
\text { Hourly } \\
(\mathrm{lb} / \mathrm{hr})\end{array}$ & $\begin{array}{c}\text { Actual } \\
\text { Annual } \\
(\mathrm{tn} / \mathrm{yr})\end{array}$ & $\begin{array}{c}\text { Maximum } \\
\text { Hourly } \\
(\mathrm{lb} / \mathrm{hr})\end{array}$ & $\begin{array}{c}\text { Maximum } \\
\text { Annual } \\
\text { (tn/yr) }\end{array}$ \\
\hline Carbon monoxide & $3.33 \mathrm{E}+00$ & $3.00 \mathrm{E}-02$ & $1.20 \mathrm{E}+01$ & $5.14 \mathrm{E}+01$ \\
Nitrogen oxides & $3.71 \mathrm{E}+00$ & $3.05 \mathrm{E}-02$ & $1.46 \mathrm{E}+01$ & $6.41 \mathrm{E}+01$ \\
Particulate & $4.81 \mathrm{E}-01$ & $5.78 \mathrm{E}-03$ & $1.23 \mathrm{E}+01$ & $6.46 \mathrm{E}+00$ \\
Lead & $2.00 \mathrm{E}-06$ & $3.00 \mathrm{E}-06$ & $2.00 \mathrm{E}-06$ & $1.10 \mathrm{E}-05$ \\
Sulfur oxides & $1.19 \mathrm{E}+00$ & $5.38 \mathrm{E}-03$ & $3.43 \mathrm{E}+01$ & $1.64 \mathrm{E}+01$ \\
VOC - nonmethane & $1.66 \mathrm{E}+00$ & $1.02 \mathrm{E}+00$ & $1.55 \mathrm{E}+01$ & $7.95 \mathrm{E}+00$ \\
\hline
\end{tabular}




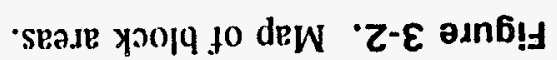

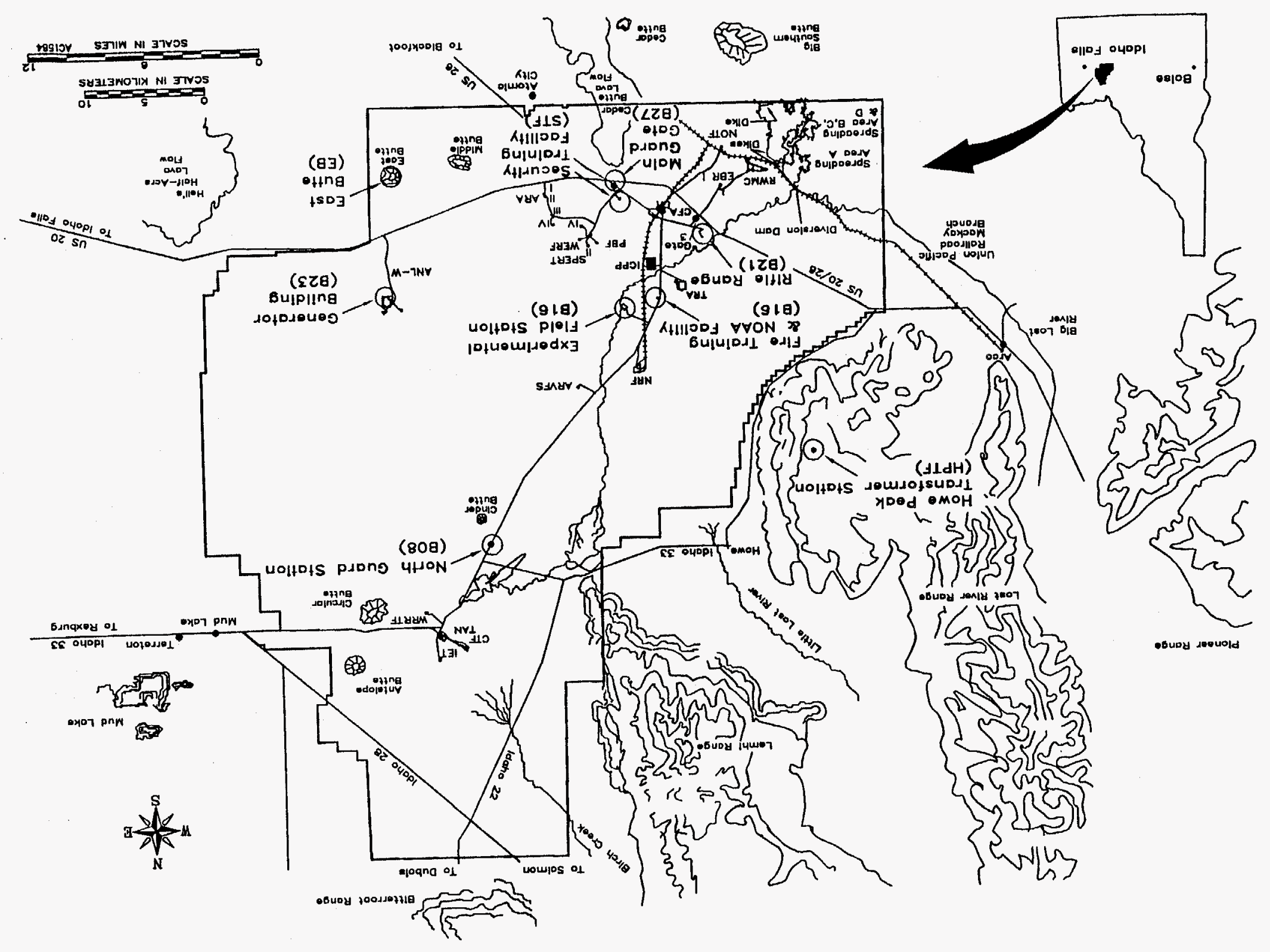




\subsection{Central Facilities Area}

\subsubsection{Area Description}

CFA is located in the southern part of the INEL, roughly 2.5 miles north of U.S. Highways 20 and 26, and maintains a population of approximately 1,400 employees. The original facilities at CFA were constructed in during 1940 through 1950 and were used to house Naval Gunnery Range personnel and later National Reactor Testing Station personnel. The facilities have since been modified to fit the changing needs of the INEL and now provide four primary types of functional space: craft, office, service, and laboratory.

The craft areas consist primarily of the four new multicraft shops as well as warehouses for craft materials storage. Activities include painting, welding, carpentry, machining, and other related crafts needed for support of the INEL.

Office space is provided for all administrative, scientific, and engineering personnel, particularly those associated with the many labs and service groups. Services at CFA are provided for the support of the INEL and include bus and vehicle maintenance, equipment mechanics, equipment operation, radio and alarm shops, telecommunication facilities, cafeterias, service stations, fuel distribution, facility maintenance, instrument calibration, and training. Laundry and respirator decontamination were discontinued in June 1993.

Laboratories are located in CFA-612, the Environmental Chemistry labs in CFA-625 and -633, the Radiological and Environmental Sciences Laboratories (RESL) in CFA-690, and the Technical Center and High Bay at CFA-686, -688 , and -689 . These labs are chemistry and engineering labs used for both research and analysis.

Figure 3-3 presents an area plot plan of CFA, highlighting a few of the primary facilities. Figure 3-4 presents a detail of the shaded area in Figure 3-3.

\subsubsection{Primary Sources}

Because of the administrative and support nature of the work performed at CFA, few sources of emissions of the same order of magnitude are found elsewhere at the site. The more significant emission sources at CFA are the many large boilers used to produce steam for most of the buildings. Large boilers are located in the following buildings:

- CFA-650 - one boiler

- CFA-662 - one full-time boiler, and one backup

- CFA-665 - one large full-time boiler

- $\quad$ CFA-671 - two large boilers

- CFA-688 - one large boiler.

Smaller boilers are located in the following areas:

- $\quad$ CFA-608 - one boiler
. $\quad$ CFA-609 - one boiler
- CFA-613 - one boiler
CFA-668 - one boiler.


All boilers at CFA burn No. 2 fuel oil, and most have a propane ignition. Most boilers provide space heating only and typically do not operate during the summer months.

The Environmental Chemistry Labs at CFA-625 are divided into two areas, each with a different function. One area is responsible for all radiologically contaminated samples, and the hoods on that half of the building vent to a single stack with a HEPA filter.

The RESL is a DOE facility that provides several support functions. There are several analytical laboratories and a few environmental laboratories. The laboratories that perform the radioisotope analysis of soil and organic samples produce virtually all of the emissions at CFA. These labs have two or three hoods that vent to large stainless steel stacks on the roof. Most stacks vent two hoods. The primary emissions from RESL are acids that are used to digest the samples and then are boiled away as part of the analytical procedure. The majority of fumehoods are currently inactive. All radiological releases are below normal background levels.

Numerous fuel storage tanks contribute significantly to the VOC emissions, but the biggest sources are the tanks at the tank farm (CFA-754) and the large fuel oil tank behind the Technical Center (CFA-708). The tank farm tanks contain No. 2 fuel oil, diesel and diesel blends, and gasoline. All are very large, aboveground, vertical tanks that dispense fuel to various tanks around the site.

The CFA landfill is estimated to be a primary source of particulate. The CFA landfill services all of the INEL, disposing only industrial and commercial wastes and asbestos in proper containers. During 1993, the INEL Landfill Complex relocated disposal activities from the CFA Landfill III Extension to the area associated with the bulky waste pit. Dirt moving activities, soil piles, and vehicle travel at the landfill are estimated to contribute a significant quantity of particulate to the atmosphere.

\subsubsection{Secondary Sources}

The secondary sources at CFA constitute the bulk of all sources at the facility. The boilers have been considered as primary sources, as have all the radiation sources. Some of the fumehoods at CFA-690 (RESL) would individually be considered as secondary sources, but since the RESL facility is considered to be a primary source, the primary and secondary sources are not differentiated in this discussion. A single health physics hood in the calibration laboratory at CFA-633 is the only secondary potential source of radiation.

Secondary sources at CFA include several fumehoods, two paint booths, several welding booths, emergency engines, heaters/furnaces, and numerous organic storage tanks. Most of the tanks, all the engines, most of the fumehoods, and all of the small heaters and furnaces have been considered as secondary sources. 


\subsubsection{Summary of CFA Emissions}

Table 3-3 is a summary of the totals for each of the principal pollutants.

Table 3-3. Summary of the totals for each of the principal pollutants at CFA.

\begin{tabular}{lcccc}
\hline \multicolumn{1}{c}{ Pollutant } & $\begin{array}{c}\text { Actual } \\
\text { Hourly } \\
(\mathrm{lb} / \mathrm{hr})\end{array}$ & $\begin{array}{c}\text { Actual } \\
\text { Annual } \\
(\mathrm{tn} / \mathrm{yr})\end{array}$ & $\begin{array}{c}\text { Maximum } \\
\text { Hourly } \\
(\mathrm{lb} / \mathrm{hr})\end{array}$ & $\begin{array}{c}\text { Maximum } \\
\text { Annual } \\
(\mathrm{tn} / \mathrm{yr})\end{array}$ \\
\hline Carbon monoxide & $4.381 \mathrm{E}+00$ & $9.518 \mathrm{E}-01$ & $1.2 \mathrm{E}+01$ & $5.4 \mathrm{E}+01$ \\
Nitrogen oxides & $1.995 \mathrm{E}+01$ & $3.870 \mathrm{E}+00$ & $5.6 \mathrm{E}+01$ & $2.4 \mathrm{E}+02$ \\
Particulate & $3.287 \mathrm{E}+01$ & $1.057 \mathrm{E}+02$ & $8.4 \mathrm{E}+01$ & $2.3 \mathrm{E}+02$ \\
Lead & $1.043 \mathrm{E}-02$ & $3.209 \mathrm{E}-04$ & $1.8 \mathrm{E}-02$ & $7.6 \mathrm{E}-03$ \\
Radionuclides & $2.199 \mathrm{E}-07$ & $1.545 \mathrm{E}-06$ & $9.4 \mathrm{E}-04$ & $1.1 \mathrm{E}-02$ \\
Sulfur oxides & $8.091 \mathrm{E}+00$ & $1.280 \mathrm{E}+01$ & $3.5 \mathrm{E}+01$ & $1.5 \mathrm{E}+02$ \\
VOC - nonmethane & $2.296 \mathrm{E}+02$ & $1.607 \mathrm{E}+01$ & $2.3 \mathrm{E}+02$ & $1.1 \mathrm{E}+01$ \\
\hline a. Units in Ci/mo and $\mathrm{Ci} / \mathrm{yr}$, respectively. & & & & \\
\hline
\end{tabular}




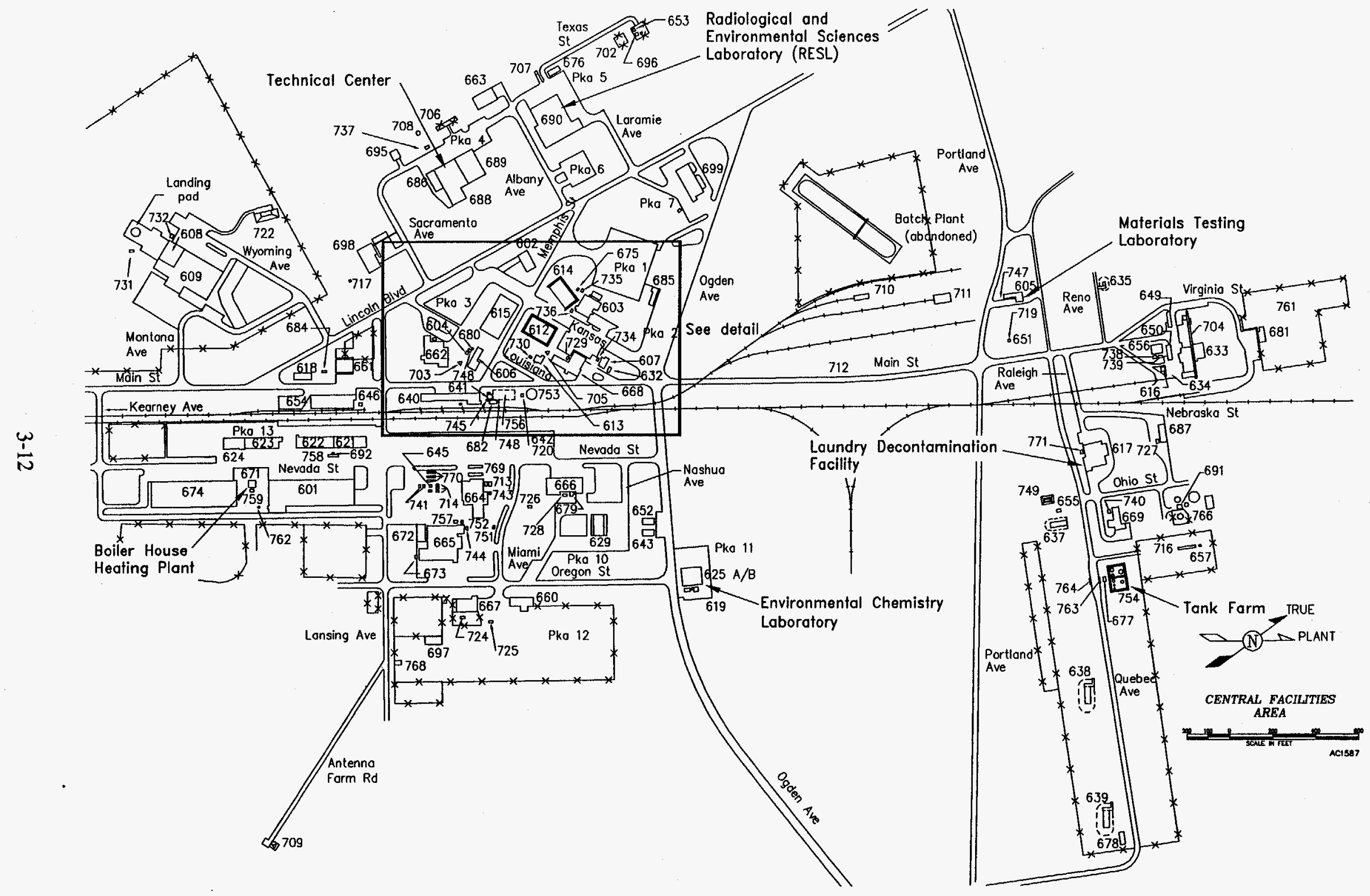

Figure 3-3. Area plot plan of the Central Facilities Area. 


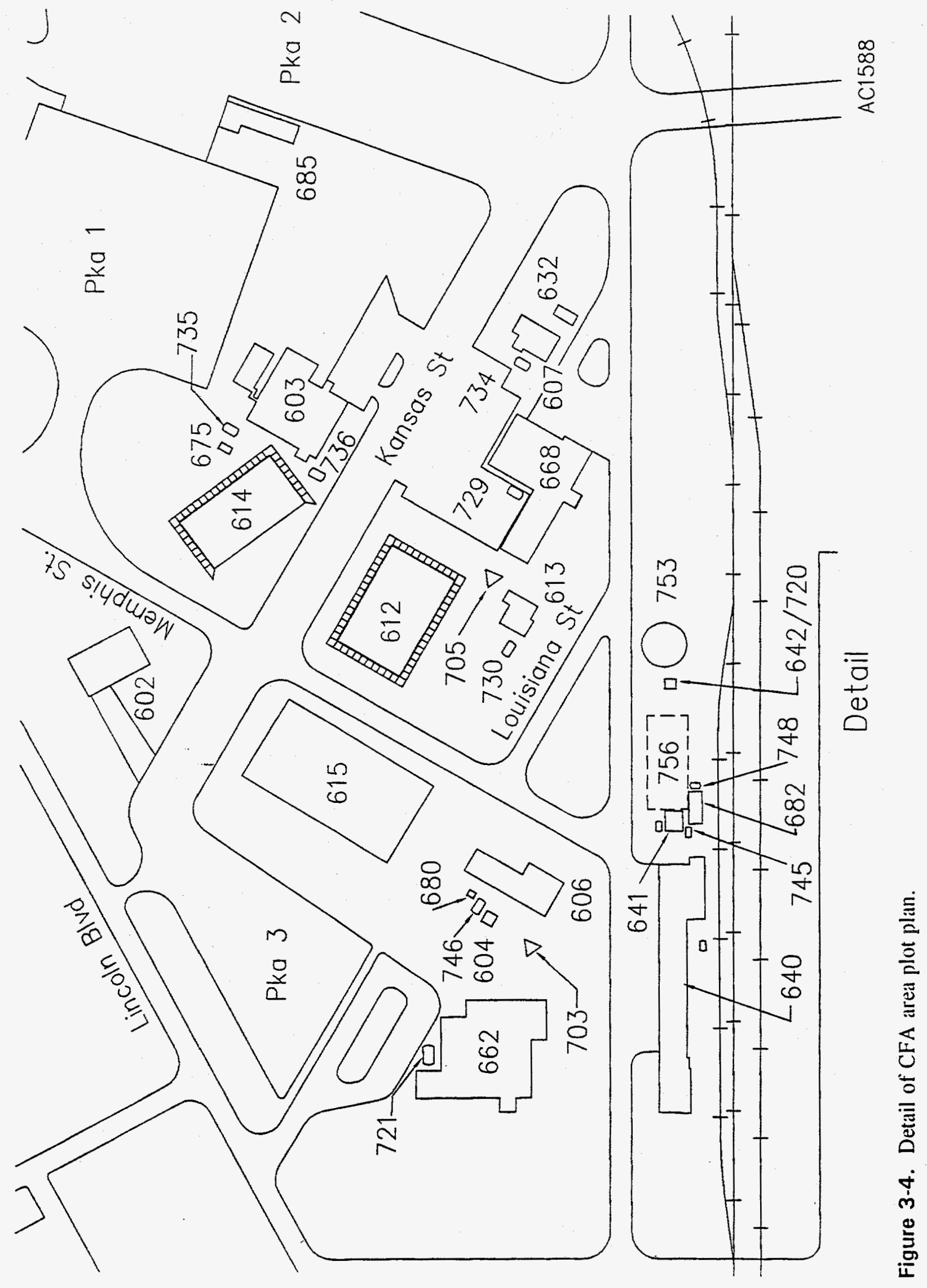




\subsection{Idaho Chemical Processing Plant}

\subsubsection{Area Description}

ICPP was originally constructed in 1953 as an engineering-scale demonstration facility to process highly enriched spent reactor fuel. However, until 1992, the plant became the INEL's principal facility for receiving, storing, reprocessing, and managing nuclear materials from test, defense, and research reactors in the United States and other countries. Since 1963, the ICPP has converted more than six million gallons of high-level radioactive liquid waste to granular solid form. Currently, ICPP has several primary functions, including fuel storage, waste management, technical support, and utilities. Figure 3-5 shows a plot plan of ICPP.

Fuel receipt and storage areas include the Fuel Receiving and Storage Building (CPP-603), the Fluorinel Dissolution Process and Fuel Storage (FAST) facility (CPP-666), and the Peach Bottom Fuel Storage Facility (CPP-749). CPP-666 stores fuels in water pools, and CPP-749 stores the fuel rods in underground dry containment. CPP-603 houses fuels in both dry and underwater storage.

Waste management facilities manage liquid, solid, and gaseous radioactive wastes generated during fuel processing. Waste management facilities include the tank farm, CPP-604, CPP-605/649, CPP-659, and the calcine storage bin sets. The tank farm area consists of large storage tanks that store high-level liquid radioactive waste before it is sent to CPP-659. CPP-659, the New Waste Calcining Facility (NWCF), is a process building used to calcine liquid high-level radioactive waste into a more stable solid high-level radioactive waste (calcine). The calcine is then temporarily stored in storage bins for until final treatment and disposal of the waste. CPP-604 houses the process equipment waste evaporators that concentrate dilute low-level radioactively contaminated liquid waste. The atmospheric protection system filters process offgas and process ventilation through banks of HEPA filters.

Technical facilities provide for chemical, radiochemical, and spectroscopic analysis and process development. Those facilities include the remote analytical facility (CPP-627), the Remote Analytical Laboratory (CPP-684), the process improvement facility (CPP-637), the process building (CPP-601), the laboratory and office building (CPP-602), and the safety and spectrometry building (CPP-630).

CPP-601 houses the alpha handling laboratory. CPP-602 contains radiochemistry, wet chemistry, quality control and accountability, spectrochemical, instrument, and methods research and development laboratories. CPP-627 incorporates remote analytical facilities and the production support analysis laboratory. CPP-637 houses technical laboratories, offices, and pilot plant facilities. CPP-630 houses the mass spectrometry laboratory.

Utility support buildings primarily include CPP-606, service building powerhouse, and CPP-687, the Coal-Fired Steam-Generating Facility (CFSGF). CPP-606 houses four boilers that are used as backup for the CFSGF (one of the boilers is not presently operable but will be used again). CFSGF houses two boilers and is the main source of steam for ICPP. CFSGF has a State of Idaho air quality prevention of significant deterioration (PSD) permit.

\subsubsection{Primary Source Description}

The Remote Analytical Laboratory (CPP-684) is used for chemical analysis of samples generated at various areas throughout ICPP. Some of those areas include the FAST facility 
(CPP-666), the process building (CPP-601), the service waste system, various pilot plants, the decontamination facility, and NWCF. The building consists of radioactive and nonradioactive laboratories, offices, and other support space. The facility was designed to segregate work areas.

The warm (slightly radioactive) laboratory area receives filtered air from the heating, ventilating, and air conditioning air supply room as four separate streams. These streams flow to the following areas (some of which may be slightly radioactive): offices, change rooms, operating gallery, and maintenance corridor; valve room and operating gallery; and the warm (radioactive) laboratory. Total flow through these areas is about $16,000 \mathrm{cfm}$, and the flow goes from the least contaminated to the most contaminated areas. These streams are combined and exhausted through a double HEPA filter to the warm laboratory exhaust stack. The warm exhaust stream is continuously sampled and monitored for radioactive material.

The cold (nonradioactive) laboratory system is supplied by two filtered streams. One stream supplies the vestibule, offices, sample data room, and toilets. The other stream supplies the cold laboratories. The laboratory stream, with a flow of about $4680 \mathrm{cfm}$, discharges unfiltered through the cold laboratory exhaust stack. The other stream, with a volume of $530 \mathrm{cfm}$, exhausts through the office area exhaust blower. As a chemical laboratory, a large variety of chemicals are used in the facility. Most of these are liquid and are used in small quantities. Organic chemicals that are sometimes used in the area include propane used as a laboratory fuel supply, isopropanol used for cleaning equipment, and methyl isobutyl ketone used as an extractant. Inorganic materials that could be present include boron, cadmium, mercury, chromium, hydrofluoric acid, and nitric acid.

ICPP, like other industrial plants, uses steam for a variety of purposes, including heating and other process needs. CFSGF is the primary facility at ICPP for generating this steam, with other oilfired boilers used as backup. This facility had a PSD permit before construction began.

CFSGF is a fluidized bed burner that burns coal to provide the heat to generate steam. This burning process generates unburned organics, particulates, sulfur oxides, nitrogen oxides, and other materials that are, after appropriate cleanup, discharged to the atmosphere. The facility consists of two burners and the associated equipment such as coal unloading facilities, an ash pit, and other items necessary to operate the facility. Particulates are removed by passing the offgas through bag filters, and a limestone injection system is used to remove most of the sulfur that is generated during the burning of the coal.

CFSGF has a design heat generation rate of $165 \mathrm{MBtu}$ per hr. The design coal consumption rate is $16,500 \mathrm{lb} / \mathrm{hr}$. At this rate, $135,000 \mathrm{lb}$ of steam are generated per hour. Offgases from the coal combustion discharge through a dedicated stack that is $150 \mathrm{ft}$ high and about $5.8 \mathrm{ft}$ in diameter. The effluent discharges at a temperature of $350^{\circ} \mathrm{F}$ and at a flow rate of $75,000 \mathrm{cfm}$, resulting in a velocity of approximately $47 \mathrm{ft} / \mathrm{sec}$.

CPP-606, the Service Building Power House, houses four boilers used as backup for the CFSGF. The boilers in CPP-606 are considered primary sources even though they are standby boilers. The four boilers consist of two Babcock \& Wilcox Company boilers, one Murray boiler, and one Cleaver Brooks boiler. These boilers have been included in the PSD permit for the Fuel Processing Restoration Facility. There are only three stacks for all four boilers because the two Babcock \& Wilcox Company boilers share a common stack. One of those boilers is presently not used but plans are being developed to bring that boiler back online. 
The FAST facility (CPP-666) is a primary facility at ICPP for storing nuclear fuel. Fuel received from other locations is brought to the FAST facility in large, shielded casks, where it is unloaded and stored in large water-filled basins.

The Fuel Storage Area consists of a truck receiving area, a cask receiving area, decontamination rooms, a fuel unloading area, and a water treatment area in addition to the fuel storage area. The decontamination area is used to remove any surface contamination that may be present on the cask. The flourinel dissolution process area contains the cells where the fuel dissolution occurs, as well as change rooms, offices and the control room, a chemical makeup area, and other support areas. Both areas share one overall ventilation system that discharges to a special, dedicated FAST stack located north of the building. This stack is approximately $160 \mathrm{ft}$ high. A bypass is available if the stack or the line leading to it becomes inoperable. The bypass is located on the roof of the CPP- 666 near the northwest corner. Total flow through the ventilation system is about 90,700 actual cubic feet per minute.

All gaseous effluents at FAST, both radiological and nonradiological, are routed through HEPA filters before discharging to the environment. In general, the offgas from each area is filtered through roughing and HEPA filters before it leaves the area. These streams are then combined with the general ventilation air, which is again filtered before releasing to the environment. The individual treatment of an offgas stream before it leaves an area is based on the knowledge of the process and potential contents of the stream, which determines the number of filter stages needed or if other cleanup equipment is appropriate. The final cleanup system that treats the stream leaving the facility consists of four pairs of prefilters followed by HEPA filters. (The stream is split into four parts as it leaves the building.) Heat recovery coils are present to help conserve and recover heat from the exiting stream. The air stream then flows through a common duct to one of three blowers, each of which is sized to handle half of the total flow. The exhaust then flows through an underground duct to the FAST stack.

The ICPP main stack is the primary emission point at ICPP because of the volume of gas discharged and the contaminants released. The main stack is $250 \mathrm{ft}$ tall and has a diameter of about $6.5 \mathrm{ft}$. Air flow through the stack is about 100,000 to $150,000 \mathrm{cfm}$, resulting in a velocity up the stack of about $61 \mathrm{ft} / \mathrm{sec}$. Offgas release points from throughout the ICPP area are collected and lead to the main stack where the emissions are monitored, sampled, and released to the environment. The streams leading to the main stack can be classified according to their origin as well as the activities from which they come. The effluent from the main stack is constantly monitored for the primary emissions, specifically nitrogen oxides and radionuclides. Releases of nitrogen oxides and radionuclides from the main stack are regulated by the Fuel Processing Restoration Facility Permit to Construct issued by the State of Idaho.

Although a large number of activities are conducted at ICPP, the primary sources that generate emissions are classified as a) nuclear fuel storage, b) treatment of the waste generated during dissolution by converting it from a liquid to a solid in a process called calcination, c) treatment of other waste streams by evaporation, d) sampling of many of the liquid streams, and e) various support activities involving chemical analysis, process development, steam generation, and other activities associated with operation of the plant.

These activities are reflected in the design of the system that collects offgases for transport to and release from the main stack. This system consists of primary parts that collect offgases from the following areas: a) general ventilation air from buildings CPP-601, CPP-602, CPP-604, CPP-633, CPP-627, and CPP-640; b) dissolver offgas lines that collect the offgases that are generated during 
the actual fuel dissolution process; c) sample offgas lines that collect emissions generated when samples are obtained by using air or steam jets to obtain samples from various tanks or lines; d) vessel offgas lines that are connected to many vessels in all parts of the plant and generate offgases as they are filled or breathe; and e) and process offgas lines from the calcination process that are high in nitrogen oxides because of the destruction of the nitrate present in the wastes, which occurs during the calcination process.

The general ventilation air typically contains only secondary quantities of emissions and comes from areas that under normal circumstances do not contain hazardous materials and that are normally occupied, so the concentration of any potentially dangerous material is minimal. Air from hoods, normally radioactive areas, and similar areas is not included in the normal ventilation air. This air, like all releases to the ICPP main stack, is processed through the Atmospheric Protection System before being released to the environment.

Releases to the main stack are highly dependent on the individual activities that are in operation at the time, and these can vary greatly over the years or throughout any given year. Operation of NWCF results in large quantities of nitrogen oxides being released; nitrogen oxide releases are minimal if NWCF is not operating.

Certain materials considered toxic by the State of Idaho could be present in the gas exhausted from the main stack. Because of the extensive cleanup system present on the offgas stream, most or all of these substances would be present in concentrations significantly below the levels considered as toxic by the State of Idaho. Laboratory ventilation air discharges to this system, and this air could contain minute quantities of the many chemicals typically used in a laboratory, although these chemicals would normally be used only in a hood with a separate discharge point. Toxic materials that could be present in the exhaust in small quantities include acetic acid, cadmium compounds, sulfuric acid, various solvents, tributyl phosphate, aluminum nitrate, ammonia, barium compounds, borates, chromium compounds, fluorides, formic acid, hydrochloric acid, nitric acid, oxalic acid, sodium hydroxide, and uranium and zirconium compounds.

\subsubsection{Secondary Sources}

ICPP contains the most secondary sources of any area at the INEL. The majority of these are organic and inorganic storage tanks, fuel burning equipment, and secondary chemical sources. Secondary sources at ICPP include organic and inorganic storage tanks, several propane burners, large engines, and small engines. Secondary sources include several chemical sources which encompass numerous fumehoods, chemical processes, blueprint machines, and painting operations.

There are also several miscellaneous sources such as chemical pumps and lines and potential sources of radionuclides (i.e., the ICPP percolation ponds). Most of these sources contribute very small quantities of air pollutants and have little impact on air quality. 


\subsubsection{Summary of ICPP emissions}

Table 3-4 presents a summary of the totals for each of the principal pollutants. The 1993 release rates for carbon monoxide emissions from CPP-787-001 have increased significantly from previous years due to the use of a new AP-42 emission factor for fluidized bed boilers.

Table 3-4. Summary of the totals for each of the principal pollutants at ICPP.

\begin{tabular}{lcccc}
\hline \multicolumn{1}{c}{ Pollutant } & $\begin{array}{c}\text { Actual } \\
\text { Hourly } \\
(\mathrm{lb} / \mathrm{hr})\end{array}$ & $\begin{array}{c}\text { Actual } \\
\text { Annual } \\
(\mathrm{tn} / \mathrm{yr})\end{array}$ & $\begin{array}{c}\text { Maximum } \\
\text { Hourly } \\
(\mathrm{lb} / \mathrm{hr})\end{array}$ & $\begin{array}{c}\text { Maximum } \\
\text { Annual } \\
\text { (tn/yr) }\end{array}$ \\
\hline Carbon monoxide & $2.012 \mathrm{E}+02$ & $4.278 \mathrm{E}+02$ & $6.5 \mathrm{E}+02$ & $2.5 \mathrm{E}+03$ \\
Nitrogen oxides & $3.246 \mathrm{E}+02$ & $5.316 \mathrm{E}+02$ & $1.8 \mathrm{E}+03$ & $7.7 \mathrm{E}+03$ \\
Particulate & $1.376 \mathrm{E}+01$ & $2.637 \mathrm{E}+00$ & $1.3 \mathrm{E}+02$ & $5.9 \mathrm{E}+02$ \\
Lead & $1.403 \mathrm{E}-03$ & $1.162 \mathrm{E}-03$ & $6.7 \mathrm{E}+01$ & $2.9 \mathrm{E}+02$ \\
Radionuclides & $5.5504 \mathrm{E}-00$ & $6.660 \mathrm{E}+01$ & $2.3 \mathrm{E}+04$ & $1.6 \mathrm{E}+05$ \\
Sulfur oxides & $3.849 \mathrm{E}+01$ & $3.629 \mathrm{E}+01$ & $2.5 \mathrm{E}+02$ & $1.1 \mathrm{E}+03$ \\
VOC - nonmethane & $2.858 \mathrm{E}+02$ & $1.612 \mathrm{E}+01$ & $4.1 \mathrm{E}+02$ & $5.4 \mathrm{E}+02$ \\
\hline a. Units in Ci/mo and Ci/yr, respectively. & & & \\
\hline
\end{tabular}




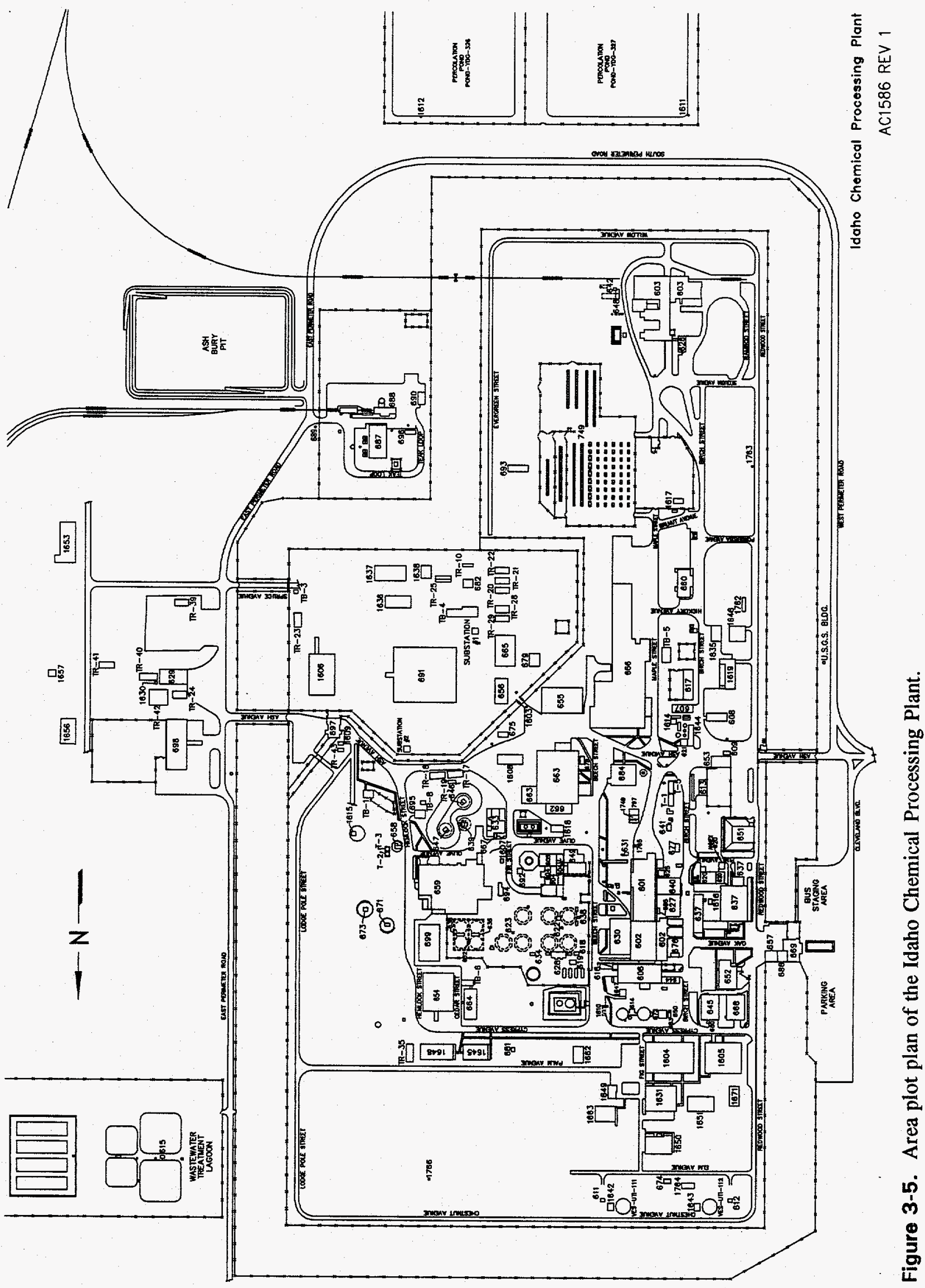




\subsection{Naval Reactor Facility}

\subsubsection{Area Description}

NRF is located in the southwestern part of the INEL site. One of the oldest areas on the INEL, NRF has operated more than 35 consecutive years and trained thousands of naval officer and enlisted personnel. NRF has provided several reactor prototypes for the U.S. Air Force and the Navy and still operates several facilities. There are five main operational areas at NRF: the Natural Circulation Reactor (S5G) prototype plant, the Large Ship Reactor (A1W) prototype plant, the Expended Core Facility (ECF), the Submarine Thermal Reactor (S1W) prototype plant, and NRF Production. An area plot plan of NRF is shown in Figure 3-6.

The S5G prototype plant currently operates as a training platform for U.S. Navy personnel who operate nuclear powered submarines. The S5G operational area includes the Test Plant Building, the S5G Cooling Tower, and several smaller buildings. S5G is scheduled to be inactivated in 1995, which will involve stopping all training, performing end-of-life testing, shutting down, defueling and inactivating the reactor plant; and preparing for long-term maintenance prior to final decommissioning.

The A1W prototype plant underwent final shutdown in January 1994. The A1W operations area includes the A1W Hull Structure Building, the A1W Operations Building, the Radioactive Waste Disposal Equipment Building, the A1W Cooling Tower, the Circulating Water Facility building, and numerous other support buildings and shops. Most of the work in the A1W operations area will consist of defueling and inactivating the A1W prototype plant.

The ECF houses hot cell facilities, shipping container loading and unloading bays, and water pits to examine and process spent nuclear fuel, prior to being transferred to ICPP. The ECF examines and evaluates performance of core components removed from submarines, surface ships, and land-based naval reactor prototypes; conducts a materials testing program involving preparing, examining, and testing material specimens that have been irradiated in the Advanced Test Reactor, located at the INEL's Test Reactor Area; unloads spent reactor core components from shipping casks; prepare spent core components for shipment to ICPP for storage; and maintains shielded shipping casks.

The S1W prototype plant was inactivated in 1989. The S1W operational area includes the S1W Main Building, which houses the inactivated S1W prototype plant, the Site Chemistry Laboratory, and various office buildings. The only regular activity occurring in the S1W area is analytical testing performed in the chemistry labs.

NRF Production is centrally located on the NRF site. The area includes machine, welding, paint, and fabrication shops, the site boilerhouse, and office spaces. Most of NRF's nonradiological maintenance and repair in support of the prototype plants and the NRF site is conducted by Production personnel in this area. All of NRF's steam for space heating is produced in the boilerhouse.

\subsubsection{Primary Sources}

The boilers account for most of the criteria pollutant emissions from NRF. The three NRF boilers are located in the boilerhouse (NRF-620), which is centrally located at the NRF site and under control of NRF Production. They provide steam for space heating in most NRF buildings. 
The NRF boilers burn primarily No. 5 fuel oil and relatively small amounts of No. 2 fuel oil during startup evolutions. The heating season at NRF typically runs from October until May, depending on demand for space heating. Normally, only one of the three boilers is operating, with a second boiler in hot standby and the third boiler in a cold layup condition. Since the inactivation of the S1W and A1W prototype plant, NRF has an excess of boiler capacity. This makes it extremely unlikely that NRF would ever need to operate more than one of the three boilers at a time.

No emission controls or monitoring are installed on the NRF boilers. Primary emissions are sulfur oxides, nitrogen oxides, carbon monoxide, and particulate.

NRF Production also has cognizance of the Power System. Upgrade emergency diesel power system. In 1991, the Power System Upgrade consolidated most of NRF's emergency power generating capability into one system. Four identical 1400-horsepower engines are housed in NRF-686. Normally, each of these engines is operated about 60 hours per year for training and preventive maintenance. Primary pollutants include carbon monoxide and nitrogen oxides. Actual emissions are small because of the limited operating schedule.

The Production Services Paint Shop Spray Booth (NRF-602-006) accounts for a large percentage of NRF's VOC emissions. The booth has a water curtain that controls emissions of particulate at or near $100 \%$ efficiency. Many items are painted just outside of the paint shop, resulting in fugitive emissions of air toxics and VOCs. For purposes of this inventory, all of the emissions due to painting performed outside the paint shop have been assigned to the booth exhaust. Emissions were calculated based on the estimated total of paints and thinners used.

In the S5G operational area, there are two primary sources of emissions. The S5G Test Plant Building Radioactive Area Ventilation system ventilates the S5G prototype plant and the plant water discharge facilities and discharges the HEPA-filtered and monitored air through the stack (NRF-633A-057). The primary emissions consist of small amounts of radionuclides.

The S5G Cooling Tower (NRF-716-001) cools secondary water from operation of the S5G plant. It is a seven-cell, induced draft tower with 22 -foot diameter venturi exhaust stacks and drift eliminators. Maximum design circulating water capacity is 37,000 gallons per minute. The operating level and schedule of the tower is extremely variable, depending on training schedules, plant power level, and ambient weather conditions. The primary emission of the cooling tower is particulate.

The primary sources of the A1W operational area include the A1W Reactor Compartment $3 \mathrm{~A}$ exhaust (NRF-617-013), the A1W Cooling Tower (NRF-708-001), the A1W Nucleonics Room Ventilation stack (NRF-616-039), the A1W RWPS Tank Ventilation (NRF-628A-006), and the emergency diesel generators \#3 and \#4 exhausts (NRF-617C-001, -002). Most of these sources are secured and will be inactivated in 1994. The ventilation systems for the inactive radiological sources (NRF-617-013, NRF-616-039, and NRF-628A-006) will still be operated and monitored, although emissions are expected to be negligible. The A1W Cooling Tower and the two A1W emergency diesel engines will no longer operate.

The ECF building has three primary sources of air emissions: Stack No. 1 (NRF-618-099), Stack No. 2 (NRF-618-103), and the High Bay roof vents (NRF-618-024 through -043). Stack No. 1 is a HEPA filtered exhaust system that ventilates hot cells, a chemistry laboratory, a decontamination shop, and various other areas of the building. The main operations produce emissions from this source are preparation of specimens for examination and evaporation of chemical descale solutions in the hot cells; waste reduction in the two evaporators used to reduce the volume of liquid waste at 
ECF; and decontamination of large pieces of equipment in Decontamination Shop No. 1. Most of the nonradiological machining work at ECF is performed in the Operations Support machine shop. The system is continuously monitored for radioactive particulate, iodine-131, and tritium. The primary emissions are VOCs and radionuclides.

ECF Stack No. 2 is a HEPA filtered exhaust system that ventilates hot cells, shipping cask unloading area (the Receiving Station), and various other areas in the building. The main operations that produce emissions from this source are a) radiological examination work in the hot cells and b) unloading, decontamination, and maintenance of spent fuel shipping containers in the Receiving Station. The system is continuously monitored for radioactive particulate and iodine-131. The primary emissions are VOCs and radionuclides.

Eighteen roof vents are located along the length of the ECF High Bay. They operate intermittently to provide temperature and radon control and to remove diesel exhaust fumes from trucks. Radiological work in the High Bay is performed underwater, in HEPA filtered containments, and in designated work areas. Welding and painting operations are also performed routinely in the high bay. The roof vents are not filtered. Three of the vents are continuously monitored for radioactive particulate and tritium. The primary emissions are VOCs from painting and metal fabricating operations, and radionuclides.

The only primary source of emissions in the S1W operational area is the S1W Building main stack (NRF-601-019), which ventilates the NRF Site Chemistry Laboratory. The stack is actually seven exhaust systems that are collocated and appear as one from the exterior; four of these seven exhaust systems are still operational and are identified as A, B, C, and F in the Air Emission Inventory. NRF-601A-019 is the emissions point for the Site Chemistry Laboratory Ventilation System. Most of NRF's analytical chemistry is performed in this area, including radiological counting of environmental monitoring samples, isotopic analysis, and water chemistry analysis. The chemistry laboratory exhaust is monitored for radioactive particulate. The primary emissions are VOCs, chlorofluorocarbons, and radionuclides.

\subsubsection{Secondary Sources}

NRF has a variety of secondary sources, including organic and inorganic liquid storage tanks, fuel burning equipment, and chemical sources. The secondary fuel burning equipment is made up of stationary diesel engines used for emergency power production and emergency water pumping systems. The chemical sources include laboratory fumehoods, a paint shop, welding exhausts, a reproduction center, and miscellaneous sources. 


\subsubsection{Summary of NRF Emissions}

Table 3-5 presents a summary of the totals for each of the principal pollutants at NRF.

Table 3-5. Summary of principal pollutants at NRF.

\begin{tabular}{lllll}
\hline \multicolumn{1}{c}{ Pollutant } & $\begin{array}{c}\text { Actual } \\
\text { Hourly } \\
(\mathrm{lb} / \mathrm{hr})\end{array}$ & $\begin{array}{c}\text { Actual } \\
\text { Annual } \\
(\mathrm{tn} / \mathrm{yr})\end{array}$ & $\begin{array}{c}\text { Maximum } \\
\text { Hourly } \\
(\mathrm{lb} / \mathrm{hr})\end{array}$ & $\begin{array}{c}\text { Maximum } \\
\text { Annual } \\
(\mathrm{tn} / \mathrm{yr})\end{array}$ \\
\hline Carbon monoxide & $6.081 \mathrm{E}+01$ & $4.583 \mathrm{E}+00$ & $8.2 \mathrm{E}+01$ & $3.6 \mathrm{E}+02$ \\
Nitrogen oxides & $2.541 \mathrm{E}+02$ & $2.951 \mathrm{E}+01$ & $3.7 \mathrm{E}+02$ & $1.6 \mathrm{E}+03$ \\
Particulate & $3.238+01$ & $2.585 \mathrm{E}+01$ & $1.5 \mathrm{E}+02$ & $6.9 \mathrm{E}+02$ \\
Lead & $2.016 \mathrm{E}-03$ & $1.386 \mathrm{E}-03$ & $5.7 \mathrm{E}-03$ & $2.5 \mathrm{E}-02$ \\
Radionuclides $^{\mathrm{a}}$ & $1.099 \mathrm{E}-01$ & $1.388 \mathrm{E}+00$ & $6.3 \mathrm{E}-01$ & $7.5 \mathrm{E}+00$ \\
Sulfur oxides & $1.460 \mathrm{E}+02$ & $9.001 \mathrm{E}+01$ & $3.9 \mathrm{E}+02$ & $1.7 \mathrm{E}+03$ \\
VOC - nonmethane & $1.122 \mathrm{E}+01$ & $3.913 \mathrm{E}+00$ & $1.4 \mathrm{E}+01$ & $4.8 \mathrm{E}+01$ \\
\hline a. Units in Ci/mo and Ci/yr, respectively. & & & \\
\hline
\end{tabular}




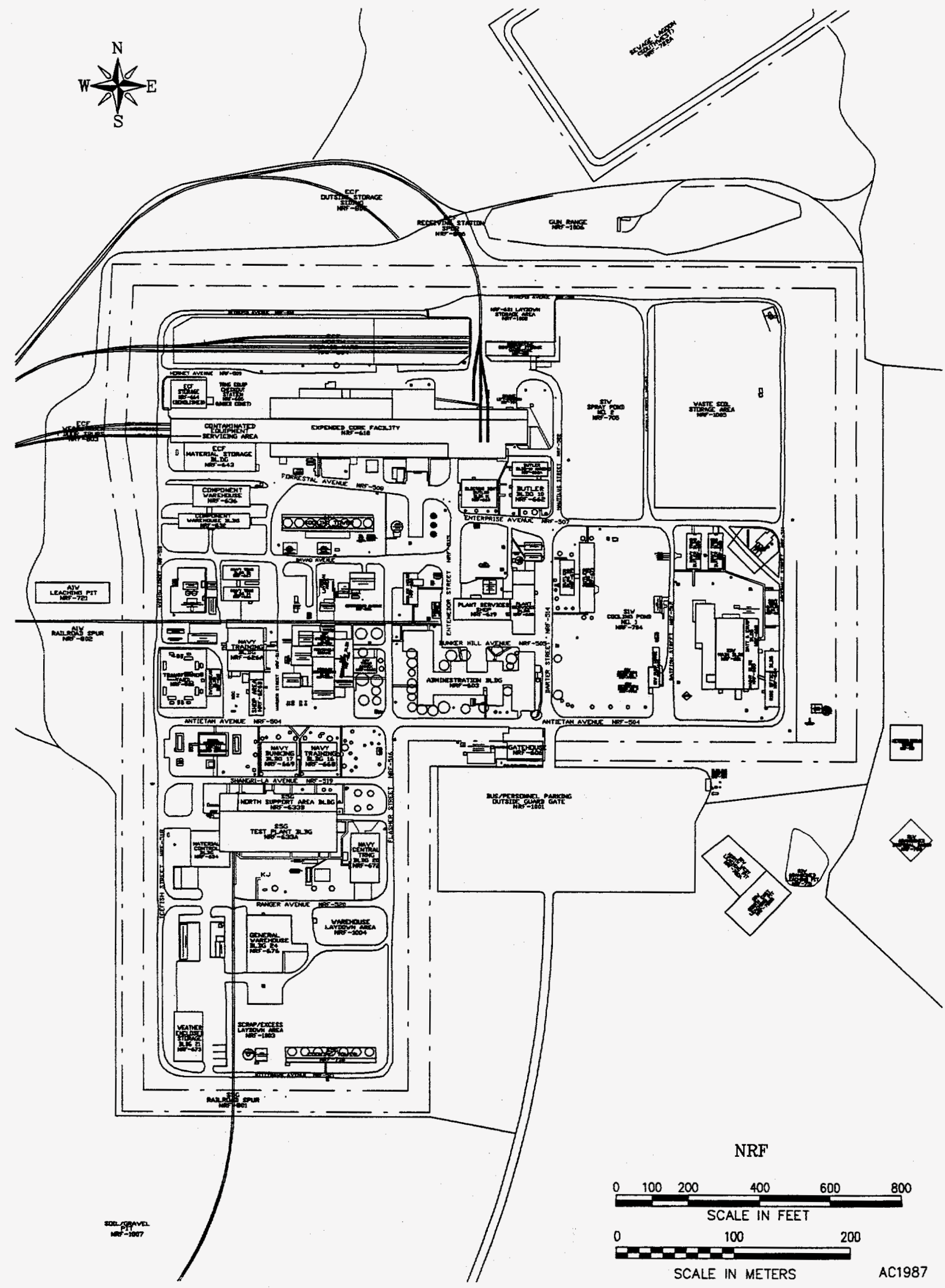

Figure 3-6. Map of NRF area. 


\subsection{Power Burst Facility}

\subsubsection{Area Description}

The PBF area is located approximately 6 miles northeast of CFA and is shown in Figure 3-7. Originally, the PBF was used to test reactor transient behavior and for safety studies on light-watermoderated enriched-fuel systems. These tests were called Special Power Excursion Reactor Test (SPERT) and commenced in the late 1950s. At that time, the PBF area consisted of the Control Area and the Reactor Area, the latter including SPERT I (now decontaminated, dismantled, and returned to its natural state), SPERT II, SPERT III, and SPERT IV reactors. The PBF Control Area served as the control center for all SPERT and PBF operations.

The PBF Control Area (Figure 3-8) now is the central administrative area for the PBF operations. The buildings at the control area house the PBF reactor controls, offices, maintenance and instrumentation areas.

The PBF Reactor Area (Figure 3-9) consists of the PBF reactor, which was constructed north of the site of the SPERT I reactor site. The SPERT I reactor was decommissioned in 1964 and the area has been revegetated. The PBF reactor has been used for reactor research on fuel behavior during normal and off-normal operating conditions but has been shut down pending inactivation.

The SPERT II area (Figure 3-10) consists mainly of the SPERT II reactor, which was constructed to study kinetic behavior for information on reactor safety. The reactor has been decommissioned, and most of the equipment (i.e., reactor vessel and primary coolant loop) has been removed. The building now houses the Waste Engineering Development Facility (WEDF), which is used for lead receiving, storing, and shipping and for developing waste treatment processes for hazardous and mixed wastes.

The SPERT III area (Figure 3-11) consisted of SPERT III Reactor Building (PER-609), the second SPERT reactor in operation and built in the late 1950s. The reactor was designed to conduct studies on high-power, high-temperature, heterogeneous, light water reactors. Its primary function was to determine the effect of water flow, pressure, and temperature on the transient characteristics of the reactor. The reactor was placed in standby in 1968 and was decontaminated and decommissioned in 1980. All system components were removed and the remaining areas were decontaminated. The area was converted to the Waste Experimental Reduction Facility (WERF). Facilities at WERF include a 4.8-million BTU/hr incinerator, a $524-\mathrm{kW}$ induction melting furnace, a 200-ton compactor, and a $960-\mathrm{ft}^{2}$ sizing shop where metallic waste is cut up using plasma arc torches. Also included are an offgas/ash solidification room, indoor mixed waste storage, and a 4,600- $\mathrm{ft}^{2}$ outdoor radioactive waste storage area. The induction furnace was used for melting metal objects and pouring them into ingot molds. The compactor is used to process all materials that cannot be processed through the incinerator (such as PVC). The solidification process is used to stabilize the incinerator ash by solidifying the ash with cement/water. WERF is presently inactive.

The SPERT IV reactor (Figure 3-12) was constructed to extend the range and type of controlled test parameters and to provide a facility for the kinetic testing of advanced-design reactor cores. The reactor has been removed, and the area is being used to store mixed waste at the Mixed Waste Storage Facility (MWSF). MWSF is now a Resource Conservation and Recovery Act (RCRA) Storage Facility under RCRA interim status for the storage of mixed waste, which is both hazardous [defined by Code of Federal Regulations (CFR) 40 CFR 261] and radioactive. MWSF has segregated 
areas to accommodate storage of polychlorinated biphenyls (PCBs), corrosives, and flammables in compliance with RCRA requirements. Special provisions for these waste forms include special isolation diking and ventilation systems.

\subsubsection{Primary Source Descriptions}

The primary sources at the PBF consists of two boilers used for heating in the winter; WEDF; and WERF.

The two boilers are located in PER-613 and PER-620. Both of the boilers have been identified in the Fuel Processing Restoration PSD permit as CFA/PER-613 B-501 (Powermaster boiler) and CFA/PEF-620 M-31 (Cyclotherm boiler). The boilers are designed to run automatically from September to May of each year and have essentially the same allowable emission level in the permit.

The WEDF facility is located in PER-612. The facility is used for receiving, storing, and shipping clean lead and the development of waste treatment processes for hazardous and mixed wastes. Currently, no continuous operations are associated with WEDF.

WERF is dedicated to the development of volume reduction processes for low-level radioactive and mixed waste. WERF consists of PER-609, PER-622, PER-623, and a storage area located northwest of PER-622. Two processes take place in PER-609: a) incineration of combustible solid and liquid low-level radioactive and mixed waste, and b) solidification, by grouting, of mixed waste. PER-622 houses sizing, compaction, and waste-sorting operations, which emit through a . Sizing reduces the volume of low-level radioactively contaminated metal for further processing or more efficient disposal at the RWMC. PER-623, the WERF Waste Storage Building (WWSB), provides interim storage of hazardous and mixed waste until the waste is treated at an INEL treatment unit or is shipped offsite for treatment and/or disposal. Compaction reduces the volume of materials that cannot be incinerated or exceed contamination limits for incineration. An open air asphalt and concrete pad is used to store low-level beta-gamma contaminated waste destined for processing. The waste can be in the form of actual structures or assemblies with the contaminated portions covered, or cargo containers containing incinerable waste. WERF is presently inactive.

\subsubsection{Secondary Sources}

The majority of the secondary sources are fuel burning equipment and VOC storage tanks. There are also two inorganic storage tanks (sulfuric acid) and a fumehood used for removing caustic and acid vapors from the demineralizer mixing tanks. The VOC storage tanks contain materials that include No. 2 diesel or gasoline. 


\subsubsection{Summary of PBF Emissions}

Table 3-6 is a summary of the totals for each of the principal pollutants.

Table 3-6. Summary of principal pollutants at PBF.

\begin{tabular}{lllll}
\hline \multicolumn{1}{c}{ Pollutant } & $\begin{array}{c}\text { Actual } \\
\text { Hourly } \\
(\mathrm{lb} / \mathrm{hr})\end{array}$ & $\begin{array}{c}\text { Actual } \\
\text { Annual } \\
(\mathrm{tn} / \mathrm{yr})\end{array}$ & $\begin{array}{c}\text { Maximum } \\
\text { Hourly } \\
(\mathrm{lb} / \mathrm{hr})\end{array}$ & $\begin{array}{c}\text { Maximum } \\
\text { Annual } \\
(\mathrm{tn} / \mathrm{yr})\end{array}$ \\
\hline Carbon monoxide & $1.382 \mathrm{E}+00$ & $1.020 \mathrm{E}-01$ & $2.3 \mathrm{E}+01$ & $5.4 \mathrm{E}+01$ \\
Nitrogen oxides & $6.293 \mathrm{E}+00$ & $4.162 \mathrm{E}-01$ & $2.0 \mathrm{E}+01$ & $8.0 \mathrm{E}+01$ \\
Particulate & $4.627 \mathrm{E}-01$ & $4.026 \mathrm{E}-02$ & $1.1 \mathrm{E}+00$ & $4.7 \mathrm{E}+00$ \\
Lead & $2.328 \mathrm{E}-05$ & $2.100 \mathrm{E}-05$ & $6.3 \mathrm{E}-05$ & $2.6 \mathrm{E}-04$ \\
Radionuclides & $2.587 \mathrm{E}-07$ & $3.107 \mathrm{E}-06$ & $5.3 \mathrm{E}+00$ & $4.7 \mathrm{E}+01$ \\
Sulfur oxides & $1.729 \mathrm{E}+00$ & $1.211 \mathrm{E}+00$ & $6.9 \mathrm{E}+00$ & $2.4 \mathrm{E}+01$ \\
VOC - nonmethane & $1.177 \mathrm{E}+00$ & $2.956 \mathrm{E}-01$ & $1.9 \mathrm{E}+00$ & $6.1 \mathrm{E}+00$ \\
\hline a. Units in Ci/mo and Ci/yr, respectively. & & & \\
\hline
\end{tabular}




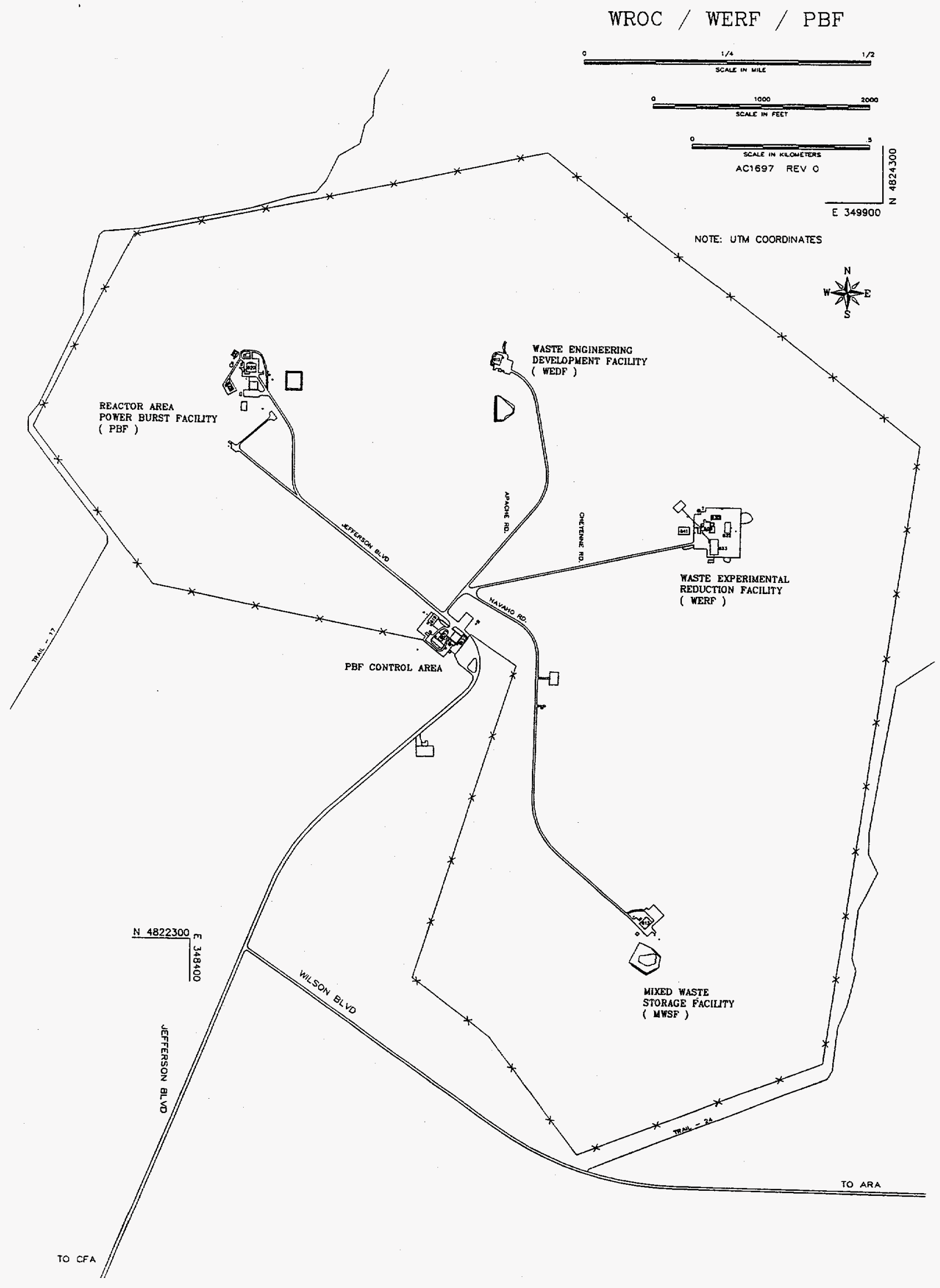

Figure 3-7. Map of PBF area. 


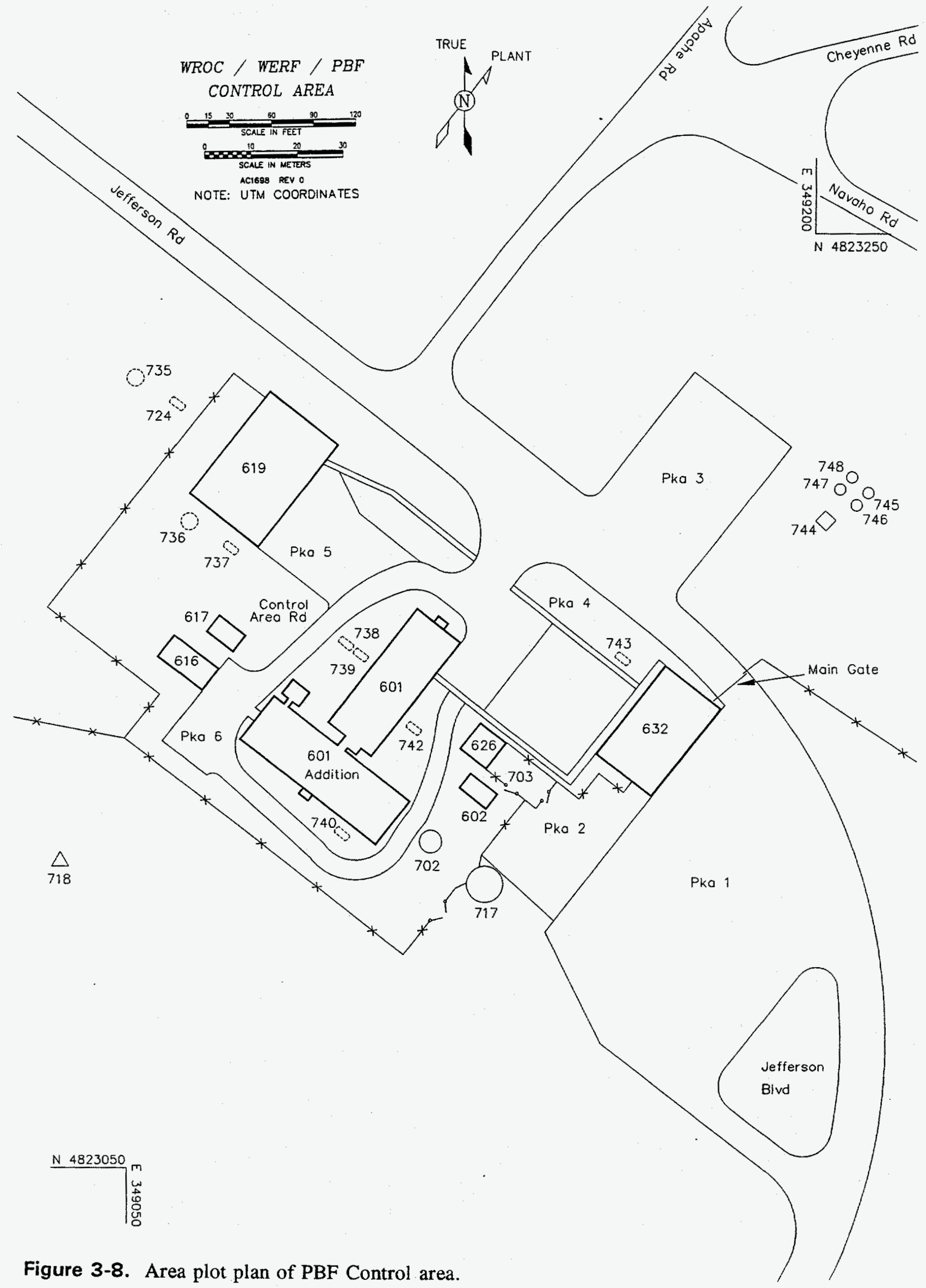




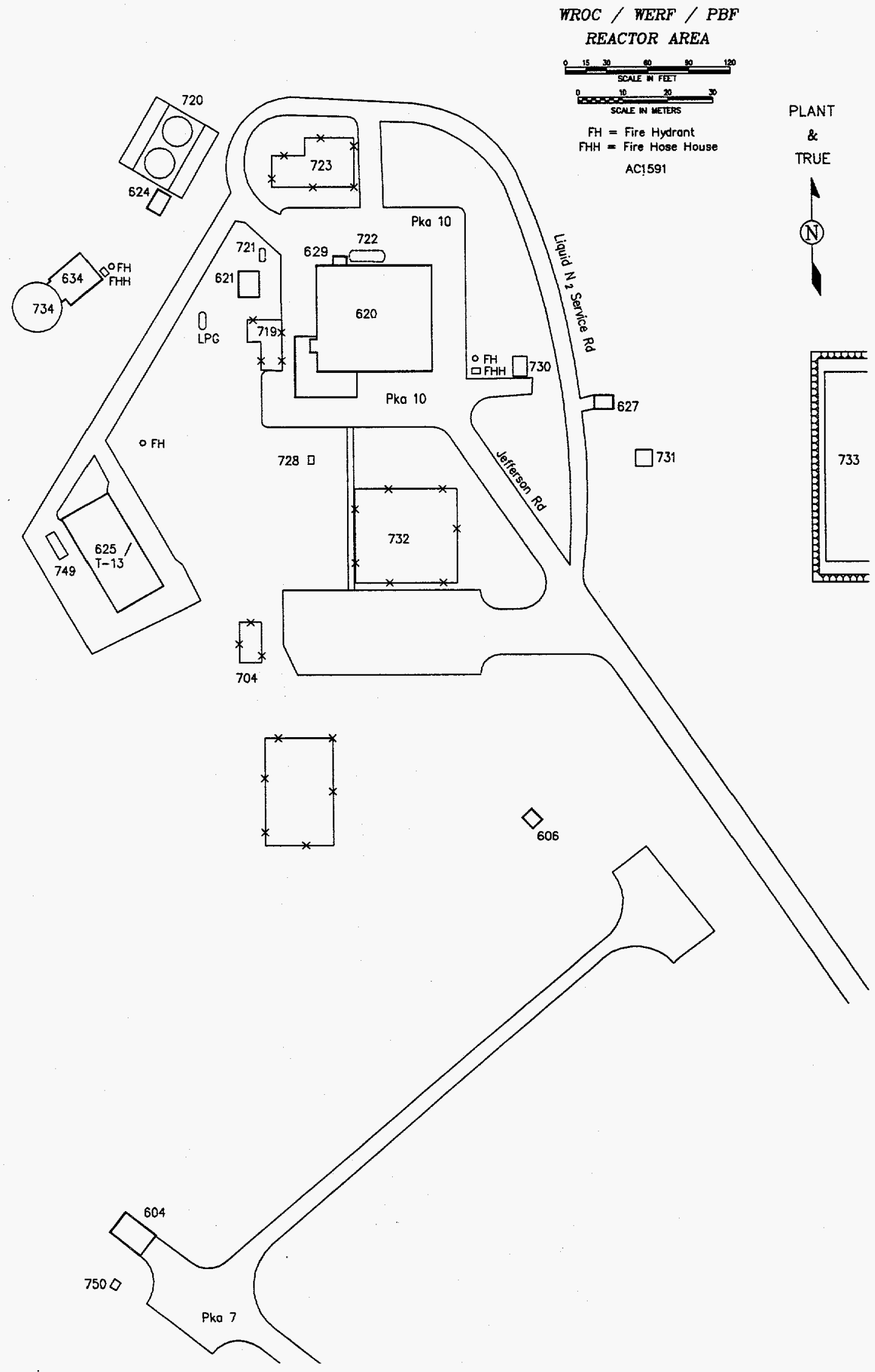

Figure 3-9. Area plot plan of PBF Reactor area. 


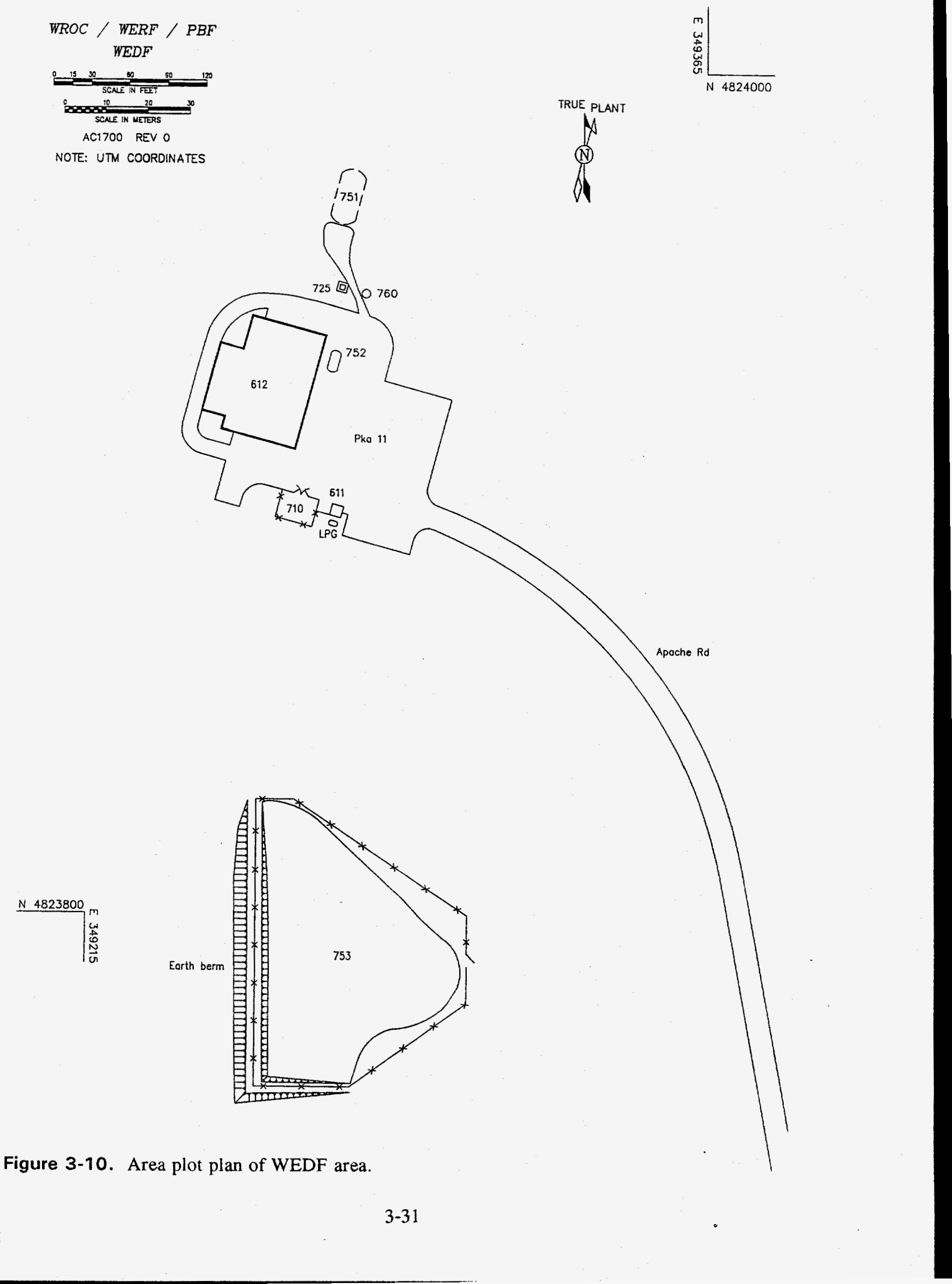




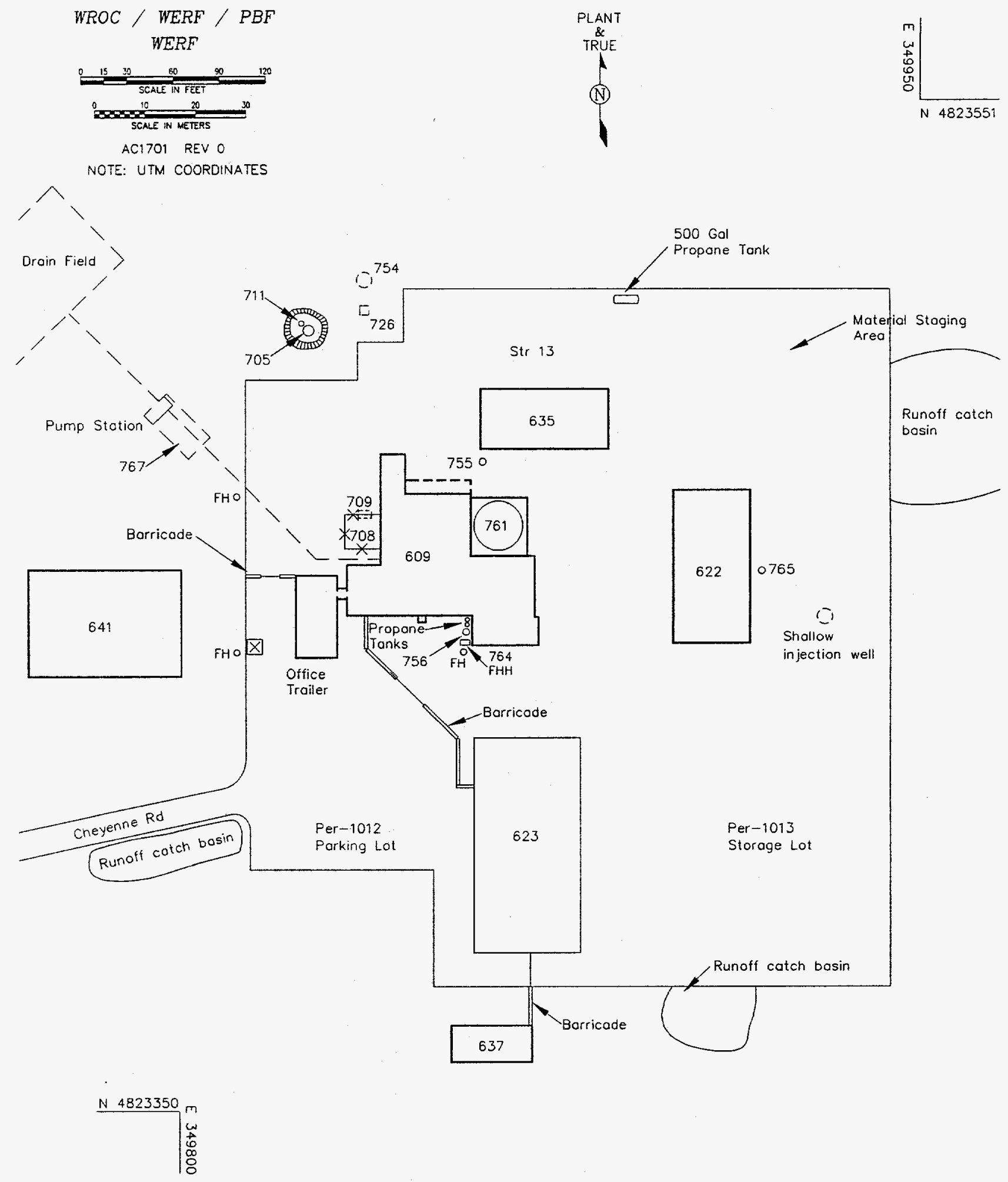

Figure 3-11. Area plot plan of WERF area. 
WROC / WERF / PBF
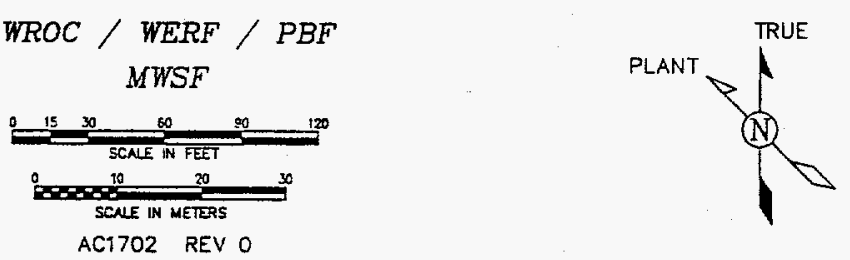

NOTE: UTM COORDINATES
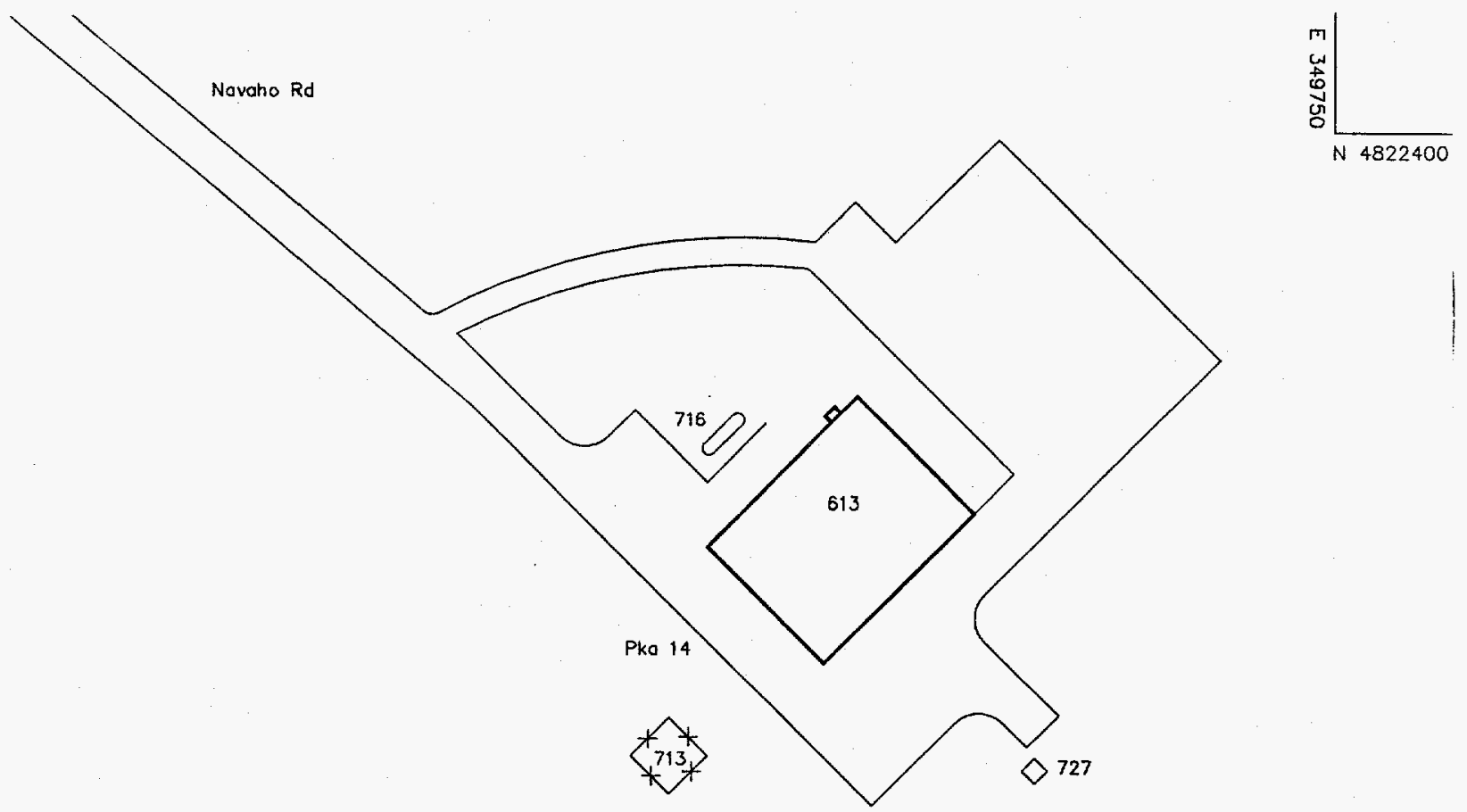

O 757

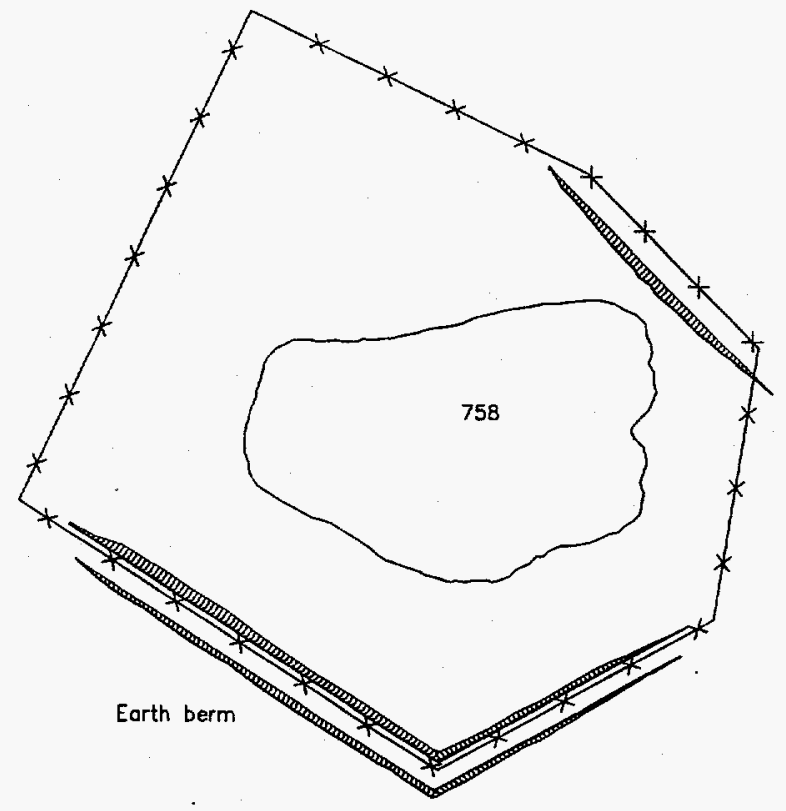

Figure 3-12. Area plot plan of MWSF area. 


\subsection{Radioactive Waste Management Complex}

\subsubsection{Area Description}

RWMC was established in 1952 and is located 7 miles southwest of CFA. RWMC, a restricted area, provides waste management for solid low-level radioactive and transuranic wastes. Waste management includes retrieval, examination, and certification of transuranic waste for ultimate disposal at the DOE Waste Isolation Pilot Plant in New Mexico. The facility also supports research and development activities for shallow land burial technology. Figure 3-13 presents a plot plan of RWMC.

RWMC is divided into four zones: the Administrative Area, the Operational Support Zone, the Subsurface Disposal Area (SDA), and the Transuranic Storage Area (TSA).

The Administrative Area is located in the northeast section of the RWMC and consists of office support buildings.

The Operational Support Zone is located west of the Administrative zone and consists of maintenance shops, change facilities, storage facilities, the guardhouse, support trailers, and the raw water supply system.

SDA occupies approximately 88 acres and is used for the permanent disposal of solid lowlevel beta-gamma waste. Before 1970, RWMC received and buried transuranic waste at SDA from both offsite and onsite facilities. Since 1970, only low-level waste has been buried at SDA. Most of the low-level waste is buried in pits, trenches, and soil vaults; however, low-level radioactively contaminated nitrate salts are stored separately on an asphalt pad, Pad A, and covered with a layer of soil.

TSA consists of several facilities and asphalt pads and occupies approximately 56 acres. TSA was established in 1970 to provide temporary storage of transuranic waste until a federal repository could be available for permanent disposal. Transuranic waste is stacked on asphalt pads and then covered with plywood, plastic sheeting, and three feet of soil. Since 1975, a movable, inflatable fabric dome known as the Air Support Weather Shield has protected the waste containers from the weather. The Stored Waste Examination Pilot Plant provides nondestructive examination and segregated storage of waste containers prior to shipment to the Waste Isolation Pilot Plant. The Stored Waste Examination Pilot Plant also vents waste containers to prevent the buildup of potentially explosive gases.

\subsubsection{Primary Source Descriptions}

There are no primary sources of air emissions at the RWMC.

\subsubsection{Secondary Sources}

There are several secondary sources of air emissions at the RWMC. These sources include primarily emergency generators or furnaces that burn propane and one diesel emergency generator and its associated fuel tank are located at WMF-603. The fumehood located at WMF-601 vents emissions from decontamination of health physics equipment. The Drum Venting Facility (WMF-615) houses the Drum Venting System. The Drum Venting System installs carbon composite 
fibers in the lids of stored waste drums to prevent hydrogen buildup inside the drums. All exhaust air from the Drum Venting System is filtered by two HEPA filters before discharging to the atmosphere. Currently the Drum Venting Facility operates on a limited basis.

\subsubsection{Summary of RWMC Emissions}

Table 3-7 is a summary of the totals for each of the principal pollutants.

Table 3-7. Summary of the totals for each of the principal pollutants at the RWMC.

\begin{tabular}{lcccc}
\hline \multicolumn{1}{c}{ Pollutant } & $\begin{array}{c}\text { Actual } \\
\text { Hourly } \\
(\mathrm{lb} / \mathrm{hr})\end{array}$ & $\begin{array}{c}\text { Actual } \\
\text { Annual } \\
(\mathrm{tn} / \mathrm{yr})\end{array}$ & $\begin{array}{c}\text { Maximum } \\
\text { Hourly } \\
(\mathrm{lb} / \mathrm{hr})\end{array}$ & $\begin{array}{c}\text { Maximum } \\
\text { Annual } \\
(\mathrm{tn} / \mathrm{yr})\end{array}$ \\
\hline Carbon monoxide & $1.346 \mathrm{E}+00$ & $6.727 \mathrm{E}-02$ & $2.7 \mathrm{E}+00$ & $1.2 \mathrm{E}+01$ \\
Nitrogen oxides & $6.197 \mathrm{E}+00$ & $3.212 \mathrm{E}-01$ & $1.2 \mathrm{E}+01$ & $5.4 \mathrm{E}+01$ \\
Particulate & $4.404 \mathrm{E}-01$ & $1.889 \mathrm{E}-02$ & $8.8 \mathrm{E}-01$ & $3.8 \mathrm{E}+00$ \\
Lead & $1.631 \mathrm{E}-05$ & $3.514 \mathrm{E}-07$ & $3.3 \mathrm{E}-05$ & $1.4 \mathrm{E}-04$ \\
Radionuclides & $1.197 \mathrm{E}-06$ & $1.430 \mathrm{E}-05$ & $1.7 \mathrm{E}-07$ & $2.0 \mathrm{E}-06$ \\
Sulfur oxides & $4.066 \mathrm{E}-01$ & $1.068 \mathrm{E}-02$ & $8.1 \mathrm{E}-01$ & $3.6 \mathrm{E}+00$ \\
VOC - nonmethane & $9.224 \mathrm{E}-01$ & $2.686 \mathrm{E}-02$ & $1.5 \mathrm{E}+00$ & $5.1 \mathrm{E}+00$ \\
\hline a. Units in Ci/mo and $\mathrm{Ci} / \mathrm{yr}$, respectively. & & & \\
\hline
\end{tabular}




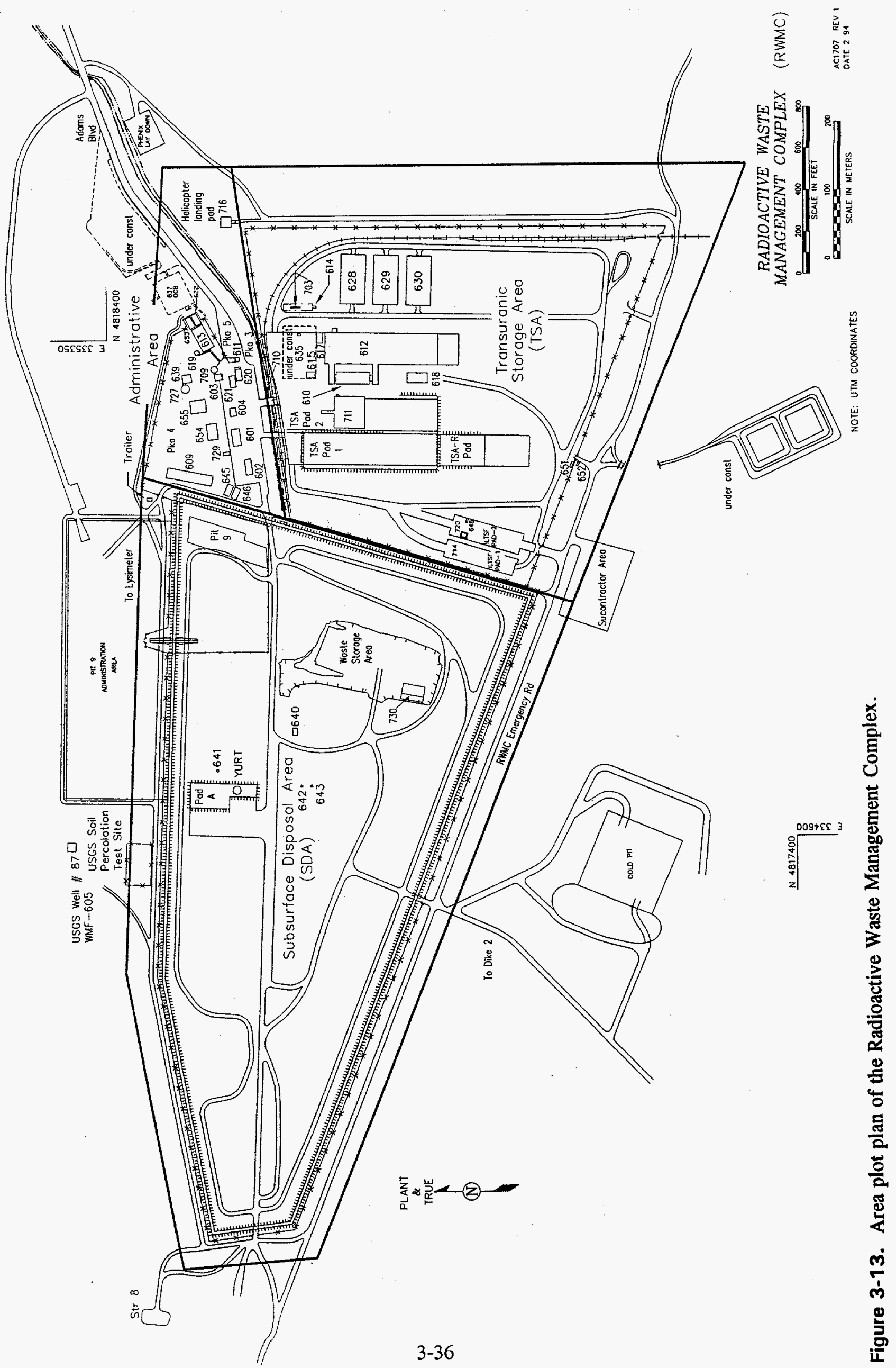




\subsection{Test Area North}

\subsubsection{Area Description}

TAN is located in the northern part of the INEL site and presently comprises three operational areas: the Technical Support Facility (TSF); the Loss Of Fluid Test (LOFT) area, which includes the Specific Manufacturing Capability (SMC) Project; and the Water Reactor Research Test Facility (WRRTF).

The TSF area functions as the administrative and support hub of TAN and houses many important programs, including Three Mile Island Unit 2 Core Offsite Examination; the Process Experimental Pilot Plant; and the Spent Fuel Program, part of SMC. Maintenance for all of TAN is also centered at TSF. Figure 3-14 is an area plot plan of the TSF area.

The LOFT area is approximately 1.5 miles northwest of the TSF area. The area includes the LOFT containment vessel and service building, the LOFT reactor control and equipment building, and numerous support facilities. The SMC area includes a large aircraft hangar that has been converted to support the manufacturing process, and numerous buildings for the various phases of the manufacturing and production process. SMC provides most of the activity at LOFT. Figure 3-15 is an area plot plan of LOFT/SMC.

The WRRTF area (see Figure 3-16) includes the Semiscale Project; the Blowdown Project, and the Two-Phase-Flow Loop Project, all of which are now decommissioned. Very little activity now exists at WRRTF, with the exception of some engineering-scale tests.

\subsubsection{Primary Sources}

The boilers at TAN constitute some of the largest sources of emissions and are present in all three of the functional TAN areas. These boilers all provide steam for space heating and are located in the following buildings:

- TAN-603 (TSF) - Two main boilers, one backup boiler

- TAN-630 (LOFT, TAN-716) - One boiler

- $\quad$ TAN-641 (WRRTF) - One main boiler, one backup boiler

- $\quad$ TAN-675 (LOFT/SMC) - Two backup boilers

- $\quad$ TAN-679 (LOFT/SMC) - One main boiler, one backup boiler.

The TAN boilers burn primarily No. 2 grade fuel oil fuel oil. Since these boilers mostly provide steam for space heating, they typically do not run during the summer months. All of the SMC boilers have an oxygen trim to reduce the nitrogen oxide emissions by $11 \%$, and the values reported here reflect that reduction.

Other than the boilers, the only other primary emission sources at TSF that are in operation are at TAN-607, the TAN Hot Shop Building. The Hot Shop is one of the world's largest hot shops, measuring $51 \times 165 \times 55 \mathrm{ft}$ and is used exclusively as part of DOE's Nuclear Spent Fuel Cask Testing program. All ventilation air exhausts to the main stack, TAN-734, on the northeast end of the building. There is a warm shop adjacent to the hot shop, where low to medium contaminated parts and equipment are fabricated and modified. This air also vents to the main stack. A smaller 
hot cell is at the south end of the Hot Shop and is used for study, observation, and analysis of small radioactive objects as well as disassembly and examination of research and commercial fuel rods. This room also vents to the main stack.

Other programs that are supported at TAN-607 include the Three-Mile Island Unit 2 Core Examination Project, where analytical data necessary to understand the Three-Mile Island accident sequence can be collected. Also, the Spent Fuel Program is present in TAN-607, which includes testing fuel storage casks with intact or consolidated fuel and developing a dry rod consolidation technology and prototypical equipment. The SMC Project also occupies the south end of TAN 607 [the Material Development Facility (MDF)] where research and development work is performed in support of the SMC Manufacturing Process.

Primary sources at LOFT, aside from the boilers, would include several sources at SMC, in buildings TAN-629 (the hangar), TAN-679, and TAN-681. Emissions from these stacks are primarily radionuclides from depleted uranium, particulate, nitrogen oxides, and some organics. Since the SMC Project is responsible for most of the activity at the LOFT Area, a thorough description of SMC is provided here.

The SMC Project is an existing facility operated by Babcock \& Wilcox Company and is a multi-phased classified project that includes the manufacturing, process reclamation, research and development, and support facilities. The SMC Project builds armor assemblies from various materials, including depleted uranium. The SMC Project produces emissions from chemical and manufacturing process, boilers, storage tanks, emergency generators, and miscellaneous building vents.

The SMC Project consists of MDF, Phase I, Phase II, and support facilities. The project life of the facility is approximately 20 years. Thereafter, it will be decontaminated and decommissioned in accordance with DOE requirements.

MDF is located in TAN-607 at the TSF area of TAN, which is approximately one mile southeast from the main SMC facilities (Phases I and II). A portion of TAN-607 was designated for use as the MDF facility. The MDF is primarily a research and development facility and involves fabrication and assembly operations to produce test size armor assemblies. The process utilizes standard metal working equipment such as punches, shears, brakes, and lasers. About 31,000 square feet is available and includes research and development processes, an analytical laboratory, and a maintenance and machine shop.

Two double-wide trailers on the east side of TAN-607 house Health Physics and locker rooms and provide controlled access to the facility. Other facilities at TSF that support SMC operations include the TAN- 602 office building, the TAN-606 carpenter shop, and the TAN-628 hazardous waste storage facility/warehouse.

SMC Phase I facilities, located within the TAN-629 hangar, contain manufacturing processes and space for offices, support functions (e.g., Health Physics, field laboratory), and service areas. Manufacturing processes are semiautomatic systems that manufacture products similar to MDF production on an automated basis to produce full-size armor assemblies at a higher throughput. Total square footage in TAN-629 for SMC use is about 80,000 square feet. TAN-675 is located on the north side of TAN-629 and houses utilities; TAN-677 is located on the south side for truck receiving and loading. 
SMC Phase II facilities consist of a manufacturing area, TAN-679, and a Process Reclamation Facility, TAN-681. Phase II production is a manufacturing process and produces deplete uranium metal that is subsequently used as feedstock for Phase I. TAN-679 operations cover an area of 64,000 square feet and include a production line; an area for shipping, receiving, and storage of materials; a Health Physics field office; maintenance area; boiler/utilities area; analytical laboratory; computer room; administrative offices; change room facilities; and a scrap recycle area. In addition, space is provided for other support requirements such as a toolroom, waste storage, rest rooms, and a lunchroom.

The Process Reclamation Facility, adjoining the northwest portion of TAN-679, contains approximately 12,000 square feet for collection, recycling, and disposition of waste and scrap material generated in solid, liquid, and gaseous form. Solid waste, scrap, and recyclable material produced in the manufacturing area are transferred to the facility for processing/packaging as required for storage and disposal. All liquid wastes are collected in storage tanks for treatment at the Process Reclamation Facility. Nitrogen oxide gas streams from the acid bath are piped to the Process Reclamation Facility for processing through a wet scrubber and filters before release to the atmosphere.

There are no primary sources at the WRRTF other than the boilers.

\subsubsection{Secondary Sources}

TAN has a wide variety of secondary sources, including chemical sources, fuel burning equipment, organic and inorganic storage tanks, and fugitive sources. Chemical sources include fumehoods, paint booths, welding booths, a blue print machine, two chemical mixing tanks, and several miscellaneous sources. Secondary fuel burning equipment includes emergency generators and a heater/furnace.

\subsubsection{Summary of TAN Emissions}

Table 3-8 is a summary of the principal pollutants from all TAN sources.

Table 3-8. Summary of the totals for each of the principal pollutants at TAN.

\begin{tabular}{lcccc}
\hline \multicolumn{1}{c}{ Pollutant } & $\begin{array}{c}\text { Actual } \\
\text { Hourly } \\
(\mathrm{lb} / \mathrm{hr})\end{array}$ & $\begin{array}{c}\text { Actual } \\
\text { Annual } \\
(\mathrm{tn} / \mathrm{yr})\end{array}$ & $\begin{array}{c}\text { Maximum } \\
\text { Hourly } \\
(\mathrm{lb} / \mathrm{hr})\end{array}$ & $\begin{array}{c}\text { Maximum } \\
\text { Annual } \\
\text { (tn/yr) }\end{array}$ \\
\hline Carbon monoxide & $1.012 \mathrm{E}+01$ & $4.560 \mathrm{E}+00$ & $2.4 \mathrm{E}+01$ & $1.1 \mathrm{E}+02$ \\
Nitrogen oxides & $4.545 \mathrm{E}+01$ & $2.050 \mathrm{E}+01$ & $1.1 \mathrm{E}+02$ & $5.0 \mathrm{E}+02$ \\
Particulate & $4.211 \mathrm{E}+00$ & $2.561 \mathrm{E}+00$ & $1.5 \mathrm{E}+01$ & $5.5 \mathrm{E}+01$ \\
Lead & $4.736 \mathrm{E}-04$ & $1.271 \mathrm{E}-03$ & $1.7 \mathrm{E}-03$ & $7.5 \mathrm{E}-03$ \\
Radionuclides & $1.742 \mathrm{E}-03$ & $1.758 \mathrm{E}-03$ & $1.2 \mathrm{E}-02$ & $1.4 \mathrm{E}-01$ \\
Sulfur oxides & $3.023 \mathrm{E}+01$ & $7.460 \mathrm{E}+01$ & $1.1 \mathrm{E}+02$ & $4.7 \mathrm{E}+02$ \\
VOC - nonmethane & $4.4281+01$ & $1.912 \mathrm{E}+01$ & $6.3 \mathrm{E}+01$ & $9.6 \mathrm{E}+01$ \\
\hline a. Units in Ci/mo and Ci/yr, respectively. & & & \\
\hline
\end{tabular}




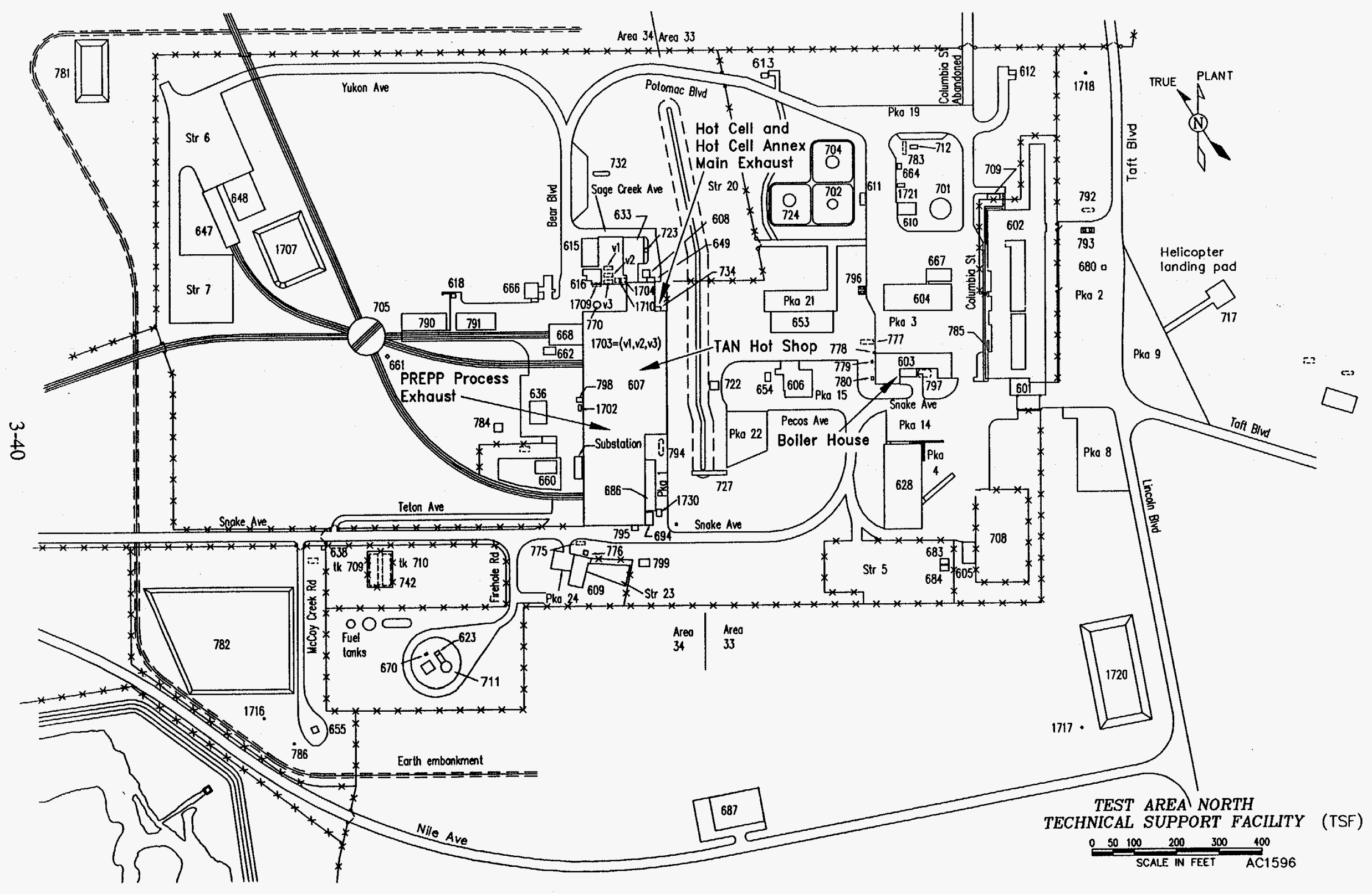

Figure 3-14. Area plot plan of Technical Support Facility. 


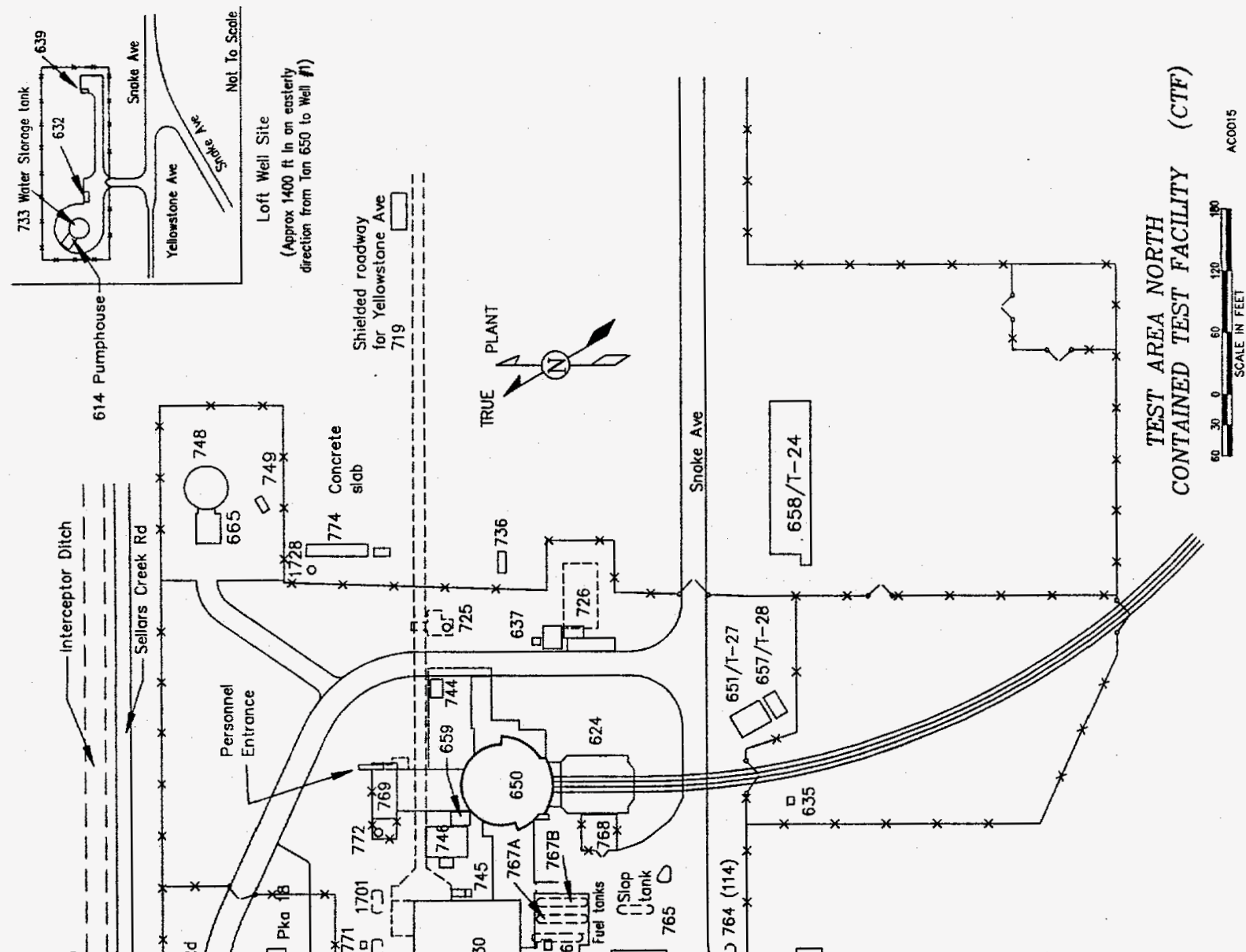

离

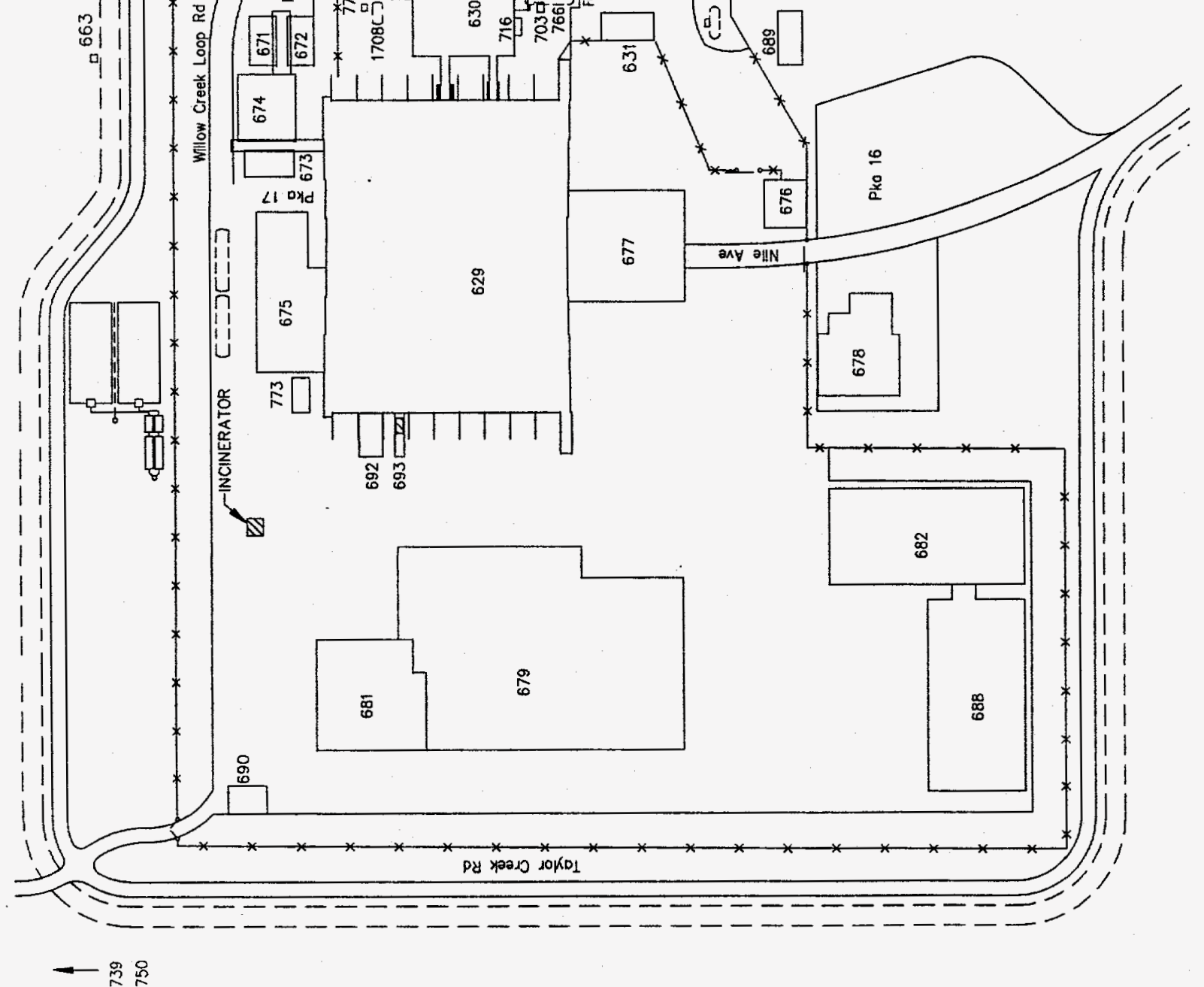

告 


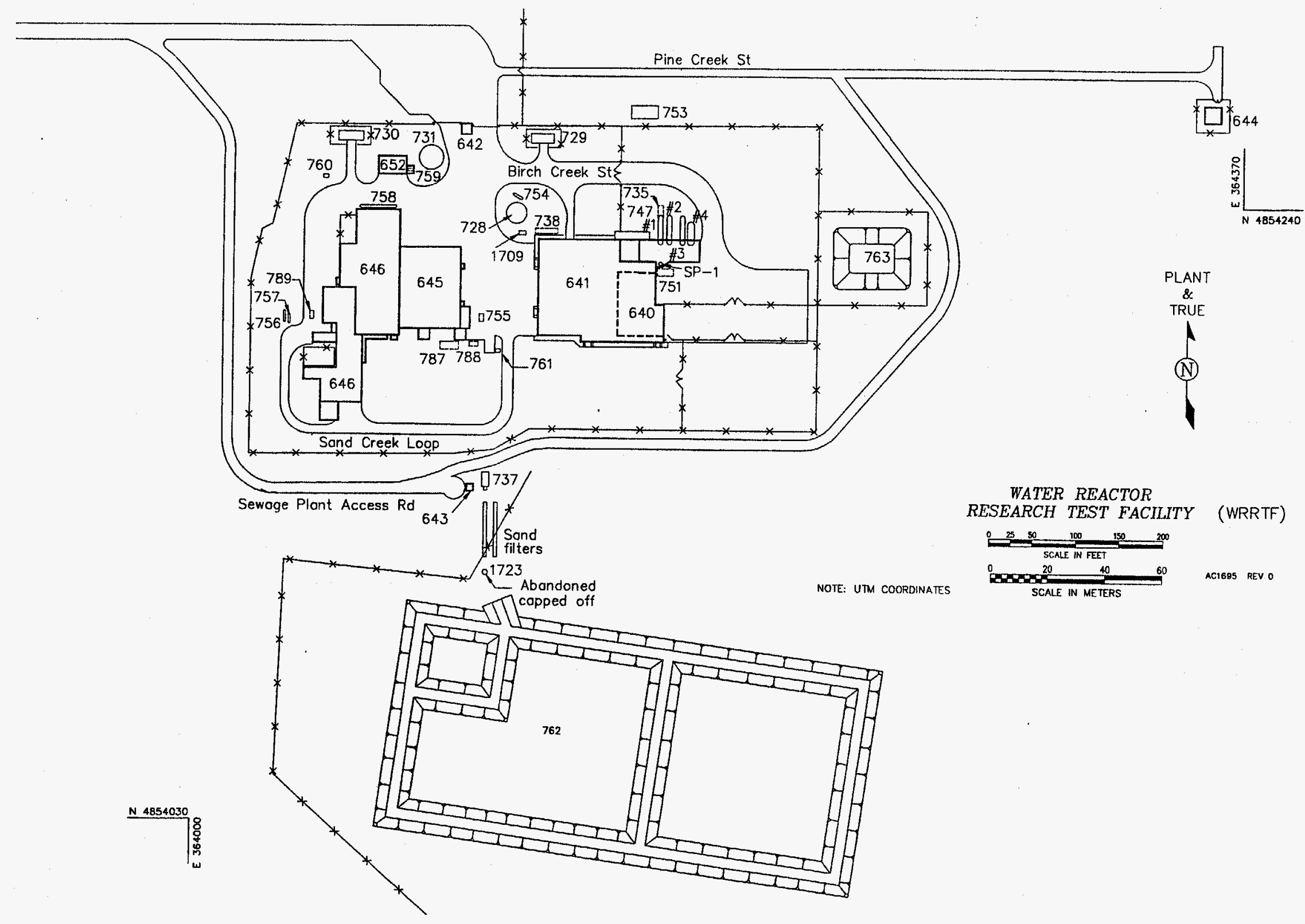

Figure 3-16. Area plot plan of Water Reactor Research Test Facility. 


\subsection{Test Reactor Area}

\subsubsection{Area Description}

TRA contains nuclear reactors used for testing fuel, materials, and reactor components in the high-neutron environment that can be obtained in the reactors. Three primary test reactors have operated in this area: The Materials Testing Reactor, the Engineering Test Reactor, and the Advanced Test Reactor. Of these reactors, only the Advanced Test Reactor is presently operating or planned to be operated. In addition to the three test reactors, this area contains support facilities for the work routinely conducted in this area, including chemistry laboratories, hot shops for the examination of highly radioactive samples, maintenance shops, water purification facilities, waste management facilities, and other facilities, some of which are currently being decommissioned.

Each reactor has a main stack from which air emissions from that reactor are discharged. This effluent consists of air from the reactor ventilation systems, sampling stations, reactor access areas, fuel storage areas (underwater), and reactor coolant water degassing areas. Since both the Materials Testing Reactor and the Engineering Test Reactor are no longer operating, effluent from these sources are minimal and negligible, respectively. Most of the emissions are radioactive materials that discharge the ventilating or degassing air. Some of the activity is formed when air or other gases become irradiated by the neutron flux in the Advanced Test Reactor. Figure 3-17 shows a plot plan of the TRA.

\subsubsection{Primary Source Descriptions}

The Advanced Test Reactor stack vents air from the main reactor building (TRA-670) including the main reactor floor and its basements. About 65,000 cubic feet per minute of air circulates through this system, flowing progressively from cleaner areas to the areas where more contamination may be present. The main source of radioactivity is the degassing tanks, where gases in the reactor coolant water are released. About 150 cubic feet per minute of gas comes from this source. Other sources of gas include vents from radioactive waste holding tanks, the experimental cubicle vents, and the reactor cooling air system.

The exhaust to the stack is monitored closely for temperature, flow rate, pressure, and radioactivity. The majority of the activity released is due to noble gas fission products such as krypton and xenon or activation products such as argon. Only about two percent of the activity is due to particulates.

The Engineering Test Reactor ventilating air discharges through the $250-\mathrm{ft}$ high Engineering Test Reactor stack. Discharges are monitored, but since the reactor is no longer operating, the ventilating air contains essentially no activity.

The Materials Testing Reactor offgas system serves the Materials Testing Reactor area including radioactive laboratories. The offgas from laboratories that routinely use acidic materials passes through a caustic scrubber prior to discharge. Other laboratory streams are HEPA filtered before the gas is released. The stack offgas is sampled and monitored, but no activity has been detected since the Materials Testing Reactor was shut down. 
The ventilation systems for most TRA-604 laboratory fumehoods and several TRA-661 laboratory fumehoods exhaust out a stack that is attached to the west side of the Materials Testing Reactor building (TRA-603). The vent emits a small quantity of VOCs and radioactivity. The exhaust stream goes through a HEPA filtering system, is monitored for radioactivity, and then emits out the stack.

The Hot Cell building, TRA-632, contains three hot cells for handling radioactive materials; the hot cell, the light cell, and the heavy cell. The cells are used for the assembly, disassembly, or destruction of radioactive materials. The light cell is also used for metallography. All three exhaust stacks are monitored for radioactivity by a common constant air monitor. All exhaust streams pass through a HEPA filtration system and an iodine removal system, either activated charcoal or silverzeolite. A very small amount of decontamination work is also performed in the cells.

\subsubsection{Secondary Sources}

TRA has numerous secondary radiological sources, including radiological fumehoods used for research and analysis.

Other secondary sources of emissions include a fumehood where only organic material is prepared for analysis, one welding hood, one metallizer hood, and two out-of-service radiological sources. The fumehoods are mainly used for either research or analysis. Some of the "radiological only" fumehoods are strictly used for sample preparation. Some of the chemicals emitted from various fumehood stacks are VOCs, nitric acid, and perchloric acid.

VOCs in the storage tanks include diesel fuel, unleaded gasoline, and recycled oil. Also included was a room exhaust where 55-gallon drums of lube oil are stored and dispensed. The fuel burning equipment includes two large bore diesel generators at the Advanced Test Reactor facility, an emergency diesel generator, and two emergency diesel fire pumps. The two fire pumps both have dual exhausts, one for each side of the engine. The inorganic storage tanks contain sulfuric acid and sodium hydroxide. These materials are used in the demineralization system and for the cooling tower system.

\subsubsection{Summary of TRA Emissions}

Table 3-9 is a summary of the totals for each of the principal pollutants.

Table 3-9. Summary of principal pollutants at TRA.

\begin{tabular}{lllll}
\hline \multicolumn{1}{c}{ Pollutant } & $\begin{array}{c}\text { Actual } \\
\text { Hourly } \\
(\mathrm{lb} / \mathrm{hr})\end{array}$ & $\begin{array}{c}\text { Actual } \\
\text { Annual } \\
(\mathrm{tn} / \mathrm{yr})\end{array}$ & $\begin{array}{c}\text { Maximum } \\
\text { Hourly } \\
(\mathrm{lb} / \mathrm{hr})\end{array}$ & $\begin{array}{c}\text { Maximum } \\
\text { Annual } \\
(\mathrm{tn} / \mathrm{yr})\end{array}$ \\
\hline Carbon monoxide & $2.207 \mathrm{E}+01$ & $2.737 \mathrm{E}+01$ & $3.1 \mathrm{E}+01$ & $1.3 \mathrm{E}+02$ \\
Nitrogen oxides & $9.209 \mathrm{E}+01$ & $1.054 \mathrm{E}+02$ & $1.3 \mathrm{E}+02$ & $5.7 \mathrm{E}+02$ \\
Particulate & $9.089 \mathrm{E}+00$ & $1.547 \mathrm{E}+01$ & $1.3 \mathrm{E}+01$ & $5.5 \mathrm{E}+01$ \\
Lead & $2.384 \mathrm{E}-04$ & $2.647 \mathrm{E}-04$ & $3.4 \mathrm{E}-04$ & $1.5 \mathrm{E}-03$ \\
Radionuclides & $1.352 \mathrm{E}+02$ & $1.622 \mathrm{E}+03$ & $9.9 \mathrm{E}+02$ & $4.3 \mathrm{E}+03$ \\
Sulfur oxides & $6.389 \mathrm{E}+00$ & $7.584 \mathrm{E}+00$ & $8.9 \mathrm{E}+00$ & $3.9 \mathrm{E}+01$ \\
VOC - nonmethane & $3.483 \mathrm{E}+01$ & $8.770 \mathrm{E}+00$ & $3.8 \mathrm{E}+01$ & $4.2 \mathrm{E}+01$ \\
\hline a. Units in Ci/mo and Ci/yr, respectively. & & & \\
\hline
\end{tabular}

Figure 3-17. Area plot plan of the Test Reactor Area. 


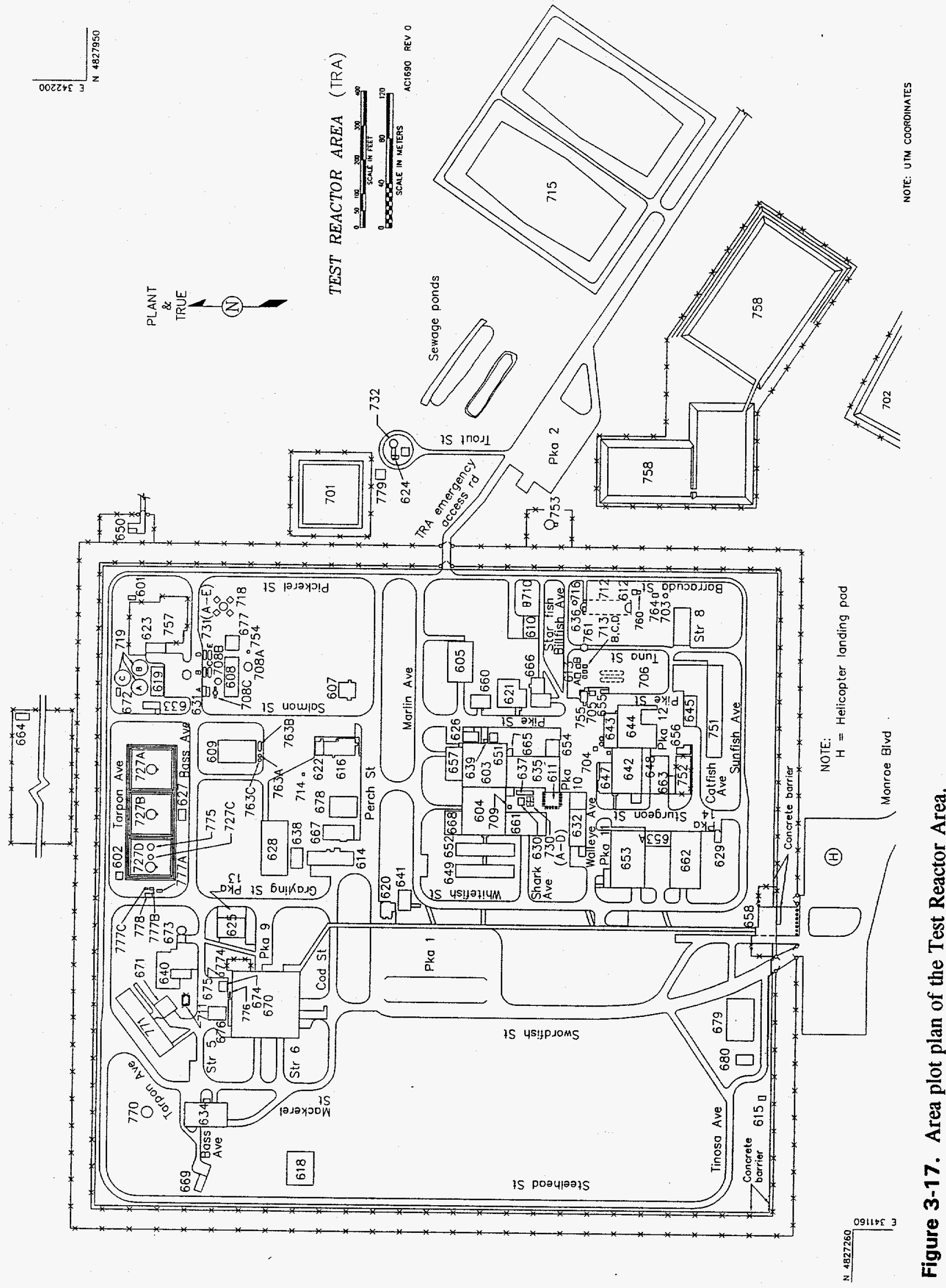




\subsection{Auxiliary Reactor Area, Boiling Water Reactor Experiment, Experimental Breeder Reactor I, and Initial Engine Test}

ARA consisted of four small reactor areas that operated between 1957 and 1965 . Since that period, all reactors have been dismantled, and for a while, the space was used for offices, testing, and laboratories. Now, because of many factors including radioactive contamination, ARA is no longer in use and has been placed on the INEL's decontamination and decommissioning list. Boilers, lab hoods, engines, main stacks, and other equipment have all been disconnected, dismantled, and their respective stacks sealed off from the inside of the building. All water and electricity have also been discontinued to the area.

ARA-IV (ARA-IV-001) is still in use at times for the destructive disposal of explosive chemicals and old live artillery shells from the Navy Gunnery Range that are periodically found around the INEL. ARA-IV (ARA-IV-002) also periodicly operates an ongoing metals research project. The project focuses on the use of explosives for development of high strength metal alloys. Table 3-10 presents a summary of the principal pollutants from ARA-IV. Figure 3-18 is a map of the overall ARA area, and Figures 3-19 to 3-21 are plot plans of ARA-I, -II, and -III, respectively.

The BORAX reactor area and EBR-I were early projects of the Argonne National Laboratory and the predecessors of the EBR-II reactor and the Argonne Lab at the INEL. The BORAX area was used between 1954 and 1964. At present, the buildings in the area have been completely decontaminated and decommissioned, torn down, and much of it buried in place. Hence, there are no sources of emissions remaining at BORAX. Figure 3-21 is a plot plan of BORAX-V, the most recent of the BORAX projects.

EBR-I, 1.5 miles north-east of the RWMC, was the world's first breeder reactor and the first reactor to produce peace-time power. Because of its historical significance, EBR-I has been designated a national historic monument and is open during the summer months for tourists to visit. There are no remaining emission sources at EBR-I. Figure 3-22 is a plot plan of the EBR-I and WMO area.

The Initial Engine Test (IET) at TAN is located approximately one mile due north of the TSF area. This area includes buildings and structures that were built in support of the nation's Aircraft Nuclear Propulsion project of the 1950s. It was later used for the Space Nuclear Auxiliary Power Transient Program of the 1960s, and then the Hallam Decontamination and Decommissioning in 1977 and 1978. The facility has been inactive for many years and is presently on the INEL's decontamination and decommissioning list. There are no longer any emission sources at IET. Figure 3-23 is a plot plan of the IET area. All of these areas were inventoried during Phase I of this project, but because of their out of service and decontamination and decommission status, none of these areas housed any sources of emissions and consequently were not included in Phase II of the inventory. 
Table 3-10. Summary of emissions at ARA-IV.

\begin{tabular}{llccc}
\hline \multicolumn{1}{c}{ Pollutant } & \multicolumn{1}{c}{$\begin{array}{c}\text { Actual } \\
\text { Hourly } \\
(\mathrm{lb} / \mathrm{hr})\end{array}$} & $\begin{array}{c}\text { Actual } \\
\text { Annual } \\
(\mathrm{tn} / \mathrm{yr})\end{array}$ & $\begin{array}{c}\text { Maximum } \\
\text { Hourly } \\
(\mathrm{lb} / \mathrm{hr})\end{array}$ & $\begin{array}{c}\text { Maximum } \\
\text { Annual } \\
(\mathrm{tn} / \mathrm{yr})\end{array}$ \\
\hline Carbon monoxide & $1.760 \mathrm{E}+00$ & $1.960 \mathrm{E}-02$ & $3.5 \mathrm{E}+00$ & $3.9 \mathrm{E}-02$ \\
Nitrogen oxides & $6.637 \mathrm{E}-02$ & $1.254 \mathrm{E}-03$ & $1.2 \mathrm{E}-01$ & $2.5 \mathrm{E}-03$ \\
Particulate & $9.070 \mathrm{E}+00$ & $2.010 \mathrm{E}-01$ & $1.8 \mathrm{E}+01$ & $4.0 \mathrm{E}-01$ \\
Sulfur oxides & $6.637 \mathrm{E}-03$ & $1.540 \mathrm{E}-04$ & $1.2 \mathrm{E}-02$ & $3.1 \mathrm{E}-04$ \\
VOC - nonmethane & $4.425 \mathrm{E}-02$ & $7.983 \mathrm{E}-04$ & $8.8 \mathrm{E}-02$ & $1.6 \mathrm{E}-03$ \\
\hline
\end{tabular}




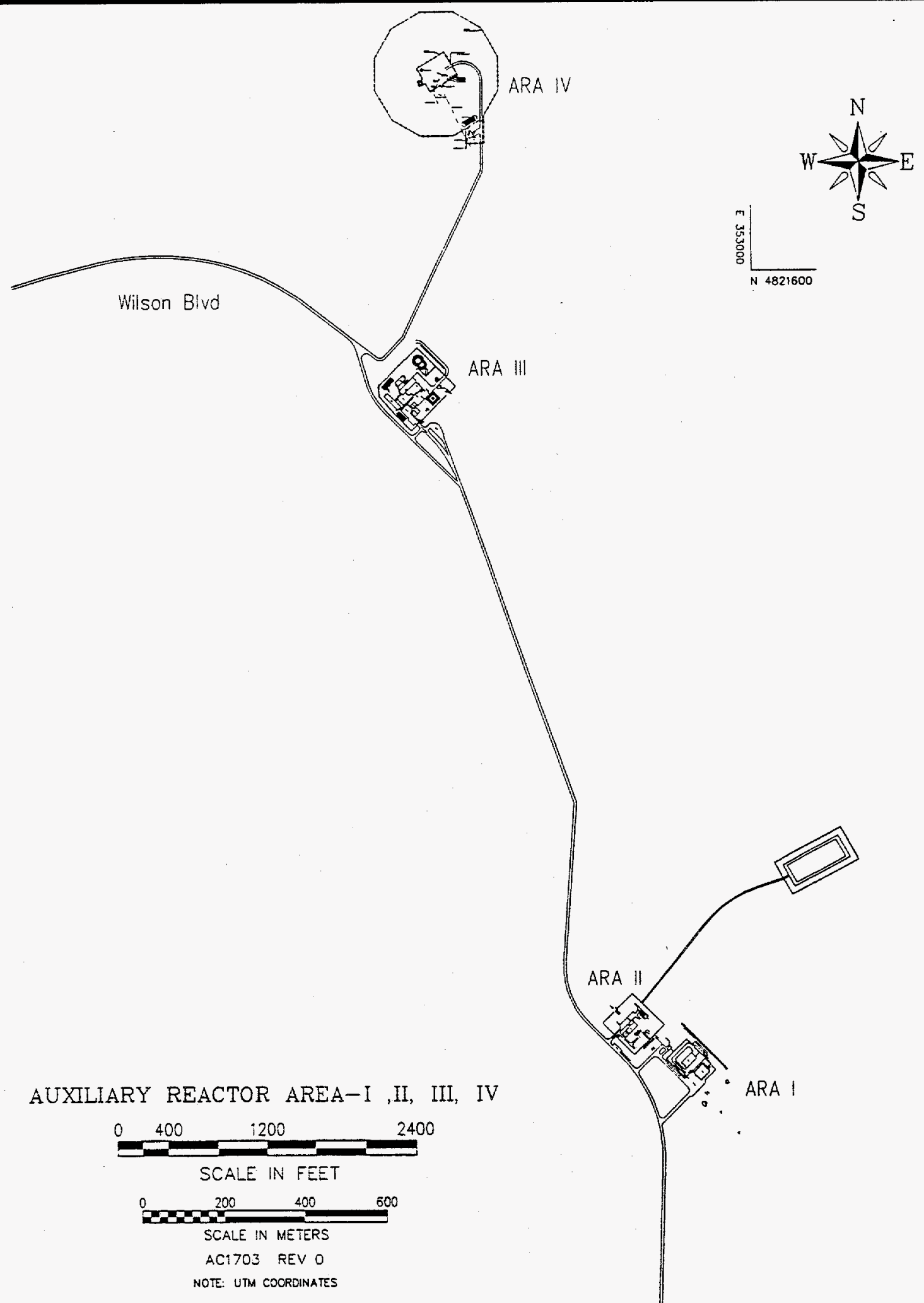

Fillmore Blvd

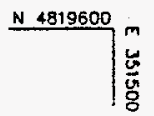

To Idaho Falls

To Central Facilities orea

and Arco Idoho

Figure 3-18. Area map of the Auxiliary Reactor Area. 


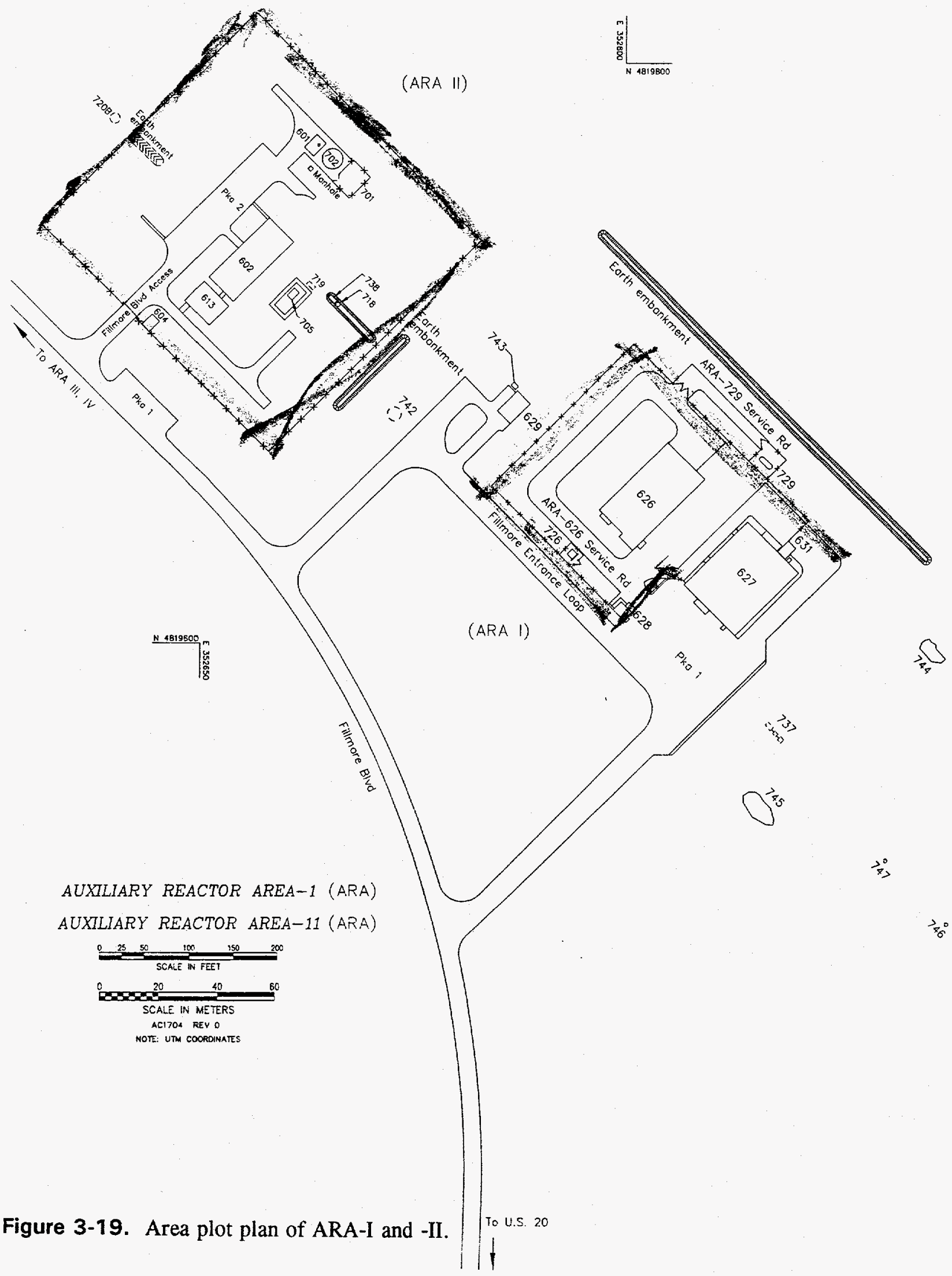




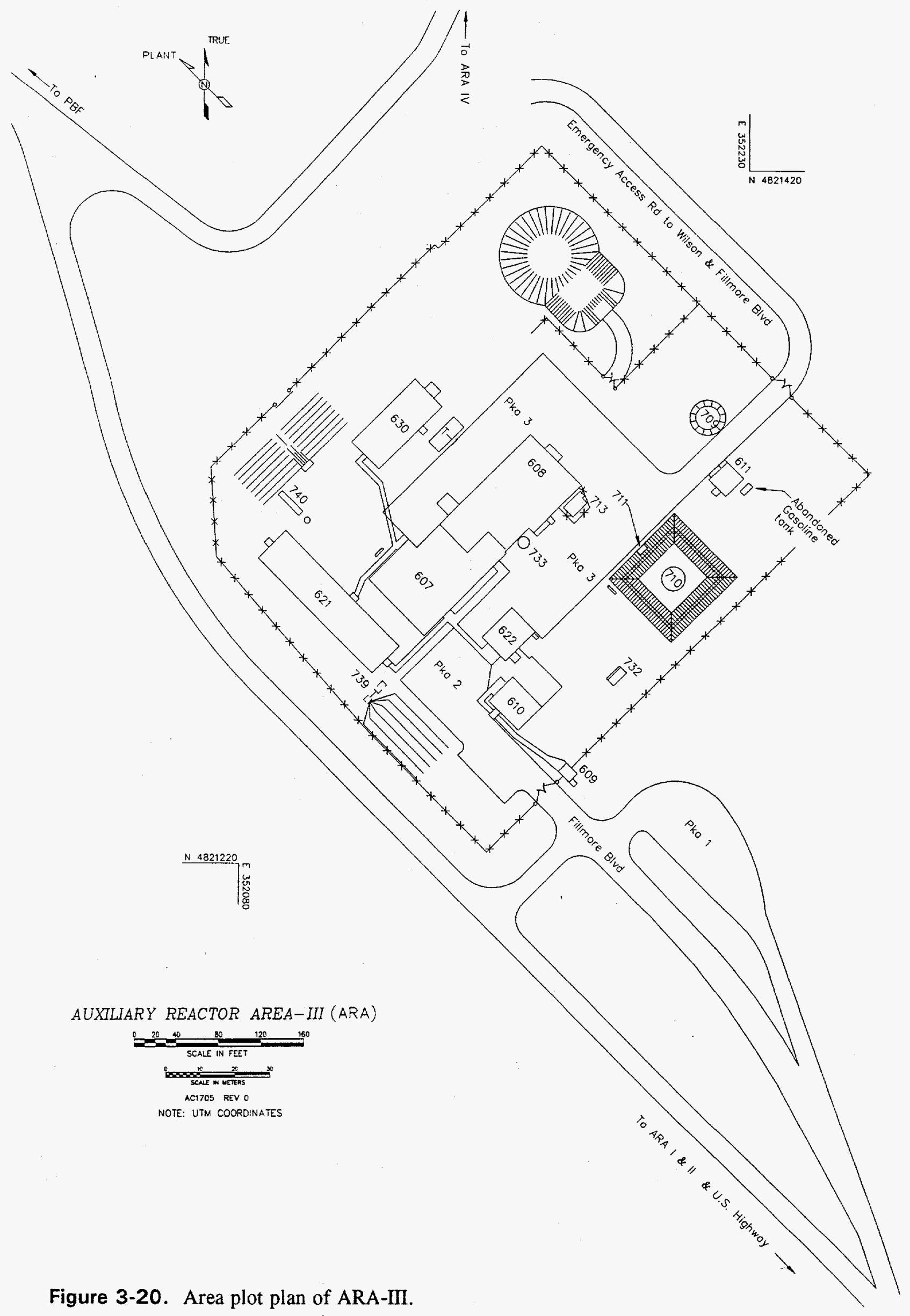




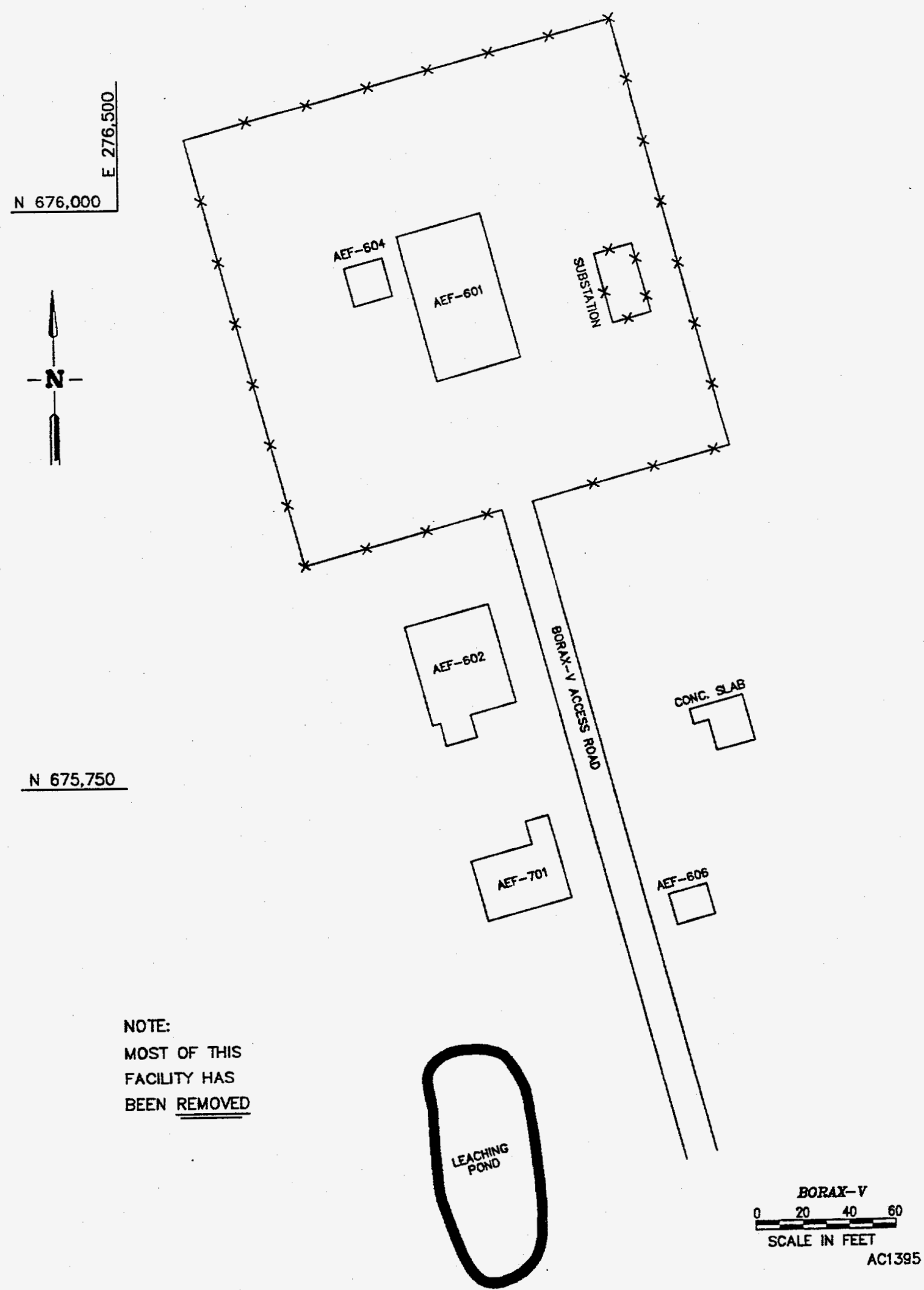

Figure 3-22. Area plot plan of BORAX-V. 


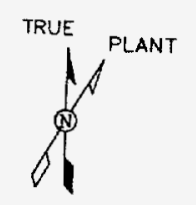

EXPERIMENTAL

BREEDER REACTOR 1
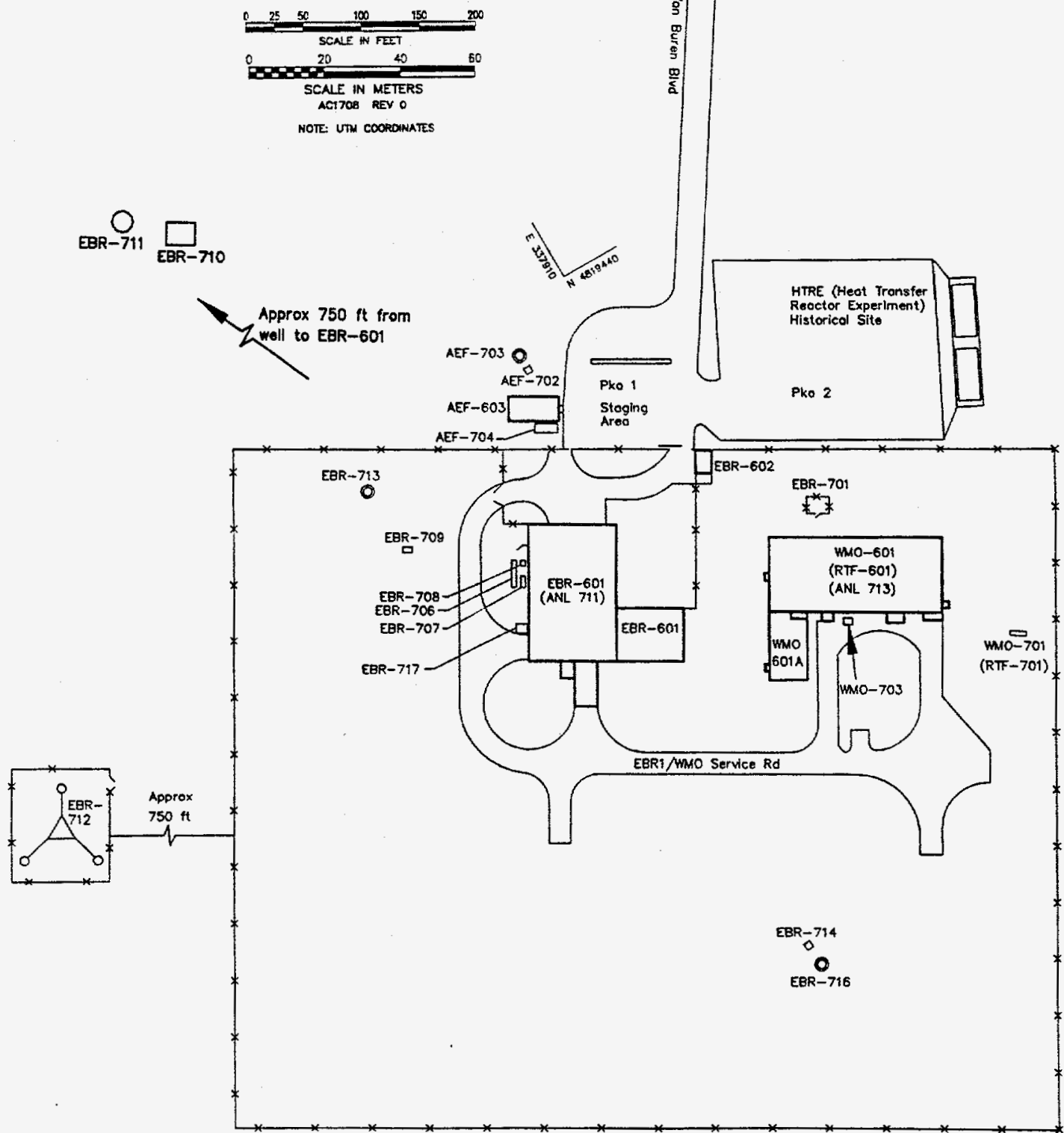

$\underset{\substack{\text { wMO-702 } \\(\mathrm{R} T \mathrm{~F}-702)}}{\mathrm{O}}$

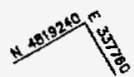

Figure 3-22. Area plot plan of EBR-I. 


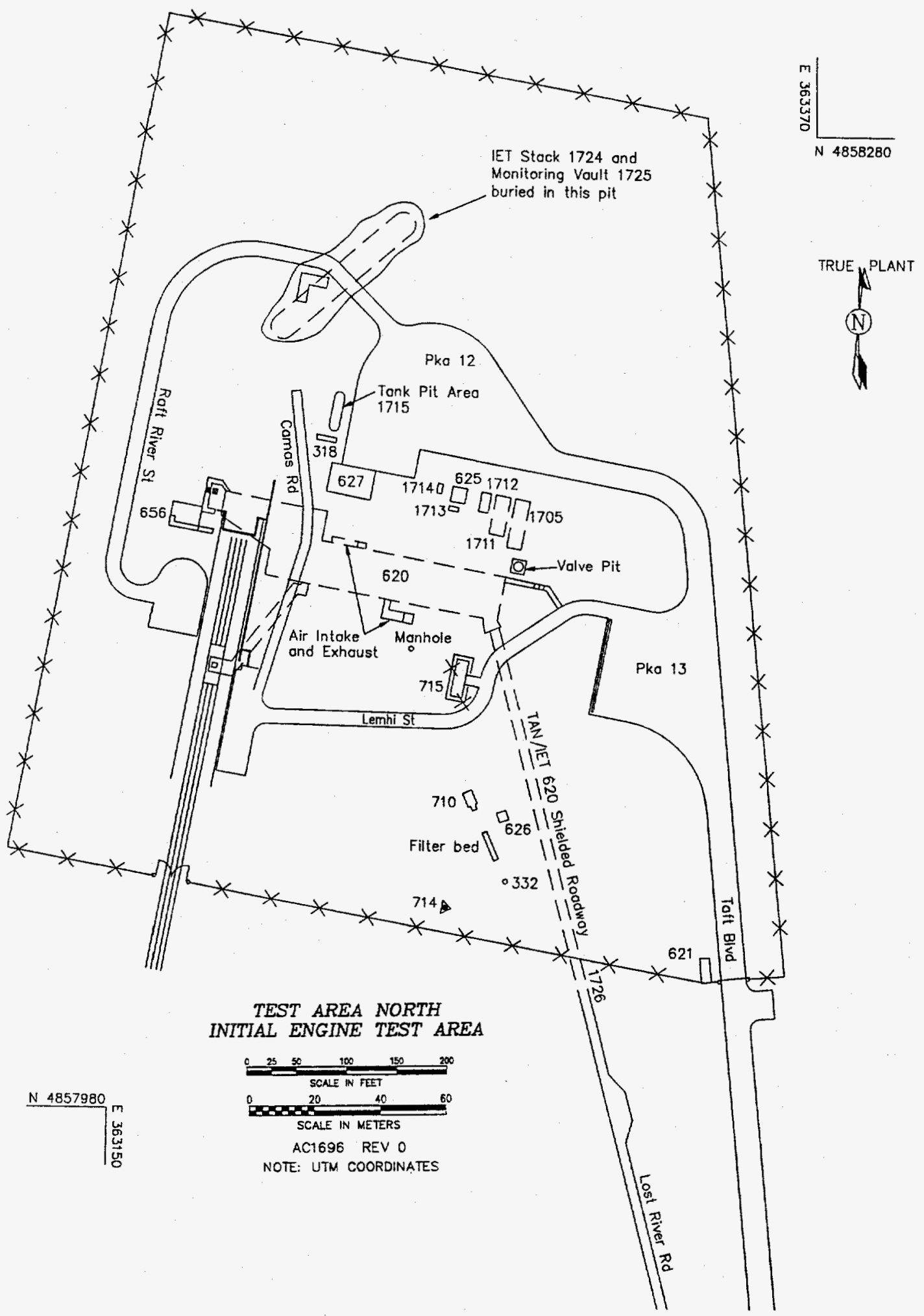

Figure 3-23. Area plot plan of IET. 


\subsection{Paved and Unpaved Roads}

There are several important paved roads on the INEL property, including both public access roads and highways, and INEL controlled roads. The public roads include U.S. Highway 20 from Idaho Falls to Arco, U.S. Highway 26 from Blackfoot to the Junction with U.S. Highway 20 on the INEL, State Highway 28 from Mud Lake to Salmon, State Highway 33 from Mud Lake to Howe, and State Highway 22 from Dubois to the Junction with State Highway 33 on the INEL. INELcontrolled roads include Lincoln Boulevard from CFA to TAN, all connecting roads from either a highway or Lincoln Boulevard to each specific area, and paved roads within each area. The following assumptions were used to calculate the emissions from the paved roads: roads at the INEL are collector streets and traffic volume on U.S. Highway 20 is 2,340 vehicles per day. No other traffic volume data is available, so the assumptions are that the particulate emissions are double for all the paved roads on U.S. Highway 20 and that vehicles travel an average of 20 miles per day onsite.

$$
\frac{2,340 \text { vehicles }}{\text { day }} \times \frac{20 \text { miles }}{\text { day }} \times \frac{365 \text { days }}{\text { year }}=\frac{17,082,000 \text { miles }}{\text { year }} .
$$

Several unpaved roads traverse the INEL, though they are very seldom used. The security guards travel these roads most frequently, though there is some secondary amount of traffic due to sampling teams. The estimate used for vehicle miles traveled on the unpaved roads is 3,000 miles per year, and the mean vehicle weight is assumed to be two tons (mostly heavy four-wheel drive vehicles.)

Table 3-11 is a summary of the estimated particulate emissions from all the roads at the INEL. The only emission type considered for both paved and unpaved roads is particulate.

Table 3-11. Particulate emissions from roads.

Emissions

\begin{tabular}{lrr}
\hline Road type & $\mathrm{lb} / \mathrm{hr}$ & ton/yr \\
\hline Paved roads & 81.1 & 222 \\
Unpaved roads & 165.6 & 10 \\
Total & 246.7 & 232 \\
\hline
\end{tabular}




\subsection{Summary of 1993 Emissions at the INEL}

For the purpose of the Air Emission Inventory, the INEL is considered a single contiguous facility, even though the emission points are divided among distinct areas within the site. Table 3-12 summarizes the total emissions of the criteria pollutants and radioactivity over the entire INEL.

Results are given as an emission rate $(\mathrm{lb} / \mathrm{hr}, \mathrm{Ci} / \mathrm{mo})$ and as annual release $(\mathrm{tn} / \mathrm{yr}, \mathrm{Ci} / \mathrm{yr})$ for stationary sources.

Table 3-12. 1993 emissions for the INEL:

\begin{tabular}{lcccc}
\hline \multicolumn{1}{c}{ Pollutant } & $\begin{array}{c}\text { Actual } \\
\text { Hourly } \\
(\mathrm{lb} / \mathrm{hr})\end{array}$ & $\begin{array}{c}\text { Actual } \\
\text { Annual } \\
(\mathrm{tn} / \mathrm{yr})\end{array}$ & $\begin{array}{c}\text { Maximum } \\
\text { Hourly } \\
(\mathrm{lb} / \mathrm{hr})\end{array}$ & $\begin{array}{c}\text { Maximum } \\
\text { Annual } \\
(\mathrm{tn} / \mathrm{yr})\end{array}$ \\
\hline Carbon monoxide & $3.2 \mathrm{E}+02$ & $4.7 \mathrm{E}+02$ & $8.7 \mathrm{E}+02$ & $3.4 \mathrm{E}+03$ \\
Nitrogen oxides & $8.17+02$ & $7.0 \mathrm{E}+02$ & $2.7 \mathrm{E}+03$ & $1.1 \mathrm{E}+04$ \\
Particulates & $3.6 \mathrm{E}+02$ & $4.1 \mathrm{E}+02$ & $9.4 \mathrm{E}+02$ & $2.2 \mathrm{E}+03$ \\
Lead & $1.5 \mathrm{E}-02$ & $4.5 \mathrm{E}-03$ & $6.7 \mathrm{E}+01$ & $2.9 \mathrm{E}+02$ \\
Radionuclide & $2.2 \mathrm{E}+02$ & $2.6 \mathrm{E}+03$ & $1.6 \mathrm{E}+05$ & $2.4 \mathrm{E}+04$ \\
Sulfur oxides & $2.8 \mathrm{E}+02$ & $2.4 \mathrm{E}+02$ & $8.6 \mathrm{E}+02$ & $3.8 \mathrm{E}+03$ \\
VOC - nonmethane & $6.7 \mathrm{E}+02$ & $7.0 \mathrm{E}+01$ & $8.4 \mathrm{E}+02$ & $9.1 \mathrm{E}+02$ \\
\hline a. Units in Ci/mo and $\mathrm{Ci} / \mathrm{yr}$, respectively. & & & \\
\hline
\end{tabular}




\section{EMISSIONS ESTIMATES FOR MOBILE SOURCES}

The INEL maintains a large inventory of vehicles to support operations. Vehicles include light-duty gas vehicles, heavy-duty diesel vehicles, buses, and construction equipment. EPA AP-42II was used to estimate emissions from the INEL mobile sources. The data and emissions calculations are maintained on a commercial spreadsheet.

Buses transport workers from the surrounding communities of Idaho Falls, Shelley, Firth, Arco, Rexberg, Pocatello, Rigby, Blackfoot, and Mackay to various locations on the INEL site. A number of buses are also maintained to provide emergency evacuation services for INEL employees. Heavy-duty diesel vehicles include garbage trucks, dump trucks, delivery trucks, and other miscellaneous nonconstruction-type equipment. Construction equipment includes gas-powered and diesel-powered front loaders, forklifts, dump trucks, cranes, scrapers, and other miscellaneous vehicles and equipment.

\subsection{Emission Estimates for Buses and Heavy-Duty Diesel Vehicles}

The INEL maintains a working inventory of approximately 265 heavy-duty diesel vehicles, comprising 140 buses, 38 evacuation buses, and 87 typical heavy-duty diesel vehicles. EPA AP-42II provides a specific methodology for estimating emissions from transit buses that operate at low speeds with high acceleration and deceleration rates. The INEL buses do not operate as typical transit buses and therefore are assumed to approximate heavy-duty diesel vehicles. Because of similarities between buses and trucks, EPA AP-42II allows for estimating emissions for buses by using the heavy-duty diesel vehicle emission factors.

EPA AP-42II, Chapter 7, presents the methodology and emissions factors for estimating emissions for heavy-duty diesel vehicles. To provide VOC, carbon monoxide, and nitrogen oxide emissions estimates for heavy-duty diesel vehicles, the model year, total mileage, annual mileage, average speed, fraction of time on the INEL proper, and fraction of time at idle was collected for each heavy-duty diesel vehicle. The emissions estimates are based on adding the emission estimates from driving and idling for each heavy-duty diesel vehicle. The emission rate (ER) from driving is calculated from multiplying the basic emission rate (BER) by a speed correction factor (SCF), as provided in Equation (4-1).

$$
E R=B E R \times S C F .
$$

The speed correction factor is calculated by Equation (4-2).

$$
S C F=\exp \left[A+(B \times s)+(C \times s)^{2}\right]
$$

where

$$
\begin{aligned}
& \mathrm{A}, \mathrm{B}, \mathrm{C}=\quad \text { emission coefficients (AP-42II, Table 2.7.6) } \\
& \mathrm{s}=\text { average vehicle speed (miles/hour). }
\end{aligned}
$$


The basic emission rate is calculated by Equation (4-3).

$$
B E R=Z M L+(D R \times M)
$$

where

$$
\begin{array}{lll}
\mathrm{ZML} & = & \text { zero mile emission level in } \mathrm{g} / \mathrm{mile} / 10,000 \text { miles (AP-42II, Table 2.7.1) } \\
\mathrm{DR} & = & \text { deterioration rate (AP-42II, Table 2.7.1) } \\
\mathrm{M} & = & \text { total mileage/10,000 miles. }
\end{array}
$$

The annual emissions released while driving for each vehicle is calculated by multiplying the emission rate in grams per mile by annual mileage.

The idle emission rate is calculated by Equation (4-4).

$$
I E R=Z M L+(D R \times M)
$$

where

$$
\begin{array}{lll}
\text { IER } & =\text { idle emssion rate } \\
\mathrm{ZML} & =\text { zero emission level in } \mathrm{g} / \mathrm{mile}(\mathrm{AP}-42 \mathrm{II} 2.7 .3) \\
\mathrm{DR} & =\text { deterioration rate in } \mathrm{g} / \mathrm{min} / \mathrm{mile}(\mathrm{AP}-42 \mathrm{II} 2.7 .3) \\
\mathrm{M} & =\text { total mileage } / 10,000 \mathrm{miles}
\end{array}
$$

The annual carbon monoxide, VOC, and nitrogen oxide emissions released while at idle for each vehicle is calculated by multiplying the idle emission rate in grams per minute by the minutes spent at idle in one year. The annual emissions for each heavy-duty diesel vehicle are calculated by adding the emissions attributed to driving and to idling for each vehicle. The total annual carbon monoxide, VOC, and nitrogen oxide emissions for all heavy-duty diesel vehicles is calculated by summing the individual heavy-duty diesel vehicle annual emissions.

For estimating particulate emissions from heavy-duty diesel vehicles, the model year and annual mileage was collected for each heavy-duty diesel vehicle. The emissions estimates are calculated for each heavy-duty diesel vehicle by Equation (4-5).

$$
E F=\left(0.7 \times M_{d} \times C F\right)+\left(0.0128 \times M_{b}\right)
$$

where

$$
\begin{array}{lll}
\mathrm{EF} & = & \text { particulate emission factor in gram/mile } \\
\mathrm{M}_{\mathrm{d}} & =\text { particle size distribution factor (AP-42II, Table 2.20) } \\
\mathrm{CF} & =\text { correction factor (AP-42II, Table 2.21) } \\
\mathrm{M}_{\mathrm{b}}= & \text { particle size distribution factor (AP-42II, Table 2.20). }
\end{array}
$$

The annual particulate emissions is calculated by multiplying $E F$ by annual mileage for each vehicle. The total annual particulate emissions for all heavy-duty diesel vehicles is calculated by summing the individual heavy-duty diesel vehicle annual particulate emissions. 
The hourly (lb/hr) emissions estimates for all pollutants are derived by dividing the total annual emissions of a given pollutant by the assumed operating schedule. All heavy-duty diesel vehicles are assumed to operate 10 hours/day, 5 days/week, and 52 weeks per year, or approximately 2,600 hours/year.

\subsection{Emission Estimates for Light-Duty Gasoline Vehicles}

The INEL maintains a working inventory of approximately 880 light-duty gasoline vehicles. The majority of the light-duty gas vehicles are used to transport employees from the outlying communities to the various INEL locations. Other uses of light-duty gas vehicles include employee and sample transportation for the Idaho Falls facilities and the INEL facilities.

EPA AP-42II, Chapter 1, presents the methodology and emissions factors for estimating emissions for light-duty gasoline vehicles. To calculate VOC, carbon monoxide, and nitrogen oxide emissions estimates for light-duty gas vehicles, the model year, total mileage, annual mileage, average speed, fraction of time on the INEL proper, and fraction of time at idle was collected for each lightduty gas vehicle. The emissions estimates are based on adding the emission estimates from driving and idling for each light-duty gas vehicle.

The methodology for calculating the light-duty gas vehicle emission mirrors the methodology for calculating heavy-duty diesel vehicle emissions. The emission rate from driving is derived by multiplying the basic emission rate by a speed correction factor, as provided in Equation (4-6).

$$
E R=B E R \times S C F
$$

where the speed correction factor is assumed to be 1.0 for light-duty gas vehicles.

The basic emission rate is calculated by Equation (4-7).

$$
B E R=Z M L+(D R \times M)
$$

where

$$
\begin{array}{lll}
\mathrm{ZML} & = & \text { zero mile emission level in } \mathrm{g} / \mathrm{mile} / 10,000 \text { miles (AP-42II, Table 2.1.1A) } \\
\mathrm{DR} & = & \text { deterioration rate }(\mathrm{AP}-42 \mathrm{II}, \text { Table 2.1.1A) } \\
\mathrm{M} & = & \text { total mileage } / 10,000 \text { miles }
\end{array}
$$

The annual emissions released while driving for each vehicle is calculated by multiplying the emission rate in grams per mile by annual mileage.

The idle emission rate is calculated by Equation (4-8).

$$
I E R=Z M L+(D R \times M)
$$

where

$\mathrm{ZML}=\quad$ zero emission level in $\mathrm{g} / \mathrm{mile}(\mathrm{AP}-42 \mathrm{II} 2.1 .3$ ) 


$$
\begin{array}{lll}
\mathrm{DR} & = & \text { deterioration rate in } \mathrm{g} / \mathrm{min} / \mathrm{mile}(\mathrm{AP}-42 \mathrm{II} 2.1 .3) \\
\mathrm{M} & = & \text { total mileage } / 10,000 \mathrm{miles}
\end{array}
$$

The annual carbon monoxide, VOC, and nitrogen oxide emissions released while at idle for each vehicle is calculated by multiplying the idle emission rate in grams per minute by the minutes spent at idle in one year. The annual emissions for each light-duty gas vehicle are calculated by adding the emissions attributed driving and emissions attributed to idling for each vehicle. The total annual carbon monoxide, VOC, and nitrogen oxide emissions for all light-duty gas vehicles is calculated by summing the individual light-duty gas vehicle annual emissions.

For estimating particulate emissions from light-duty gas vehicles, the model year and annual mileage was collected for each light-duty gas vehicle. The emissions estimates are calculated for each light-duty gas vehicle by Equation (4-9).

$$
E F=\left(0.7 \times M_{d} \times C F\right)+\left(0.0128 \times M_{b}\right)
$$

where

$$
\begin{array}{lll}
\mathrm{EF} & = & \text { particulate emission factor in gram/mile } \\
\mathrm{M}_{\mathrm{d}} & = & \text { particle size distribution factor (AP-42II, Table 2.20) } \\
\mathrm{CF} & = & \text { correction factor (AP-42II, Table 2.21) } \\
\mathrm{M}_{\mathrm{b}} & = & \text { particle size distribution factor (AP-42II, Table 2.20) }
\end{array}
$$

The annual particulate emissions is calculated by multiplying $E F$ by annual mileage for each vehicle, and the total annual particulate emissions for all light-duty gas vehicles is calculated by summing the individual light-duty gas vehicle annual particulate emissions.

The hourly $(\mathrm{lb} / \mathrm{hr})$ emissions estimates for all pollutants are derived by dividing the total annual emissions of a given pollutant by the assumed operating schedule. All light-duty gas vehicles are assumed to operate 10 hours/day, 5 days/week, and 52 weeks per year, or approximately 2,600 hours per year.

\subsection{Emission Estimates for Construction Equipment}

The INEL maintains a working inventory of approximately 108 pieces of construction equipment. EPA AP-42II Section II-7 presents the methodology and emissions factors for estimating emissions for light-duty construction equipment. To provide VOC, carbon monoxide, nitrogen oxide, and particulate emissions estimates for construction equipment, the annual hourly usage was collected. EPA AP-42II, Section II, Table II-7.1, presents the emission factors for diesel powered construction equipment, and EPA AP-42II Section II, Table II-7.2, presents the emission factors for gasoline powered construction equipment.

As defined by EPA AP-42II, the construction equipment are divided into ten different categories, comprising tract-type tractor, wheeled tractor, wheeled dozer, scraper, motor grader, wheeled loader, tracktype loader, off-highway truck, roller, and miscellaneous equipment. EPA AP$42 \mathrm{II}$ provides emission factors for each pollutant type for each category.

The emissions for each piece of equipment is calculated by multiplying the corresponding equipment and pollutant emission factor $(\mathrm{lb} / \mathrm{hr})$ by the annual hourly usage. The total annual 
emissions is calculated by summing the individual annual emissions. The hourly emissions for construction equipment emissions are calculated by dividing the total annual emissions by the total operating hours of the construction equipment.

\subsection{Vehicle Emission Estimate Assumptions}

Several assumptions are required to estimate vehicle emissions and provide a more conservative, or overestimated, emissions estimate.

- Vehicles receive typical in-use maintenance.

- Vehicles are not involved in an inspection and maintenance program.

- Crankcase and evaporative hydrocarbon emissions are insignificant.

- Hydrocarbon emissions are total hydrocarbons and include methane, aldehydes, and other non-VOC hydrocarbons.

- Vehicles operate in a hot stabilized condition.

- Ambient temperature has no affect on emissions estimates.

- Tire wear particulate is larger than $10 \mathrm{E}-6 \mathrm{~m}$.

- High altitude emission factors apply.

- Humidity correction for nitrogen oxides calculation is not applicable.

- If a vehicle or construction equipment cannot be readily classified into EPA AP-42II types, the worst-case classification is used.

- Miscellaneous correction factors for the light-duty gas vehicle do not appreciably improve emission estimates.

- Particulate emissions for light-duty gas vehicles approximate heavy-duty diesel vehicle particulate emissions; therefore, the same methodology for calculating particulate emissions is utilized.

- $\quad$ Light-duty gas vehicle speed correction factor equals 1 .

- Heavy-duty diesel vehicle and light-duty gas vehicles operate 10 hours/day, 5 . days/week, and 52 weeks per year, or approximately 2,600 hours/year.

\subsection{Mobile Emissions Estimates for 1993}

Mobile emissions estimates for 1993 were calculated with the updated emission factors as presented in EPA AP-42IIA. Table 4-1 presents the emissions estimates for each vehicle type and Table 4-2 presents the total emissions estimates. 
Table 4-1. Vehicle fleet emissions for the INEL, 1993.

\begin{tabular}{lrr}
\hline Vehicle Emissions & $\mathrm{lb} / \mathrm{hr}$ & ton/yr \\
\hline Buses & 5.79 & 7.52 \\
VOC & 16.03 & 20.83 \\
CO & 16.00 & 21.80 \\
NOx & 1.70 & 2.21 \\
PM & & \\
Construction Equipment & 1.29 & 3.47 \\
VOC & 16.48 & 40.58 \\
CO & 2.18 & 9.57 \\
NOx & 0.19 & 0.84 \\
PM & & \\
Diesel Vehicles & 2.69 & 3.50 \\
VOC & 6.54 & 8.50 \\
CO & 6.77 & 8.80 \\
NOx & 0.69 & 0.90 \\
PM & & \\
Gasoline Vehicles & 5.77 & 7.5 \\
VOC & 76.23 & 99.1 \\
CO & 6.54 & 8.5 \\
NOx & 7.16 & 11.3 \\
PM & & \\
\hline
\end{tabular}

Table 4-2. Total estimated annual emissions.

\begin{tabular}{lrr}
\hline & \multicolumn{2}{c}{1993 Emissions } \\
\hline Emissions & $\mathrm{lb} / \mathrm{hr}$ & ton/yr \\
\hline VOC & 15.54 & 21.99 \\
CO & 115.28 & 169.02 \\
NOx & 31.49 & 47.67 \\
PM & 9.74 & 15.25 \\
\hline
\end{tabular}




\section{EMISSIONS ESTIMATES FOR STATIONARY SOURCES}

The following describes the various calculations used to estimate the emissions from sources based on the data collected in the initial Phase II of the inventory and each successive update. Each section includes a list of assumptions that were made and calculational methods as applicable. Appendix C presents the data used to calculate the 1993 Air Emission Inventory.

One of the important considerations for regulatory purposes is an understanding of maximum emissions. Currently, the inventory requires the estimation of maximum emissions for each source. Maximum emission estimates represent emissions associated with the maximum operation of the given source. Sources with permits have already had maximum values attributed to them, and these have been included in the inventory as they appear in the permit or application. Other maximum values were estimated as outlined in the following sections. If a maximum emission estimate could not be determined, the actual emission estimates are utilized as the maximum emissions estimates.

Several calculations are performed by the database. The types of sources that the database produced calculations for are diesel and gas engines; boilers, furnaces, and heaters; and volatile organic compound storage tanks. AP-42 equations and tables were used in the calculations.

\subsection{Industrial Engine Emissions}

\subsubsection{Methodology and Assumptions}

Industrial stationary engines are commonly used throughout the INEL for emergency electrical power generation and water pumping. These sources generally operate on a routine schedule of 0.5 hours per week. This routine operation and maintenance is required to ensure that the systems are ready when needed. The operation schedule during an emergency is dependent on the nature of the problem. Based on discussions with the maintenance people around the facility, the usual power outage lasts from 1 to 4 hours. Power outages occur infrequently and at any time, so a specific schedule is impossible to predict.

Two basic categories of engines with two fuel types are covered by these calculations. These categories generally include gasoline and diesel industrial engines with power ratings up to $600 \mathrm{hp}$ and large bore diesel engines with displacements greater than 560 in. ${ }^{3} /$ cylinder. Emissions from these sources include carbon monoxide, hydrocarbons, nitrogen oxides, sulfur oxides, lead, and particulates. The emissions for these sources are estimated based on published emission factors found in EPA's AP-42 Volume I.

A few industrial engines at the INEL have horsepower ratings in excess of $600 \mathrm{hp}$ but are not classifiable as large bore diesel engines. A consultant from Radian reviewed this issue, and after talking with the respective manufacturers of these engines, determined that the AP-42 factors for engines under $600 \mathrm{hp}$ were appropriate in each case.

Assumptions:

- Operation schedule was based on routine operation according to information supplied by maintenance personnel. 
- The primary method for estimating emissions was based on fuel consumption. Generally, fuel figures were available for most engines and were a better estimate than estimating an operating schedule.

- If fuel consumption figures were not available, estimates were based on engine power and operating schedule.

- Where several engines are operated from a common fuel tank, the fuel consumption for each engine was based on the ratio of each engine's power rating to the total for all the engines.

The following steps are required to estimate the emissions from industrial engines.

1. Determine engine size (horsepower, cubic inch displacement)

2. Look up emission factors in AP-42, Table 3.3-1.

3. Apply factor to either the fuel consumed or the operating schedule, and convert the units to pounds per hour and tons per year.

In the event that the data were limited, maximum and actual fuel consumption rates were sometimes obtained by one of the following methods. Since most of the engines at the INEL are for emergency purposes, they typically run only during preventative maintenance checks. Mechanics at several areas indicated that the engines are checked at 50\% load. A large quantity of data was collected to determine on the average what percentage of the maximum fuel throughput is burned at $50 \%$ load, and it was determined to be roughly $50 \%$. Therefore, if the maximum throughput was known, but not the actual, the actual was assumed to be $50 \%$ of the maximum, assuming that virtually all run time is at $50 \%$ load. Likewise, if the actual was known but not the maximum, the same relationship was assumed to be true. In some rare cases, no information was available, and throughputs were determined to be the same as for similar engines with the same horsepower rating.

It was also determined to be necessary to check the validity of some throughput data since it appeared that the assumed throughput compared to the horsepower was indicating engine efficiency well in excess of the 35\% average. To do this, a spreadsheet was developed with all the engines and their respective throughputs and horsepowers included. The efficiency was calculated and those with suspiciously high values were re-checked and corrected.

\subsubsection{Maximum Emission Estimates}

The method for determining maximum emissions from all standard sources of fuel burning equipment was identical to the AP-42 method used to calculate actual emissions. The only difference is that the maximum rate of fuel consumption for 8,760 hours of operation is applied to the emission factors. The maximum fuel consumption rate was generally available from information either directly on the piece of equipment or from data provided by vendors. In a few instances, assumptions had to be made based on a knowledge of operation schedules. For example, most emergency generators are operated for a known period of time each week for preventive maintenance purposes. When they do run, they typically run at $50 \%$ load. Vendor data indicates that on the average, when an industrial engine runs at $50 \%$ load, the fuel consumption rate is roughly $50 \%$ of the maximum. Therefore, if normal consumption rates are known from fuel tank loading information, then a good approximation of the maximum fuel consumption rate can be made knowing this $50 \%$ relationship. Sometimes it 
was useful to work this same relationship the other way, estimating the normal rate of consumption when only the maximum was known.

\subsubsection{Calculations Performed by the Database} equation.

The emission calculations for internal combustion engines (diesel and gas) used the following

$$
\text { Gal/year } \times \mathrm{AP}-42 \text { factor }(\mathrm{lb} / 1,000 \mathrm{gal}) / 2,000(\mathrm{lb} / \mathrm{ton}) / 1,000=\text { yearly emission (ton/year) }
$$

Using the operation schedule provided on the data sheets, the hourly emissions were calculated as follows.

$\mathrm{Gal} / \mathrm{hr} \times \mathrm{AP}-42$ factor $(\mathrm{lb} / 1,000 \mathrm{gal}) / 1,000=$ hourly emission $(\mathrm{lb} / \mathrm{hr})$.

\subsection{Boiler Emissions}

\subsubsection{Methodology and Assumptions}

Boilers are used throughout the INEL primarily to provide space heating and process steam. Boiler fuels range from natural gas to coal. Boiler sizes range from residential sized heaters (greater than $1 \mathrm{E}+06 \mathrm{Btu} / \mathrm{hr})$ to the large coal fired steam generation facility at ICPP $(8.3 \mathrm{E}+07 \mathrm{Btu} / \mathrm{hr})$.

Boiler operation schedules vary depending on operations, weather, and reactor schedules. Because of the critical need for boilers in several areas, many boiler installations include up to $100 \%$ backup capacity for emergency purposes. These backup boilers are generally only operated for maintenance purposes. The best way to determine boiler use is to measure boiler fuel consumption. Fuel consumption automatically takes into account both hours of operation and boiler load. Fuel consumption figures are typically well documented and reliable.

Boiler emissions include carbon monoxide, nitrogen oxides, sulfur dioxide, volatile organics, lead, and particulates. These emissions are estimated using published emission factors found in AP-42.

Assumptions:

- Operation schedule is based on best estimates of boiler operators or maintenance staff.

- Emission estimates are primarily based on the annual fuel consumption.

- When several boilers share a common fuel source, the emissions for each boiler are based on the ratio of the individual capacity to the total capacity.

- During the initial inventory process, the sulfur content for No. 2 fuel oil was considered to be 0.24 weight percent, and 0.9 weight percent for No. 5 fuel oil. However, per the present vendor contracts, the current emissions estimates use the sulfur content of No. 2 fuel oil as 0.5 weight percent and the sulfur content of No. 5 fuel oil as 1.5 weight percent. 
- In several instances, a boiler may burn a mixture of No. 1 fuel oil and No. 2 fuel oil; in such cases, the emissions estimates assumed all fuel burn is represented by No. 2 fuel oil.

The following steps are required to determine the emissions from boilers.

1. Determine fuel type (coal, oil, natural gas).

2. Determine boiler capacity (utility, industrial, commercial, residential).

3. Look up emission factor in appropriate AP-42 table (Table 1.3-1, AP-42, Vol. 1).

4. Multiply emission factor by fuel consumed and correct units to $\mathrm{lb} / \mathrm{hr}$ or ton/year.

\subsubsection{Maximum Emission Estimates}

The method for determining maximum emissions from all standard sources of fuel burning equipment was identical to the AP-42 method used to calculate actual emissions. The only difference is that the maximum rate of fuel consumption for 8,760 hours of operation is applied to the emission factors. The maximum fuel consumption rate was generally available from information either directly on the piece of equipment or from data provided by vendors. In a few instances, assumptions had to be made based on a knowledge of operation schedules. For example, most emergency generators are operated for a known period of time each week for preventive maintenance purposes. When they do run, they typically run at $50 \%$ load. Vendor data indicates that on the average, when an industrial engine runs at $50 \%$ load, the fuel consumption rate is roughly $50 \%$ of the maximum. Therefore, if normal consumption rates are known from fuel tank loading information, then a good approximation of the maximum fuel consumption rate can be made knowing this $50 \%$ relationship. Sometimes it was useful to work this same relationship the other way, estimating the normal rate of consumption when only the maximum was known.

\subsubsection{Calculations Performed by the Database}

The emission calculations for boilers, heaters, and furnaces used the following equation.

$$
\mathrm{Gal} / \mathrm{yr} \times \mathrm{AP}-42 \text { factor(lb/1,000 gal)/2,000 (lb/ton)/1,000 = yearly emission (ton } / \mathrm{yr}) .
$$

Using the operation schedule provided on the data sheets, the hourly emissions were calculated as follows:

Gal/year $\times$ AP -42 factor $(\mathrm{lb} / 1,000 \mathrm{gal}) / 1,000=$ hourly emission $(\mathrm{lb} / \mathrm{hr})$.

\subsection{Radionuclide Sources}

\subsubsection{Methodology and Assumptions}

Data from monitored INEL radiological sources is managed by EG\&G Idaho's Environmental Support Group. The annual National Emission Standards for Hazardous Air Pollutants (NESHAPS) for INEL Radiological Emissions Report (DOE-ID 1990) and the annual/monthly Radioactive Waste 
Management Information System reports are utilized for reporting the emissions of monitored radiological sources. The types of information collected include the activity for major radionuclide types, gross alpha, gross beta/gamma, stack air flow, and physical stack dimensions.

Emission estimates for nonmonitored sources were obtained from NESHAPs permits and safety documentation and by process knowledge. The annual NESHAPs report also provides information regarding nonmonitored sources.

\subsubsection{Maximum Emission Estimates}

A majority of the maximum values for radionuclide sources not covered by permits were obtained from NESHAPs 40 CFR 61.93 Monitoring Requirements for Radiological Emission Sources at INEL (DOE-ID 1990). This document provides unabated emission estimates based on process design and operating parameters, or monitoring data. Since the completion of the above report, reassessment of several radiological sources resulted in changes to the associated maximum emissions. The changes to the reassessed maximum emission estimates are represented in the current annual NESHAPs report and the current Air Emission Inventory report. The maximum unabated values are considered to be the maximum values for radiological sources for the inventory.

\subsection{Laboratory Fumehood Calculations}

\subsubsection{Methodology and Assumptions}

Many of the buildings at the INEL have laboratories with fumehoods. These hoods are used for chemical analysis, radiological analysis, chemical storage, and research and development. The types of pollutants that may be involved include acids, bases, volatile organics, particulates, and a variety of other chemicals and gases that may or may not be of regulatory concern. The majority of hoods are used mostly for precautionary measures or infrequent experimental work, but some are used routinely for both research and analysis.

In general, process knowledge provides the emissions estimates for laboratory fumehoods. Process knowledge included laboratory fumehood chemical inventories and associated uses. Because of the wide variety of materials that could be used in a laboratory hood, the laboratory custodians and technicians were relied upon to provide information about potential emissions based on knowledge of hood use and present programs. Whenever there was any question about quantities that were actually emitted, the most conservative estimate was used. The most conservative estimate is to assume $100 \%$ of the chemical inventory are emitted. Whenever possible, log books were referred to for the numbers and types of analysis/experiments that are performed in specific hoods over a period of several months.

Assumptions:

- Acids and bases are not emitted unless they are heated or boiled off, in which case $100 \%$ is assumed emitted.

- $100 \%$ of the volatile organic compounds are vented unless there is knowledge of disposal procedures that can account for a known percentage of volatile organic compounds used in the hoods. 
- Solid chemicals mixed in solution remain in solution and are not otherwise emitted to the atmosphere.

- Laboratories with more than one hood are assumed to emit an equal distribution of the identified quantities of pollutants from that lab, unless the custodians specifically indicate otherwise.

\subsubsection{Maximum Emission Estimates}

As with radionuclide sources, it is very difficult to quantify the maximum amount of material that could be emitted from a laboratory fumehood. The only reasonable means for doing so in the context of this inventory was to assume that the actual emission rate was reasonably representative of the maximum and multiply that value by 8,760 hours to obtain the maximum yearly emissions.

\subsection{Painting Operations Calculations}

\subsubsection{Methodology and Assumptions}

A variety of painting operations occur at the INEL, including spray booths, brush applications inside craft shops, spraying and brushing on location, paint mixing, and brush/equipment cleaning. The paint booths are typically the only sources with a designated blower specific to that source. Any painting that occurs elsewhere in the shop is either considered to be vented from a nearby room exhaust, or through the paint booth, whichever is most appropriate.

For convenience, all painting that occurs on location around the INEL is attributed to the paint shop that supplied the paint, and all emissions are assumed to vent with the paint booth. Information about the materials used in the paint booths was provided by shop managers and material safety data sheets.

Emissions estimates associated with painting operations were hand calculated and based on process knowledge of the given operation. The database does not provide calculations for these types of operations.

Assumptions:

- $100 \%$ of VOCs from paint is emitted

- $15 \%$ of paint solids is emitted from spraying activities

- $0 \%$ of solids is emitted from brush application activities

- $40 \%$ of lacquer thinner and other thinners is evaporated to the atmosphere $(60 \%$ is disposed of in satellite accumulation areas)

- $10 \%$ of mineral spirits solvent is evaporated to the atmosphere $(90 \%$ is disposed of in satellite accumulation area)

- All painting operations are associated with a vent

- $90 \%$ filter efficiency for particulate in spray booth 
- $0 \%$ filter efficiency for all volatile organic compounds, as well as for particulate from activities outside the spray booth

- Typical operating schedule (if not provided by operator) is 4 hours/day, 5 days/week, 52 weeks/year, or 1,040 hours per year.

\subsubsection{Maximum Emission Estimates}

Maximum emission estimates from paint booths are based on the assumption that the average spray gun can spray 2.5 gallons of paint per hour and that $100 \%$ of the solvents purchased for paint thinning and brush cleaning are emitted. An emission rate can then be determined in the same manner as for the actual emissions, assuming 8,760 hours of operation.

\subsection{Organic Storage Tank Calculations}

\subsubsection{Methodology and Assumptions}

Organic storage tanks are used primarily for fuel oil and gasoline storage, and occasionally for solvent storage. Most of tanks are underground, but a few of them are aboveground, and can be either outside or inside a building. Emissions from tanks occur when the vapor space is either pressurized by a change in temperature or pressure, relieving the pressure by breathing out of the vent (breathing loss), or when the tank is filled, displacing the vapor out of the tank (working loss). Aboveground tanks are much more susceptible to daily temperature changes, and tank color and paint condition were considered in calculating their emissions.

Organic storage tanks that are aboveground with a horizontal orientation pose a unique problem from an AP-42 standpoint, since the empirical equation is specifically for vertical tanks. The equation considers the tank diameter as a function of the liquid surface area, but clearly the diameter on a horizontal tank will have a much different effect on the surface area than will the diameter of a vertical tank. In order to correct for this, an average surface area is computed for horizontal tanks, and then an equivalent diameter factor is calculated based on that area. This diameter is then inserted into the AP-42 equation directly as though it were for a vertical tank.

Assumptions:

- Daily temperature change of underground tanks and inside tanks is approximately zero, and therefore the breathing loss is also approximately zero

- $\quad$ Average atmospheric pressure is $12.3 \mathrm{psi}$

- Working loss emissions are equal to volume of vapor displaced by fuel during tank filling. The number of times the tank is filled is assumed to be equal to the annual throughput/volume of the tank.

- The vapor space height for horizontal cylindrical tanks is approximated as though the tank were of square cross section. This greatly simplifies the calculation. 
The fill rates of the tanks were provided by the EG\&G Idaho Traffic Division as follows:

Above ground tanks: trucks pump at $200 \mathrm{gal} / \mathrm{min}$

Underground tanks: gravity fed at $100 \mathrm{gal} / \mathrm{min}$

CFA-754 and TAN-702, -704, and -724: self pumping at $90 \mathrm{gal} / \mathrm{min}$.

\subsubsection{Maximum Emission Estimates}

Currently, the inventory does not provide for maximum calculations for organic storage tanks. The recently published Supplement E to EPA AP-42 provides emissions estimates that approximate the maximum emissions for storage tanks. The Air Emission Inventory System will be upgraded to reflect EPA AP -42 emissions estimates for maximum emissions from organic storage tanks. If a maximum value for a tank was not provided, the Air Emission Inventory System assigns the actual emissions estimates to the maximum.

\subsubsection{Calculations Performed by the Database}

In calculating the emissions from breathing losses, the equation on page 4.3-5 of AP-42 was used. The average ambient diurnal temperature change was assumed to be zero for tanks that were below ground or inside of buildings. Equation (2), on page 4.3-8 of AP-42, was used to calculate the emission from working loss. Both of these produce values given in $\mathrm{lb} /$ year and were divided by $2,000 \mathrm{lb} /$ ton to achieve an answer in tons/year.

The hourly emissions for organic storage tanks were calculated by adding the hourly emissions for breathing loss and working loss. The hourly emissions for working loss were calculated by determining the minutes of operation for each tank by the following:

$\mathrm{Gal} / \mathrm{yr} /$ Fill rate $(\mathrm{gal} / \mathrm{min})=$ minutes of operation per year $(\mathrm{min} / \mathrm{yr})$

and

Annual emissions (ton $/ \mathrm{yr}) \times 2,000(\mathrm{lb} / \mathrm{ton}) \times 60(\mathrm{~min} / \mathrm{hr}) /$ minutes of operation $(\mathrm{min} / \mathrm{yr})$ $=$ emissions per hour $(\mathrm{lb} / \mathrm{hr})$.

The hourly emissions for breathing loss were calculated by determining the hours of operation for each tank by the following:

Annual emissions (ton/yr) $\times 2,000(\mathrm{lb} / \mathrm{ton}) / \mathrm{hour}$ of operation $(\mathrm{min} / \mathrm{yr})$

$=$ emissions per hour $(\mathrm{lb} / \mathrm{hr})$.

\subsection{Emissions from Welding Operations}

\subsubsection{Methodology and Assumptions}

Welding operations are located at ANL-W, CFA, ICPP, and TAN. During welding, a percentage of the welding rod is deposited and the balance goes to fume. The fumes are then 
removed by the ventilation system and released to the atmosphere. In order to calculate the amount and composition of the fume released to the atmosphere, the type and amount of welding rod used per year at each welding operation, the percentage of welding rod used that goes to fume for each rod type, the composition of the fumes from each rod type, and the stack parameters of the ventilation systems information was collected.

\section{Assumptions:}

- $\quad$ All fumes produced during welding are vented through the stack on the associated ventilation system.

- Fumes produced during tungsten inert gas welding are negligible (Barnes, Tak) and thus are not considered.

- The percent fume generated and fume constituents will be the same for welding rods of the same type but different manufacturers.

- For modeling purposes, all welding fumes generated in a building will be vented to the atmosphere through one stack.

Formula:

Amount of rod used $\times \frac{\text { weight } \% \text { of fumes }}{100}=$ fumes generated $(\mathrm{lb})$

Fumes generated $(\mathrm{lb}) \times \frac{\text { weight } \% \text { of constituent }}{100}=$ constituent generated $(\mathrm{lb})$.

\subsubsection{Maximum Emission Estimates}

The maximum emissions from welding booths are based on welders' estimates that each welder in any given booth can burn a maximum of ten pounds of weld rod per hour. Multiplying the particulate factors for ten pounds per hour provides the emission rate, and multiplying the rate by 8,760 hours per year gives the annual maximum quantity.

\subsection{Main Stacks}

\subsubsection{Methodology and Assumptions}

Main stacks are large emission points that consist of several effluent streams culminating in a single, typically very large stack, such as the ICPP main stack. Each main stack is unique: processes that it exhausts are peculiar to that stack alone. The general method used for determining the emissions from these sources is to track each individual effluent stream to its source and estimate the emissions. The main stack's emissions then are the sum of each contributing source. Main stack emission estimates were determined using stack monitoring results, process knowledge, existing permits, permit applications, engineering drawings, interviews with cognizant engineers, and calculations. 


\subsubsection{Maximum Emission Estimates}

The maximum emissions for main stacks were typically determined from either permit values or cognitive engineers. Some National Environmental Policy Act documents, including environmental assessments, were also used.

\subsection{Paved and Unpaved Roads}

Fugitive dust from paved and unpaved roads is calculated using AP-42, Volume 1, Section 11.2. The particulate matter from paved roads includes reentrained mineral matter as well as particulates emitted directly by the vehicle, such as engine exhaust, wear of bearings and brake linings, and tire wear. For unpaved roads, the primary source of particulate will be the silt in the road itself that is kicked up in the wake of a passing vehicle.

For the sake of the inventory, a generic source number had to be attributed to the roads to match the format for the rest of the database. Hence, paved roads have been given the source number INEL-100-001, and unpaved roads have been given the source number INEL-101-001.

Assumptions:

- All paved roads on the INEL are collector streets as defined in Section 11.2 of AP42 , Volume 1.

- The only significant traffic on unpaved roads is by the security guards that patrol the INEL.

- Silt content on the unpaved roads is approximately the same as for the surrounding soil. A value of $25 \%$ silt is used ("Generalized Geologic Framework of the National Reactor Testing Station, Idaho," R.L. Nace, P.T. Voegeli, J.R. Jones, and M.

Deutsch, Geological Survey Professional Paper 725-B, 1975).

- Average traveling speed on unpaved roads is $25 \mathrm{mph}$.

- 2,340 vehicles/day on U.S. Highway 20 on the average. This data is collected on U.S. Highway 20 approximately 5 miles west of Idaho Falls and includes the INEL bus fleet. Because no data is available for any of the other roads that cross the INEL, the inventory simply doubles the number of vehicles that travel on U.S. Highway 20 and assumes that it is representative of the daily traffic on site (i.e., 4,680 vehicles/day)

\subsection{Miscellaneous Sources}

\subsubsection{Methodology and Assumptions}

Occasionally during the inventory, a source was encountered that did not fit into any of the above categories. Each of these had to be handled on a case-by-case basis. Calculations were typically based on a set of assumptions that allowed these sources to be characterized in a fashion similar to other more familiar sources. These assumptions and calculations were documented and attached to the field data sheets. 


\subsubsection{Maximum Emission Estimates}

Unusual or unique source types that did not fit the above source types had maximum emissions calculated on a case by case basis. The most common method was to assume that the hourly emission rate was the maximum and multiply by 8,760 hours for the annual quantity. If a maximum emission estimate could not be assigned, the actual emissions estimates were utilized as the maximums. 


\section{REFERENCES}

DOE-ID, 1993, Idaho National Engineering Laboratory Technical Site Information, DOE/ID-10401, May 1993.

DOE-ID, 1992, Air Emission Inventory for the Idaho National Engineering Laboratory-1990\& 1991 Emissions Report, U.S. Department of Energy, Field Office, Idaho, DOE/ID-10433(92), June 1992.

DOE-ID, 1991, Air Emission Inventory for the Idaho National Engineering Laboratory, DOE/ID-10432(91), March 1991.

DOE 1990, NESHAPs 40 CRF 61.93 Monitoring Requirements for Radiological Emission Sources at INEL, DOE/ID-10310, November 1990.

EPA, Compilation of Air Pollutant Emission Factors, U.S. Environmental Protection Agency, AP-42, current revision. 
Appendix A

Phase I \& II Forms 


$$
\text { A-2 }
$$




\section{DOE-ID ECO Air Emission Inventory - 1989}

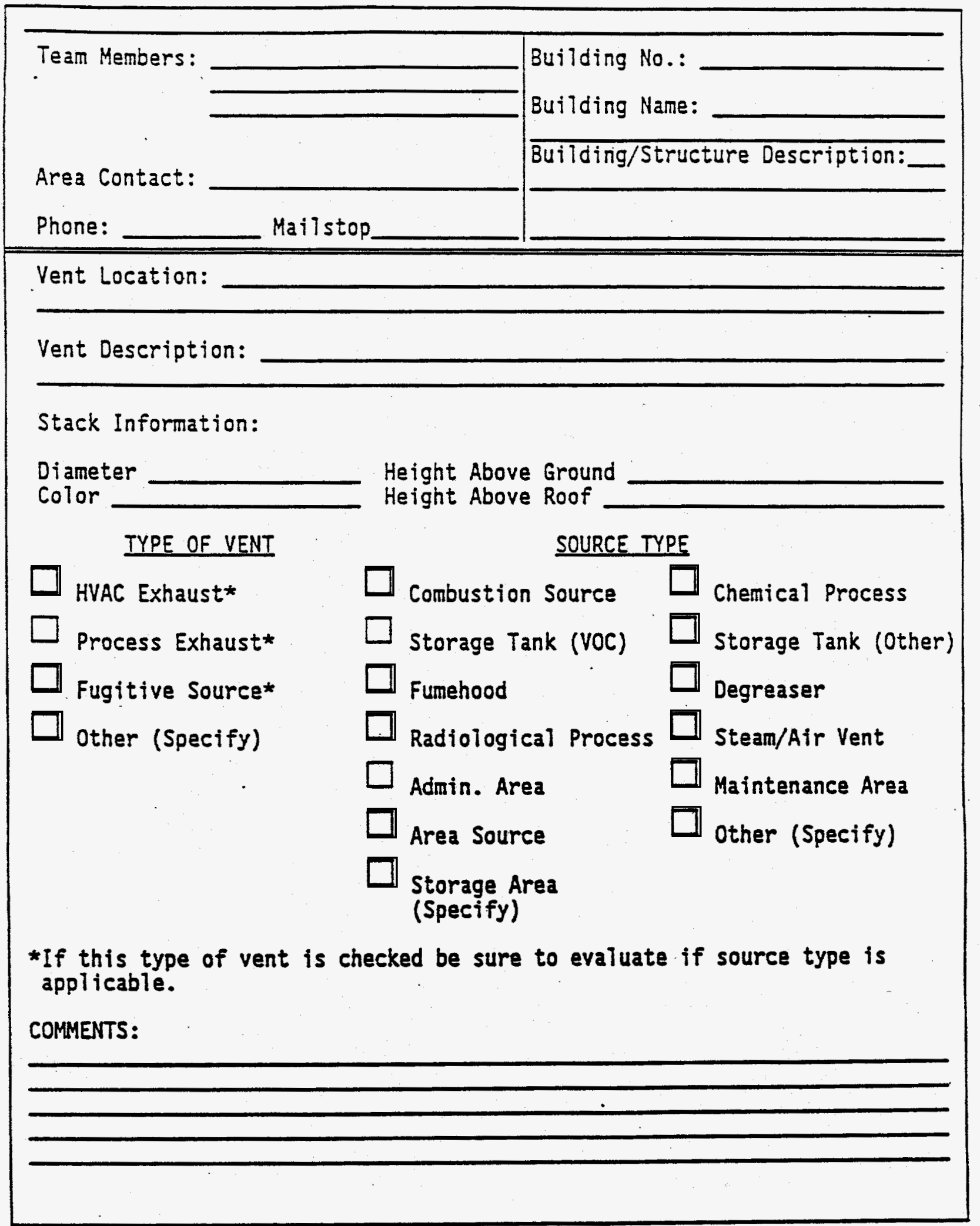

DOE/ECO REY. 1

Form 1 


\begin{tabular}{|c|c|c|}
\hline \multirow{3}{*}{$\begin{array}{l}\text { Area Contact: } \\
\text { Phone: }\end{array}$} & & \multirow{3}{*}{$\begin{array}{l}\text { Building No.: } \\
\text { Building Name: } \\
\text { Building/Structure Description: }\end{array}$} \\
\hline & & \\
\hline & _ Mailstop. & \\
\hline $\begin{array}{l}\text { Source } \\
\text { Number }\end{array}$ & $\mid \begin{array}{l}\text { Data } \\
\text { (Yes }\end{array}$ & $\begin{array}{l}\text { Description } \\
\text { (type and location) }\end{array}$ \\
\hline & & \\
\hline & & \\
\hline & & \\
\hline & & \\
\hline & & \\
\hline & & \\
\hline & & \\
\hline & & \\
\hline & & \\
\hline & & \\
\hline & & \\
\hline & & \\
\hline & & \\
\hline & & \\
\hline & & \\
\hline & & \\
\hline & & \\
\hline & & \\
\hline & & 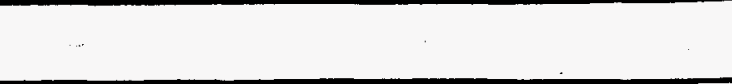 \\
\hline
\end{tabular}


DOE-ID ECO Air Emission Inventory Phase II, 1990

\begin{tabular}{|c|c|c|}
\hline ieam & Date & $\begin{array}{l}\text { Contact } \\
\text { Phone Number }\end{array}$ \\
\hline \multicolumn{3}{|c|}{ Source Number (Area - Euilding - Source Number) } \\
\hline
\end{tabular}

\section{PROCESS DATA}

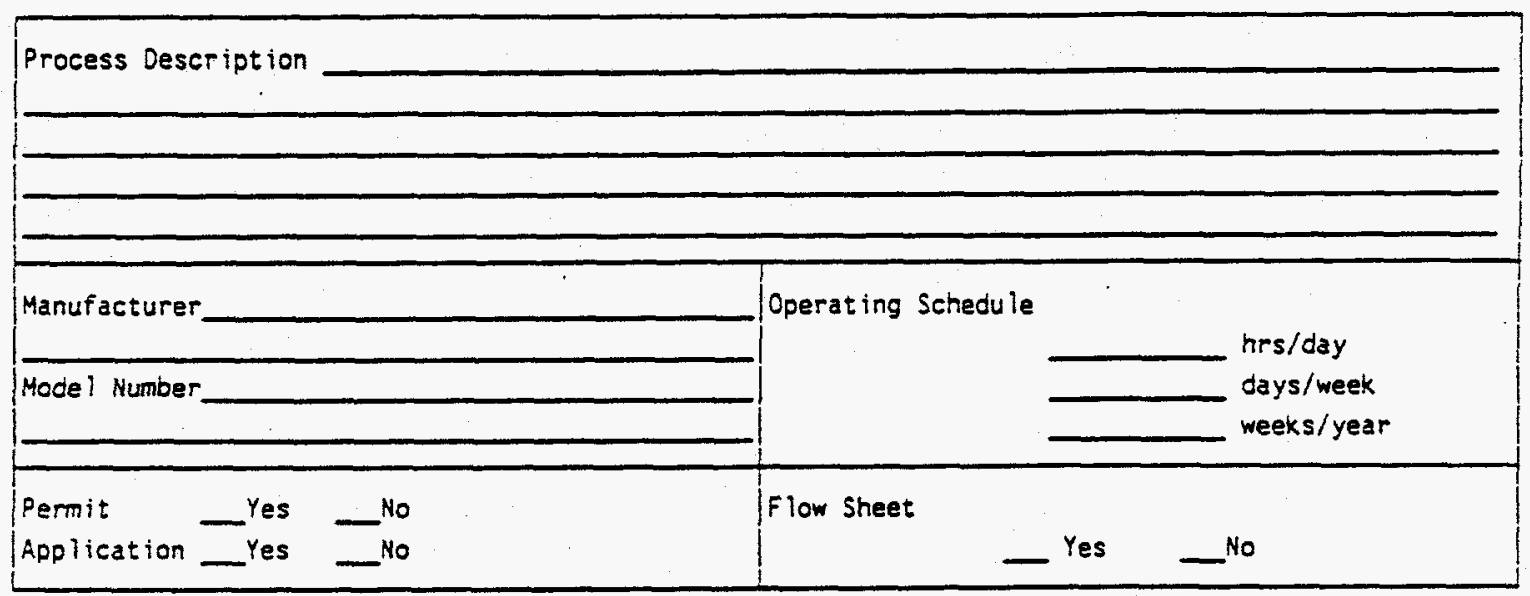

\section{STACK DATA}

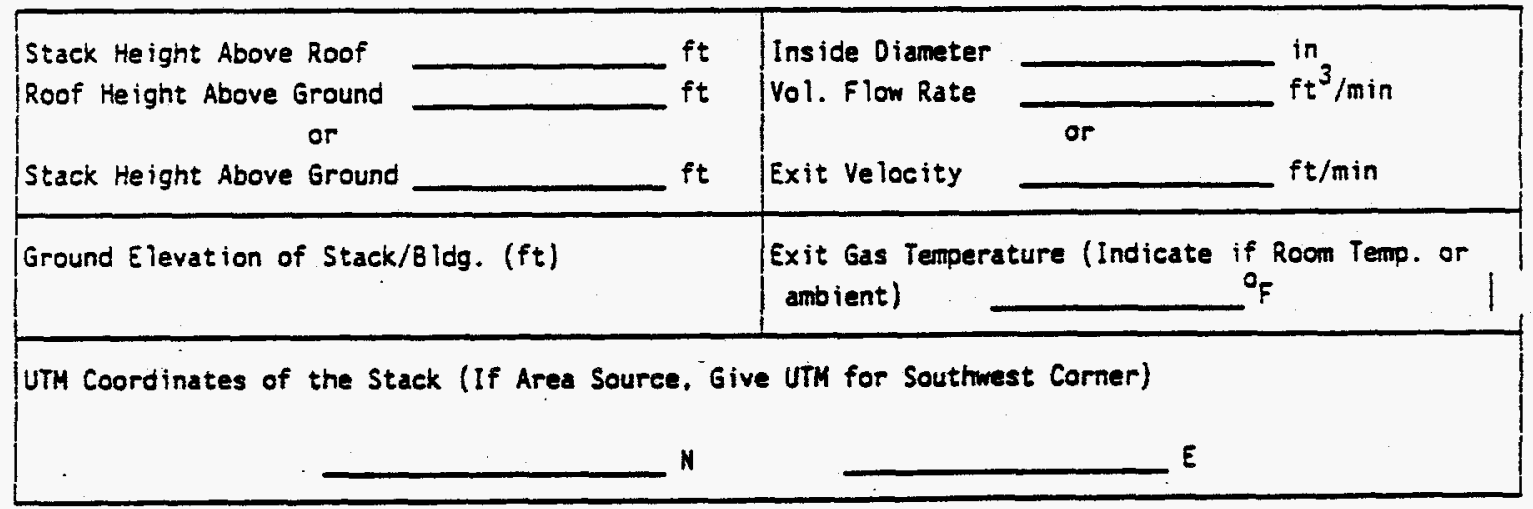

\section{DATA CATEGORY}

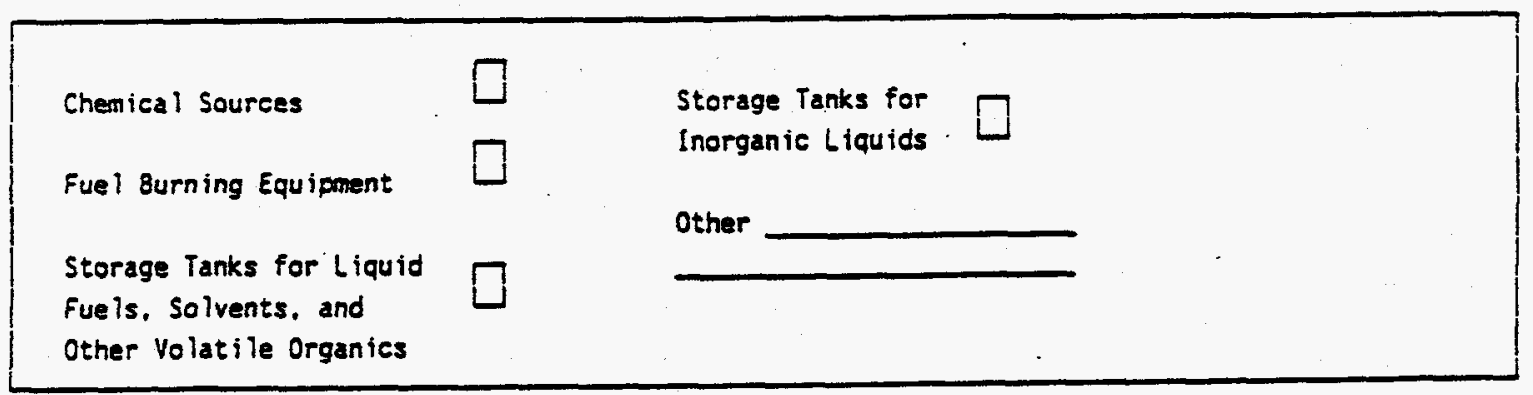


Source Number

Comments :

References (People or documents):

Prints or photos: 
DOE-IO ECO Air Emission Inventory Phase II-1990
Chemical Sources

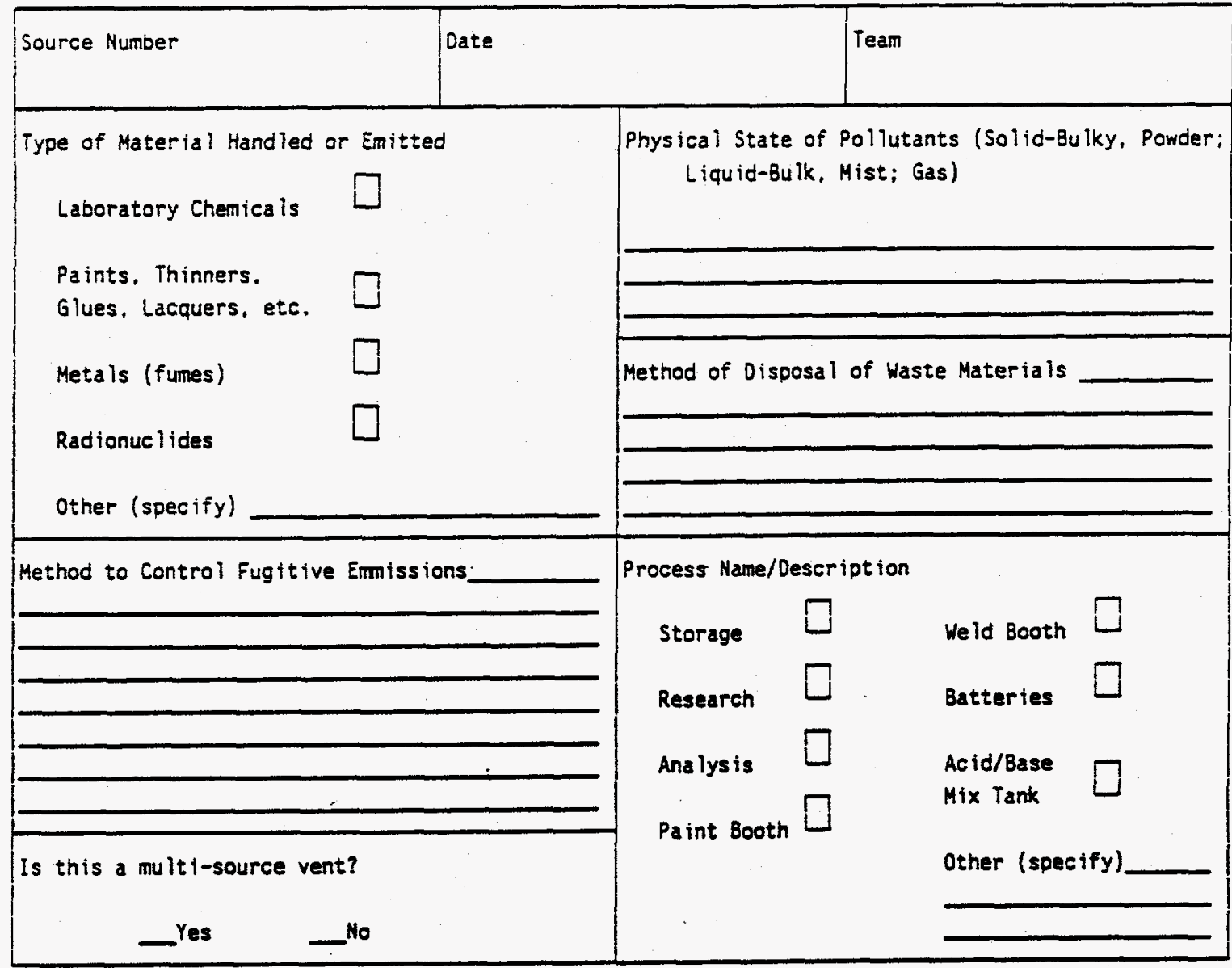




\section{DOE-ID ECO Air Emission Inventory Phase II-1990 \\ Fuel Burning Equipment}

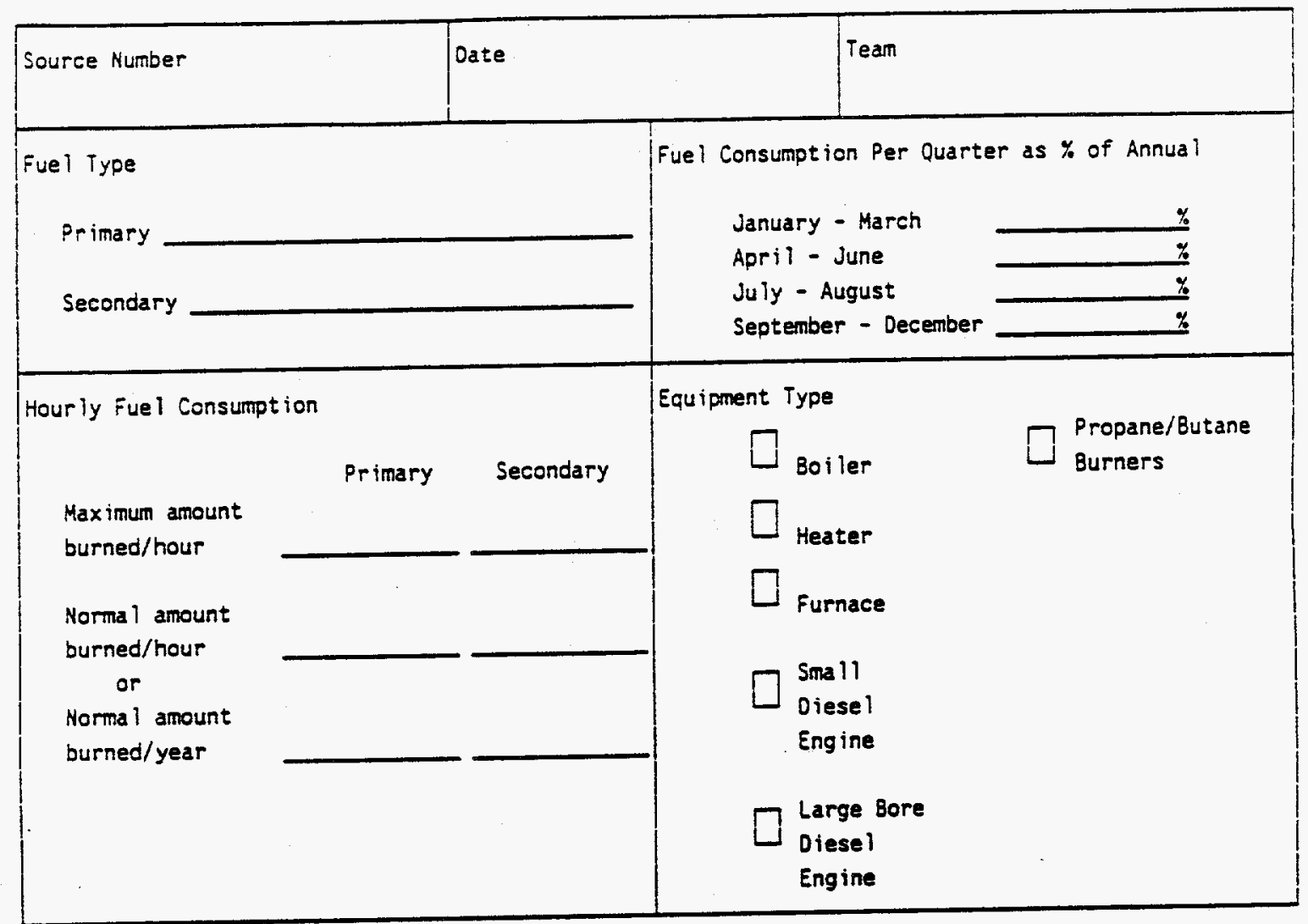




\section{DOE-ID ECO Air Emission Inventory Phase II-1990 \\ Storage Tanks for Liquid Fuels, Solvents, and Other Volatile Organic Compounds}

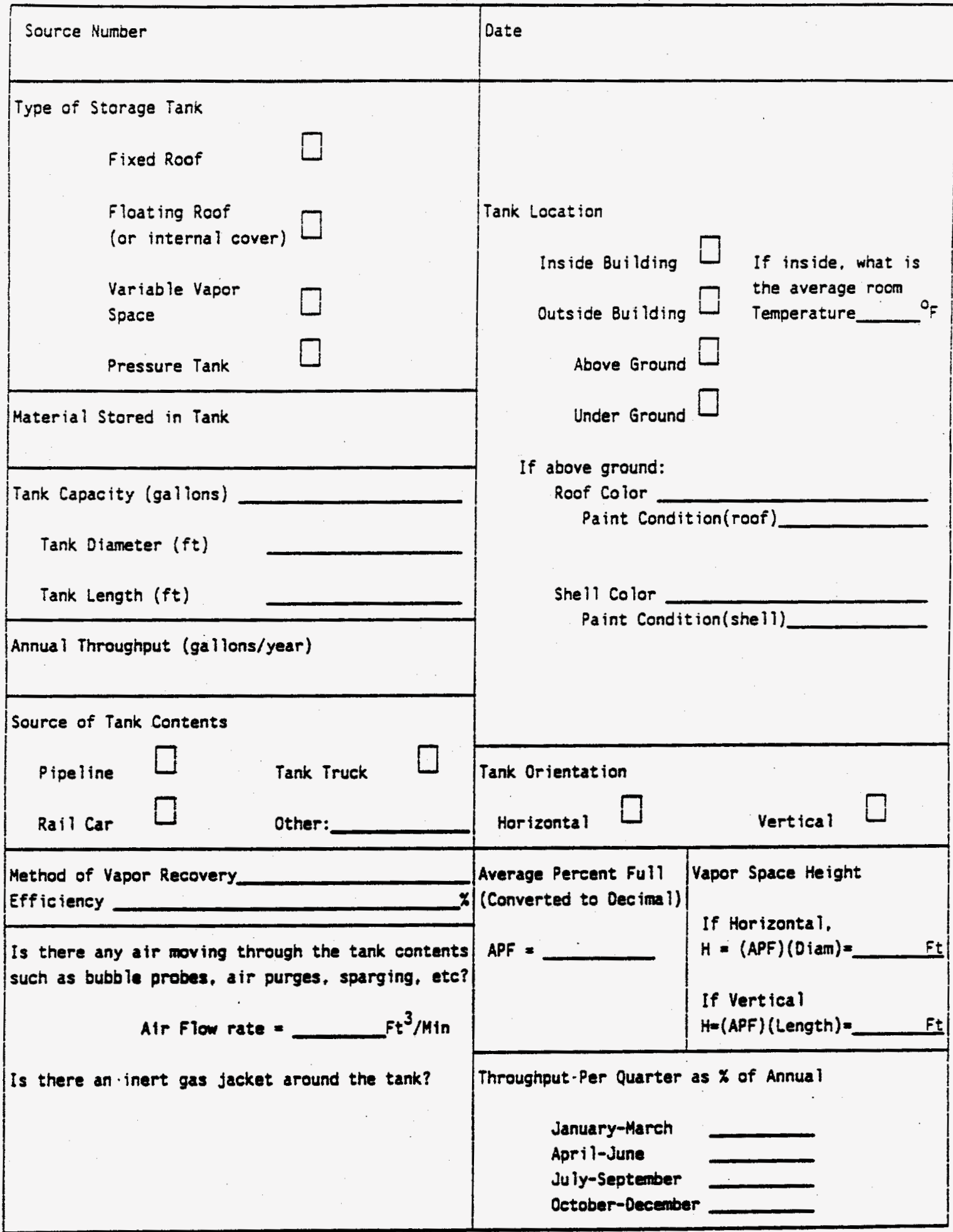




\section{DOE-ID ECO Air Emission Inventory Phase II-1990 Inorganic Storage Tanks}

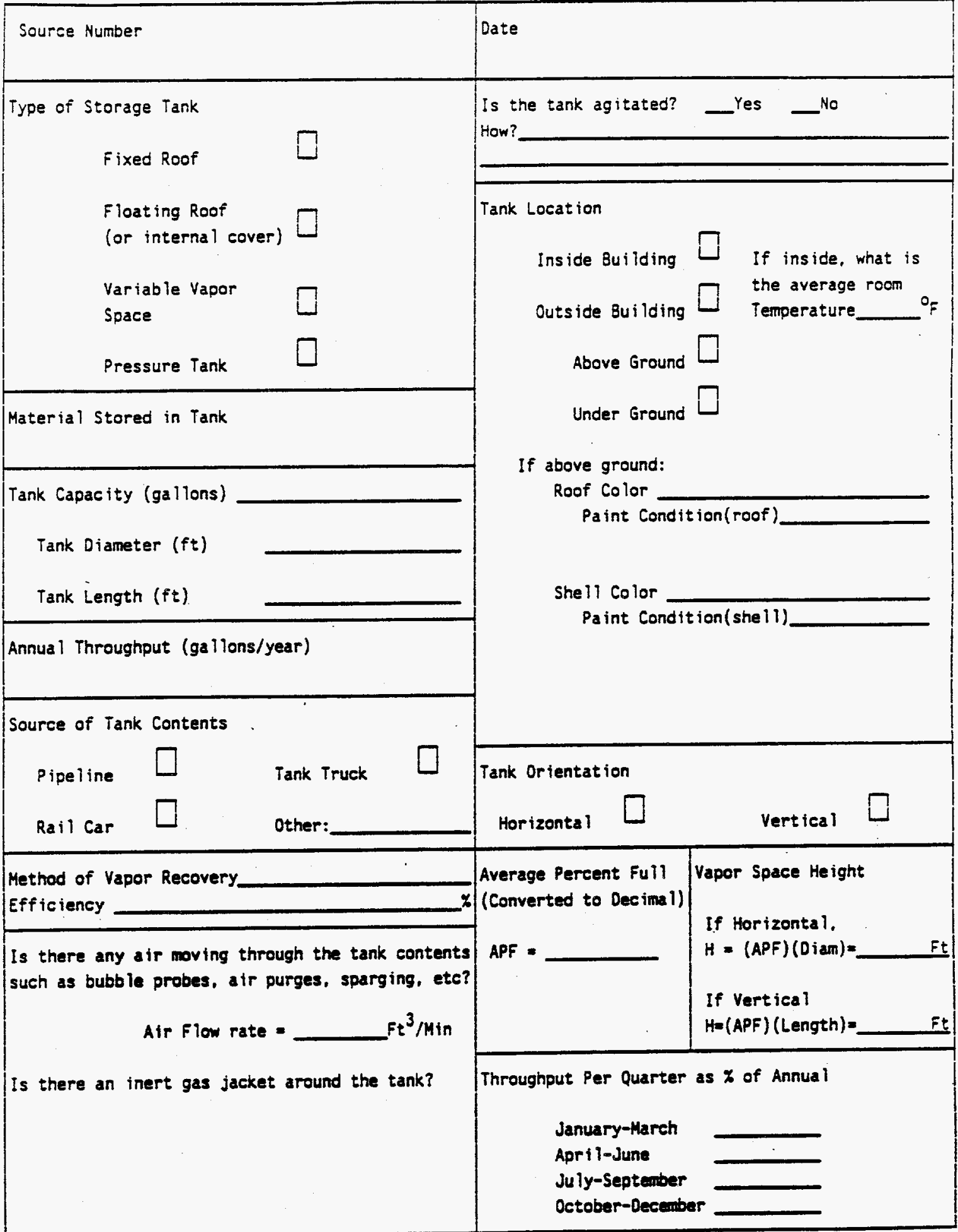


DOE-IO ECO Air Emission Inventory Phase II-1990
Laboratory Fumehood Inventory

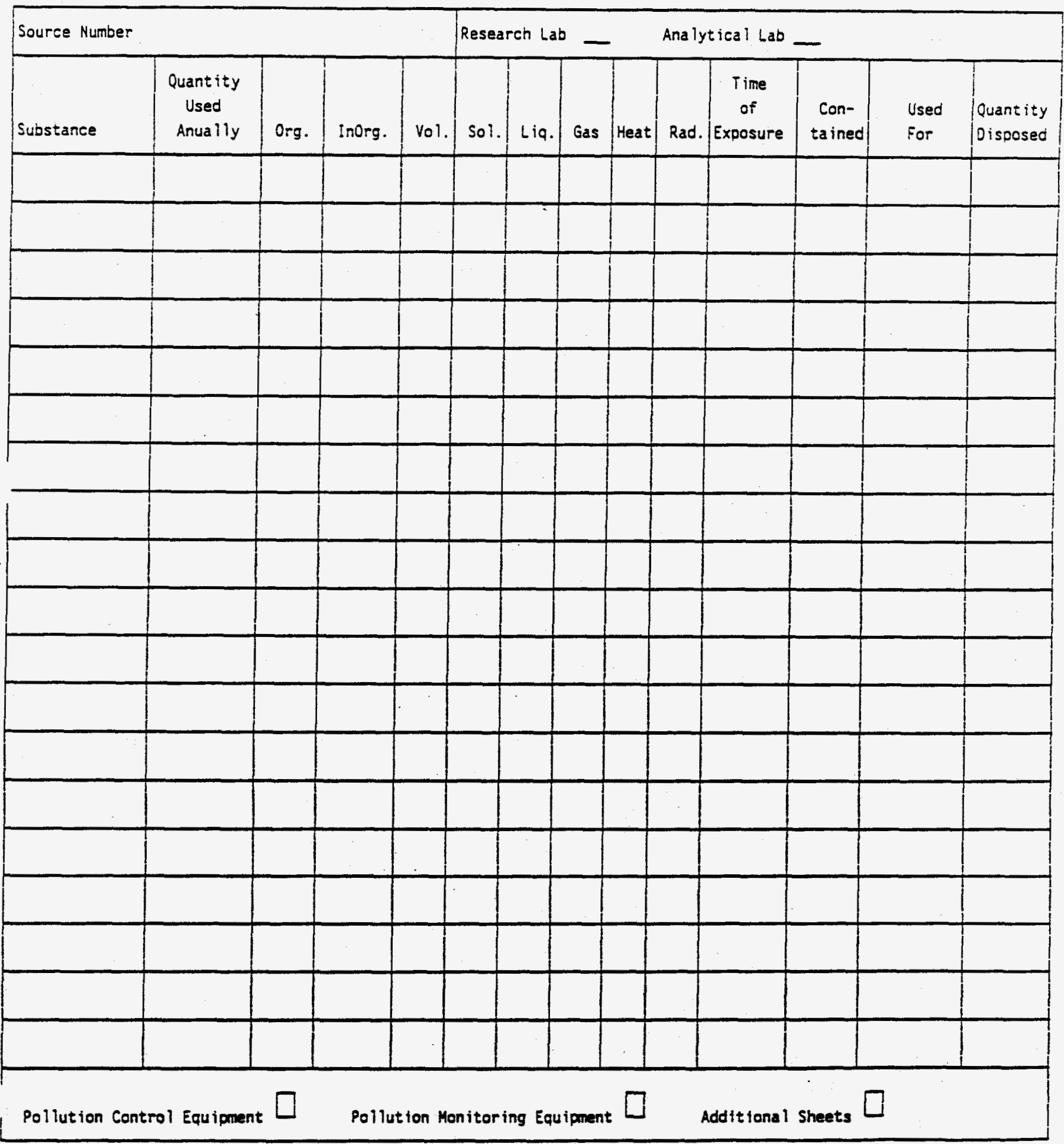


DOE-ID ECO Air Emmision Inventory Phase II-1990

Field Data Form for Surface Coating Operations (Paint Booths)

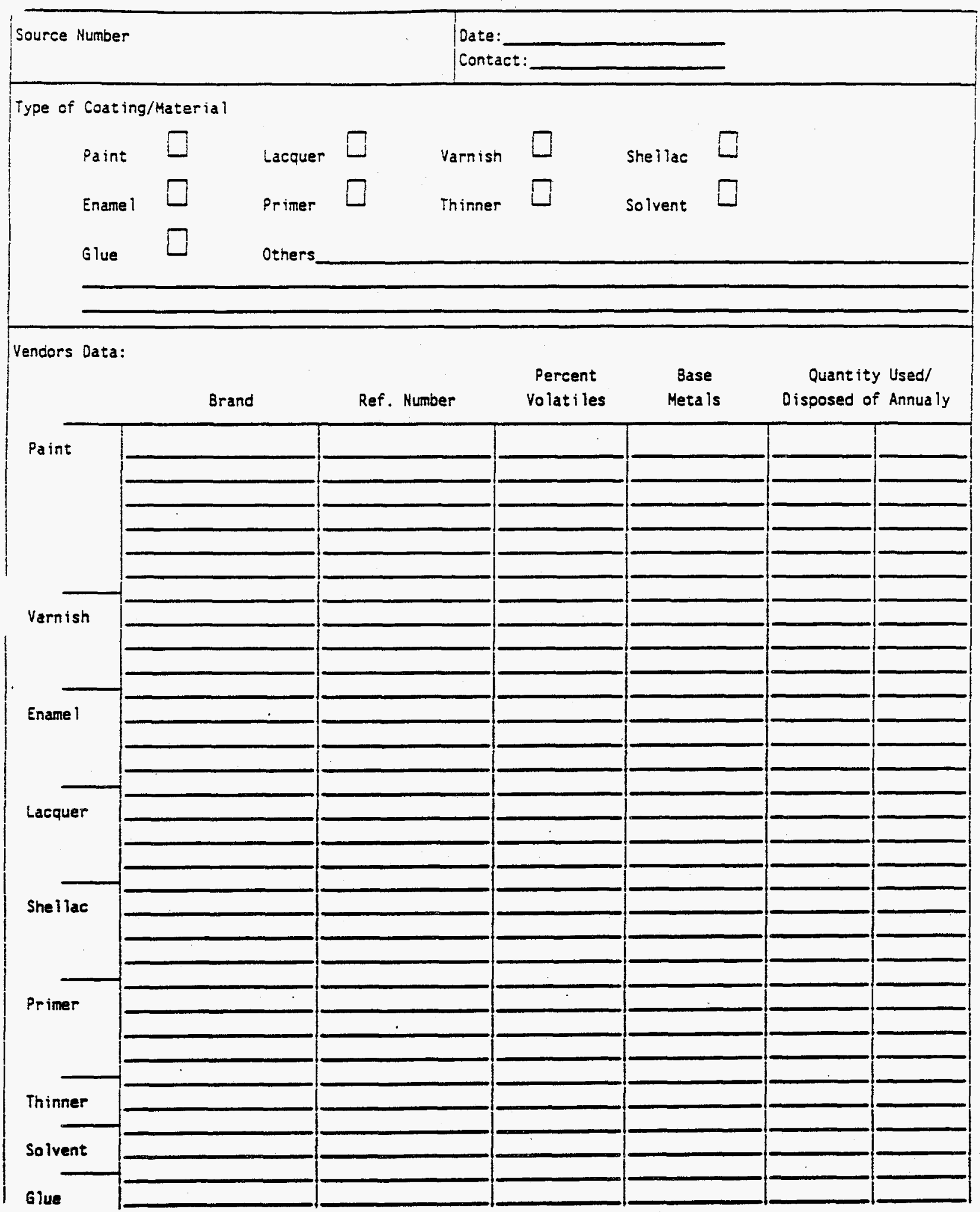

Pollution Control Equipment

Pollution Monitoring Equipment

Additional Sheets 
WELD BOOTH

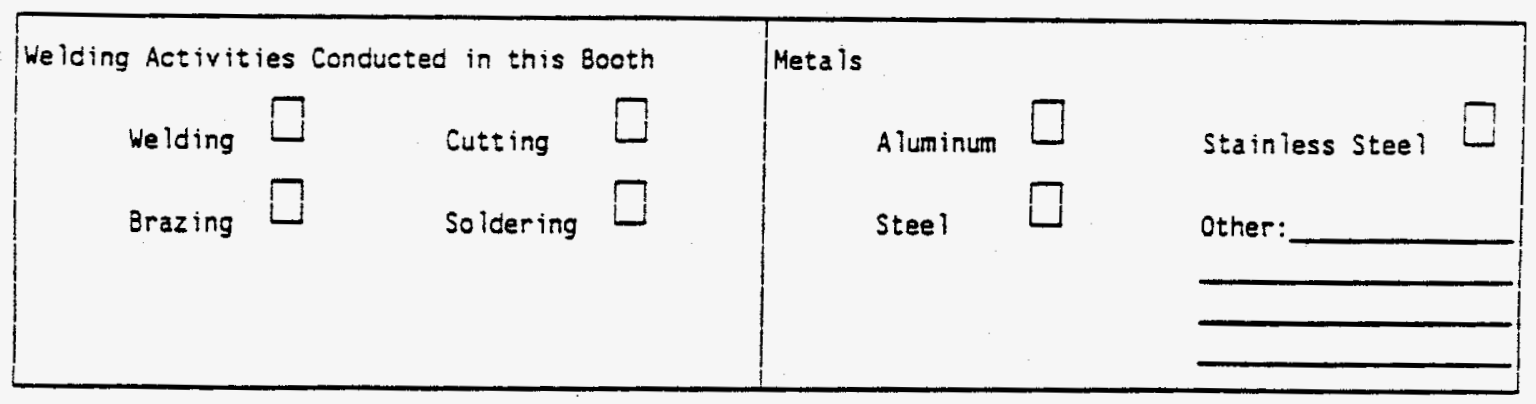

\section{BATTERIES}

\begin{tabular}{|l|l|l|}
\hline Number of Batteries & Condition of Batteries & Is exhaust powered? \\
\hline
\end{tabular}

\section{ACID/BASE MIX TANKS}

\begin{tabular}{|l|l|l|}
\hline Volume of Tank (gallons) & Is tank covered by something other than hood?/Is tank agitated? \\
\hline
\end{tabular}

Pollution Control Equipnent

Pollution Monitoring Equipment

Coments: 


\section{BOILERS}

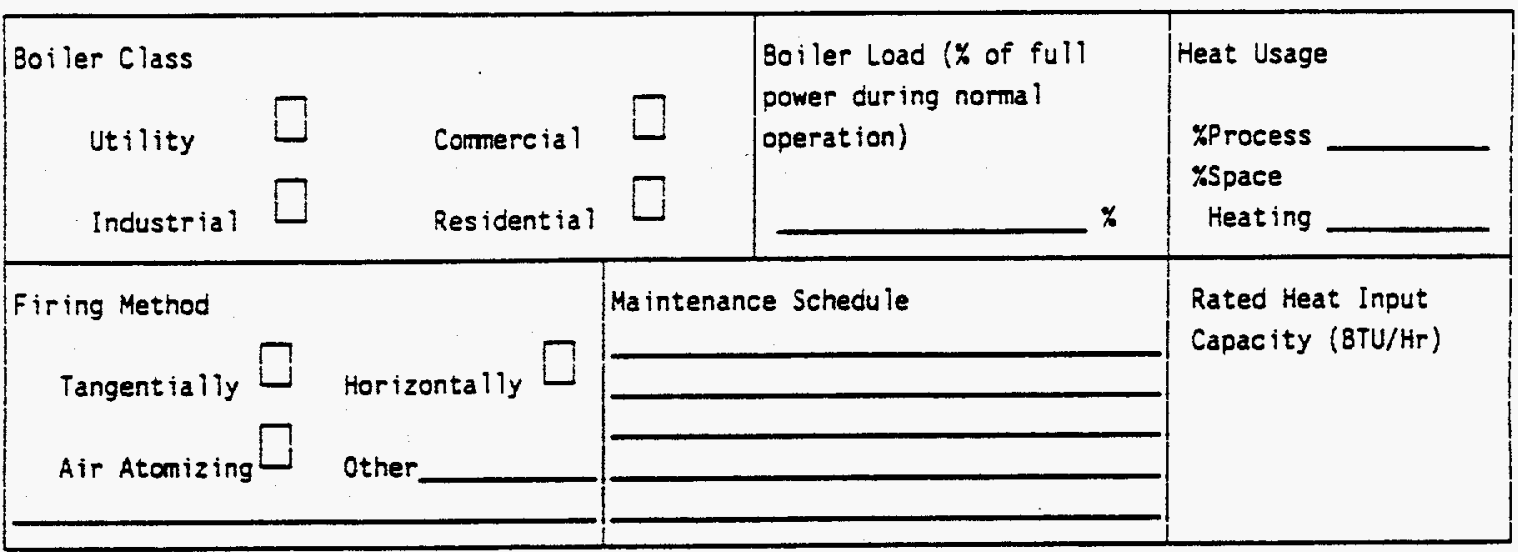

\section{GAS/DIESEL INDUSTRIAL ENGINES}

\begin{tabular}{|l|l|l|}
\hline Eng ine Horsepower & $\begin{array}{l}\text { If engine burns gasoline, is there a day tank that feeds the } \\
\text { engine? } \\
\text { Energency Use Only? }\end{array}$ If Yes, how many hours per day is the day tank full? \\
\hline Any re levant manufacturers data on releases: \\
\hline No
\end{tabular}

LARGE BORE DIESEL ENGINES (560 Cubic inch Displacenent or Larger)

\begin{tabular}{|l|l|l|}
\hline Engine Horsepowar & Emergency Oniy? & Cubic Inch Disp lacement \\
\hline Hanufacturer guaranteed releases: & Hp & In \\
\hline
\end{tabular}


DOE-ID ECO Emmision Inventory Phase II-1990

Field Data Form for Liquid Propane Combustion Sources

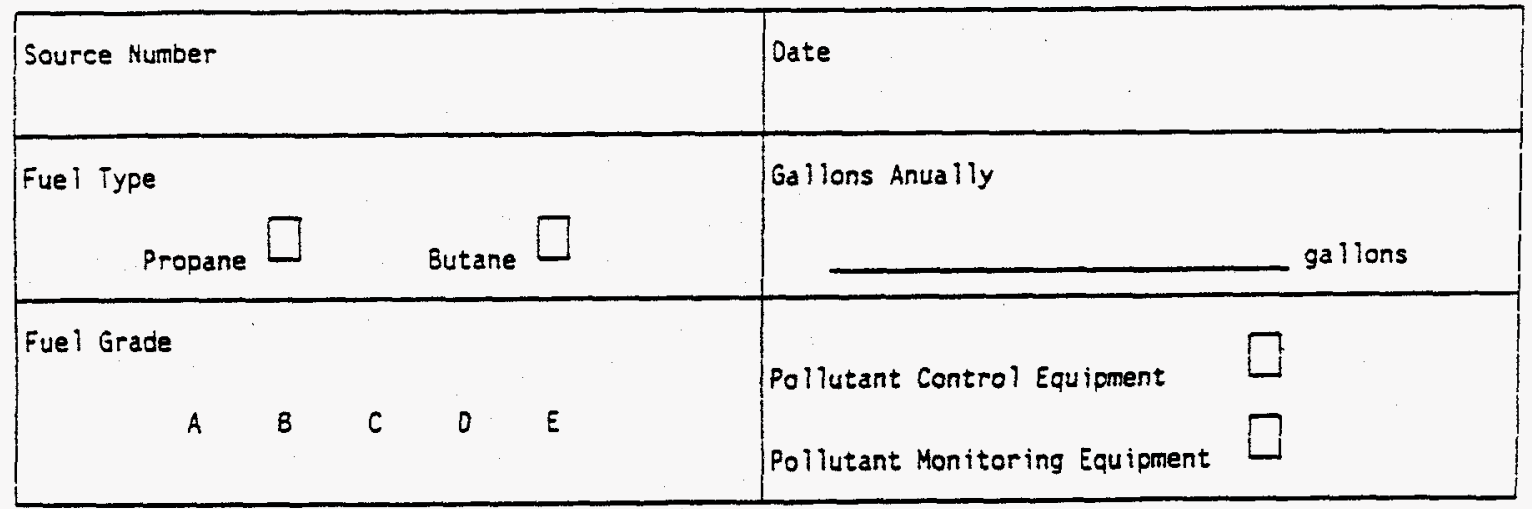




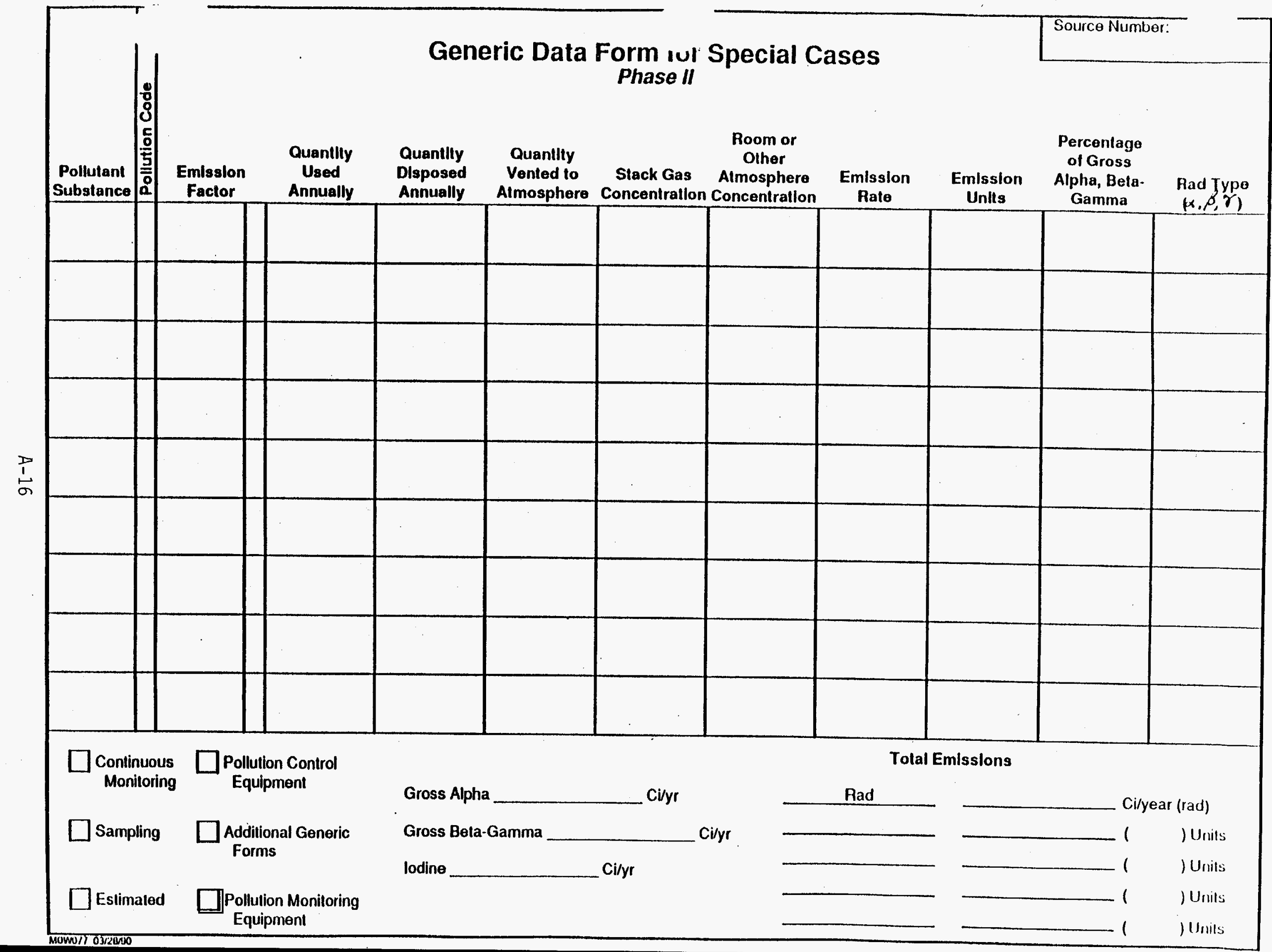


DOE-ID ECO Air Emission Inventory Phase II-1990

Pollution Control Equipment Suppliment

Source Number
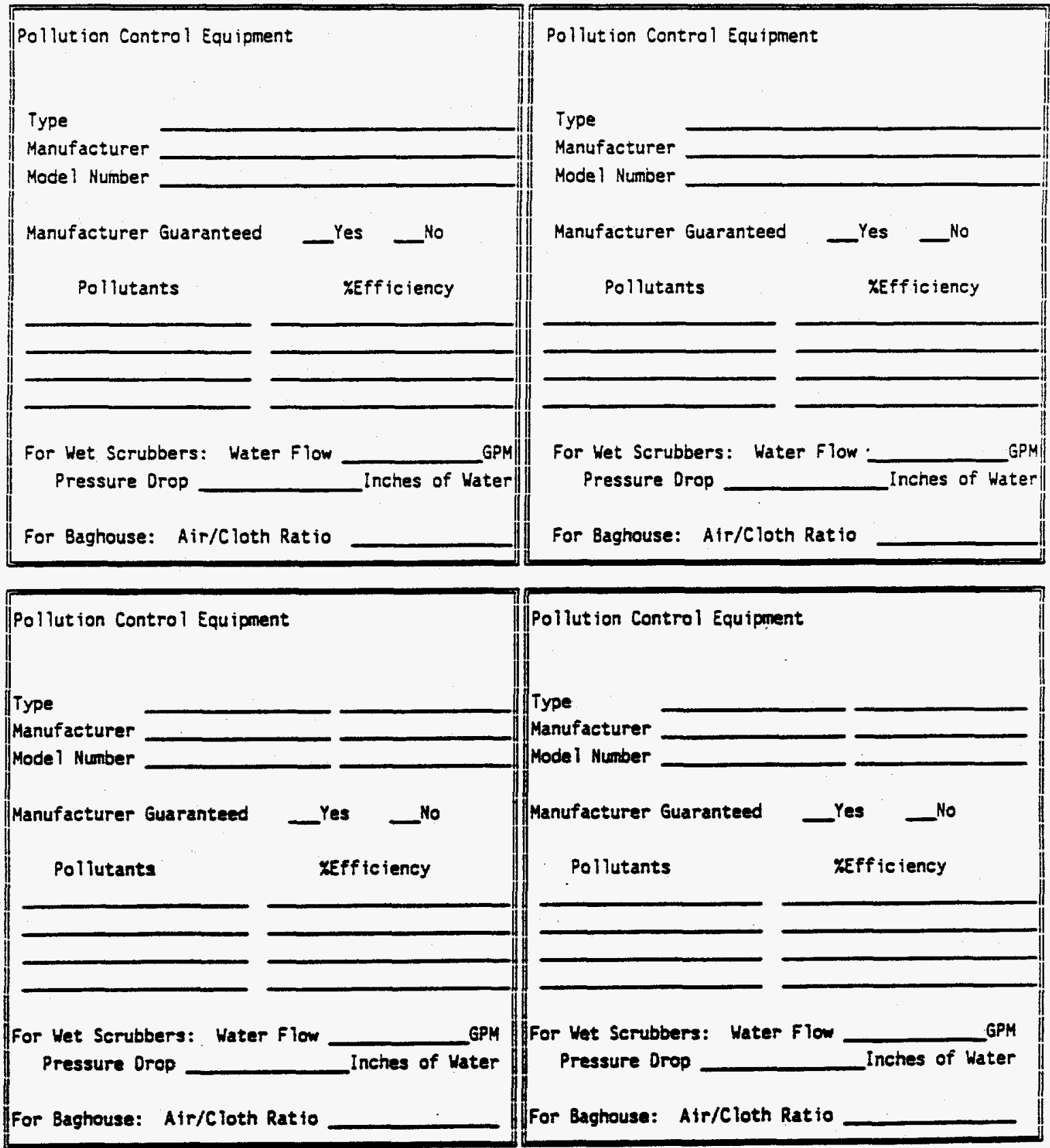
DOE-ID ECO Air Emission Inventory Phase II-1990

Pollution Monitoring Equipment Suppliment

Source Number

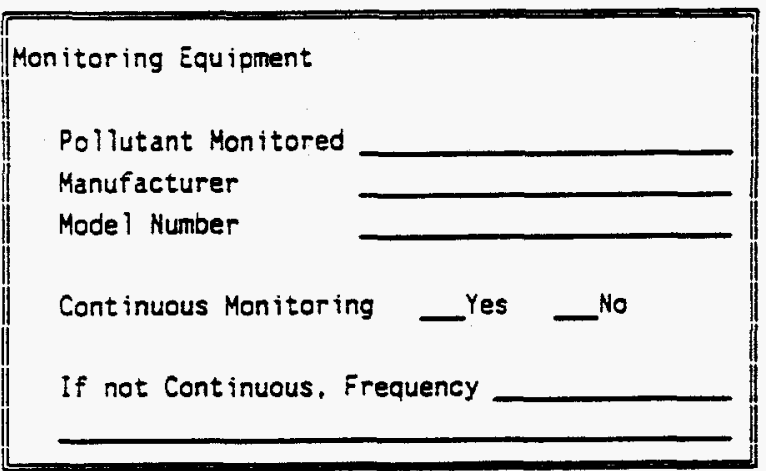

Honitoring Equipment

Pollutant Monitored

Manufacturer

Model Number

Continuous Monitoring Yes

No

If not Cont inuous. Frequency

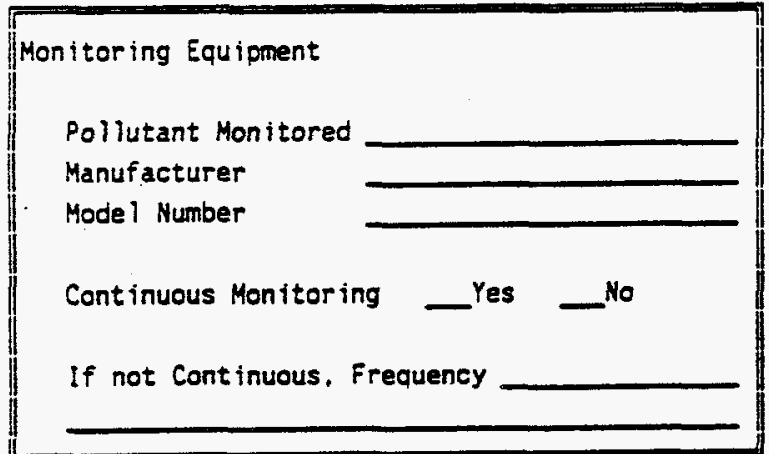

Monitoring Equipment

Pollutant Monitored

Manufacturer

Model Number

Continuous Monitoring

Yes

No

If not Continuous, Frequency
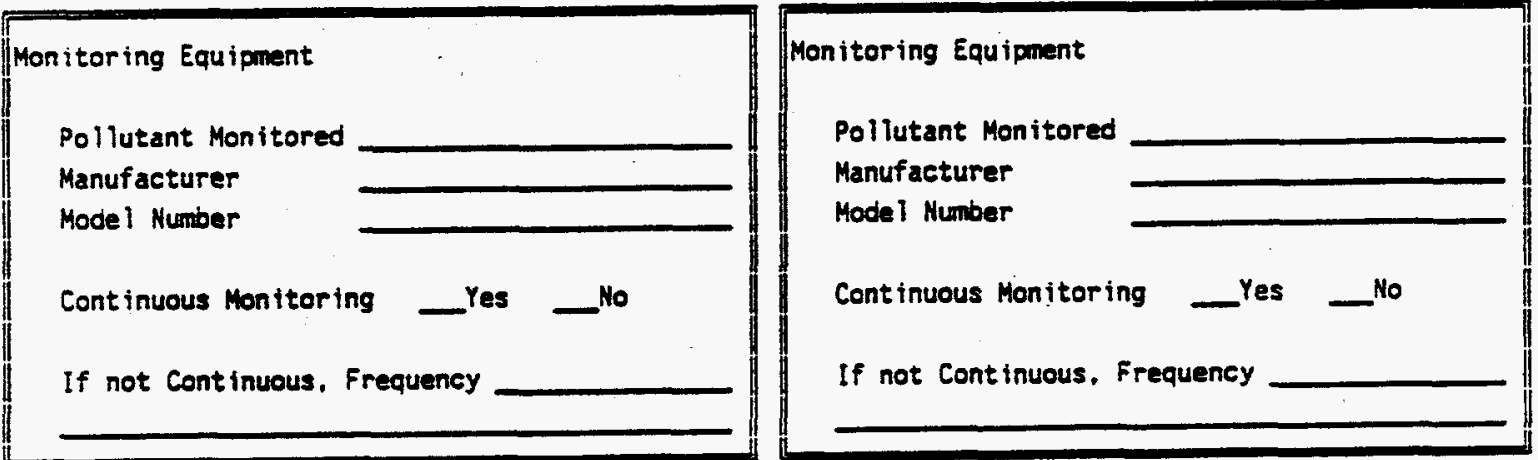


\section{Laboratory Fume Hood Suppliment}

side 2

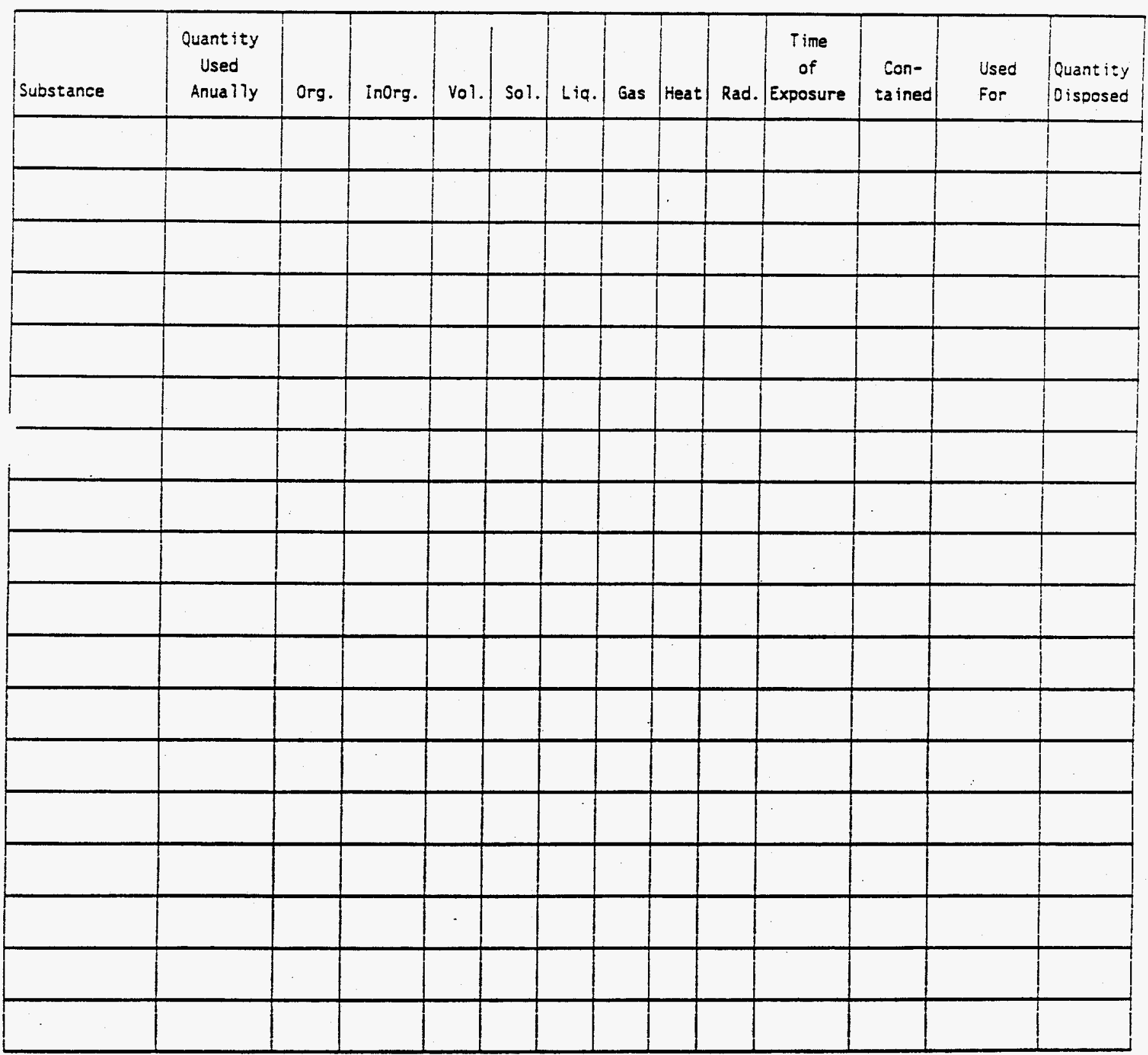

Additional Sheets $\square$ 


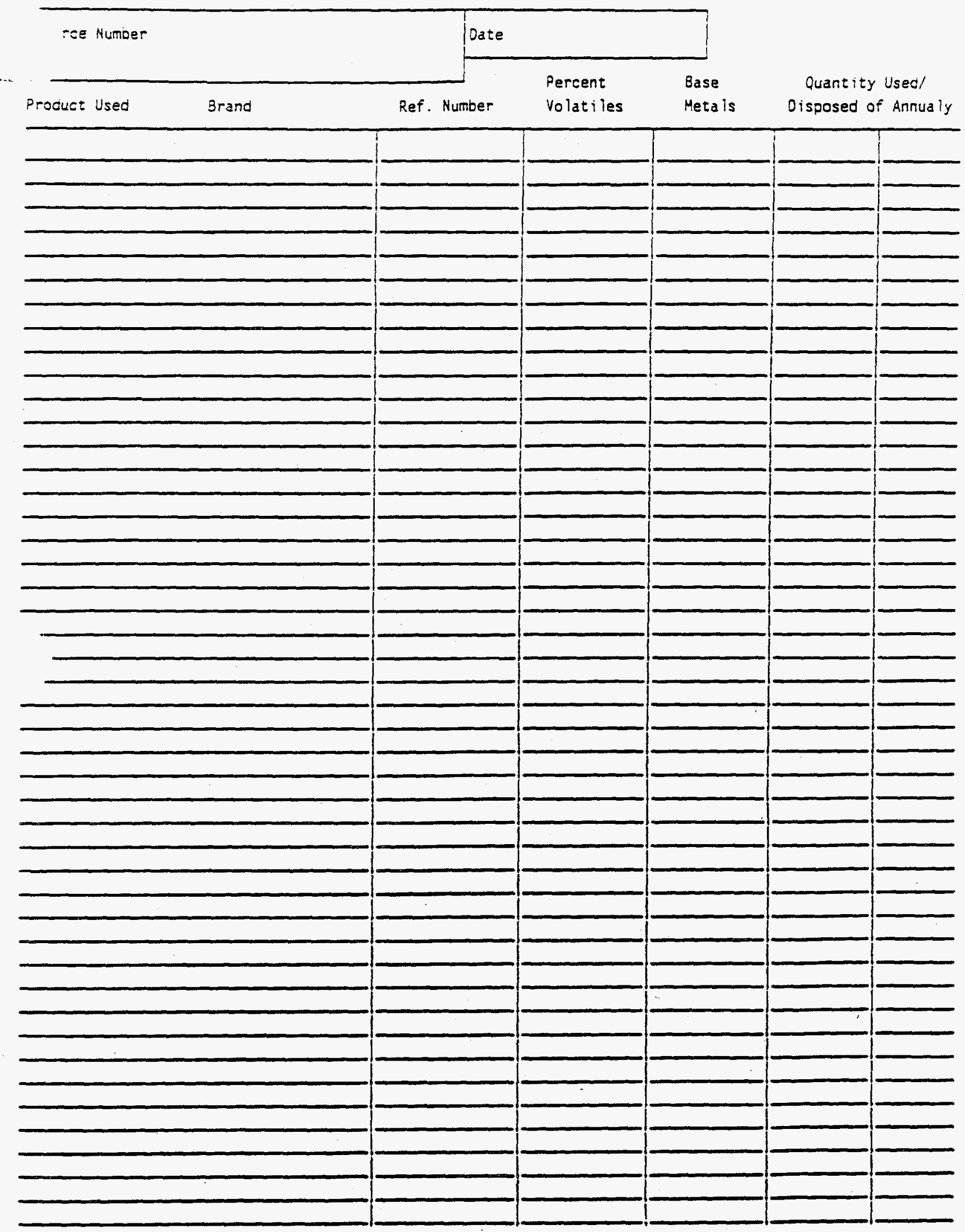


Appendix B

1993 Air Emission Inventory Emissions Tables 
B-2 


\section{Appendix B}

\section{Air Emission Inventory Emissions Tables}

This appendix presents the breakdown of emissions estimates as presented in the summary tables within the document text. The first set of tables present the summary of emissions for each pollutant for each area. The second set of tables present the ranking of the more significant sources for each pollutant. The final set of tables present the complete breakdown of the emissions for each source and area. 

SUMMARY OF CARBON MONOXIDE EMISSIONS AT THE INEL

\begin{tabular}{|c|c|c|c|c|}
\hline AREA & $\begin{array}{r}\text { ACTUAL } \\
\text { CO } \\
\text { TNS } / Y R\end{array}$ & $\begin{array}{r}\text { ACTUAL } \\
\text { CO } \\
\text { LBS/HR }\end{array}$ & $\begin{array}{r}\text { MAX } \\
\text { CO } \\
\text { TNS } / Y R\end{array}$ & LBS/HR \\
\hline $\begin{array}{l}N 1 \\
R A \\
08 \\
16 \\
21 \\
27\end{array}$ & $\begin{array}{l}E+00 \\
B E-02 \\
E E-03 \\
B E-02 \\
E-03 \\
E-04 \\
E E-01 \\
B E+02 \\
E-06 \\
E+00 \\
E-01 \\
E+00 \\
E+01 \\
E-02\end{array}$ & $\begin{array}{l}2 E+01 \\
0 E+00 \\
0 E-01 \\
3 E+00 \\
0 E-03 \\
0 E-01 \\
1 E+00 \\
2 E+02 \\
0 E-03 \\
1 E+01 \\
2 E+00 \\
2 E+01 \\
7 E+01 \\
6 E+00\end{array}$ & $\begin{array}{l}0 E+02 \\
0 E-02 \\
4 E+00 \\
6 E+01 \\
0 E-02 \\
4 E+00 \\
1 E+01 \\
9 E+03 \\
D E-03 \\
4 E+02 \\
3 E+01 \\
E+02 \\
D E+02 \\
+E+01\end{array}$ & $\begin{array}{l}1 E+01 \\
0 E+00 \\
0 E-01 \\
1 E+01 \\
O E-03 \\
O E-01 \\
S E+01 \\
1 E+02 \\
D E-03 \\
9 E+01 \\
1 E+01 \\
B E+01 \\
1 E+01 \\
3 E+00\end{array}$ \\
\hline & & $E+02$ & $E+03$ & $\mathrm{EE}+0$ \\
\hline
\end{tabular}

SUMMARY OF LEAD EMISSIONS AT THE INEL

\begin{tabular}{|c|c|c|c|c|}
\hline AREA & $\begin{array}{r}\text { ACTUAL } \\
\text { LEAD } \\
\text { TNS/YR }\end{array}$ & $\begin{array}{r}\text { ACTUAL } \\
\text { LEAD } \\
\text { LBS/HR }\end{array}$ & $\begin{array}{r}\text { MAX } \\
\text { LEAD } \\
\text { TNS/YR }\end{array}$ & $\begin{array}{r}\text { MA } \\
\text { LEA } \\
\text { LBS/H }\end{array}$ \\
\hline $\begin{array}{l}\text { ANL } \\
\text { B21 } \\
\text { CFA } \\
\text { CPP } \\
\text { NRF } \\
\text { PER } \\
\text { TAN }\end{array}$ & $\begin{array}{l}3.156 E-04 \\
3.000 E-06 \\
3.209 E-04 \\
1.162 E-03 \\
1.386 E-03 \\
2.100 E-05 \\
1.271 E-03\end{array}$ & $\begin{array}{l}6.858 E-04 \\
2.000 E-06 \\
1.043 E-02 \\
1.403 E-03 \\
2.016 E-03 \\
2.328 E-05 \\
4.736 E-04\end{array}$ & $\begin{array}{l}3.834 E-03 \\
1.100 E-05 \\
7.564 E-02 \\
2.913 E+02 \\
2.483 E-02 \\
2.624 E-04 \\
7.484 E-03\end{array}$ & $\begin{array}{l}8.75 \\
2.000 \\
1.75 \\
6.65 \\
5.670 \\
6.26 \\
1.705\end{array}$ \\
\hline & & $.503 E-02$ & & \\
\hline
\end{tabular}

SUMMARY OF NITROGEN OXIDES EMISSIONS AT THE INEL

\begin{tabular}{|c|c|c|c|c|}
\hline & $\begin{array}{r}\text { ACTUAL } \\
\text { NOX }\end{array}$ & $\begin{array}{r}\text { ACTUAL } \\
\text { NOX }\end{array}$ & $\begin{array}{r}\text { MAX } \\
\text { NOX } \\
\text { TNS } / Y R\end{array}$ & LBS \\
\hline REA & TNS/YR & LBS/HR & TNS/YR & LBS \\
\hline & 0 & 11 & $E+02$ & 1.393 \\
\hline & -03 & & 03 & \\
\hline 08 & -02 & +00 & $E+01$ & \\
\hline 16 & -02 & $E+00$ & $E+01$ & \\
\hline 327 & -03 & $=+\infty$ & 01 & \\
\hline CFA & $0 E+00$ & $E+01$ & $2.433 \mathrm{E}+02$ & \\
\hline$C P$ & $6 E+02$ & $6 \mathrm{E}+02$ & $7.681 E+03$ & 1. \\
\hline PT & $E-05$ & 1. & & \\
\hline$R F$ & +01 & +02 & 03 & \\
\hline ER & 01 & 6. & & \\
\hline A! & $E+01$ & $E+01$ & 5. & \\
\hline & $E+02$ & $P E+01$ & $E+02$ & \\
\hline & & .00 & $E+01$ & \\
\hline & & 02 & & \\
\hline
\end{tabular}


SUMMARY OF PARTICULATE EMISSIONS AT THE INEL

\begin{tabular}{|c|c|c|c|c|}
\hline AREA & $\begin{array}{l}\text { ACTUAL } \\
\text { PART. } \\
\text { TNS } / Y R\end{array}$ & $\begin{array}{l}\text { ACTUAL } \\
\text { PART. } \\
\text { LBS/HR }\end{array}$ & $\begin{array}{r}\text { MAX } \\
\text { PART. } \\
\text { TNS/YR }\end{array}$ & $\begin{array}{r}\text { MAX } \\
\text { PART. } \\
\text { LBS/HR }\end{array}$ \\
\hline & & & & \\
\hline NL & $2.536 \mathrm{E}+01$ & $1.085 E+01$ & $1.032 E+02$ & $2.412 \mathrm{E}+\mathrm{O}$ \\
\hline ARA & $2.010 E-01$ & $9.070 E+00$ & $4.020 E-01$ & $1.810 E+01$ \\
\hline B08 & $1.089 \mathrm{E}-03$ & $8.375 E-02$ & 7.337E-01 & $1.675 \mathrm{E}-01$ \\
\hline B16 & $4.580 E-03$ & $3.127 E-01$ & $2 E+00$ & $E+00$ \\
\hline B21 & OEE-06 & $2.400 \mathrm{E}$ & DE- -05 & $=-06$ \\
\hline BL & $1.089 E-04$ & $8.375 E-02$ & $7.337 E-01$ & $1.675 E-01$ \\
\hline CFA & $1.057 E+02$ & $3.287 E+01$ & $54 E+02$ & $8.405 E+01$ \\
\hline Cre & $2.637 E+00$ & $1.376 E+01$ & $75 E+02$ & $17 E+02$ \\
\hline HPTF & $0 E-06$ & $3.760 E-04$ & JOE- 03 & $00 E-04$ \\
\hline INEL & $2.299 E+02$ & $2.467 E+02$ & $0 E+02$ & $32 E+02$ \\
\hline NRF & $2.585 E+01$ & $3.238 E+01$ & $6.849 E+02$ & $27 E+02$ \\
\hline$E R$ & $4.026 E-02$ & $4.627 \mathrm{E}-01$ & $4.679 E+00$ & $1.070 E+00$ \\
\hline TAN & $2.561 E+00$ & $4.211 E+00$ & $5.507 E+01$ & $1.460 \mathrm{E}+01$ \\
\hline TRA & $E+01$ & $39 E+00$ & $E E+01$ & $1.255 \mathrm{E}+01$ \\
\hline \multirow{2}{*}{ WMF } & $=-02$ & $04 E-01$ & $3.846 E+00$ & $3.773 E-01$ \\
\hline & $4.078 E+02$ & $3.603 \mathrm{E}+02$ & $2.190 \mathrm{E}+03$ & $9.345 E+0$ \\
\hline
\end{tabular}

SUMMARY OF RAD EMISSIONS AT THE INEL

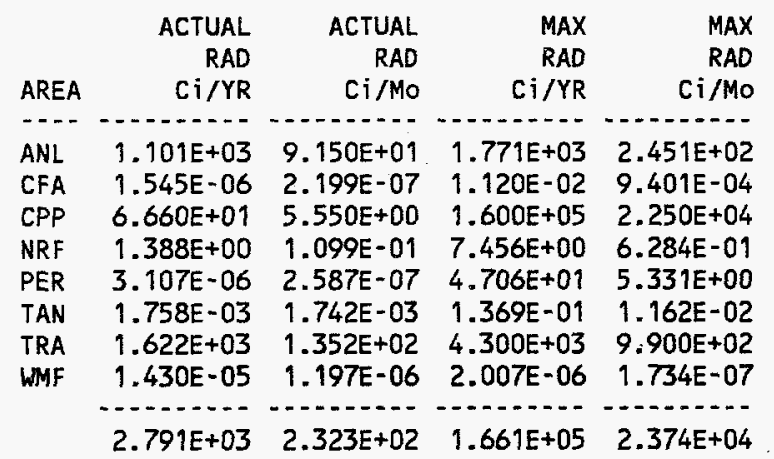

SUMMARY OF SULFUR OXIDES EMISSIONS AT THE INEL

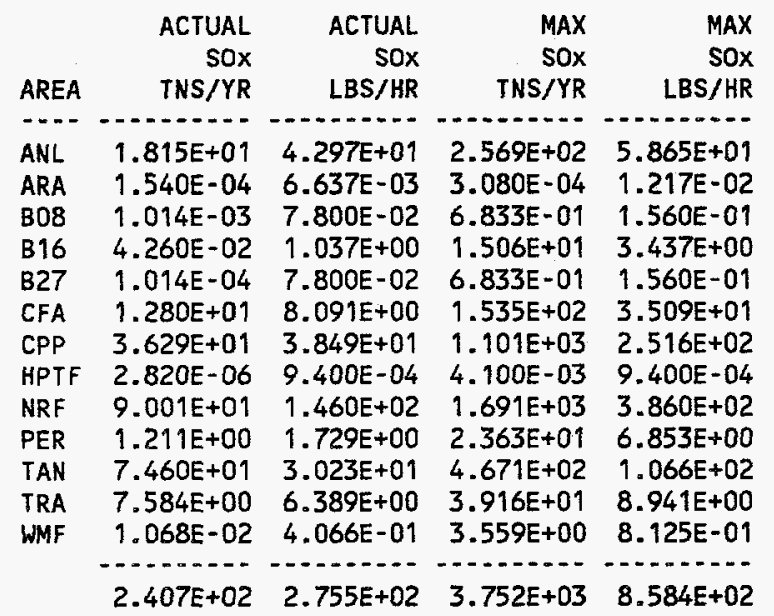


EXECUTIVE SUMMARY OF NON-METHANE VOC EMISSIONS AT THE INEL

\begin{tabular}{|c|c|c|c|c|}
\hline S & $\begin{array}{r}\text { ACTUAL } \\
\text { NON- } \\
\text { MEHTANE } \\
\text { VOC } \\
\text { TNS/YR }\end{array}$ & $\begin{array}{r}\text { ACTUAL } \\
\text { NON- } \\
\text { METHANE } \\
\text { VOC } \\
\text { LBS/HR }\end{array}$ & $\begin{array}{r}\text { MAX } \\
\text { NON- } \\
\text { MEHTANE } \\
\text { VOC } \\
\text { TNS/YR }\end{array}$ & $\begin{array}{l}\text { MAX } \\
\text { NON- } \\
\text { THANE } \\
\text { VOC } \\
\text { SS/HR }\end{array}$ \\
\hline $\begin{array}{l}10 \\
21 \\
23 \\
7\end{array}$ & $\begin{array}{l}7 E+00 \\
3 E-04 \\
7 E-03 \\
8 E-01 \\
0 E-02 \\
7 E-04 \\
3 E-04 \\
7 E+01 \\
2 E+01 \\
0 E-06 \\
3 E+00 \\
6 E-01 \\
2 E+01 \\
0 E+00 \\
6 E-02\end{array}$ & $\begin{array}{l}4 E-01 \\
8 E-01 \\
0 E-02 \\
0 E-01 \\
4 E-01 \\
6 E+02 \\
8 E+02 \\
0 E-04 \\
2 E+01 \\
7 E+00 \\
8 E+01 \\
3 E+01 \\
4 E-01\end{array}$ & $\begin{array}{l}E+01 \\
E-03 \\
E-01 \\
E+00 \\
E-01 \\
E-04 \\
E-01 \\
E+02 \\
E+02 \\
E-03 \\
E+01 \\
E+00 \\
E+01 \\
E+01 \\
E+00\end{array}$ & $\begin{array}{l}E-0 \\
E-0 \\
E+02 \\
E+02 \\
E-02 \\
E+0 \\
E+0 \\
E+0 \\
E+0\end{array}$ \\
\hline & & & $10 E+02$ & \\
\hline
\end{tabular}


DESCENDING RANK OF EMISSIONS RATES AT THE INEL

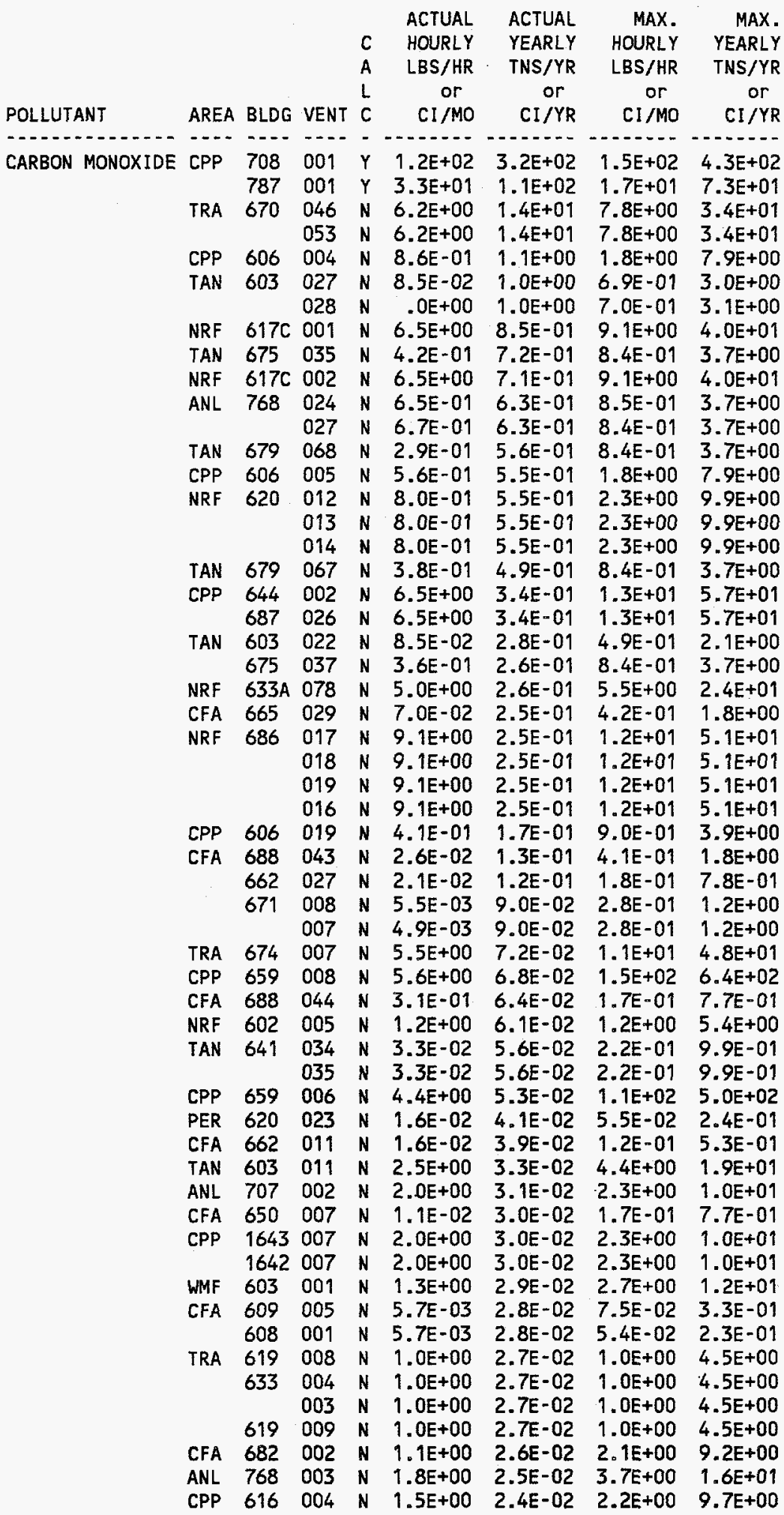


DESCENDING RANK OF EMISSIONS RATES AT THE INEL

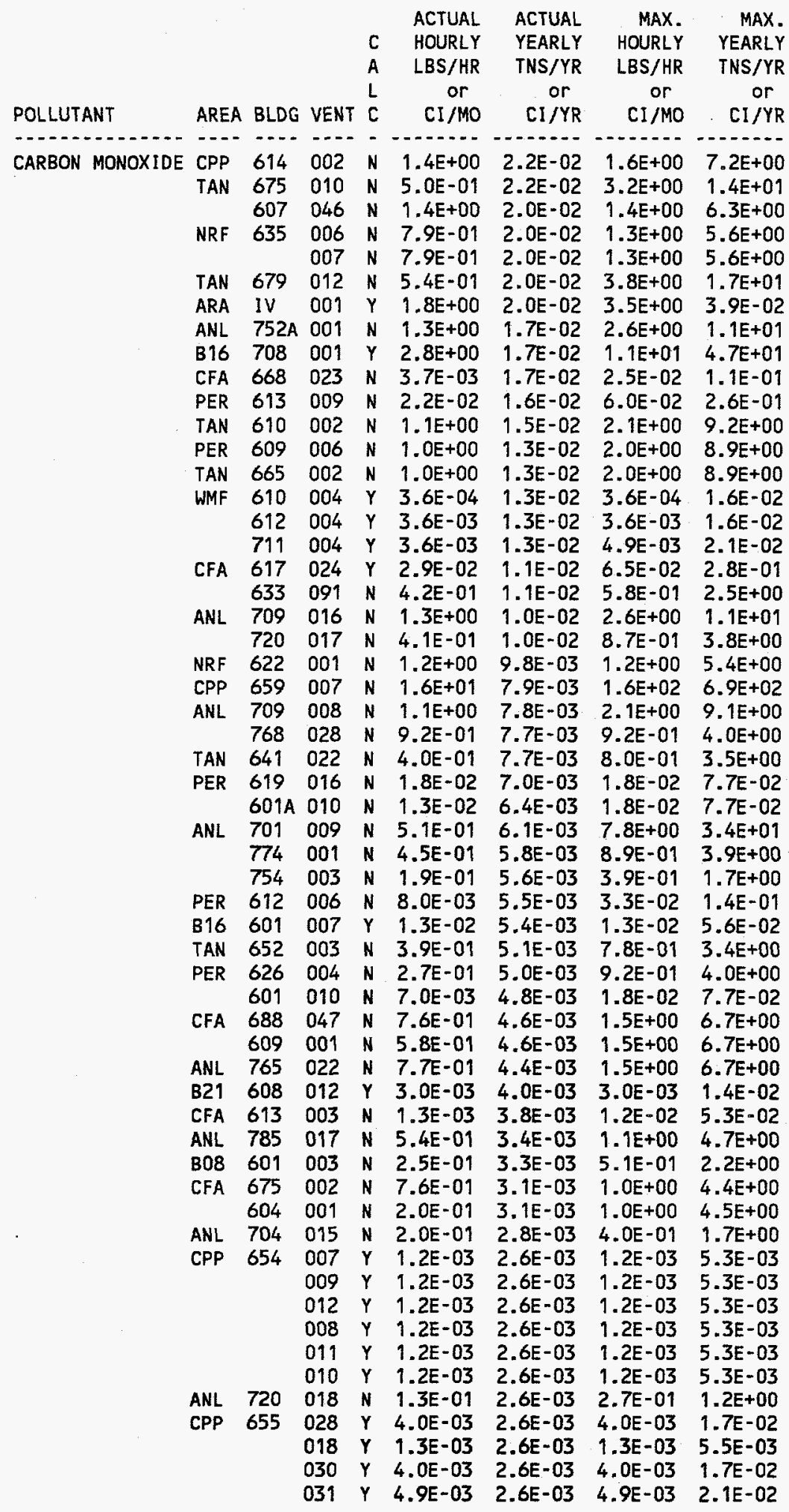


DESCENDING RANK OF EMISSIONS RATES AT THE INEL

\begin{tabular}{|c|c|c|c|c|c|c|c|c|}
\hline POLLUTANT & AREA & BLDG & VENT & C & $\begin{array}{c}\text { ACTUAL } \\
\text { HOURLY } \\
\text { LBS/HR } \\
\text { or } \\
\text { CI/MO }\end{array}$ & $\begin{array}{c}\text { ACTUAL } \\
\text { YEARLY } \\
\text { TNS/YR } \\
\text { or } \\
C I / Y R\end{array}$ & $\begin{array}{l}\text { MAX. } \\
\text { HOURLY } \\
\text { LBS/HR } \\
\text { or } \\
\text { CI/MO }\end{array}$ & $\begin{array}{l}\text { MAX. } \\
\text { YEARLY } \\
\text { TNS /YR } \\
\text { or } \\
C I / Y R\end{array}$ \\
\hline NITROGEN OXIDES & $\begin{array}{l}\text { CPP } \\
\text { TAN } \\
\text { NRF } \\
\text { TAN } \\
\\
\text { NRF } \\
\text { ANL } \\
\\
\text { TAN } \\
\text { CPP } \\
\text { TAN } \\
\text { CPP } \\
\\
\text { TAN } \\
\text { CFA } \\
\text { NRF }\end{array}$ & $\begin{array}{l}606 \\
688 \\
662 \\
671 \\
\\
674 \\
602 \\
659 \\
688 \\
659 \\
641 \\
620 \\
662 \\
681 \\
603 \\
707 \\
1643 \\
1642 \\
603 \\
633 \\
619\end{array}$ & $\begin{array}{l}001 \\
001 \\
046 \\
053 \\
014 \\
012 \\
013 \\
004 \\
028 \\
027 \\
001 \\
022 \\
035 \\
002 \\
027 \\
024 \\
068 \\
005 \\
067 \\
026 \\
002 \\
037 \\
029 \\
078 \\
019 \\
018 \\
016 \\
017 \\
019 \\
043 \\
027 \\
007 \\
008 \\
007 \\
005 \\
008 \\
044 \\
006 \\
035 \\
034 \\
023 \\
011 \\
012 \\
011 \\
002 \\
007 \\
007 \\
001 \\
004 \\
009 \\
008 \\
003 \\
007 \\
002 \\
003 \\
001 \\
005\end{array}$ & $\begin{array}{l}Y \\
Y \\
N \\
N \\
N \\
N \\
N \\
N \\
N \\
N \\
N \\
N \\
N \\
N \\
N \\
N \\
N \\
N \\
N \\
N \\
N \\
N \\
N \\
N \\
N\end{array}$ & $\begin{array}{l}1.7 E+02 \\
2.0 E+01 \\
2.4 E+01 \\
2.4 E+01 \\
8.8 E+00 \\
8.8 E+00 \\
8.8 E+00 \\
3.4 E+00 \\
.0 E+00 \\
3.4 E-01 \\
2.5 E+01 \\
9.4 E-01 \\
1.7 E+00 \\
2.5 E+01 \\
2.7 E+00 \\
2.6 E+00 \\
1.2 E+00 \\
2.3 E+00 \\
1.5 E+00 \\
2.5 E+01 \\
2.5 E+01 \\
1.4 E+00 \\
2.8 E-01 \\
1.9 E+01 \\
3.5 E+01 \\
3.5 E+01 \\
3.5 E+01 \\
3.5 E+01 \\
1.6 E+00 \\
1.0 E-01 \\
8.4 E-02 \\
2.0 E-02 \\
2.2 E-02 \\
2.5 E+01 \\
5.6 E+00 \\
2.2 E+01 \\
1.2 E+00 \\
2.0 E+01 \\
1.3 E-01 \\
1.3 E-01 \\
6.6 E-02 \\
6.6 E-02 \\
5.3 E-01 \\
1.2 E+01 \\
9.4 E+00 \\
9.4 E+00 \\
9.4 E+00 \\
6.1 E+00 \\
4.7 E+00 \\
4.7 E+00 \\
4.7 E+00 \\
4.7 E+00 \\
4.3 E-02 \\
5.2 E+00 \\
8.4 E+00 \\
2.3 E-02 \\
2.3 E-02\end{array}$ & $\begin{array}{l}4.6 E+02 \\
6.3 E+01 \\
5.3 E+01 \\
5.2 E+01 \\
6.1 E+00 \\
6.1 E+00 \\
6.1 E+00 \\
4.3 E+00 \\
4.0 E+00 \\
4.0 E+00 \\
3.3 E+00 \\
3.0 E+00 \\
2.9 E+00 \\
2.8 E+00 \\
2.5 E+00 \\
2.5 E+00 \\
2.2 E+00 \\
2.2 E+00 \\
2.0 E+00 \\
1.3 E+00 \\
1.3 E+00 \\
1.0 E+00 \\
1.0 E+00 \\
1.0 E+00 \\
9.6 E-01 \\
9.6 E-01 \\
9.6 E-01 \\
9.6 E-01 \\
7.0 E-01 \\
5.1 E-01 \\
4.7 E-01 \\
3.6 E-01 \\
3.6 E-01 \\
3.3 E-01 \\
2.8 E-01 \\
2.6 E-01 \\
2.6 E-01 \\
2.4 E-01 \\
2.2 E-01 \\
2.2 E-01 \\
1.6 E-01 \\
1.6 E-01 \\
1.5 E-01 \\
1.5 E-01 \\
1.4 E-01 \\
1.4 E-01 \\
1.4 E-01 \\
1.3 E-01 \\
1.2 E-01 \\
1.2 E-01 \\
1.2 E-01 \\
1.2 E-01 \\
1.2 E-01 \\
1.2 E-01 \\
1.2 E-01 \\
1.1 E-01 \\
1.1 E-01\end{array}$ & $\begin{array}{l}3.9 E+02 \\
1.0 E+02 \\
3.0 E+01 \\
3.0 E+01 \\
2.5 E+01 \\
2.5 E+01 \\
2.5 E+01 \\
7.2 E+00 \\
2.8 E+00 \\
2.8 E+00 \\
3.5 E+01 \\
5.3 E+00 \\
3.3 E+00 \\
3.5 E+01 \\
3.4 E+00 \\
3.4 E+00 \\
3.3 E+00 \\
7.2 E+00 \\
3.3 E+00 \\
5.0 E+01 \\
5.0 E+01 \\
3.3 E+00 \\
1.7 E+00 \\
2.1 E+01 \\
4.5 E+01 \\
4.5 E+01 \\
4.5 E+01 \\
4.5 E+01 \\
3.6 E+00 \\
1.6 E+00 \\
7.1 E-01 \\
1.1 E+00 \\
1.1 E+00 \\
5.1 E+01 \\
5.6 E+00 \\
5.6 E+02 \\
7.0 E-01 \\
5.2 E+02 \\
9.0 E-01 \\
9.0 E-01 \\
2.2 E-01 \\
4.8 E-01 \\
.0 E+00 \\
2.0 E+01 \\
1.1 E+01 \\
1.0 E+01 \\
1.0 E+01 \\
1.2 E+01 \\
4.7 E+00 \\
4.7 E+00 \\
4.7 E+00 \\
4.7 E+00 \\
7.0 E-01 \\
9.6 E+00 \\
1.7 E+01 \\
2.1 E-01 \\
3.0 E-01\end{array}$ & $\begin{array}{l}1.7 \mathrm{E}+03 \\
4.5 \mathrm{E}+02 \\
1.3 \mathrm{E}+02 \\
1.3 \mathrm{E}+02 \\
1.1 \mathrm{E}+02 \\
1.1 \mathrm{E}+02 \\
1.1 \mathrm{E}+02 \\
3.2 \mathrm{E}+01 \\
1.2 \mathrm{E}+01 \\
1.2 \mathrm{E}+01 \\
1.5 \mathrm{E}+02 \\
2.3 \mathrm{E}+01 \\
1.5 \mathrm{E}+01 \\
1.5 \mathrm{E}+02 \\
1.5 \mathrm{E}+01 \\
1.5 \mathrm{E}+01 \\
1.5 \mathrm{E}+01 \\
3.2 \mathrm{E}+01 \\
1.5 \mathrm{E}+01 \\
2.2 \mathrm{E}+02 \\
2.2 \mathrm{E}+02 \\
1.5 \mathrm{E}+01 \\
7.3 \mathrm{E}+00 \\
9.3 \mathrm{E}+01 \\
2.0 \mathrm{E}+02 \\
2.0 \mathrm{E}+02 \\
2.0 \mathrm{E}+02 \\
2.0 \mathrm{E}+02 \\
1.6 \mathrm{E}+01 \\
7.1 \mathrm{E}+00 \\
3.1 \mathrm{E}+00 \\
4.9 \mathrm{E}+00 \\
4.9 \mathrm{E}+00 \\
2.2 \mathrm{E}+02 \\
2.5 \mathrm{E}+01 \\
2.5 \mathrm{E}+03 \\
3.1 \mathrm{E}+00 \\
2.3 \mathrm{E}+03 \\
3.9 \mathrm{E}+00 \\
3.9 \mathrm{E}+00 \\
9.6 \mathrm{E}-01 \\
2.1 \mathrm{E}+00 \\
1.0 \mathrm{E}+01 \\
8.8 \mathrm{E}+01 \\
4.7 \mathrm{E}+01 \\
4.6 \mathrm{E}+01 \\
4.6 \mathrm{E}+01 \\
5.3 \mathrm{E}+01 \\
2.1 \mathrm{E}+01 \\
2.1 \mathrm{E}+01 \\
3.4 \mathrm{E}+01 \\
1.3 \mathrm{E}+001 \\
1.3 \mathrm{E}+00\end{array}$ \\
\hline
\end{tabular}


DESCENDING RANK OF EMISSIONS RATES AT THE INEL

\begin{tabular}{|c|c|c|c|c|c|c|c|c|}
\hline POLLUTANT & AREA & BLDG & VENT & $\begin{array}{l}C \\
A \\
L \\
C\end{array}$ & $\begin{array}{c}\text { ACTUAL } \\
\text { HOURLY } \\
\text { LBS/HR } \\
\text { or } \\
\mathrm{CI} / \mathrm{MO}\end{array}$ & $\begin{array}{c}\text { ACTUAL } \\
\text { YEARLY } \\
\text { TNS/YR } \\
\text { or } \\
\mathrm{CI} / \mathrm{YR} \\
\end{array}$ & $\begin{array}{l}\text { MAX. } \\
\text { HOURLY } \\
\text { LBS/HR } \\
\text { or } \\
\text { CI } / \text { MO }\end{array}$ & $\begin{array}{c}\text { MAX. } \\
\text { YEARLY } \\
\text { TNS } / Y R \\
\text { or } \\
\text { CI/YR } \\
-.--\end{array}$ \\
\hline NITROGEN OXIDES & $\begin{array}{l}\text { CPP } \\
\text { TAN } \\
\text { CPP } \\
\text { TAN } \\
\text { NRF } \\
\text { TAN } \\
\text { NRF } \\
\text { TAN } \\
\text { ANL } \\
\text { TAN } \\
\text { CFA } \\
\text { PER } \\
\text { WMF }\end{array}$ & $\begin{array}{l}616 \\
607 \\
614 \\
675 \\
635 \\
607 \\
635 \\
679 \\
752 A \\
610 \\
668 \\
613 \\
610 \\
612 \\
711 \\
609 \\
665 \\
617 \\
633 \\
720 \\
622 \\
709 \\
768 \\
641 \\
709 \\
701 \\
774 \\
754 \\
601 A \\
619 \\
652 \\
626 \\
612 \\
625 \\
609 \\
688 \\
765 \\
601 \\
601 \\
785 \\
601 \\
604 \\
675 \\
613 \\
704 \\
654\end{array}$ & $\begin{array}{l}004 \\
119 \\
002 \\
010 \\
007 \\
046 \\
006 \\
012 \\
001 \\
002 \\
023 \\
009 \\
004 \\
004 \\
004 \\
006 \\
002 \\
024 \\
091 \\
017 \\
001 \\
016 \\
028 \\
022 \\
008 \\
009 \\
001 \\
003 \\
010 \\
016 \\
003 \\
004 \\
006 \\
009 \\
001 \\
047 \\
022 \\
007 \\
010 \\
017 \\
003 \\
001 \\
002 \\
003 \\
015 \\
012 \\
010 \\
008 \\
007 \\
009 \\
011 \\
018 \\
019 \\
026 \\
028 \\
030 \\
031\end{array}$ & $\begin{array}{l}N \\
Y \\
N \\
N \\
N \\
N \\
N \\
N \\
N \\
N \\
N \\
N \\
Y \\
Y \\
Y \\
N \\
N \\
Y \\
N \\
N \\
N \\
N \\
N \\
N \\
N \\
N \\
N \\
N \\
N \\
N \\
N \\
N \\
N \\
Y \\
N \\
N \\
N \\
Y \\
N \\
N \\
N \\
N\end{array}$ & $\begin{array}{l}7.0 \mathrm{E}+00 \\
1.0 \mathrm{E}-01 \\
6.6 \mathrm{E}+00 \\
2.3 \mathrm{E}+00 \\
3.6 \mathrm{E}+00 \\
6.6 \mathrm{E}+00 \\
3.6 \mathrm{E}+00 \\
2.5 \mathrm{E}+00 \\
6.1 \mathrm{E}+00 \\
5.2 \mathrm{E}+00 \\
1.5 \mathrm{E}-02 \\
8.6 \mathrm{E}-02 \\
1.8 \mathrm{E}-03 \\
1.8 \mathrm{E}-02 \\
1.8 \mathrm{E}-02 \\
4.7 \mathrm{E}+00 \\
4.7 \mathrm{E}+00 \\
1.3 \mathrm{E}-01 \\
1.9 \mathrm{E}+00 \\
1.9 \mathrm{E}+00 \\
5.6 \mathrm{E}+00 \\
5.0 \mathrm{E}+00 \\
4.2 \mathrm{E}+00 \\
1.8 \mathrm{E}+00 \\
4.3 \mathrm{E}+00 \\
2.3 \mathrm{E}+00 \\
2.1 \mathrm{E}+00 \\
8.9 \mathrm{E}-01 \\
5.2 \mathrm{E}-02 \\
6.3 \mathrm{E}-02 \\
1.8 \mathrm{E}+00 \\
1.2 \mathrm{E}+00 \\
3.2 \mathrm{E}-02 \\
2.1 \mathrm{E}-02 \\
2.6 \mathrm{E}+00 \\
3.5 \mathrm{E}+00 \\
3.5 \mathrm{E}+00 \\
4.6 \mathrm{E}-02 \\
2.8 \mathrm{E}-02 \\
2.5 \mathrm{E}+00 \\
1.2 \mathrm{E}+00 \\
9.4 \mathrm{E}-01 \\
3.5 \mathrm{E}+00 \\
4.7 \mathrm{E}-03 \\
9.4 \mathrm{E}-01 \\
5.9 \mathrm{E}-03 \\
5.9 \mathrm{E}-03 \\
5.9 \mathrm{E}-03 \\
5.9 \mathrm{E}-03 \\
5.9 \mathrm{E}-03 \\
5.9 \mathrm{E}-03 \\
6.2 \mathrm{E}-03 \\
2.4 \mathrm{E}-02 \\
1.4 \mathrm{E}-02 \\
1.9 \mathrm{E}-02 \\
1.9 \mathrm{E}-02 \\
2.4 \mathrm{E}-02\end{array}$ & $\begin{array}{l}1.1 \mathrm{E}-01 \\
1.1 \mathrm{E}-01 \\
1.0 \mathrm{E}-01 \\
1.0 \mathrm{E}-01 \\
9.4 \mathrm{E}-02 \\
9.4 \mathrm{E}-02 \\
9.4 \mathrm{E}-02 \\
9.3 \mathrm{E}-02 \\
7.9 \mathrm{E}-02 \\
7.0 \mathrm{E}-02 \\
6.6 \mathrm{E}-02 \\
6.5 \mathrm{E}-02 \\
6.2 \mathrm{E}-02 \\
6.2 \mathrm{E}-02 \\
6.2 \mathrm{E}-02 \\
6.1 \mathrm{E}-02 \\
6.1 \mathrm{E}-02 \\
5.3 \mathrm{E}-02 \\
4.9 \mathrm{E}-02 \\
4.7 \mathrm{E}-02 \\
4.5 \mathrm{E}-02 \\
4.0 \mathrm{E}-02 \\
3.5 \mathrm{E}-02 \\
3.5 \mathrm{E}-02 \\
3.0 \mathrm{E}-02 \\
2.8 \mathrm{E}-02 \\
2.7 \mathrm{E}-02 \\
2.6 \mathrm{E}-02 \\
2.6 \mathrm{E}-02 \\
2.5 \mathrm{E}-02 \\
2.3 \mathrm{E}-02 \\
2.3 \mathrm{E}-02 \\
2.2 \mathrm{E}-02 \\
2.2 \mathrm{E}-02 \\
2.1 \mathrm{E}-02 \\
2.1 \mathrm{E}-02 \\
2.0 \mathrm{E}-02 \\
1.9 \mathrm{E}-02 \\
1.9 \mathrm{E}-02 \\
1.5 \mathrm{E}-02 \\
1.5 \mathrm{E}-02 \\
1.4 \mathrm{E}-02 \\
1.4 \mathrm{E}-02 \\
1.4 \mathrm{E}-02 \\
1.3 \mathrm{E}-02 \\
1.3 \mathrm{E}-02 \\
1.3 \mathrm{E}-02 \\
1.3 \mathrm{E}-02 \\
1.3 \mathrm{E}-02 \\
1.3 \mathrm{E}-02 \\
1.3 \mathrm{E}-02 \\
1.3 \mathrm{E}-02 \\
1.3 \mathrm{E}-02 \\
1.3 \mathrm{E}-02 \\
1.3 \mathrm{E}-02 \\
1.3 \mathrm{E}-02 \\
1.3 \mathrm{E}-02\end{array}$ & $\begin{array}{l}1.0 \mathrm{E}+01 \\
1.0 \mathrm{E}-01 \\
7.6 \mathrm{E}+00 \\
1.4 \mathrm{E}+01 \\
5.9 \mathrm{E}+00 \\
6.6 \mathrm{E}+00 \\
5.9 \mathrm{E}+00 \\
1.7 \mathrm{E}+01 \\
1.2 \mathrm{E}+01 \\
9.6 \mathrm{E}+00 \\
9.8 \mathrm{E}-02 \\
2.4 \mathrm{E}-01 \\
1.8 \mathrm{E}-03 \\
1.8 \mathrm{E}-02 \\
2.4 \mathrm{E}-02 \\
9.4 \mathrm{E}+00 \\
9.4 \mathrm{E}+00 \\
3.0 \mathrm{E}-01 \\
2.7 \mathrm{E}+00 \\
4.0 \mathrm{E}+00 \\
5.6 \mathrm{E}+00 \\
1.0 \mathrm{E}+01 \\
4.2 \mathrm{E}+00 \\
3.7 \mathrm{E}+00 \\
8.0 \mathrm{E}+00 \\
3.6 \mathrm{E}+01 \\
4.1 \mathrm{E}+00 \\
1.8 \mathrm{E}+00 \\
7.0 \mathrm{E}-02 \\
6.3 \mathrm{E}-02 \\
3.6 \mathrm{E}+00 \\
4.2 \mathrm{E}+00 \\
1.3 \mathrm{E}-01 \\
6.3 \mathrm{E}-02 \\
7.0 \mathrm{E}+00 \\
7.0 \mathrm{E}+00 \\
7.1 \mathrm{E}+00 \\
4.6 \mathrm{E}-02 \\
7.0 \mathrm{E}-02 \\
5.0 \mathrm{E}+00 \\
2.3 \mathrm{E}+00 \\
4.7 \mathrm{E}+00 \\
4.6 \mathrm{E}+00 \\
4.3 \mathrm{E}-02 \\
1.8 \mathrm{E}+00 \\
5.9 \mathrm{E}-03 \\
5.9 \mathrm{E}-03 \\
5.9 \mathrm{E}-03 \\
5.9 \mathrm{E}-03 \\
5.9 \mathrm{E}-03 \\
5.9 \mathrm{E}-03 \\
6.2 \mathrm{E}-03 \\
2.4 \mathrm{E}-02 \\
1.4 \mathrm{E}-02 \\
1.9 \mathrm{E}-02 \\
1.9 \mathrm{E}-02 \\
2.4 \mathrm{E}-02\end{array}$ & $\begin{array}{l}4.4 \mathrm{E}+01 \\
1.1 \mathrm{E}-01 \\
3.3 \mathrm{E}+01 \\
6.3 \mathrm{E}+01 \\
2.6 \mathrm{E}+01 \\
2.9 \mathrm{E}+01 \\
2.6 \mathrm{E}+01 \\
7.6 \mathrm{E}+01 \\
5.2 \mathrm{E}+01 \\
4.2 \mathrm{E}+01 \\
4.3 \mathrm{E}-01 \\
1.1 \mathrm{E}+00 \\
7.7 \mathrm{E}-02 \\
7.7 \mathrm{E}-02 \\
1.0 \mathrm{E}-01 \\
4.1 \mathrm{E}+01 \\
4.1 \mathrm{E}+01 \\
1.3 \mathrm{E}+00 \\
1.2 \mathrm{E}+01 \\
1.7 \mathrm{E}+01 \\
2.5 \mathrm{E}+01 \\
4.4 \mathrm{E}+01 \\
1.8 \mathrm{E}+01 \\
1.6 \mathrm{E}+01 \\
3.5 \mathrm{E}+01 \\
1.6 \mathrm{E}+02 \\
1.8 \mathrm{E}+01 \\
7.8 \mathrm{E}+00 \\
3.1 \mathrm{E}-01 \\
2.8 \mathrm{E}-01 \\
1.6 \mathrm{E}+01 \\
1.8 \mathrm{E}+01 \\
5.8 \mathrm{E}-01 \\
6.5 \mathrm{E}-02 \\
3.1 \mathrm{E}+01 \\
3.1 \mathrm{E}+01 \\
3.1 \mathrm{E}+01 \\
2.0 \mathrm{E}-01 \\
3.1 \mathrm{E}-01 \\
2.2 \mathrm{E}+01 \\
1.0 \mathrm{E}-01 \\
1.0 \mathrm{E}+01 \\
2.5 \mathrm{E}-02 \\
8.5 \mathrm{E}-02 \\
1.0 \mathrm{E}-01\end{array}$ \\
\hline
\end{tabular}


DESCENDING RANK OF EMISSIONS RATES AT THE INEL

\begin{tabular}{|c|c|c|c|c|c|c|c|c|}
\hline POLLUTANT & AREA & BLDG & VENT & $\begin{array}{l}C \\
A \\
L \\
C\end{array}$ & $\begin{array}{c}\text { ACTUAL } \\
\text { HOURLY } \\
\text { LBS/HR } \\
\text { or } \\
\mathrm{CI} / \mathrm{MO}\end{array}$ & $\begin{array}{c}\text { ACTUAL } \\
\text { YEARLY } \\
\text { INS } / Y R \\
\text { Or } \\
\mathrm{CI} / \mathrm{YR}\end{array}$ & $\begin{array}{c}\text { MAX. } \\
\text { HOURLY } \\
\text { LBS/HR } \\
\text { or } \\
\text { CI/MO }\end{array}$ & $\begin{array}{c}\text { MAX. } \\
\text { YEARLY } \\
\text { TNS/YR } \\
\text { or } \\
C I / Y R\end{array}$ \\
\hline \multirow{58}{*}{ PARTICULATE } & & & 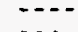 & & 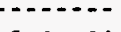 & 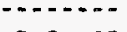 & 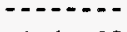 & - \\
\hline & INEL & 100 & 001 & $Y$ & 8. $1 E+01$ & $2.2 \mathrm{E}+02$ & $1.6 E+02$ & $4.4 E+02$ \\
\hline & CFA & 100 & 001 & $Y$ & $2.3 \mathrm{E}+01$ & $1.0 \mathrm{E}+02$ & $3.8 E+01$ & $1.7 E+02$ \\
\hline & ANL & 757 & 001 & $Y$ & $5.6 E+00$ & $2.5 E+01$ & $1.2 E+01$ & $5.5 \mathrm{E}+01$ \\
\hline & NRF & 716 & 001 & $Y$ & $3.0 \mathrm{E}+00$ & $1.3 E+01$ & $4.2 E+01$ & $1.9 E+02$ \\
\hline & INEL & 101 & 001 & $Y$ & $1.7 E+02$ & $9.9 E+00$ & $3.3 E+02$ & $2.0 E+01$ \\
\hline & NRF & 708 & 001 & $Y$ & $1.9 \mathrm{E}+00$ & $8.5 E+00$ & $6.8 E+01$ & $3.0 E+02$ \\
\hline & TRA & 670 & 046 & N & $2.4 \mathrm{E}+00$ & $5.3 E+00$ & $3.0 E+00$ & $1.3 E+01$ \\
\hline & & & 053 & N & $2.4 \mathrm{E}+00$ & $5.2 E+00$ & $3.0 E+00$ & $1.3 E+01$ \\
\hline & & 771 & 001 & $Y$ & $1.1 E+00$ & $5.0 E+00$ & $1.5 E+00$ & $6.6 E+00$ \\
\hline & CFA & 623 & 007 & $Y$ & $7.8 E+00$ & $3.0 \mathrm{E}+00$ & $3.9 \mathrm{E}+01$ & 4. $.0 E+01$ \\
\hline & CPP & 787 & 001 & $Y$ & $4.4 E-01$ & $1.4 E+00$ & 1. $1 E+01$ & $4.8 E+01$ \\
\hline & NRF & 620 & 013 & N & $1.6 \mathrm{E}+00$ & 1.1E+00 & $4.5 E+00$ & 2.0E+01 \\
\hline & & & 012 & N & $1.6 E+00$ & $1.1 E+00$ & $4.5 \mathrm{E}+00$ & 2. $0 E+01$ \\
\hline & & & 014 & N & $1.6 E+00$ & 1. $1 E+00$ & $4.5 E+00$ & $2.0 E+01$ \\
\hline & TAN & 603 & 022 & N & $1.7 E-01$ & 5.5E-01 & 9.7E-01 & $4.2 E+00$ \\
\hline & CFA & 101 & 001 & $Y$ & $1.3 E-01$ & 5.5E-01 & $2.8 E+00$ & $6.3 E-01$ \\
\hline & CPP & 606 & 004 & N & $3.4 E-01$ & $4.3 E-01$ & $7.2 E-01$ & $3.2 E+00$ \\
\hline & TAN & 603 & 027 & N & $3.4 E-02$ & $4.0 \mathrm{E}-01$ & $2.8 \mathrm{E}-01$ & $1.2 E+00$ \\
\hline & & & 028 & N & $.0 E+00$ & 4.0E-01 & $2.8 E-01$ & $1.2 E+00$ \\
\hline & NRF & $617 \mathrm{C}$ & 001 & N & $2.5 E+00$ & $3.2 E-01$ & $3.5 E+00$ & $1.5 E+01$ \\
\hline & TAN & 675 & 035 & N & 1.7E-01 & $2.9 E-01$ & $3.4 E-01$ & $1.5 E+00$ \\
\hline & NRF & $617 \mathrm{C}$ & 002 & $\mathrm{~N}$ & $2.5 \mathrm{E}+00$ & $2.8 E-01$ & $3.5 E+00$ & $1.5 E+01$ \\
\hline & ANL & 768 & 024 & $\mathbf{N}$ & $2.6 E-01$ & $2.5 E-01$ & $3.4 E-01$ & $1.5 E+00$ \\
\hline & & & 027 & N & 2.7E-01 & $2.5 E-01$ & $3.4 E-01$ & $1.5 E+00$ \\
\hline & TAN & 679 & 068 & $\mathbf{N}$ & $1.2 E-01$ & $2.2 E-01$ & $3.4 E-01$ & $1.5 E+00$ \\
\hline & $\mathrm{CPP}$ & 606 & 005 & N & $2.3 E-01$ & $2.2 E-01$ & $7.2 \mathrm{E}-01$ & $3.2 E+00$ \\
\hline & TAN & 679 & 067 & $N$ & $1.5 E-01$ & 2.0E-01 & $3.4 \mathrm{E}-01$ & $1.5 E+00$ \\
\hline & & 606 & 005 & $\mathbf{Y}$ & $4.4 E-01$ & $1.8 \mathrm{E}-01$ & $1.0 \mathrm{E}+00$ & $4.4 E+00$ \\
\hline & CFA & 665 & 050 & $Y$ & $1.9 E-01$ & $1.5 \mathrm{E}-01$ & $1.9 E-01$ & 2.7E-01 \\
\hline & CPP & 687 & 026 & $N$ & $2.5 E+00$ & 1.3E-01 & $5.0 E+00$ & $2.2 E+01$ \\
\hline & & 644 & 002 & $\mathrm{~N}$ & $2.5 E+00$ & $1.3 E-01$ & $5.0 \mathrm{E}+00$ & 2. $2 E+01$ \\
\hline & TAN & 675 & 037 & N & $1.4 E-01$ & $1.0 E-01$ & $3.4 E-01$ & $1.5 \mathrm{E}+00$ \\
\hline & ARA & IV & 001 & $\gamma$ & $9.0 E+00$ & 1.0E-01 & $1.8 E+01$ & 2.0E-01 \\
\hline & CFA & 665 & 029 & $N$ & $2.8 E-02$ & $1.0 E-01$ & $1.7 E-01$ & 7.3E-01 \\
\hline & NRF & $633 A$ & 078 & N & $1.9 E+00$ & 1.0E-01 & $2.1 E+00$ & $9.3 E+00$ \\
\hline & ARA & IV & 002 & $\gamma$ & 5.0E $=02$ & $1.0 E-01$ & 1.0E-01 & 2.0E-01 \\
\hline & TAN & 636 & 002 & $Y$ & 2.3E-02 & $9.8 \mathrm{E}-02$ & 2. $1 E+00$ & $9.0 E+00$ \\
\hline & NRF & 686 & 019 & N & $3.5 E+00$ & $9.6 \mathrm{E}-02$ & $4.5 \mathrm{E}+00$ & 2. $0 \mathrm{E}+01$ \\
\hline & & & 018 & $\mathbf{N}$ & $3.5 E+00$ & $9.6 E-02$ & $4.5 E+00$ & $2.0 E+01$ \\
\hline & & & 016 & N & $3.5 E+00$ & $9.6 \mathrm{E}-02$ & $4.5 E+00$ & 2. $0 E+01$ \\
\hline & & & 017 & $\mathrm{~N}$ & $3.5 E+00$ & $9.6 E-02$ & $4.5 E+00$ & 2. $0 \mathrm{E}+01$ \\
\hline & CPP & 606 & 019 & $\mathbf{N}$ & $1.6 E-01$ & $7.0 \mathrm{E}-02$ & $3.6 E-01$ & $1.6 E+00$ \\
\hline & & 794 & 001 & $Y$ & $1.0 E+00$ & $6.5 \mathrm{E}-02$ & 1. $1 E+00$ & $1.0 \mathrm{E}-01$ \\
\hline & & 025 & 001 & $Y$ & $1.9 E-01$ & $5.7 E-02$ & 1.1E-01 & $4.8 E-01$ \\
\hline & CFA & 688 & 043 & $\mathbf{N}$ & 1. $0 E-02$ & $5.1 E-02$ & $1.6 E-01$ & $7.1 E-01$ \\
\hline & & 662 & 027 & $\mathrm{~N}$ & $8.4 E-03$ & $4.7 \mathrm{E}-02$ & $7.1 \mathrm{E}-02$ & $3.1 E-01$ \\
\hline & & 623 & 017 & $Y$ & $8.0 E-02$ & 4. OE- 02 & $9.0 \mathrm{E}-02$ & 1.0E-01 \\
\hline & & 671 & 008 & N & $2.2 E-03$ & $3.6 E-02$ & 1.1E-01 & $4.9 E-01$ \\
\hline & & & 007 & $\mathbf{N}$ & 2. $0 \mathrm{E}-03$ & 3.6E-02 & 1.1E-01 & 4.9E-01 \\
\hline & TAN & 604 & 022 & $Y$ & $5.2 E-02$ & 2.7E-02 & 1.1E-01 & $5.1 E-01$ \\
\hline & CPP & 659 & 008 & $\mathbf{N}$ & $2.2 E+00$ & 2.6E-02 & $5.6 E+01$ & $2.5 E+02$ \\
\hline & NRF & $633 A$ & 089 & $Y$ & 3.3E-01 & $2.6 \mathrm{E}-02$ & $3.3 E-01$ & $1.4 E+00$ \\
\hline & CFA & 688 & 044 & $\mathbf{N}$ & $1.2 E-01$ & $2.6 \mathrm{E}-02$ & 7.0E-02 & $3.1 E-01$ \\
\hline & TRA & 674 & 007 & $N$ & $1.8 E+00$ & $2.4 \mathrm{E}-02$ & $3.6 E+00$ & $1.6 E+01$ \\
\hline & TAN & 641 & 035 & $\mathbf{N}$ & $1.3 E-02$ & $2.3 E-02$ & $9.0 \mathrm{E}-02$ & $3.9 E-01$ \\
\hline & & & 034 & $\mathrm{~N}$ & $1.3 \mathrm{E}-02$ & 2.3E-02 & $9.0 \mathrm{E}-02$ & $3.9 E-01$ \\
\hline & & 602 & 005 & $\mathbf{N}$ & 4. . $0 E-01$ & $2.0 \mathrm{E}-02$ & 4.0E-01 & $1.8 E+00$ \\
\hline
\end{tabular}


DESCENDING RANK OF EMISSIONS RATES AT THE INEL

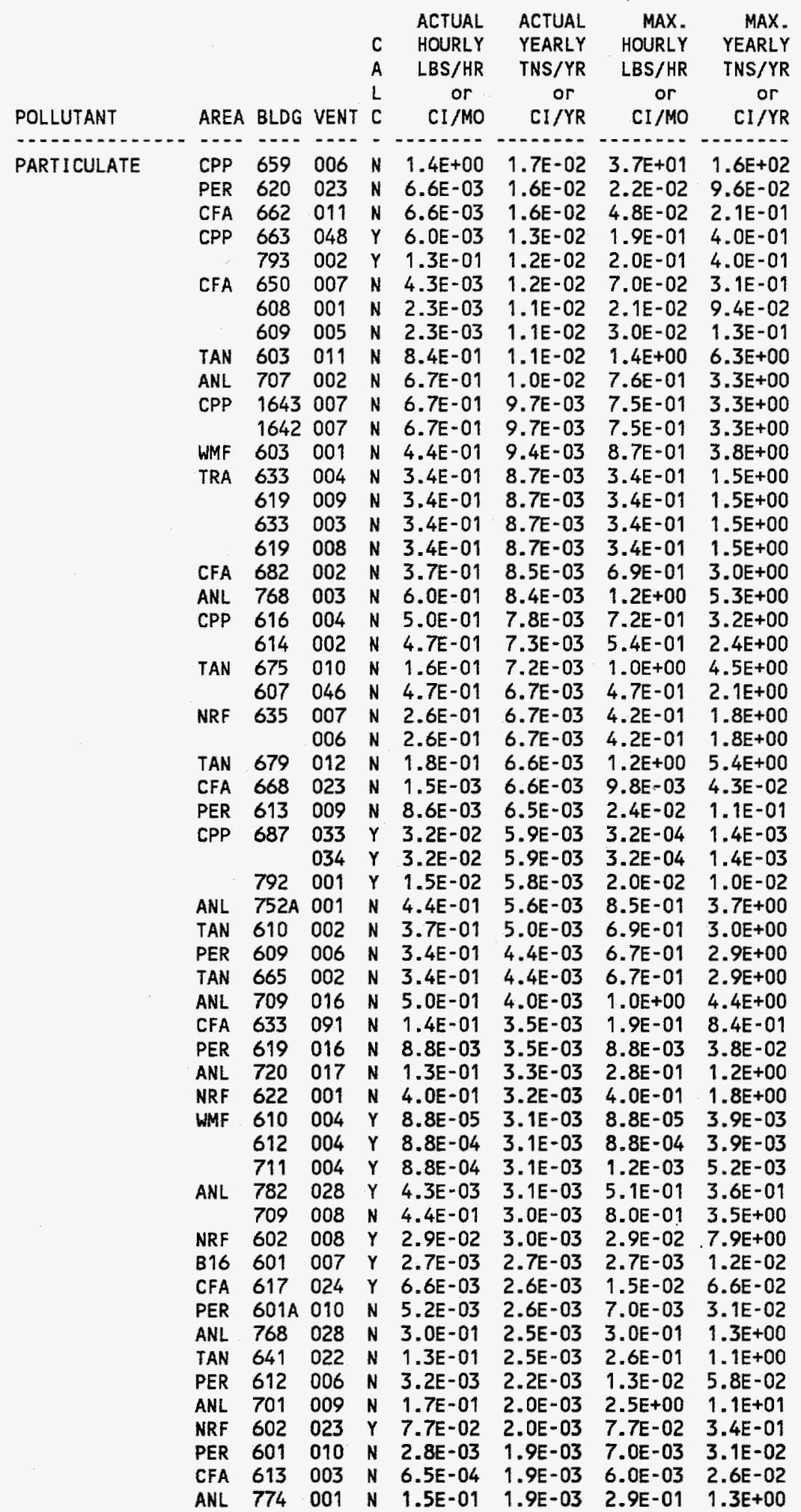


DESCENDING RANK OF EMISSIONS RATES AT THE INEL

\begin{tabular}{|c|c|c|c|c|c|c|c|c|}
\hline POLLUTANT & AREA & BLDG & VENT & $\begin{array}{l}L \\
C\end{array}$ & $\begin{array}{c}\text { ACTUAL } \\
\text { HOURLY } \\
\text { LBS/HR } \\
\text { or } \\
\text { CI/MO }\end{array}$ & $\begin{array}{c}\text { ACTUAL } \\
\text { YEARLY } \\
\text { TNS/YR } \\
\text { or } \\
\text { CI/YR }\end{array}$ & $\begin{array}{c}\text { MAX. } \\
\text { HOURLY } \\
\text { LBS } / H R \\
\text { or } \\
\mathrm{CI} / \mathrm{MO}\end{array}$ & $\begin{array}{c}\text { MAX. } \\
\text { YEARLY } \\
\text { TNS } / Y R \\
\text { or } \\
\mathrm{CI} / \mathrm{YR}\end{array}$ \\
\hline & & & & & & & & \\
\hline \multirow[t]{58}{*}{ PB } & $C P P$ & 787 & 001 & $Y$ & $9.4 E-04$ & 7.1E-04 & $6.7 E+01$ & 2. $9 \mathrm{E}+02$ \\
\hline & NRF & 620 & 013 & $N$ & $6.7 E-04$ & $4.6 E-04$ & $1.9 E-03$ & $8.3 E-03$ \\
\hline & & & 012 & N & $6.7 E-04$ & $4.6 E-04$ & $1.9 \mathrm{E}-03$ & 8.3E-03 \\
\hline & & & 014 & N & $6.7 \mathrm{E}-04$ & $4.6 E-04$ & $1.9 E-03$ & 8.3E-03 \\
\hline & CPP & 606 & 004 & N & $2.2 E-04$ & $2.7 E-04$ & $4.5 E-04$ & $2.0 \mathrm{E}-03$ \\
\hline & TAN & 603 & 028 & $N$ & $.0 E+00$ & $2.5 E-04$ & $1.8 E-04$ & $7.7 \mathrm{E}-04$ \\
\hline & & & 027 & $\mathbf{N}$ & 2.1E-05 & $2.5 \mathrm{E}-04$ & 1.7E-04 & $7.6 \mathrm{E}-04$ \\
\hline & & & 022 & $\mathbf{N}$ & $7.1 E-05$ & $2.3 E-04$ & $4.1 \mathrm{E}-04$ & $1.8 E-03$ \\
\hline & & 675 & 035 & $\mathbf{N}$ & 1.1E-04 & $1.8 E-04$ & $2.1 E-04$ & $9.2 E-04$ \\
\hline & ANL & 768 & 027 & $\mathbf{N}$ & $1.7 \mathrm{E}-04$ & $1.6 E-04$ & 2.1E-04 & $9.2 \mathrm{E}-04$ \\
\hline & & & 024 & N & $1.6 E-04$ & $1.6 E-04$ & $2.1 \mathrm{E}-0.4$ & $9.3 E-04$ \\
\hline & TAN & 679 & 068 & N & $7.4 E-05$ & $1.4 \mathrm{E}-04$ & $2.1 E-04$ & $9.2 E-04$ \\
\hline & $\mathrm{CPP}$ & 606 & 005 & $\mathbf{N}$ & $1.4 \mathrm{E}-04$ & $1.4 E-04$ & $4.5 E-04$ & $2.0 E-03$ \\
\hline & TAN & 679 & 067 & $\mathrm{~N}$ & $9.5 E-05$ & $1.2 E-04$ & $2.1 E-04$ & $9.2 E-04$ \\
\hline & & 675 & 037 & N & $9.0 E-05$ & $6.6 E-05$ & 2.1E-04 & $9.2 E-04$ \\
\hline & CFA & 665 & 029 & N & $1.8 \mathrm{E}-05$ & $6.3 E-05$ & $1.0 \mathrm{E}-04$ & $4.6 E-04$ \\
\hline & CPP & 606 & 019 & N & $1.0 E-04$ & $4.4 E-05$ & $2.3 E-04$ & $9.9 E-04$ \\
\hline & CFA & 682 & 002 & $Y$ & 1.9E-03 & $4.3 E-05$ & 3.5E-03 & $1.5 \mathrm{E}-02$ \\
\hline & & 688 & 043 & N & $6.4 E-06$ & $3.2 E-05$ & 1. $.0 \mathrm{E}-04$ & $4.5 E-04$ \\
\hline & & 662 & 027 & N & 5.3E-06 & $2.9 E-05$ & 4.5E-05 & $2.0 \mathrm{E}-04$ \\
\hline & & & 008 & N & $1.4 E-06$ & 2.3E-05 & $7.0 E-05$ & $3.1 E-04$ \\
\hline & & & 007 & N & $1.2 E-06$ & $2.3 E-05$ & $7.0 \mathrm{E}-05$ & $3.1 E-04$ \\
\hline & & 633 & 091 & Y & $7.0 \mathrm{E}-04$ & $1.8 E-05$ & $9.8 E-04$ & 4.3E-03 \\
\hline & & 688 & 044 & N & $7.7 E-05$ & $1.6 E-05$ & $4.4 \mathrm{E}-05$ & $1.9 E-04$ \\
\hline & TAN & 641 & 035 & N & $8.3 E-06$ & $1.4 E-05$ & $5.6 E-05$ & $2.5 E-04$ \\
\hline & & & 034 & N & $8.3 E-06$ & $1.4 \mathrm{E}-05$ & $5.6 E-05$ & $2.5 E-04$ \\
\hline & CFA & 668 & 006 & Y & $3.9 E-03$ & $1.2 E-05$ & $3.9 E-03$ & 1.7E-02 \\
\hline & PER & 620 & 023 & $\mathbf{N}$ & 4.1E-06 & $1.0 E-05$ & $1.4 E-05$ & 6.0E-05 \\
\hline & CFA & 662 & 011 & $\mathbf{N}$ & 4.1E-06 & $9.8 \mathrm{E}-06$ & $3.0 E-05$ & $1.3 E-04$ \\
\hline & & 688 & 047 & $y$ & 1.3E-03 & $7.7 E-06$ & $2.6 \mathrm{E}-03$ & $1.1 \mathrm{E}-02$ \\
\hline & & 609 & 001 & Y & $9.8 E-04$ & $7.7 E-06$ & $2.6 E-03$ & 1.1E-02 \\
\hline & & 650 & 007 & $\mathrm{~N}$ & $2.7 E-06$ & $7.4 E-06$ & 4.4E-05 & $1.9 \mathrm{E}-04$ \\
\hline & & 608 & 001 & N & $1.4 E-06$ & 7.0E-06 & $1.3 E-05$ & $5.9 E-05$ \\
\hline & & 609 & 005 & $\mathrm{~N}$ & $1.4 E-06$ & $7.0 E-06$ & $1.9 \mathrm{E}-05$ & $8.2 E-05$ \\
\hline & & 675 & 002 & Y & $1.3 E-03$ & 5. 1E-06 & $1.7 E-03$ & $7.4 \mathrm{E}-03$ \\
\hline & & 604 & 001 & $Y$ & $3.4 E-04$ & $5.1 E-06$ & $1.7 E-03$ & $7.5 E-03$ \\
\hline & CFA & 668 & 023 & $\mathbf{N}$ & $9.4 E-07$ & $4.1 E-06$ & $6.1 E-06$ & 2.7E-05 \\
\hline & PER & 613 & 009 & $\mathbf{N}$ & $5.4 E-06$ & 4.0E-06 & 1.5E-05 & 6.6E-05 \\
\hline & B21 & 608 & 012 & $y$ & $2.0 E-06$ & $3.0 \mathrm{E}-06$ & 2.0E-06 & 1.1E-05 \\
\hline & PER & 619 & 016 & N & $4.4 \mathrm{E}-06$ & $1.8 E-06$ & $4.4 E-06$ & 1.9E-05 \\
\hline & & $601 \mathrm{~A}$ & 010 & N & $3.3 E-06$ & $1.6 E-06$ & 4.4E-06 & $1.9 \mathrm{E}-05$ \\
\hline & & 612 & 006 & N & $2.0 E-06$ & $1.4 \mathrm{E}-06$ & $8.3 E-06$ & $3.6 E-05$ \\
\hline & & 601 & 010 & $\mathbf{N}$ & $1.8 E-06$ & $1.2 E-06$ & $4.4 E-06$ & $1.9 \mathrm{E}-05$ \\
\hline & CFA & 613 & 003 & $\mathbf{N}$ & $3.3 E-07$ & $9.6 E-07$ & 3.0E-06 & 1.3E-05 \\
\hline & ANL & 768 & 022 & $\mathrm{~N}$ & $1.6 E-04$ & $6.3 E-07$ & 2.1E-04 & $9.3 E-04$ \\
\hline & & & 034 & N & $1.9 E-04$ & $6.3 E-07$ & $2.3 E-04$ & $1.0 E-03$ \\
\hline & & 721 & 004 & N & $3.1 E-06$ & $5.8 E-07$ & 3.1E-06 & $1.4 \mathrm{E}-05$ \\
\hline & CFA & 607 & 004 & N & $1.6 E-10$ & $5.4 \mathrm{E}-07$ & 6.0E-06 & 2.6E-05 \\
\hline & PER & 632 & 008 & N & $3.1 E-07$ & $3.0 E-07$ & $2.8 E-06$ & $1.2 \mathrm{E}-05$ \\
\hline & & & 007 & N & $3.1 E-07$ & $3.0 E-07$ & $2.8 E-06$ & $1.2 E-05$ \\
\hline & & 619 & 015 & N & 1.7E-06 & $1.6 \mathrm{E}-07$ & $1.7 E-06$ & $7.4 E-06$ \\
\hline & NRF & 601 & 036 & Y & $2.5 E-12$ & $3.8 E-13$ & $2.5 E-12$ & $1.1 E-11$ \\
\hline & CFA & 665 & 028 & N & $.0 E+00$ & $.0 E+00$ & $4.5 E-05$ & 2.0E-04 \\
\hline & PER & 625 & 001 & $Y$ & $.0 E+00$ & $.0 E+00$ & $.0 E+00$ & $.0 E+00$ \\
\hline & & 621 & 005 & $y$ & $.0 E+00$ & $.0 E+0 D$ & $.0 E+00$ & $.0 E+00$ \\
\hline & & 665 & 030 & N & $.0 E+00$ & $.0 E+00$ & $4.5 E-05$ & 2. $0 E-04$ \\
\hline & PER & 755 & 001 & $Y$ & $.0 E+00$ & $.0 E+00$ & $5.0 E-06$ & $9.8 E-06$ \\
\hline & TAN & 716 & 004 & $\mathbf{N}$ & $.0 E+00$ & $.0 E+00$ & $8.8 E-05$ & $3.8 E-04$ \\
\hline
\end{tabular}


DESCENDING RANK OF EMISSIONS RATES AT THE INEL

\begin{tabular}{|c|c|c|c|c|c|c|c|c|}
\hline POLLUTANT & AREA & BLDG & VENT & $\begin{array}{l}C \\
A \\
L \\
C\end{array}$ & $\begin{array}{l}\text { ACTUAL } \\
\text { HOURLY } \\
\text { LBS/HR } \\
\text { or } \\
\mathrm{CI} / \mathrm{MO}\end{array}$ & $\begin{array}{c}\text { ACTUAL } \\
\text { YEARLY } \\
\text { TNS/YR } \\
\text { or } \\
C I / Y R\end{array}$ & $\begin{array}{c}\text { MAX. } \\
\text { HOURLY } \\
\text { LBS/HR } \\
\text { or } \\
\mathrm{Cl} / \mathrm{MO}\end{array}$ & $\begin{array}{c}\text { MAX. } \\
\text { YEARLY } \\
\text { TNS/YR } \\
\text { or } \\
\text { CI } / \text { YR }\end{array}$ \\
\hline RADIONUCLIDE & & 770 & ח01 & - & $13 F+0 ?$ & $15 F+$ & & \\
\hline RADIONUCLIDE & TRA & 770 & 001 & $Y$ & $1.3 \mathrm{E}+02$ & $1.5 E+03$ & $9.9 E+02$ & $4.3 E+03$ \\
\hline & ANL & 764 & 001 & $Y$ & $8.5 E+01$ & $1.0 E+03$ & $1.9 E+02$ & $1.3 E+03$ \\
\hline & TRA & 715 & 001 & & 1.0E+01 & $1.2 E+02$ & $.0 E+00$ & $.0 E+00$ \\
\hline & $\begin{array}{l}\text { ANL } \\
\text { CPP }\end{array}$ & 785 & $\begin{array}{l}018 \\
001\end{array}$ & $\begin{array}{l}Y \\
y\end{array}$ & $\begin{array}{l}6.5 E+00 \\
5.6 F+00\end{array}$ & $\begin{array}{l}.7 E+01 \\
6.7 E+01\end{array}$ & $\begin{array}{l}2.9 E+01 \\
1.3 E+04\end{array}$ & \\
\hline & ANL & 777 & 002 & $Y$ & $\begin{array}{l}3.0 E+00 \\
1.5 E-01\end{array}$ & $1.8 \mathrm{E}+00$ & $1.5 \mathrm{E}-01$ & $\begin{array}{l}1.5 \mathrm{E}+05 \\
1.8 \mathrm{E}+00\end{array}$ \\
\hline & & 720 & 007 & Y & $1.4 E-01$ & $8.5 E-01$ & $3.0 E+09$ & $3.6 \mathrm{E}+02$ \\
\hline & NRF & 618 & 103 & $Y$ & 5.1E-02 & $6.1 E-01$ & $1.7 E-01$ & $2.0 E+00$ \\
\hline & ANL & 793 & 001 & $Y$ & $3.7 E-02$ & $4.4 \mathrm{E}-01$ & $3.7 E-02$ & $4.4 E-01$ \\
\hline & NRF & $633 A$ & 057 & Y & $2.6 E-02$ & $3.1 E-01$ & $1.9 \mathrm{E}-01$ & $2.3 E+00$ \\
\hline & ANL & 798 & 017 & $Y$ & $2.3 E-02$ & $2.8 E-01$ & $2.3 E-02$ & $2.8 E-01$ \\
\hline & NRF & 618 & 099 & Y & $1.7 E-02$ & 2.0E-01 & 4.7E-02 & 5.6E-01 \\
\hline & & $628 A$ & 006 & Y & $1.3 E-02$ & 1.5E-01 & 1.8E-01 & 2. $1 E+00$ \\
\hline & & $\begin{array}{l}617 \\
616\end{array}$ & 013 & $y$ & $\begin{array}{l}7.7 E-04 \\
3 E-03\end{array}$ & $\begin{array}{l}9.2 E-03 \\
16 E-02\end{array}$ & $5.8 E-03$ & 7.0E-02 \\
\hline & TRA & 668 & $\begin{array}{l}059 \\
013\end{array}$ & $\begin{array}{l}Y \\
Y\end{array}$ & $8.3 E-04$ & $1.0 E-02$ & $\begin{array}{l}7.9 E-02 \\
8.3 E-03\end{array}$ & $\begin{array}{l}2.3 E-01 \\
1.0 F-01\end{array}$ \\
\hline & & 710 & 001 & $y$ & $2.5 E-04$ & $3.0 E-03$ & $4.4 E-05$ & $1.9 E-04$ \\
\hline & TAN & 607 & 119 & $Y$ & $1.7 E-03$ & $1.7 E-03$ & $5.5 E-04$ & $4.0 \mathrm{E}-03$ \\
\hline & NRF & 618 & 043 & $Y$ & $6.6 E-05$ & $7.9 E-04$ & $1.1 \mathrm{E}-03$ & $1.3 \mathrm{E}-02$ \\
\hline & & & 040 & $Y$ & $6.6 E-05$ & $7.9 E-04$ & $1.1 E-03$ & $1.3 E-02$ \\
\hline & & & 041 & $Y$ & $6.6 E-05$ & $7.9 E-04$ & $1.1 E-03$ & $1.3 E-02$ \\
\hline & & & 039 & $Y$ & $6.6 \mathrm{E}-05$ & $7.9 E-04$ & $1.1 \mathrm{E}-03$ & $1.3 E-02$ \\
\hline & & & 028 & $Y$ & $6.6 E-05$ & $7.9 E-04$ & $1.1 E-03$ & $1.3 E-02$ \\
\hline & & & 026 & $\mathbf{Y}$ & $6.6 E-05$ & $7.9 E-04$ & $1.1 E-03$ & $1.3 E-02$ \\
\hline & & & 038 & Y & $6.6 E-05$ & $7.9 E-04$ & $1.1 E-03$ & $1.3 E-02$ \\
\hline & & & 035 & Y & $6.6 E-05$ & $7.9 E-04$ & $1.1 E-03$ & $1.3 E-02$ \\
\hline & & & 036 & $Y$ & $6.6 E-05$ & $7.9 E-04$ & $1.1 E-03$ & $1.3 E-02$ \\
\hline & & & 029 & Y & $6.6 E-05$ & 7.9E-04 & $1.1 E-03$ & $1.3 E-02$ \\
\hline & & & 033 & $\mathbf{Y}$ & $6.6 E-05$ & $7.9 E-04$ & $1.1 E-03$ & $1.3 E-02$ \\
\hline & & & 034 & $\mathbf{Y}$ & $6.6 \mathrm{E}-05$ & 7.9E-04 & $1.1 E-03$ & $1.3 \mathrm{E}-02$ \\
\hline & & & $\begin{array}{l}025 \\
027\end{array}$ & $\begin{array}{l}Y \\
Y\end{array}$ & $\begin{array}{l}6.6 E-05 \\
6.6 E-05\end{array}$ & $\begin{array}{l}7.9 E-04 \\
7.9 E-04\end{array}$ & $\begin{array}{l}1.1 E-03 \\
1.1 E-03\end{array}$ & $\begin{array}{l}1.3 \mathrm{E}-02 \\
1.3 \mathrm{E}-02\end{array}$ \\
\hline & CPP & 603 & 001 & $\gamma$ & 1.7E-05 & $2.0 E-04$ & $8.0 E-07$ & $9.6 E-06$ \\
\hline & ANL & 752 & 004 & $\mathbf{Y}$ & $1.6 \mathrm{E}-05$ & $1.9 E-04$ & $5.2 E-02$ & $6.3 E-01$ \\
\hline & NRF & $601 A$ & 019 & Y & $1.3 E-05$ & $1.5 E-04$ & $3.8 E-05$ & $4.5 E-04$ \\
\hline & CPP & 684 & 001 & Y & $5.5 E-06$ & $6.6 E-05$ & $8.8 E-02$ & 1. $1 E+00$ \\
\hline & & 767 & 001 & $Y$ & 5.0E-06 & $6.0 \mathrm{E}-05$ & $1.0 E+04$ & $1.0 E+04$ \\
\hline & NRF & $720 \mathrm{~A}$ & 001 & & 2.3E-06 & 2.7E-05 & $2.3 E-06$ & $2.8 E-05$ \\
\hline & CPP & 1612 & 001 & $Y$ & $1.4 \mathrm{E}-06$ & 1.7E-05 & $1.1 E-04$ & 1.3E-03 \\
\hline & WMF & 615 & 001 & $Y$ & $1.0 E-06$ & $1.2 \mathrm{E}-05$ & $3.4 E-09$ & $6.8 E-09$ \\
\hline & CPP & 765 & 003 & Y & 7.7E-07 & $9.2 E-06$ & 7.7E-07 & $9.2 E-06$ \\
\hline & & 791 & 004 & Y & $7.7 E-07$ & $9.2 \mathrm{E}-06$ & 7.7E-07 & $9.2 E-06$ \\
\hline & & 627 & 013 & $Y$ & $6.3 E-07$ & $7.6 E-06$ & $1.3 E-06$ & $1.5 E-05$ \\
\hline & NRF & 616 & 012 & Y & $5.8 E-07$ & 6.9E-06 & $1.0 E-03$ & $1.2 \mathrm{E}-02$ \\
\hline & & 721 & 001 & & $5.2 E-07$ & $6.2 E-06$ & $5.2 E-07$ & $6.3 E-06$ \\
\hline & TAN & 734 & 001 & $Y$ & $5.0 E-07$ & $6.0 \mathrm{E}-06$ & $5.3 E-03$ & $6.3 E-02$ \\
\hline & & 607 & 039 & $Y$ & -07 & $5.7 E-06$ & $1.2 E-03$ & $1.5 E-02$ \\
\hline & & 629 & 013 & $Y$ & $3.6 E-07$ & 4.3E-06 & $1.3 E-03$ & $1.6 E-02$ \\
\hline & NRF & $722 A$ & 001 & & 2.7E-07 & $3.2 E-06$ & $2.7 E-07$ & $3.2 E-06$ \\
\hline & PER & 620 & 016 & Y & $2.6 E-07$ & $3.1 E_{-}-06$ & 4.4E-04 & $5.2 E-03$ \\
\hline & CPP & 760 & 002 & Y & 2.4E-07 & $2.8 E-06$ & $1.8 \mathrm{E}-07$ & $2.2 E-06$ \\
\hline & TAN & 681 & 012 & Y & 2.2E-07 & $2.6 E-06$ & $8.4 E-05$ & $1.0 E-03$ \\
\hline & WMF & 601 & 009 & Y & $1.7 E-07$ & $2.0 \mathrm{E}-06$ & $1.7 E-07$ & $2.0 E-06$ \\
\hline & TAN & 681 & 018 & Y & $1.2 E-07$ & $1.4 E-06$ & $5.5 E-05$ & $6.6 E-04$ \\
\hline & ANL & 752 & 005 & $Y$ & $1.2 E-07$ & $1.4 E-06$ & $3.8 E-04$ & $4.6 E-03$ \\
\hline & TAN & 679 & 025 & $Y$ & $1.0 E-07$ & $1.2 E-06$ & $3.5 E-04$ & $4.2 E-03$ \\
\hline & NRF & FUG & 002 & & 18 & 6 & $E-08$ & \\
\hline
\end{tabular}


DESCENDING RANK OF EMISSIONS RATES AT THE INEL

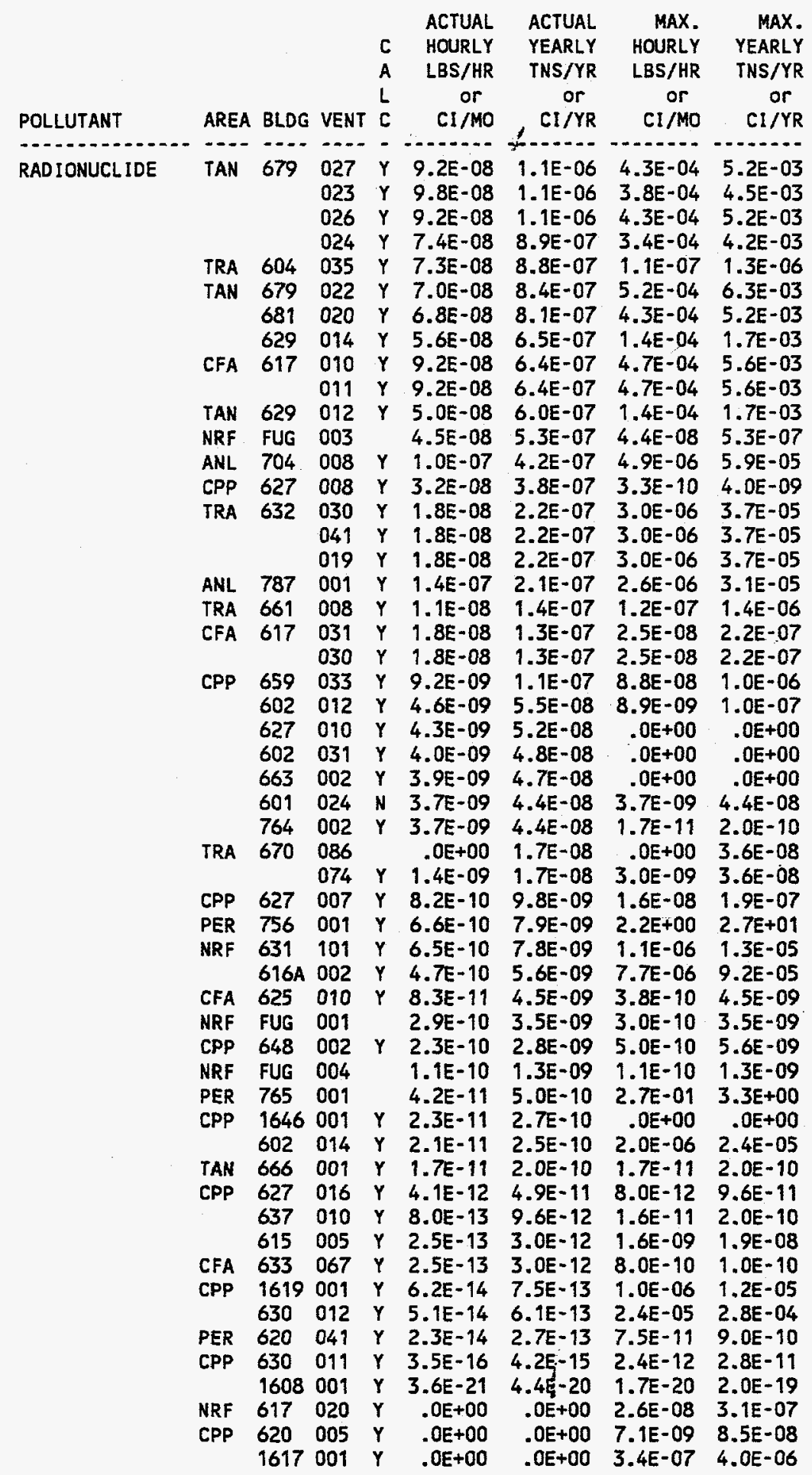


DESCENDING RANK OF EMISSIONS RATES AT THE INEL

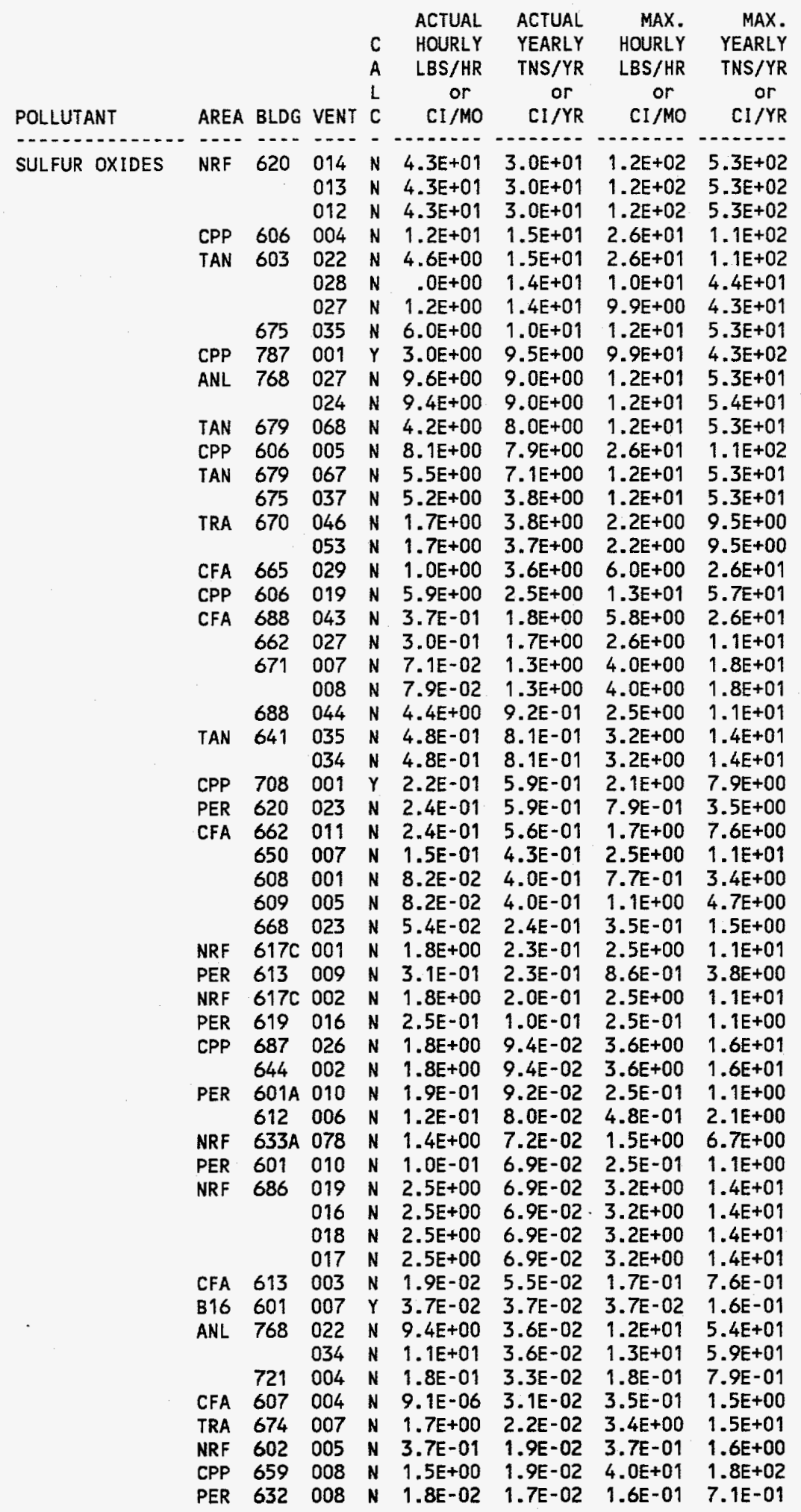


DESCENDING RANK OF EMISSIONS RATES AT THE INEL

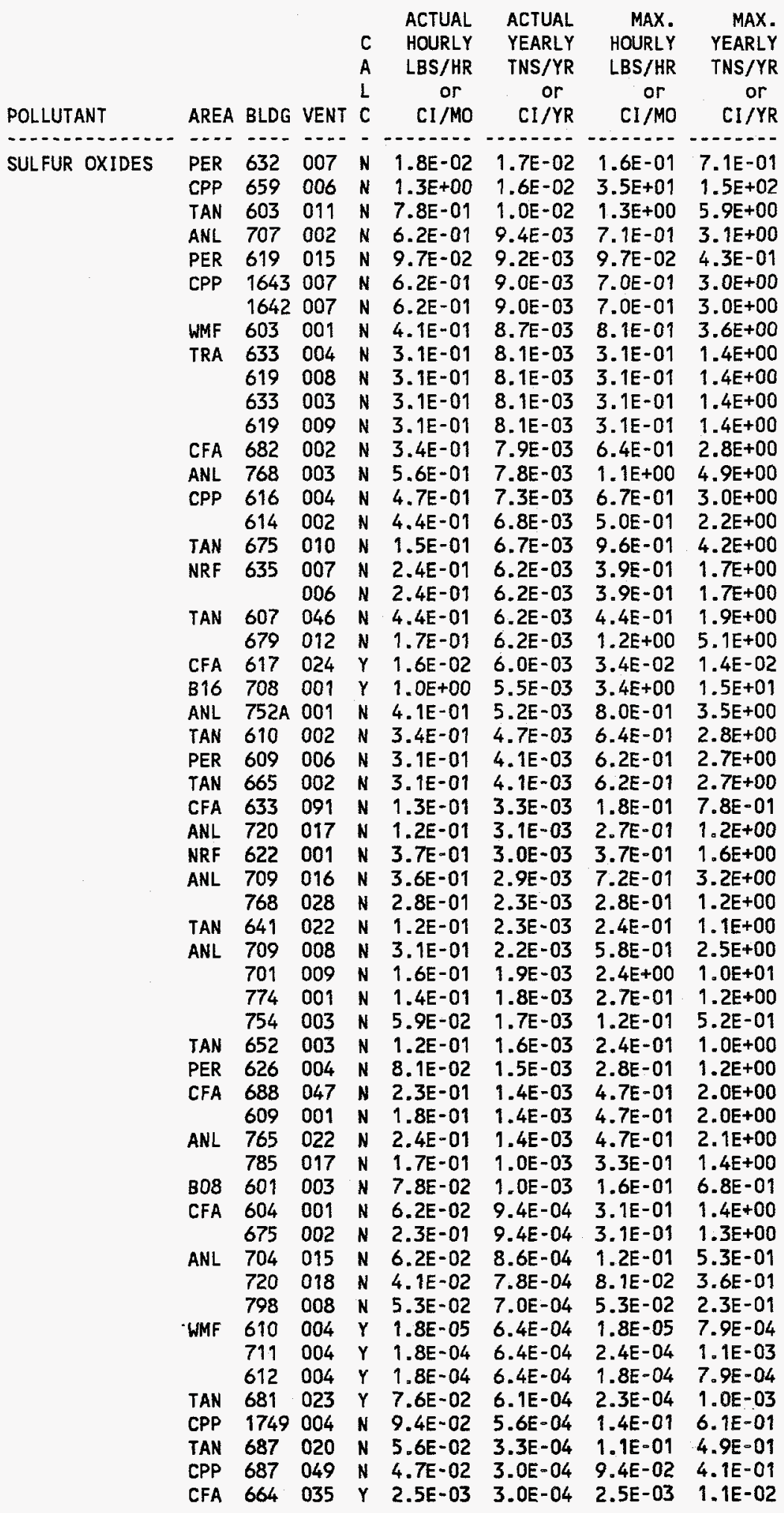


DESCENDING RANK OF EMISSIONS RATES AT THE INEL

\begin{tabular}{|c|c|c|c|c|c|c|c|c|}
\hline POLLUTANT & AREA & BLDG & VENT & $\begin{array}{l}C \\
A \\
L \\
C\end{array}$ & $\begin{array}{c}\text { ACTUAL } \\
\text { HOURLY } \\
\text { LBS/HR } \\
\text { or } \\
\mathrm{CI} / \mathrm{MO}\end{array}$ & $\begin{array}{c}\text { ACTUAL } \\
\text { YEARLY } \\
\text { TNS/YR } \\
\text { or } \\
C I / Y R\end{array}$ & $\begin{array}{c}\text { MAX. } \\
\text { HOURLY } \\
\text { LBS/HR } \\
\text { or } \\
\mathrm{CI} / \mathrm{MO}\end{array}$ & $\begin{array}{c}\text { MAX. } \\
\text { YEARLY } \\
\text { TNS } / Y R \\
\text { or } \\
\text { CI } / Y R\end{array}$ \\
\hline & & & & & & & & \\
\hline \multirow{57}{*}{ VOC-NONMETHANE } & CPP & 708 & 001 & $Y$ & $3.7 E+00$ & $9.9 E+00$ & $1.2 E+01$ & $8.7 E+00$ \\
\hline & TAN & 724 & 002 & N & $1.1 E+00$ & $4.7 E+00$ & 1. $1 E+\infty 0$ & $4.7 \mathrm{E}+00$ \\
\hline & $\mathrm{CPP}$ & $701 \mathrm{~A}$ & 001 & N & $1.0 E+00$ & $3.9 E+00$ & $1.0 E+00$ & $3.9 \mathrm{E}+00$ \\
\hline & CFA & 102 & 001 & $Y$ & $7.5 E-01$ & $3.3 E+00$ & $7.5 E-01$ & $3.3 E+00$ \\
\hline & TAN & 704 & 001 & N & 7.0E-01 & $2.8 E+00$ & $7.0 \mathrm{E}-01$ & $2.8 E+00$ \\
\hline & TRA & 640 & 004 & N & 6.3E-01 & $2.7 E+00$ & $6.3 E-01$ & $2.7 E+00$ \\
\hline & CFA & 623 & 017 & $Y$ & $5.4 E-01$ & $2.4 E+00$ & $1.7 E+00$ & $7.4 E+01$ \\
\hline & & 101 & 001 & $Y$ & 4.7E-01 & $2.1 E+00$ & $4.7 E-01$ & $2.1 E+00$ \\
\hline & TAN & $767 B$ & 001 & N & 4.9E-01 & 1. $9 \mathrm{E}+00$ & $4.9 E-01$ & $1.9 \mathrm{E}+00$ \\
\hline & & $767 \mathrm{~A}$ & 001 & N & 4. $9 E-01$ & $1.9 E+00$ & 4.9E-01 & $1.9 E+00$ \\
\hline & ANL & $755 \mathrm{~A}$ & 001 & N & 4. $9 E-01$ & $1.6 E+00$ & $4.9 \mathrm{E}-01$ & $1.6 E+00$ \\
\hline & TAN & 701 & 001 & Y & $0.0 E+00$ & $1.5 E+00$ & $0.0 E+00$ & $1.5 \mathrm{E}+00$ \\
\hline & & 681 & 004 & $\mathrm{~N}$ & $3.9 \mathrm{E}-01$ & $1.5 E+00$ & $3.9 E-01$ & $1.5 E+00$ \\
\hline & & 675 & 024 & N & $3.9 E-01$ & $1.5 \mathrm{E}+00$ & $3.9 E-01$ & $1.5 E+00$ \\
\hline & TRA & 670 & 046 & $\mathrm{~N}$ & $6.2 \mathrm{E}-01$ & $1.4 E+00$ & $7.8 E-01$ & $3.4 E+00$ \\
\hline & ANL & 757 & 001 & Y & $3.1 E-01$ & $1.4 \mathrm{E}+00$ & $2.9 \mathrm{E}-01$ & $1.3 E+00$ \\
\hline & CFA & 103 & 001 & $Y$ & 3. 1E-01 & $1.4 \mathrm{E}+00$ & 3. 1E-01 & $1.4 E+00$ \\
\hline & TRA & 670 & 053 & N & $6.2 E-01$ & $1.4 E+00$ & $7.8 \mathrm{E}-01$ & $3.4 E+00$ \\
\hline & & 771 & 001 & $Y$ & $2.9 E-01$ & $1.3 E+00$ & $2.9 E-01$ & $1.3 E+00$ \\
\hline & TAN & 702 & 001 & N & $3.3 E-01$ & $1.2 \mathrm{E}+00$ & $3.3 E-01$ & $1.2 E+00$ \\
\hline & CFA & 100 & 001 & $Y$ & $3.6 \mathrm{E}-01$ & 1. $1 E+00$ & $3.6 \mathrm{E}-01$ & $1.6 E+00$ \\
\hline & TAN & 724 & 001 & N & $2.2 E-01$ & $9.6 \mathrm{E}-01$ & 2.2E-01 & $9.6 E-01$ \\
\hline & CFA & 754 & 003 & $\mathrm{~N}$ & 2. $9 E+01$ & $9.5 E-01$ & $2.9 E+01$ & $9.5 E-01$ \\
\hline & B16 & 708 & 001 & $Y$ & $3.5 E-01$ & $9.5 \mathrm{E}-01$ & $1.3 E+00$ & $5.7 E+00$ \\
\hline & CFA & 754 & 007 & N & $2.9 E+01$ & $9.1 E-01$ & $2.9 E+01$ & $9.1 \mathrm{E}-01$ \\
\hline & $\mathrm{CPP}$ & 7018 & 001 & N & $2.6 E-01$ & $6.4 E-01$ & $2.6 E-01$ & $6.4 E-01$ \\
\hline & TAN & 675 & 021 & $\mathrm{~N}$ & 1.9E-01 & $5.6 \mathrm{E}-01$ & $1.9 E-01$ & $5.6 E-01$ \\
\hline & TRA & 727 & 004 & N & $2.1 E-01$ & $5.3 E-01$ & 2. 1E-01 & $5.3 E-01$ \\
\hline & NRF & 711 & 003 & N & $1.2 E-01$ & 5.1E-01 & $1.2 E-01$ & $5.1 E-01$ \\
\hline & & & 001 & N & $1.2 E-01$ & 5.1E-01 & $1.2 E-01$ & $5.1 E-01$ \\
\hline & & & 002 & N & $1.2 \mathrm{E}-01$ & 5.1E-01 & $1.2 \mathrm{E}-01$ & 5.1E-01 \\
\hline & CFA & 665 & 050 & Y & 6.4E-01 & 5.0E-01 & $6.4 E-01$ & $9.3 E-01$ \\
\hline & NRF & 747 & 002 & $\mathrm{~N}$ & $1.1 \mathrm{E}-01$ & 4.8E-01 & 1.1E-01 & $4.8 E-01$ \\
\hline & & & 001 & $\mathrm{~N}$ & $1.1 E-01$ & $4.8 \mathrm{E}-01$ & $1.1 \mathrm{E}-01$ & $4.8 E-01$ \\
\hline & ANL & $755 \mathrm{~B}$ & 002 & N & 2.3E-01 & $4.8 \mathrm{E}-01$ & 2.3E-01 & $4.8 \mathrm{E}-01$ \\
\hline & CFA & 732 & 001 & $\mathrm{~N}$ & $1.6 E-01$ & 4.4E-01 & $1.6 \mathrm{E}-01$ & $4.4 E-01$ \\
\hline & TRA & 775 & 001 & $\mathrm{~N}$ & $1.8 \mathrm{E}-01$ & $4.3 \mathrm{E}-01$ & $1.8 \mathrm{E}-01$ & 4.3E-01 \\
\hline & CFA & 708 & 001 & N & 2.1E-01 & 4.1E-01 & 2.1E-01 & 4.1E-01 \\
\hline & TRA & 707 & 001 & $\mathrm{~N}$ & $2.7 E+01$ & $3.7 \mathrm{E}-01$ & $2.7 E+01$ & $3.7 E-01$ \\
\hline & TAN & 702 & 002 & N & 8.3E-02 & $3.6 \mathrm{E}-01$ & 8.3E-02 & $3.6 \mathrm{E}-01$ \\
\hline & CFA & 754 & 006 & N & $1.3 E-01$ & $3.5 E-01$ & $1.3 E-01$ & $3.5 E-01$ \\
\hline & & 623 & 005 & $Y$ & 8.0E-02 & $3.5 \mathrm{E}-01$ & 2.9E-01 & $1.3 E+00$ \\
\hline & TRA & 727 & 003 & N & $1.6 \mathrm{E}-01$ & $3.3 E-01$ & $1.6 \mathrm{E}-01$ & $3.3 E-01$ \\
\hline & TAN & 783 & 001 & N & $E+01$ & E-01 & $3.2 E+01$ & 3.1E-01 \\
\hline & CPP & 663 & 048 & Y & $1.5 E-01$ & $3.1 \mathrm{E}-01$ & 5. $3 E+00$ & 1. $1 \mathrm{E}+01$ \\
\hline & & 787 & 001 & Y & $9.1 E-02$ & 2.9E-01 & $8.7 E+00$ & $3.8 \mathrm{E}+01$ \\
\hline & CFA & 713 & 001 & N & $3.2 E+01$ & $2.7 \mathrm{E}-01$ & $3.2 E+01$ & 2.7E-01 \\
\hline & TAN & 679 & 013 & N & $1.2 E-01$ & $2.7 \mathrm{E}-01$ & $1.2 \mathrm{E}-01$ & 2.7E-01 \\
\hline & NRF & 602 & 006 & Y & $2.5 E-01$ & 2.6E-01 & $2.5 E-01$ & $1.1 E+00$ \\
\hline & TRA & 614 & 032 & Y & $5.4 E-02$ & $2.4 \mathrm{E}-01$ & $5.4 \mathrm{E}-02$ & $2.4 \mathrm{E}-01$ \\
\hline & CFA & 731 & 001 & $\mathrm{~N}$ & $9.3 E+00$ & $2.3 \mathrm{E}-01$ & $9.3 E+00$ & $2.3 E-01$ \\
\hline & & 754 & 001 & N & $1.0 \mathrm{E}-01$ & $2.3 E-01$ & $1.0 E-01$ & $2.3 \mathrm{E}-01$ \\
\hline & TAN & 792 & 001 & N & $1.1 \mathrm{E}-01$ & $2.2 \mathrm{E}-01$ & $1.1 E-01$ & 2.2E-01 \\
\hline & CFA & 713 & 002 & N & $3.2 E+01$ & $2.2 E-01$ & $3.2 E+01$ & 2.2E-01 \\
\hline & & 754 & 002 & N & $9.7 \mathrm{E}-02$ & $2.0 \mathrm{E}-01$ & $9.7 \mathrm{E}-02$ & 2. $0 E-01$ \\
\hline & & 759 & 001 & $\mathrm{~N}$ & $9.6 E-02$ & $9.7 \mathrm{E}-01$ & $9.6 E-02$ & $1.7 \mathrm{E}-01$ \\
\hline & CPP & $702 B$ & 001 & $N$ & $1.5 \mathrm{E}-01$ & $1.6 \mathrm{E}-01$ & 1.5E-01 & $1.6 \mathrm{E}-0$ \\
\hline
\end{tabular}


DESCENDING RANK OF EMISSIONS RATES AT THE INEL

\begin{tabular}{|c|c|c|c|c|c|c|c|c|}
\hline POLLUTANT & AREA & BLDG & VENT & $\begin{array}{l}C \\
A \\
L \\
C\end{array}$ & $\begin{array}{c}\text { ACTUAL } \\
\text { HOURLY } \\
\text { LBS/HR } \\
\text { or } \\
\mathrm{CI} / \mathrm{MO}\end{array}$ & $\begin{array}{c}\text { ACTUAL } \\
\text { YEARLY } \\
\text { TNS/YR } \\
\text { Or } \\
\mathrm{CI} / \mathrm{YR}\end{array}$ & $\begin{array}{c}\text { MAX. } \\
\text { HOURLY } \\
\text { LBS/HR } \\
\text { or } \\
\text { CI } / \text { MO }\end{array}$ & $\begin{array}{c}\text { MAX. } \\
\text { YEARLY } \\
\text { TNS/YR } \\
\text { or } \\
\text { CI/YR }\end{array}$ \\
\hline 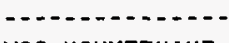 & & & & & & & & \\
\hline \multirow[t]{57}{*}{ VOC-NONMETHANE } & $\mathrm{CPP}$ & $702 A$ & 001 & $N$ & $1.5 \mathrm{E}-01$ & $1.6 E-01$ & $1.5 E-01$ & $1.6 \mathrm{E}-01$ \\
\hline & TAN & 675 & 011 & $N$ & $9.3 E-02$ & $1.5 E-01$ & $9.3 E-02$ & $1.5 \mathrm{E}-01$ \\
\hline & PER & 609 & 010 & $\mathbf{N}$ & $4.8 E-02$ & $1.3 \mathrm{E}-01$ & $4.8 \mathrm{E}-02$ & $1.3 E-01$ \\
\hline & ANL & 768 & 133 & $Y$ & $3.0 E-02$ & $1.3 E-01$ & 2. $0 \mathrm{E}-02$ & $8.9 E-02$ \\
\hline & & 754 & 005 & $N$ & 8. $1 E-02$ & $1.2 \mathrm{E}-01$ & 8. $1 E-02$ & $1.2 E-01$ \\
\hline & & & & $\mathrm{N}$ & $8.1 E-02$ & $1.2 \mathrm{E}-01$ & $8.1 E-02$ & $1.2 \mathrm{E}-01$ \\
\hline & & 757 & 001 & $\mathrm{~N}$ & $8.4 E-02$ & $1.1 E-01$ & $8.4 \mathrm{E}-02$ & 1. $1 E-01$ \\
\hline & & 625 & 009 & $Y$ & 1. $1 E-01$ & 1.1E-01 & 3. $1 E-01$ & $3.2 E-01$ \\
\hline & TAN & 629 & 014 & $Y$ & $1.1 E+00$ & $1.1 \mathrm{E}-01$ & $4.0 E+00$ & $2.1 E+00$ \\
\hline & & & 012 & Y & 1. $1 E+00$ & $1.1 \mathrm{E}-01$ & $4.0 E+00$ & $2.1 E+00$ \\
\hline & CFA & 721 & 001 & $\mathrm{~N}$ & 8.1E-02 & 1.0E-01 & 8. $1 E-02$ & $1.0 E-01$ \\
\hline & CPP & 703 & 002 & $\mathrm{~N}$ & $3.2 E+01$ & $9.8 \mathrm{E}-02$ & $3.2 \mathrm{E}+01$ & $9.8 E-02$ \\
\hline & NRF & $617 \mathrm{C}$ & 001 & $\mathrm{~N}$ & $6.5 E-01$ & 8.4E-02 & $9.1 E-01$ & $4.0 E+00$ \\
\hline & & $759 \mathrm{~B}$ & 001 & $\mathrm{~N}$ & $1.3 E-01$ & $7.9 E-02$ & $1.3 E-01$ & $7.9 E-02$ \\
\hline & & $759 A$ & 001 & $\mathbf{N}$ & $1.3 E-01$ & $7.9 \mathrm{E}-02$ & $1.3 E-01$ & $7.9 E-02$ \\
\hline & & $601 \mathrm{~A}$ & 019 & $Y$ & 3.7E-02 & $7.8 E-02$ & $9.9 E-02$ & $4.3 E-01$ \\
\hline & CPP & 602 & 012 & Y & $7.3 E-02$ & $7.6 E-02$ & $2.4 E-01$ & $2.5 E-01$ \\
\hline & & 659 & 011 & N & $7.5 E-02$ & $7.6 \mathrm{E}-02$ & $7.5 E-02$ & $7.6 \mathrm{E}-02$ \\
\hline & & & 010 & $\mathbf{N}$ & $7.5 E-02$ & $7.6 E-02$ & $7.5 E-02$ & $7.6 \mathrm{E}-02$ \\
\hline & NRF & 739 & 002 & $\mathrm{~N}$ & $1.7 \mathrm{E}-02$ & $7.6 \mathrm{E}-02$ & $1.7 \mathrm{E}-02$ & $7.6 \mathrm{E}-02$ \\
\hline & & & 001 & $\mathrm{~N}$ & $1.7 E-02$ & $7.6 E-02$ & $1.7 E-02$ & $7.6 \mathrm{E}-02$ \\
\hline & & 709 & 001 & $\mathrm{~N}$ & $1.3 E-01$ & $7.2 E-02$ & $1.3 E-01$ & $7.2 E-02$ \\
\hline & & $617 \mathrm{C}$ & 002 & $\mathrm{~N}$ & $6.5 E-01$ & $7.2 \mathrm{E}-02$ & $9.1 E-01$ & $4.0 E+00$ \\
\hline & TAN & 603 & 027 & $N$ & $5.8 \mathrm{E}-03$ & $6.8 \mathrm{E}-02$ & $4.7 E-02$ & 2.0E-01 \\
\hline & & & 028 & N & $.0 E+00$ & $6.8 E-02$ & $4.7 E-02$ & 2. 1E-01 \\
\hline & ANL & 742 & 005 & $\mathrm{~N}$ & $7.2 E-02$ & $6.2 \mathrm{E}-02$ & $7.2 E-02$ & $6.2 E-02$ \\
\hline & NRF & 622 & 007 & $N$ & $1.3 E-01$ & $6.2 E-02$ & $1.3 E-01$ & $6.2 \mathrm{E}-02$ \\
\hline & ANL & 768 & 005 & $N$ & $7.2 E-02$ & $6.1 E-02$ & $7.2 E-02$ & 6.1E-02 \\
\hline & CFA & 625 & 010 & $Y$ & $5.8 E-02$ & $6.0 \mathrm{E}-02$ & $1.8 \mathrm{E}-01$ & $1.8 \mathrm{E}-01$ \\
\hline & B21 & 608 & 008 & $Y$ & $1.3 E-02$ & $5.8 E-02$ & $6.6 E-02$ & $2.9 E-01$ \\
\hline & ANL & 742 & 002 & N & $3.2 E+01$ & $5.8 E-02$ & $3.2 E+01$ & $5.8 \mathrm{E}-02$ \\
\hline & & & 006 & $\mathrm{~N}$ & $2.0 E+01$ & $5.7 \mathrm{E}-02$ & $2.0 E+01$ & 5.7E-02 \\
\hline & PER & 722 & 001 & N & $7.0 E-02$ & $5.2 E-02$ & $7.0 \mathrm{E}-02$ & $5.2 E-02$ \\
\hline & ANL & 752 & 005 & Y & $1.1 E-02$ & $4.8 E-02$ & 1.1E-02 & $4.8 \mathrm{E}-02$ \\
\hline & & & 004 & Y & $1.1 E-02$ & $4.8 E-02$ & $1.1 \mathrm{E}-02$ & $4.8 E-02$ \\
\hline & NRF & 618 & 103 & $Y$ & $1.1 \mathrm{E}-02$ & $4.4 E-02$ & $1.1 \mathrm{E}-02$ & $6.2 \mathrm{E}-02$ \\
\hline & CPP & 606 & 004 & $N$ & $3.4 E-02$ & $4.3 E-02$ & $7.2 \mathrm{E}-02$ & $3.2 E-01$ \\
\hline & CFA & 741 & 001 & $N$ & $6.7 E-02$ & $4.1 \mathrm{E}-02$ & $6.7 \mathrm{E}-02$ & 4.1E-02 \\
\hline & & & 002 & $\mathrm{~N}$ & $6.7 E-02$ & $4.1 \mathrm{E}-02$ & $6.7 \mathrm{E}-02$ & 4.1E-02 \\
\hline & & 609 & 017 & Y & $8.0 \mathrm{E}-03$ & $3.8 E-02$ & 8.0E-03 & $3.8 E-02$ \\
\hline & & & 018 & $Y$ & $8.0 E-03$ & $3.8 E-02$ & $8.0 E-03$ & $3.8 E-02$ \\
\hline & & 688 & 003 & $\mathrm{~N}$ & $8.3 E-03$ & $3.6 E-02$ & $8.3 E-03$ & $3.6 E-02$ \\
\hline & CPP & 663 & 054 & $Y$ & $1.7 \mathrm{E}-02$ & $3.6 E-02$ & 8. $0 \mathrm{E}-01$ & $1.7 E+00$ \\
\hline & NRF & 603 & 031 & $Y$ & $3.4 \mathrm{E}-02$ & $3.6 \mathrm{E}-02$ & $3.4 E-02$ & 1.5E-01 \\
\hline & & 618 & 099 & $Y$ & $7.8 E-03$ & $3.4 E-02$ & $7.8 E-03$ & $4.8 E-02$ \\
\hline & CPP & 644 & 002 & N & $6.5 E-01$ & $3.4 E-02$ & $1.3 E+00$ & $5.7 E+00$ \\
\hline & & 687 & 026 & N & $6.5 E-01$ & $3.4 E-02$ & $1.3 E+00$ & $5.7 E+00$ \\
\hline & & 644 & 013 & N & $1.2 E-01$ & $3.1 E-02$ & $1.2 \mathrm{E}-01$ & 3.1E-02 \\
\hline & TRA & 674 & 007 & N & $2.4 E+00$ & $3.1 E-02$ & $4.8 E+00$ & 2. 1E+01 \\
\hline & NRF & 620 & 014 & N & $4.5 E-02$ & $3.1 E-02$ & $1.3 E-01$ & $5.5 E-01$ \\
\hline & & & 012 & N & $4.5 E-02$ & $3.1 E-02$ & $1.3 E-01$ & $5.5 E-01$ \\
\hline & & & 013 & $N$ & $4.5 E-02$ & $3.1 E-02$ & $1.3 E-01$ & $5.5 E-01$ \\
\hline & & $617 c$ & 003 & N & $3.4 E-01$ & $3.0 E-02$ & $3.4 E-01$ & $3.0 E-02$ \\
\hline & & 675 & 035 & $N$ & 1.7E-02 & $2.9 E-02$ & $3.4 E-02$ & $1.5 E-01$ \\
\hline & CPP & 703 & 001 & N & $6.4 E-02$ & $2.8 E-02$ & $6.4 E-02$ & $2.8 E-02$ \\
\hline & CFA & 684 & 002 & $Y$ & $9.1 E+01$ & $2.8 E-02$ & $9.1 E+01$ & 6.0E-02 \\
\hline & NRF & 602 & 005 & N & $5.3 \mathrm{E}-01$ & 2.7E-02 & $5.3 E-01$ & $2.3 E+00$ \\
\hline
\end{tabular}




\begin{tabular}{|c|c|c|c|}
\hline AREA & BLDG & VENT & POLLUTANT \\
\hline$\cdots$ & $-\cdot-\cdot$ & --- & (1) \\
\hline ANL & 701 & 009 & CARBON MONOXIDE \\
\hline & 704 & 015 & \\
\hline & 707 & 002 & \\
\hline & 709 & 008 & \\
\hline & & 016 & \\
\hline & 720 & 017 & \\
\hline & & 018 & \\
\hline & 721 & 004 & \\
\hline & $752 \mathrm{~A}$ & 001 & \\
\hline & 754 & 003 & \\
\hline & 765 & 022 & \\
\hline & 768 & 003 & \\
\hline & & 022 & \\
\hline & & 024 & \\
\hline & & 027 & \\
\hline & & 028 & \\
\hline & & 034 & \\
\hline & 774 & 001 & \\
\hline & 785 & 016 & \\
\hline & & 017 & \\
\hline & $789 A$ & 007 & \\
\hline & $\begin{array}{l}798 \\
* * * *\end{array}$ & $\begin{array}{l}008 \\
* * * *\end{array}$ & $* * * * * * * * * * * * * * *$ \\
\hline & & & \\
\hline
\end{tabular}

SOURCE TYPE

FUEL BURNING EQUIPMENT

FUEL BURNING EQUIPMENT

FUEL BURNING EQUIPMENT

FUEL BURNING EQUIPMENT

FUEL BURNING EQUIPMENT

FUEL BURNING EQUIPMENT

FUEL BURNING EQUIPMENT

FUEL BURNING EQUIPMENT

FUEL BURNING EQUIPMENT

FUEL BURNING EQUIPMENT

FUEL BURNING EQUIPMENT

FUEL BURNING EQUIPMENT

FUEL BURNING EQUIPMENT

FUEL BURNING EQUIPMENT

FUEL BURNING EQUIPMENT

FUEL BURNING EQUIPMENT

FUEL BURNING EQUIPMENT

FUEL BURNING EQUIPMENT

FUEL BURNING EQUIPMENT

FUEL BURNING EQUIPMENT

FUEL BURNING EQUIPMENT

FUEL BURNING EQUIPMENT

$\begin{array}{lll}701 & 009 & \text { NITROGEN OXIDES } \\ 704 & 015 & \\ 707 & 002 & \\ 709 & 008 & \\ & 016 & \\ 720 & 017 \\ & 018 \\ 721 & 004 \\ 752 A & 001 \\ 752 & 003 \\ 754 & 003 \\ 765 & 022 \\ 768 & 003 \\ & 022 \\ & 024 \\ & 027 \\ & 028 \\ & 034 \\ 774 & 001 \\ 785 & 016 & \\ & 017 \\ 789 A & 007 & \\ 798 & 008 & \\ * * * * * * * * * * * * * * * * * * * * \\ \end{array}$

701009 PARTICULATE

$704 \quad 015$

$707 \quad 002$

$709 \quad 008$

016

$\begin{array}{ll}720 & 017\end{array}$

018

$\begin{array}{ll}721 & 004\end{array}$

752A 001

FUEL BURNING EQUIPMENT FUEL BURNING EQUIPMENT FUEL BURNING EQUIPMENT FUEL BURNING EQUIPMENT FUEL BURNING EQUIPMENT FUEL BURNING EQUIPMENT FUEL BURNING EQUIPMENT FUEL BURNING EQUIPMENT FUEL BURNING EQUIPMENT
FUEL BURNING EQUIPMENT FUEL BURNING EQUIPMENT FUEL BURNING EQUIPMEN FUEL BURNING EQUIPMENT FUEL BURNING EQUIPMENT FUEL BURNING EQUIPINENT FUEL BURNING EQUIPMENT FUEL BURNING EQUIPMENT FUEL BURNING EQUIPMENT FUEL BURNING EQUIPMENT FUEL BURNING EQUIPMENT FUEL BURNING EQUIPMENT FUEL BURNING EQUIPMENT FUEL BURNING EQUIPMENT FUEL BURNING EQUIPMENT FUEL BURNING EQUIPMENT FUEL BURNING EQUIPMENT

\begin{tabular}{|c|c|c|c|c|}
\hline $\mathrm{C}$ & $\begin{array}{l}\text { ACTUAL } \\
\text { HOURLY }\end{array}$ & $\begin{array}{l}\text { ACTUAL } \\
\text { YEARLY }\end{array}$ & $\begin{array}{l}\text { MAX. } \\
\text { HOURLY }\end{array}$ & $\begin{array}{r}\text { MAX. } \\
\text { YEARLY }\end{array}$ \\
\hline & LBS/HR & TNS/YR & LBS/HR & TNS/YR \\
\hline L & or & or & or & or \\
\hline & $\mathrm{CI} / \mathrm{MO}$ & $\mathrm{Cl} / \mathrm{YR}$ & CI/MO & $\mathrm{CI} / \mathrm{YR}$ \\
\hline N & 5.1E-01 & $6.1 \mathrm{E}-03$ & $7.8 E+00$ & $3.4 \mathrm{E}+01$ \\
\hline $\mathbf{N}$ & 2.0E-01 & $2.8 E-03$ & $4.0 E-01$ & 1. $7 \mathrm{E}+00$ \\
\hline $\mathbf{N}$ & $2.0 E+00$ & $3.1 E-02$ & $2.3 E+00$ & 1. $.0 E+01$ \\
\hline N & $1.1 E+00$ & $7.8 E-03$ & 2. $1 E+00$ & $9.1 E+00$ \\
\hline N & $1.3 E+00$ & $1.0 E-02$ & $2.6 E+00$ & 1. $1 E+01$ \\
\hline $\mathbf{N}$ & 4.1E-01 & 1.0E-02 & $8.7 E-01$ & $3.8 E+00$ \\
\hline N & 1.3E-09 & $2.6 \mathrm{E}-03$ & 2.7E-01 & $1.2 E+00$ \\
\hline $\mathbf{N}$ & $1.3 E-02$ & $2.3 E-03$ & $1.3 E-02$ & $5.5 E-02$ \\
\hline N & $1.3 E+00$ & $1.7 \mathrm{E}-02$ & $2.6 E+00$ & 1. $1 E+01$ \\
\hline N & 1.9E-01 & $5.6 E-03$ & $3.9 E-01$ & $1.7 E+00$ \\
\hline N & 7.7E-01 & $4.4 E-03$ & $1.5 E+00$ & $6.7 E+00$ \\
\hline N & $1.8 E+00$ & $2.5 \mathrm{E}-02$ & $3.7 E+00$ & 1. $.6 E+01$ \\
\hline $\mathbf{N}$ & $6.5 E-01$ & $2.5 E-03$ & $8.5 E-01$ & $3.7 E+\infty 0$ \\
\hline $\mathbf{N}$ & $6.5 E-01$ & $6.3 E-01$ & $8.5 E-01$ & $3.7 E+00$ \\
\hline N & 6.7E-01 & $6.3 E-01$ & $8.4 E-01$ & $3.7 E+00$ \\
\hline N & $9.2 E-01$ & $7.7 E-03$ & $9.2 E-01$ & $4.0 E+00$ \\
\hline $\mathbf{N}$ & 7.5E-01 & $2.5 E-03$ & $9.4 E-01$ & $4.9 E+00$ \\
\hline $\mathbf{N}$ & 4.5E-01 & 03 & $8.9 E-01$ & $3.9 E+00$ \\
\hline $\mathbf{N}$ & $1.5 E-01$ & $8.7 E-04$ & $4.8 E-01$ & $2.1 E+00$ \\
\hline $\mathbf{N}$ & $5.4 E-01$ & $3.4 E-03$ & 1. $1 E+00$ & $4.7 E+00$ \\
\hline $\mathbf{N}$ & $.0 E+00$ & $.0 E+00$ & $.0 E+00$ & $.0 E+00$ \\
\hline & $1.7 \mathrm{E}-01$ & $2.3 E-03$ & 1.7E-01 & 7.6E-01 \\
\hline & 15 & 14 & $3,25+01$ & $+0 ?$ \\
\hline & & & & \\
\hline $\mathbf{N}$ & $2.3 E+00$ & 2. $8 \mathrm{E}-02$ & $3.6 E+01$ & $1.6 E+02$ \\
\hline & $9.4 E-01$ & $1.3 \mathrm{E}-02$ & $1.8 E+00$ & 8.0E+00 \\
\hline $\mathbf{N}$ & $9.4 E+00$ & $1.4 \mathrm{E}-01$ & $1.1 E+01$ & $4.7 E+01$ \\
\hline $\mathbf{N}$ & $4.3 E+00$ & $3.0 E-02$ & $8.0 E+00$ & $3.5 \mathrm{E}+01$ \\
\hline $\mathbf{N}$ & $5.0 E+00$ & $4.0 \mathrm{E}-02$ & 1. $.0 E+01$ & $4.4 E+01$ \\
\hline $\mathbf{N}$ & $1.9 E+00$ & 4.7E-02 & $4.0 E+00$ & $1.7 E+01$ \\
\hline & $6.1 \mathrm{E}-01$ & $1.2 \mathrm{E}-02$ & $1.2 E+00$ & $5.3 E+00$ \\
\hline & 4.5E-02 & 8.3E-03 & 4.5E-02 & 2.0E-01 \\
\hline & $6.1 E+00$ & $7.9 E-02$ & 1. $2 E+01$ & $5.2 E+01$ \\
\hline & $8.9 E-01$ & $2.6 \mathrm{E}-02$ & $1.8 \mathrm{E}+00$ & $7.8 \mathrm{E}+00$ \\
\hline & $3.5 E+00$ & $2.0 E-02$ & $7.1 E+00$ & $3.1 E+01$ \\
\hline$N$ & $8.4 E+00$ & $1.2 E-01$ & $1.7 E+01$ & $7.4 E+01$ \\
\hline & $2.6 \mathrm{E}+00$ & 1.0E-02 & $3.4 E+00$ & $1.5 \mathrm{E}+01$ \\
\hline $\mathbf{N}$ & $2.6 E+00$ & $2.5 E+00$ & $3.4 E+00$ & $1.5 E+01$ \\
\hline $\mathbf{N}$ & $2.7 E+00$ & $2.5 E+00$ & $3.4 E+00$ & $1.5 E+01$ \\
\hline & $4.2 E+00$ & $3.5 E-02$ & $4.2 E+00$ & $1.8 \mathrm{E}+01$ \\
\hline & $3.0 E+00$ & $1.0 E-02$ & $3.7 E+00$ & $1.6 E+01$ \\
\hline $\mathbf{N}$ & 2. $1 E+00$ & $2.7 \mathrm{E}-02$ & $4.1 E+00$ & $1.8 E+01$ \\
\hline & 7.0E-01 & $4.0 \mathrm{E}-03$ & $2.2 E+00$ & $9.7 E+00$ \\
\hline $\mathbf{N}$ & $2.5 \mathrm{E}+00$ & $1.5 \mathrm{E}-02$ & $5.0 E+00$ & $2.2 E+01$ \\
\hline & $.0 E+00$ & $.0 E+00$ & $.0 E+\infty 0$ & $.0 E+00$ \\
\hline & 8.0E-01 & -02 & $8.0 E-01$ & $E+00$ \\
\hline & & & & \\
\hline & $6.5 \mathrm{E}+01$ & $5.7 E+00$ & $1.4 \mathrm{E}+02$ & $6.1 E+02$ \\
\hline N & $1.7 E-01$ & 2. $0 \mathrm{E}-03$ & $2.5 E+00$ & 1. $1 \mathrm{E}+01$ \\
\hline $\mathbf{N}$ & 6.7E-02 & $9.2 \mathrm{E}-04$ & 1. $3 E-01$ & 5.7E-01 \\
\hline N & 6.7E-01 & $1.0 \mathrm{E}-02$ & $7.6 E-01$ & $3.3 E+00$ \\
\hline N & $4.4 E-01$ & $3.0 \mathrm{E}-03$ & 8.0E-01 & $3.5 E+00$ \\
\hline $\mathbf{N}$ & 5.0E-01 & $4.0 \mathrm{E}-03$ & 1. $.0 E+00$ & $4.4 E+00$ \\
\hline $\mathbf{N}$ & $1.3 \mathrm{E}-01$ & $3.3 E-03$ & $2.8 E-01$ & $1.2 E+00$ \\
\hline N & $4.4 E-02$ & $8.4 E-04$ & 8.7E-02 & $3.8 E-01$ \\
\hline$N$ & $6.3 E-03$ & $1.2 E-03$ & 6.3E-03 & $2.7 E-02$ \\
\hline N & $4.4 E-01$ & $5.6 E-03$ & $8.5 E-01$ & $3.7 E+00$ \\
\hline
\end{tabular}




\begin{tabular}{|c|c|c|c|c|c|c|c|c|c|}
\hline AREA & BLDG & VENT & POLLUTANT & SOURCE TYPE & $\begin{array}{l}C \\
A \\
L \\
C\end{array}$ & $\begin{array}{c}\text { ACTUAL } \\
\text { HOURLY } \\
\text { LBS } / H R \\
\text { or } \\
\mathrm{CI} / \mathrm{MO}\end{array}$ & $\begin{array}{c}\text { ACTUAL } \\
\text { YEARLY } \\
\text { TNS } / Y R \\
\text { or } \\
C I / Y R\end{array}$ & $\begin{array}{c}\text { MAX. } \\
\text { HOURLY } \\
\text { LBS/HR } \\
\text { or } \\
\mathrm{CI} / \mathrm{MO}\end{array}$ & $\begin{array}{c}\text { MAX. } \\
\text { YEARLY } \\
\text { TNS/YR } \\
\text { OF } \\
\text { CI/YR }\end{array}$ \\
\hline 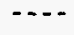 & $\cdots$ & -... & & & & & & & \\
\hline \multirow[t]{57}{*}{ ANL } & 753 & 006 & PARTI CULATE & CHEMICAL SOURCES & $Y$ & $.0 E+00$ & $.0 E+00$ & 2.1E-01 & 1. $1 E-01$ \\
\hline & & 029 & & CHEMICAL SOURCES & $Y$ & $3.3 E-03$ & $1.7 E-03$ & 2.1E-01 & $1.1 E-01$ \\
\hline & 754 & 003 & & FUEL BURNING EQUIPMENT & $\mathbf{N}$ & $6.4 \mathrm{E}-02$ & $1.8 \mathrm{E}-03$ & $1.3 \mathrm{E}-01$ & $5.6 \mathrm{E}-01$ \\
\hline & 757 & 001 & & COOLING TOWER & Y & $5.6 E+00$ & $2.5 \mathrm{E}+01$ & $1.2 E+01$ & $5.5 E+01$ \\
\hline & 759 & 009 & & CHEMICAL SOURCES & $\mathbf{Y}$ & $.0 E+00$ & $.0 E+00$ & $.0 E+00$ & $.0 \mathrm{E}+00$ \\
\hline & 765 & 022 & & FUEL BURNING EQUIPMENT & $\mathbf{N}$ & $2.5 E-01$ & $1.5 E-03$ & $5.1 E-01$ & $2.2 \mathrm{E}+00$ \\
\hline & 768 & 003 & & FUEL BURNING EQUIPMENT & $\mathrm{N}$ & $6.0 E-01$ & $8.4 \mathrm{E}-03$ & $1.2 E+00$ & $5.3 E+00$ \\
\hline & & 022 & & FUEL BURNING EQUIPMENT & N & $2.6 E-01$ & $1.0 E-03$ & $3.4 \mathrm{E}-01$ & $1.5 \mathrm{E}+00$ \\
\hline & & 024 & & FUEL BURNING EQUIPMENT & N & $2.6 \mathrm{E}-01$ & $2.5 E-01$ & $3.4 E-01$ & $1.5 E+00$ \\
\hline & & 027 & & FUEL BURNING EQUIPMENT & N & $2.7 E-01$ & $2.5 E-01$ & $3.4 E-01$ & $1.5 \mathrm{E}+00$ \\
\hline & & 028 & & FUEL BURNING EQUIPMENT & $\mathbf{N}$ & $3.0 \mathrm{E}-01$ & $2.5 E-03$ & $3.0 \mathrm{E}-01$ & $1.3 E+00$ \\
\hline & & 034 & & FUEL BURNING EQUIPMENT & $\mathbf{N}$ & $3.0 E-01$ & 1.0E-03 & 3.7E-01 & $1.6 E+00$ \\
\hline & 774 & 001 & & FUEL BURNING EQUIPMENT & N & $1.5 \mathrm{E}-01$ & $1.9 E-03$ & $2.9 E-01$ & $1.3 \mathrm{E}+00$ \\
\hline & 782 & 028 & & CHEMICAL SOURCES & $Y$ & $4.3 E-03$ & $3.1 \mathrm{E}-03$ & $5.1 \mathrm{E}-01$ & $3.6 \mathrm{E}-01$ \\
\hline & 785 & 016 & & FUEL BURNING EQUIPMENT & $N$ & $5.0 E-02$ & $2.8 E-04$ & $1.6 \mathrm{E}-01$ & $6.9 E-01$ \\
\hline & & 017 & & FUEL BURNING EQUIPMENT & $\mathbf{N}$ & $1.8 E-01$ & $1.1 \mathrm{E}-03$ & $3.6 E-01$ & $1.6 \mathrm{E}+00$ \\
\hline & 788 & 013 & & CHEMICAL SOURCES & $Y$ & $1.9 E-04$ & $4.9 E-06$ & $1.3 E-01$ & 5.7E-01 \\
\hline & & 014 & & CHEMICAL SOURCES & Y & $1.8 \mathrm{E}-03$ & $7.1 E-05$ & $1.8 E-02$ & $7.9 E-02$ \\
\hline & $789 \mathrm{~A}$ & 007 & & FUEL BURNING EQUIPMENT & $\mathbf{N}$ & $.0 E+00$ & $.0 E+00$ & $.0 E+00$ & $.0 E+00$ \\
\hline & 798 & 008 & & FUEL BURNING EQUIPMENT & $\mathrm{N}$ & $5.7 E-02$ & $7.5 E-04$ & $5.7 \mathrm{E}-02$ & $2.5 \mathrm{E}-01$ \\
\hline & $\star \star \star \star \star *$ & $\star \star \star * * *$ & 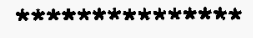 & & & $-\ldots+\ldots$ & $-\ldots$ & 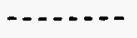 & -....... \\
\hline & & & sum & & & $1.1 E+01$ & $2.5 E+01$ & $2.4 E+01$ & $1.0 \mathrm{E}+02$ \\
\hline & 721 & 004 & PB & FUEL BURNING EQUIPMENT & $\mathrm{N}$ & $3.1 E-06$ & $5.8 E-07$ & $3.1 E-06$ & $1.4 \mathrm{E}-05$ \\
\hline & 768 & 022 & & FUEL BURNING EQUIPMENT & $\mathrm{N}$ & $1.6 \mathrm{E}-04$ & $6.3 E-07$ & 2. 1E-04 & $9.3 E-04$ \\
\hline & & 024 & & FUEL BURNING EQUIPMENT & $\mathrm{N}$ & $1.6 \mathrm{E}-04$ & $1.6 \mathrm{E}-04$ & $2.1 \mathrm{E}-04$ & $9.3 E-04$ \\
\hline & & 027 & & FUEL BURNING EQUIPMENT & $\mathbf{N}$ & $1.7 E-04$ & $1.6 E-04$ & $2.1 E-04$ & $9.2 E-04$ \\
\hline & & 034 & & FUEL BURNING EQUIPMENT & N & $1.9 E-04$ & $6.3 E-07$ & $2.3 E-04$ & $1.0 \mathrm{E}-03$ \\
\hline & $\star * \star \star *$ & & $\star \star \star * \star * \star * \star * * * * * * * *$ & & & & & & \\
\hline & & & sum & & & $6.9 E-04$ & $3.2 E-04$ & $8.8 E-04$ & $3.8 E-03$ \\
\hline & 704 & 008 & RADIONUCLIDE & CHEMICAL SOURCES & $Y$ & 1. $0 E-07$ & $4.2 E-07$ & $4.9 E-06$ & $5.9 E-05$ \\
\hline & 720 & 007 & & CHEMICAL SOURCES & $\gamma$ & $1.4 E-01$ & $8.5 E-01$ & $3.0 E+01$ & $3.6 E+02$ \\
\hline & & 027 & & SUSPECT WASTE TANK & $Y$ & $.0 E+00$ & $.0 E+00$ & $.0 E+00$ & $.0 \mathrm{E}+00$ \\
\hline & 752 & 004 & & CHEMICAL SOURCES & $\gamma$ & $1.6 \mathrm{E}-05$ & $1.9 E-04$ & $5.2 E-02$ & $6.3 E-01$ \\
\hline & & 005 & & CHEMICAL SOURCES & Y & $1.2 E-07$ & $1.4 E-06$ & $3.8 E-04$ & $4.6 \mathrm{E}-03$ \\
\hline & 764 & 001 & & CHEMICAL SOURCES & Y & $8.5 E+01$ & $1.0 E+03$ & $1.9 E+02$ & $1.3 \mathrm{E}+03$ \\
\hline & 766 & 056 & & CHEMICAL SOURCES & & $.0 E+00$ & $.0 E+00$ & $.0 E+00$ & $.0 E+00$ \\
\hline & & 057 & & CHEMICAL SOURCES & & $.0 E+00$ & $.0 E+00$ & $.0 E+00$ & $.0 E+00$ \\
\hline & 768 & 105 & & SUSPECT WATER WASTE (RAD) & $Y$ & $.0 E+00$ & $.0 E+00$ & $4.8 E-08$ & $5.7 E-07$ \\
\hline & & 108 & & CHEMICAL SOURCES & y & $.0 E+00$ & $.0 \mathrm{E}+00$ & $7.5 E-12$ & $9.0 E-10$ \\
\hline & 774 & 008 & & REACTOR ROOM VENTILATION & $\mathbf{Y}$ & $.0 E+00$ & $.0 E+00$ & $2.9 E-03$ & $3.5 E-02$ \\
\hline & & 025 & & REACTOR COOLING AIR & $\mathbf{Y}$ & $.0 E+00$ & $.0 E+00$ & $1.3 E-06$ & $1.5 E-05$ \\
\hline & 776 & 001 & & REACTOR VESSEL & Y & $.0 E+00$ & $.0 \mathrm{E}+00$ & $2.5 E-04$ & $3.1 E-03$ \\
\hline & 777 & 002 & & REACTOR COOLING AIR EXH. & Y & $1.5 E-01$ & $1.8 \mathrm{E}+00$ & $1.5 E-01$ & $1.8 \mathrm{E}+00$ \\
\hline & 784 & 010 & & CHEMICAL SOURCES & $Y$ & $.0 E+00$ & $.0 E+00$ & $.0 E+00$ & $.0 E+00$ \\
\hline & 785 & 011 & & ROOM EXHAUST & $y$ & $.0 E+00$ & $.0 E+00$ & $.0 E+00$ & $.0 E+00$ \\
\hline & & 018 & & CHEMICAL SOURCES & $\mathbf{Y}$ & $6.5 E+00$ & $7.7 E+01$ & $2.9 E+01$ & $1.1 E+02$ \\
\hline & 787 & 001 & & CHEMICAL SOURCES & $Y$ & $1.4 E-07$ & 2. $1 E-07$ & $2.6 \mathrm{E}-06$ & 3. IE-05 \\
\hline & 793 & 001 & & CHEMICAL SOURCES & $\mathrm{Y}$ & $3.7 \mathrm{E}-02$ & $4.4 \mathrm{E}-01$ & $3.7 E-02$ & 4.4E-01 \\
\hline & $793 \mathrm{~A}$ & 029 & & STORAGE TANK - VOC & y & $.0 E+00$ & $.0 E+00$ & $.0 E+00$ & $.0 E+00$ \\
\hline & & 030 & & STORAGE TANK - VOC & y & $.0 E+00$ & $.0 E+00$ & $.0 E+00$ & $.0 E+00$ \\
\hline & 794 & 006 & & STORAGE FACILITY & y & $.0 \mathrm{E}+00$ & $.0 E+00$ & $.0 E+00$ & $.0 E+00$ \\
\hline & 798 & 017 & & CHEMICAL SOURCES & Y & $2.3 E-02$ & $2.8 E-01$ & 2.3E-02 & $2.8 E-01$ \\
\hline & 799 & 003 & & CHEMICAL SOURCES & $\mathbf{Y}$ & $.0 E+00$ & $.0 E+00$ & $.0 E+00$ & $.0 E+00$ \\
\hline & & 010 & & CHEMICAL SOURCES & $Y$ & $.0 E+00$ & $.0 E+00$ & $.0 E+00$ & $.0 E+00$ \\
\hline & * & * & $* * * *$ & & & & & & \\
\hline & & & sum & & & $9.2 \mathrm{E}+01$ & 1. $1 \mathrm{E}+03$ & $2.5 E+02$ & $1.8 E+03$ \\
\hline & 701 & 009 & SULFUR OXIDES & FUEL BURNING EQUIPMENT & $\mathbf{N}$ & $1.6 E-01$ & $1.9 E-03$ & $2.4 E+00$ & $1.0 E+01$ \\
\hline
\end{tabular}


AREA BLDG VENT POLLUTANT

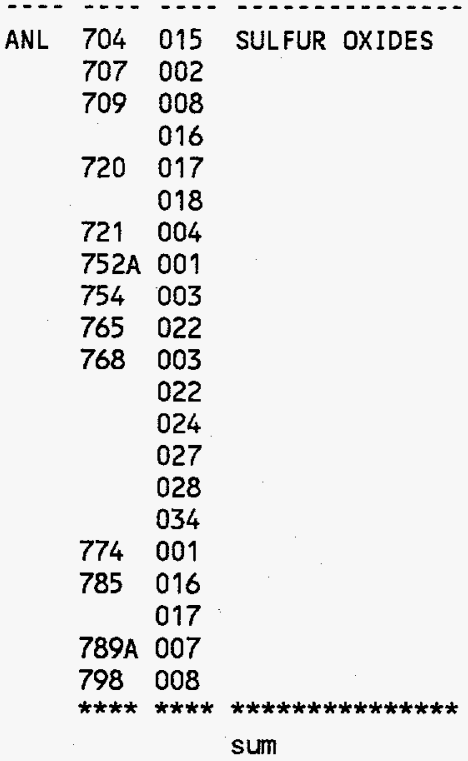

701009 VOC-NONMETHANE 012 020

$704 \quad 008$ 015

\begin{tabular}{ll}
$707 \quad 001$ \\
\hline
\end{tabular} 002

709001 008 009 016

$\begin{array}{ll}720 & 017\end{array}$ 018 021 022 025

$721 \quad 003$ 004

742002

005 006

$752 \quad 004$ 005

752A 001 005

$753 \quad 006$ 029

$754 \quad 001$ 003

$755 \mathrm{~A} 001$

755B 002

$\begin{array}{ll}757 & 001\end{array}$

$\begin{array}{ll}765 & 022\end{array}$ 073
SOURCE TYPE

FUEL BURNING EQUIPMENT FUEL BURNING EQUIPMENT FUEL BURNING EQUIPMENT FUEL BURNING EQUIPMENT FUEL BURNING EQUIPMENT FUEL BURNING EQUIPMENT FUEL BURNING EQUIPMENT FUEL BURNING EQUIPMENT FUEL BURNING EQUIPMENT FUEL BURNING EQUIPMENT FUEL BURNING EQUIPMENT FUEL BURNING EQUIPMENT FUEL BURNING EQUIPMENT FUEL BURNING EQUIPMENT FUEL BURNING EQUIPMENT FUEL BURNING EQUIPMENT FUEL BURNING EQUIPMENT FUEL BURNING EQUIPMENT FUEL BURNING EQUIPMENT FUEL BURNING EQUIPMENT FUEL BURNING EQUIPMENT

FUEL BURNING EQUIPMENT STORAGE TANK - VOC STORAGE TANK - VOC CHEMICAL SOURCES FUEL BURNING EQUIPMENT STORAGE TANK - VOC FUEL BURNING EQUIPMENT STORAGE TANK - VOC FUEL BURNING EQUIPMENT STORAGE TANK - VOC FUEL BURNING EQUIPMENT FUEL BURNING EQUIPMENT FUEL BURNING EQUIPMENT STORAGE TANK - VOC STORAGE TANK - VOC STORAGE TANK - VOC STORAGE TANK - VOC FUEL BURNING EQUIPMENT STORAGE TANK - VOC STORAGE TANK - VOC STORAGE TANK - VOC CHEMICAL SOURCES CHEMICAL SOURCES FUEL BURNING EQUIPMENT STORAGE TANK - VOC CHEMICAL SOURCES CHEMICAL SOURCES STORAGE TANK - VOC FUEL BURNING EQUIPMENT STORAGE TANK - VOC STORAGE TANK - VOC COOLING TOWER FUEL BURNING EQUIPMENT STORAGE TANK - VOC

\begin{tabular}{|c|c|c|c|c|}
\hline & $\begin{array}{l}\text { ACTUAL } \\
\text { HOURLY }\end{array}$ & $\begin{array}{l}\text { ACTUAL } \\
\text { YEARLY }\end{array}$ & $\begin{array}{l}\text { MAX. } \\
\text { HOURLY }\end{array}$ & $\begin{array}{r}\text { MAX. } \\
\text { YEARLY }\end{array}$ \\
\hline A & LBS/HR & TNS/YR & LBS/HR & TNS/YR \\
\hline 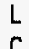 & or & or & or & or \\
\hline C & CI/MO & $\mathrm{CI} / \mathrm{YR}$ & $\mathrm{CI} / \mathrm{MO}$ & \\
\hline N & $6.2 \mathrm{E}-02$ & $8.6 E-04$ & $1.2 \mathrm{E}-01$ & 5.3E-01 \\
\hline N & $6.2 E-01$ & $9.4 E-03$ & 7.1E-01 & $3.1 E+00$ \\
\hline N & 3.1E-01 & $2.2 E-03$ & $5.8 E-01$ & $2.5 \mathrm{E}+00$ \\
\hline N & $3.6 E-01$ & $2.9 \mathrm{E}-03$ & $7.2 E-01$ & $3.2 E+00$ \\
\hline N & $1.2 E-01$ & $3.1 E-03$ & 2.7E-01 & $1.2 \mathrm{E}+00$ \\
\hline N & 4.1E-02 & $7.8 E-04$ & $8.1 E-02$ & $3.6 \mathrm{E}-01$ \\
\hline N & $1.8 E-01$ & 3.3E-02 & $1.8 \mathrm{E}-01$ & $7.9 \mathrm{E}-01$ \\
\hline N & 4. 1E-01 & $5.2 E-03$ & 8.0E-01 & $3.5 E+00$ \\
\hline N & $5.9 E-02$ & $1.7 E-03$ & $1.2 E-01$ & $5.2 E-01$ \\
\hline N & 2.4 & $1.4 \mathrm{E}-03$ & -01 & $2.1 E+00$ \\
\hline $\mathbf{N}$ & $5.6 \mathrm{E}-01$ & $7.8 \mathrm{E}-03$ & $E+00$ & 4. $9 E+00$ \\
\hline $\mathbf{N}$ & $9.4 E+00$ & $3.6 \mathrm{E}-02$ & $1.2 E+01$ & $5.4 E+01$ \\
\hline N & $9.4 \mathrm{E}+00$ & $9.0 \mathrm{E}+00$ & $1.2 E+01$ & $5.4 E+01$ \\
\hline N & $9.6 E+00$ & $9.0 E+00$ & $1.2 E+01$ & $5.3 E+01$ \\
\hline $\mathbf{N}$ & $2.8 \mathrm{E}-01$ & $2.3 E-03$ & 2.8E-01 & $1.2 \mathrm{E}+00$ \\
\hline $\mathrm{N}$ & +01 & $3.6 \mathrm{E}$ & $1.3 E+01$ & $.9 E+01$ \\
\hline $\mathbf{N}$ & $1.4 E-01$ & $1.8 E-03$ & 2.7E-01 & $2 E+00$ \\
\hline N & 4.7E-02 & $2.7 E-04$ & $1.5 E-01$ & $6.4 E-01$ \\
\hline N & 1.7E-01 & 1.0E-03 & 3.3E-01 & $1.4 E+00$ \\
\hline N & $.0 E+00$ & $.0 E+00$ & $.0 E+00$ & $.0 E+00$ \\
\hline $\mathbf{N}$ & $5.3 E-02$ & $7.0 \mathrm{E}-04$ & $5.3 E-02$ & 2.3E-01 \\
\hline & $4.3 E+01$ & $1.8 E+01$ & $5.9 \mathrm{E}+01$ & $2.6 E+C$ \\
\hline $\mathbf{N}$ & $2.2 E-01$ & $2.7 \mathrm{E}-03$ & $3.4 E+00$ & $1.5 F+01$ \\
\hline N & $1.2 E-02$ & $3.2 E-03$ & $1.2 \mathrm{E}-02$ & $3.2 E-03$ \\
\hline N & $3.4 E-02$ & $2.4 \mathrm{E}-04$ & $3.4 E-02$ & $2.4 E-04$ \\
\hline Y & $3.0 \mathrm{E}-04$ & $1.3 E-03$ & $6.6 \mathrm{E}-03$ & 1.5E-02 \\
\hline N & 8.9E-02 & $1.2 \mathrm{E}-03$ & $1.7 E-01$ & $7.6 E-01$ \\
\hline $\mathbf{N}$ & $3.5 \mathrm{E}-02$ & $3.6 E-03$ & $3.5 E-02$ & $3.6 E-03$ \\
\hline$\sqrt{ }$ & $8.9 E-01$ & $1.3 E-02$ & $1.0 E+00$ & $4.4 E+00$ \\
\hline N & 1.7E-01 & 8.7E-03 & $1.7 \mathrm{E}-01$ & 8.7E-03 \\
\hline $\mathbf{N}$ & $1.1 \mathrm{E}-01$ & $7.8 E-04$ & 2.1E-01 & $9.1 E-01$ \\
\hline . & $.0 E+00$ & $.0 E+00$ & +00 & +00 \\
\hline 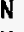 & 1.3E-01 & 1.0E-03 & 2.6E-01 & 1. $1 E+00$ \\
\hline $\mathbf{N}$ & 1.8E-01 & 4.5E-03 & $3.8 E-01$ & $1.7 E+00$ \\
\hline N & $5.8 E-02$ & $1.1 E-03$ & $1.2 \mathrm{E}-01$ & 5.1E-01 \\
\hline 1 & $3.4 E-03$ & $1.6 E-04$ & $3.4 E-03$ & $1.6 E-04$ \\
\hline$\sqrt{ }$ & $3.4 E-03$ & $1.4 E-04$ & $3.4 \mathrm{E}-03$ & $1.4 E-04$ \\
\hline & & 4. & -02 & -03 \\
\hline $\mathbf{N}$ & $6.2 E-02$ & 1.7E-02 & $6.2 F-02$ & \\
\hline 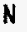 & $1.8 \mathrm{E}-03$ & 3.3E-04 & $1.8 \mathrm{E}-03$ & $7.8 E-03$ \\
\hline 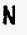 & $3.2 E+01$ & $5.8 E-02$ & $3.2 \mathrm{E}+01$ & $5.8 E-02$ \\
\hline & 7.2E-02 & $6.2 E-02$ & $7.2 E-02$ & $6.2 E-02$ \\
\hline & $2.0 E+01$ & $.7 E-02$ & 2. $.0 E+01$ & $5.7 E-02$ \\
\hline & 1. & $4.8 E-02$ & 02 & $4.8 E-02$ \\
\hline & $1.1 E-02$ & $4.8 \mathrm{E}-02$ & $1.1 \mathrm{E}-02$ & $E-02$ \\
\hline $\mathbf{m}$ & $5.8 E-01$ & $7.5 E-03$ & $1.1 E+00$ & $5.0 E+00$ \\
\hline $\mathbf{N}$ & $6.2 \mathrm{E}-02$ & $1.7 E-02$ & $6.2 E-02$ & $1.7 E-02$ \\
\hline & $.0 E+00$ & $.0 E+00$ & $8.0 E+00$ & $4.2 E+00$ \\
\hline & 00 & 00 & $1.2 E+01$ & $1.2 E+00$ \\
\hline & 1.7E-01 & 1.7E-03 & 1.7E-01 & 1.7E-03 \\
\hline & 8.5E-02 & $2.4 E-03$ & $1.7 E-01$ & $7.4 E-01$ \\
\hline & 4.9E-01 & $1.6 E+00$ & 4.9E-01 & $1.6 \mathrm{E}+00$ \\
\hline & 2.3E-01 & $4.8 E-01$ & 2.3E-01 & $4.8 E-01$ \\
\hline & 3.1E-01 & $1.4 E+00$ & $2.9 E-01$ & $1.3 E+00$ \\
\hline & 3.4E-01 & $1.9 E-03$ & 6.7E-01 & $2.9 E+0$ \\
\hline & 5.9E-02 & $6.2 E-03$ & $=-02$ & -03 \\
\hline
\end{tabular}




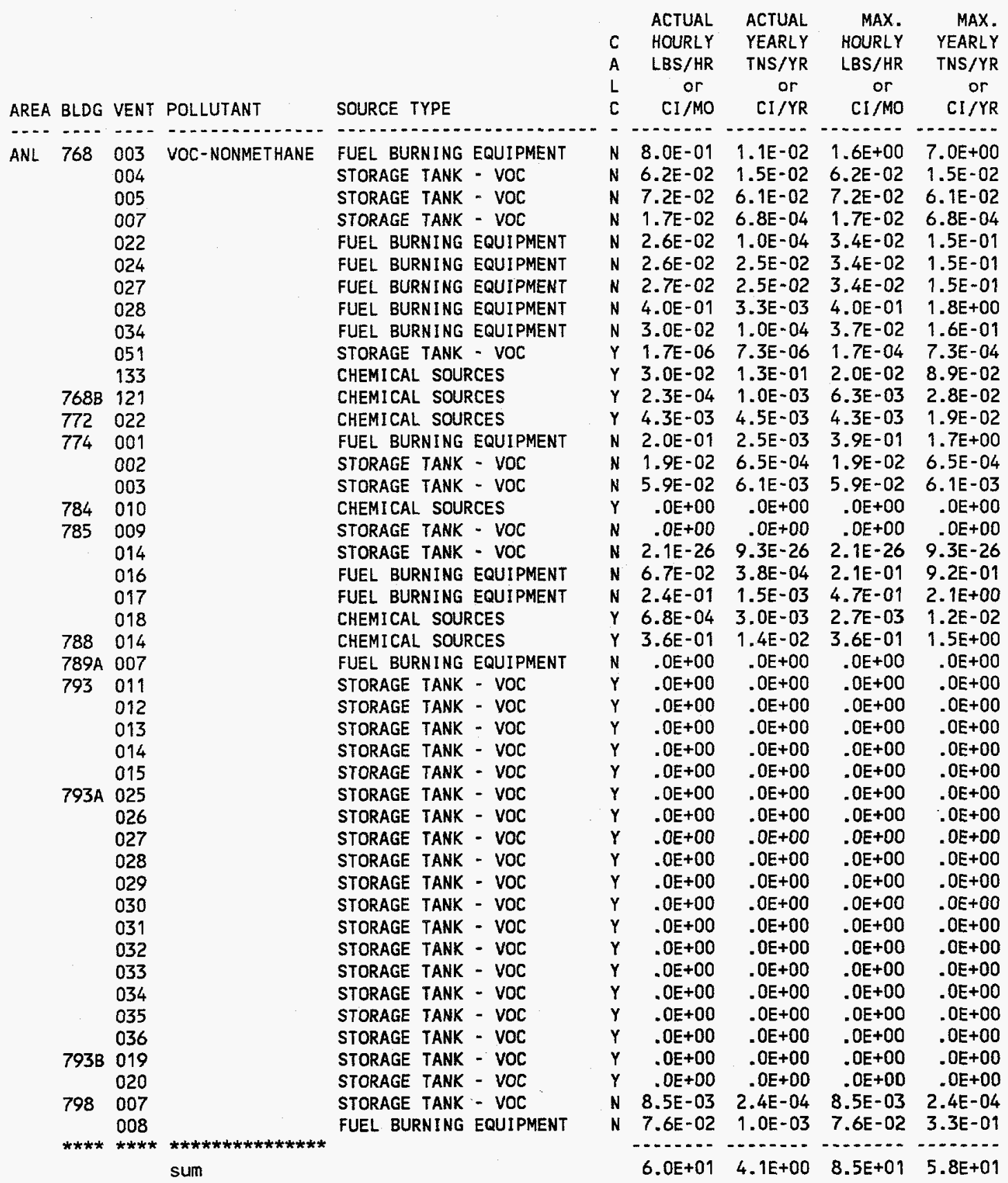




\begin{tabular}{|c|c|c|c|c|c|c|c|c|c|}
\hline AREA & BLDG & $\begin{array}{l}\text { VENT } \\
-. . .\end{array}$ & POLLUTANT & SOURCE TYPE & $\begin{array}{l}\text { C } \\
\text { A } \\
\text { L } \\
\text { C } \\
-\end{array}$ & $\begin{array}{c}\text { ACTUAL } \\
\text { HOURLY } \\
\text { LBS } / H R \\
\text { or } \\
\mathrm{CI} / \mathrm{MO}\end{array}$ & $\begin{array}{c}\text { ACTUAL } \\
\text { YEARLY } \\
\text { TNS/YR } \\
\text { or } \\
\text { CI/YR }\end{array}$ & $\begin{array}{l}\text { MAX. } \\
\text { HOURLY } \\
\text { LBS/HR } \\
\text { or } \\
\mathrm{CI} / \mathrm{MO}\end{array}$ & $\begin{array}{l}\text { MAX. } \\
\text { YEARLY } \\
\text { TNS /YR } \\
\text { or } \\
\text { CI/YR }\end{array}$ \\
\hline RA & IV & 001 & $\begin{array}{l}\text { CARBON MONOXIDE } \\
\text { sum }\end{array}$ & CHEMICAL SOURCES & $\bar{y}$ & $1.8 \mathrm{E}+00$ & $2.0 E-02$ & $3.5 \mathrm{E}+00$ & $\begin{array}{r}3.9 E-02 \\
-.0--- \\
3.9 E-02\end{array}$ \\
\hline & $\begin{array}{l}\text { IV } \\
* * * *\end{array}$ & $\begin{array}{l}001 \\
002 \\
\star * * *\end{array}$ & $\begin{array}{l}\text { NITROGEN OXIDES } \\
\star \star \star \star \star \star \star \star \star \star \star * * * * \\
\text { sum }\end{array}$ & $\begin{array}{l}\text { CHEMICAL SOURCES } \\
\text { CHEMICAL SOURCES }\end{array}$ & $\begin{array}{l}Y \\
Y\end{array}$ & $\begin{array}{r}6.6 E-02 \\
3.7 E-04 \\
-6.6 E-02\end{array}$ & $\begin{array}{r}6.3 E-04 \\
6.3 E-04 \\
1.3 E-03\end{array}$ & $\begin{array}{r}1.2 \mathrm{E}-01 \\
7.3 \mathrm{E}-04 \\
1.2 \mathrm{E}-01\end{array}$ & $\begin{array}{r}1.3 E-03 \\
1.3 E-03 \\
-2.5 E-03\end{array}$ \\
\hline & $\begin{array}{l}\text { IV } \\
\star * * *\end{array}$ & $\begin{array}{l}001 \\
002 \\
* * * *\end{array}$ & 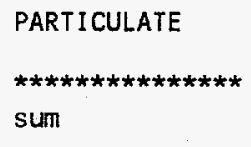 & $\begin{array}{l}\text { CHEMICAL SOURCES } \\
\text { CHEMICAL SOURCES }\end{array}$ & $\begin{array}{l}Y \\
Y\end{array}$ & $\begin{array}{r}9.0 E+00 \\
5.0 E-02 \\
9.1 E+00\end{array}$ & $\begin{array}{r}1.0 E-01 \\
1.0 E-01 \\
2.0 E-01\end{array}$ & $\begin{array}{r}1.8 E+01 \\
1.0 E-01 \\
1.8 E+01\end{array}$ & $\begin{array}{r}2.0 E-01 \\
2.0 E-01 \\
4.0 E-01\end{array}$ \\
\hline & $\begin{array}{l}\text { IV } \\
* * * *\end{array}$ & $\begin{array}{l}001 \\
002 \\
* * * *\end{array}$ & 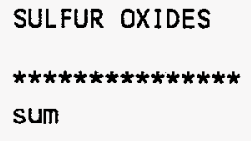 & $\begin{array}{l}\text { CHEMICAL SOURCES } \\
\text { CHEMICAL SOURCES }\end{array}$ & $\begin{array}{l}Y \\
Y\end{array}$ & $\begin{array}{r}6.6 \mathrm{E}-03 \\
3.7 \mathrm{E}-05 \\
6.6 \mathrm{E}-03\end{array}$ & $\begin{array}{r}7.7 E-05 \\
7.7 E-05 \\
\hdashline 1.5 E-04\end{array}$ & $\begin{array}{r}1.2 \mathrm{E}-02 \\
7.3 \mathrm{E}-05 \\
-1.2 \mathrm{E}-02\end{array}$ & $\begin{array}{r}1.5 E-04 \\
1.5 E-04 \\
3.1 E-04\end{array}$ \\
\hline & $\begin{array}{l}\text { IV } \\
\star * * *\end{array}$ & $\begin{array}{l}001 \\
002 \\
* * * *\end{array}$ & $\begin{array}{l}\text { VOC-NONMETHANE } \\
\star * * * * * * * * * * * * * * \\
\text { sum }\end{array}$ & $\begin{array}{l}\text { CHEMICAL SOURCES } \\
\text { CHEMICAL SOURCES }\end{array}$ & $\begin{array}{l}Y \\
Y\end{array}$ & $\begin{array}{r}4.4 E-02 \\
2.5 E-04 \\
4.4 E-02\end{array}$ & $\begin{array}{r}4.0 E-04 \\
4.0 E-04 \\
-2.0 E-04\end{array}$ & $\begin{array}{r}8.8 E-02 \\
4.9 E-04 \\
8.8 E-02\end{array}$ & $\begin{array}{r}8.0 \mathrm{E}-04 \\
8.0 \mathrm{E}-04 \\
1.6 \mathrm{E}-03\end{array}$ \\
\hline EA & BLDG & VENT & POLLUTANT & SOURCE TYPE & $\begin{array}{l}\text { C } \\
\text { A } \\
\text { L } \\
\text { C }\end{array}$ & $\begin{array}{c}\text { ACTUAL } \\
\text { HOURLY } \\
\text { LBS/HR } \\
\text { or } \\
\mathrm{CI} / \mathrm{MO}\end{array}$ & $\begin{array}{c}\text { ACTUAL } \\
\text { YEARLY } \\
\text { TNS/YR } \\
\text { or } \\
C I / Y R\end{array}$ & $\begin{array}{l}\text { MAX. } \\
\text { HOURLY } \\
\text { LBS/HR } \\
\text { or } \\
\mathrm{CI} / \mathrm{MO}\end{array}$ & $\begin{array}{l}\text { MAX. } \\
\text { YEARLY } \\
\text { TNS } / Y R \\
\text { or } \\
\text { CI } / Y R\end{array}$ \\
\hline 08 & $\begin{array}{l}601 \\
* \star \star *\end{array}$ & $\underset{* * * *}{003}$ & $\begin{array}{l}\text { CARBON MONOXIDE } \\
\star * * * * * * * * * * * * * * \\
\text { sum }\end{array}$ & FUEL BURNING EQUIPMENT & $\mathbf{N}$ & $\begin{array}{r}2.5 E-01 \\
2.5 E-01\end{array}$ & $\begin{array}{r}3.3 E-03 \\
3.3 E-03\end{array}$ & $\begin{array}{r}5.1 E-01 \\
5.1 E-01\end{array}$ & $\begin{array}{r}2.2 E+00 \\
2.2 E+00\end{array}$ \\
\hline & $\begin{array}{l}601 \\
* * * *\end{array}$ & $\begin{array}{l}003 \\
\star \star \star \star \star\end{array}$ & $\begin{array}{l}\text { NITROGEN OXIDES } \\
\star \star \star \star \star \star * \star * \star * \star \star \star \star \star * \\
\text { sum }\end{array}$ & FUEL BURNING EQUIPME & N & $\begin{array}{r}1.2 E+00 \\
1.2 E+00\end{array}$ & $\begin{array}{r}1.5 E-02 \\
\hdashline 1.5 E-02\end{array}$ & $\begin{array}{r}2.3 E+00 \\
2.3 E+00\end{array}$ & $\begin{array}{r}1.0 E+01 \\
\hdashline 1.0 E+01\end{array}$ \\
\hline & $\begin{array}{l}601 \\
* * * *\end{array}$ & $\begin{array}{l}003 \\
\star \star \star \star \star\end{array}$ & $\begin{array}{l}\text { PART ICULATE } \\
* \star * \star * * * * * * * * * * \\
\text { sum }\end{array}$ & FUEL BURNING EQUIPMENT & $N$ & $\begin{array}{r}8.4 E-02 \\
-8.4 E-02\end{array}$ & $\begin{array}{r}1.1 E-03 \\
-1.1 E-03\end{array}$ & $\begin{array}{r}1.7 E-01 \\
\hdashline 1.7 E-01\end{array}$ & $\begin{array}{r}7.3 E-01 \\
7.3 E-01\end{array}$ \\
\hline & $\begin{array}{l}601 \\
\star * \star * *\end{array}$ & $\begin{array}{l}003 \\
\star \star \star \star \star\end{array}$ & $\begin{array}{l}\text { SULFUR OXIDES } \\
\star * * * * * * * * * * * * * * \\
\text { sum }\end{array}$ & FUEL BURNING EQUIPMENT & N & $\begin{array}{r}7.8 \mathrm{E}-02 \\
7.8 \mathrm{E}-02\end{array}$ & $\begin{array}{r}1.0 E-03 \\
\hdashline 1.0 E-03\end{array}$ & $\begin{array}{r}1.6 E-01 \\
1.6 E-01\end{array}$ & $\begin{array}{r}6.8 E-01 \\
-6.8 E-01\end{array}$ \\
\hline & 601 & $\begin{array}{l}001 \\
003 \\
\star * \star \star\end{array}$ & $\begin{array}{l}\text { VOC-NONMETHANE } \\
\star * \star * * * * * * * * * * * * \\
\text { sum }\end{array}$ & $\begin{array}{l}\text { STORAGE TANK - VOC } \\
\text { FUEL BURNING EQUIPMENT }\end{array}$ & N & $\begin{array}{r}3.4 E-01 \\
1.1 E-01 \\
4.5 E-01\end{array}$ & $\begin{array}{l}3.1 E-04 \\
1.4 E-03 \\
1.8 E-03\end{array}$ & $\begin{array}{r}3.4 E-01 \\
2.2 E-01 \\
5.6 E-01\end{array}$ & $\begin{array}{r}3.1 E-04 \\
9.8 E-01 \\
9.8 E-01\end{array}$ \\
\hline
\end{tabular}




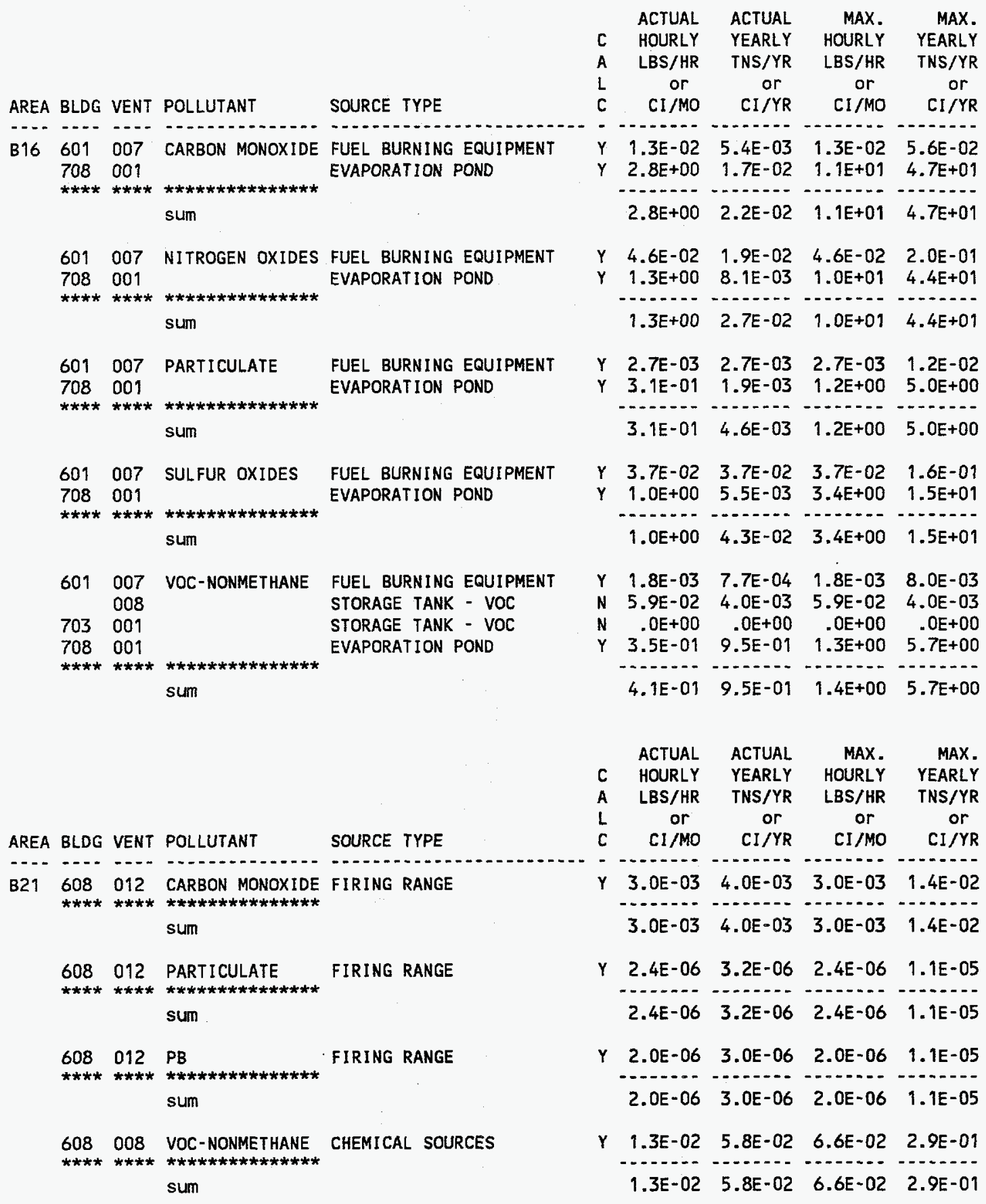




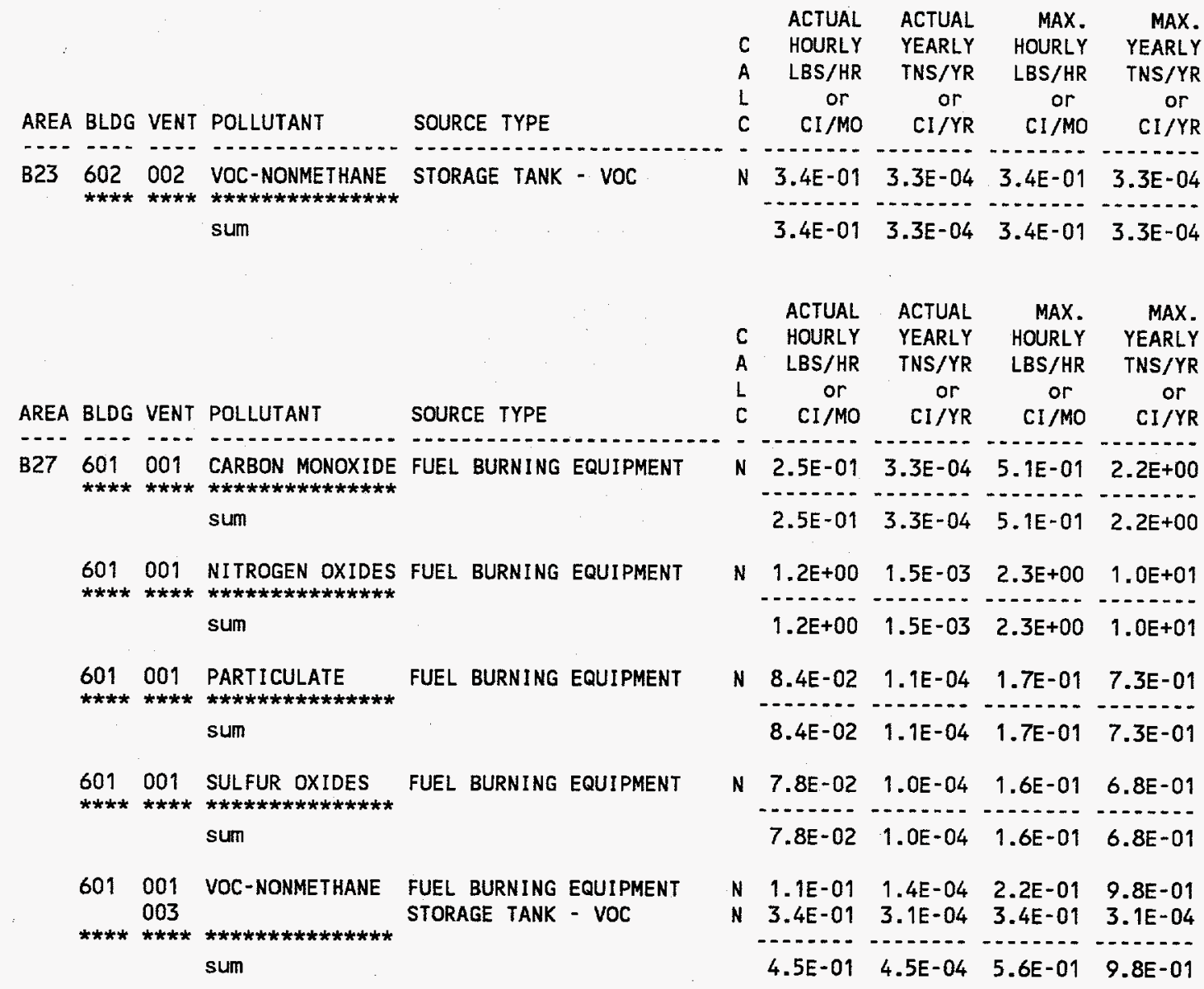




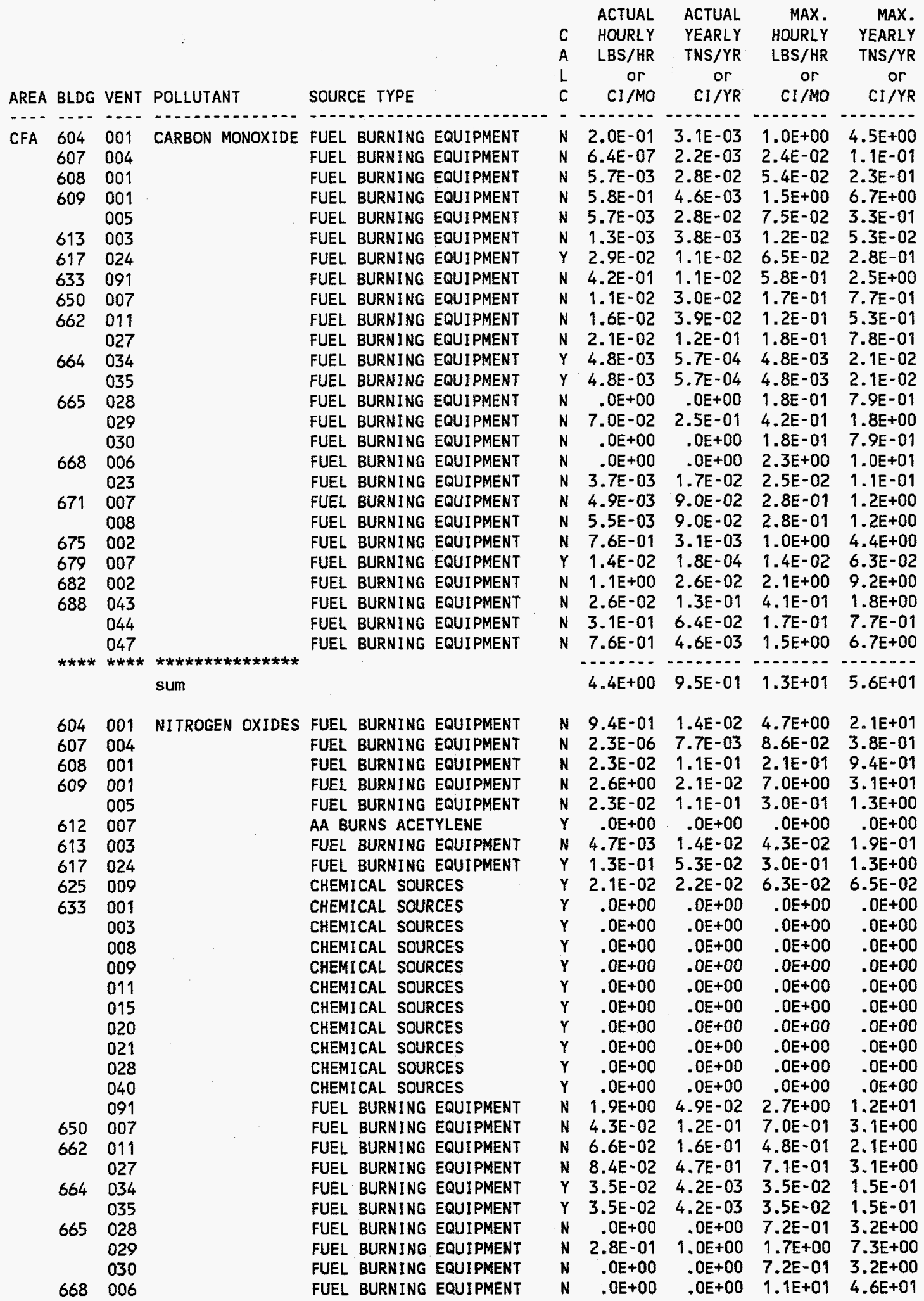




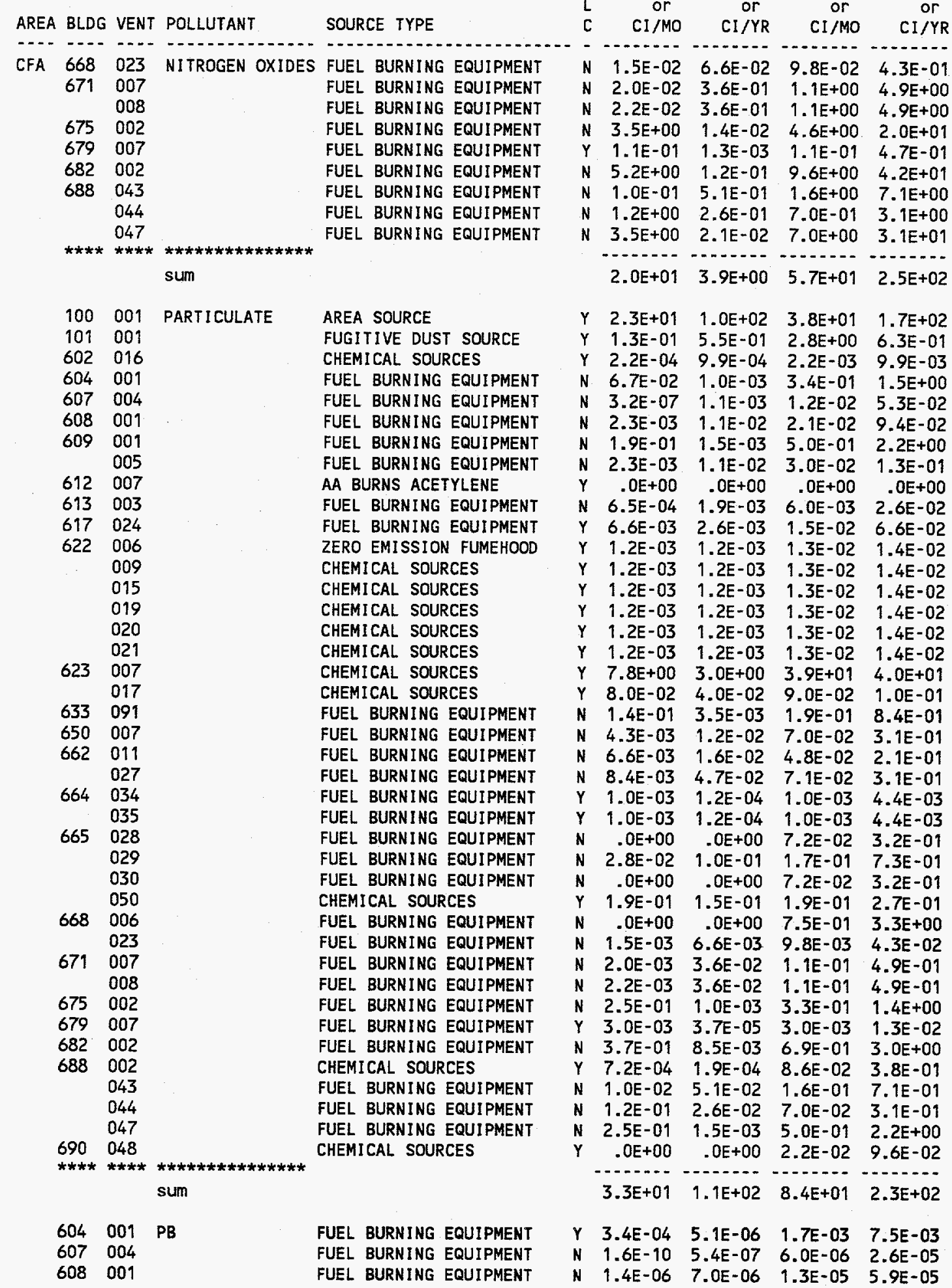




\begin{tabular}{|c|c|c|c|}
\hline $\begin{array}{l}\text { AREA } \\
-\ldots .\end{array}$ & $\begin{array}{l}\text { BLDG } \\
-\ldots\end{array}$ & VENT & $\begin{array}{l}\text { POLLUTANT } \\
\end{array}$ \\
\hline CFA & 609 & $\begin{array}{l}001 \\
005\end{array}$ & PB \\
\hline & 613 & 003 & \\
\hline & 633 & 091 & \\
\hline & 650 & 007 & \\
\hline & 662 & $\begin{array}{l}011 \\
027\end{array}$ & \\
\hline & 665 & $\begin{array}{l}028 \\
029 \\
030\end{array}$ & \\
\hline & 668 & $\begin{array}{l}006 \\
023\end{array}$ & \\
\hline & 671 & $\begin{array}{l}007 \\
008\end{array}$ & \\
\hline & 675 & 002 & \\
\hline & 682 & 002 & \\
\hline & 688 & 043 & \\
\hline & & $\begin{array}{l}044 \\
047\end{array}$ & \\
\hline & 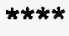 & $\star \star \star \star \star$ & 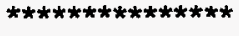 \\
\hline
\end{tabular}

$\begin{array}{lll}617 & 010 & \text { RADIONUCLIDE } \\ 011 & \\ 026 & \\ 030 & \\ 031 & \\ 033 & \\ & 034 & \\ 625 & 010 & \\ 633 & 001 & \\ & 003 & \\ & 008 & \\ 009 & \\ 011 & \\ 015 & \\ 020 & \\ 021 & \\ 028 & \\ 040 & \\ 067 & \\ 690 & 042 & \\ * * * * & * * * * & * * * * * * * * * * * * * * \\ & & \text { sUm }\end{array}$

$\begin{array}{lll}604 & 001 & \text { SULFUR OXIDES } \\ 607 & 004 & \\ 608 & 001 \\ 609 & 001 & \\ & 005 & \\ 613 & 003 \\ 617 & 024 \\ 633 & 091 \\ 650 & 007 \\ 662 & 011 \\ & 027 \\ 664 & 034 \\ & 035 \\ 665 & 028\end{array}$

SOURCE TYPE

FUEL BURNING EQUIPMENT FUEL BURNING EQUIPMENT FUEL BURNING EQUIPMENT FUEL BURNING EQUIPMENT FUEL BURNING EQUIPMENT FUEL BURNING EQUIPMENT FUEL BURNING EQUIPMENT FUEL BURNING EQUIPMENT FUEL BURNING EQUIPMENT FUEL BURNING EQUIPMENT FUEL BURNING EQUIPMENT FUEL BURNING EQUIPMENT FUEL BURNING EQUIPMENT FUEL BURNING EQUIPMENT FUEL BURNING EQUIPMENT FUEL BURNING EQUIPMENT FUEL BURNING EQUIPMENT FUEL BURNING EQUIPMENT FUEL, BURNING EQUIPMENT

LAUNDRY DRYER

LAUNDRY DRYER RAD DECON HOOD RESP DRYING OVEN \#1 RESP DRYING OVEN \#2 RAD DECON HOODS RAD DECON HOODS CHEMICAL SOURCES CHEMICAL SOURCES CHEMICAL SOURCES CHEMICAL SOURCES CHEMICAL SOURCES CHEMICAL SOURCES CHEMICAL SOURCES CHEMICAL SOURCES CHEMICAL SOURCES CHEMICAL SOURCES CHEMICAL SOURCES RAD SOURCE CHEMICAL SOURCES

FUEL BURNING EQUIPMENT FUEL BURNING EQUIPMENT FUEL BURNING EQUIPMENT FUEL BURNING EQUIPMENT FUEL BURNING EQUIPMENT FUEL BURNING EQUIPMENT FUEL BURNING EQUIPMENT FUEL BURNING EQUIPMENT FUEL BURNING EQUIPMENT FUEL BURNING EQUIPMENT FUEL BURNING EQUIPMENT FUEL BURNING EQUIPMENT FUEL BURNING EQUIPMENT FUEL BURNING EQUIPMENT

\begin{tabular}{|c|c|c|c|c|}
\hline & & & 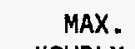 & \\
\hline & & $y$ & RLY & \\
\hline & S/HR & /YR & tR & s) \\
\hline & $\mathrm{CI} / \mathrm{M}$ & $\mathrm{CI} / \mathrm{YR}$ & CI/MO & $\mathrm{Cl} / \mathrm{Y}$ \\
\hline & 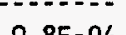 & 7750 & & \\
\hline & 8F- $>$ & 16 & 3 & \\
\hline & & & & \\
\hline & 34 & & & \\
\hline & 2.7E-06 & & & \\
\hline & .06 & & & \\
\hline & & & & $n=$. \\
\hline & 05 & & & \\
\hline & $1.8 E-05$ & 6. & & \\
\hline & $.0 E+00$ & 00 & & \\
\hline & $3.9 E-03$ & 1.2 & & 1. \\
\hline & 9.4E-07 & & & \\
\hline & & & & \\
\hline & 1.4 & & & \\
\hline & & & & \\
\hline & 1. & 4.7 & & \\
\hline & & & & \\
\hline & & & & \\
\hline & & & & \\
\hline & & & & \\
\hline & & 3 & & \\
\hline & $9.2 E-08$ & 6.4 & 04 & \\
\hline & 9.2 & 6.4 & & \\
\hline & & & & \\
\hline & 1. & 1.3 & & \\
\hline & 1. & 1.3 & & \\
\hline & & & & \\
\hline & & & & \\
\hline & 8.3 & 4.5 & 3.8 & \\
\hline & .0 & & 30 & \\
\hline & & & & \\
\hline & & & & \\
\hline & & & & \\
\hline & & & & \\
\hline & & & & \\
\hline & .0 & &. & . \\
\hline & .0 & & & \\
\hline & & & & \\
\hline & & & & \\
\hline & 2.5 & & 10 & \\
\hline & & & & \\
\hline & & & & \\
\hline & & & -01 & \\
\hline & & & & \\
\hline & & 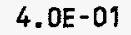 & & 3 \\
\hline & & & & 2 \\
\hline & & & & \\
\hline & & & & \\
\hline & & & & \\
\hline & 1. & 13 & & \\
\hline & & & 00 & $+c$ \\
\hline & & & & \\
\hline & & & & \\
\hline & & & & \\
\hline & & & & \\
\hline & & $.0 E+0 C$ & +1 & 1.15 \\
\hline
\end{tabular}




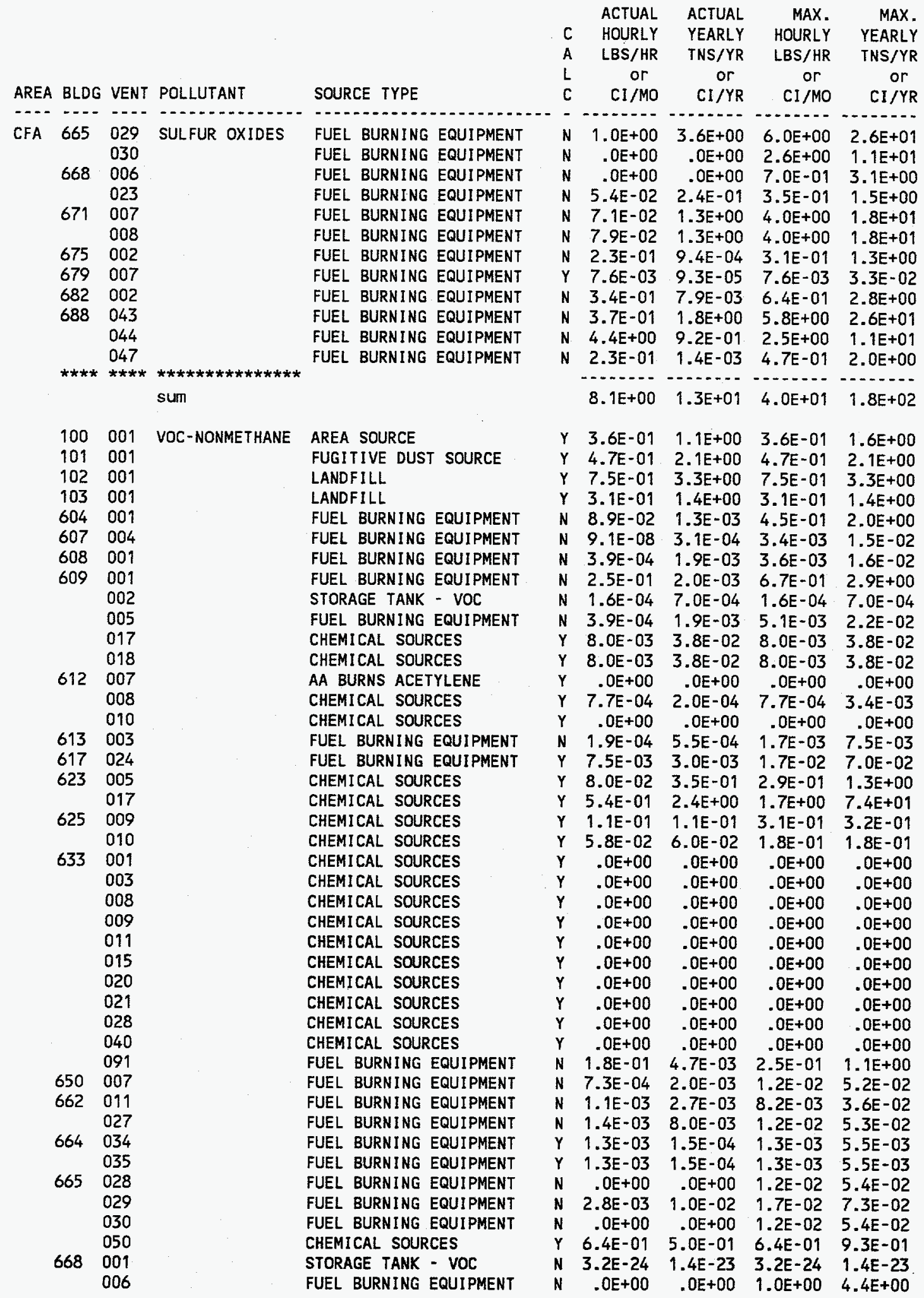




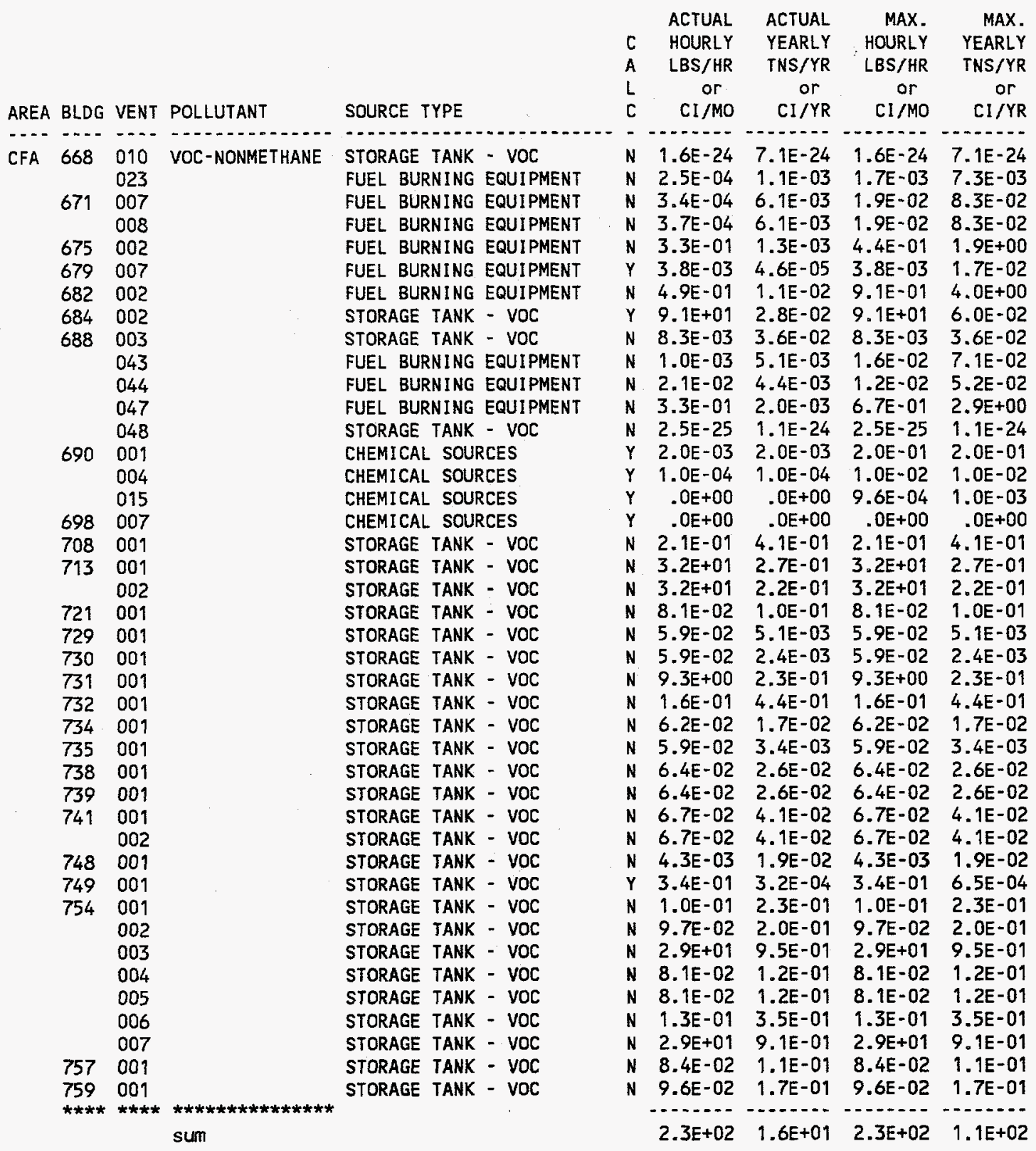


AREA BLDG VENT POLLUTTANT

CPP

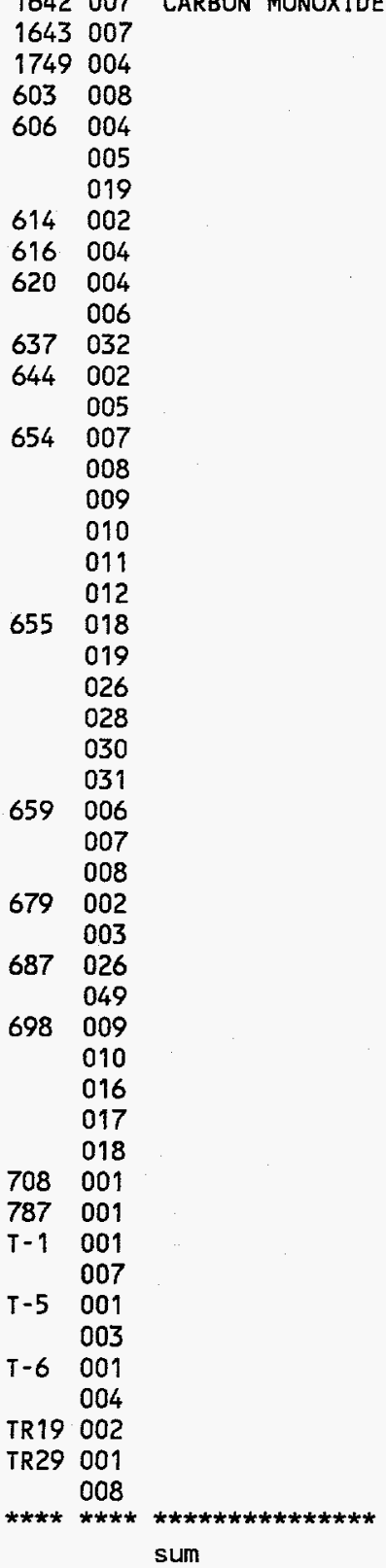

1642007 NITROGEN OXIDES FUEL BURNING EQUIPMENT 1643007

1749004

603008

606004

005
SOURCE TYPE

FUEL BURNING EQUIPMENT FUEL BURNING EQUIPMENT FUEL BURNING EQUIPMENT FUEL BURNING EQUIPMENT FUEL BURNING EQUIPMENT FUEL BURNING EQUIPMENT FUEL BURNING EQUIPMENT FUEL BURNING EQUIPMENT FUEL BURNING EQUIPMENT PILOT PLANT

PILOT PLANT

PILOT PLANT

FUEL BURNING EQUIPMENT FUEL BURNING EQUIPMENT FUEL BURNING EQUIPMENT FUEL BURNING EQUIPMENT FUEL BURNING EQUIPMENT FUEL BURNING EQUIPMENT FUEL BURNING EQUIPMENT FUEL BURNING EQUIPMENT FUEL BURNING EQUIPMENT FUEL BURNING EQUIPMENT FUEL BURNING EQUIPMENT FUEL BURNING EQUIPMENT FUEL BURNING EQUIPMENT FUEL BURNING EQUIPMENT FUEL BURNING EQUIPMENT FUEL BURNING EQUIPMENT FUEL BURNING EQUIPMENT FUEL BURNING EQUIPMENT FUEL BURNING EQUIPMENT FUEL BURNING EQUIPMENT FUEL BURNING EQUIPMENT FUEL BURNING EQUIPMENT FUEL BURNING EQUIPMENT FUEL BURNING EQUIPMENT FUEL BURNING EQUIPMENT FUEL BURNING EQUIPMENT MAIN STACK

FUEL BURNING EQUIPMENT FUEL BURNING EQUIPMENT FUEL BURNING EQUIPMENT FUEL BURNING EQUIPMENT FUEL BURNING EQUIPMENT FUEL BURNING EQUIPMENT FUEL BURNING EQUIPMENT FUEL BURNING EQUIPMENT FUEL BURNING EQUIPMENT FUEL BURNING EQUIPMENT

FUEL BURNING EQUIPMENT FUEL BURNING EQUIPMENT FUEL BURNING EQUIPMENT FUEL BURNING EQUIPMENT FUEL BURNING EQUIPMENT

\begin{tabular}{|c|c|c|c|c|}
\hline & $\begin{array}{l}\text { ACTUAL } \\
\text { HOURLY }\end{array}$ & $\begin{array}{l}\text { ACTUAL } \\
\text { YEARLY }\end{array}$ & $\begin{array}{l}\text { MAX. } \\
\text { HOURLY }\end{array}$ & $\begin{array}{l}\text { MAX. } \\
\text { YEARLY }\end{array}$ \\
\hline A & LBS/HR & TNS/YR & LBS/HR & TNS/YR \\
\hline 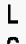 & or & or & or & or \\
\hline C & CI/MO & $\mathrm{CI} / \mathrm{YR}$ & $\mathrm{CI} / \mathrm{MO}$ & $\mathrm{Cl} / \mathrm{YR}$ \\
\hline N & $2.0 E+00$ & $3.0 E-02$ & $2.3 E+00$ & $1.0 E+01$ \\
\hline N & $2.0 E+00$ & $3.0 \mathrm{E}-02$ & 2. $3 \mathrm{E}+00$ & $1.0 E+01$ \\
\hline N & $3.1 E-01$ & $1.8 \mathrm{E}-03$ & $4.6 E-01$ & 2. $0 E+00$ \\
\hline Y & $1.1 E-02$ & $1.9 E-04$ & $2.3 \mathrm{E}-02$ & $9.9 E-02$ \\
\hline 18 & $8.6 E-01$ & $1.1 E+00$ & $1.8 \mathrm{E}+00$ & $7.9 E+00$ \\
\hline N & $5.6 \mathrm{E}-01$ & $5.5 E-01$ & $1.8 E+00$ & $7.9 \mathrm{E}+00$ \\
\hline $\mathbf{N}$ & 4. IE-01 & 1.7E-01 & $9.0 \mathrm{E}-01$ & $3.9 E+00$ \\
\hline N & $1.4 E+00$ & $2.2 E-02$ & $1.6 E+00$ & $7.2 \mathrm{E}+00$ \\
\hline $\mathbf{N}$ & $1.5 E+00$ & $2.4 \mathrm{E}-02$ & $2.2 E+00$ & $9.7 E+00$ \\
\hline 1 & $.0 E+00$ & $.0 E+00$ & $4.7 E+00$ & $2.2 E+00$ \\
\hline$Y$ & $.0 E+00$ & $.0 E+00$ & $1.8 E+01$ & $6.4 E+00$ \\
\hline$Y$ & $9.6 \mathrm{E}-04$ & 4. $9 E-05$ & 2. $0 E+00$ & 1. $.0 E+00$ \\
\hline $\mathbf{w}$ & $6.5 \mathrm{E}+00$ & $3.4 E-01$ & $1.3 E+01$ & $5.7 E+01$ \\
\hline Ix & $1.5 E-01$ & 8.0E-04 & 3.1E-01 & $1.3 E+00$ \\
\hline Y & $1.2 E-03$ & $2.6 \mathrm{E}-03$ & $1.2 E-03$ & $5.3 E-03$ \\
\hline$Y$ & 1.2 & $2.6 \mathrm{E}-03$ & $1.2 E-03$ & $5.3 \mathrm{E}-03$ \\
\hline Y & $1.2 E-03$ & $2.6 E-03$ & $1.2 E-03$ & 5.3E-03 \\
\hline Y & $1.2 \mathrm{E}-03$ & $2.6 E-03$ & $1.2 E-03$ & 5.3 \\
\hline$Y$ & 1.2E-03 & 2.6E-03 & $1.2 E-03$ & $5.3 E-03$ \\
\hline $\mathrm{I}$ & $1.2 \mathrm{E}-03$ & $2.6 E-03$ & $1.2 \mathrm{E}-03$ & 5.3E-03 \\
\hline 1 & 1.3E-03 & $2.6 \mathrm{E}-03$ & $1.3 \mathrm{E}-03$ & $5.5 E-03$ \\
\hline & 4.9 & $2.6 E-03$ & $4.9 E-03$ & $2.1 \mathrm{E}-02$ \\
\hline Y & 2.9 & 2.6E-03 & $2.9 E-03$ & $1.3 E-02$ \\
\hline$Y$ & $4.0 E-03$ & $2.6 E-03$ & 4.0E-03 & $.7 E-02$ \\
\hline Y & 4.0E-03 & 2.6E-03 & 4.0E-03 & $1.7 E-02$ \\
\hline I & $4.9 E-03$ & $2.6 E-03$ & 4. $9 E-03$ & 2.1E-02 \\
\hline N & $4.4 E+00$ & -02 & $1.1 E+02$ & $O E+02$ \\
\hline $\mathbf{N}$ & $1.6 E+01$ & 03 & $1.6 E+02$ & $6.9 E+02$ \\
\hline$v$ & $5.6 \mathrm{E}+00$ & $6.8 \mathrm{E}-02$ & $1.5 E+02$ & $E+02$ \\
\hline Y & $2.2 E-03$ & $1.3 E-03$ & $2.2 \mathrm{E}-03$ & $9.5 E-03$ \\
\hline Y & $2.2 E-03$ & $1.3 E-03$ & $2.2 E-03$ & $9.5 \mathrm{E}-03$ \\
\hline $\mathbf{N}$ & $6.5 E+00$ & $3.4 E-01$ & 1.3E+01 & $5.7 E+01$ \\
\hline N & $1.5 E-01$ & 04 & 3.1E-01 & $1.3 E+00$ \\
\hline Y & 1.4 & 3. & .03 & -03 \\
\hline$Y$ & 1.4E-03 & 3.7E-04 & $1.4 \mathrm{E}-03$ & -03 \\
\hline Y & $1.4 \mathrm{E}-03$ & $3.7 E-04$ & $1.4 \mathrm{E}-03$ & $6.3 E-03$ \\
\hline Y & $1.4 E-03$ & $3.7 E-04$ & $1.4 E-03$ & 6.3E-03 \\
\hline Y & $1.4 E-03$ & $3.7 E-04$ & $1.4 E-03$ & $6.3 E-03$ \\
\hline$Y$ & 1.2 & $E+02$ & $1.5 E+02$ & $3 E+02$ \\
\hline Y & $3.3 E+01$ & 02 & -01 & +01 \\
\hline r & $1.6 E-03$ & $6.2 \mathrm{E}-04$ & $1.6 E-03$ & $7.1 E-03$ \\
\hline$r$ & $1.6 E-03$ & $6.2 E-04$ & $1.6 E-03$ & 7.1E-03 \\
\hline 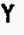 & $9.0 E-04$ & $6.2 E-04$ & $9.0 \mathrm{E}-04$ & $3.9 E-03$ \\
\hline Y & $9.0 \mathrm{E}-04$ & $6.2 E-04$ & $9.0 \mathrm{E}-04$ & $9 E-03$ \\
\hline Y & $1.7 \mathrm{E}-03$ & $1.7 E-03$ & 1.7E-03 & $7.4 E-03$ \\
\hline & 1. & 1.7E-03 & $1.7 \mathrm{E}-03$ & .03 \\
\hline & 9.0E-05 & $5.6 \mathrm{E}-04$ & $9.0 E-05$ & $5.6 E-04$ \\
\hline & $9.0 \mathrm{E}-04$ & $6.8 \mathrm{E}-04$ & $9.0 E-04$ & $3.9 E-03$ \\
\hline & $9.0 E-04$ & $6.8 E-04$ & $9.0 E-04$ & $.9 E-03$ \\
\hline & & $43 F+02$ & & \\
\hline & The & 4.JETUC & 0.35 Tuc & $+0=$ \\
\hline & $9.4 E+00$ & $1.4 \mathrm{E}-01$ & 1. $.0 E+01$ & 4. \\
\hline & $9.4 E+00$ & $1.4 \mathrm{E}-01$ & $1.0 E+01$ & $4.6 E+01$ \\
\hline & $1.4 E+00$ & $8.4 E-03$ & $2.1 E+00$ & $9.2 E+00$ \\
\hline & $5.5 E-02$ & 9.0E-04 & 1.1E-01 & $4.9 E-01$ \\
\hline & $3.4 E+00$ & $4.3 E+00$ & $7.2 E+00$ & $3.2 E+01$ \\
\hline & $2.3 E+00$ & $2.2 E+00$ & $7.2 E+00$ & $3.2 E+0$ \\
\hline
\end{tabular}




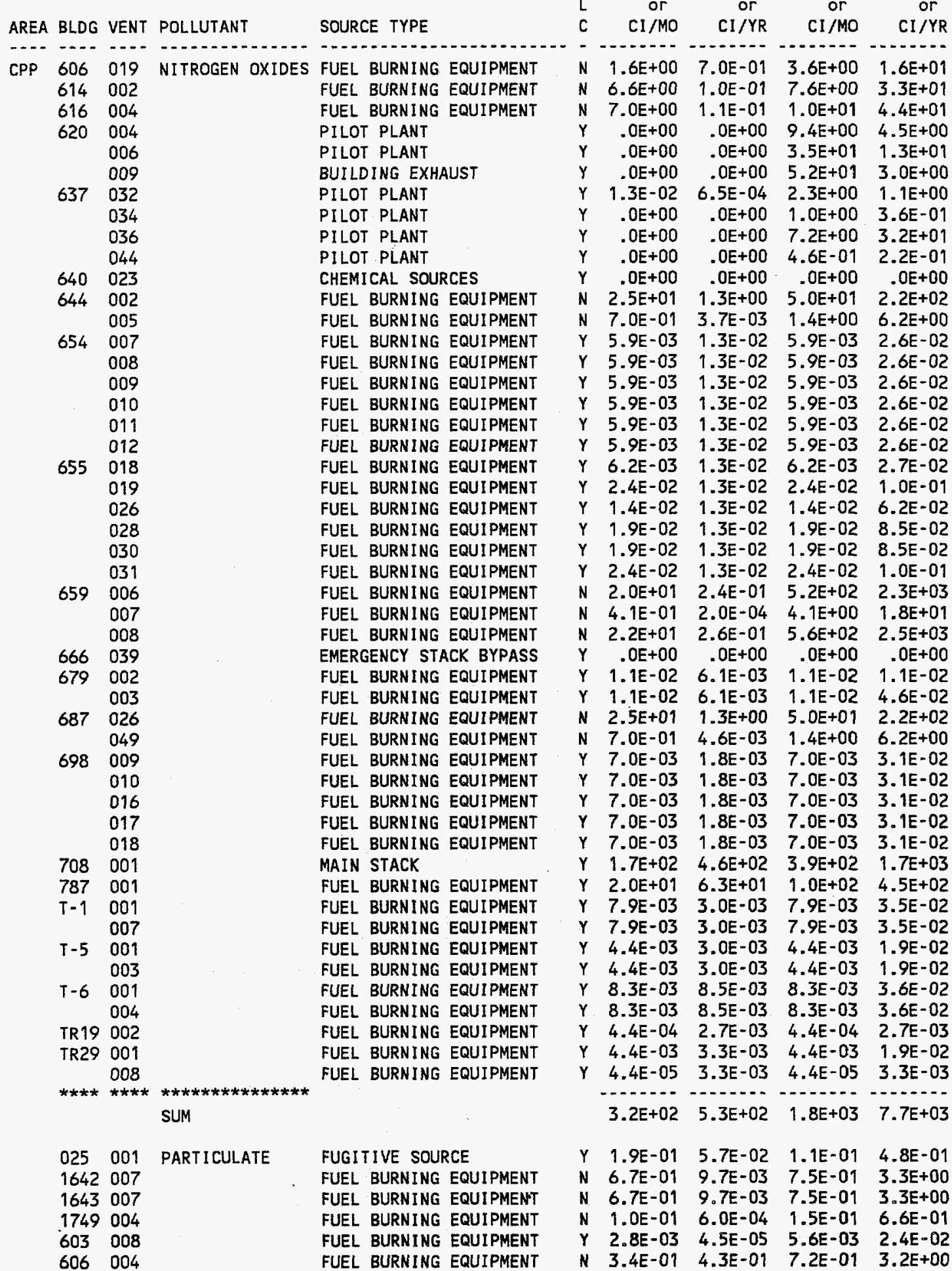




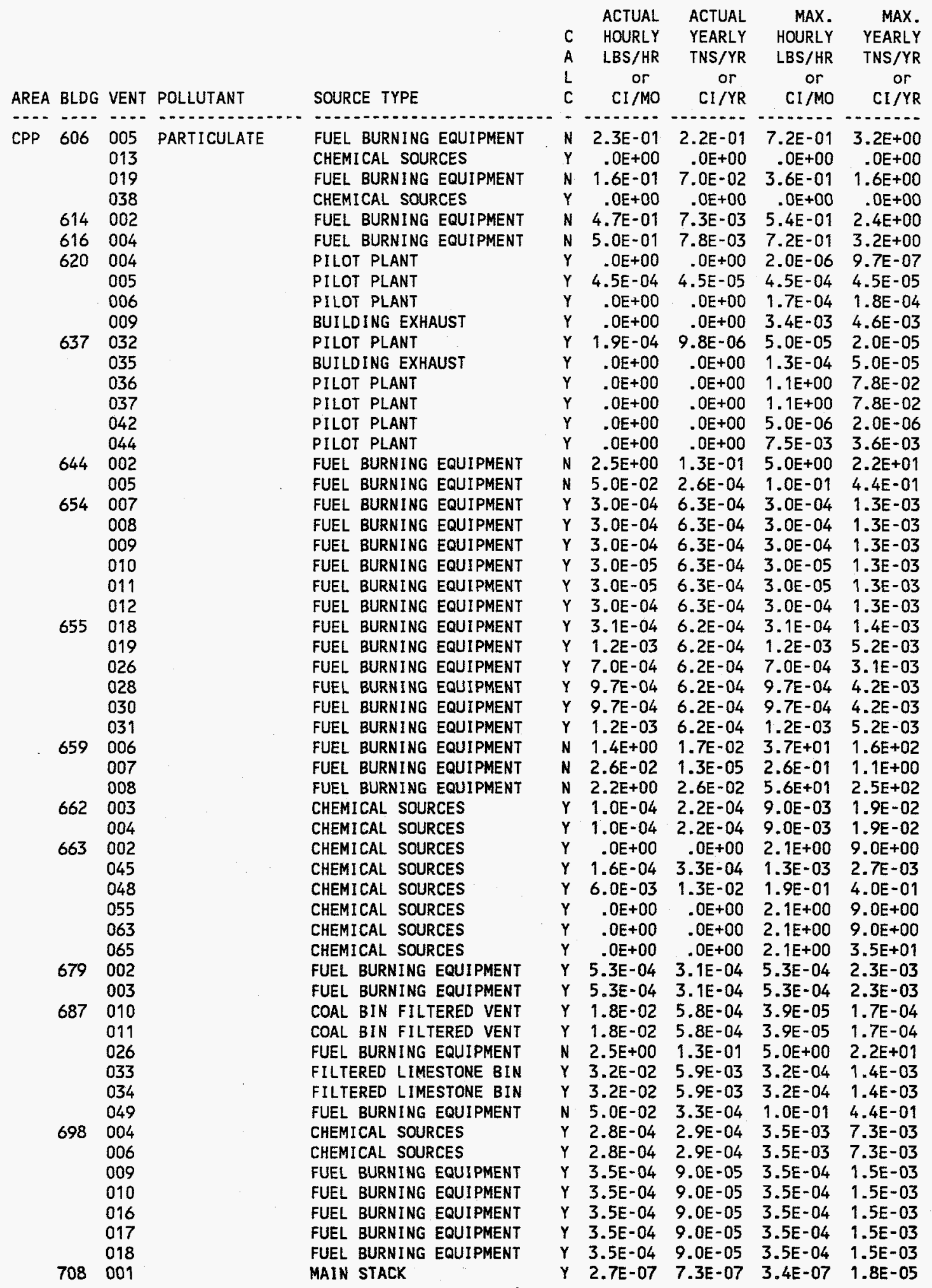




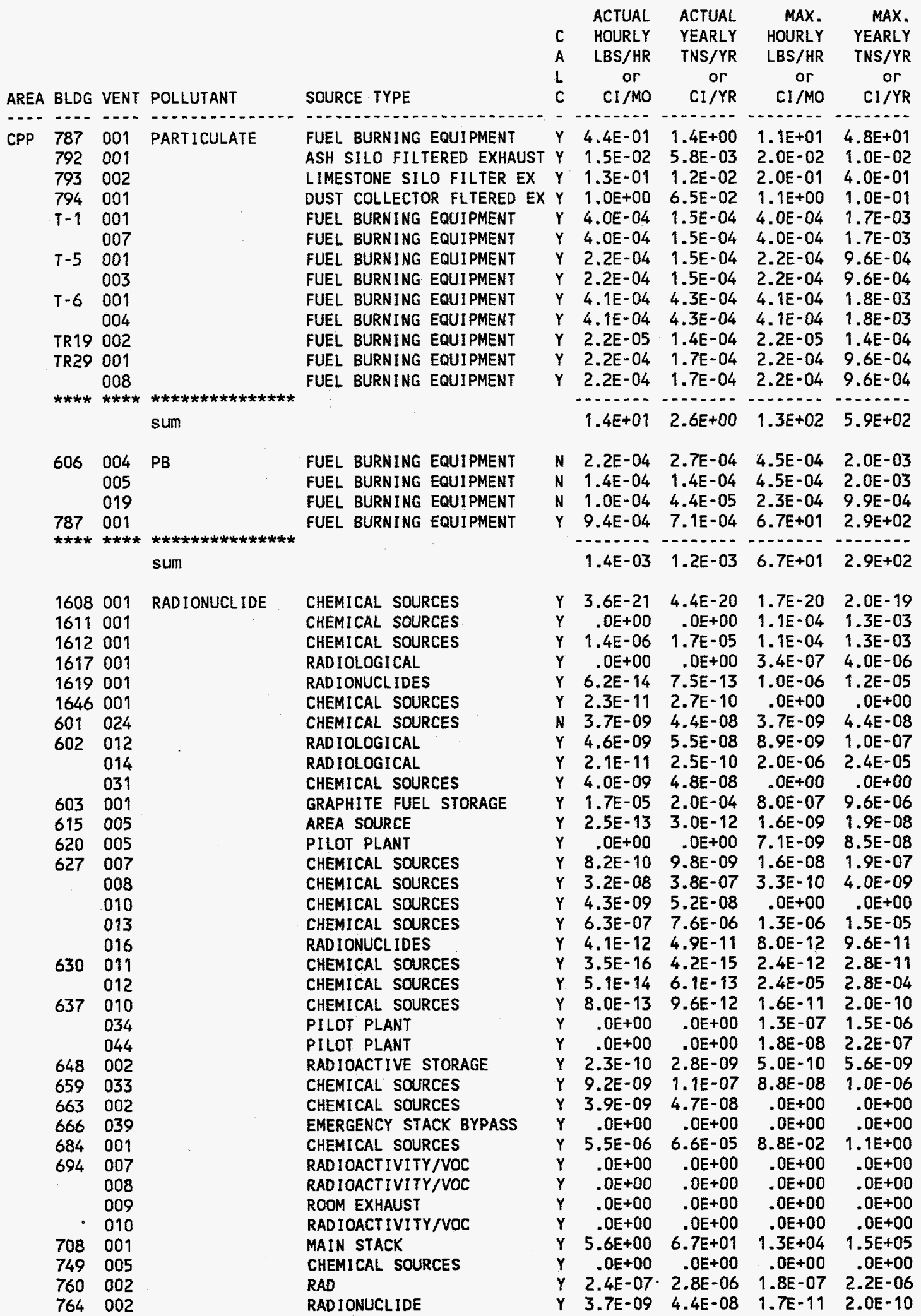




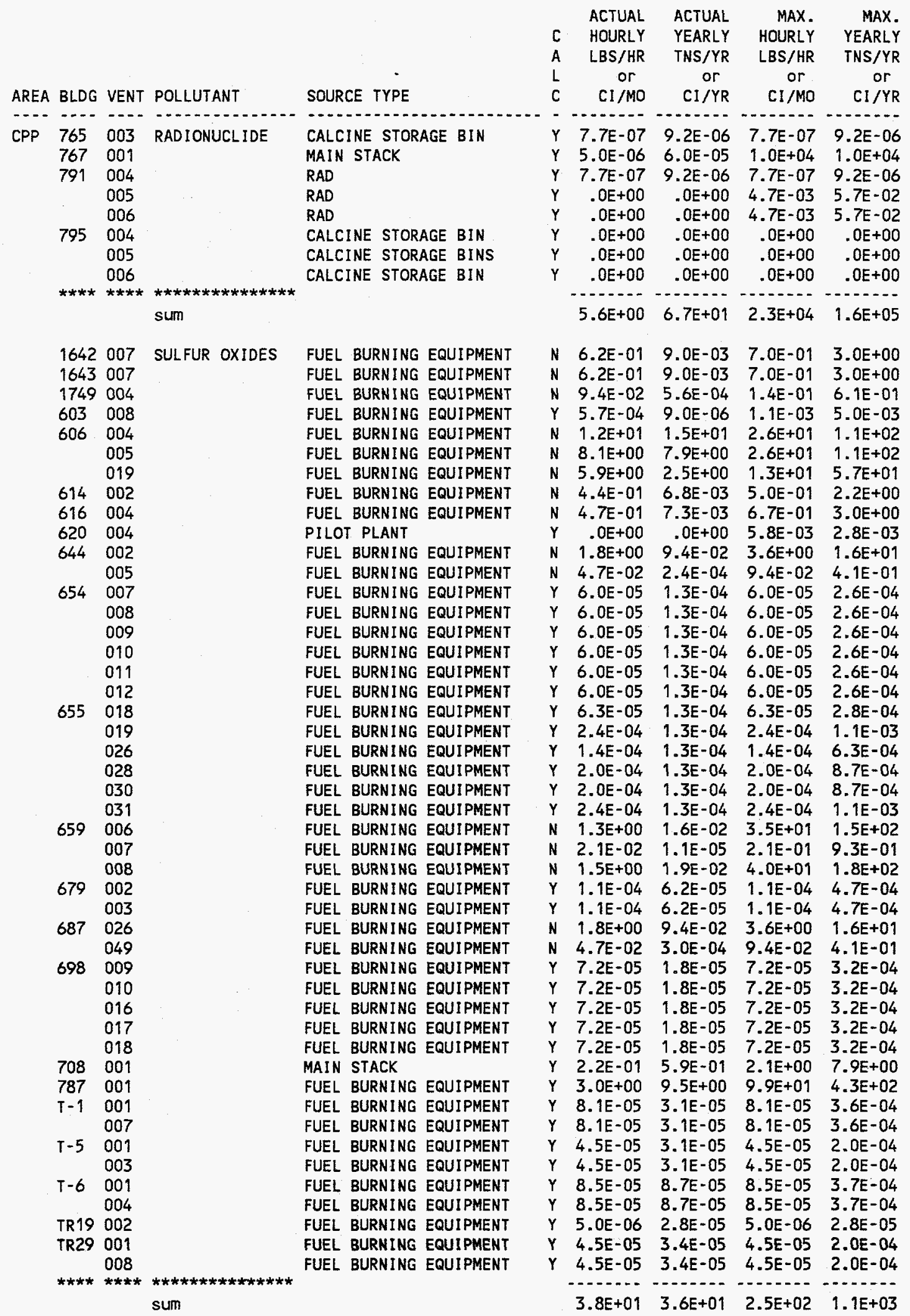




\begin{tabular}{|c|c|c|c|c|c|c|c|c|c|}
\hline AREA & BLDG & VENT & POLLUTANT & SOURCE TYPE & $\begin{array}{l}C \\
A \\
L \\
C\end{array}$ & $\begin{array}{c}\text { ACTUAL } \\
\text { HOURLY } \\
\text { LBS/HR } \\
\text { or } \\
\mathrm{CI} / \mathrm{MO}\end{array}$ & $\begin{array}{c}\text { ACTUAL } \\
\text { YEARLY } \\
\text { TNS/YR } \\
\text { Or } \\
\text { CI/YR }\end{array}$ & $\begin{array}{l}\text { MAX. } \\
\text { HOURLY } \\
\text { LBS/HR } \\
\text { or } \\
\mathrm{CI} / \mathrm{MO}\end{array}$ & $\begin{array}{c}\text { MAX. } \\
\text { YEARLY } \\
\text { TNS/YR } \\
\text { or } \\
\text { CI } / Y R\end{array}$ \\
\hline & & & 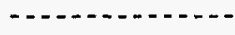 & & - & & & & \\
\hline \multirow{7}{*}{ CPP } & 1611 & 001 & VOC-NONMETHANE & CHEMICAL SOURCES & $Y$ & $.0 E+00$ & $.0 E+00$ & $.0 E+00$ & $.0 E+00$ \\
\hline & 1612 & 001 & טים & CHEMICAL SOURCES & Y & $.0 E+C O$ & $.0 \mathrm{E}+00$ & $.0 E+\infty O$ & $.0 E+00$ \\
\hline & 1642 & 003 & & STORAGE TANK - VOC & $\mathrm{N}$ & $.0 E+00$ & $.0 E+00$ & $.0 E+00$ & $.0 E+00$ \\
\hline & & 007 & & FUEL BURNING EQUIPMENT & N & $8.9 E-01$ & $1.3 \mathrm{E}-02$ & $9.9 E-01$ & $4.4 E+00$ \\
\hline & 1643 & 003 & & STORAGE TANK - VOC & $\mathrm{N}$ & $1.7 E-01$ & 5.0E-03 & $1.7 E-01$ & $5.0 E-03$ \\
\hline & & 007 & & FUEL BURNING EQUIPMENT & $\mathrm{N}$ & $8.9 E-01$ & $1.3 E-02$ & $9.9 E-01$ & $4.4 E+00$ \\
\hline & 1749 & 002 & & STORAGE TANK - VOC & $\mathbf{N}$ & $3.4 \mathrm{E}-01$ & $3.0 E-03$ & $3.4 E-01$ & $3.0 E-03$ \\
\hline & & 004 & & FUEL BURNING EQUIPMENT & N & $1.3 E-01$ & $8.0 E-04$ & $2.0 E-01$ & $8.8 E-01$ \\
\hline & 601 & 016 & & STORAGE TANK - VOC & Y & $. \mathrm{OE}+00$ & $.0 E+00$ & $.0 E+00$ & $.0 E+00$ \\
\hline & & 024 & & CHEMICAL SOURCES & $\mathbf{Y}$ & $2.9 E+00$ & $1.4 E-03$ & $2.9 E+00$ & $1.4 E-03$ \\
\hline \multirow{3}{*}{\multicolumn{2}{|c|}{602}} & 012 & & RADIOLOGICAL & $Y$ & $7.3 E-02$ & $7.6 \mathrm{E}-02$ & $2.4 E-01$ & 2.5E-01 \\
\hline & & 014 & & RADIOLOGICAL & $\mathbf{Y}$ & $.0 E+00$ & $.0 E+00$ & $1.3 \mathrm{E}-02$ & $1.4 \mathrm{E}-02$ \\
\hline & & 031 & & CHEMICAL SOURCES & Y & $.0 E+00$ & $.0 E+00$ & $.0 E+00$ & $.0 E+00$ \\
\hline & 603 & 008 & & FUEL BURNING EQUIPMENT & Y & $3.0 E-03$ & $4.8 \mathrm{E}-05$ & $5.9 E-03$ & $2.6 E-02$ \\
\hline \multirow{3}{*}{\multicolumn{2}{|c|}{606}} & 004 & & FUEL BURNING EQUIPMENT & $\mathrm{N}$ & $3.4 E-02$ & 4.3E-02 & $7.2 E-02$ & $3.2 E-01$ \\
\hline & & 005 & & FUEL BURNING EQUIPMENT & N & $2.3 \mathrm{E}-02$ & $2.2 E-02$ & $7.2 E-02$ & $3.2 E-01$ \\
\hline & & 019 & & FUEL BURNING EQUIPMENT & $\mathbf{N}$ & $1.6 \mathrm{E}-02$ & $7.0 E-03$ & $3.6 \mathrm{E}-02$ & $1.6 \mathrm{E}-01$ \\
\hline \multirow{2}{*}{\multicolumn{2}{|c|}{614}} & 001 & & STORAGE TANK - VOC & N & $3.4 E-01$ & $1.8 \mathrm{E}-03$ & $3.4 \mathrm{E}-01$ & $1.8 \mathrm{E}-03$ \\
\hline & & 002 & & FUEL BURNING EQUIPMENT & N & $6.2 E-01$ & $9.7 \mathrm{E}-03$ & $7.2 \mathrm{E}-01$ & $3.1 E+00$ \\
\hline \multirow{2}{*}{\multicolumn{2}{|c|}{616}} & 004 & & FUEL BURNING EQUIPMENT & $\mathrm{N}$ & $6.7 E-01$ & $1.0 E-02$ & $9.6 E-01$ & $4.2 \mathrm{E}+00$ \\
\hline & & 007 & & STORAGE TANK - VOC & $\mathbf{N}$ & $3.4 \mathrm{E}-01$ & 2.1E-03 & $3.4 E-01$ & $2.1 \mathrm{E}-03$ \\
\hline & \multirow[t]{4}{*}{620} & 002 & & STORAGE TANK - VOC & N & $2.4 \mathrm{E}-03$ & $1.1 \mathrm{E}-02$ & $2.4 E-03$ & 1.1E-02 \\
\hline & & 004 & & PILOT PLANT & $Y$ & $.0 E+00$ & $.0 E+00$ & $2.0 \mathrm{E}-03$ & $9.7 E-04$ \\
\hline & & 005 & & PILOT PLANT & Y & $2.9 \mathrm{E}-02$ & $2.3 E-04$ & $2.9 E-02$ & $7.0 \mathrm{E}-02$ \\
\hline & & 006 & & PILOT PLANT & Y & $.0 E+00$ & $.0 E+00$ & $6.9 E-03$ & $2.5 E-03$ \\
\hline \multirow{3}{*}{\multicolumn{2}{|c|}{627}} & 007 & & CHEMICAL SOURCES & $\mathbf{Y}$ & $.0 E+00$ & $.0 E+00$ & $1.3 E-03$ & $5.7 \mathrm{E}-03$ \\
\hline & & 008 & & CHEMICAL SOURCES & $Y$ & $9.8 \mathrm{E}-04$ & $4.3 E-03$ & $1.6 E-02$ & 1.7E-02 \\
\hline & & 013 & & CHEMICAL SOURCES & Y & $.0 E+00$ & $.0 E+00$ & $1.3 E-03$ & $5.7 E-03$ \\
\hline & 630 & 012 & & CHEMICAL SOURCES & Y & $6.4 E-04$ & $6.7 \mathrm{E}-04$ & $8.1 E-03$ & $3.6 E-02$ \\
\hline \multirow{2}{*}{\multicolumn{2}{|c|}{637}} & 010 & & CHEMICAL SOURCES & Y & $1.8 \mathrm{E}-03$ & $3.8 E-03$ & $1.0 \mathrm{E}-01$ & 2.1E-01 \\
\hline & & 032 & & PILOT PLANT & $Y$ & $.0 E+00$ & $.0 E+00$ & $3.2 E-03$ & $4.6 E-04$ \\
\hline & \multirow[t]{5}{*}{644} & 002 & & FUEL BURNING EQUIPMENT & N & $6.5 E-01$ & $3.4 \mathrm{E}-02$ & $1.3 E+00$ & $5.7 E+00$ \\
\hline & & 004 & & STORAGE TANK - VOC & N & $1.2 \mathrm{E}+02$ & $9.8 \mathrm{E}-05$ & $1.2 E+02$ & $9.8 E-05$ \\
\hline & & 005 & & FUEL BURNING EQUIPMENT & N & $6.7 E-02$ & $3.5 E-04$ & $1.3 E-01$ & $5.9 E-01$ \\
\hline & & 006 & & STORAGE TANK - VOC & N & 7.7E-03 & $2.8 \mathrm{E}-04$ & $7.7 \mathrm{E}-03$ & $2.8 E-04$ \\
\hline & & 013 & & STORAGE TANK - VOC & $\mathrm{N}$ & $1.2 E-01$ & $3.1 E-02$ & $1.2 \mathrm{E}-01$ & $3.1 \mathrm{E}-02$ \\
\hline \multirow{6}{*}{\multicolumn{2}{|c|}{654}} & 007 & & FUEL BURNING EQUIPMENT & $Y$ & $3.2 \mathrm{E}-04$ & $6.7 E-04$ & $3.2 E-04$ & $1.4 E-03$ \\
\hline & & 008 & & FUEL BURNING EQUIPMENT & $Y$ & $3.2 E-04$ & $6.7 E-04$ & $3.2 E-04$ & $1.4 E-03$ \\
\hline & & 009 & & FUEL BURNING EQUIPMENT & Y & $3.2 E-04$ & $6.7 E-04$ & $3.2 E-04$ & $1.4 \mathrm{E}-03$ \\
\hline & & 010 & & FUEL BURNING EQUIPMENT & $\mathbf{Y}$ & $3.2 E-04$ & $6.7 E-04$ & $3.2 E-04$ & $1.4 \mathrm{E}-03$ \\
\hline & & 011 & & FUEL BURNING EQUIPMENT & $Y$ & $3.2 E-04$ & $6.7 E-04$ & $3.2 E-04$ & $1.4 E-03$ \\
\hline & & 012 & & FUEL BURNING EQUIPMENT & Y & $3.2 E-04$ & $6.7 E-04$ & $3.2 E-04$ & $1.4 \mathrm{E}-03$ \\
\hline \multirow{6}{*}{\multicolumn{2}{|c|}{655}} & 018 & & FUEL BURNING EQUIPMENT & $Y$ & $3.3 E-04$ & $6.7 E-04$ & $3.3 E-04$ & $1.4 E-03$ \\
\hline & & 019 & & FUEL BURNING EQUIPMENT & $\mathbf{Y}$ & $1.3 E-03$ & $6.7 E-04$ & $1.3 E-03$ & $5.6 \mathrm{E}-03$ \\
\hline & & 026 & & FUEL BURNING EQUIPMENT & Y & $7.5 \mathrm{E}-04$ & $6.7 \mathrm{E}-04$ & $7.5 E-04$ & $3.3 E-03$ \\
\hline & & 028 & & FUEL BURNING EQUIPMENT & Y & $1.0 E-03$ & $6.7 \mathrm{E}-04$ & $1.0 \mathrm{E}-03$ & $4.5 E-03$ \\
\hline & & 030 & & FUEL BURNING EQUIPMENT & $Y$ & $1.0 \mathrm{E}-03$ & $6.7 E-04$ & $1.0 \mathrm{E}-03$ & $4.5 E-03$ \\
\hline & & 031 & & FUEL BURNING EQUIPMENT & $\mathbf{Y}$ & $1.3 \mathrm{E}-03$ & $6.7 E-04$ & $1.3 E-03$ & $5.6 E-03$ \\
\hline \multirow{6}{*}{\multicolumn{2}{|c|}{659}} & 006 & & FUEL BURNING EQUIPMENT & $\mathrm{N}$ & $1.9 E+00$ & $2.3 E-02$ & $5.0 E+01$ & $2.2 E+02$ \\
\hline & & 007 & & FUEL BURNING EQUIPMENT & $\mathrm{N}$ & $5.5 \mathrm{E}-01$ & $2.7 E-04$ & $5.5 E+00$ & $2.4 E+01$ \\
\hline & & 008 & & FUEL BURNING EQUIPMENT & $\mathbf{N}$ & $5.6 E-01$ & $6.8 E-03$ & $1.5 E+01$ & $6.4 E+01$ \\
\hline & & 010 & & STORAGE TANK - VOC & N & $7.5 E-02$ & $7.6 E-02$ & $7.5 E-02$ & $7.6 E-02$ \\
\hline & & 011 & & STORAGE TANK - VOC & $\mathbf{N}$ & $7.5 E-02$ & $7.6 E-02$ & $7.5 E-02$ & $7.6 \mathrm{E}-02$ \\
\hline & & 035 & & STORAGE TANK - VDC & $\mathrm{N}$ & $1.2 \mathrm{E}+02$ & $5.8 \mathrm{E}-05$ & $1.2 E+02$ & $5.8 E-05$ \\
\hline & 663 & 002 & & CHEMICAL SOURCES & Y & $.0 E+00$ & $.0 E+00$ & $8.0 E+00$ & $3.5 E+01$ \\
\hline
\end{tabular}




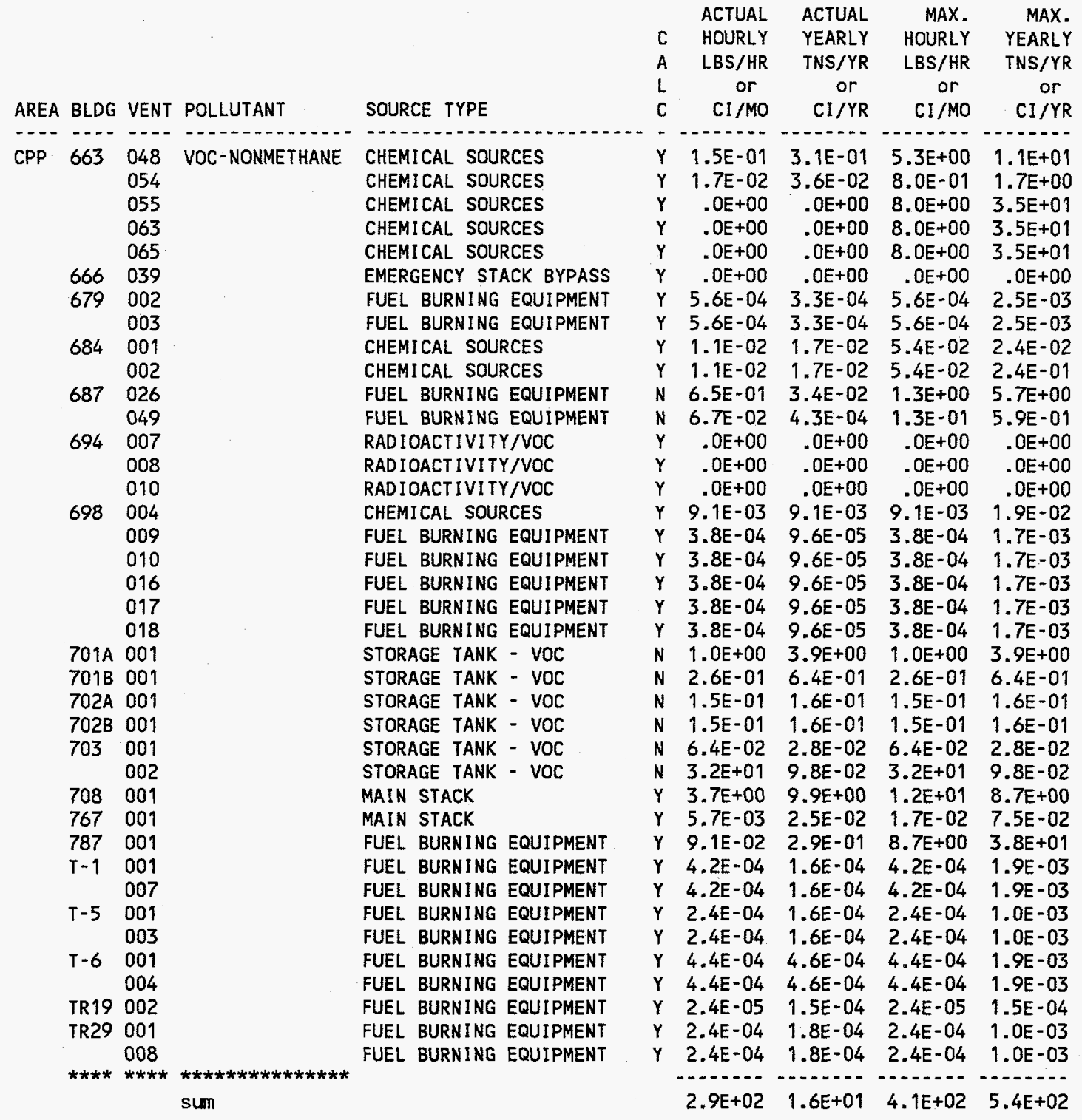




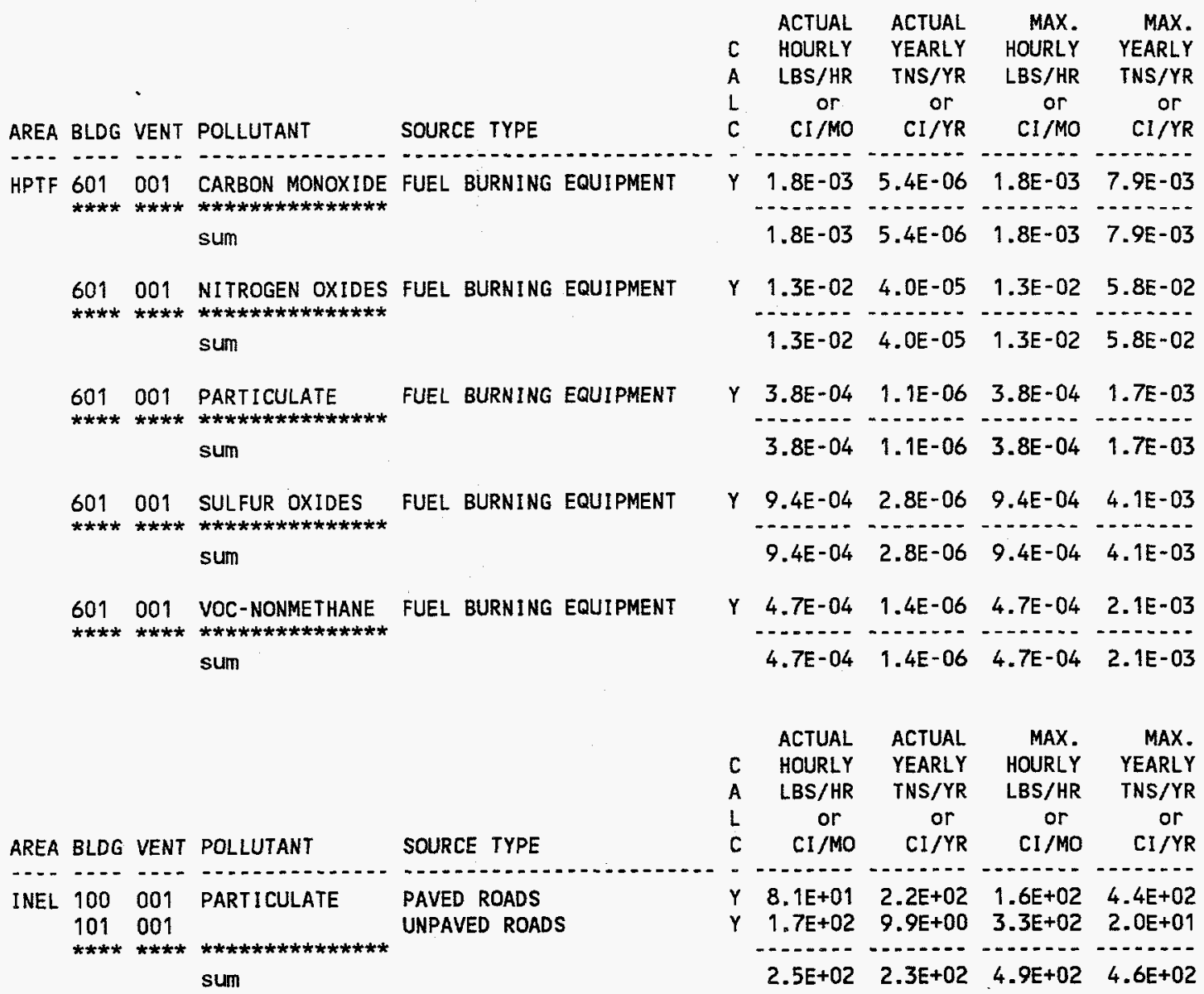




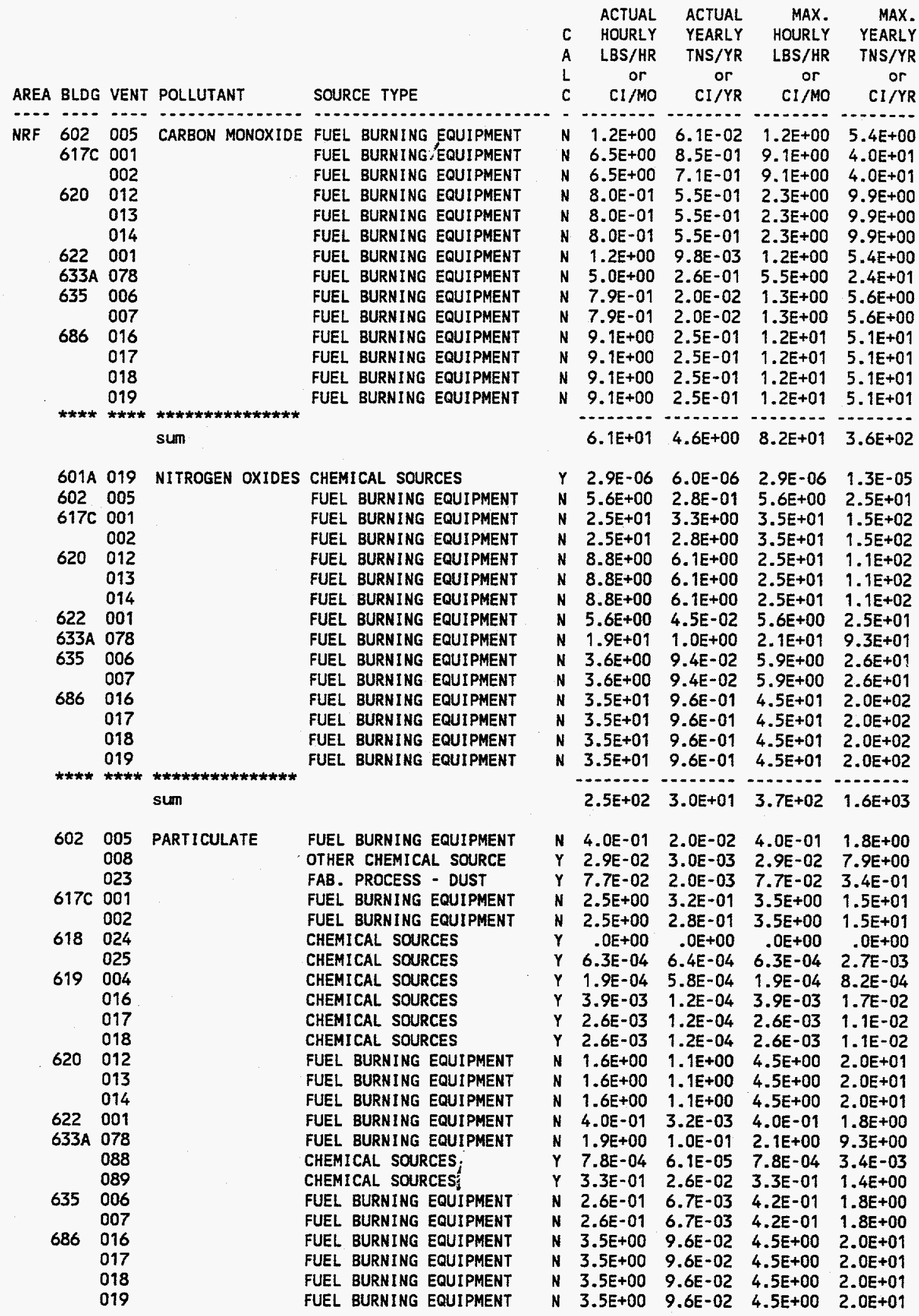




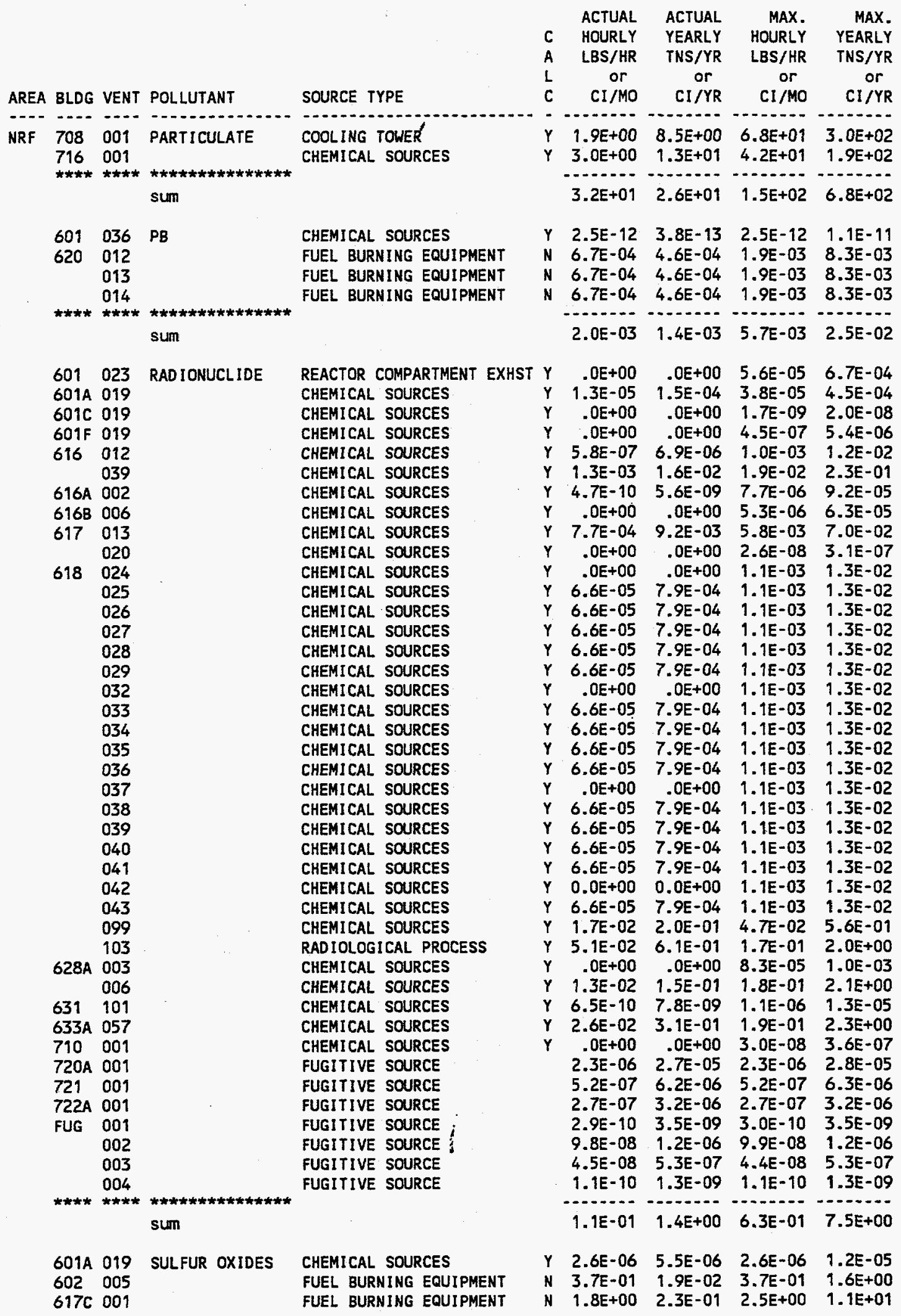




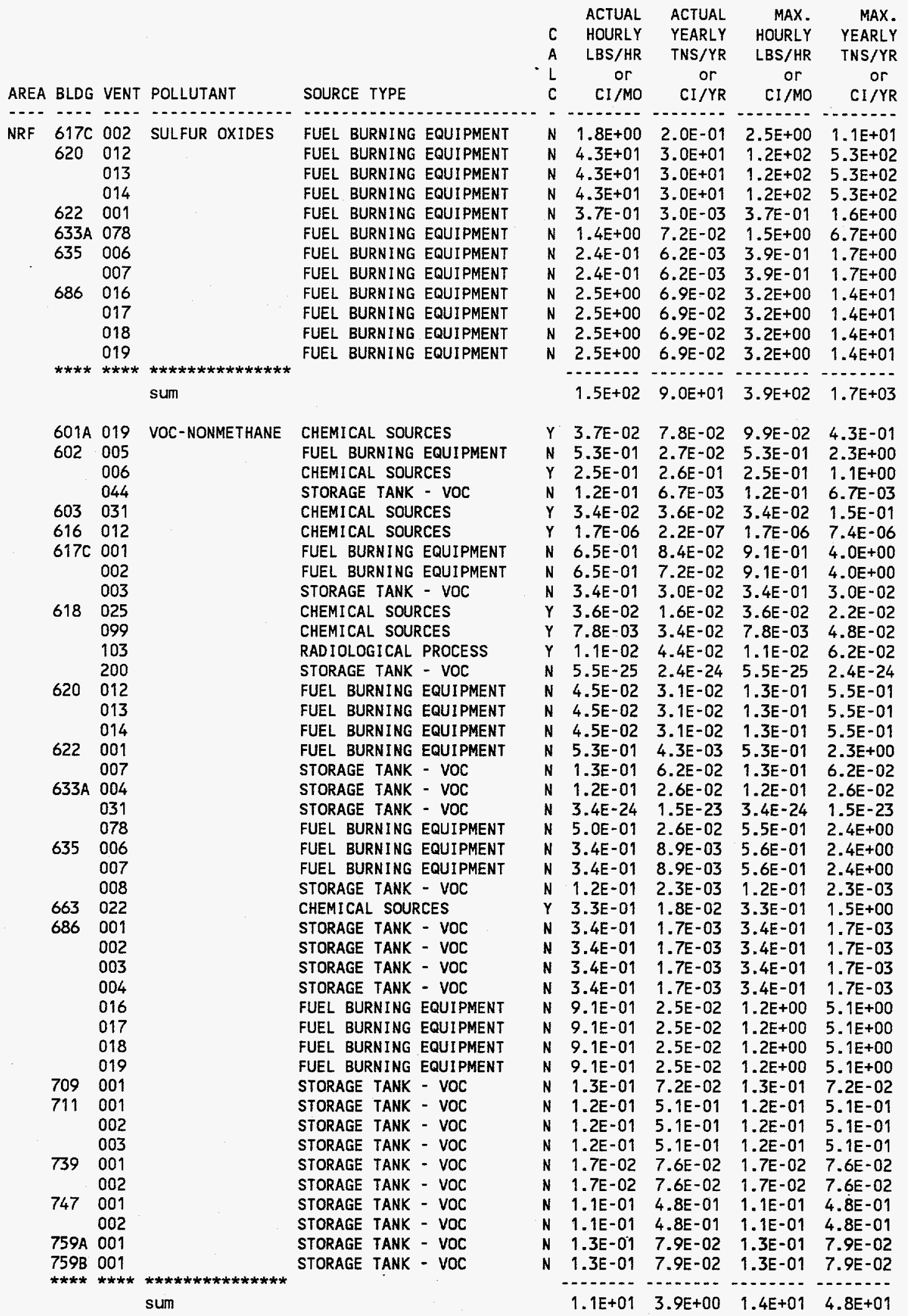


AREA BLDG VENT POLLUTANT

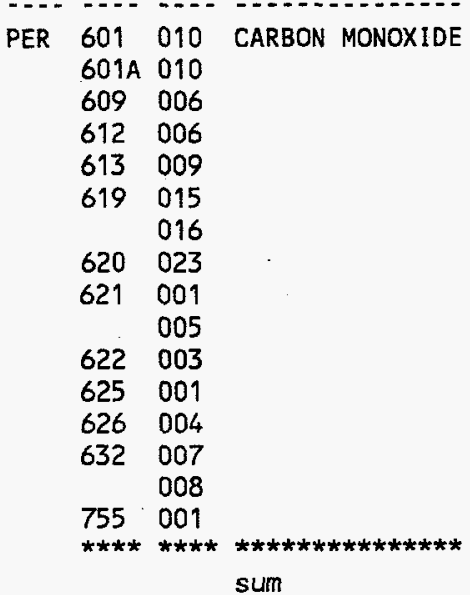

$\begin{array}{lll}601 & 010 & \text { NITROGEN OXIDES } \\ 601 A & 010 \\ 609 & 006 \\ 612 & 006 \\ 613 & 009 \\ 619 & 015 \\ & 016 \\ 620 & 023 \\ 621 & 001 \\ & 005 \\ 622 & 003 \\ 625 & 001 \\ 626 & 004 \\ 632 & 007 \\ & 008 \\ 755 & 001 \\ 756 & 001 \\ * * * * * * * * * * * * * * * * * * * * * *\end{array}$

sum

$\begin{array}{lll}601 & 010 & \text { PARTICULATE } \\ 601 A & 010 & \\ 609 & 006 & \\ 612 & 006 & \\ 613 & 009 & \\ 619 & 015 & \\ & 016 & \\ 620 . & 023 & \\ 621 & 001 & \\ & 005 & \\ 622 & 003 & \\ 625 & 001 & \\ 626 & 004 & \\ 632 & 007 & \\ & 008 & \\ 755 & 001 & \\ * * * * & * * * * & * * * * * * * * * * * * * \\ & & \text { sUm } \\ 601 & 010 & \text { PB } \\ 601 A & 010 & \end{array}$

SOURCE TYPE

FUEL BURNING EQUIPMENT FUEL BURNING EQUIPMENT FUEL BURNING EQUIPMENT FUEL BURNING EQUIPMENT FUEL BURNING EQUIPMENT FUEL BURNING EQUIPMENT FUEL BURNING EQUIPMENT FUEL BURNING EQUIPMENT FUEL BURNING EQUIPMENT FUEL BURNING EQUIPMENT RAD PROCESS

FUEL BURNING EQUIPMENT FUEL BURNING EQUIPMENT FUEL BURNING EQUIPMENT FUEL BURNING EQUIPMENT CHEMICAL SOURCES$$
\text { CHEMICAL SOURCES }
$$

FUEL BURNING EQUIPMENT FUEL BURNING EQUIPMENT FUEL BURNING EQUIPMENT FUEL BURNING EQUIPMENT FUEL BURNING EQUIPMENT FUEL BURNING EQUIPMENT FUEL BURNING EQUIPMENT FUEL BURNING EQUIPMENT FUEL BURNING EQUIPMENT FUEL BURNING EQUIPMENT RAD PROCESS

FUEL BURNING EQUIPMENT FUEL. BURNING EQUIPMENT FUEL BURNING EQUIPMENT FUEL BURNING EQUIPMENT CHEMICAL SOURCES RADIOLOGICAL PROCESS RAD

FUEL BURNING EQUIPMENT FUEL BURNING EQUIPMENT FUEL BURNING EQUIPMENT FUEL BURNING EQUIPMENT FUEL BURNING EQUIPMENT FUEL BURNING EQUIPMENT FUEL BURNING EQUIPMENT FUEL BURNING EQUIPMENT FUEL BURNING EQUIPMENT FUEL BURNING EQUIPMENT RAD PROCESS

FUEL. BURNING EQUIPMENT FUEL BURNING EQUIPMENT FUEL BURNING EQUIPMENT FUEL BURNING EQUIPMENT CHEMICAL SOURCES

FUEL BURNING EQUIPMENT FUEL BURNING EQUIPMENT

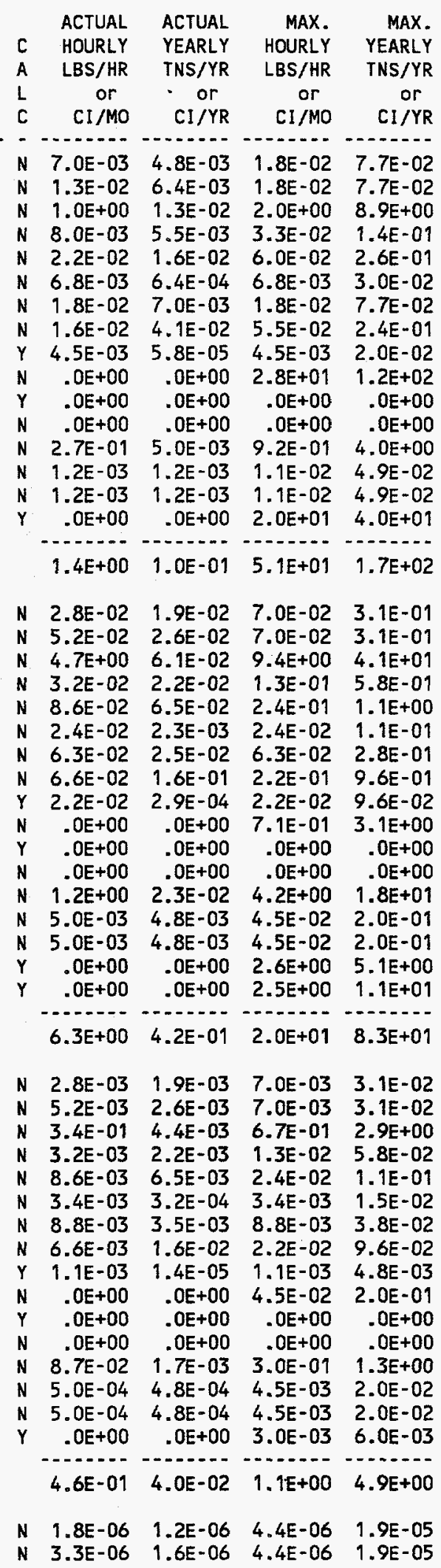




\begin{tabular}{|c|c|c|c|c|c|c|c|c|c|}
\hline AREA & BLDG & VENT & POLLUTANT & SOURCE TYPE & $\begin{array}{l}C \\
A \\
L \\
C\end{array}$ & $\begin{array}{c}\text { ACTUAL } \\
\text { HOURLY } \\
\text { LBS } / H R \\
\text { or } \\
\mathrm{CI} / \mathrm{MO}\end{array}$ & $\begin{array}{c}\text { ACTUAL } \\
\text { YEARLY } \\
\text { TNS/YR } \\
\text { or } \\
\text { CI } / Y R\end{array}$ & $\begin{array}{l}\text { MAX. } \\
\text { HOURLY } \\
\text { LBS/HR } \\
\text { or } \\
\text { CI/MO }\end{array}$ & $\begin{array}{c}\text { MAX. } \\
\text { YEARLY } \\
\text { TNS } / Y R \\
\text { or } \\
\mathrm{CI} / \mathrm{YR}\end{array}$ \\
\hline PER & $\begin{array}{l}612 \\
613 \\
619 \\
\\
620 \\
621 \\
625 \\
632\end{array}$ & $\begin{array}{l}006 \\
009 \\
015 \\
016 \\
023 \\
005 \\
001 \\
007 \\
008 \\
001 \\
\star \star \star \star\end{array}$ & $\begin{array}{l}\star \star * * * \star * * \star * * * * * * * * \\
\operatorname{sum}\end{array}$ & $\begin{array}{l}\text { FUEL BURNING EQUIPMENT } \\
\text { FUEL BURNING EQUIPMENT } \\
\text { FUEL BURNING EQUIPMENT } \\
\text { FUEL BURNING EQUIPMENT } \\
\text { FUEL BURNING EQUIPMENT } \\
\text { FUEL BURNING EQUIPMENT } \\
\text { FUEL BURNING EQUIPMENT } \\
\text { FUEL BURNING EQUIPMENT } \\
\text { FUEL BURNING EQUIPMENT } \\
\text { CHEMICAL SOURCES }\end{array}$ & $\begin{array}{l}N \\
N \\
N \\
N \\
N \\
Y \\
Y \\
N \\
N \\
Y\end{array}$ & $\begin{array}{r}2.0 \mathrm{E}-06 \\
5.4 \mathrm{E}-06 \\
1.7 \mathrm{E}-06 \\
4.4 \mathrm{E}-06 \\
4.1 \mathrm{E}-06 \\
.0 \mathrm{E}+00 \\
.0 \mathrm{E}+00 \\
3.1 \mathrm{E}-07 \\
3.1 \mathrm{E}-07 \\
.0 \mathrm{E}+00 \\
2.3 \mathrm{E}-05\end{array}$ & $\begin{array}{r}1.4 \mathrm{E}-06 \\
4.0 \mathrm{E}-06 \\
1.6 \mathrm{E}-07 \\
1.8 \mathrm{E}-06 \\
1.0 \mathrm{E}-05 \\
.0 \mathrm{O}+00 \\
.0 \mathrm{E}+00 \\
3.0 \mathrm{E}-07 \\
3.0 \mathrm{E}-07 \\
.0 \mathrm{E}+00 \\
2.1 \mathrm{E}-05\end{array}$ & $\begin{array}{r}8.3 E-06 \\
1.5 E-05 \\
1.7 E-06 \\
4.4 E-06 \\
1.4 E-05 \\
.0 E+00 \\
.0 E+00 \\
2.8 E-06 \\
2.8 E-06 \\
5.0 E-06 \\
6.3 E-05\end{array}$ & $\begin{array}{r}3.6 E-05 \\
6.6 E-05 \\
7.4 E-06 \\
1.9 E-05 \\
6.0 E-05 \\
.0 E+00 \\
.0 E+00 \\
1.2 E-05 \\
1.2 E-05 \\
9.8 E-06 \\
\hdashline 2.6 E-04\end{array}$ \\
\hline & $\begin{array}{l}622 \\
730 \\
731 \\
733 \\
755 \\
756 \\
765 \\
\star \star \star \star\end{array}$ & $\begin{array}{l}016 \\
041 \\
003 \\
001 \\
002 \\
001 \\
001 \\
001 \\
001 \\
\star * \star *\end{array}$ & $\begin{array}{l}\text { } \\
\operatorname{sum}\end{array}$ & $\begin{array}{l}\text { RAD SOURCE } \\
\text { RAD SOURCE } \\
\text { RAD PROCESS } \\
\text { RAD SOURCE } \\
\text { RAD SOURCE } \\
\text { RAD SOURCE } \\
\text { CHEMICAL SOURCES } \\
\text { RADIOLOGICAL PROCESS } \\
\text { CHEMICAL SOURCES }\end{array}$ & $\begin{array}{l}Y \\
Y \\
Y \\
Y \\
Y \\
Y \\
Y \\
Y\end{array}$ & $\begin{array}{r}2.6 \mathrm{E}-07 \\
2.3 \mathrm{E}-14 \\
. \mathrm{OE}+00 \\
. \mathrm{OE}+00 \\
. \mathrm{OE}+00 \\
.0 \mathrm{OE}+00 \\
.0 \mathrm{E}+00 \\
6.6 \mathrm{E}-10 \\
4.2 \mathrm{E}-11 \\
2.6 \mathrm{E}-07\end{array}$ & $\begin{array}{r}3.1 \mathrm{E}-06 \\
2.7 \mathrm{E}-13 \\
.0 \mathrm{O}+00 \\
.0 \mathrm{OE}+00 \\
.0 \mathrm{O}+00 \\
.0 \mathrm{E}+00 \\
.0 \mathrm{E}+00 \\
7.9 \mathrm{E}-09 \\
5.0 \mathrm{E}-10 \\
3.1 \mathrm{E}-06\end{array}$ & $\begin{array}{r}4.4 E-04 \\
7.5 E-11 \\
.0 E+00 \\
.0 E+00 \\
.0 E+00 \\
.0 E+00 \\
2.8 E+00 \\
2.2 E+00 \\
2.7 E-01 \\
5 . .2 E+00\end{array}$ & $\begin{array}{r}5.2 E-03 \\
9.0 E-10 \\
.0 E+00 \\
.0 E+00 \\
.0 E+00 \\
.0 E+00 \\
1.7 E+01 \\
2.7 E+01 \\
3.3 E+00 \\
4.7 E+01\end{array}$ \\
\hline & $\begin{array}{l}601 \\
601 A \\
609 \\
612 \\
613 \\
619 \\
620 \\
621 \\
625 \\
626 \\
632\end{array}$ & $\begin{array}{l}010 \\
010 \\
006 \\
006 \\
009 \\
015 \\
016 \\
023 \\
001 \\
005 \\
001 \\
004 \\
007 \\
008 \\
001 \\
\star * * *\end{array}$ & 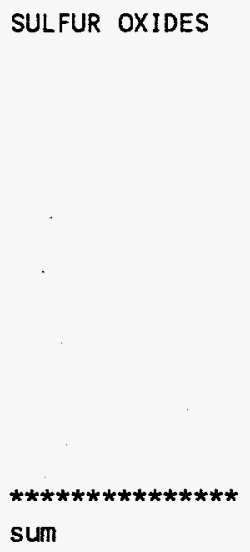 & $\begin{array}{l}\text { FUEL BURNING EQUIPMENT } \\
\text { FUEL BURNING EQUIPMENT } \\
\text { FUEL BURNING EQUI PMENT } \\
\text { FUEL BURNING EQUIPMENT } \\
\text { FUEL BURNING EQUIPMENT } \\
\text { FUEL BURNING EQUIPMENT } \\
\text { FUEL BURNING EQUIPMENT } \\
\text { FUEL BURN ING EQUIPMENT } \\
\text { FUEL BURN ING EQUIPMENT } \\
\text { FUEL BURNING EQUIPMENT } \\
\text { FUEL BURNING EQUIPMENT } \\
\text { FUEL BURNING EQUIPMENT } \\
\text { FUEL BURN ING EQUIPMENT } \\
\text { FUEL BURNING EQUIPMENT } \\
\text { CHEMICAL SOURCES }\end{array}$ & $\begin{array}{l}N \\
N \\
N \\
N \\
N \\
N \\
N \\
N \\
Y \\
N \\
N \\
N \\
N \\
N \\
Y\end{array}$ & $\begin{array}{r}1.0 \mathrm{E}-01 \\
1.9 \mathrm{E}-01 \\
3.1 \mathrm{E}-01 \\
1.2 \mathrm{E}-01 \\
3.1 \mathrm{E}-01 \\
9.7 \mathrm{E}-02 \\
2.5 \mathrm{E}-01 \\
2.4 \mathrm{E}-01 \\
2.3 \mathrm{E}-04 \\
.0 \mathrm{E}+00 \\
.0 \mathrm{E}+00 \\
8.1 \mathrm{E}-02 \\
1.8 \mathrm{E}-02 \\
1.8 \mathrm{E}-02 \\
.0 \mathrm{E}+00 \\
\hdashline 1 .-2 \mathrm{E}+00\end{array}$ & $\begin{array}{r}6.9 \mathrm{E}-02 \\
9.2 \mathrm{E}-02 \\
4.1 \mathrm{E}-03 \\
8.0 \mathrm{E}-02 \\
2.3 \mathrm{E}-01 \\
9.2 \mathrm{E}-03 \\
1.0 \mathrm{E}-01 \\
5.9 \mathrm{E}-01 \\
2.9 \mathrm{E}-06 \\
.0 \mathrm{E}+00 \\
.0 \mathrm{E}+00 \\
1.5 \mathrm{E}-03 \\
1.7 \mathrm{E}-02 \\
1.7 \mathrm{E}-02 \\
.0 \mathrm{O}+00 \\
-1.2 \mathrm{C}+00\end{array}$ & $\begin{array}{r}2.5 \mathrm{E}-01 \\
2.5 \mathrm{E}-01 \\
6.2 \mathrm{E}-01 \\
4.8 \mathrm{E}-01 \\
8.6 \mathrm{E}-01 \\
9.7 \mathrm{E}-02 \\
2.5 \mathrm{E}-01 \\
7.9 \mathrm{E}-01 \\
2.3 \mathrm{E}-04 \\
3.7 \mathrm{E}-02 \\
.0 \mathrm{E}+00 \\
2.8 \mathrm{E}-01 \\
1.6 \mathrm{E}-01 \\
1.6 \mathrm{E}-01 \\
2.6 \mathrm{E}+00 \\
-2--0 \\
6.9 \mathrm{E}+00\end{array}$ & $\begin{array}{r}1.1 E+00 \\
1.1 E+00 \\
2.7 E+00 \\
2.1 E+00 \\
3.8 E+00 \\
4.3 E-01 \\
1.1 E+00 \\
3.5 E+00 \\
1.0 E-03 \\
1.6 E-01 \\
.0 E+00 \\
1.2 E+00 \\
7.1 E-01 \\
7.1 E-01 \\
5.2 E+00 \\
-12 .-1 \\
2.4 E+01\end{array}$ \\
\hline & $\begin{array}{l}601 \\
601 A \\
609\end{array}$ & $\begin{array}{l}010 \\
010 \\
006 \\
010 \\
006 \\
009 \\
015 \\
016 \\
023 \\
001 \\
005 \\
001 \\
002 \\
004 \\
004\end{array}$ & VOC-NONMETHANE & $\begin{array}{l}\text { FUEL BURNING EQUIPMENT } \\
\text { FUEL BURNING EQUIPMENT } \\
\text { FUEL BURNING EQUIPMENT } \\
\text { STORAGE TANK - VOC } \\
\text { FUEL BURNING EQUIPMENT } \\
\text { FUEL BURNING EQUIPMENT } \\
\text { FUEL BURNING EQUIPMENT } \\
\text { FUEL BURNING EQUIPMENT } \\
\text { FUEL BURNING EQUIPMENT } \\
\text { FUEL BURNING EQUIPMENT } \\
\text { FUEL BURNING EQUIPMENT } \\
\text { FUEL BURNING EQUIPMENT } \\
\text { STORAGE TANK - VOC } \\
\text { STORAGE TANK - VOC } \\
\text { FUEL BURNING EQUIPMENT }\end{array}$ & $\begin{array}{l}N \\
N \\
N \\
N \\
N \\
N \\
N \\
N \\
N \\
Y \\
N \\
N \\
N \\
N \\
N\end{array}$ & $\begin{array}{l}4.8 \mathrm{E}-04 \\
8.8 \mathrm{E}-04 . \\
4.5 \mathrm{E}-01 \\
4.8 \mathrm{E}-02 \\
5.4 \mathrm{E}-04 \\
1.5 \mathrm{E}-03 \\
9.6 \mathrm{E}-04 \\
2.5 \mathrm{E}-03 \\
1.1 \mathrm{E}-03 \\
1.2 \mathrm{E}-03 \\
.0 \mathrm{E}+00 \\
.0 \mathrm{E}+00 \\
4.5 \mathrm{E}-26 \\
7.2 \mathrm{E}-05 \\
1.2 \mathrm{E}-01\end{array}$ & $\begin{array}{l}3.3 \mathrm{E}-04 \\
4.3 \mathrm{E}-04 \\
5.8 \mathrm{E}-03 \\
1.3 \mathrm{E}-01 \\
3.8 \mathrm{E}-04 \\
1.1 \mathrm{E}-03 \\
9.1 \mathrm{E}-05 \\
1.0 \mathrm{E}-03 \\
2.8 \mathrm{E}-03 \\
1.5 \mathrm{E}-05 \\
.0 \mathrm{E}+00 \\
.0 \mathrm{E}+00 \\
2.0 \mathrm{E}-25 \\
3.2 \mathrm{E}-04 \\
2.2 \mathrm{E}-03\end{array}$ & $\begin{array}{l}1.2 \mathrm{E}-03 \\
1.2 \mathrm{E}-03 \\
8.9 \mathrm{E}-01 \\
4.8 \mathrm{E}-02 \\
2.2 \mathrm{E}-03 \\
4.1 \mathrm{E}-03 \\
9.6 \mathrm{E}-04 \\
2.5 \mathrm{E}-03 \\
3.7 \mathrm{E}-03 \\
1.2 \mathrm{E}-03 \\
9.5 \mathrm{E}-01 \\
.0 \mathrm{E}+00 \\
4.5 \mathrm{E}-26 \\
7.2 \mathrm{E}-05 \\
4.0 \mathrm{E}-01\end{array}$ & $\begin{array}{l}5.2 \mathrm{E}-03 \\
5.2 \mathrm{E}-03 \\
3.9 \mathrm{E}+00 \\
1.3 \mathrm{E}-01 \\
9.8 \mathrm{E}-03 \\
1.8 \mathrm{E}-02 \\
4.2 \mathrm{E}-03 \\
1.1 \mathrm{E}-02 \\
1.6 \mathrm{E}-02 \\
5.3 \mathrm{E}-03 \\
4.2 \mathrm{E}+00 \\
.0 \mathrm{E}+00 \\
2.0 \mathrm{E}-25 \\
3.2 \mathrm{E}-04 \\
1.8 \mathrm{E}+00\end{array}$ \\
\hline
\end{tabular}




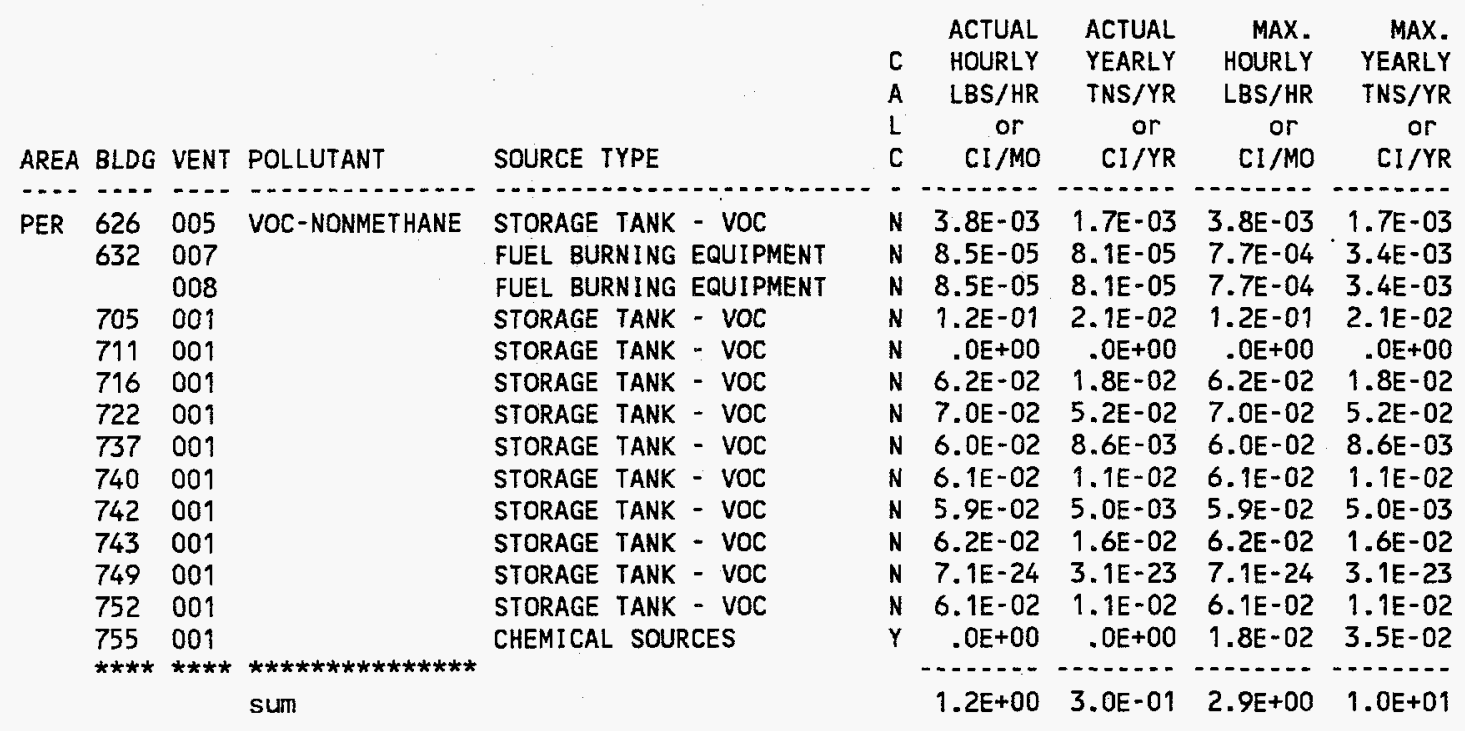


AREA BLDG VENT POLLUTANT

$\begin{array}{cccc}\text { TRA } & 619 & 008 & \text { CARBON MONOXIDE } \\ & 009 & \\ 633 & 003 & \\ & 004 & \\ 670 & 046 & \\ & 053 & \\ 674 & 007 & \\ * * * * & * * * * * * * * * * * * * * * * * \\ & & \text { sum }\end{array}$

SOURCE TYPE

FUEL BURNING EQUIPMENT FUEL BURNING EQUIPMENT FUEL BURNING EQUIPMENT FUEL BURNING EQUIPMENT FUEL BURNING EQUIPMENT FUEL BURNING EQUIPMENT FUEL BURNING EQUIPMENT

$$
\text { sum }
$$

619008 NITROGEN OXIDES FUEL BURNING EQUIPMENT 009 633003 004

$670 \quad 046$

053

674007

$* * * * * * * * * * * * * * * * * * * * * * *$

sum

$\begin{array}{lll}619 & 008 & \text { PARTICULATE } \\ & 009 & \\ 633 & 003 & \\ & 004 & \\ 653 & 028 & \\ & 041 \\ 670 & 046 & \\ & 053 \\ 674 & 007 & \\ 771 & 001 & \\ * * * * & * * * * * * * * * * * * * * * * * * \\ & & \text { sum }\end{array}$

$\begin{array}{lll}604 & 035 & \text { RADIONUCLIDE } \\ 632 & 015 \\ & 019 & \\ & 030 & \\ & 041 & \\ 635 & 030 & \\ & 031 \\ 660 & 004 \\ 661 & 008 \\ 665 & 001 \\ 668 & 013 \\ 670 & 074 \\ & 086 \\ & 098 \\ 710 & 001 & \\ 715 & 001 & \\ 770 & 001 & \\ * * * * & * * * * * * * * * * * * * * * * * * \\ & & \end{array}$

sum

CHEMICAL SOURCES CHEMICAL SOURCES CHEMICAL SOURCES CHEMICAL SOURCES CHEMICAL SOURCES RADIOLOGICAL RADIOLOGICAL HOOD

CHEMICAL SOURCES TRITIUM TRAP EXHAUST CHEMICAL SOURCES RADIOACTIVE HOOD CHEMICAL SOURCES RAD/CHEMICAL RADIOLOGICAL EVAPORATION POND RADIOLOGICAL

FUEL BURNING EQUIPMENT FUEL BURNING EQUIPMENT FUEL BURNING EQUIPMENT CHEMICAL SOURCES FUL BURNING EQUIPMENT BUR FUEL BURNING EQUIPMENT EQUIPMENT COOLING TOWER

FUEL BURNING EQUIPMENT

\begin{tabular}{|c|c|c|c|c|}
\hline C & $\begin{array}{l}\text { ACTUAL } \\
\text { HOURLY }\end{array}$ & $\begin{array}{l}\text { ACTUAL } \\
\text { YEARLY }\end{array}$ & $\begin{array}{l}\text { MAX. } \\
\text { HOURLY }\end{array}$ & $\begin{array}{r}\text { MAX. } \\
\text { YEARLY }\end{array}$ \\
\hline & LBS/HR & TNS/YR & LBS/HR & TNS /YR \\
\hline & or & or & or & or \\
\hline & $\mathrm{CI} / \mathrm{MO}$ & $\mathrm{CI} / \mathrm{YR}$ & $\mathrm{Cl} / \mathrm{MO}$ & CI/YR \\
\hline \multirow{9}{*}{ 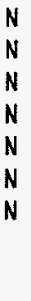 } & 1. $.0 E+00$ & 2. $7 \mathrm{E}-02$ & $1.0 E+00$ & $4.5 E+00$ \\
\hline & $1.0 E+00$ & 2.7E-02 & 1. $.0 E+00$ & $.5 E+00$ \\
\hline & $1.0 E+00$ & $2.7 E-02$ & $1.0 E+00$ & $4.5 E+00$ \\
\hline & 1. $.0 E+00$ & $2.7 E-02$ & 1. $.0 E+00$ & $4.5 E+00$ \\
\hline & $6.2 E+00$ & $1.4 E+01$ & $7.8 E+00$ & $3.4 E+01$ \\
\hline & $6.2 E+00$ & $1.4 E+01$ & $7.8 E+00$ & $3.4 E+01$ \\
\hline & $5.5 E+00$ & $7.2 E-02$ & $E+01$ & $4.8 \mathrm{E}+01$ \\
\hline & & &.- & \\
\hline & $2.2 E+01$ & 2.7E+01 & $3.1 E+01$ & $1.3 E+02$ \\
\hline \multirow{9}{*}{$\begin{array}{l}\mathrm{N} \\
\mathrm{N}\end{array}$} & $4.7 E+00$ & $1.2 E-01$ & $4.7 E+00$ & 2.1E+01 \\
\hline & $4.7 E+00$ & $1.2 \mathrm{E}-01$ & $4.7 E+00$ & 2. $1 E+01$ \\
\hline & $4.7 E+00$ & $1.2 E-01$ & $4.7 E+00$ & 2. $1 E+01$ \\
\hline & $4.7 E+00$ & $1.2 E-01$ & $4.7 E+00$ & 2. $1 E+01$ \\
\hline & $2.4 \mathrm{E}+01$ & $5.3 E+01$ & $3.0 E+01$ & $1.3 E+02$ \\
\hline & $2.4 E+01$ & $5.2 E+01$ & $3.0 E+01$ & $1.3 E+02$ \\
\hline & $2.5 \mathrm{E}+01$ & $3.3 E-01$ & $5.1 E+01$ & $2.2 E+02$ \\
\hline & & -- & - & \\
\hline & $9.2 E+01$ & $1.1 E+02$ & $1.3 E+02$ & $5.7 E+02$ \\
\hline \multirow{12}{*}{$\begin{array}{l}N \\
N \\
N \\
N \\
Y \\
Y \\
N \\
N \\
N \\
Y\end{array}$} & $3.4 \mathrm{E}-01$ & 8.7E-03 & $3.4 \mathrm{E}-01$ & $1.5 \mathrm{E}+00$ \\
\hline & $3.4 \mathrm{E}-01$ & 8.7E-03 & $3.4 \mathrm{E}-01$ & $1.5 E+00$ \\
\hline & $3.4 E-01$ & 8.7E-03 & $3.4 E-01$ & $1.5 E+00$ \\
\hline & $3.4 E-01$ & $8.7 E-03$ & 3.6 & $1.5 E+00$ \\
\hline & $3.6 E-08$ & $1.5 E-03$ & $7.8 \mathrm{E}-02$ & 01 \\
\hline & $1.5 E-02$ & $6.0 E-04$ & $1.5 E-02$ & $1.1 E-03$ \\
\hline & $2.4 E+00$ & $5.3 E+00$ & $3.0 E+00$ & $1.3 E+01$ \\
\hline & $2.4 E+00$ & $5.2 E+00$ & $3.0 \mathrm{E}+00$ & $1.3 E+01$ \\
\hline & $1.8 \mathrm{E}+00$ & $2.4 E-02$ & $3.6 E+00$ & $1.6 \mathrm{E}+01$ \\
\hline & 1. $1 E+00$ & $5.0 E+00$ & $1.5 E+00$ & $+\infty$ \\
\hline & & & & \\
\hline & $9.1 E+00$ & $1.5 E+01$ & $1.3 \mathrm{E}+01$ & $5.5 E+01$ \\
\hline Y & $7.3 E-08$ & $8.8 E-07$ & 1.1E-07 & $1.3 E-06$ \\
\hline Y & $E+00$ & $.0 E+00$ & $4.5 E-05$ & $5.4 E-04$ \\
\hline Y & $1.8 \mathrm{E}$ & 2. $2 E-07$ & 3.0E-06 & $3.7 E-05$ \\
\hline Y & $1.8 E-08$ & $2.2 E-07$ & $3.0 \mathrm{E}-06$ & 3.7E-05 \\
\hline Y & $1.8 \mathrm{E}-08$ & $2.2 E-07$ & $3.0 \mathrm{E}-06$ & $3.7 \mathrm{E}-05$ \\
\hline Y & $.0 E+00$ & $.0 E+00$ & $.0 E+00$ & $.0 E+00$ \\
\hline $\mathbf{Y}$ & $.0 E+00$ & $.0 E+00$ & $.0 E+00$ & $.0 E+00$ \\
\hline Y & $.0 E+00$ & $.0 \mathrm{E}+00$ & $.0 E+00$ & $.0 E+00$ \\
\hline$Y$ & $1.1 E-08$ & $1.4 E-07$ & $1.2 E-07$ & $1.4 E-06$ \\
\hline$y$ & .0 & $.0 E+00$ & $.0 E+00$ & $\mathrm{OF}+0$ \\
\hline & 8.3E-04 & $1.0 E-02$ & 8.3E-03 & 1.0E-01 \\
\hline \multirow{7}{*}{$Y$} & 1. $4 \mathrm{E}-09$ & 1.7E-08 & 3.0E-09 & $3.6 E-08$ \\
\hline & $.0 E+00$ & $1.7 E-08$ & $.0 E+00$ & $3.6 E-08$ \\
\hline & $.0 E+00$ & $.0 E+00$ & $3.0 \mathrm{E}-09$ & $3.6 E-08$ \\
\hline & $.5 \mathrm{E}-04$ & 3.0E-03 & 4. $4 \mathrm{E}-05$ & 1.9E-04 \\
\hline & & & & \\
\hline & & & $9.9 E+02$ & $4.3 E+03$ \\
\hline & & & 02 & $.3 E+0 S$ \\
\hline
\end{tabular}
MENT 


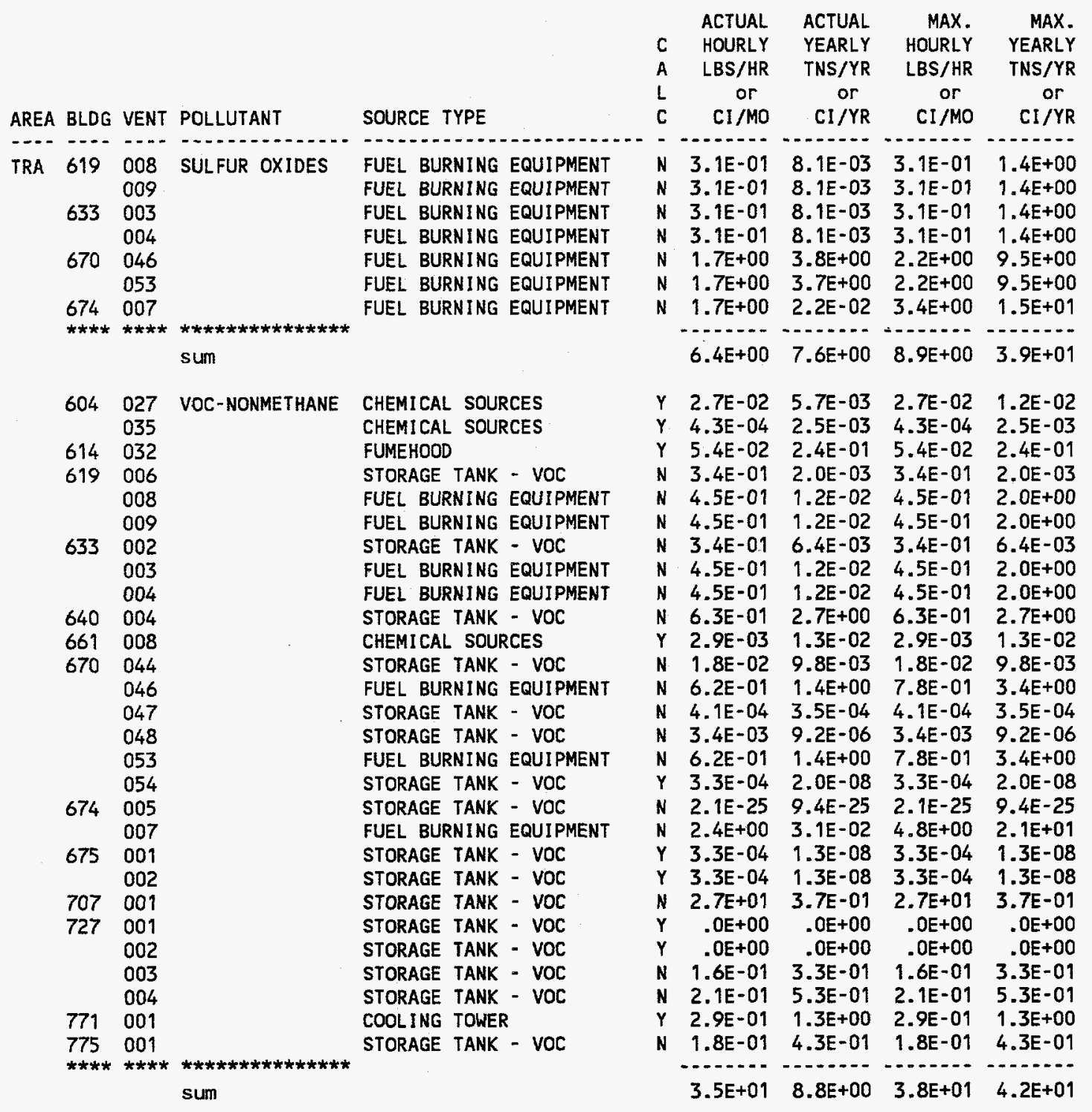




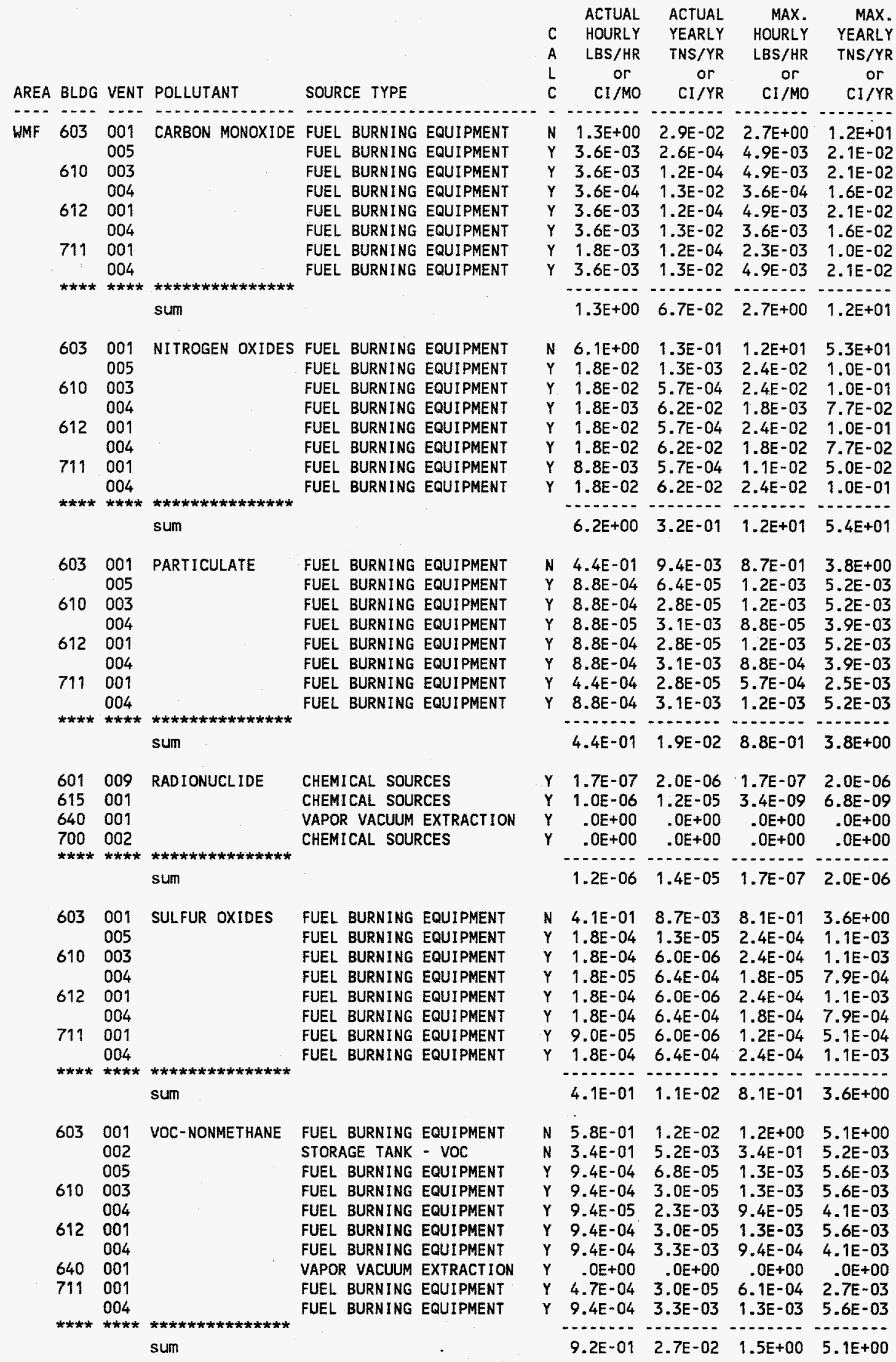


AREA BLDG VENT POLLUTANT

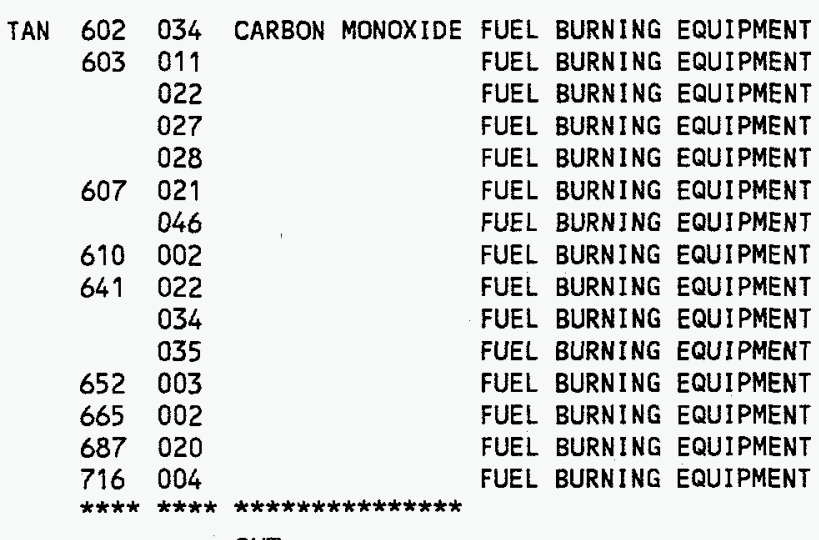

sum

602034 NITROGEN OXIDES FUEL BURNING EQUIPMENT 603011 022

027 028

$607 \quad 021$ 046

$610 \quad 002$

641022

$$
034
$$

$652 \quad 003$

665002

$\begin{array}{ll}687 & 020\end{array}$

716004

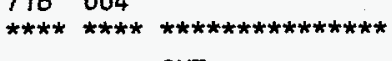

sum

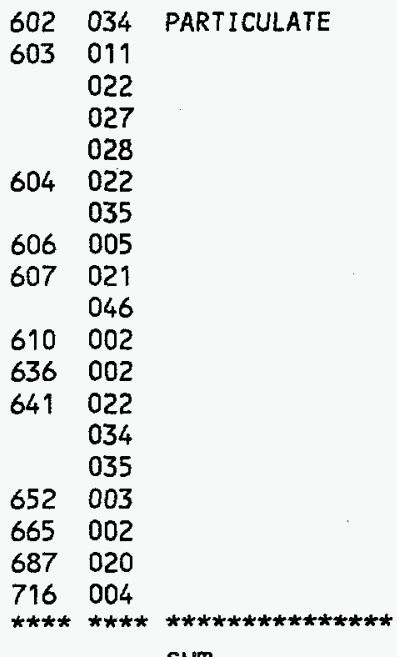

sum
SOURCE TYPE

FUEL BURNING EQUIPMENT

FUEL BURNING EQUIPMENT

FUEL BURNING EQUIPMENT

FUEL BURNING EQUIPMENT

FUEL BURNING EQUIPMENT

FUEL BURNING EQUIPMENT

FUEL BURNING EQUIPMENT

FUEL BURNING EQUIPMENT

FUEL BURNING EQUIPMENT

FUEL BURNING EQUIPMENT

FUEL BURNING EQUIPMENT

FUEL BURNING EQUIPMENT

FUEL BURNING EQUIPMENT

FUEL BURNING EQUIPMENT FUEL BURNING EQUIPMENT FUEL BURNING EQUIPMENT FUEL BURNING EQUIPMENT FUEL BURNING EQUIPMENT GR INDER FUMEHOOD SAWDUST PARTICULATE FUEL BURNING EQUIPMENT FUEL BURNING EQUIPMENT FUEL BURNING EQUIPMENT CHEMICAL SOURCES

FUEL BURNING EQUIPMENT FUEL BURNING EQUIPMENT FUEL BURNING EQUIPMENT FUEL BURNING EQUIPMENT FUEL BURNING EQUIPMENT FUEL BURNING EQUIPMENT FUEL BURNING EQUIPMENT
FUEL. BURNING EQUIPMENT CHEMICAL SOURCES

\begin{tabular}{|c|c|c|c|c|}
\hline$C$ & $\begin{array}{l}\text { ACTUAL } \\
\text { HOURLY }\end{array}$ & $\begin{array}{l}\text { ACTUAL } \\
\text { YEARLY }\end{array}$ & $\begin{array}{l}\text { MAX. } \\
\text { HOURLY }\end{array}$ & $\begin{array}{l}\text { MAX. } \\
\text { YFARIY }\end{array}$ \\
\hline $\mathcal{A}^{A}$ & LBS/HR & TNS/YR & LBS/HR & TNS /YR \\
\hline L & or & or & or & or \\
\hline C & $\mathrm{CI} / \mathrm{MO}$ & $\mathrm{CI} / \mathrm{YR}$ & $\mathrm{Cl} / \mathrm{MO}$ & $C I / Y R$ \\
\hline & & & & \\
\hline & $.0 E+00$ & $.0 E+00$ & $1.4 \mathrm{E}-02$ & $6.3 E-02$ \\
\hline $\mathbb{N}$ & $2.5 E+00$ & 3.3E-02 & $4.4 E+00$ & $1.9 E+01$ \\
\hline$N$ & $8.5 E-02$ & $2.8 E-01$ & $4.9 E-01$ & $2.1 E+00$ \\
\hline $\mathbf{N}$ & $8.5 E-02$ & $1.0 E+00$ & $6.9 E-01$ & $3.0 E+00$ \\
\hline $\mathbf{N}$ & $.0 E+00$ & 1. $.0 E+00$ & 7.0E-01 & $3.1 E+00$ \\
\hline $\mathbf{N}$ & $.0 E+00$ & $.0 E+00$ & $.0 E+00$ & $.0 E+00$ \\
\hline $\mathbf{N}$ & $1.4 \mathrm{E}+00$ & 2.0E-02 & $1.4 E+00$ & $6.3 E+00$ \\
\hline $\mathbf{N}$ & $1.1 E+00$ & $1.5 E-02$ & 2. $1 E+00$ & $9.2 E+00$ \\
\hline $\mathbf{N}$ & 4.0E-01 & 7.7E-03 & 8.0E-01 & $3.5 E+00$ \\
\hline $\mathbf{N}$ & $3.3 \mathrm{E}-02$ & $5.6 E-02$ & $2.2 E-01$ & $9.9 E-01$ \\
\hline $\mathbf{N}$ & $3.3 E-02$ & $5.6 E-02$ & $2.2 E-01$ & $9.9 E-01$ \\
\hline $\mathbf{N}$ & $3.9 E-01$ & $5.1 E-03$ & $7.8 E-01$ & $3.4 \mathrm{E}+00$ \\
\hline $\mathbf{N}$ & $1.0 E+00$ & $1.3 \mathrm{E}-02$ & $2.0 \mathrm{E}+00$ & $8.9 E+00$ \\
\hline $\mathbf{N}$ & $1.8 \mathrm{E}-01$ & $1.1 E-03$ & $3.7 E-01$ & $1.6 \mathrm{E}+00$ \\
\hline & $.0 E+00$ & $.0 E+00$ & $3.5 E-01$ & $1.5 E+00$ \\
\hline & 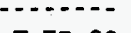 & $\cdots$ & -1 & - \\
\hline & $7.3 E+00$ & $2.5 E+00$ & $1.5 \mathrm{E}+01$ & $6.4 E+01$ \\
\hline & $.0 E+00$ & $.0 E+00$ & 7.0E-02 & 3. 1E-01 \\
\hline $\mathbf{N}$ & $1.2 \mathrm{E}+01$ & $1.5 E-01$ & 2.0E+01 & $8.8 E+01$ \\
\hline $\mathbf{N}$ & $9.4 \mathrm{E}-01$ & $3.0 E+00$ & $5.3 E+00$ & $2.3 E+01$ \\
\hline $\mathbf{N}$ & $3.4 E-01$ & $4.0 E+00$ & $2.8 E+00$ & $1.2 E+01$ \\
\hline N & $.0 E+00$ & $4.0 E+00$ & $2.8 E+00$ & $1.2 E+01$ \\
\hline $\mathbf{N}$ & $.0 E+00$ & $.0 E+00$ & $.0 E+00$ & $.0 E+00$ \\
\hline $\mathbf{N}$ & $6.6 E+00$ & $9.4 E-02$ & $6.6 \mathrm{E}+00$ & $2.9 \mathrm{E}+01$ \\
\hline N & $5.2 E+00$ & $7.0 E-02$ & $9.6 E+00$ & $4.2 E+01$ \\
\hline $\mathbf{N}$ & $1.8 E+00$ & $3.5 E-02$ & $3.7 E+00$ & $1.6 E+01$ \\
\hline $\mathrm{N}$ & $1.3 \mathrm{E}-01$ & 2.2E-01 & 9.0E-01 & $3.9 \mathrm{E}+00$ \\
\hline $\mathbf{N}$ & 1.3E-01 & $2.2 E-01$ & $9.0 \mathrm{E}-01$ & $3.9 E+00$ \\
\hline $\mathbf{N}$ & $1.8 \mathrm{E}+00$ & 2.3E-02 & $3.6 \mathrm{E}+00$ & $1.6 E+01$ \\
\hline r & $4.7 E+00$ & $6.1 E-02$ & $9.4 E+00$ & 4. $1 E+01$ \\
\hline $\mathbf{N}$ & $8.4 E-01$ & $4.9 E-03$ & $1.7 E+00$ & $7.4 E+00$ \\
\hline $\mathbf{N}$ & $.0 E+00$ & $.0 E+00$ & $1.4 E+00$ & $6.1 E+00$ \\
\hline & & & & \\
\hline & $3.4 E+01$ & $1.2 E+01$ & $6.9 E+01$ & $3.0 E+02$ \\
\hline Y & $.0 E+00$ & $.0 E+00$ & $3.5 E-03$ & $1.5 \mathrm{E}-02$ \\
\hline $\mathbf{N}$ & $8.4 E-01$ & 1.1E-02 & $1.4 E+00$ & $6.3 E+00$ \\
\hline $\mathrm{N}$ & $1.7 \mathrm{E}-01$ & $5.5 E-01$ & $9.7 E-01$ & $4.2 E+00$ \\
\hline N & $3.4 E-02$ & 4.0E-01 & $2.8 E-01$ & $1.2 E+00$ \\
\hline N & $.0 E+00$ & $4.0 E-01$ & $2.8 E-01$ & $1.2 E+00$ \\
\hline Y & $5.2 E-02$ & $2.7 E-02$ & $1.1 E-01$ & 5.1E-01 \\
\hline Y & $.0 E+00$ & $.0 \mathrm{E}+00$ & $1.0 \mathrm{E}+00$ & $.0 E+00$ \\
\hline Y & $4.4 E-01$ & $1.8 \mathrm{E}-01$ & $1.0 \mathrm{E}+00$ & 4. $4 E+00$ \\
\hline N & $.0 E+00$ & $.0 \mathrm{E}+00$ & $.0 E+00$ & $.0 E+00$ \\
\hline $\mathbf{N}$ & 4.7E-01 & 6.7E-03 & 4.7E-01 & $2.1 E+00$ \\
\hline 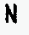 & 3.7E-01 & $5.0 E-03$ & $6.9 E-01$ & $3.0 E+00$ \\
\hline$Y$ & 2.3E-02 & $9.8 E-02$ & $2.1 E+00$ & $9.0 \mathrm{E}+00$ \\
\hline$N$ & 1.3E-01 & $2.5 E-03$ & $2.6 E-01$ & 1.1E+00 \\
\hline $\mathrm{N}$ & $1.3 E-02$ & 2.3E-02 & $9.0 \mathrm{E}-02$ & $3.9 E-01$ \\
\hline N & $1.3 E-02$ & 2.3E-02 & 9.0E-02 & $3.9 E-01$ \\
\hline N & $1.3 \mathrm{E}-01$ & $1.7 \mathrm{E}-03$ & 2.5E-01 & 1. $1 E+00$ \\
\hline N & $3.4 \mathrm{E}-01$ & 4. $4 E-03$ & 6.7E-01 & $2.9 \mathrm{E}+00$ \\
\hline$N$ & $6.0 \mathrm{E}-02$ & $3.5 E-04$ & $1.2 E-01$ & 5.3E-01 \\
\hline $\mathbf{N}$ & $.0 E+00$ & $.0 E+00$ & $1.4 \mathrm{E}-01$ & 6. $1 E-01$ \\
\hline & & • & 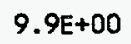 & W \\
\hline
\end{tabular}




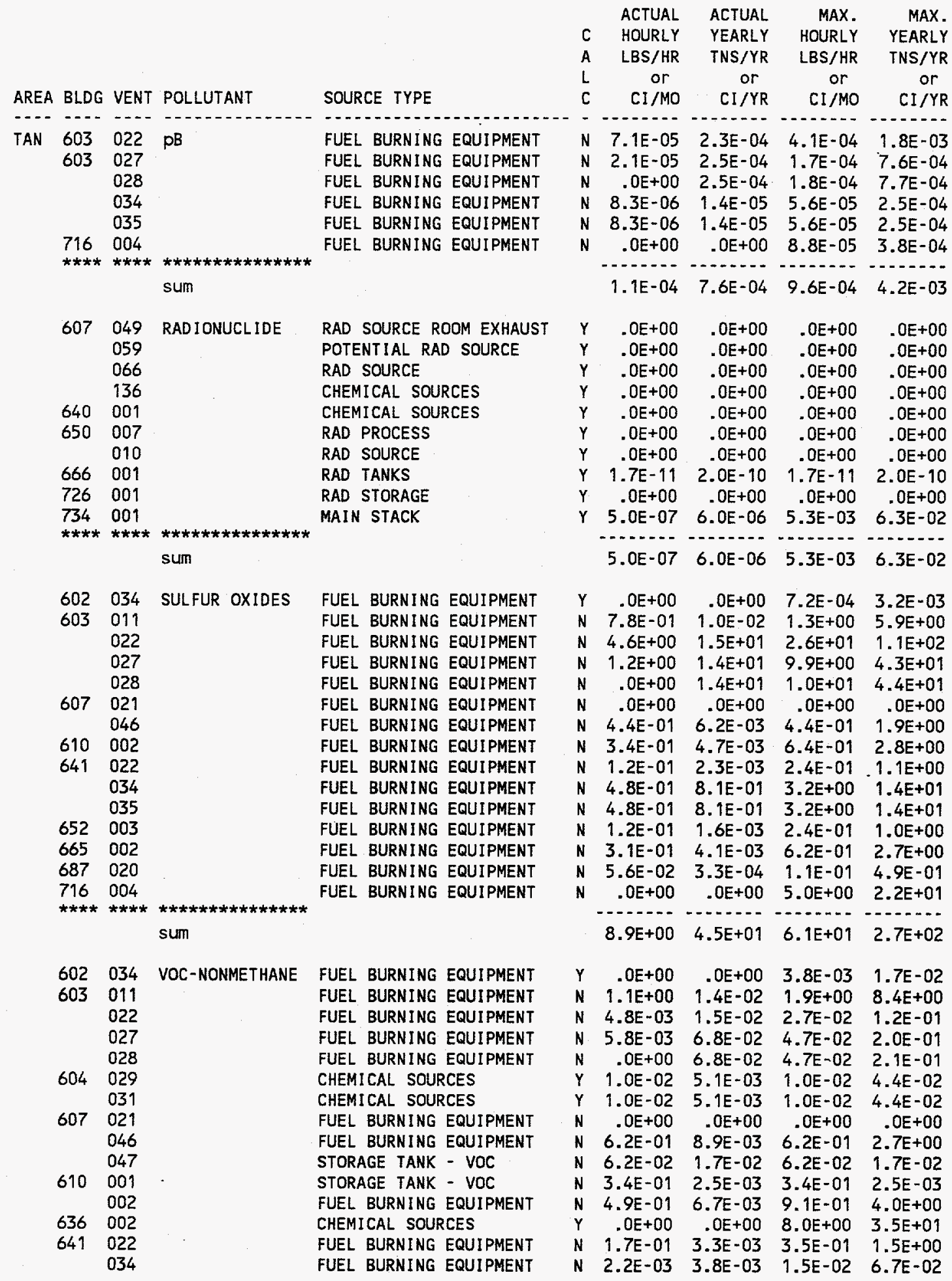




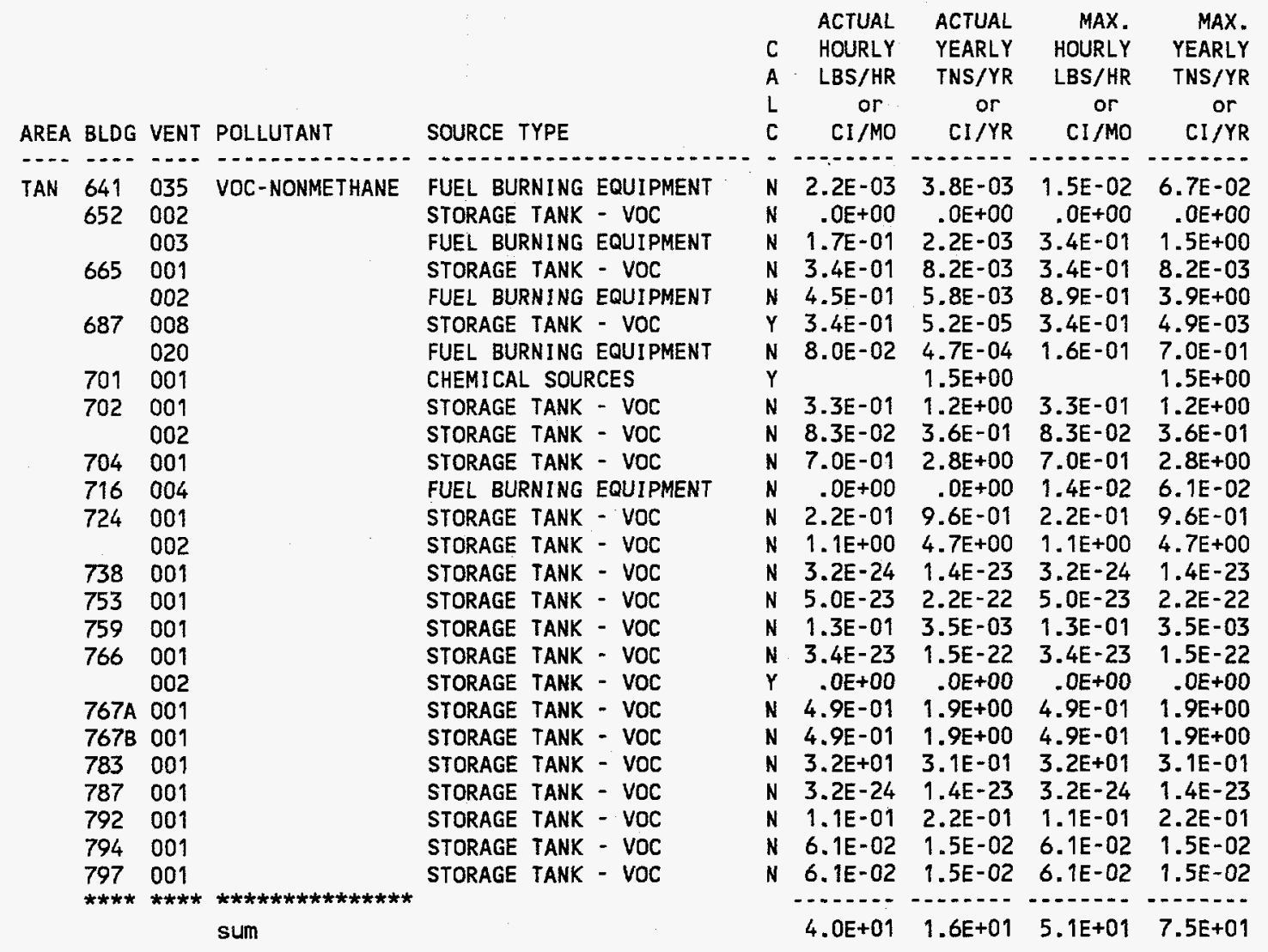


AREA BLDG VENT POLLUTANT

SOURCE TYPE

$\begin{array}{ccc}\text { TAN } 675 & 010 & \text { CARBON MONOXIDE } \\ & 035 \\ & 037 & \\ 679 & 012 & \\ & 067 & \\ & 068 & \\ 681 & 023 & \\ * * * * & * * * * * * * * * * * * * * * * * \\ & & \text { sum }\end{array}$

\begin{tabular}{|c|c|c|}
\hline \multirow{3}{*}{$\begin{array}{l}607 \\
675\end{array}$} & 119 & NITROGEN OXIDES \\
\hline & 010 & \\
\hline & 035 & \\
\hline \multirow{3}{*}{679} & 012 & \\
\hline & 067 & \\
\hline & 068 & \\
\hline \multirow[t]{2}{*}{681} & 012 & \\
\hline & 023 & \\
\hline ** & $\star \star * * *$ & $\star * * * * * * * * *$ \\
\hline & & su \\
\hline
\end{tabular}

$\begin{array}{lll}607 & 039 & \text { PARTICULATE } \\ & 041 \\ 629 & 002 \\ & 012 \\ & 014 \\ 675 & 010 \\ & 035 \\ & \\ 675 & 037 \\ 679 & 012 \\ & 067 \\ & 068 \\ 681 & 023 & \\ * \star * * & * * * * * * * * * * * * * * * * * *\end{array}$

sum

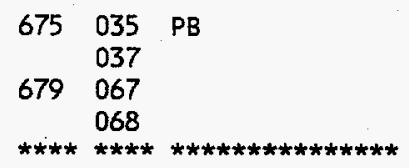

sum

$\begin{array}{lll}607 & 039 & \text { RADIONUCLIDE } \\ & 119 & \\ 629 & 012 & \\ & 013 & \\ & 014 & \\ 679 & 022 & \\ & 023 & \\ & 024 & \\ & 025 \\ & 026 \\ & 027 & \\ 681 & 012 & \\ & 018 & \\ & 020 & \\ * * * * & * * * * * * * * * * * * * * * * * \\ & & \text { sum }\end{array}$

FUEL BURNING EQUIPMENT FUEL BURNING EQUIPMENT FUEL BURNING EQUIPMENT FUEL BURNING EQUIPMENT FUEL BURNING EQUIPMENT FUEL BURNING EQUIPMENT FUEL BURNING EQUIPMENT

S CHEMICAL SOURCES FUEL BURNING EQUIPMENT FUEL BURNING EQUIPMENT FUEL BURNING EQUIPMENT FUEL BURNING EQUIPMENT FUEL BURNING EQUIPMENT FUEL BURNING EQUIPMENT CHEMICAL SOURCES FUEL BURNING EQUIPMENT

CHEMICAL SOURCES

CHEMICAL SOURCES

CHEMICAL SOURCES

MANUFACTURING PROCESS

MANUFACTURING PROCESS

FUEL BURNING EQUIPMENT

FUEL BURNING EQUIPMENT

FUEL BURNING EQUIPMENT

FUEL BURNING EQUIPMENT

FUEL BURNING EQUIPMENT

FUEL BURNING EQUIPMENT FUEL BURNING EQUIPMENT

FUEL BURNING EQUIPMENT FUEL BURNING EQUIPMENT FUEL BURNING EQUIPMENT FUEL BURNING EQUIPMENT

CHEMICAL SOURCES CHEMICAL SOURCES MANUFACTURING PROCESS CHEMICAL SOURCES MANUFACTURING PROCESS CHEMICAL SOURCES CHEMICAL SOURCES CHEMICAL SOURCES MANUFACTURING PROCESS MANUFACTURING PROCESS MANUFACTURING PROCESS CHEMICAL SOURCES MANUFACTURING PROCESS MANUFACTURING PROCESS
N $\quad 1.1 \mathrm{E}-04 \quad 1.8 \mathrm{E}-04 \quad 2.1 \mathrm{E}-04 \quad 9.2 \mathrm{E}-04$

N $\quad 9.0 \mathrm{E}-05 \quad 6.6 \mathrm{E}-05 \quad 2.1 \mathrm{E}-04 \quad 9.2 \mathrm{E}-04$

N $9.5 \mathrm{E}-05 \quad 1.2 \mathrm{E}-04 \quad 2.1 \mathrm{E}-04 \quad 9.2 \mathrm{E}-04$

N $\quad 7.4$ E-05 $1.4 E-04 \quad 2.1 E-04 \quad 9.2 E-04$ $3.6 E-04 \quad 5.1 E-04 \quad 8.4 E-04 \quad 3.7 E-03$

$\begin{aligned} & Y \\ & Y\end{aligned} \quad 4.7 E-07 \quad 5.7 E-06 \quad 1.2 E-03 \quad 1.5 E-02$

$Y \quad 1.7 E-03 \quad 1.7 E-03 \quad 5.5 E-04 \quad 4.0 E-03$

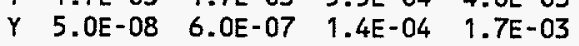

$Y \quad 3.6 E-07 \quad 4.3 E-06 \quad 1.3 E-03 \quad 1.6 E-02$

$\begin{array}{lllll}Y & 5.6 E-08 & 6.5 E-07 & 1.4 E-04 & 1.7 E-03\end{array}$

$Y \quad 7.0 E-08 \quad 8.4 E-07 \quad 5.2 E-04 \quad 6.3 E-03$

$Y \quad 9.8 E-08 \quad 1.1 E-06 \quad 3.8 E-04 \quad 4.5 E-03$

$Y \quad 7.4 E-08 \quad 8.9 E-07 \quad 3.4 E-04 \quad 4.2 E-03$

$Y \quad 1.0 E-07 \quad 1.2 E-06 \quad 3.5 E-04 \quad 4.2 E-03$

$Y \quad 9.2 E-08 \quad 1.1 E-06 \quad 4.3 E-04 \quad 5.2 E-03$

$Y \quad 9.2 \mathrm{E}-08 \quad 1.1 \mathrm{E}-06 \quad 4.3 \mathrm{E}-04 \cdot 5.2 \mathrm{E}-03$

$Y \quad 2.2 E-07 \quad 2.6 E-06 \quad 8.4 E-05 \quad 1.0 E-03$

$Y \quad 1.2 E-07 \quad 1.4 E-06 \quad 5.5 E-05 \quad 6.6 E-04$

$Y \quad 6.8 E-08 \quad 8.1 E-07 \quad 4.3 E-04 \quad 5.2 E-03$

$\begin{array}{llll}1.7 \mathrm{E}-03 & 1.8 \mathrm{E}-03 & 6.4 \mathrm{E}-03 & 7.4 \mathrm{E}-02\end{array}$ 
ACTUAL ACTUAL MAX. MAX.

\begin{tabular}{|c|c|c|c|c|}
\hline & ACTUAL & ACTUAL & MAX. & MAX. \\
\hline$C$ & HOURLY & YEARLY & HOURLY & YEARLY \\
\hline A & LBS/HR & TNS/YR & LBS/HR & TNS/YR \\
\hline L & or & or & or & or \\
\hline C & $\mathrm{Cl} / \mathrm{MO}$ & $\mathrm{CI} / \mathrm{YR}$ & $\mathrm{CI} / \mathrm{MO}$ & $\mathrm{CI} / \mathrm{YR}$ \\
\hline - & $\ldots$ & -- & $\ldots$. & \\
\hline $\mathbf{N}$ & $1.5 E-01$ & $6.7 E-03$ & $9.6 E-01$ & $4.2 E+00$ \\
\hline N & $6.0 E+00$ & $1.0 \mathrm{E}+01$ & $1.2 E+01$ & $3 E+01$ \\
\hline$N$ & $5.2 E+00$ & $3.8 E+00$ & $1.2 E+01$ & $5.3 E+01$ \\
\hline $\mathbf{N}$ & $1.7 E-01$ & $6.2 E-03$ & $1.2 E+00$ & $5.1 E+00$ \\
\hline N & $5.5 E+00$ & $7.1 E+00$ & 1. $2 E+01$ & $5.3 E+01$ \\
\hline & $4.2 E+00$ & $8.0 E+00$ & $1.2 E+01$ & $5.3 E+01$ \\
\hline T & $7.6 E-02$ & $6.1 E-04$ & $2.3 E-04$ & $1.0 E-03$ \\
\hline &.-- & $\cdots$ & 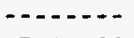 & --- \\
\hline & 2. $1 E+01$ & $2.9 E+01$ & $5.0 E+01$ & 2. $2 E+02$ \\
\hline Y & $3.9 E-02$ & $1.0 E-04$ & $5.0 E-02$ & $6.0 E-03$ \\
\hline$Y$ & $5.1 E-03$ & 5.1E-03 & $8.2 E-02$ & $3.3 E-01$ \\
\hline$Y$ & $4.5 E-02$ & $4.2 E-04$ & $5.2 E-02$ & 1.6E-03 \\
\hline$Y$ & 1. $1 E+00$ & 1. $1 E-01$ & $4.0 \mathrm{E}+00$ & $2.1 E+00$ \\
\hline$Y$ & 1. $1 E+00$ & 1. $1 E-01$ & $4.0 E+00$ & 2. $1 E+00$ \\
\hline $\mathbf{N}$ & $2.2 E-01$ & $9.6 \mathrm{E}-03$ & 1. $4 E+00$ & $6.0 E+00$ \\
\hline $\mathrm{N}$ & $9.3 E-02$ & $1.5 E-01$ & $9.3 E-02$ & $1.5 E-01$ \\
\hline $\mathbf{N}$ & $3.6 E-02$ & $1.7 \mathrm{E}-03$ & $3.6 E-02$ & $1.7 E-03$ \\
\hline$N$ & 3.7E-02 & $9.0 E-03$ & $3.7 E-02$ & $9.0 E-03$ \\
\hline $\mathbf{N}$ & $1.9 E-01$ & $5.6 E-01$ & $1.9 E-01$ & $5.6 E-01$ \\
\hline N & $3.9 E-01$ & $1.5 E+00$ & $3.9 E-01$ & $1.5 E+00$ \\
\hline N & 1.7E-02 & $2.9 E-02$ & $3.4 E-02$ & $1.5 E-01$ \\
\hline$N$ & $1.4 E-02$ & 1. $0 \mathrm{E}-02$ & $3.4 E-02$ & $1.5 E-01$ \\
\hline $\mathbf{N}$ & $2.4 E-01$ & $8.8 E-03$ & $1.6 \mathrm{E}+00$ & $7.2 E+00$ \\
\hline $\mathbf{N}$ & $1.2 E-01$ & 2.7E-01 & $1.2 E-01$ & $2.7 E-01$ \\
\hline $\mathbf{N}$ & $1.5 E-02$ & $2.0 E-02$ & $3.4 E-02$ & $1.5 E-01$ \\
\hline N & $1.2 E-02$ & $2.2 E-02$ & $3.4 E-02$ & $1.5 E-01$ \\
\hline $\mathbf{N}$ & $9.0 \mathrm{E}-03$ & $2.3 E-02$ & $9.0 \mathrm{E}-03$ & $2.3 E-02$ \\
\hline$N$ & $3.7 E-02$ & $6.8 E-03$ & $3.7 E-02$ & $6.8 E-03$ \\
\hline $\mathbf{N}$ & $3.9 E-01$ & $1.5 E+00$ & 3.9E-01 & $1.5 E+00$ \\
\hline & $9.1 E-02$ & $7.3 E-04$ & $1.2 E-03$ & $5.3 E-03$ \\
\hline & $-n$ & $-\ldots$ & 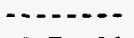 & 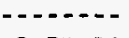 \\
\hline & $4.3 E+00$ & $4.3 E+00$ & $1.3 E+01$ & $2.2 E+01$ \\
\hline
\end{tabular}


Appendix $C$

Supporting Data for the

1993 Air Emission Inventory for the INEL 


$$
\text { C-2 }
$$




\section{Appendix C}

\section{Supporting Data for the 1993 Air Emission Inventory for the INEL}

This appendix presents the data collected for the current update of the Air Emission Inventory System and describes each report form in detail. All the forms list the area, building, and stack number. The following presents the information as titled on each form.

\section{C.1 AIR EMISSION INVENTORY PROCESS PARAMETERS}

This form contains the operating schedule for the process associated with the stack emissions.

Column 1. Hr/Day - the number of hours in a day the equipment or process operates.

Column 2. Days/Week - the number of days in a week the equipment or process operates.

Column 3. Weeks/Year - the number of weeks in a year the equipment or process operates.

Column 4. Status - status of source (active, inactive, D\&D).

\section{C.2 AIR EMISSION INVENTORY STACK PARAMETERS}

This form lists of all the stack parameters currently recorded for each stack.

Column 1. Exit Temp $\left({ }^{\circ} \mathrm{F}\right)-$ the exit temperature of the emissions from the vent in degrees

Fahrenheit.

Column 2. Temp Type - the character field for the temperature which describes it as either ambient or room temperature.

Column 3. Flow Rate - the flow rate of the emissions from the stack in cubic feet per minute.

Column 4. Velocity - the velocity of the emissions from the stack in feet per minute.

Column 5. Hgt grnd - the height of the stack from the ground in feet.

Column 6. Elev - the elevation of the stack from sea level in feet.

Column 7. Dia or Length - the diameter of a round stack or the length of a stack for rectangular stacks in inches.

Column 8. Width - the width of a stack for rectangular stacks in inches.

Column 9. UTM Northing - the universal transverse mercator (UTM) northing coordinate in meters.

Column 10. UTM Easting - the UTM easting coordinate in meters. 


\section{C.3 AIR EMISSION INVENTORY FUEL BURNING EQUIPMENT PART I}

This form lists information about the fuel burning equipment currently emitting emissions at the site.

Column 1. E - The type of fuel burning equipment: B - Boiler, F - Furnace, H - Heater, L - Large Engine, P - Propane Burner, or S -Small Engine.

Column 2. Primary Normal per Hour - the normal hourly fuel through put for the primary fuel type for this piece of equipment in gallons per hour.

Column 3. Primary Normal per Year - the normal yearly fuel through put for the primary fuel type for this piece of equipment in gallons per year.

Column 4. Primary Max per Hour - the maximum hourly fuel through put for the primary fuel type for this piece of equipment in gallons per hour.

Column 5. Primary Fuel - the primary fuel type burned in this equipment. See the list of fuel types in Table C-1.

Column 6. Second Normal per Hour - the normal hourly fuel through put for the secondary fuel type for this piece of equipment in gallons per hour.

Column 7. Second Normal per Year - the normal yearly fuel through put for the secondary fuel type for this piece of equipment in gallons per year.

Column 8. Second Max per Hour - the maximum hourly fuel through put for the secondary fuel type for this piece of equipment in gallons per hour.

Column 9. Secondary Fuel - the secondary fuel type burned in this equipment.

Table C-1. Fuel types and grades for primary and secondary fuels.

\begin{tabular}{lclc}
\hline & & & \\
Fuel type & Grade & Fuel type & Grade \\
\hline Diesel & 1 & Diesel & 2 \\
Fuel oil & 1 & Fuel oil & 2 \\
Fuel oil & 4 & Fuel oil & 5 \\
Fuel oil & 6 & & \\
Propane & A & Propane & B \\
Propane & C & Propane & D \\
Propane & E & & \\
Butane & A & Butane & B \\
Butane & C & Butane & D \\
Butane & E & & \\
Gasoline & 7 & Gasoline & 10 \\
Gasoline & 13 & Natural gas & 0 \\
Gasohol & 0 & JP-4 & 0 \\
\hline
\end{tabular}




\section{C.4 AIR EMISSION INVENTORY FUEL BURNING EQUIPMENT PART II}

This form is part two of the information about fuel burning equipment.

Column 1. E - The type of fuel burning equipment: B - Boiler, F - Furnace, H - Heater, L - Large Engine, P - Propane Burner, or S -Small Engine.

Column 2. Rated Heat - the rated heat value for a boiler.

Column 3. Class - the class of boiler, furnace or heater.

Column 4. Large Engine Horse Power - the horsepower for large engines.

Column 5. Small Engine Horse Power - the horsepower for small engines.

\section{C.5 AIR EMISSION INVENTORY ORGANIC STORAGE TANKS - PART I}

This form contains information about the organic storage tanks.

Column 1. Annual Thru Put - the annual material through put for the tank in gallons per year.

Column 2. Ave. \% Full - the average percent full of the tank.

Column 3. Fill Rate - the fill rate for the tank during refilling process in gallons per minute.

Column 4. Vapor Space Height - the vapor space height of the tank in feet.

Column 5. Capacity - the capacity of the tank in gallons.

Column 6. Tank Dia - the tank diameter in feet.

Column 7. Tank Length - the length of the tank in feet.

Column 8. Tank Type - the type of tank. (fixed roof, floating roof, variable vapor space, or pressure tank)

Column 9. Material Stored - the material stored in the tank.

Column 10. Tank Location - the location of the tank, either inside or outside of a building.

C.6 AIR EMISSION INVENTORY ORGANIC STORAGE TANKS PART II

This form contains information about the organic storage tanks.

Column 1. Air Flow Rate - the air flow rate through the tank in cubic feet per minute.

Column 2. $\mathrm{J}-(\mathrm{Y} / \mathrm{N})$ is there an inert gas jacket around the tank. 
Column 3. Vapor Recovery Method - the vapor recovery method used for the tank.

Column 4. \% Recover Eff - the efficiency of the recovery method stated above.

Column 5. Tank Location - the location of the tank, either under ground or above ground.

Column 6. Orient - the orientation of the tank, horizontal or vertical.

Column 7. Roof Color - the color of the roof.

Column 8. Roof Cond - the condition of the paint on the roof.

Column 9. Shell Color - the color of the shell. See Table C-2 for a preferred list of colors.

Column 10. Shell Cond - the condition of the paint on the shell.

\section{C.7 AIR EMISSION INVENTORY INORGANIC STORAGE TANKS - PART I}

This form contains information about the inorganic storage tanks.

Column 1. Annual Thru Put - the annual material through put for the tank in gallons per year.

Column 2. Ave. \% Full - the average percent full of the tank.

Column 3. Fill Rate - the fill rate for the tank during refilling process in gallons per minute.

Column 4. Vapor Space Height - the vapor space height of the tank in feet.

Column 5. Capacity - the capacity of the tank in gallons.

Column 6. Tank Dia - the tank diameter in feet.

Column 7. Tank Length - the length of the tank in feet.

Column 8. Tank Type - the type of tank. (fixed roof, floating roof, variable vapor space, or pressure tank)

Column 9. Material Stored - the material stored in the tank.

Column 10. Tank Location - the location of the tank, either inside or outside of a building.

Table C-2. Preferred conditions and colors for tanks.

Preferred Colors:

White

Light grey

Grey

Preferred Conditions:
Shiny silver

Medium grey

Aluminum, specular

Good
Flat silver

Silver, dull

Aluminum, diffuse 


\section{C.8 AIR EMISSION INVENTORY INORGANIC STORAGE TANKS - PART II}

This form contains information about the inorganic storage tanks.

Column 1. Air Flow Rate - the air flow rate through the tank in cubic feet per minute.

Column 2. $J-(\mathrm{Y} / \mathrm{N})$ is there an inert gas jacket around the tank.

Column 3. Vapor Recovery Method - the vapor recovery method used for the tank.

Column 4. \% Recover Eff - the efficiency of the recovery method stated above.

Column 5. Tank Location - the location of the tank, either under ground or above ground.

Column 6. Orient - the orientation of the tank, horizontal or vertical.

Column 7. Roof Color - the color of the roof.

Column 8. Roof Cond - the condition of the paint on the roof.

Column 9. Shell Color - the color of the shell.

Column 10. Shell Cond - the condition of the paint on the shell. See Table 2 for a preferred list of colors.

\section{C.9 AIR EMISSION INVENTORY PROCESS CONTROL EQUIPMENT}

This form lists the emissions control equipment for a source.

\section{C-10 AIR EMISSION INVENTORY MONITORING EQUIPMENT}

This form lists the monitoring equipment for a source. 

Update Survey for AIR EMISSIONS INVENTORY PROCESS PARAMETERS - 1993 Page: 1

\begin{tabular}{|c|c|c|c|c|c|c|}
\hline AREA BLDG & VENT & SOURCE TYPE & $\begin{array}{l}\mathrm{Hr} / \\
\text { Day }\end{array}$ & $\begin{array}{r}\text { Days/ } \\
\text { Week }\end{array}$ & $\begin{array}{r}\text { Weeks/ } \\
\text { Year }\end{array}$ & Status \\
\hline ANL 701 & 009 & FUEL BURNING EQUIPMENT & .30 & 1.00 & 52.00 & ACTIVE \\
\hline & 012 & STORAGE TANK - VOC & 24.00 & 7.00 & 52.00 & ACTIVE \\
\hline & 020 & STORAGE TANK - VOC & 24.00 & 7.00 & 52.00 & ACTIVE \\
\hline 704 & 008 & CHEMICAL SOURCES & 24.00 & 7.00 & 52.00 & ACTIVE \\
\hline & 015 & FUEL BURNING EQUIPMENT & 1.00 & 1.00 & 26.00 & ACTIVE \\
\hline 307 & 001 & STORAGE TANK - VOC & 24.00 & 7.00 & 52.00 & ACTIVE \\
\hline & 002 & FUEL BURNING EQUIPMENT & .50 & 1.00 & 52.00 & ACTIVE \\
\hline 709 & 001 & STORAGE TANK - VOC & 24.00 & 7.00 & 52.00 & ACTIVE \\
\hline & 008 & FUEL BURNING EQUIPMENT & .84 & 1.00 & 16.00 & ACTIVE \\
\hline & 009 & STORAGE TANK - VOC & 24.00 & 7.00 & 52.00 & ACTIVE \\
\hline & 016 & FUEL BURNING EQUIPMENT & .94 & 1.00 & 16.00 & ACTIVE \\
\hline 720 & 007 & CHEMICAL SOURCES & 24.00 & 7.00 & 52.00 & ACTIVE \\
\hline & 017 & FUEL BURNING EQUIPMENT & .48 & 1.00 & 52.00 & ACTIVE \\
\hline & 018 & FUEL BURNING EQUIPMENT & .48 & 1.00 & 52.00 & ACTIVE \\
\hline & 021 & STORAGE TANK - VOC & 24.00 & 7.00 & 52.00 & ACTIVE \\
\hline & 022 & STORAGE TANK - VOC & 24.00 & 7.00 & 52.00 & ACTIVE \\
\hline & 025 & STORAGE TANK - VOC & 24.00 & 7.00 & 52.00 & ACTIVE \\
\hline & 027 & SUSPECT WASTE TANK & 24.00 & 7.00 & 52.00 & ACTIVE \\
\hline 721 & 003 & STORAGE TANK - VOC & 24.00 & 7.00 & 52.00 & ACTIVE \\
\hline & 004 & FUEL BURNING EQUIPMENT & 24.00 & 7.00 & 52.00 & ACTIVE \\
\hline 742 & 002 & STORAGE TANK - VOC & 24.00 & 7.00 & 52.00 & ACTIVE \\
\hline & 005 & STORAGE TANK - VOC & 24.00 & 7.00 & 52.00 & ACTIVE \\
\hline & 006 & STORAGE TANK - VOC & 24.00 & 7.00 & 52.00 & ACTIVE \\
\hline 752 & 004 & CHEMICAL SOURCES & 24.00 & 7.00 & 52.00 & ACTIVE \\
\hline & 005 & CHEMICAL SOURCES & 24.00 & 7.00 & 52.00 & ACTIVE \\
\hline & 098 & CHEMICAL SOURCES & .00 & .00 & .00 & ACTIVE \\
\hline $752 \mathrm{~A}$ & 001 & FUEL BURNING EQUIPMENT & .50 & 1.00 & 52.00 & ACTIVE \\
\hline & 005 & STORAGE TANK - VOC & 24.00 & 7.00 & 52.00 & ACTIVE \\
\hline 753 & 006 & CHEMICAL SOURCES & .00 & .00 & .00 & INACTIVE \\
\hline & 024 & CHEMICAL SOURCES & 24.00 & 7.00 & 52.00 & ACTIVE \\
\hline & 029 & CHEMICAL SOURCES & 4.00 & 5.00 & 52.00 & ACTIVE \\
\hline
\end{tabular}


Update Survey for AIR EMISSIONS INVENTORY PROCESS PARAMETERS - 1993 Page:

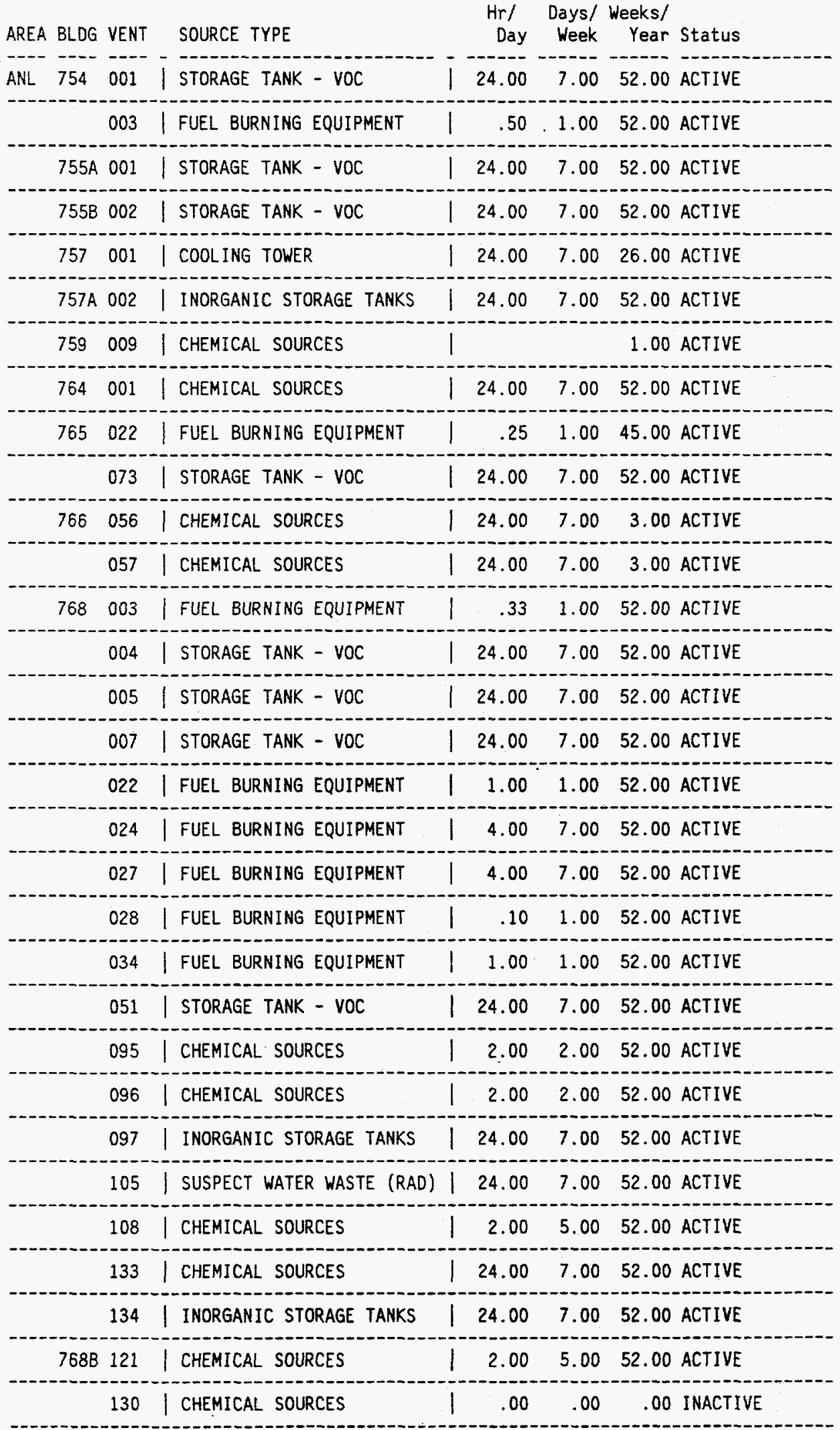


Update Survey for AIR EMISSIONS INVENTORY PROCESS PARAMETERS - 1993 Page:

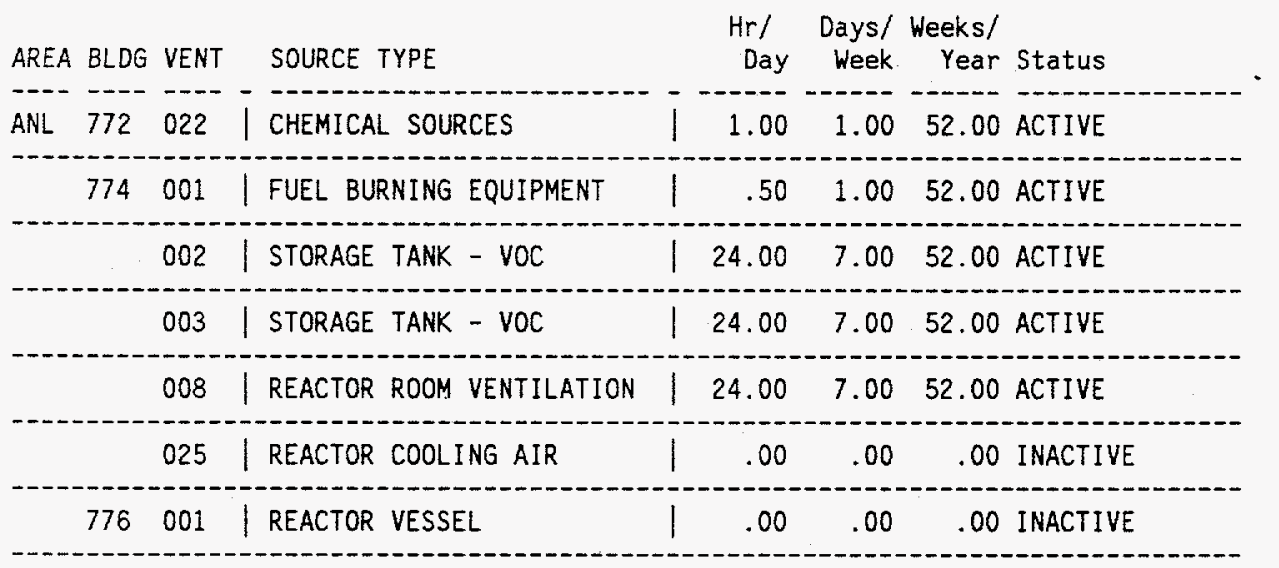

777002 REACTOR COOLING AIR EXH. | 24.00 7.00 52.00 ACTIVE

\begin{tabular}{rl|l}
782 & 001 & $\mid$
\end{tabular}

\begin{tabular}{|c|c|c|c|c|c|}
\hline 784 & 010 & CHEMICAL SOURCES & .00 & .00 & .00 INACTIVE \\
\hline 785 & 009 & STORAGE TANK - VOC & 24.00 & 7.00 & $52.00 \mathrm{ACTIVE}$ \\
\hline & 011 & ROOM EXHAUST & .00 & .00 & .00 ACTIVE \\
\hline & 014 & STORAGE TANK - VOC & 24.00 & 7.00 & 52.00 ACTIVE \\
\hline & 016 & FUEL BURNING EQUIPMENT & .21 & 1.00 & 52.00 ACTIVE \\
\hline & 017 & FUEL BURNING EQUIPMENT & .24 & 1.00 & 52.00 ACTIVE \\
\hline & 018 & CHEMICAL SOURCES & 24.00 & 7.00 & 52.00 ACTIVE \\
\hline 787 & 001 & CHEMICAL SOURCES & 24.00 & 7.00 & 52.00 ACTIVE \\
\hline 788 & 013 & CHEMICAL SOURCES & 1.00 & 1.00 & 52.00 ACTIVE \\
\hline & 014 & CHEMICAL SOURCES & 1.00 & 1.00 & 52.00 ACTIVE \\
\hline 789 & 001 & CHEMICAL SOURCES & 1.00 & 1.00 & 2.00 ACTIVE \\
\hline $789 \mathrm{~A}$ & 007 & FUEL BURNING EQUIPMENT & .00 & .00 & .00 INACTIVE \\
\hline 793 & 001 & CHEMICAL SOURCES & 8.00 & 5.00 & 20.00 ACTIVE \\
\hline & 011 & STOQRAGE TANK - VOC & 24.00 & 3.00 & 1.00 ACTIVE \\
\hline & 012 & STORAGE TANK - VOC & 8.00 & 5.00 & 5.00 ACTIVE \\
\hline & 013 & STORAGE TANK - VOC & 8.00 & 5.00 & 5.00 ACTIVE \\
\hline & 014 & STORAGE TANK - VOC & 8.00 & 3.00 & 2.00 ACTIVE \\
\hline & 015 & STORAGE TANK - VOC & 8.00 & 3.00 & 2.00 ACTIVE \\
\hline $793 A$ & 025 & STORAGE TANK - VOC & 24.00 & 7.00 & 52.00 ACTIVE \\
\hline & 026 & STORAGE TANK - VOC & 24.00 & 7.00 & 52.00 ACTIVE \\
\hline & 027 & STORAGE TANK - VOC & 24.00 & 7.00 & 52.00 ACTIVE \\
\hline
\end{tabular}


Update Survey for AIR EMISSIONS INVENTORY PROCESS PARAMETERS - 1993 Page:

\begin{tabular}{l} 
AREA BLDG VENT \\
\hline ANL SOURCE TYPE
\end{tabular}


Update Survey for AIR EMISSIONS INVENTORY PROCESS PARAMETERS - 1993 Page: 5

\begin{tabular}{|c|c|c|c|c|c|c|}
\hline AREA BLDG & VENT & SOURCE TYPE & $\begin{array}{l}\mathrm{Hr} / \\
\text { Day }\end{array}$ & $\begin{array}{r}\text { Days/ } \\
\text { Week }\end{array}$ & $\begin{array}{r}\text { Weeks/ } \\
\text { Year }\end{array}$ & Status \\
\hline ARA IV & 001 & CHEMICAL SOURCES & 1.00 & 2.00 & 12.00 & ACTIVE \\
\hline & 002 & CHEMICAL SOURCES & 23.00 & 1.00 & 1.00 & ACTIVE \\
\hline
\end{tabular}

Update Survey for AIR EMISSIONS INVENTORY PROCESS PARAMETERS - 1993 Page: 6

\begin{tabular}{|c|c|c|c|c|c|c|}
\hline AREA BLDG & VENT & SOURCE TYPE & $\begin{array}{l}\mathrm{Hr} / \\
\text { Day }\end{array}$ & $\begin{array}{r}\text { Days/ } \\
\text { Week }\end{array}$ & $\begin{array}{r}\text { Weeks/ } \\
\text { Year }\end{array}$ & Status \\
\hline 601 & 001 & STORAGE TANK - VOC & 24.00 & 7.00 & 52.00 & ACTIVE \\
\hline & 003 & FUEL BURNING EQUIPMENT & 1.00 & 1.00 & 26.00 & ACTIVE \\
\hline
\end{tabular}

Update Survey for AIR EMISSIONS INVENTORY PROCESS PARAMETERS - 1993 Page: 7

\begin{tabular}{|c|c|c|c|c|c|c|c|}
\hline AREA & BLDG & VENT & SOURCE TYPE & $\begin{array}{l}\mathrm{Hr} / \\
\text { Day }\end{array}$ & $\begin{array}{r}\text { Days/ } \\
\text { Week }\end{array}$ & $\begin{array}{l}\text { Weeks/ } \\
\text { Year }\end{array}$ & Status \\
\hline B16 & 601 & 007 & FUEL BURNING EQUIPMENT & 4.00 & 7.00 & 30.00 & ACTIVE \\
\hline & & 008 & STORAGE TANK - VOC & 24.00 & 7.00 & 52.00 & ACTIVE \\
\hline & 703 & 001 & STORAGE TANK - VOC & 24.00 & 7.00 & 52.00 & ACTIVE \\
\hline & 708 & 001 & EVAPORATION POND & 24.00 & 7.00 & 52.00 & ACTIVE \\
\hline
\end{tabular}

Update Survey for AIR EMISSIONS INVENTORY PROCESS PARAMETERS - 1993 Page: 8

\begin{tabular}{|c|c|c|c|c|c|c|c|}
\hline AREA & BLDG & VENT & SOURCE TYPE & $\begin{array}{c}\mathrm{Hr} / \\
\text { Day }\end{array}$ & $\begin{array}{r}\text { Days/ } \\
\text { Week }\end{array}$ & $\begin{array}{r}\text { Weeks/ } \\
\text { Year }\end{array}$ & Status \\
\hline 1 & 608 & 008 & CHEMICAL SOURCES & 12.00 & 7.00 & 52.00 & ACTIVE \\
\hline & & 012 & FIRING RANGE & 24.00 & 7.00 & 52.0 & ACTIVE \\
\hline
\end{tabular}

Update Survey for AIR EMISSIONS INVENTORY PROCESS PARAMETERS - 1993 Page: 9

\begin{tabular}{|c|c|c|c|c|c|c|}
\hline ARE & BLDG VENT & SOURCE TYPE & $\begin{array}{l}\mathrm{Hr} / \\
\text { Day }\end{array}$ & $\begin{array}{r}\text { Days/ } \\
\text { Week }\end{array}$ & $\begin{array}{r}\text { Weeks/ } \\
\text { Year }\end{array}$ & Status \\
\hline 33 & $602 \quad 002$ & STORAGE TANK - VOC & 1.00 & 1.00 & 26.00 & ACTIVE \\
\hline
\end{tabular}

Update Survey for AIR EMISSIONS INVENTORY PROCESS PARAMETERS - 1993 Page: 10

\begin{tabular}{|c|c|c|c|c|c|c|}
\hline AREA BLDG & VENT & SOURCE TYPE & $\begin{array}{l}\mathrm{Hr} / \\
\text { Day }\end{array}$ & $\begin{array}{r}\text { Days/ } \\
\text { Week }\end{array}$ & $\begin{array}{c}\text { Weeks/ } \\
\text { Year }\end{array}$ & Status \\
\hline B27 601 & 001 & FUEL BURNING EQUIPMENT. & .50 & 1.00 & 52.00 & ACTIVE \\
\hline & 003 & STORAGE TANK - VOC & 24.00 & 7.00 & 52.00 & ACTIVE \\
\hline
\end{tabular}


Update Survey for AIR EMISSIONS INVENTORY PROCESS PARAMETERS - 1993 Page: 11

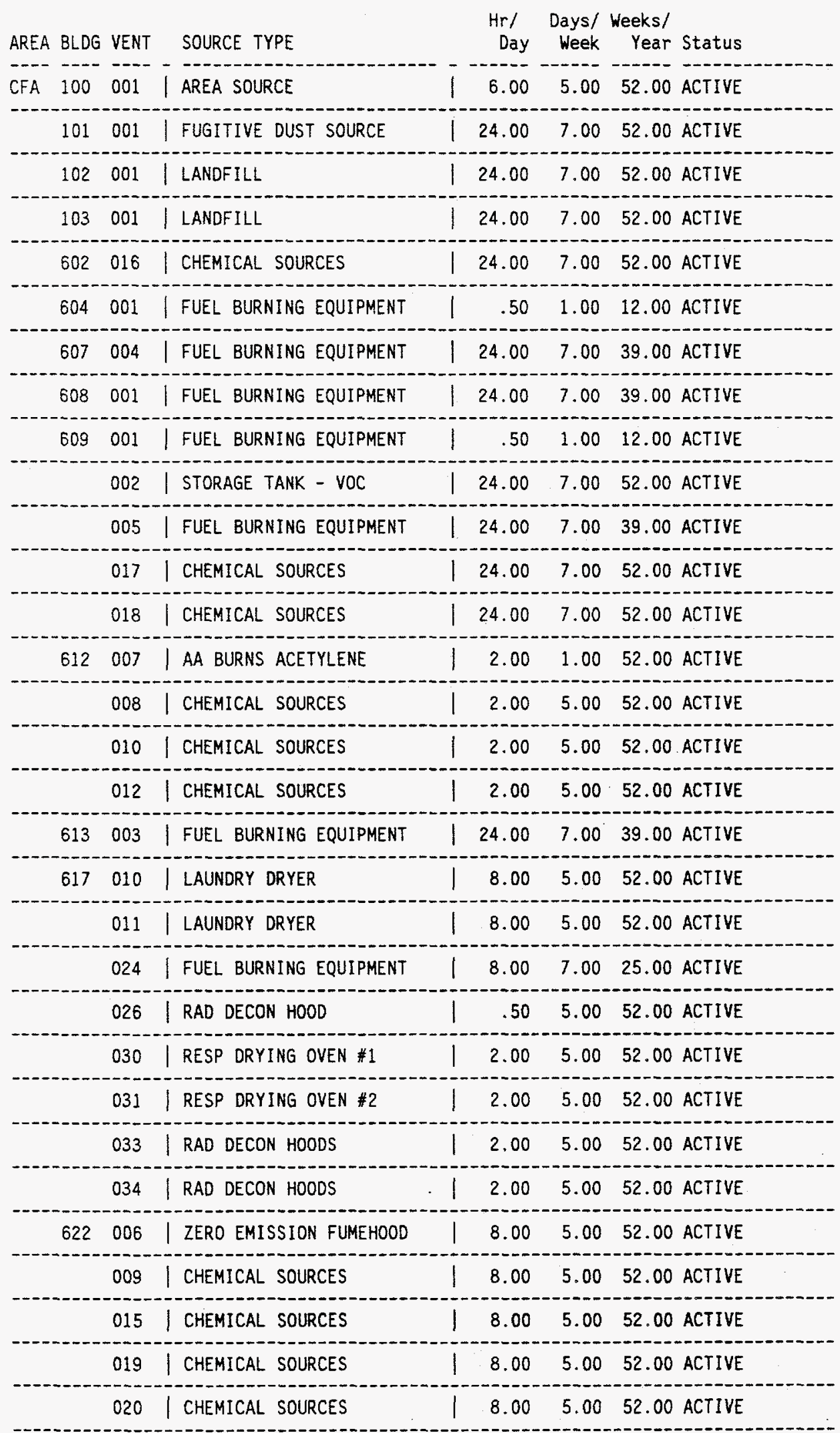


Update Survey for AIR EMISSIONS INVENTORY PROCESS PARAMETERS - 1993 Page: 12

\begin{tabular}{|c|c|c|c|c|c|c|c|c|}
\hline AR & BLDG & VENT & SOURCE TYPE & & $\begin{array}{c}\mathrm{Hr} / \\
\text { Day }\end{array}$ & $\begin{array}{r}\text { Days/ } \\
\text { Week }\end{array}$ & $\begin{array}{r}\text { Weeks/ } \\
\text { Year }\end{array}$ & Status \\
\hline$C$ & 622 & 021 & I CHEMICAL SOURCES & | & 8.00 & 5.00 & 52.00 & ACTIVE \\
\hline & 623 & 005 & I CHEMICAL SOURCES & 1 & 4.00 & 5.00 & 52.00 & D\&D \\
\hline & & 007 & I CHEMICAL SOURCES & 1 & 3.00 & 5.00 & 52.00 & ACTIVE \\
\hline & & 017 & I CHEMICAL SOURCES & 1 & 4.00 & 5.00 & 52.00 & ACTIVE \\
\hline & 624 & 009 & I CHEMICAL SOURCES & 1 & .00 & .00 & .00 & INACTIVE \\
\hline & 625 & 009 & I CHEMICAL SOURCES & 1 & 8.00 & 5.00 & 52.00 & ACTIVE \\
\hline & & 010 & I CHEMICAL SOURCES & 1 & 8.00 & 5.00 & 52.00 & ACTIVE \\
\hline & 633 & 001 & I CHEMICAL SOURCES & 1 & .00 & .00 & .00 & INACTIVE \\
\hline & & 003 & I CHEMICAL SOURCES & 1 & .00 & .00 & .00 & INACTIVE \\
\hline & & 008 & I CHEMICAL SOURCES & 1 & .00 & .00 & .00 & INACTIVE \\
\hline & & 009 & I CHEMICAL SOURCES & 1 & .00 & .00 & .00 & INACTIVE \\
\hline & & 011 & I CHEMICAL SOURCES & | & .00 & .00 & .00 & INACTIVE \\
\hline & & 015 & I CHEMICAL SOURCES & 1 & .00 & .00 & .00 & INACTIVE \\
\hline & & 020 & I CHEMICAL SOURCES & 1 & .00 & .00 & .00 & INACTIVE \\
\hline & & 021 & I CHEMICAL SOURCES & 1 & .00 & .00 & .00 & INACTIVE \\
\hline & & 028 & I CHEMICAL SOURCES & 1 & .00 & .00 & .00 & INACTIVE \\
\hline & & 040 & I CHEMICAL SOURCES & 1 & .00 & .00 & .00 & INACTIVE \\
\hline & & 067 & I RAD SOURCE & I & .50 & 1.50 & 52.00 & ACTIVE \\
\hline & & 091 & I FUEL BURNING EQUIPMENT & 1 & 1.00 & 1.00 & 50.00 & ACTIVE \\
\hline & 650 & 007 & I FUEL BURNING EQUIPMENT & 1 & 24.00 & 7.00 & 39.00 & ACTIVE \\
\hline & 662 & 011 & | FUEL BURNING EQUIPMENT & 1 & 24.00 & 7.00 & 20.00 & ACTIVE \\
\hline & & 027 & | FUEL BURNING EQUIPMENT & 1 & 24.00 & 7.00 & 48.00 & ACTIVE \\
\hline & 664 & 034 & | FUEL BURNING EQUIPMENT & | & 4.00 & 5.00 & 52.00 & ACTIVE \\
\hline & & 035 & | FUEL BURNING EQUIPMENT & I & 4.00 & 5.00 & 52.00 & ACTIVE \\
\hline & 665 & 028 & | FUEL BURNING EQUIPMENT & | & .00 & .00 & .00 & INACTIVE \\
\hline & & 029 & | FUEL BURNING EQUIPMENT & 1 & 24.00 & 7.00 & 39.00 & ACTIVE \\
\hline & & 030 & | FUEL BURNING EQUIPMENT & 1 & .00 & .00 & .00 & INACTIVE \\
\hline & & 050 & I CHEMICAL SOURCES & 1 & 6.00 & 5.00 & 52.00 & ACTIVE \\
\hline & 668 & 001 & I STORAGE TANK - VOC & 1 & .00 & .00 & .00 & INACTIVE \\
\hline & & 006 & | FUEL BURNING EQUIPMENT & & .50 & .25 & 52.00 & ACTIVE \\
\hline & & 010 & I STORAGE TANK - VOC & & .00 & .00 & .00 & INACTIVE \\
\hline
\end{tabular}


Update Survey for AIR EMISSIONS INVENTORY PROCESS PARAMETERS - 1993 Page:

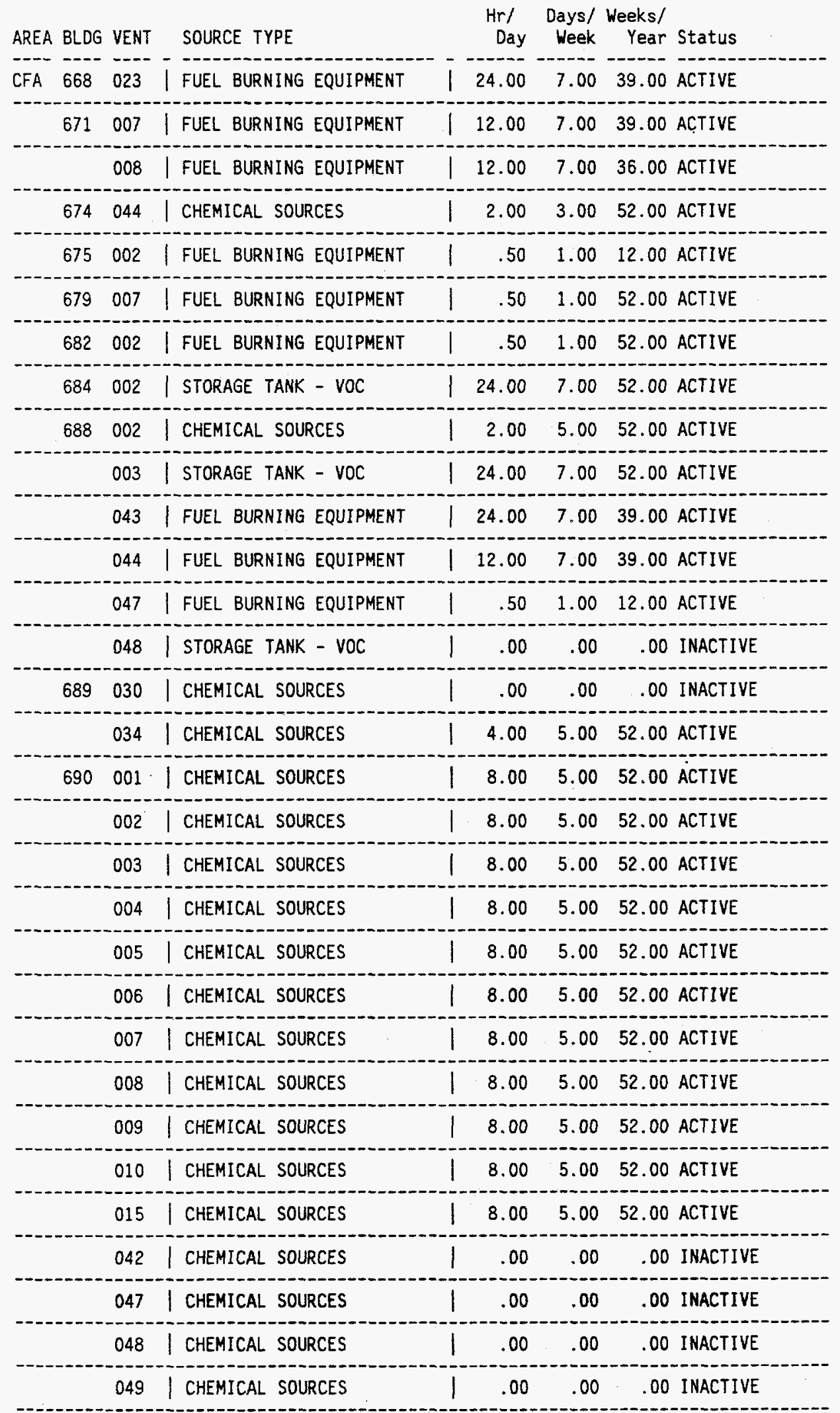


Update Survey for AIR EMISSIONS INVENTORY PROCESS PARAMETERS - 1993 Page: 14

\begin{tabular}{|c|c|c|c|c|c|c|c|}
\hline AREA & BLDG & VENT & SOURCE TYPE & $\begin{array}{l}\mathrm{Hr} / \\
\text { Day }\end{array}$ & $\begin{array}{r}\text { Days/ } \\
\text { Week }\end{array}$ & $\begin{array}{r}\text { Weeks/ } \\
\text { Year }\end{array}$ & Status \\
\hline FA & 690 & 059 & CHEMICAL SOURCES & .00 & .00 & .00 & INACTIVE \\
\hline & 698 & 007 & CHEMICAL SOURCES & 2.00 & 1.00 & 1.00 & ACTIVE \\
\hline & & 013 & CHEMICAL SOURCES & 8.00 & 2.00 & 52.00 & ACTIVE \\
\hline & 708 & 001 & STORAGE TANK - VOC & 24.00 & 7.00 & 52.00 & ACTIVE \\
\hline & 713 & 001 & STORAGE TANK - VOC & 24.00 & 7.00 & 52.00 & ACTIVE \\
\hline & & 002 & STORAGE TANK - VOC & 24.00 & 7.00 & 52.00 & ACTIVE \\
\hline & 721 & 001 & STORAGE TANK - VOC & 24.00 & 7.00 & 52.00 & ACTIVE \\
\hline & 729 & 001 & STORAGE TANK - VOC & 24.00 & 7.00 & 52.00 & ACTIVE \\
\hline & 730 & 001 & STORAGE TANK - VOC & 24.00 & 7.00 & 52.00 & ACTIVE \\
\hline & 731 & 001 & STORAGE TANK - VOC & 24.00 & 7.00 & 52.00 & ACTIVE \\
\hline & 732 & 001 & STORAGE TANK - VOC & 24.00 & 7.00 & 52.00 & ACTIVE \\
\hline & 734 & 001 & STORAGE TANK - VOC & 24.00 & 7.00 & 52.00 & ACTIVE \\
\hline & 735 & 001 & STORAGE TANK - VOC & 24.00 & 7.00 & 52.00 & ACTIVE \\
\hline & 738 & 001 & STORAGE TANK - VOC & 24.00 & 7.00 & 52.00 & ACTIVE \\
\hline & 739 & 001 & STORAGE TANK - VOC & 24.00 & 7.00 & 52.00 & ACTIVE \\
\hline & 741 & 001 & STORAGE TANK - VOC & 24.00 & 7.00 & 52.00 & ACTIVE \\
\hline & & 002 & STORAGE TANK - VOC & 24.00 & 7.00 & 52.00 & ACTIVE \\
\hline & 748 & 001 & STORAGE TANK - VOC & 24.00 & 7.00 & 52.00 & ACTIVE \\
\hline & 749 & 001 & STORAGE TANK - VOC & 24.00 & 7.00 & 52.00 & ACTIVE \\
\hline & 751 & 004 & FUEL BURNING EQUIPMENT & 4.00 & 7.00 & 39.00 & ACTIVE \\
\hline & 754 & 001 & STORAGE TANK - VOC & 24.00 & 7.00 & 52.00 & ACTIVE \\
\hline & & 002 & STORAGE TANK - VOC & 24.00 & 7.00 & 52.00 & ACTIVE \\
\hline & & 003 & STORAGE TANK - VOC & 24.00 & 7.00 & 52.00 & ACTIVE \\
\hline & & 004 & STORAGE TANK - VOC & 24.00 & 7.00 & 52.00 & ACTIVE \\
\hline & & 005 & STORAGE TANK - VOC & 24.00 & 7.00 & 52.00 & ACTIVE \\
\hline & & 006 & STORAGE TANK - VOC & 24.00 & 7.00 & 52.00 & ACTIVE \\
\hline & & 007 & STORAGE TANK - VOC & 24.00 & 7.00 & 52.00 & ACTIVE \\
\hline & 757 & 001 & STORAGE TANK - VOC & 24.00 & 7.00 & 52.00 & ACTIVE \\
\hline & 759 & 001 & STORAGE TANK - VOC & 24.00 & 7.00 & 52.00 & ACTIVE \\
\hline
\end{tabular}


Update Survey for AIR EMISSIONS INVENTORY PROCESS PARAMETERS - 1993 Page: 15

\begin{tabular}{|c|c|c|c|c|c|c|c|}
\hline AREA & BLDG & VENT & SOURCE TYPE & $\begin{array}{c}\mathrm{Hr} / \\
\text { Day }\end{array}$ & $\begin{array}{l}\text { Days/ } \\
\text { Week }\end{array}$ & $\begin{array}{l}\text { Weeks/ } \\
\text { Year }\end{array}$ & Status \\
\hline CPP & 012 & 001 & INORGANIC STORAGE TANKS & 24.00 & 7.00 & 52.00 & ACTIVE \\
\hline & 025 & 001 & FUGITIVE SOURCE & 24.00 & 7.00 & 52.00 & ACTIVE \\
\hline & 1605 & 004 & CHEMICAL SOURCES & 2.00 & 1.00 & 52.00 & ACTIVE \\
\hline & & 018 & CHEMICAL SOURCES & 8.00 & 5.00 & 52.00 & ACTIVE \\
\hline & 1608 & 001 & CHEMICAL SOURCES & 24.00 & 7.00 & 52.00 & ACTIVE \\
\hline & 1611 & 001 & CHEMICAL SOURCES & 24.00 & 7.00 & 26.00 & ACTIVE \\
\hline & 1612 & 001 & CHEMICAL SOURCES & 24.00 & 7.00 & 26.00 & ACTIVE \\
\hline & 1617 & 001 & RADIOLOGICAL & 24.00 & 7.00 & 52.00 & ACTIVE \\
\hline & 1619 & 001 & RADIONUCLIDES & 24.00 & 7.00 & 52.00 & ACTIVE \\
\hline & & 004 & HAZARD WASTE ACCUMULATION & 24.00 & 7.00 & 52.00 & ACTIVE \\
\hline & & 005 & RADIOACTIVITY & .00 & .00 & .00 & ACTIVE \\
\hline & & 006 & RADIOACTIVE/CHEMICAL & .00 & .00 & .00 & ACTIVE \\
\hline & 1642 & 003 & STORAGE TANK - VOC & 24.00 & 7.00 & 52.00 & ACTIVE \\
\hline & & 007 & FUEL BURNING EQUIPMENT & 10.00 & 1.00 & 52.00 & ACTIVE \\
\hline & 1643 & 003 & STORAGE TANK - VOC & 24.00 & 7.00 & 52.00 & ACTIVE \\
\hline & & 007 & FUEL BURNING EQUIPMENT & 10.00 & 1.00 & 52.00 & ACTIVE \\
\hline & 1646 & 001 & CHEMICAL SOURCES & 24.00 & 7.00 & 52.00 & ACTIVE \\
\hline & 1749 & 002 & STORAGE TANK - VOC & 24.00 & 7.00 & 52.00 & ACTIVE \\
\hline & & 004 & FUEL BURNING EQUIPMENT & 23.00 & 1.00 & 52.00 & ACTIVE \\
\hline & 601 & 002 & INORGANIC STORAGE TANKS & 24.00 & 7.00 & 52.00 & ACTIVE \\
\hline & & 008 & CHEMICAL SOURCES & .00 & .00 & .00 & ACTIVE \\
\hline & & 009 & INORGANIC STORAGE TANKS & 24.00 & 7.00 & 52.00 & ACTIVE \\
\hline & & 010 & INORGANIC STORAGE TANKS & 24.00 & 7.00 & 52.00 & ACTIVE \\
\hline & & 011 & CHEMICAL SOURCES & 24.00 & 7.00 & 52.00 & ACTIVE \\
\hline & & 013 & INORGANIC STORAGE TANKS & 24.00 & 7.00 & 52.00 & ACTIVE \\
\hline & & 014 & CHEMICAL SOURCES & 24.00 & 7.00 & 52.00 & ACTIVE \\
\hline & & 016 & STORAGE TANK - VOC & 24.00 & 7.00 & 52.00 & ACTIVE \\
\hline & & 024 & CHEMICAL SOURCES & 24.00 & 7.00 & 52.00 & ACTIVE \\
\hline & 602 & 012 & RADIOLOGICAL & 8.00 & 5.00 & 52.00 & ACTIVE \\
\hline & & 014 & RADIOLOGICAL & 8.00 & 5.00 & 52.00 & ACTIVE \\
\hline & & 031 & CHEMICAL SOURCES & 8.00 & 5.00 & 52.00 & ACTIVE \\
\hline
\end{tabular}


Update Survey for AIR EMISSIONS INVENTORY PROCESS PARAMETERS - 1993 Page: 16

\begin{tabular}{|c|c|c|c|c|c|c|c|}
\hline AREA & BLDG & VENT & SOURCE TYPE & $\begin{array}{l}\mathrm{Hr} / \\
\text { Day }\end{array}$ & $\begin{array}{r}\text { Days/ } \\
\text { Week }\end{array}$ & $\begin{array}{r}\text { Weeks/ } \\
\text { Year }\end{array}$ & Status \\
\hline CPP & 603 & 001 & GRAPHITE FUEL STORAGE & 24.00 & 7.00 & 52.00 & ACTIVE \\
\hline & & 008 & FUEL BURNING EQUIPMENT & 1.00 & 7.00 & 52.00 & ACTIVE \\
\hline & 604 & 011 & INORGANIC STORAGE TANKS & 24.00 & 7.00 & 52.00 & ACTIVE \\
\hline & 606 & 004 & FUEL BURNING EQUIPMENT & 24.00 & 7.00 & 44.00 & ACTIVE \\
\hline & & 005 & FUEL BURNING EQUIPMENT & 24.00 & 7.00 & 44.00 & ACTIVE \\
\hline & & 013 & I CHEMICAL SOURCES & 24.00 & 7.00 & 52.00 & ACTIVE \\
\hline & & 019 & FUEL BURNING EQUIPMENT & 24.00 & 7.00 & 52.00 & ACTIVE \\
\hline & & 038 & | CHEMICAL SOURCES & 2.50 & 1.00 & 16.00 & ACTIVE \\
\hline & 614 & 001 & STORAGE TANK - VOC & 24.00 & 7.00 & 52.00 & ACTIVE \\
\hline & & 002 & FUEL BURNING EQUIPMENT & 10.00 & 1.00 & 30.00 & ACTIVE \\
\hline & 615 & 005 & AREA SOURCE & 24.00 & 7.00 & 52.00 & ACTIVE \\
\hline & 616 & 004 & FUEL BURNING EQUIPMENT & 10.00 & 1.00 & 30.00 & ACTIVE \\
\hline & & 007 & STORAGE TANK - VOC & 24.00 & 7.00 & 52.00 & ACTIVE \\
\hline & 620 & 001 & CHEMICAL SOURCES & 24.00 & 7.00 & 52.00 & ACTIVE \\
\hline & & 002 & STORAGE TANK - VOC & 24.00 & 7.00 & 52.00 & ACTIVE \\
\hline & & 004 & PILOT PLANT & 8.00 & 5.00 & 24.00 & ACTIVE \\
\hline & & 005 & PILOT PLANT & 24.00 & 7.00 & 52.00 & ACTIVE \\
\hline & & 006 & PILOT PLANT & 8.00 & 5.00 & 52.00 & ACTIVE \\
\hline & & 009 & BUILDING EXHAUST & 24.00 & 7.00 & 52.00 & ACTIVE \\
\hline & 621 & 003 & CHEMICAL SOURCES & 1.00 & 1.00 & 33.00 & ACTIVE \\
\hline & 627 & 007 & CHEMICAL SOURCES & 24.00 & 7.00 & 52.00 & ACTIVE \\
\hline & & 008 & CHEMICAL SOURCES & 24.00 & 7.00 & 52.00 & ACTIVE \\
\hline & & 010 & CHEMICAL SOURCES & 24.00 & 7.00 & 52.00 & ACTIVE \\
\hline & & 013 & CHEMICAL SOURCES & 24.00 & 7.00 & 52.00 & ACTIVE \\
\hline & & 016 & I RADIONUCLIDES & 24.00 & 7.00 & 52.00 & ACTIVE \\
\hline & 630 & 011 & CHEMICAL SOURCES & .00 & .00 & .00 & ACTIVE \\
\hline & & 012 & CHEMICAL SOURCES & .00 & .00 & .00 & ACTIVE \\
\hline & 633 & 021 & INORGANIC STORAGE TANKS & 24.00 & 7.00 & 52.00 & ACTIVE \\
\hline & 637 & 010 & I CHEMICAL SOURCES & 16.00 & 5.00 & 52.00 & ACTIVE \\
\hline & & 021 & I WORKBENCH EXHAUST & 16.00 & 5.00 & 52.00 & ACTIVE \\
\hline & & 032 & PILOT PLANT & 8.00 & 5.00 & 24.00 & ACTIVE \\
\hline
\end{tabular}


Update Survey for AIR EMISSIONS INVENTORY PROCESS PARAMETERS - 1993 Page:

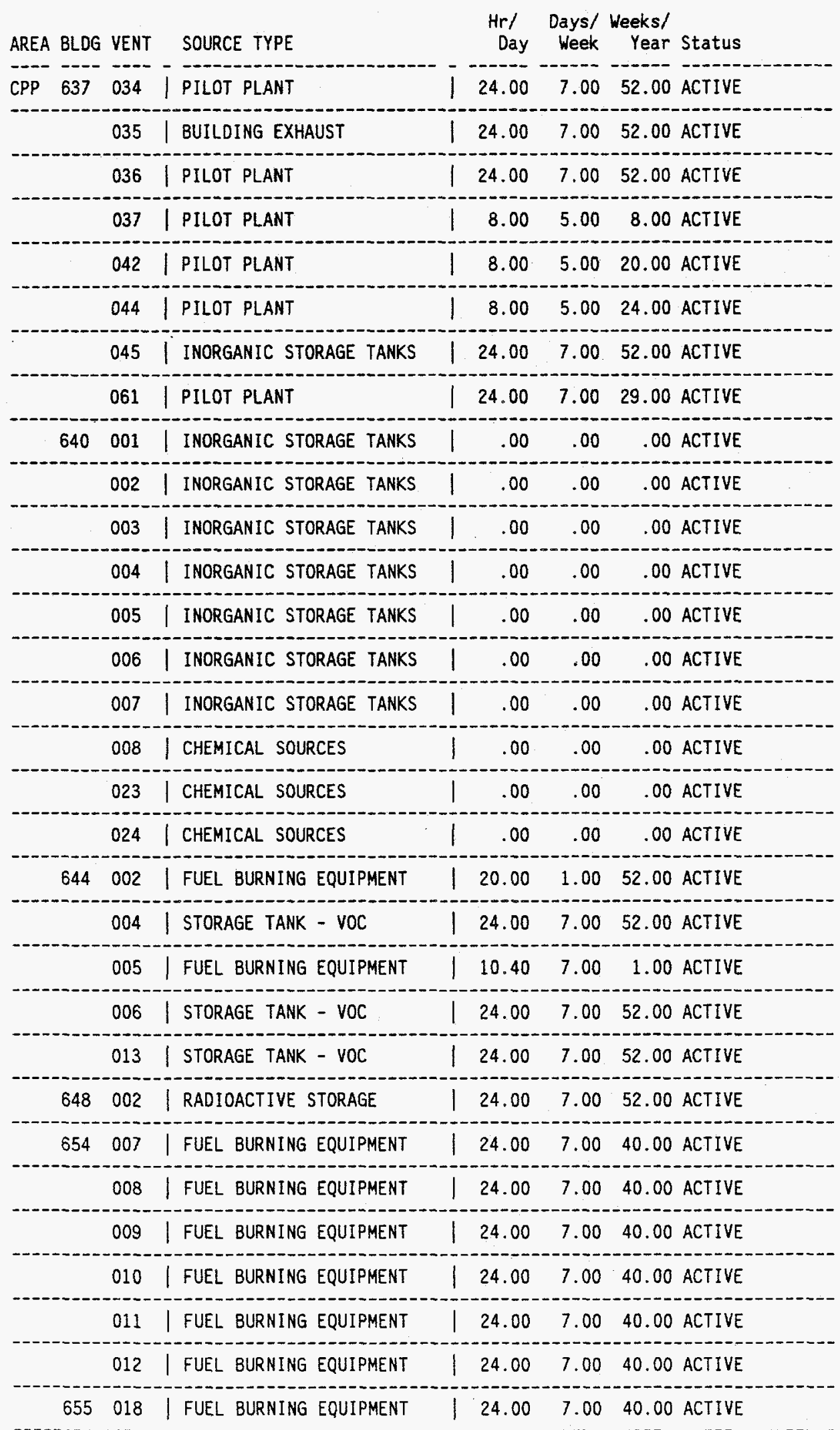


Update Survey for AIR EMISSIONS INVENTORY PROCESS PARAMETERS - 1993 Page: 18

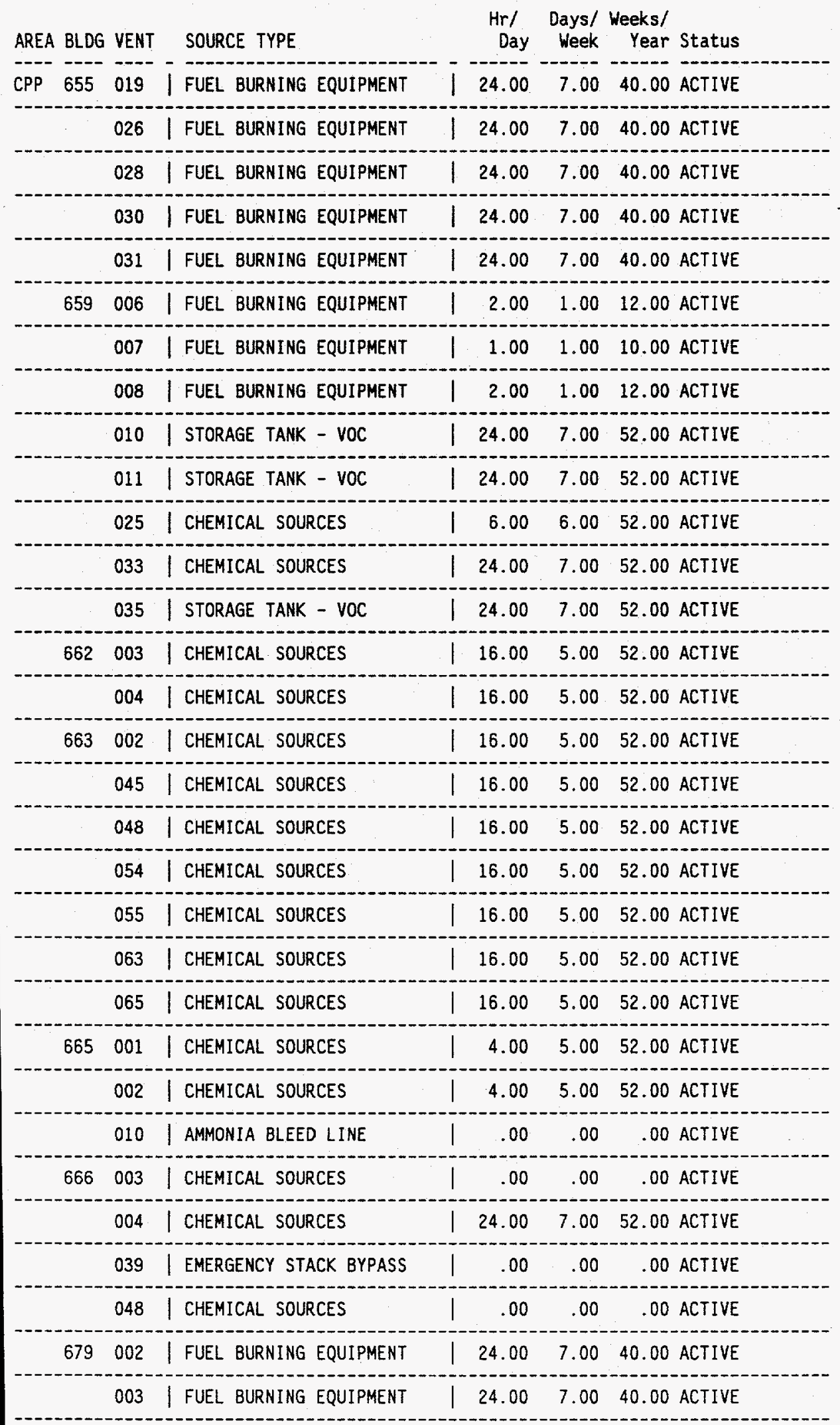


Update Survey for AIR EMISSIONS INVENTORY PROCESS PARAMETERS - 1993 Page:

\begin{tabular}{|c|c|c|c|c|c|c|c|}
\hline AREA & BLDG & VENT & SOURCE TYPE & $\begin{array}{c}\mathrm{Hr} / \\
\text { Day }\end{array}$ & $\begin{array}{l}\text { Days/ } \\
\text { Week }\end{array}$ & $\begin{array}{l}\text { Weeks/ } \\
\text { Year }\end{array}$ & Status \\
\hline$P P$ & 684 & 001 & CHEMICAL SOURCES & 24.00 & 7.00 & 52.00 & ACTIVE \\
\hline & & 002 & CHEMICAL SOURCES & 24.00 & 7.00 & 52.00 & ACTIVE \\
\hline & 687 & 010 & COAL BIN FILTERED VENT & 24.00 & 7.00 & 52.00 & ACTIVE \\
\hline & & 011 & COAL BIN FILTERED VENT & 24.00 & 7.00 & 52.00 & ACTIVE \\
\hline & & 026 & FUEL BURNING EQUIPMENT & 20.00 & 1.00 & 52.00 & ACTIVE \\
\hline & & 033 & FILTERED LIMESTONE BIN & 24.00 & 7.00 & 52.00 & ACTIVE \\
\hline & & 034 & FILTERED LIMESTONE BIN & 24.00 & 7.00 & 52.00 & ACTIVE \\
\hline & & 044 & CHEMICAL SOURCES & 24.00 & 7.00 & 52.00 & ACTIVE \\
\hline & & 049 & FUEL BURNING EQUIPMENT & .25 & 1.00 & 52.00 & ACTIVE \\
\hline & 694 & 007 & RADIOACTIVITY/VOC & 24.00 & 7.00 & 52.00 & ACTIVE \\
\hline & & 008 & RADIOACTIVITY/VOC & 24.00 & 7.00 & 52.00 & ACTIVE \\
\hline & & 009 & ROOM EXHAUST & 24.00 & 7.00 & 52.00 & ACTIVE \\
\hline & & 010 & RADIOACTIVITY/VOC & 24.00 & 7.00 & 52.00 & ACTIVE \\
\hline & 698 & 004 & CHEMICAL SOURCES & 16.00 & 5.00 & 52.00 & ACTIVE \\
\hline & & 006 & CHEMICAL SOURCES & 16.00 & 5.00 & 52.00 & ACTIVE \\
\hline & & 009 & FUEL BURNING EQUIPMENT & 24.00 & 7.00 & 52.00 & ACTIVE \\
\hline & & 010 & FUEL BURNING EQUIPMENT & 24.00 & 7.00 & 52.00 & ACTIVE \\
\hline & & 016 & FUEL BURNING EQUIPMENT & 24.00 & 7.00 & 52.00 & ACTIVE \\
\hline & & 017 & FUEL BURNING EQUIPMENT & 24.00 & 7.00 & 52.00 & ACTIVE \\
\hline & & 018 & FUEL BURNING EQUIPMENT & 24.00 & 7.00 & 52.00 & ACTIVE \\
\hline & $701 \mathrm{~A}$ & 001 & STORAGE TANK - VOC & 24.00 & 7.00 & 52.00 & ACTIVE \\
\hline & $701 \mathrm{~B}$ & 001 & STORAGE TANK - VOC & 24.00 & 7.00 & 52.00 & ACTIVE \\
\hline & $702 \mathrm{~A}$ & 001 & STORAGE TANK - VOC & 24.00 & 7.00 & 52.00 & ACTIVE \\
\hline & $702 B$ & 001 & STORAGE TANK - VOC & 24.00 & 7.00 & 52.00 & ACTIVE \\
\hline & 703 & 001 & STORAGE TANK - VOC & 24.00 & 7.00 & 52.00 & ACTIVE \\
\hline & & 002 & STORAGE TANK - VOC & 24.00 & 7.00 & 52.00 & ACTIVE \\
\hline & 708 & 001 & MAIN STACK & 24.00 & 7.00 & 52.00 & ACTIVE \\
\hline & 716 & 003 & CHEMICAL SOURCES & 24.00 & 7.00 & 52.00 & ACTIVE \\
\hline & $719 \mathrm{~A}$ & 001 & INORGANIC STORAGE TANKS & 24.00 & 7.00 & 52.00 & ACTIVE \\
\hline & $719 B$ & 001 & INORGANIC STORAGE TANKS & 24.00 & 7.00 & 52.00 & ACTIVE \\
\hline & $720 \mathrm{~A}$ & 001 & INORGANIC STORAGE TANKS & 24.00 & 7.00 & 52.00 & ACTIVE \\
\hline
\end{tabular}


Update Survey for AIR EMISSIONS INVENTORY PROCESS PARAMETERS - 1993 Page: 20

\begin{tabular}{|c|c|c|c|c|c|c|}
\hline AREA BLDG & VENT & SOURCE TYPE & $\begin{array}{l}\text { Hr/ } \\
\text { Day }\end{array}$ & $\begin{array}{r}\text { Days/ } \\
\text { Week }\end{array}$ & $\begin{array}{l}\text { Weeks/ } \\
\text { Year }\end{array}$ & Status \\
\hline $720 B$ & 001 & | INORGANIC STORAGE TANKS & 1. 24.00 & 7.00 & 52.00 & ACTIVE \\
\hline $720 \mathrm{C}$ & 001 & I INORGANIC STORAGE TANKS & 1. 24.00 & 7.00 & 52.00 & ACTIVE \\
\hline 727 & 002 & I INORGANIC STORAGE TANKS & 124.00 & 7.00 & 52.00 & ACTIVE \\
\hline & 003 & I INORGANIC STORAGE TANKS & 124.00 & 7.00 & 52.00 & ACTIVE \\
\hline 732 & 001 & I RADIONUCLIDE & 1. 24.00 & 7.00 & 52.00 & ACTIVE \\
\hline 742 & 001 & I RADIONUCLIDE & 124.00 & 7.00 & 52.00 & ACTIVE \\
\hline 746 & 001 & | RADIONUCLIDE & 124.00 & 7.00 & 52.00 & ACTIVE \\
\hline 749 & 001 & I CHEMICAL SOURCES & .00 & .00 & .00 & ACTIVE \\
\hline & 005 & I CHEMICAL SOURCES & .00 & .00 & .00 & ACTIVE \\
\hline 757 & 001 & I INORGANIC STORAGE TANKS & 124.00 & 7.00 & 52.00 & ACTIVE \\
\hline 760 & 002 & I RAD & 124.00 & 7.00 & 52.00 & ACTIVE \\
\hline 764 & 002 & I RADIONUCLIDE & 18.00 & 7.00 & 52.00 & ACTIVE \\
\hline 765 & 003 & I CALCINE STORAGE BIN & 124.00 & 7.00 & 52.00 & ACTIVE \\
\hline 767 & 001 & I MAIN STACK & 124.00 & 7.00 & 52.00 & ACTIVE \\
\hline 775 & 005 & I STORAGE TANK - VOC & 124.00 & 7.00 & 52.00 & ACTIVE \\
\hline 787 & 001 & | FUEL BURNING EQUIPMENT & | 24.00 & 7.00 & 52.00 & ACTIVE \\
\hline 791 & 004 & I RAD & 1. 24.00 & 7.00 & 52.00 & ACTIVE \\
\hline & 005 & I RAD & 124.00 & 7.00 & 52.00 & ACTIVE \\
\hline & 006 & I RAD & | 24.00 & 7.00 & 52.00 & ACTIVE \\
\hline 792 & 001 & | ASH SILO FILTERED EXHAUST & 124.00 & 7.00 & 52.00 & ACTIVE \\
\hline & 002 & | CHEMICAL SOURCES & 1.2 .00 & 7.00 & 52.00 & ACTIVE \\
\hline & 003 & | CHEMICAL SOURCES & 2.00 & 7.00 & 52.00 & ACTIVE \\
\hline 793 & 002 & I LIMESTONE SILO FILTER EX & 124.00 & 7.00 & 52.00 & ACTIVE \\
\hline 794 & 001 & I DUST COLLECTOR FLTERED EX & 24.00 & 7.00 & 52.00 & ACTIVE \\
\hline 795 & 004 & I CALCINE STORAGE BIN & 24.00 & 7.00 & 52.00 & ACTIVE \\
\hline & 005 & I CALCINE STORAGE BINS & 124.00 & 7.00 & 52.00 & ACTIVE \\
\hline & 006 & I CALCINE STORAGE BIN & 124.00 & 7.00 & 52.00 & ACTIVE \\
\hline 798 & 001 & I INORGANIC STORAGE TANKS & .00 & .00 & .00 & ACTIVE \\
\hline$T-1$ & 001 & | FUEL BURNING EQUIPMENT & 124.00 & 7.00 & 40.00 & ACTIVE \\
\hline & 007 & I FUEL BURNING EQUIPMENT & 24.00 & 7.00 & 40.00 & ACTIVE \\
\hline$T-5$ & 001 & I FUEL BURNING EQUIPMENT & 24.00 & 7.00 & 40.00 & ACTIVE \\
\hline
\end{tabular}


Update Survey for AIR EMISSIONS INVENTORY PROCESS PARAMETERS - 1993 Page: 21

AREA BLDG VENT SOURCE TYPE

$\mathrm{Hr} /$ Days/ Weeks/

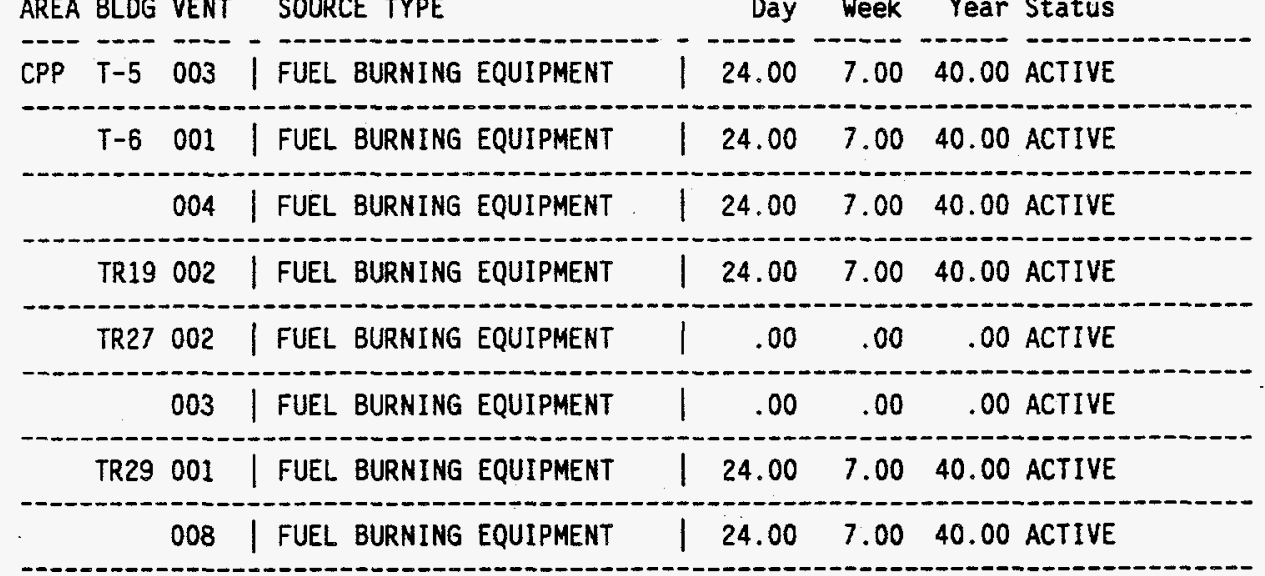


Update Survey for AIR EMISSIONS INVENTORY PROCESS PARAMETERS - 1993 Page: 22

Hr/ Days/Weeks/

AREA BLDG VENT SOURCE TYPE

Day Week Year Status

HPTF 601001 | FUEL BURNING EQUIPMENT | .50 $1.00 \quad 52.00$ ACTIVE 
Update Survey for AIR EMISSIONS INVENTORY PROCESS PARAMETERS - 1993 Page: 23

\begin{tabular}{|c|c|c|c|c|c|c|c|}
\hline AREA & BLDG & VENT & SOURCE TYPE & $\begin{array}{c}\mathrm{Hr} / \\
\text { Day }\end{array}$ & $\begin{array}{r}\text { Days/ } \\
\text { Week }\end{array}$ & $\begin{array}{r}\text { Weeks/ } \\
\text { Year }\end{array}$ & Status \\
\hline INE & 100 & 001 & PAVED ROADS & 15.00 & 7.00 & 52.00 & ACTIVE \\
\hline & 101 & 001 & UNPAVED ROADS & 124.00 & 7.00 & 52.00 & ACTIVE \\
\hline
\end{tabular}


Update Survey for AIR EMISSIONS INVENTORY PROCESS PARAMETERS - 1993 Page: 24

\begin{tabular}{|c|c|c|c|c|c|}
\hline AREA BLDG & VENT & SOURCE TYPE & $\begin{array}{l}\mathrm{Hr} / \\
\text { Day }\end{array}$ & $\begin{array}{l}\text { Days/ } \\
\text { Week }\end{array}$ & $\begin{array}{l}\text { Weeks/ } \\
\text { Year Status }\end{array}$ \\
\hline RF 601 & 023 & I REACTOR COMPARTMENT EXHST & 1.00 & 1.00 & $1.00 \mathrm{ACTIVE}$ \\
\hline & 036 & I CHEMICAL SOURCES & 6.00 & 2.00 & 25.00 ACTIVE \\
\hline $601 \mathrm{~A}$ & 019 & I CHEMICAL SOURCES & 124.00 & 7.00 & 52.00 ACTIVE \\
\hline $601 C$ & 019 & I CHEMICAL SOURCES & | 24.00 & 7.00 & 52.00 ACTIVE \\
\hline $601 \mathrm{~F}$ & 019 & I CHEMICAL SOURCES & | 24.00 & 7.00 & 52.00 ACTIVE \\
\hline 602 & 005 & | FUEL BURNING EQUIPMENT & 2.00 & 1.00 & 52.00 ACTIVE \\
\hline & 006 & I CHEMICAL SOURCES & 2.00 & 5.00 & 52.00 ACTIVE \\
\hline & 008 & I OTHER CHEMICAL SOURCE & 4.00 & 1.00 & 52.00 ACTIVE \\
\hline & 023 & I FAB. PROCESS - DUST & 1.00 & 1.00 & 52.00 ACTIVE \\
\hline & 037 & I CHEMICAL SOURCES & 1.00 & 1.00 & 40.00 ACTIVE \\
\hline & 044 & I STORAGE TANK - VOC & 24.00 & 7.00 & 52.00 ACTIVE \\
\hline 603 & 031 & I CHEMICAL SOURCES & 8.00 & 5.00 & 52.00 ACTIVE \\
\hline 616 & 012 & | CHEMICAL SOURCES & 1.00 & 5.00 & 52.00 ACTIVE \\
\hline & 039 & | CHEMICAL SOURCES & 1 24.00 & 7.00 & 52.00 ACTIVE \\
\hline $616 \mathrm{~A}$ & 002 & I CHEMICAL SOURCES & 4.00 & 1.00 & 1.00 ACTIVE \\
\hline 6168 & 006 & I CHEMICAL SOURCES & .00 & .00 & .00 ACTIVE \\
\hline 617 & 013 & | CHEMICAL SOURCES & 124.00 & 7.00 & 52.00 ACTIVE \\
\hline & 020 & I CHEMICAL SOURCES & 124.00 & 7.00 & 52.00 ACTIVE \\
\hline $617 C$ & 001 & I FUEL BURNING EQUIPMENT & 3.00 & 1.00 & 50.00 ACTIVE \\
\hline & 002 & I FUEL BURNING EQUIPMENT & 7.00 & 1.00 & 50.00 ACTIVE \\
\hline & 003 & I STORAGE TANK - VOC & 124.00 & 7.00 & 52.00 ACTIVE \\
\hline 618 & 024 & I CHEMICAL SOURCES & .00 & .00 & .00 INACTIVE \\
\hline & 025 & I CHEMICAL SOURCES & 5.00 & 5.00 & 52.00 ACTIVE \\
\hline & 026 & I CHEMICAL SOURCES & 5.00 & 5.00 & 52.00 ACTIVE \\
\hline & 027 & I CHEMICAL SOURCES & 5.00 & 5.00 & 52.00 ACTIVE \\
\hline & 028 & I CHEMICAL SOURCES & 5.00 & 5.00 & 52.00 ACTIVE \\
\hline & 029 & I CHEMICAL SOURCES & 5.00 & 5.00 & 52.00 ACTIVE \\
\hline & 032 & I CHEMICAL SOURCES & .00 & .00 & .00 INACTIVE \\
\hline & 033 & I CHEMICAL SOURCES & 5.00 & 5.00 & 52.00 ACTIVE \\
\hline & 034 & I CHEMICAL SOURCES & 5.00 & 5.00 & 52.00 ACTIVE \\
\hline & 035 & I CHEMICAL SOURCES & 5.00 & 5.00 & 52.00 ACTIVE \\
\hline
\end{tabular}


Update Survey for AIR EMISSIONS INVENTORY PROCESS PARAMETERS - 1993 Page: 25

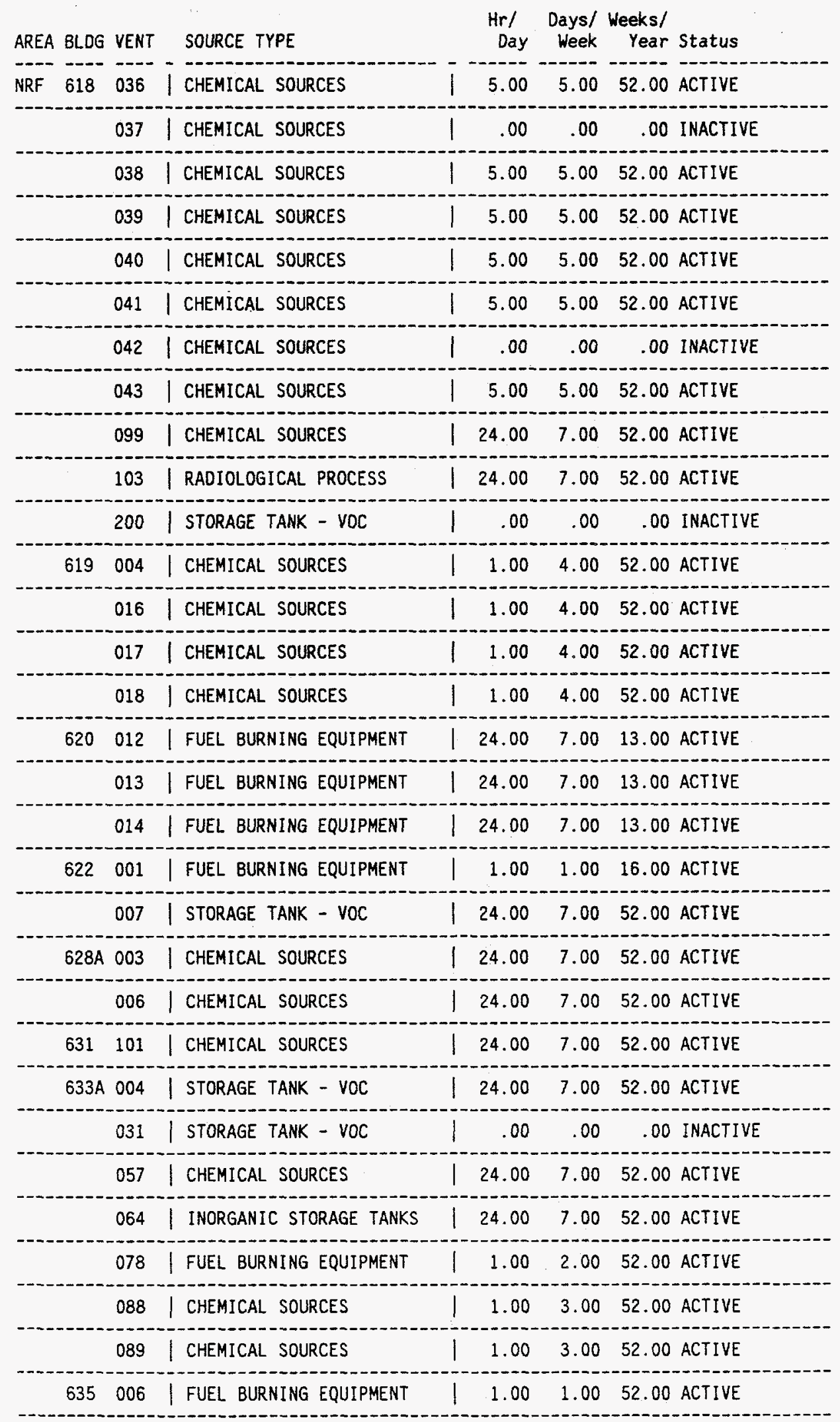


Update Survey for AIR EMISSIONS INVENTORY PROCESS PARAMETERS - 1993 Page: 26

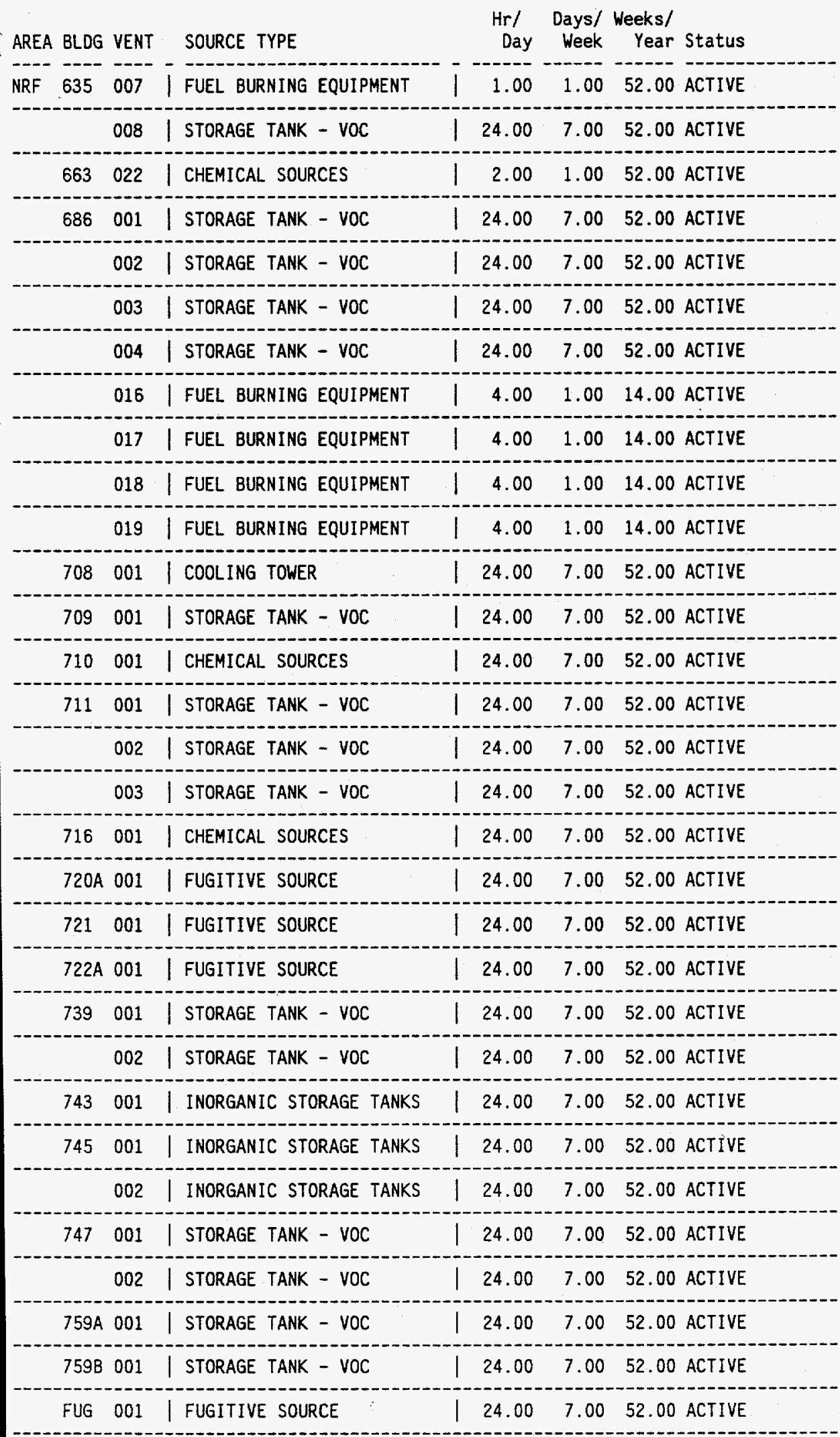


Update Survey for AIR EMISSIONS INVENTORY PROCESS PARAMETERS - 1993 Page: 27

\begin{tabular}{|c|c|c|c|c|c|c|c|}
\hline AREA & BLDG VENT & SOURCE TYPE & & $\begin{array}{c}\mathrm{Hr} / \\
\text { Day }\end{array}$ & $\begin{array}{c}\text { Days / } \\
\text { Week }\end{array}$ & $\begin{array}{l}\text { Weeks/ } \\
\text { Year }\end{array}$ & Status \\
\hline NRF & FUG 002 & FUGITIVE SOURCE & 1 & 24.00 & 7.00 & 52.00 & ACTIVE \\
\hline & 003 & FUGITIVE SOURCE & I & 24.00 & 7.00 & 52.00 & ACTIVE \\
\hline & 004 & FUGITIVE SOURCE & 1 & 24.00 & 7.00 & 52.00 & ACTIVE \\
\hline
\end{tabular}


Update Survey for AIR EMISSIONS INVENTORY PROCESS PARAMETERS - 1993 Page: 28

\begin{tabular}{|c|c|c|c|c|c|c|c|}
\hline AREA & BLDG & VENT & SOURCE TYPE & $\begin{array}{l}\mathrm{Hr} / \\
\text { Day }\end{array}$ & $\begin{array}{r}\text { Days/ } \\
\text { Week }\end{array}$ & $\begin{array}{r}\text { Weeks/ } \\
\text { Year }\end{array}$ & Status \\
\hline & --- & --- & 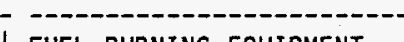 & ---- & $-2--2$ & $--\infty$ & --- \\
\hline PER & 601 & 010 & FUEL BURNING EQUIPMENT & 6.00 & 7.00 & 26.00 & ACTIVE \\
\hline & $601 A$ & 010 & FUEL BURNING EQUIPMENT & 6.00 & 7.00 & 26.00 & ACTIVE \\
\hline & 609 & 006 & FUEL BURNING EQUIPMENT & .50 & 1.00 & 52.00 & ACTIVE \\
\hline & & 010 & STORAGE TANK - VOC & 24.00 & 7.00 & 52.00 & ACTIVE \\
\hline & 612 & 006 & FUEL BURNING EQUIPMENT & 6.00 & 7.00 & 26.00 & ACTIVE \\
\hline & 613 & 009 & FUEL BURNING EQUIPMENT & 6.00 & 7.00 & 26.00 & ACTIVE \\
\hline & 619 & 015 & FUEL BURNING EQUIPMENT & 24.00 & 7.00 & 36.00 & ACTIVE \\
\hline & & 016 & I FUEL BURNING EQUIPMENT & 24.00 & 7.00 & 36.00 & ACTIVE \\
\hline & 620 & 001 & INORGANIC STORAGE TANKS & 24.00 & 7.00 & 52.00 & ACTIVE \\
\hline & & 002 & CHEMICAL SOURCES & & & & ACTIVE \\
\hline & & 016 & RAD SOURCE & 24.00 & 7.00 & 52.00 & ACTIVE \\
\hline & & 023 & FUEL BURNING EQUIPMENT & 24.00 & 7.00 & 36.00 & ACTIVE \\
\hline & & 041 & RAD SOURCE & 24.00 & 7.00 & 52.00 & ACTIVE \\
\hline & 621 & 001 & FUEL BURNING EQUIPMENT & .50 & 1.00 & 52.00 & ACTIVE \\
\hline & & 005 & FUEL BURNING EQUIPMENT & .00 & .00 & .00 & INACTIVE \\
\hline & 622 & 003 & RAD PROCESS & .00 & .00 & .00 & INACTIVE \\
\hline & 624 & 005 & INORGANIC STORAGE TANKS & 24.00 & 7.00 & 52.00 & ACTIVE \\
\hline & 625 & 001 & FUEL BURNING EQUIPMENT & .00 & .00 & .00 & INACTIVE \\
\hline & & 002 & STORAGE TANK - VOC & .00 & .00 & .00 & INACTIVE \\
\hline & & 004 & STORAGE TANK - VOC & .00 & .00 & .00 & INACTIVE \\
\hline & 626 & 004 & FUEL BURNING EQUIPMENT & .50 & 1.00 & 52.00 & ACTIVE \\
\hline & & 005 & STORAGE TANK - VOC & 24.00 & 7.00 & 52.00 & ACTIVE \\
\hline & 632 & 007 & | FUEL BURNING EQUIPMENT & 6.00 & 7.00 & 26.00 & ACTIVE \\
\hline & & 008 & | FUEL BURNING EQUIPMENT & 6.00 & 7.00 & 26.00 & ACTIVE \\
\hline & 705 & 001 & STORAGE TANK - VOC & 24.00 & 7.00 & 52.00 & ACTIVE \\
\hline & 711 & 001 & STORAGE TANK - VOC & 24.00 & 7.00 & 52.00 & ACTIVE \\
\hline & 716 & 001 & STORAGE TANK - VOC & 24.00 & 7.00 & 52.00 & ACTIVE \\
\hline & 722 & 001 & STORAGE TANK - VOC & 24.00 & 7.00 & 52.00 & ACTIVE \\
\hline & 730 & 001 & RAD SOURCE & 1.24 .00 & 7.00 & 52.00 & ACTIVE \\
\hline & 731 & 002 & I RAD SOURCE & 124.00 & 7.00 & 52.00 & ACTIVE \\
\hline & 733 & 001 & I RAD SOURCE & 24.00 & 7.00 & 52.00 & ACTIVE \\
\hline
\end{tabular}


Update Survey for AIR EMISSIONS INVENTORY PROCESS PARAMETERS - 1993 Page: 29

\begin{tabular}{|c|c|c|c|c|c|c|c|}
\hline AREA & BLDG & VENT & SOURCE TYPE & $\begin{array}{l}\mathrm{Hr} / \\
\text { Day }\end{array}$ & $\begin{array}{l}\text { Days/ } \\
\text { Week }\end{array}$ & $\begin{array}{l}\text { Weeks/ } \\
\text { Year }\end{array}$ & Status \\
\hline$E R$ & 737 & 001 & STORAGE TANK - VOC & 24.00 & 7.00 & 52.00 & ACTIVE \\
\hline & 740 & 001 & STORAGE TANK - VOC & 24.00 & 7.00 & 52.00 & ACTIVE \\
\hline & 742 & 001 & STORAGE TANK - VOC & 24.00 & 7.00 & 52.00 & ACTIVE \\
\hline & 743 & 001 & STORAGE TANK - VOC & 24.00 & 7.00 & 52.00 & ACTIVE \\
\hline & 749 & 001 & STORAGE TANK - VOC & .00 & .00 & .00 & INACTIVE \\
\hline & 752 & 001 & STORAGE TANK - VOC & 24.00 & 7.00 & 52.00 & ACTIVE \\
\hline & 755 & 001 & CHEMICAL SOURCES & & & & ACTIVE \\
\hline & 756 & 001 & RADIOLOGICAL PROCESS & .00 & .00 & .00 & ACTIVE \\
\hline & 765 & 001 & CHEMICAL SOURCES & .00 & .00 & .00 & ACTIVE \\
\hline
\end{tabular}


Update Survey for AIR EMISSIONS INVENTORY PROCESS PARAMETERS - 1993 Page: 30

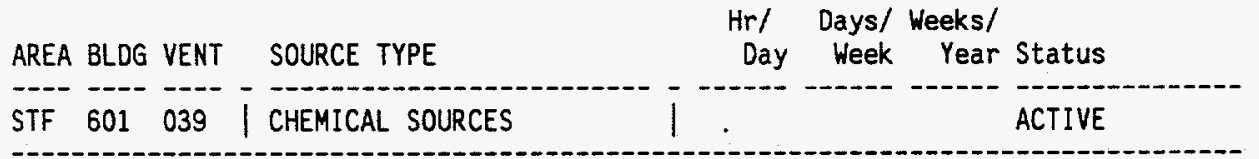


Update Survey for AIR EMISSIONS INVENTORY PROCESS PARAMETERS - 1993 Page: 31

\begin{tabular}{|c|c|c|c|c|c|c|c|}
\hline AREA & BLDG & VENT & SOURCE TYPE & $\begin{array}{l}\mathrm{Hr} / \\
\text { Day }\end{array}$ & $\begin{array}{l}\text { Days/ } \\
\text { Week }\end{array}$ & $\begin{array}{l}\text { Weeks/ } \\
\text { Year }\end{array}$ & Status \\
\hline TAN & 602 & 034 & FUEL BURNING EQUIPMENT & .00 & .00 & .00 & INACTIVE \\
\hline & & 066 & CHEMICAL SOURCES & .00 & .00 & .00 & INACTIVE \\
\hline & 603 & 011 & FUEL BURNING EQUIPMENT & .50 & 1.00 & 52.00 & ACTIVE \\
\hline & & 022 & I FUEL BURNING EQUIPMENT & 2.40 & .70 & 3.00 & ACTIVE \\
\hline & & 027 & FUEL BURNING EQUIPMENT & 24.00 & 7.00 & 32.00 & ACTIVE \\
\hline & & 028 & FUEL BURNING EQUIPMENT & 24.00 & 7.00 & 32.00 & ACTIVE \\
\hline & 604 & 022 & CHEMICAL SOURCES & 2.00 & 1.00 & 52.00 & ACTIVE \\
\hline & & 029 & CHEMICAL SOURCES & 8.00 & 1.00 & 2.00 & ACTIVE \\
\hline & & 031 & I CHEMICAL SOURCES & .50 & 1.00 & 16.00 & ACTIVE \\
\hline & & 035 & I GRINDER FUMEHOOD & .50 & 5.00 & 52.00 & ACTIVE \\
\hline & 606 & 005 & SAWDUST PARTICULATE & 5.00 & 5.00 & 50.00 & ACTIVE \\
\hline & 607 & 013 & I CHEMICAL SOURCES & 2.00 & 1.00 & 2.00 & ACTIVE \\
\hline & & 021 & I FUEL BURNING EQUIPMENT & .50 & 1.00 & 52.00 & $D \& D$ \\
\hline & & 039 & | CHEMICAL SOURCES & 10.00 & 4.00 & 50.00 & ACTIVE \\
\hline & & 041 & I CHEMICAL SOURCES & 6.00 & 4.00 & 50.00 & ACTIVE \\
\hline & & 046 & FUEL BURNING EQUIPMENT & .50 & 1.00 & 52.00 & ACTIVE \\
\hline & & 047 & STORAGE TANK - VOC & 24.00 & 7.00 & 52.00 & ACTIVE \\
\hline & & 049 & I RAD SOURCE ROOM EXHAUS & 24.00 & 7.00 & 52.00 & $D \& D$ \\
\hline & & 059 & I POTENTIAL RAD SOURCE & 24.00 & 7.00 & 52.00 & $D \& D$ \\
\hline & & 066 & I RAD SOURCE & & & & $D \& D$ \\
\hline & & 119 & CHEMICAL SOURCES & 10.00 & 4.00 & 52.00 & ACTIVE \\
\hline & & 136 & I CHEMICAL SOURCES & & & & 080 \\
\hline & 610 & 001 & STORAGE TANK - VOC & 24.00 & 7.00 & 52.00 & ACTIVE \\
\hline & & 002 & I FUEL BURNING EQUIPMENT & .50 & 1.00 & 52.00 & ACTIVE \\
\hline & 629 & 002 & I CHEMICAL SOURCES & 10.00 & 4.00 & 26.00 & ACTIVE \\
\hline & & 012 & I MANUFACTURING PROCESS & 10.00 & 4.00 & 52.00 & ACTIVE \\
\hline & & 013 & I CHEMICAL SOURCES & 24.00 & 7.00 & 52.00 & ACTIVE \\
\hline & & 014 & | MANUFACTURING PROCESS & 10.00 & 4.00 & 52.00 & ACTIVE \\
\hline & 636 & 002 & I CHEMICAL SOURCES & .00 & .00 & .00 & ACTIVE \\
\hline & 640 & 001 & I CHEMICAL SOURCES & .00 & .00 & .00 & INACTIVE \\
\hline & 641 & 022 & | FUEL BURNING EQUIPMENT & .50 & 1.00 & 52.00 & ACTIVE \\
\hline
\end{tabular}


Update Survey for AIR EMISSIONS INVENTORY PROCESS PARAMETERS - 1993 Page: 32

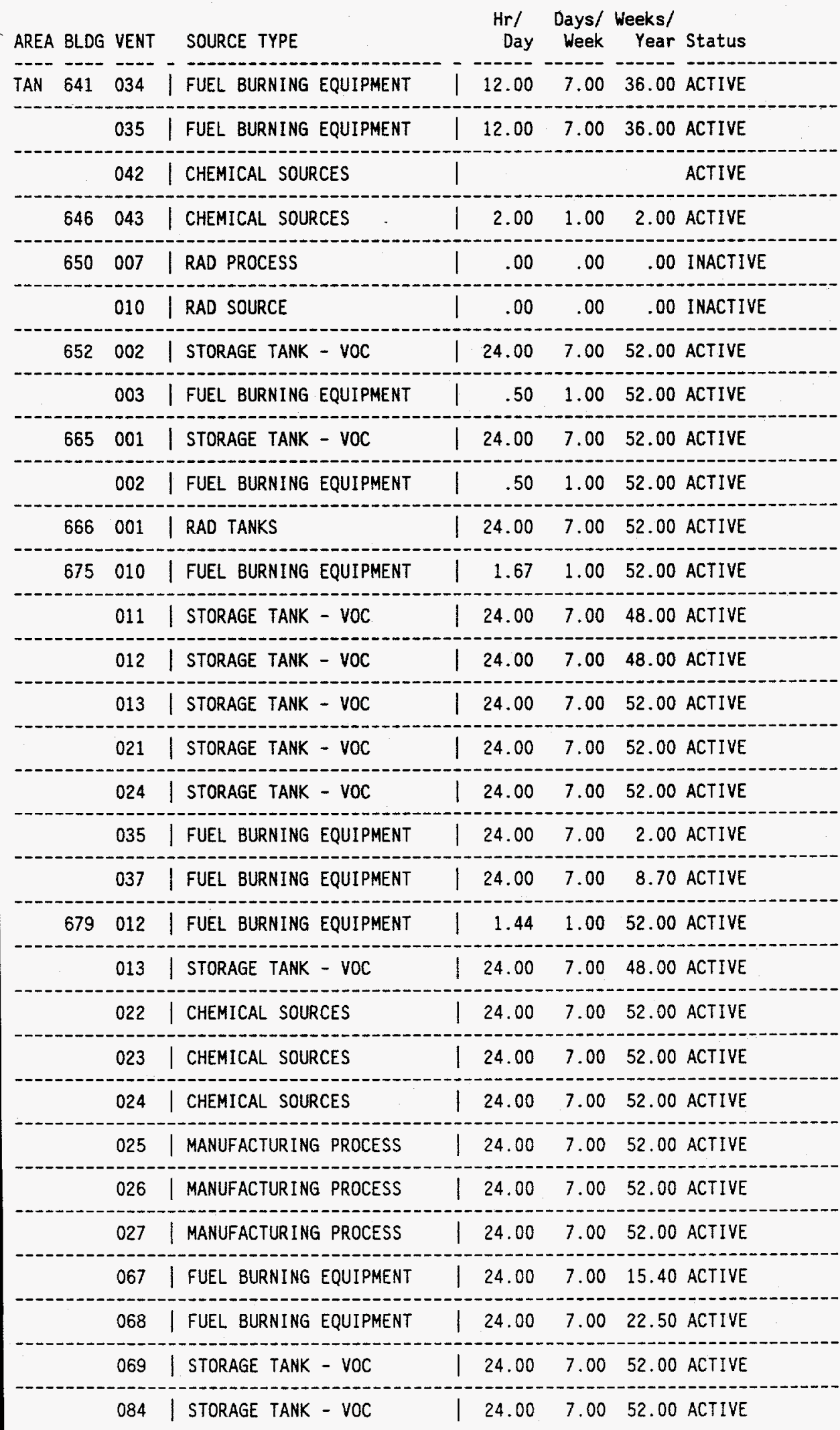


Update Survey for AIR EMISSIONS INVENTORY PROCESS PARAMETERS - 1993 Page: 33

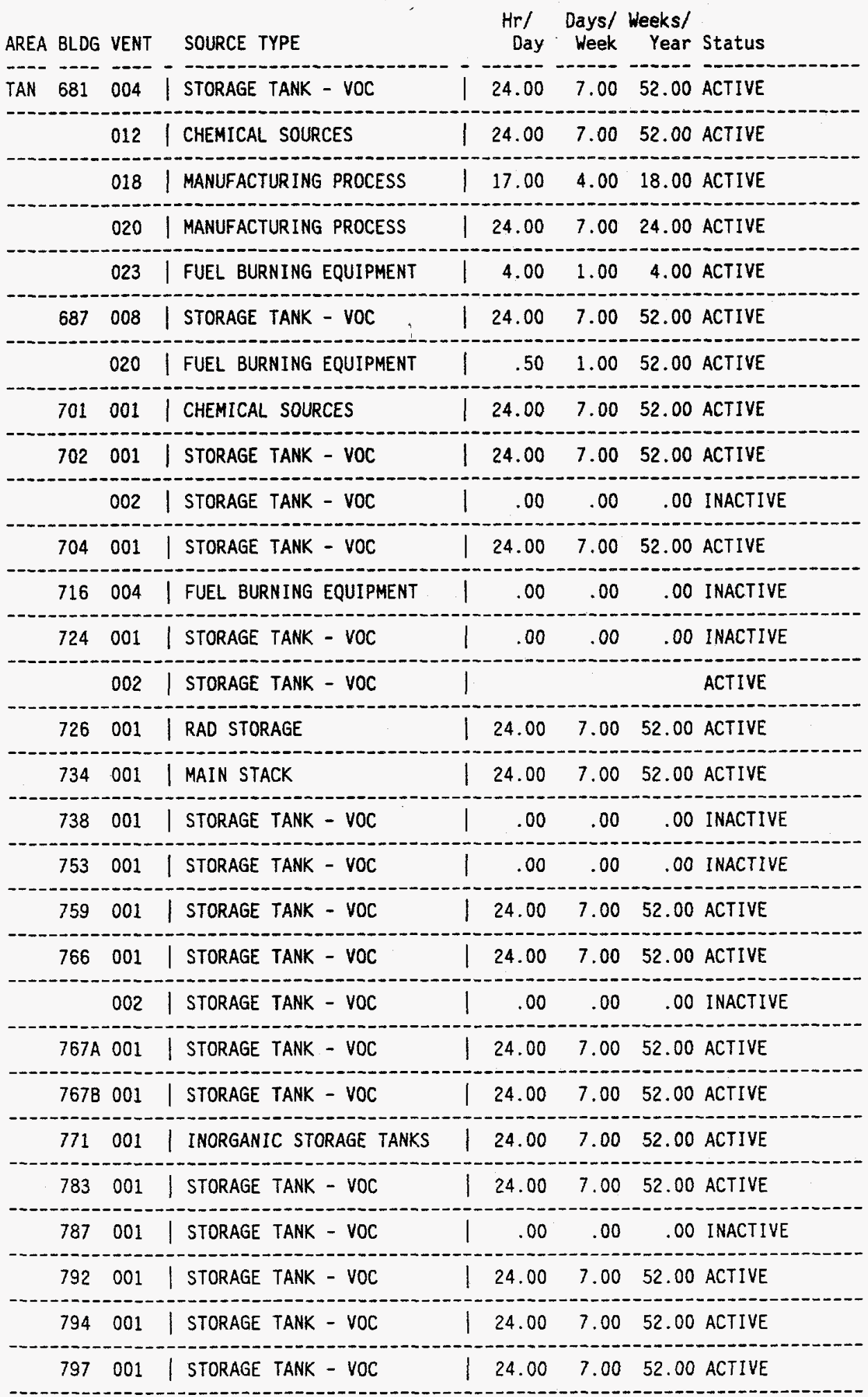


Update Survey for AIR EMISSIONS INVENTORY PROCESS PARAMETERS - 1993 Page: 34

\begin{tabular}{|c|c|c|c|c|c|c|c|}
\hline AREA & BLDG & VENT & SOURCE TYPE & $\underset{\mathrm{Hr} /}{\text { Day }}$ & $\begin{array}{r}\text { Days/ } \\
\text { Week }\end{array}$ & $\begin{array}{r}\text { Weeks/ } \\
\text { Year }\end{array}$ & Status \\
\hline RA & 604 & 027 & CHEMICAL SOURCES & 8.00 & 1.00 & 52.00 & ACTIVE \\
\hline & & 035 & CHEMICAL SOURCES & 24.00 & 7.00 & 52.00 & ACTIVE \\
\hline & & 072 & CHEMICAL SOURCES & 24.00 & 7.00 & 52.00 & ACTIVE \\
\hline & & 073 & CHEMICAL SOURCES & 24.00 & 7.00 & 52.00 & ACTIVE \\
\hline & & 074 & CHEMICAL SOURCES & 24.00 & 7.00 & 52.00 & ACTIVE \\
\hline & & 077 & ORGANIC MATERIAL PREP & 24.00 & 7.00 & 52.00 & ACTIVE \\
\hline & 608 & 005 & INORGANIC STORAGE TANKS & 24.00 & 7.00 & 52.00 & ACTIVE \\
\hline & & 008 & INORGANIC STORAGE TANKS & 24.00 & 7.00 & 52.00 & ACTIVE \\
\hline & & 012 & INORGANIC STORAGE TANKS & .00 & .00 & .00 & INACTIVE \\
\hline & & 013 & INORGANIC STORAGE TANKS & .00 & .00 & .00 & INACTIVE \\
\hline & 614 & 032 & FUMEHOOD & 8.00 & 5.00 & 2.00 & ACTIVE \\
\hline & 619 & 006 & STORAGE TANK - VOC & 24.00 & 7.00 & 52.00 & ACTIVE \\
\hline & & 008 & FUEL BURNING EQUIPMENT & .50 & 1.00 & 52.00 & ACTIVE \\
\hline & & 009 & FUEL BURNING EQUIPMENT & .50 & 1.00 & 52.00 & ACTIVE \\
\hline & 632 & 015 & CHEMICAL SOURCES & 8.00 & 2.00 & 1.00 & ACTIVE \\
\hline & & 019 & CHEMICAL SOURCES & 24.00 & 7.00 & 52.00 & ACTIVE \\
\hline & & 030 & CHEMICAL SOURCES & 24.00 & 7.00 & 52.00 & ACTIVE \\
\hline & & 041 & CHEMICAL SOURCES & 24.00 & 7.00 & 52.00 & ACTIVE \\
\hline & 633 & 002 & STORAGE TANK - VOC & 24.00 & 7.00 & 52.00 & ACTIVE \\
\hline & & 003 & FUEL BURNING EQUIPMENT & 1.00 & 1.00 & 52.00 & ACTIVE \\
\hline & & 004 & FUEL BURNING EQUIPMENT & 1.00 & 1.00 & 52.00 & ACTIVE \\
\hline & 635 & 030 & RADIOLOGICAL & .00 & .00 & .00 & INACTIVE \\
\hline & & 031 & RADIOLOGICAL & .00 & .00 & .00 & INACTIVE \\
\hline & 640 & 004 & STORAGE TANK - VOC & 24.00 & 7.00 & 52.00 & ACTIVE \\
\hline & 653 & 028 & CHEMICAL SOURCES & 8.00 & 2.00 & 52.00 & ACTIVE \\
\hline & & 041 & CHEMICAL SOURCES & 8.00 & 1.00 & 10.00 & ACTIVE \\
\hline & 660 & 004 & HOOD & 8.00 & 1.00 & 52.00 & ACTIVE \\
\hline & 661 & 008 & CHEMICAL SOURCES & 24.00 & 7.00 & 52.00 & ACTIVE \\
\hline & 665 & 001 & TRITIUM TRAP EXHAUST & .00 & .00 & .00 & INACTIVE \\
\hline & 668 & 013 & CHEMICAL SOURCES & 24.00 & 7.00 & 52.00 & ACTIVE \\
\hline & & 015 & CHEMICAL SOURCES & 8.00 & 5.00 & 52.00 & ACTIVE \\
\hline
\end{tabular}


Update Survey for AIR EMISSIONS INVENTORY PROCESS PARAMETERS - 1993 Page: 35

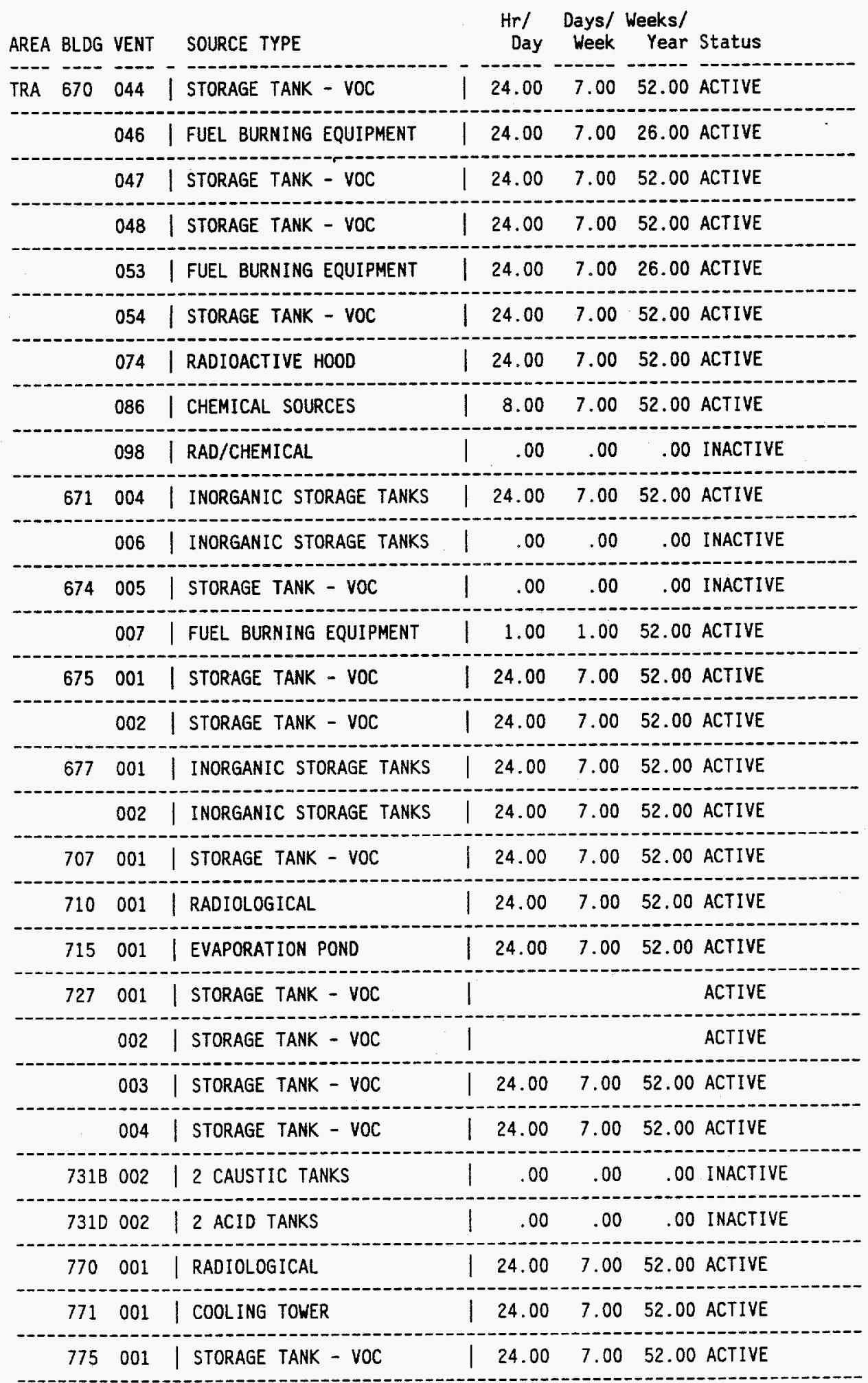


Update Survey for AIR EMISSIONS INVENTORY PROCESS PARAMETERS - 1993 Page: 36

\begin{tabular}{|c|c|c|c|c|c|c|c|}
\hline AREA & BLDG & VENT & SOURCE TYPE & $\begin{array}{l}\mathrm{Hr} / \\
\text { Day }\end{array}$ & $\begin{array}{r}\text { Days/ } \\
\text { Week }\end{array}$ & $\begin{array}{r}\text { Weeks/ } \\
\text { Year }\end{array}$ & Status \\
\hline MF & 601 & 009 & CHEMICAL SOURCES & 24.00 & 7.00 & 52.00 & ACTIVE \\
\hline & 603 & 001 & FUEL BURNING EQUIPMENT & 1.00 & 1.00 & 52.00 & ACTIVE \\
\hline & & 002 & STORAGE TANK - VOC & 24.00 & 7.00 & 52.00 & ACTIVE \\
\hline & & 005 & FUEL BURNING EQUIPMENT & 1.00 & 1.00 & 52.00 & ACTIVE \\
\hline & & 008 & FUEL BURNING EQUIPMENT & & & & ACTIVE \\
\hline & 610 & 003 & FUEL BURNING EQUIPMENT & 1.00 & 1.00 & 52.00 & ACTIVE \\
\hline & & 004 & FUEL BURNING EQUIPMENT & 1.00 & 2.00 & 30.00 & ACTIVE \\
\hline & 612 & 001 & FUEL BURNING EQUIPMENT & 1.00 & 1.00 & 52.00 & ACTIVE \\
\hline & & 004 & FUEL BURNING EQUIPMENT & 1.00 & 2.00 & 30.00 & ACTIVE \\
\hline & 615 & 001 & CHEMICAL SOURCES & .00 & .00 & .00 & ACTIVE \\
\hline & 640 & 001 & VAPOR VACUUM EXTRACTION & .00 & .00 & .00 & ACTIVE \\
\hline & 700 & 002 & CHEMICAL SOURCES & .00 & .00 & .00 & ACTIVE \\
\hline & 711 & 001 & FUEL BURNING EQUIPMENT & 1.00 & 1.00 & 52.00 & ACTIVE \\
\hline & & 004 & FUEL BURNING EQU & 1.00 & 1.00 & 52.00 & ACTIVE \\
\hline
\end{tabular}




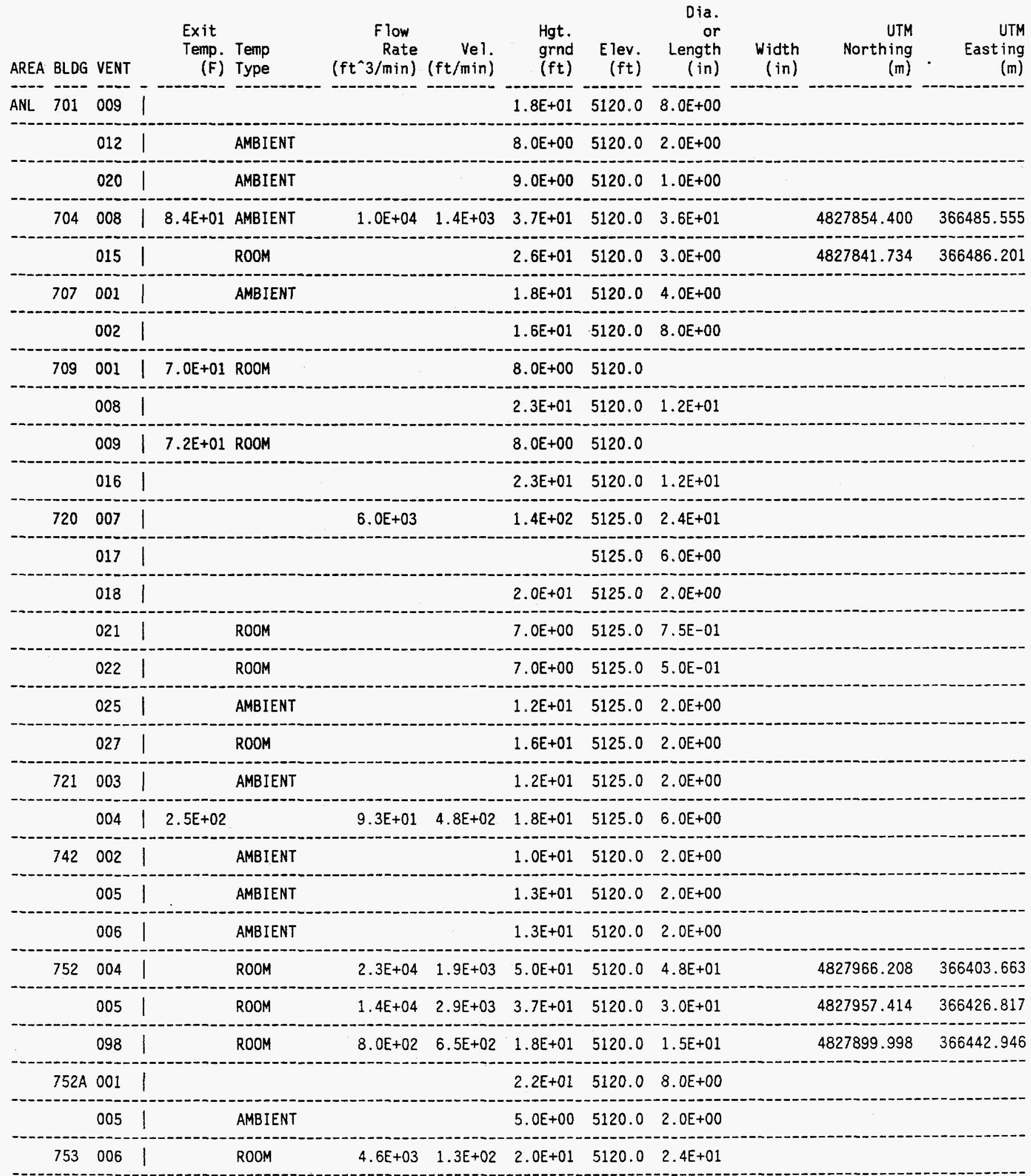




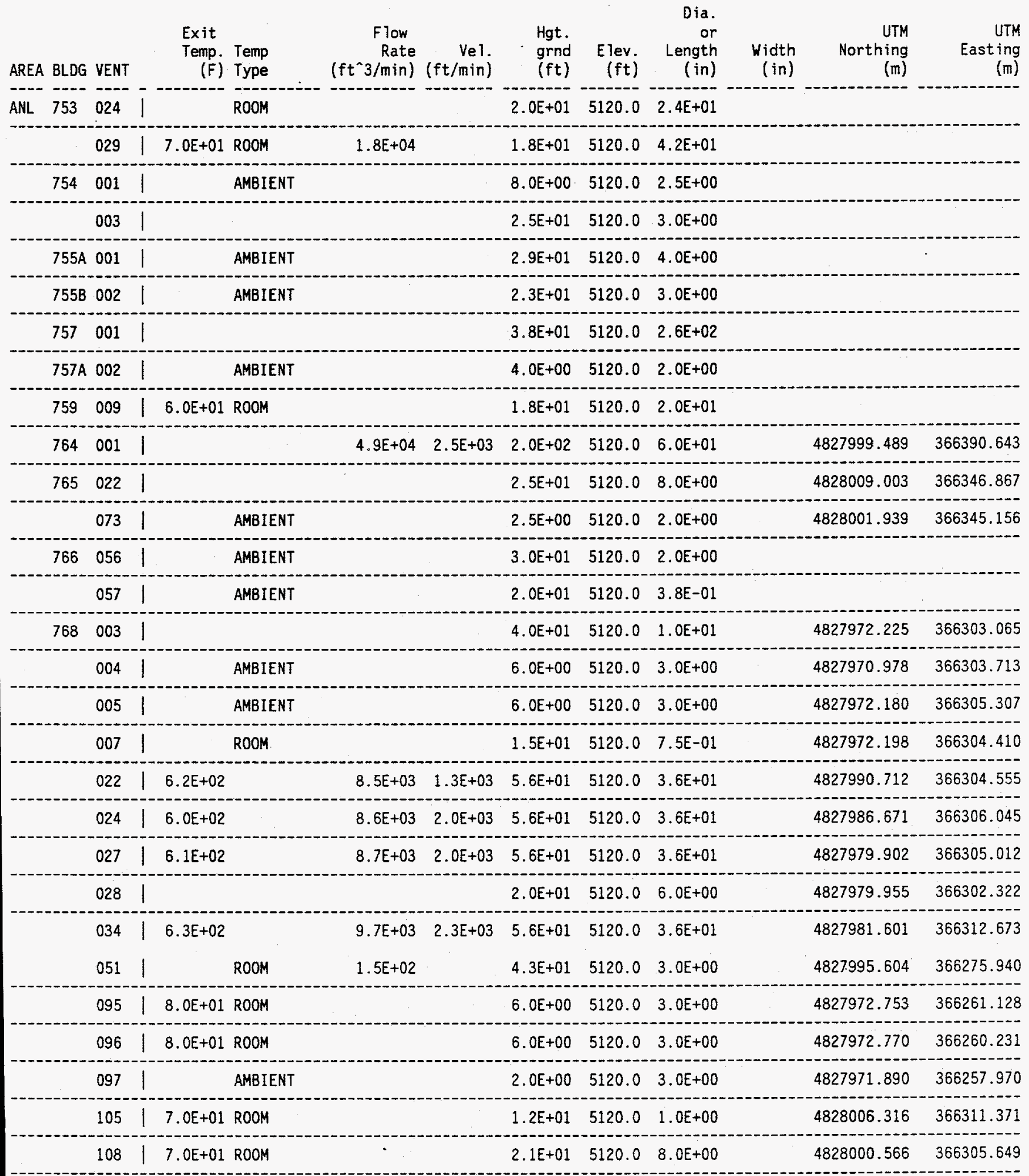




\begin{tabular}{|c|c|c|c|c|c|c|c|c|c|c|}
\hline AREA BLDG & $\begin{array}{l}\text { Exit } \\
\text { Temp. } \\
\text { (F) }\end{array}$ & $\begin{array}{l}\text { Temp } \\
\text { Type }\end{array}$ & $\begin{array}{r}\text { Flow } \\
\text { Rate } \\
\left(\mathrm{ft}^{\wedge} 3 / \mathrm{min}\right)\end{array}$ & $\begin{array}{r}\text { Vel } \\
(\mathrm{ft} / \mathrm{min})\end{array}$ & $\begin{array}{l}\text { Hgt. } \\
\text { grnd } \\
(\mathrm{ft})\end{array}$ & $\begin{array}{l}\text { Elev. } \\
(\mathrm{ft})\end{array}$ & $\begin{array}{r}\text { Dia. } \\
\text { or } \\
\text { Length } \\
\text { (in) }\end{array}$ & $\begin{array}{r}\text { Width } \\
(\text { in) }\end{array}$ & $\begin{array}{r}\text { UTM } \\
\text { Northing } \\
(\mathrm{m})\end{array}$ & $\begin{array}{r}\text { UTM } \\
\text { Easting } \\
(\mathrm{m})\end{array}$ \\
\hline IL $\quad 768$ & 133 & & & & $2.0 E+01$ & 5120.0 & $6.3 E+00$ & & 4828009.920 & 366269.945 \\
\hline & 134 & AMBIENT & & & $1.2 E+01$ & 5120.0 & $1.5 E+00$ & & & \\
\hline $768 \mathrm{~B}$ & 121 & ROOM & 1. $5 E+02$ & & $2.2 E+01$ & 5120.0 & $1.0 E+01$ & & 4828005.981 & 366281.755 \\
\hline & 130 & & & & & 5120.0 & $3.0 \mathrm{E}+00$ & $.0 E+00$ & 4828007.483 & 366283.804 \\
\hline 772 & $7.2 E+01$ & ROOM & $2.7 E+02$ & $1.5 E+02$ & 2. $.0 E+01$ & 5120.0 & $1.8 \mathrm{E}+01$ & & & \\
\hline 774 & 001 & & & & $1.6 E+01$ & 5120.0 & $6.0 E+00$ & & 4827798.650 & 366433.524 \\
\hline & 002 & ROOM & & & 1. $0 E+01$ & 5120.0 & $1.5 E+00$ & & 4827800.810 & 366433.567 \\
\hline & 003 & AMBIENT & & & $1.0 E+01$ & 5120.0 & $2.0 E+00$ & & 4827794.948 & 366433.451 \\
\hline & $7.0 E+01$ & ROOM & $2.0 E+03$ & $5.7 E+03$ & $2.5 E+01$ & 5120.0 & $8.0 E+00$ & & 4827799.921 & 366462.711 \\
\hline & 025 & $\mathrm{ROOH}$ & $9.0 E+01$ & $1.8 \mathrm{E}+03$ & $2.5 E+01$ & 5120.0 & $3.0 E+00$ & & 4827804.816 & 366464.828 \\
\hline 776 & 001 & & & & $3.3 E+01$ & 5120.0 & & & 4827809.002 & 366502.597 \\
\hline 777 & | $5.0 E+01$ & & $4.7 E+03$ & $1.5 E+03$ & $7.5 E+01$ & 5120.0 & $2.4 E+01$ & & 4827771.817 & 366479.200 \\
\hline 782 & 0011 & & & & 1. $0 \mathrm{E}+01$ & 5120.0 & $1.2 E+01$ & $8.0 E+00$ & & \\
\hline & 028 & ROOM & 1. $7 E+03$ & & $2.7 E+01$ & 5120.0 & $1.0 E+00$ & $2.0 E+00$ & & \\
\hline 784 & 010 & ROOM & $1.6 \mathrm{E}+03$ & $2.0 E+03$ & $2.0 E+01$ & 5120.0 & $1.2 E+01$ & & & \\
\hline 785 & 7. $2 E+01$ & ROOM & & & $5.0 E+00$ & 5120.0 & $7.5 E-01$ & & 4828125.633 & 366379.249 \\
\hline & 011 & ROOM & & & $9.4 \mathrm{E}+01$ & 5120.0 & $1.0 \mathrm{E}+01$ & & 4828118.381 & 366371.478 \\
\hline & 014 & & & & $1.0 \mathrm{E}+01$ & 5120.0 & $2.0 E+00$ & & 4828126.134 & 366354.136 \\
\hline & 016 & & & & $2.5 E+01$ & 5120.0 & $8.0 E+00$ & & 4828125.991 & 366361.311 \\
\hline & 017 & & & & $2.5 E+01$ & 5120.0 & $8.0 E+00$ & & 4828125.955 & 366363.105 \\
\hline & 018 & ROOM & $4.6 E+04$ & $2.6 E+03$ & $9.4 E+01$ & 5120.0 & $8.4 E+01$ & $3.0 E+01$ & 4828118.403 & 366370.357 \\
\hline 787 & 001 & ROOM & 1. $.0 E+04$ & $1.8 E+03$ & $3.3 E+01$ & 5120.0 & $3.2 E+01$ & & 4828043.663 & 366388.607 \\
\hline 788 & 013 & ROOM & $2.0 E+03$ & $3.7 \mathrm{E}+03$ & $2.5 E+01$ & 5120.0 & $1.0 E+01$ & & & \\
\hline & 014 & ROOM & $3.5 E+03$ & $8.8 E+02$ & $8.0 E+00$ & 5120.0 & $2.4 E+01$ & & & \\
\hline 789 & 0011 & ROOM & & & $8.0 E+00$ & 5120.0 & $6.0 E+00$ & & & \\
\hline $789 \mathrm{~A}$ & $007 \quad$ & & $.0 E+00$ & $.0 E+00$ & $1.0 E+01$ & 5120.0 & $4.0 E+00$ & & & \\
\hline 793 & 0011 & & 1. $.0 E+04$ & & $4.8 E+01$ & 5120.0 & $4.2 E+01$ & & & \\
\hline & 011 & & & & $2.0 E+01$ & 5120.0 & $8.0 E+00$ & & & \\
\hline & 012 & & & & $2.0 E+01$ & 5120.0 & $1.5 E+\infty 0$ & & & \\
\hline
\end{tabular}




\begin{tabular}{|c|c|c|c|c|c|c|c|c|c|c|c|c|}
\hline AREA & BLDG & VENT & $\begin{array}{l}\text { Exit } \\
\text { Temp. } \\
\text { (F) }\end{array}$ & $\begin{array}{l}\text { Temp } \\
\text { Type }\end{array}$ & $\begin{array}{r}\text { Flow } \\
\text { Rate } \\
\left(\mathrm{ft}^{\wedge} 3 / \mathrm{min}\right)\end{array}$ & $\begin{array}{r}\text { Vel } \\
(\mathrm{ft} / \mathrm{min})\end{array}$ & $\begin{array}{l}\text { Hgt. } \\
\text { grnd } \\
\text { (ft) }\end{array}$ & $\begin{array}{l}\text { Elev. } \\
(\mathrm{ft})\end{array}$ & $\begin{array}{r}\text { Dia. } \\
\text { or } \\
\text { Length } \\
\text { (in) }\end{array}$ & $\begin{array}{c}\text { Width } \\
\text { (in) }\end{array}$ & $\begin{array}{r}\text { UTM } \\
\text { Northing } \\
(\mathrm{m})\end{array}$ & $\begin{array}{r}\text { UTM } \\
\text { East ing } \\
(\mathrm{m})\end{array}$ \\
\hline ANL & 793 & 013 & & & & & $2.0 E+01$ & 5120.0 & $1.5 E+00$ & & & \\
\hline & & 014 & & & & & 2. $.0 E+01$ & 5120.0 & $1.5 E+00$ & & & \\
\hline & & 015 & & & & & $2.0 E+01$ & 5120.0 & $1.5 \mathrm{E}+00$ & & & . \\
\hline & $793 A$ & 025 & & & & & $1.4 E+01$ & 5120.0 & $4.0 E+00$ & & & \\
\hline & & 026 & & & & & $1.4 \mathrm{E}+01$ & 5120.0 & $4.0 E+00$ & & & \\
\hline & & 027 & & & & & $7.0 E+00$ & 5120.0 & $4.8 \mathrm{E}+01$ & & & \\
\hline & & 028 & & & & & $7.0 E+00$ & 5120.0 & $4.0 E+00$ & & & \\
\hline & & 029 & & & & & $1.0 E+01$ & 5120.0 & $4.0 E+00$ & & & \\
\hline & & 030 & & & & & $1.0 E+01$ & 5120.0 & $4.0 E+00$ & & & \\
\hline & & 031 & & & & & $1.0 E+01$ & 5120.0 & $4.0 \mathrm{E}+00$ & & & \\
\hline & & 032 & & & & & $1.0 E+01$ & 5120.0 & $4.0 E+00$ & & & \\
\hline & & 033 & & & & & $9.0 E+00$ & 5120.0 & $4.0 E+00$ & & & \\
\hline & & 034 & & & & & $9.0 E+00$ & 5120.0 & $4.0 E+00$ & & & \\
\hline & & 035 & & & & & $9.0 E+00$ & 5120.0 & $4.0 \mathrm{E}+00$ & & & \\
\hline & & 036 & & & & & $9.0 E+00$ & 5120.0 & $4.0 E+00$ & & & \\
\hline & $793 B$ & 019 & & & & & $1.4 E+01$ & 5120.0 & $4.0 E+00$ & & & \\
\hline & & 020 & & & & & $1.4 E+01$ & 5120.0 & $1.0 E+00$ & & & \\
\hline & 794 & 006 & & AMBIENT & & & $1.6 E+01$ & 5120.0 & $1.0 \mathrm{E}+01$ & & & \\
\hline & 798 & 007 & & ROOM & & & $1.5 E+01$ & 5120.0 & $1.5 E+00$ & & 4828146.902 & 366411.525 \\
\hline & & 008 & & & & & $1.5 E+01$ & 5120.0 & $2.0 E+00$ & & 4828148.154 & 366410.653 \\
\hline & & 017 & & & $2.8 E+03$ & & $6.0 E+01$ & 5120.0 & $3.6 E+01$ & & 4828145.918 & 366398.944 \\
\hline & 799 & 003 & & ROOM & & & 2. $2 E+01$ & 5120.0 & $1.2 E+01$ & $1.2 E+01$ & 4828221.302 & 366271.020 \\
\hline & & 010 & $.0 E+00$ & & $2.9 E+04$ & $8.7 E+04$ & $2.0 E+01$ & 5120.0 & $4.0 E+00$ & & 4828210.939 & 366264.533 \\
\hline
\end{tabular}




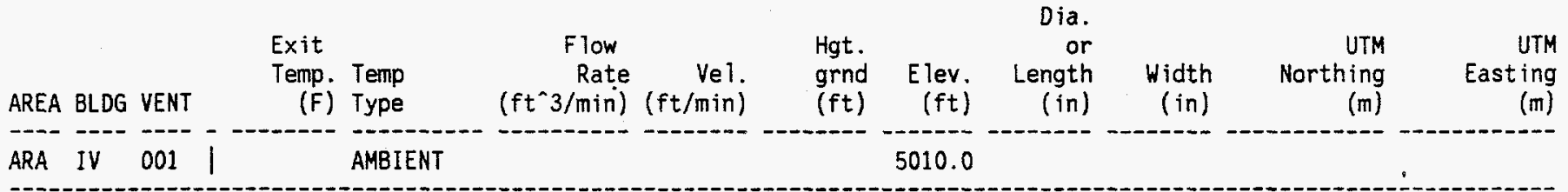

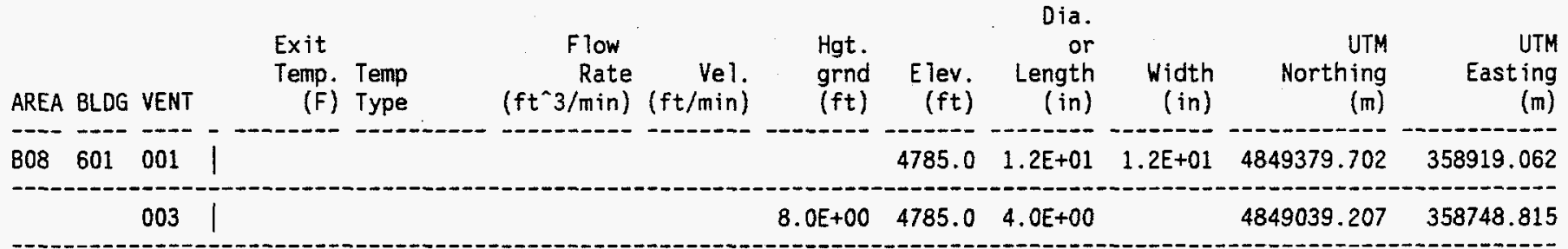

\begin{tabular}{|c|c|c|c|c|c|c|c|c|c|c|c|c|}
\hline AREA & BLDG & VENT & $\begin{array}{l}\text { Exit } \\
\text { Temp. } \\
\text { (F) }\end{array}$ & $\begin{array}{l}\text { Temp } \\
\text { Type }\end{array}$ & $\begin{array}{r}\text { Flow } \\
\text { Rate } \\
\left(\mathrm{ft}^{\wedge} 3 / \mathrm{min}\right)\end{array}$ & $\begin{array}{r}\text { Vel. } \\
(\mathrm{ft} / \mathrm{min})\end{array}$ & $\begin{array}{l}\text { Hgt. } \\
\text { grnd } \\
\text { (ft) }\end{array}$ & $\begin{array}{l}\text { Elev. } \\
(\mathrm{ft})\end{array}$ & $\begin{array}{r}\text { Dia. } \\
\text { or } \\
\text { Length } \\
\text { (in) }\end{array}$ & $\begin{array}{c}\text { Width } \\
\text { (in) }\end{array}$ & $\begin{array}{r}\text { UTM } \\
\text { Northing } \\
(\mathrm{m})\end{array}$ & $\begin{array}{r}\text { UTM } \\
\text { Easting } \\
\text { (m) }\end{array}$ \\
\hline B16 & 601 & 007 & $2.5 E+02$ & & $9.6 E+01$ & $1.2 E+02$ & $1.8 \mathrm{E}+01$ & 4904.0 & $1.2 E+01$ & & 4828774.079 & 343507.764 \\
\hline & & 008 & & AMBIENT & & & $1.2 E+01$ & 4904.0 & $1.5 E+00$ & & 4828774.920 & 343507.803 \\
\hline & 703 & 001 & & AMBIENT & & & 1. $5 E+01$ & 4904.0 & $3.0 E+00$ & & 4828810.330 & 343635.903 \\
\hline & 708 & 001 & & AMBIENT & & & $.0 E+00$ & & $2.0 \mathrm{E}+01$ & $2.0 E+01$ & 4828810.692 & 343635.500 \\
\hline
\end{tabular}

\begin{tabular}{|c|c|c|c|c|c|c|c|c|c|c|c|c|}
\hline AREA & BLDG & VENT & $\begin{array}{l}\text { Exit } \\
\text { Temp. } \\
\text { (F) }\end{array}$ & $\begin{array}{l}\text { Temp } \\
\text { Type }\end{array}$ & $\begin{array}{r}\text { Flow } \\
\text { Rate } \\
\text { (ft^3/min) }\end{array}$ & $\begin{array}{r}\text { Ve } T \\
(\mathrm{ft} / \mathrm{min})\end{array}$ & $\begin{array}{l}\text { Hgt. } \\
\text { grnd } \\
\text { (ft) }\end{array}$ & $\begin{array}{l}\text { Elev. } \\
(\mathrm{ft})\end{array}$ & $\begin{array}{r}\text { Dia. } \\
\text { or } \\
\text { Length } \\
(\text { in })\end{array}$ & $\begin{array}{l}\text { Width } \\
\text { (in) }\end{array}$ & $\begin{array}{r}\text { UTM } \\
\text { Northing } \\
\text { (m) }\end{array}$ & $\begin{array}{r}\text { UTM } \\
\text { Easting } \\
(\mathrm{m})\end{array}$ \\
\hline B21 & 608 & 008 & & AMBIENT & 1. $2 E+03$ & $7.1 E+02$ & 2. $1 E+01$ & 4974.0 & $8.8 \mathrm{E}+00$ & & 4822745.696 & 341245.663 \\
\hline & & 012 & & ROOM & $5.7 E+03$ & 5. $7 E+02$ & $1.7 E+01$ & 4973.0 & $2.4 \mathrm{E}+01$ & $6.0 E+01$ & 4822819.840 & 341338.312 \\
\hline
\end{tabular}

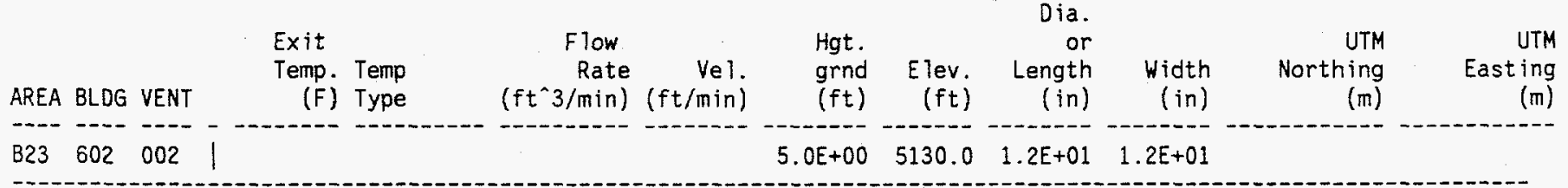




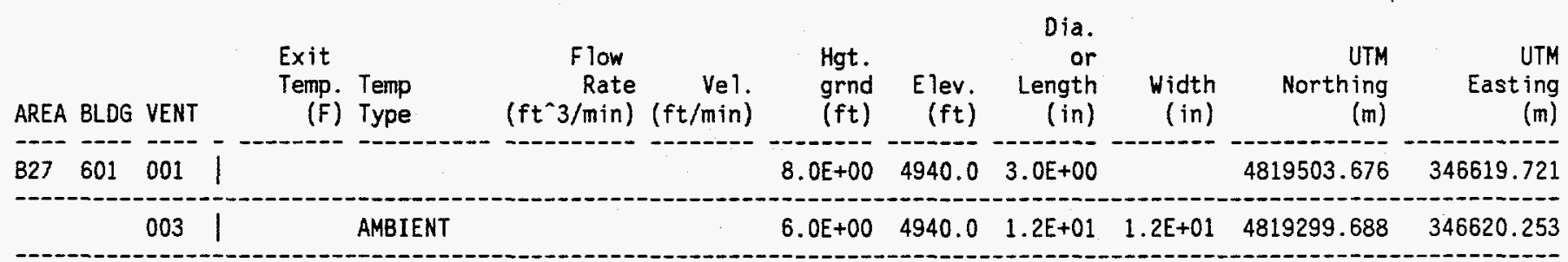

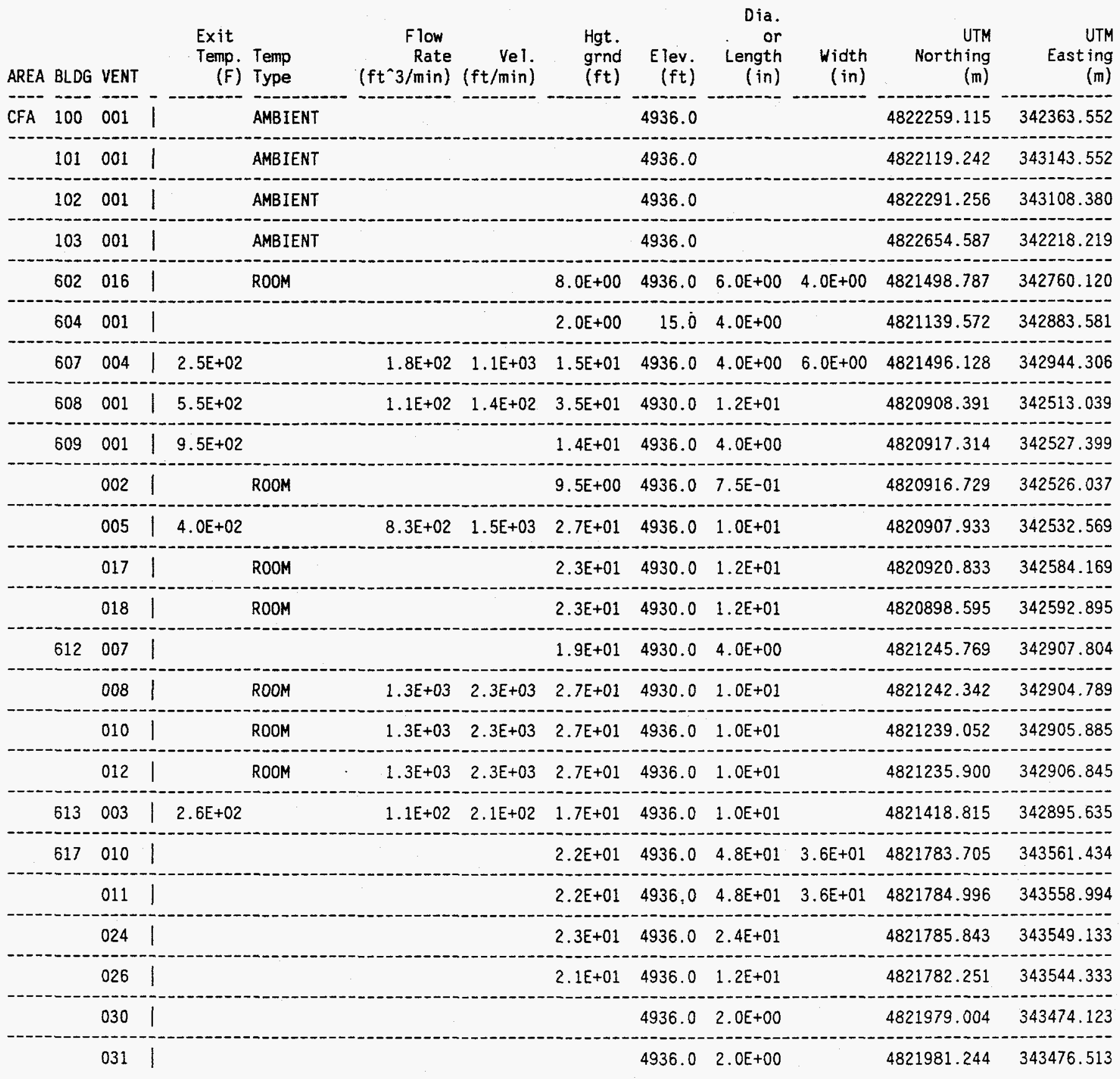




\begin{tabular}{|c|c|c|c|c|c|c|c|c|c|c|}
\hline & 033 & ROOM & & & $2.1 E+01$ & 4936.0 & 1. $.0 E+01$ & $1.8 E+01$ & 4821767.574 & 343538.377 \\
\hline & 034 & ROOM & & & $2.1 E+01$ & 4936.0 & $1.0 \mathrm{E}+01$ & $1.8 \mathrm{E}+01$ & 4821765.739 & 343537.660 \\
\hline 622 & 009 & ROOM & $.0 E+\infty 0$ & & 1. $2 E+01$ & 4936.0 & $1.2 E+01$ & $1.2 E+01$ & 4820879.434 & 342827.035 \\
\hline & 015 & ROOM & $2.0 E+03$ & $2.0 E+03$ & $1.2 E+01$ & 4936.0 & $1.2 E+01$ & $1.2 E+01$ & 4820871.722 & 342826.854 \\
\hline & 019 & & $.0 E+\infty O$ & & $4.0 E+00$ & 4936.0 & 1. $2 \mathrm{E}+01$ & & 4820866.001 & 342833.908 \\
\hline
\end{tabular}




\begin{tabular}{|c|c|c|c|c|c|c|c|c|c|c|c|c|}
\hline AREA & BLDG & VENT & $\begin{array}{l}\text { Exit } \\
\text { Temp. } \\
\text { (F) }\end{array}$ & $\begin{array}{l}\text { Temp } \\
\text { Type }\end{array}$ & $\begin{array}{r}\text { Flow } \\
\text { Rate } \\
\left(\mathrm{ft}^{\wedge} 3 / \mathrm{min}\right)\end{array}$ & $\begin{array}{r}\text { Vel } \\
(\mathrm{ft} / \mathrm{min})\end{array}$ & $\begin{array}{l}\text { Hgt. } \\
\text { grnd } \\
\text { (ft) }\end{array}$ & $\begin{array}{l}\text { Elev. } \\
(f t)\end{array}$ & $\begin{array}{r}\text { Dia. } \\
\text { or } \\
\text { Length } \\
\text { (in) }\end{array}$ & $\begin{array}{l}\text { Width } \\
\text { (in) }\end{array}$ & $\begin{array}{r}\text { UTM } \\
\text { Northing } \\
(m)\end{array}$ & $\begin{array}{r}\text { UTM } \\
\text { Easting } \\
\text { (m) }\end{array}$ \\
\hline CFA & 622 & 020 & & & $.0 E+00$ & & 1. $2 \mathrm{E}+01$ & 4936.0 & 1. $2 E+01$ & & 4820868.029 & 342839.571 \\
\hline & & 021 & & & $.0 E+00$ & & $1.2 E+01$ & 4936.0 & $1.2 E+01$ & & 4820872.578 & 342843.046 \\
\hline & 623 & 005 & & ROOM & $1.5 \mathrm{E}+03$ & $4.8 E+02$ & $6.0 E+00$ & 4936.0 & $2.4 E+01$ & & 4820849.104 & 342804.089 \\
\hline & & 007 & $7.0 \mathrm{E}+01$ & ROOM & & & $2.5 E+01$ & & $6.0 E+01$ & & & \\
\hline & & 017 & & ROOM & $2.5 E+04$ & $2.6 E+03$ & $3.0 E+01$ & 4936.0 & $4.2 E+01$ & & 4820847.206 & 342806.066 \\
\hline & 624 & 009 & & ROOM & $5.0 E+02$ & $5.7 E+03$ & $2.9 E+01$ & 4936.0 & $4.0 \mathrm{E}+00$ & & 4820805.839 & 342777.259 \\
\hline & 625 & 009 & & ROOM & $1.5 E+04$ & $4.8 E+03$ & $3.0 E+01$ & 4936.0 & $2.4 E+01$ & & 4821212.735 & 343344.884 \\
\hline & & 010 & & ROOM & $7.9 E+03$ & $3.6 E+03$ & $3.0 \mathrm{E}+01$ & 4936.0 & $2.0 E+01$ & & 4821218.497 & 343336.035 \\
\hline & 633 & 001 & & ROOM & $.0 E+00$ & $.0 E+00$ & $2.7 E+01$ & 4936.0 & $1.2 E+01$ & $9.0 E+00$ & 4821933.883 & 343540.902 \\
\hline & & 003 & & ROOM & $.0 E+00$ & $.0 E+00$ & $2.7 E+01$ & 4936.0 & $1.2 E+01$ & $9.0 E+00$ & 4821938.887 & 343538.099 \\
\hline & & 008 & & ROOM & $.0 E+00$ & $.0 E+00$ & $2.7 E+01$ & 4936.0 & 1. $2 E+01$ & $9.0 E+00$ & 4821942.417 & 343545.592 \\
\hline & & 009 & & ROOM & $.0 E+00$ & $.0 E+00$ & $3.9 E+01$ & 4936.0 & $9.0 E+00$ & & 4821943.384 & 343543.818 \\
\hline & & 011 & & ROOM & $.0 E+00$ & $.0 E+00$ & $2.7 E+01$ & 4936.0 & 1. $2 E+01$ & $9.0 E+00$ & 4821946.804 & 343542.775 \\
\hline & & 015 & & ROOM & $.0 E+00$ & $.0 E+00$ & $2.0 E+01$ & 4936.0 & $1.2 E+01$ & $9.0 \mathrm{E}+00$ & 4821940.168 & 343536.108 \\
\hline & & 020 & & ROOM & $.0 E+00$ & $.0 E+00$ & $2.0 E+01$ & 4936.0 & $1.4 E+01$ & $1.0 E+01$ & 4821942.997 & 343533.928 \\
\hline & & 021 & & ROOM & $.0 E+00$ & $.0 E+00$ & $2.0 E+01$ & 4936.0 & $1.4 E+01$ & $1.0 E+01$ & 4821945.470 & 343533.761 \\
\hline & & 028 & & ROOM & $.0 E+00$ & $.0 E+00$ & 2. $O E+01$ & 4936.0 & $1.4 \mathrm{E}+01$ & $1.1 E+01$ & 4821950.861 & 343527.599 \\
\hline & & 040 & & ROOM & $.0 E+00$ & $.0 E+00$ & 2. $0 E+01$ & 4936.0 & $1.4 \mathrm{E}+01$ & $1.1 E+01$ & 4821955.426 & 343517.151 \\
\hline & & 067 & & ROOM & & & $1.6 E+01$ & 4936.0 & $1.2 \mathrm{E}+01$ & & 4821977.496 & 343523.728 \\
\hline & & 091 & & & & & 1. $3 E+01$ & 4936.0 & $3.0 E+00$ & & 4821947.374 & 343558.059 \\
\hline & 650 & 007 & $3.3 E+02$ & & $1.1 E+03$ & $2.1 \mathrm{E}+03$ & $3.4 E+01$ & 4936.0 & $1.2 E+01$ & & 4821935.912 & 343506.815 \\
\hline & 662 & 011 & $4.5 E+02$ & & $8.4 E+02$ & & $4.8 E+01$ & 4936.0 & $1.2 E+01$ & & 4821120.115 & 342843.444 \\
\hline & & 027 & $5.5 E+02$ & & $1.3 E+03$ & $5.9 E+02$ & $3.6 \mathrm{E}+01$ & 4934.0 & $1.8 \mathrm{E}+01$ & & 4821107.283 & 342851.005 \\
\hline & 664 & 034 & & & & & $2.2 E+01$ & 4936.0 & $1.0 E+01$ & & 4821014.008 & 343064.891 \\
\hline & & 035 & & & & & $2.2 E+01$ & 4936.0 & $1.0 E+01$ & & 4821011.801 & 343066.861 \\
\hline & 665 & 028 & $2.5 E+02$ & & $2.6 \mathrm{E}+03$ & $3.3 E+03$ & $3.6 E+01$ & 4936.0 & $1.2 E+01$ & & 4820979.503 & 343075.315 \\
\hline & & 029 & $2.4 \mathrm{E}+02$ & & $2.6 E+03$ & $2.4 E+03$ & $3.1 E+01$ & 4936.0 & $2.0 E+01$ & & 4820983.022 & 343070.007 \\
\hline & & 030 & $2.5 \mathrm{E}+02$ & & $2.6 E+03$ & $3.3 E+03$ & $3.7 E+01$ & 4936.0 & 1. $2 E+01$ & & 4820977.710 & 343072.803 \\
\hline & & 050 & & & & & $4.2 E+01$ & & $3.6 E+01$ & & 4821163.388 & 343030.991 \\
\hline
\end{tabular}




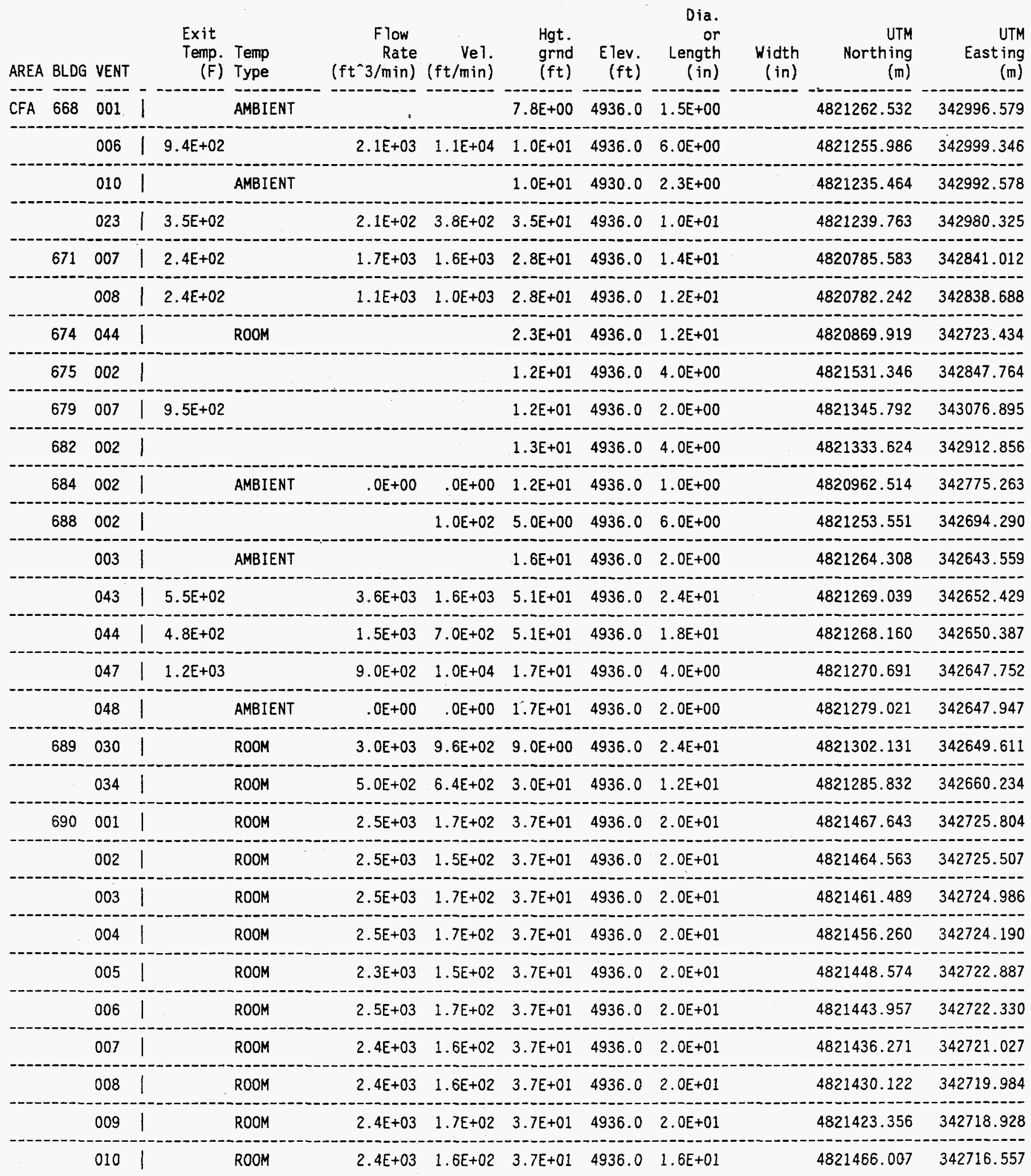




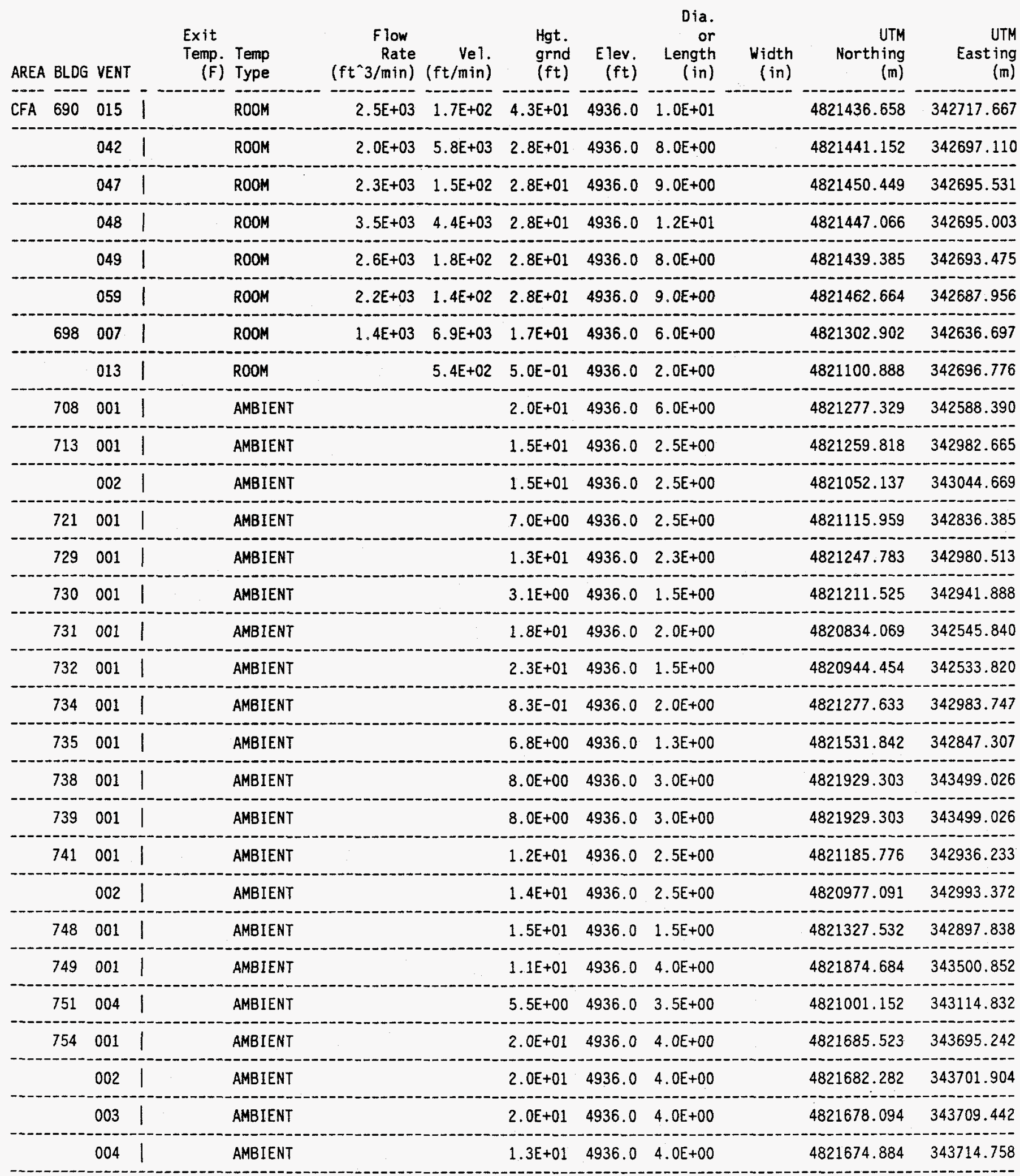




\begin{tabular}{|c|c|c|c|c|c|c|c|c|c|c|c|}
\hline AREA & BLDG & VENT & $\begin{array}{l}\text { Exit } \\
\text { Temp } \\
\text { (F) }\end{array}$ & $\begin{array}{l}\text { Temp } \\
\text { Type }\end{array}$ & 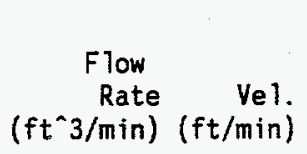 & $\begin{array}{l}\text { Hgt. } \\
\text { grnd } \\
(\mathrm{ft})\end{array}$ & $\begin{array}{l}\text { Elev. } \\
(\mathrm{ft})\end{array}$ & $\begin{array}{r}\text { Dia. } \\
\text { or } \\
\text { Length } \\
\text { (in) }\end{array}$ & $\begin{array}{r}\text { Width } \\
\text { (in) }\end{array}$ & $\begin{array}{r}\text { UTM } \\
\text { Northing } \\
(\mathrm{m})\end{array}$ & $\begin{array}{r}\text { UTM } \\
\text { East ing } \\
\text { (m) }\end{array}$ \\
\hline CFA & 754 & 005 & & AMBIENT & & $1.3 E+01$ & 4936.0 & $4.0 E+00$ & & 4821672.625 & 343718.972 \\
\hline & & 006 & & AMBIENT & & $1.7 \mathrm{E}+01$ & 4936.0 & $4.0 E+00$ & & 4821687.459 & 343718.194 \\
\hline & & 007 & & AMBIENT & & $2.2 E+01$ & 4936.0 & $4.0 E+00$ & & 4821694.543 & 343705.558 \\
\hline & 757 & 001 & & AMBIENT & & $1.8 E+01$ & 4936.0 & $2.8 E+00$ & & 4820979.739 & 43065.213 \\
\hline & 759 & 001 & & AMBIENT & & $9.8 E+00$ & 4936.0 & $3.0 \mathrm{E}+00$ & & 4820783.355 & 342843.880 \\
\hline
\end{tabular}




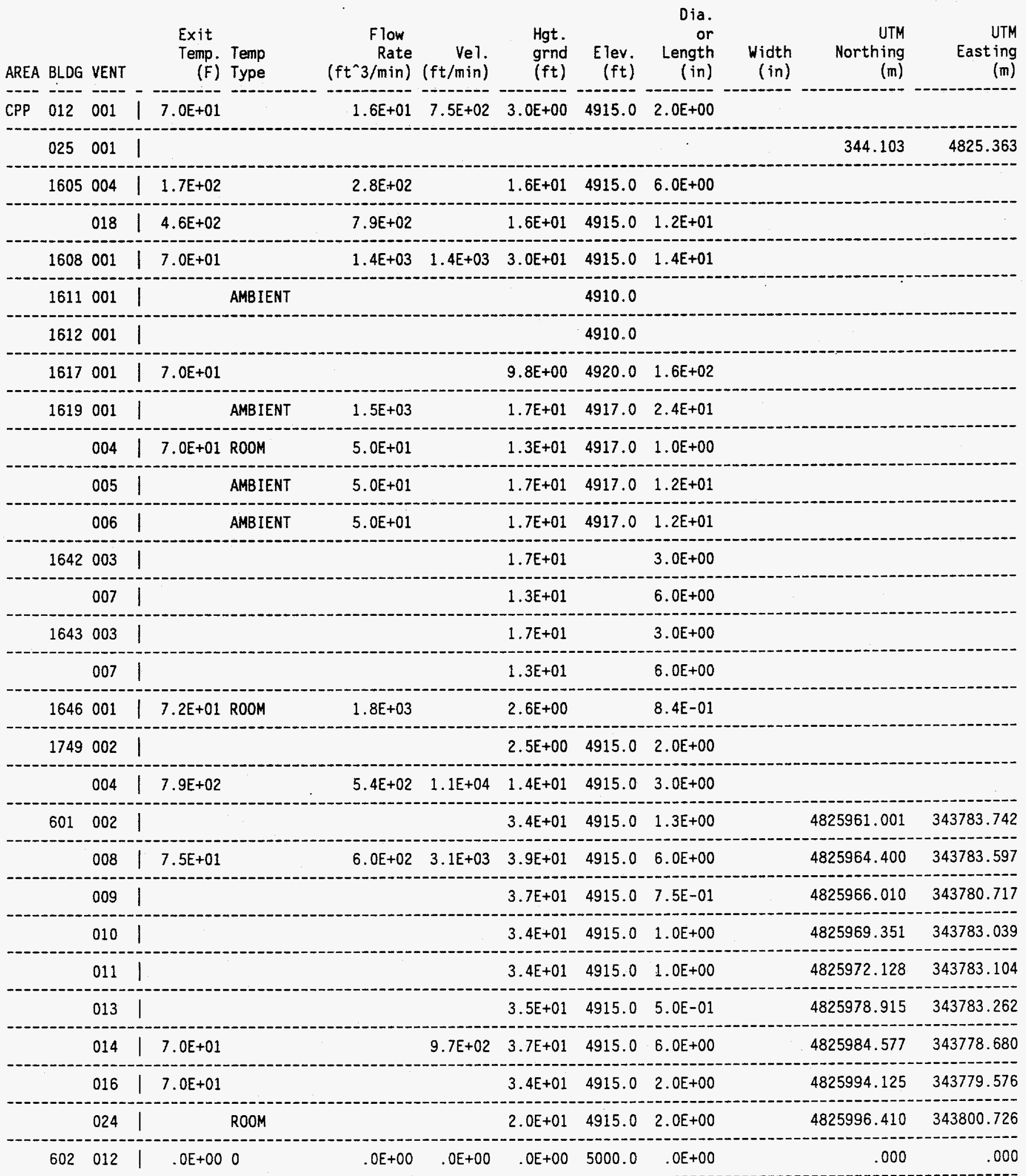




\begin{tabular}{|c|c|c|c|c|c|c|c|c|c|c|c|c|}
\hline REA & BLDG & VENT & $\begin{array}{l}\text { Exit } \\
\text { Temp. } \\
\text { (F) }\end{array}$ & $\begin{array}{l}\text { Temp } \\
\text { Type }\end{array}$ & $\begin{array}{r}\text { Flow } \\
\text { Rate } \\
\left(\mathrm{ft}^{\wedge} 3 / \mathrm{min}\right)\end{array}$ & $\begin{array}{r}\text { Vel. } \\
(\mathrm{ft} / \mathrm{min})\end{array}$ & $\begin{array}{l}\text { Hgt. } \\
\text { grnd } \\
\text { (ft) }\end{array}$ & $\begin{array}{l}\text { Elev. } \\
\text { (ft) }\end{array}$ & $\begin{array}{r}\text { Dia. } \\
\text { or } \\
\text { Length } \\
\text { (in) }\end{array}$ & $\begin{array}{r}\text { Width } \\
\text { (in) }\end{array}$ & $\begin{array}{r}\text { UTM } \\
\text { Northing } \\
(\mathrm{m})\end{array}$ & $\begin{array}{r}\text { UTM } \\
\text { East ing } \\
\text { (m) }\end{array}$ \\
\hline$P$ & 602 & 014 & & & & & $3.6 E+01$ & 4915.0 & $4.0 E+00$ & & & \\
\hline & & 031 & & & $2.5 E+03$ & $6.0 E+02$ & 4. $7 E+01$ & & $1.4 \mathrm{E}+01$ & & 4826043.291 & 343789.025 \\
\hline & 603 & 001 & $7.0 E+01$ & $\mathrm{ROOM}$ & $1.7 E+04$ & $3.0 E+03$ & $6.5 E+01$ & 4917.0 & $3.2 E+01$ & & 4825267.612 & 343747.400 \\
\hline & & 008 & & & & & $9.0 E+00$ & 4915.0 & $4.0 E+00$ & & 4825276.380 & 343741.992 \\
\hline & 604 & 011 & & ROOM & & & $1.9 E+01$ & 4915.0 & $1.0 E+00$ & & 4825969.026 & 343889.862 \\
\hline & 606 & 004 & $4.5 E+02$ & & $9.8 E+03$ & $6.1 E+02$ & $4.3 E+01$ & 4915.0 & $5.4 \mathrm{E}+01$ & & 4826090.293 & 343811.889 \\
\hline & & 005 & $4.5 E+02$ & & $9.8 E+03$ & $6.1 E+02$ & $4.3 E+01$ & 4915.0 & $5.4 E+01$ & & 4826088.442 & 343811.846 \\
\hline & & 013 & & & & & & 4915.0 & & & 4826085.628 & 343800.110 \\
\hline & & 019 & $4.5 E+02$ & & $9.8 E+03$ & $6.1 E+02$ & $4.5 \mathrm{E}+01$ & 4915.0 & $5.4 \mathrm{E}+01$ & & 4826089.915 & 343788.315 \\
\hline & & 038 & $7.0 E+01$ & ROOM & $6.1 E+02$ & $3.1 E+03$ & $6.0 \mathrm{E}+01$ & 4915.0 & $6.0 E+00$ & & 4826081.404 & 343809.213 \\
\hline & 614 & 001 & $7.0 E+01$ & & & & 1. $3 E+01$ & 4915.0 & $1.3 \mathrm{E}+00$ & & -21.000 & 23.000 \\
\hline & & 002 & $8.5 E+02$ & & $2.2 E+03$ & $1.6 \mathrm{E}+04$ & $1.2 \mathrm{E}+01$ & 4915.0 & $5.0 E+00$ & & & \\
\hline & 615 & 005 & & AMBIENT & & & & 4920.0 & & & & \\
\hline & 616 & 004 & & & & & $8.5 E+00$ & 4915.0 & $4.0 E+00$ & & & \\
\hline & & 007 & & & & & $5.6 \mathrm{E}+00$ & 4915.0 & $3.0 E+00$ & & & \\
\hline & 620 & 001 & & & & & $3.5 E+01$ & 4915.0 & $1.8 \mathrm{E}+01$ & & 4825974.270 & 343704.377 \\
\hline & & 002 & & & & & $7.2 E+00$ & 4915.0 & $3.0 E+00$ & & 4825957.674 & 343701.297 \\
\hline & & 004 & $8.6 E+01$ & & 4. $7 E+03$ & $1.3 \mathrm{E}+04$ & $4.2 E+01$ & 4915.0 & $8.0 E+00$ & & 4825966.860 & 343704.429 \\
\hline & & 005 & 7. $7 E+01$ & & $4.5 E+03$ & $5.8 E+03$ & $7.1 E+01$ & 4915.0 & $1.2 \mathrm{E}+01$ & & 4825975.294 & 343700.137 \\
\hline & & 006 & $8.6 E+01$ & & $4.9 E+03$ & $1.4 \mathrm{E}+04$ & $4.2 E+01$ & 4915.0 & $8.0 E+00$ & & 4825973.480 & 343698.523 \\
\hline & & 009 & & ROOM & & & $6.0 E+01$ & 4915.0 & $2.4 \mathrm{E}+01$ & & 4825971.702 & 343695.340 \\
\hline & 621 & 003 & & & $6.1 E+02$ & $1.8 \mathrm{E}+03$ & $2.0 E+01$ & 4915.0 & $6.0 E+00$ & $8.0 E+00$ & & \\
\hline & 627 & 007 & $7.0 E+01$ & ROOM & $1.2 E+03$ & $8.8 E+03$ & $6.8 E+01$ & 4915.0 & $1.0 \mathrm{E}+01$ & & 4826012.686 & 343751.281 \\
\hline & & 008 & & 70 & $9.8 \mathrm{E}+03$ & $5.0 E+03$ & $6.8 E+01$ & 4915.0 & $1.9 \mathrm{E}+01$ & & 4826009.256 & 343752.772 \\
\hline & & 010 & 7. $0 E+01$ & ROOM & $1.6 E+03$ & $1.5 E+03$ & $6.8 E+01$ & 4915.0 & $1.4 \mathrm{E}+01$ & & 4825996.608 & 343752.477 \\
\hline & & 013 & $7.0 \mathrm{E}+01$ & ROOM & $1.6 E+04$ & $2.9 \mathrm{E}+03$ & $6.5 E+01$ & 4915.0 & $3.2 E+01$ & & 4825992.461 & 343758.216 \\
\hline & & 016 & $7.0 E+01$ & & & & 2. $6 E+01$ & 4915.0 & $3.0 E+00$ & & 4825997.774 & 343755.422 \\
\hline & 630 & 011 & & AMBIENT & & & $4.0 E+01$ & 4915.0 & $2.0 E+01$ & & & \\
\hline & & 012 & $7.0 \mathrm{E}+01$ & & $7.2 E+04$ & $2.3 \mathrm{E}+04$ & $3.2 E+01$ & 4915.0 & $2.4 E+01$ & & & \\
\hline
\end{tabular}




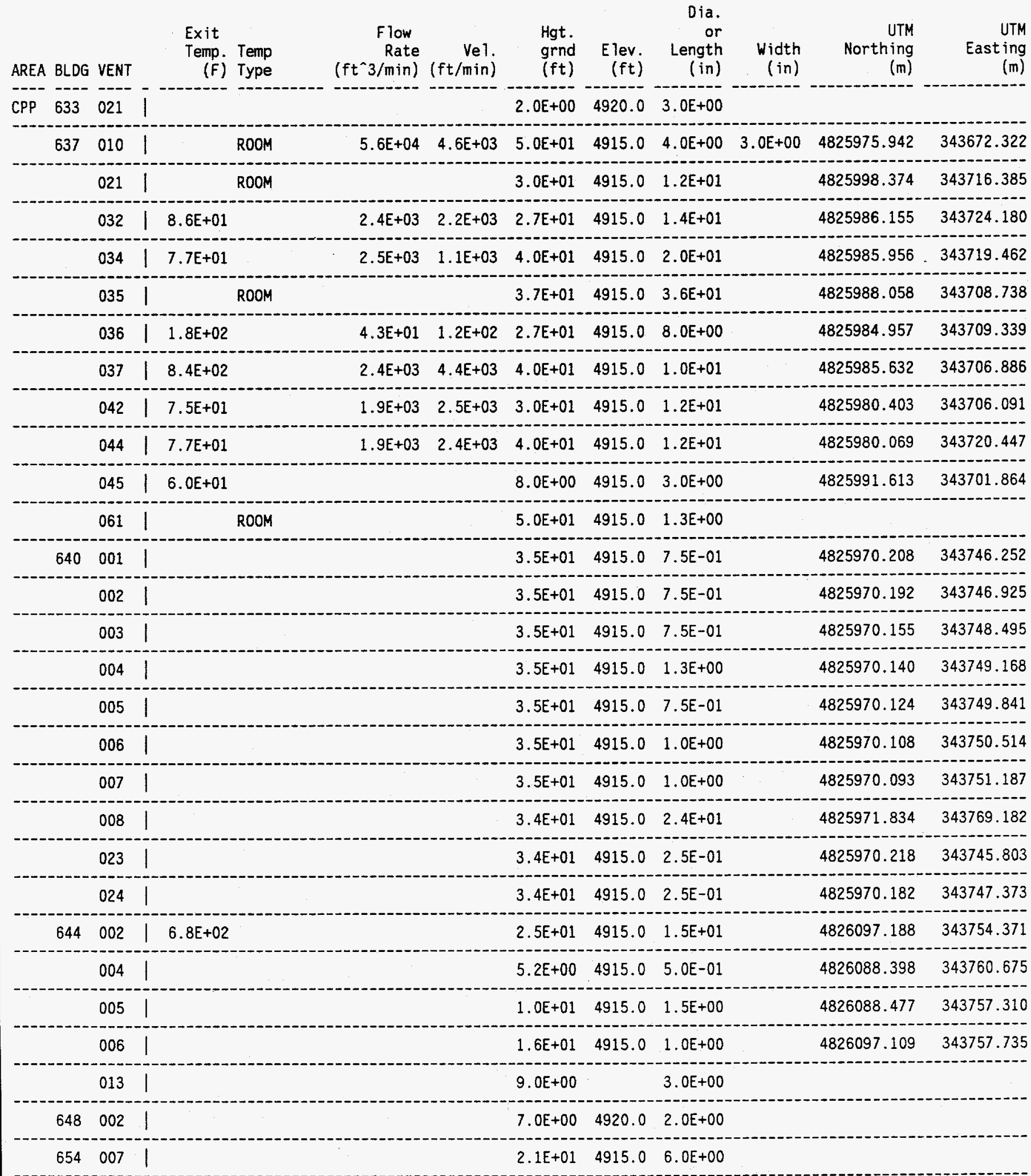




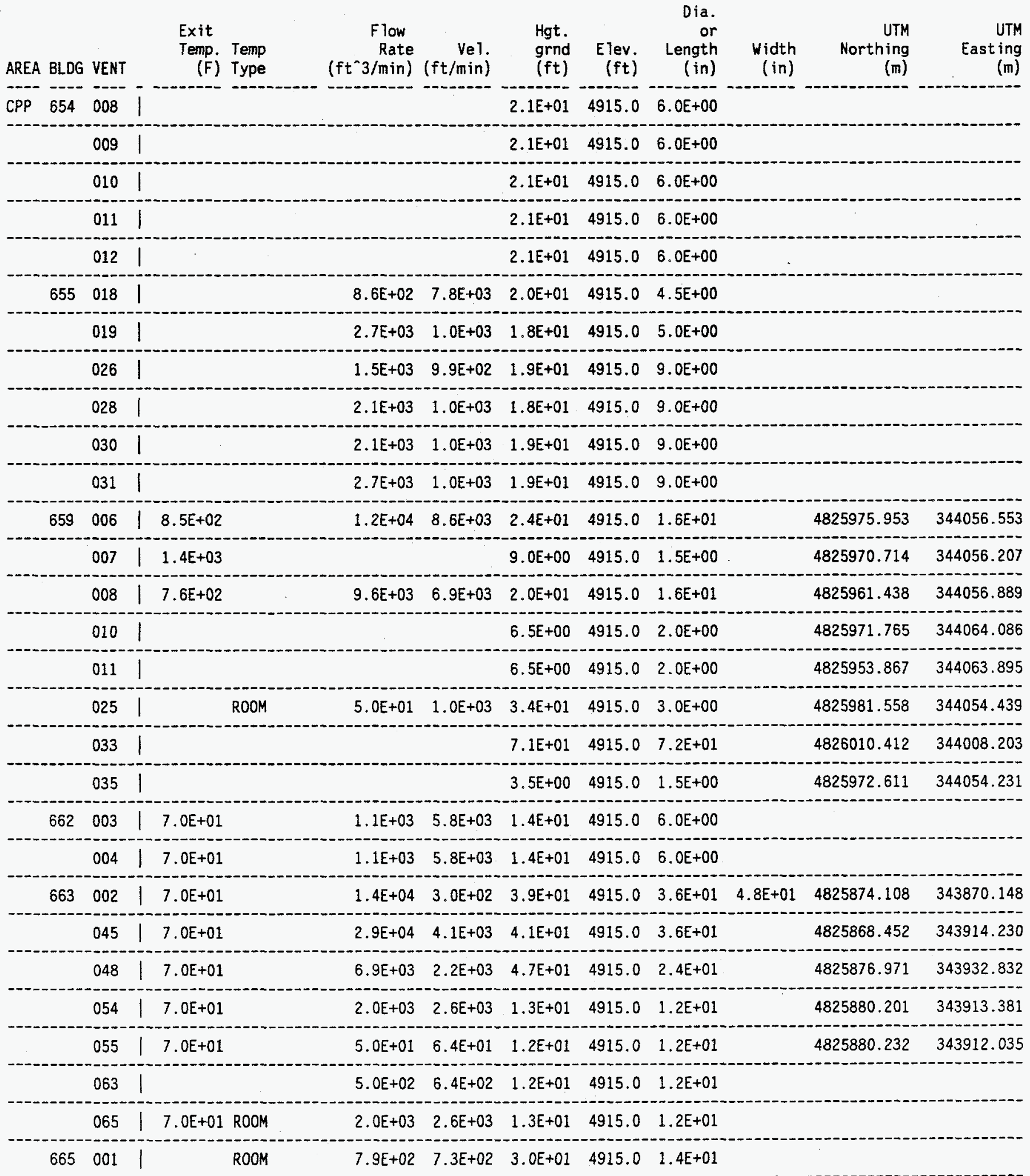




\begin{tabular}{|c|c|c|c|c|c|c|c|c|c|c|}
\hline AREA BLDG & $\begin{array}{l}\text { Exit } \\
\text { Temp. } \\
\text { (F) }\end{array}$ & $\begin{array}{l}\text { Temp } \\
\text { Type }\end{array}$ & $\begin{array}{r}\text { Flow } \\
\text { Rate } \\
\left(\mathrm{ft}^{\wedge} 3 / \mathrm{min}\right)\end{array}$ & $\begin{array}{r}\text { Vel. } \\
\text { (ft/min) }\end{array}$ & $\begin{array}{l}\text { Hgt. } \\
\text { grnd } \\
\text { (ft) }\end{array}$ & $\begin{array}{l}\text { Elev. } \\
(\mathrm{ft})\end{array}$ & $\begin{array}{r}\text { Dia. } \\
\text { or } \\
\text { Length } \\
\text { (in) }\end{array}$ & $\begin{array}{l}\text { Width } \\
\text { (in) }\end{array}$ & $\begin{array}{r}\text { UTM } \\
\text { Northing } \\
(\mathrm{m})\end{array}$ & $\begin{array}{r}\text { UTM } \\
\text { Easting } \\
(\mathrm{m})\end{array}$ \\
\hline PP 665 & 002 & ROOM & $7.9 E+02$ & $7.3 E+02$ & $3.0 E+01$ & 4915.0 & 1. $4 \mathrm{E}+01$ & & & \\
\hline & 010 & AMBIENT & & & $1.0 E+01$ & 4915.0 & $3.8 \mathrm{E}-01$ & & & \\
\hline 666 & $7.0 E+01$ & & & & $1.0 E+01$ & 4917.0 & $2.0 E+00$ & & 4825758.816 & 343784.197 \\
\hline & 7. $. \mathrm{EE}+01$ & & & & $1.5 E+01$ & 4917.0 & $1.0 E+00$ & & 4825756.965 & 343784.154 \\
\hline & 039 & ROOM & & & $3.5 E+01$ & 4915.0 & $1.2 E+02$ & $1.2 E+02$ & 4825781.535 & 343789.439 \\
\hline & $048 \mid 7.0 E+01$ & & & & $4.4 E+01$ & 4917.0 & $1.0 E+00$ & & 4825785.672 & 343823.875 \\
\hline 679 & 002 & & 1. $2 \mathrm{E}+03$ & $6.9 E+02$ & $1.7 \mathrm{E}+01$ & 4915.0 & $5.0 E+00$ & & & \\
\hline & 003 & & $1.2 E+03$ & $6.9 E+02$ & $1.7 E+01$ & 4915.0 & $5.0 E+00$ & & & \\
\hline 684 & 001 & ROOM & $1.6 \mathrm{E}+04$ & $3.7 E+03$ & $5.0 E+01$ & 4915.0 & $2.8 \mathrm{E}+01$ & & 4825853.159 & 343802.104 \\
\hline & 002 & ROOM & $4.7 E+03$ & $2.7 E+03$ & $4.0 E+01$ & 4915.0 & $1.8 \mathrm{E}+01$ & & 4825857.587 & 343797.494 \\
\hline 687 & 010 & AMBIENT & $5.0 E+02$ & $3.4 E+03$ & $6.0 E+01$ & 4917.0 & $5.0 E+00$ & & 4825452.931 & 344089.512 \\
\hline & 011 & AMBIENT & $5.0 E+02$ & $3.4 E+03$ & $6.0 E+01$ & 4917.0 & $5.0 E+00$ & & 4825439.049 & 344089.190 \\
\hline & 026 & & & & $2.2 E+01$ & 4917.0 & $2.0 E+01$ & & 4825423.484 & 344108.131 \\
\hline & 033 & AMBIENT & $8.4 E+02$ & $3.1 E+03$ & $6.0 E+01$ & 4917.0 & $7.0 E+00$ & & 4825439.227 & 344094.805 \\
\hline & 034 & AMBIENT & $8.4 E+02$ & $3.1 E+03$ & $6.0 E+01$ & 4917.0 & $7.0 E+00$ & & 4825452.806 & 344094.896 \\
\hline & 1 $7.0 E+01$ & & & & $6.0 E+01$ & 4917.0 & $4.8 \mathrm{E}+01$ & & 4825455.882 & 344108.659 \\
\hline & 049 & & & & & & & & & \\
\hline 694 & $5.3 E+01$ & & & & $2.3 \mathrm{E}+01$ & 4920.0 & $1.2 \mathrm{E}+01$ & & 4825988.668 & 343961.015 \\
\hline & $5.3 E+01$ & & & & $2.3 \mathrm{E}+01$ & 4920.0 & $1.2 E+01$ & & 4825988.051 & 343961.001 \\
\hline & 009 & ROOM & & & $2.1 E+01$ & 4915.0 & $6.5 E+00$ & & 4825979.188 & 343957.204 \\
\hline & $010 \mid 5.3 E+01$ & & & & $2.3 E+01$ & 4920.0 & $1.2 E+01$ & & 4825976.334 & 343960.504 \\
\hline 698 & 004 & ROOM & & & $5.0 E+00$ & 4915.0 & $1.2 E+01$ & & & \\
\hline & 0061 & ROOM & & & $8.0 \mathrm{E}+00$ & 4915.0 & 1. $O E+01$ & $1.2 E+01$ & & \\
\hline & 009 & & $8.5 E+02$ & $6.4 \mathrm{E}+02$ & $1.8 \mathrm{E}+01$ & 4915.0 & $4.0 E+00$ & & & \\
\hline & 010 & & $8.5 E+02$ & $6.4 E+02$ & $1.8 \mathrm{E}+01$ & 4915.0 & $4.0 E+00$ & & & \\
\hline & 016 & & $8.5 E+02$ & $6.4 E+02$ & $1.8 E+01$ & 4915.0 & $4.0 E+00$ & & & \\
\hline & 017 & & $8.5 E+02$ & $6.4 E+02$ & $1.8 E+01$ & 4915.0 & $4.0 E+00$ & & & \\
\hline- & 0181 & & $8.5 E+02$ & $6.4 E+02$ & $1.8 E+01$ & 4915.0 & $4.0 E+00$ & & & \\
\hline $701 \mathrm{~A}$ & 001 & & & & $3.4 E+01$ & 4915.0 & $6.0 E+00$ & & 4826119.362 & 343875.854 \\
\hline
\end{tabular}




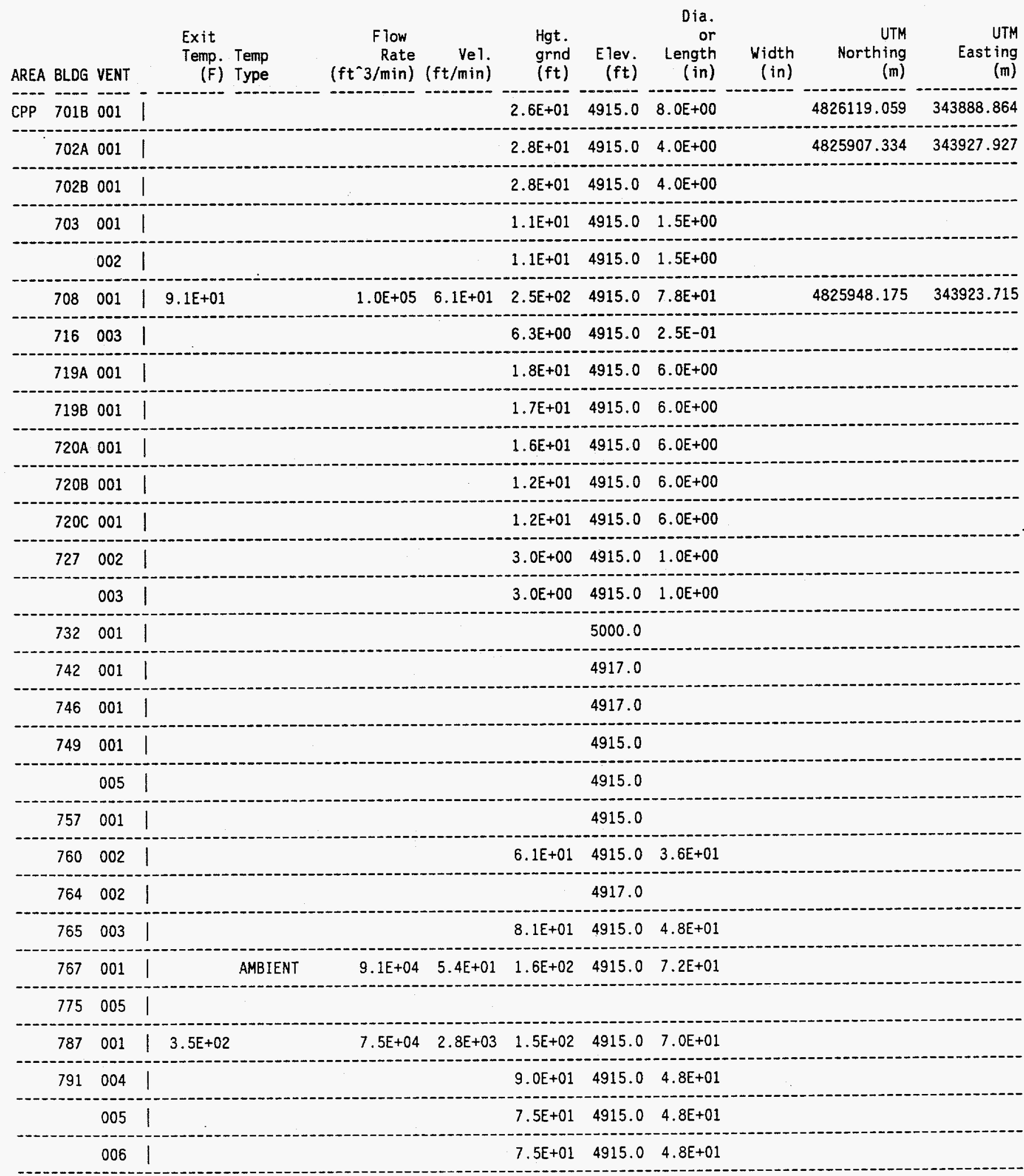




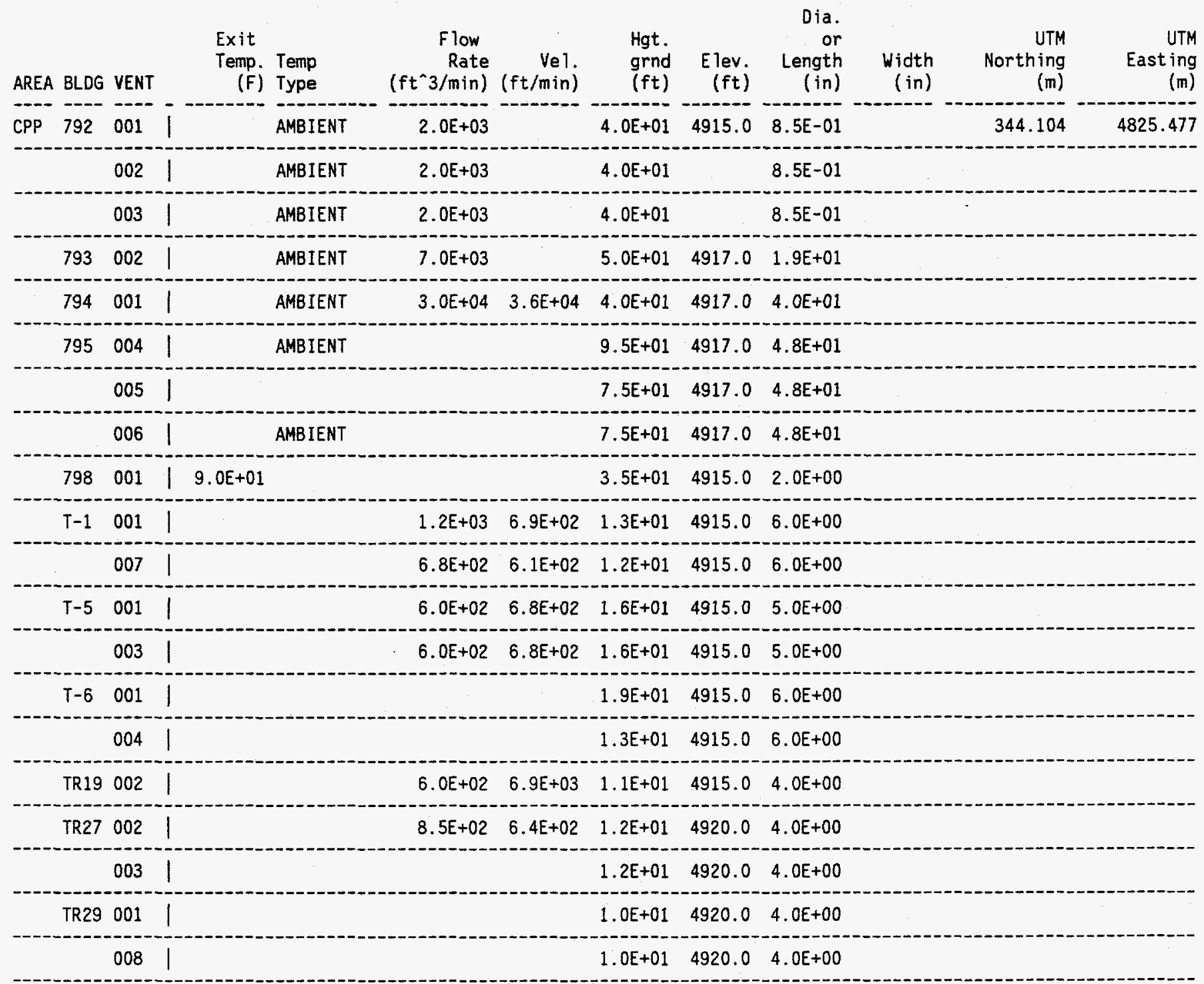




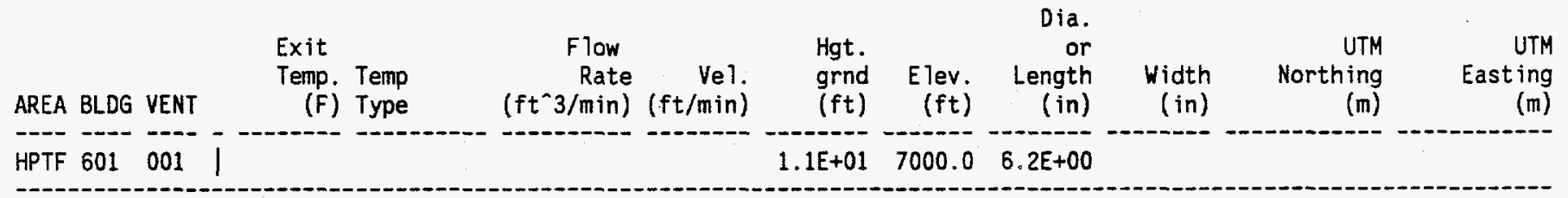




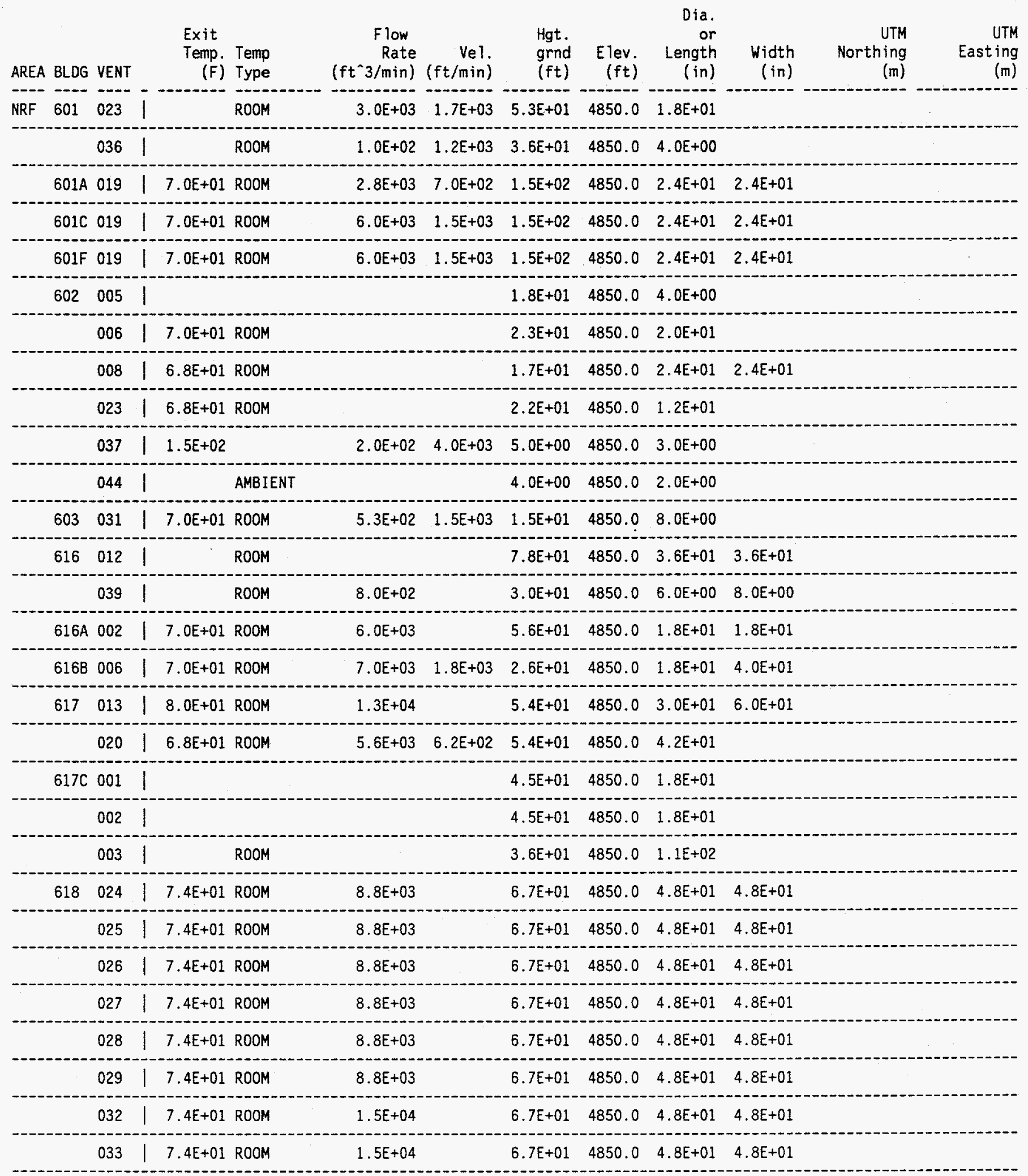




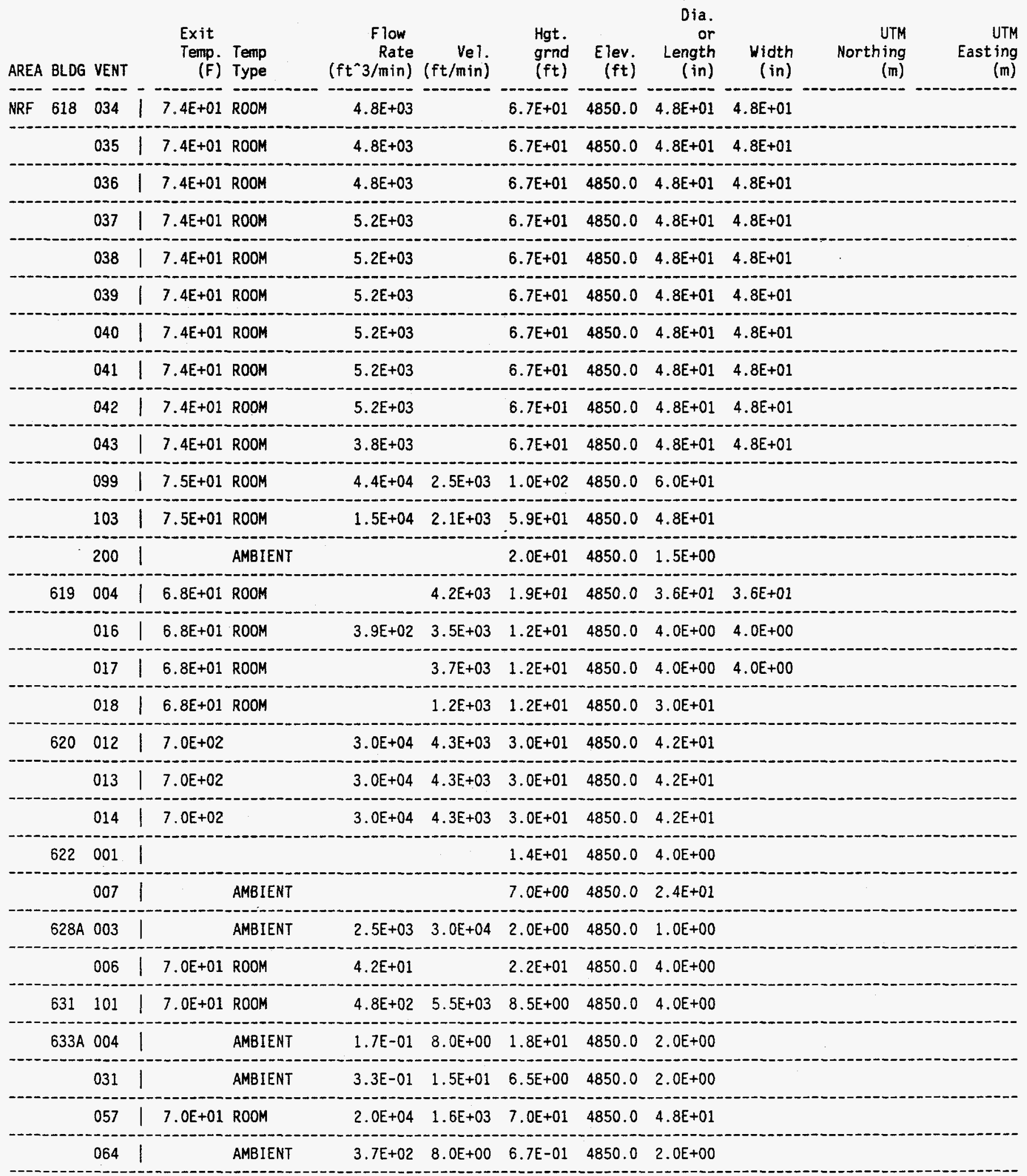




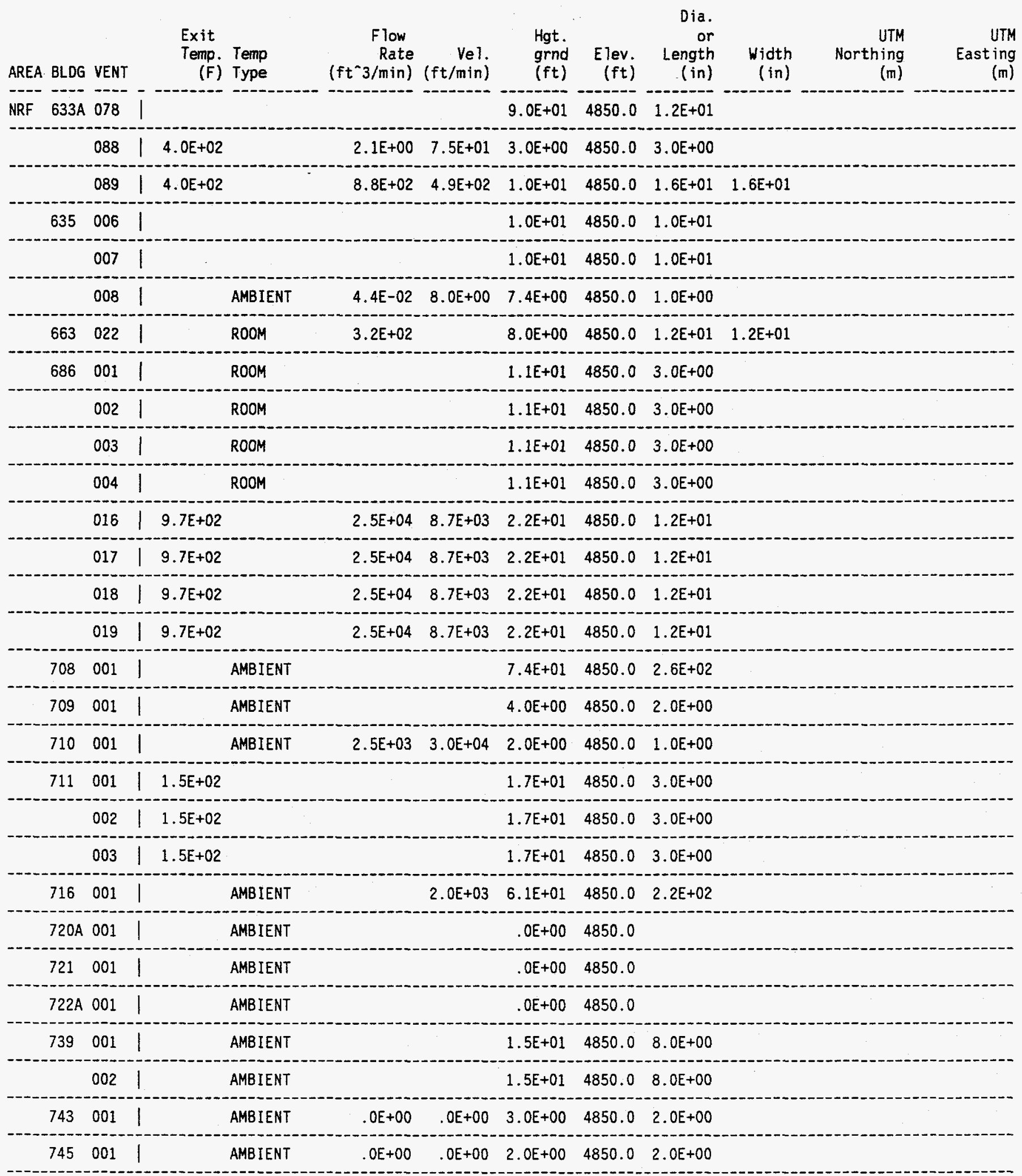




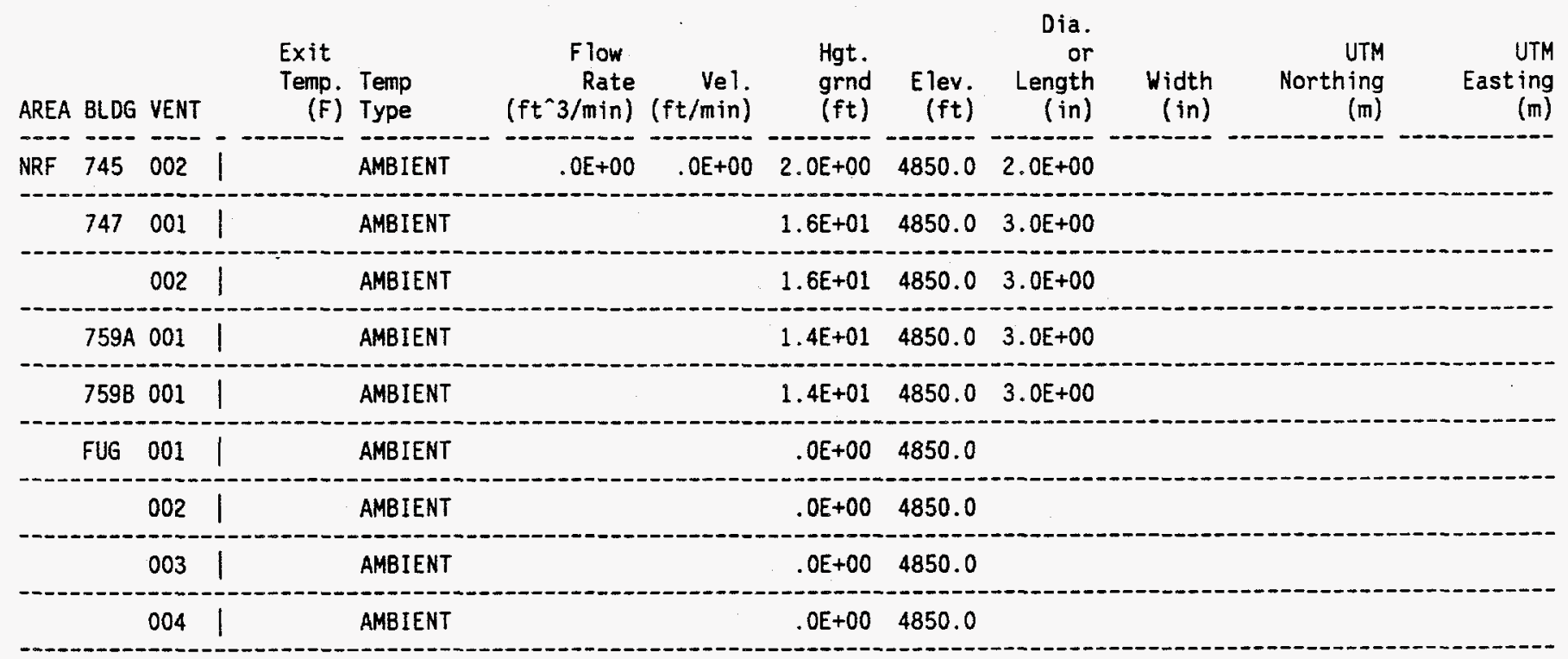




\begin{tabular}{|c|c|c|c|c|c|c|c|c|c|c|c|c|}
\hline AREA & BLDG & VENT & $\begin{array}{l}\text { Exit } \\
\text { Temp. } \\
\text { (F) }\end{array}$ & $\begin{array}{l}\text { Temp } \\
\text { Type }\end{array}$ & $\begin{array}{r}\text { Flow } \\
\text { Rate } \\
\left(\mathrm{ft}^{\wedge} 3 / \mathrm{min}\right)\end{array}$ & $\begin{array}{r}\text { Vel. } \\
(\mathrm{ft} / \mathrm{min})\end{array}$ & $\begin{array}{l}\text { Hgt. } \\
\text { grnd } \\
(f t)\end{array}$ & $\begin{array}{l}\text { Elev. } \\
\text { (ft) }\end{array}$ & $\begin{array}{r}\text { Dia. } \\
\text { or } \\
\text { Length } \\
\text { (in) }\end{array}$ & $\begin{array}{l}\text { Width } \\
\text { (in) }\end{array}$ & $\begin{array}{r}\text { UTM } \\
\text { Northing } \\
(\mathrm{m})\end{array}$ & $\begin{array}{r}\text { UTM } \\
\text { Easting } \\
(\mathrm{m})\end{array}$ \\
\hline ER & 601 & 010 & $2.5 E+02$ & & 3. $.0 E+02$ & $6.8 E+02$ & $2.2 E+01$ & & $1.0 E+00$ & & 4823154.517 & 349113.613 \\
\hline & $601 \mathrm{~A}$ & 010 & $2.5 \mathrm{E}+02$ & & $3.0 E+02$ & 4. $0 E+02$ & 2. $1 E+01$ & & 1. $2 E+01$ & & 4823341.118 & 349022.563 \\
\hline & 609 & 006 & $5.4 E+02$ & & $3.0 E+02$ & 1. $6 \mathrm{E}+02$ & 1. $4 E+01$ & & $6.0 \mathrm{E}+00$ & & 4823482.348 & 349847.312 \\
\hline & & 010 & & ROOM & & $.0 E+00$ & $1.4 E+01$ & & $1.3 E+00$ & & 4823480.522 & 349846.148 \\
\hline & 612 & 006 & $2.5 E+02$ & & $2.4 E+02$ & $4.5 E+02$ & $2.8 \mathrm{E}+01$ & & 1. $.0 E+01$ & & 4824140.448 & 349205.191 \\
\hline & 613 & 009 & $2.5 E+02$ & & $4.5 E+02$ & $1.4 E+02$ & $5.5 E+01$ & 4976.0 & 1. $2 \mathrm{E}+01$ & & 4819040.122 & 344789.180 \\
\hline & 619 & 015 & 2. $5 E+02$ & & $5.0 E+01$ & 1. $4 \mathrm{E}+\mathrm{O} 2$ & $2.7 \mathrm{E}+01$ & 4922.0 & $8.0 E+00$ & & 4823404.306 & 349009.516 \\
\hline & & 016 & $2.5 E+02$ & & $1.3 E+02$ & $1.7 \mathrm{E}+02$ & 2. $6 E+01$ & 4922.0 & $1.2 E+01$ & & 4823406.658 & 349006.830 \\
\hline & 620 & 001 & & AMBIENT & $.0 E+00$ & $.0 E+O O$ & $7.6 E+00$ & 4922.0 & $5.0 \mathrm{E}-01$ & & 4823912.360 & 348580.029 \\
\hline & & 002 & & ROOM & $6.3 E+02$ & $7.5 E+02$ & $1.9 E+01$ & 4922.0 & $1.0 E+01$ & $.2 E+01$ & 4823901.598 & 348578.215 \\
\hline & & 016 & & ROOM & $5.0 E+03$ & 1. $6 \mathrm{E}+03$ & $7.5 E+01$ & 4922.0 & $2.0 E+01$ & & 4823914.611 & 48562.345 \\
\hline & & 023 & $4.5 E+02$ & & $5.8 E+02$ & $1.1 E+03$ & $1.2 E+01$ & 4922.0 & $1.0 E+01$ & & 4823912.644 & 348553.770 \\
\hline & & 041 & & ROOM & $6.6 E+02$ & $6.6 E+02$ & 1. $5 E+01$ & 4922.0 & $1.2 E+01$ & $.2 E+01$ & 4823892.966 & 348550.408 \\
\hline & 621 & 001 & & & & & $1.0 E+01$ & 4922.0 & $2.0 E+00$ & & 4824111.537 & 348476.524 \\
\hline & & 005 & & & & & $1.0 \mathrm{E}+01$ & 4922.0 & $3.0 \mathrm{E}+00$ & & 4824128.328 & 348469.602 \\
\hline & 622 & 003 & $.0 E+00$ & & $.0 E+\infty$ & $.0 E+O O$ & 4. $5 E+01$ & 4944.0 & $1.6 \mathrm{E}+01$ & & 4823456.989 & 349918.586 \\
\hline & 624 & 005 & & AMBIENT & & $.0 E+00$ & $4.0 E+00$ & 4922.0 & $5.0 E-01$ & & 4824134.796 & 348450.987 \\
\hline & 625 & 001 & & AMBIENT & & $.0 E+\infty 0$ & $1.0 E+01$ & 4922.0 & $1.2 E+01$ & & 4824066.972 & 348428.851 \\
\hline & & 002 & & AMBIENT & & $.0 E+00$ & $1.4 E+01$ & 4922.0 & $5.0 \mathrm{E}-01$ & & 4824069.800 & 348431.722 \\
\hline & & 004 & & AMBIENT & & $.0 E+00$ & $1.5 \mathrm{E}+01$ & 4922.0 & $5.0 \mathrm{E}-01$ & & 4824063.341 & 348433.054 \\
\hline & 626 & 004 & & & & & $1.1 E+01$ & 4922.0 & $4.0 E+00$ & & 4823344.479 & 349061.153 \\
\hline & & 005 & & AMBIENT & $.0 E+00$ & $.0 E+00$ & $1.3 \mathrm{E}+01$ & 4922.0 & $1.0 \mathrm{E}+00$ & & 4823345.452 & 349036.125 \\
\hline & 632 & 007 & $2.5 E+02$ & & $8.0 E+01$ & $1.5 E+02$ & $2.5 E+01$ & 4922.0 & $1.0 E+01$ & & 4823365.036 & 349090.326 \\
\hline & & 008 & $2.5 E+02$ & & $8.0 E+01$ & $1.5 E+02$ & $2.5 E+01$ & 4922.0 & $1.0 E+01$ & & 4823339.550 & 349094.793 \\
\hline & 705 & 001 & & AMBIENT & & $.0 E+00$ & $1.4 \mathrm{E}+01$ & 4944.0 & $3.0 E+00$ & & 4823718.366 & 349763.795 \\
\hline & 711 & 001 & & $A M B$ & & & & 4922.0 & & & & \\
\hline & 716 & 001 & & AMBIENT & & $.0 E+\infty 0$ & $4.5 E+00$ & 4976.0 & $2.0 \mathrm{E}+00$ & & 4822571.297 & 349605.555 \\
\hline & 722 & 001 & & AMBIENT & & $.0 E+00$ & $4.0 E+00$ & 4922.0 & $2.0 E+00$ & & 4824128.784 & 348494.453 \\
\hline & 730 & 001 & & AMBIENT & $.0 E+00$ & $.0 E+00$ & $1.2 E+01$ & 4922.0 & $3.0 E+00$ & & 4824099.015 & 348534.659 \\
\hline
\end{tabular}




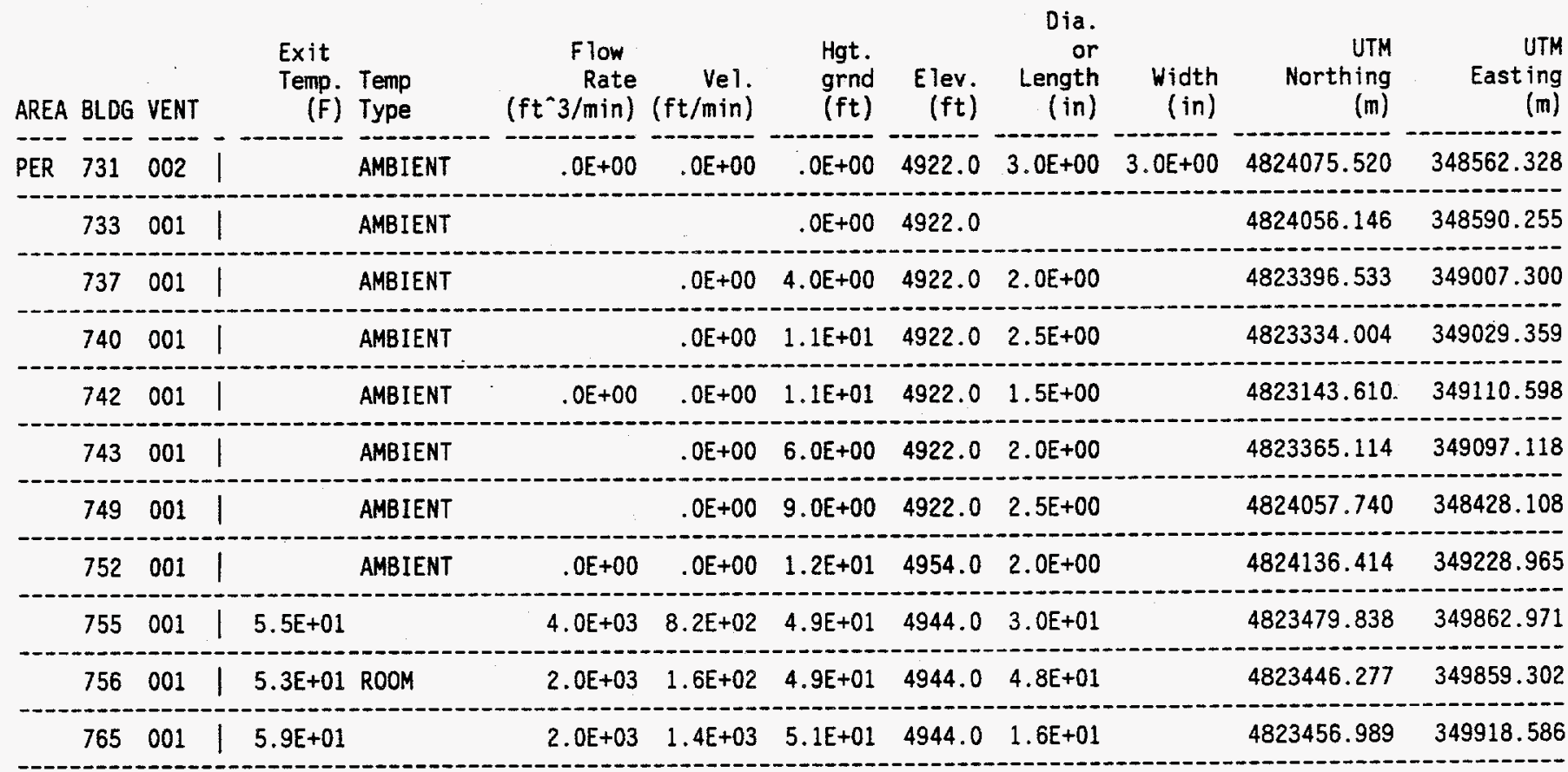


Update Survey for AIR EMISSIONS INVENTORY STACK PARAMETERS - 1993

Page: 30

\begin{tabular}{|c|c|c|c|c|c|c|c|c|c|c|c|}
\hline AREA BLDG & VENT & $\begin{array}{l}\text { Exit } \\
\text { Temp. } \\
\text { (F) }\end{array}$ & $\begin{array}{l}\text { Temp } \\
\text { Type }\end{array}$ & $\begin{array}{r}\text { Flow } \\
\text { Rate } \\
\text { (ft^3/min) }\end{array}$ & $\begin{array}{r}V e 1 \\
\text { (ft/min) }\end{array}$ & $\begin{array}{l}\text { Hgt. } \\
\text { grnd } \\
\text { (ft) }\end{array}$ & $\begin{array}{l}\text { Elev. } \\
(\mathrm{ft})\end{array}$ & $\begin{array}{r}\text { Dia. } \\
\text { or } \\
\text { Length } \\
\text { (in) }\end{array}$ & $\begin{array}{l}\text { Width } \\
\text { (in) }\end{array}$ & $\begin{array}{r}\text { UTM } \\
\text { Northing } \\
(\mathrm{m})\end{array}$ & $\begin{array}{r}\text { UTM } \\
\text { East ing } \\
(\mathrm{m})\end{array}$ \\
\hline STF 601 & 039 & & AMBIENT & & & $3 E+01$ & & $6.0 E+00$ & & & \\
\hline
\end{tabular}




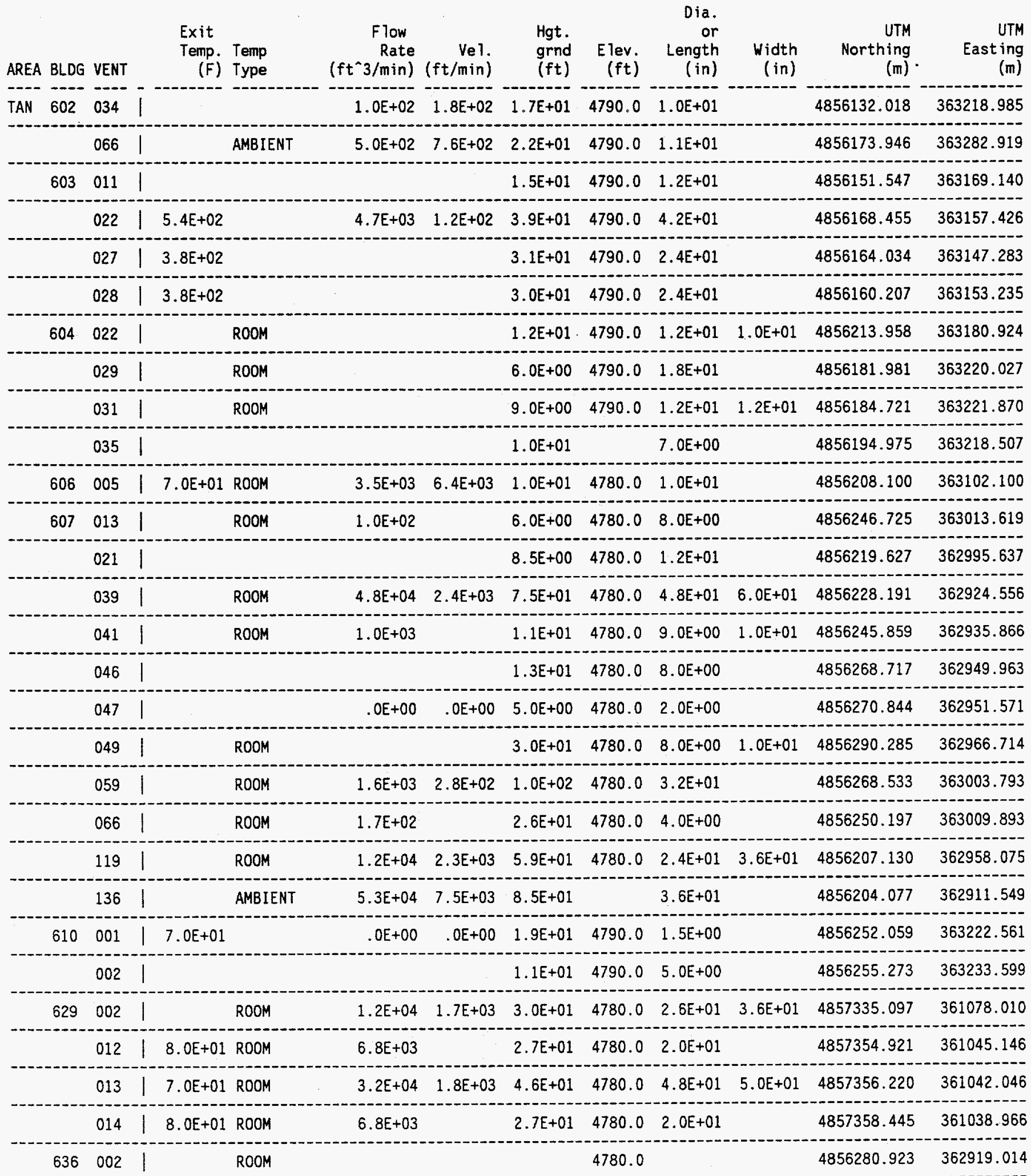




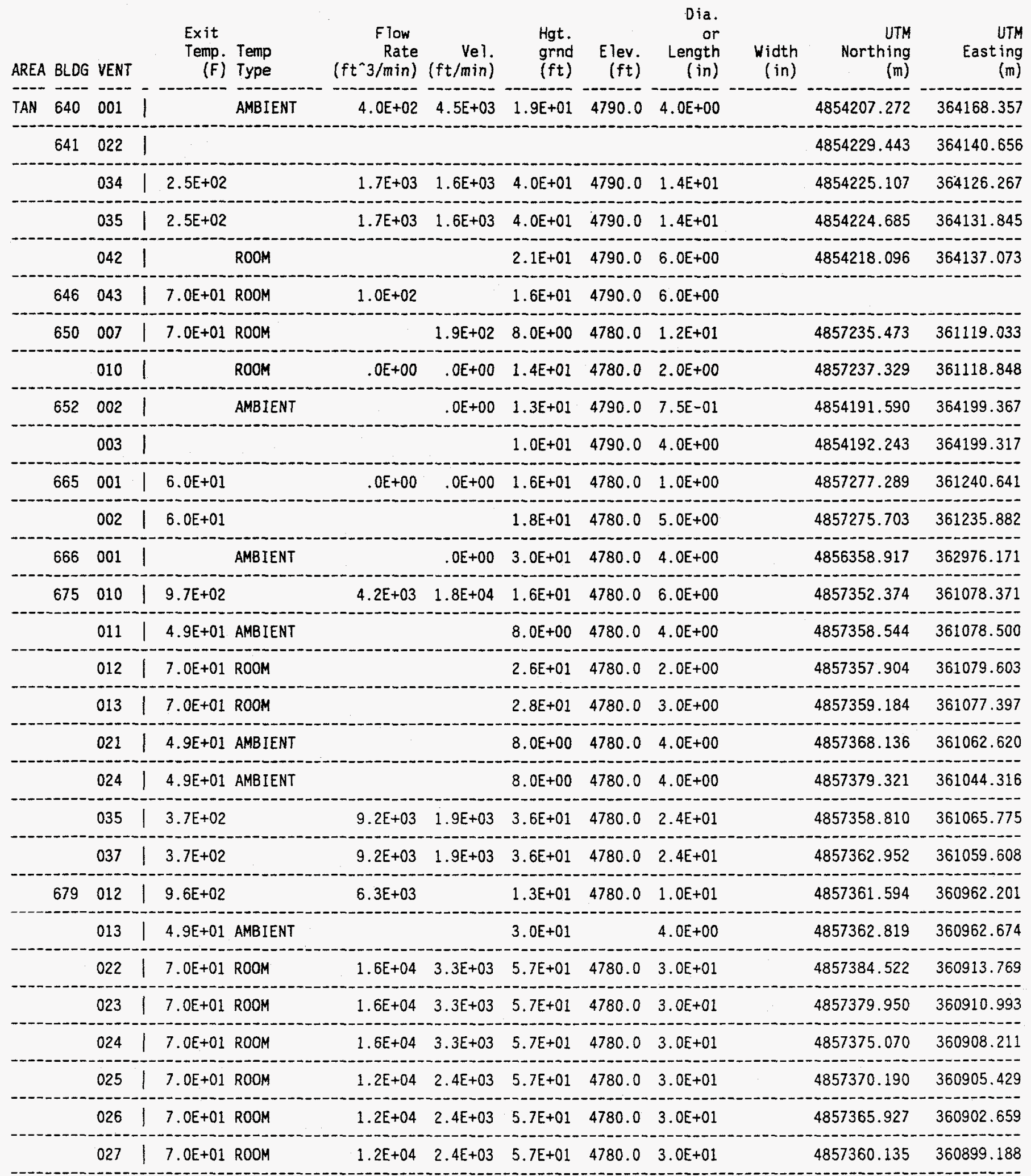




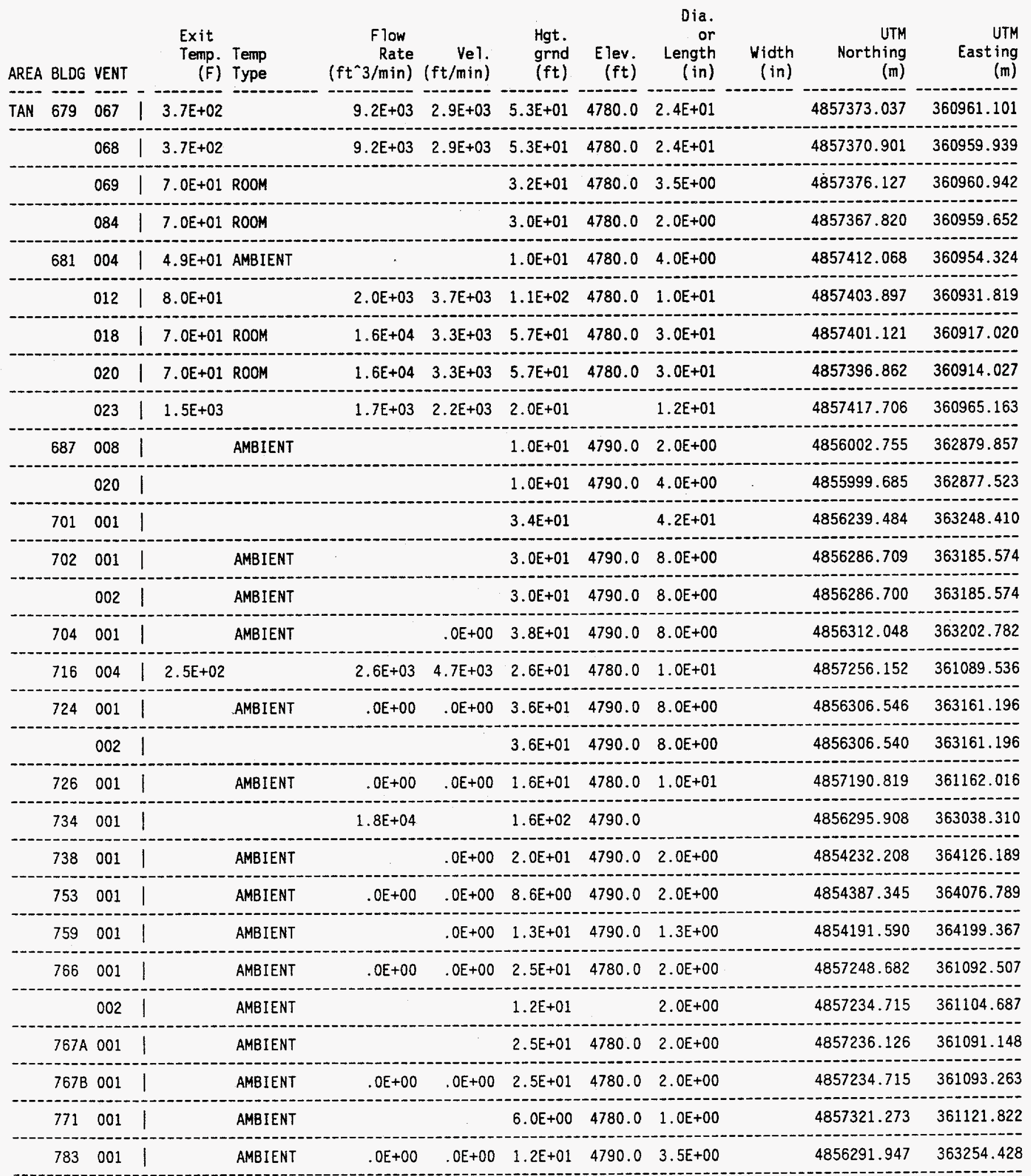




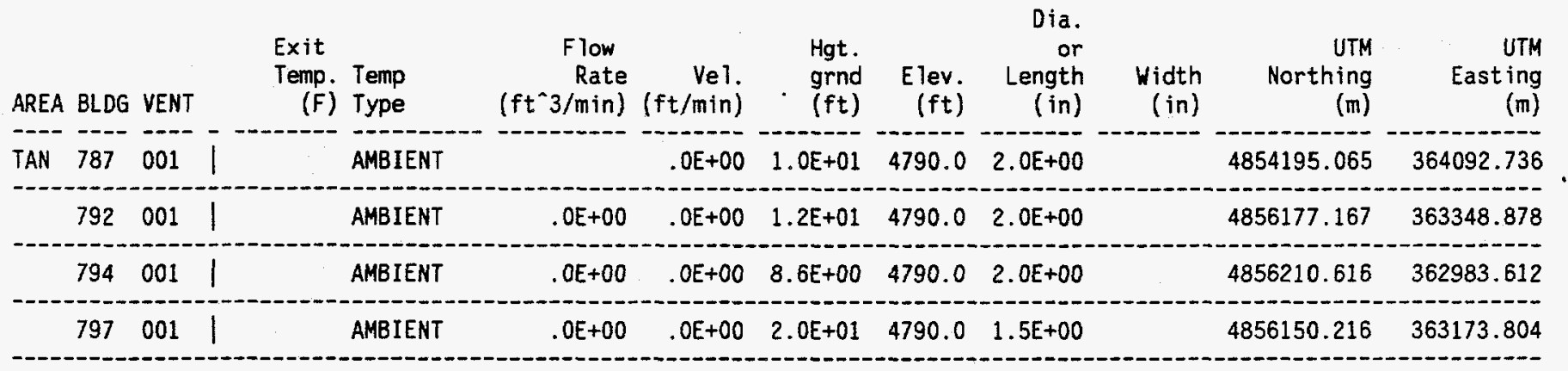




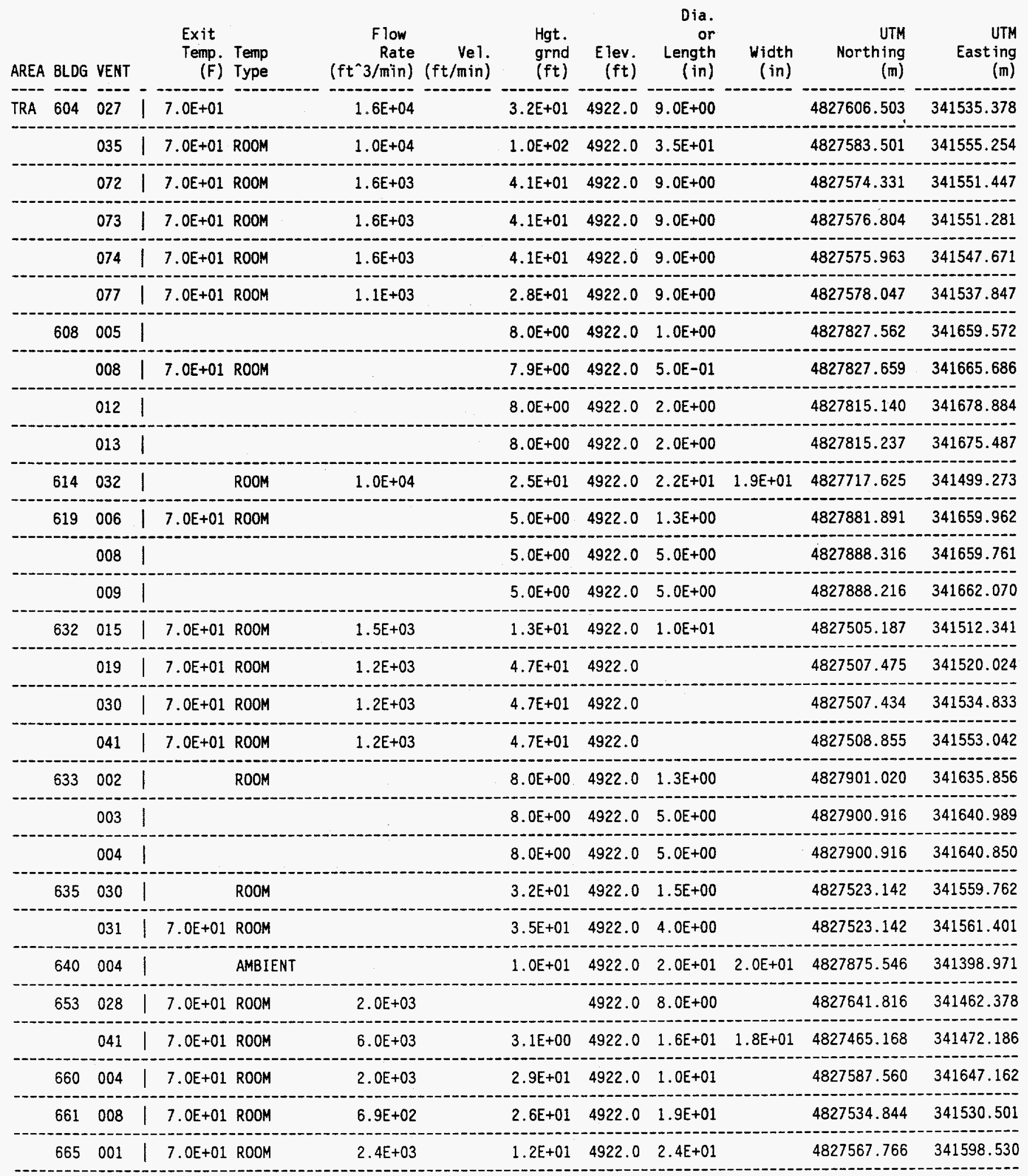




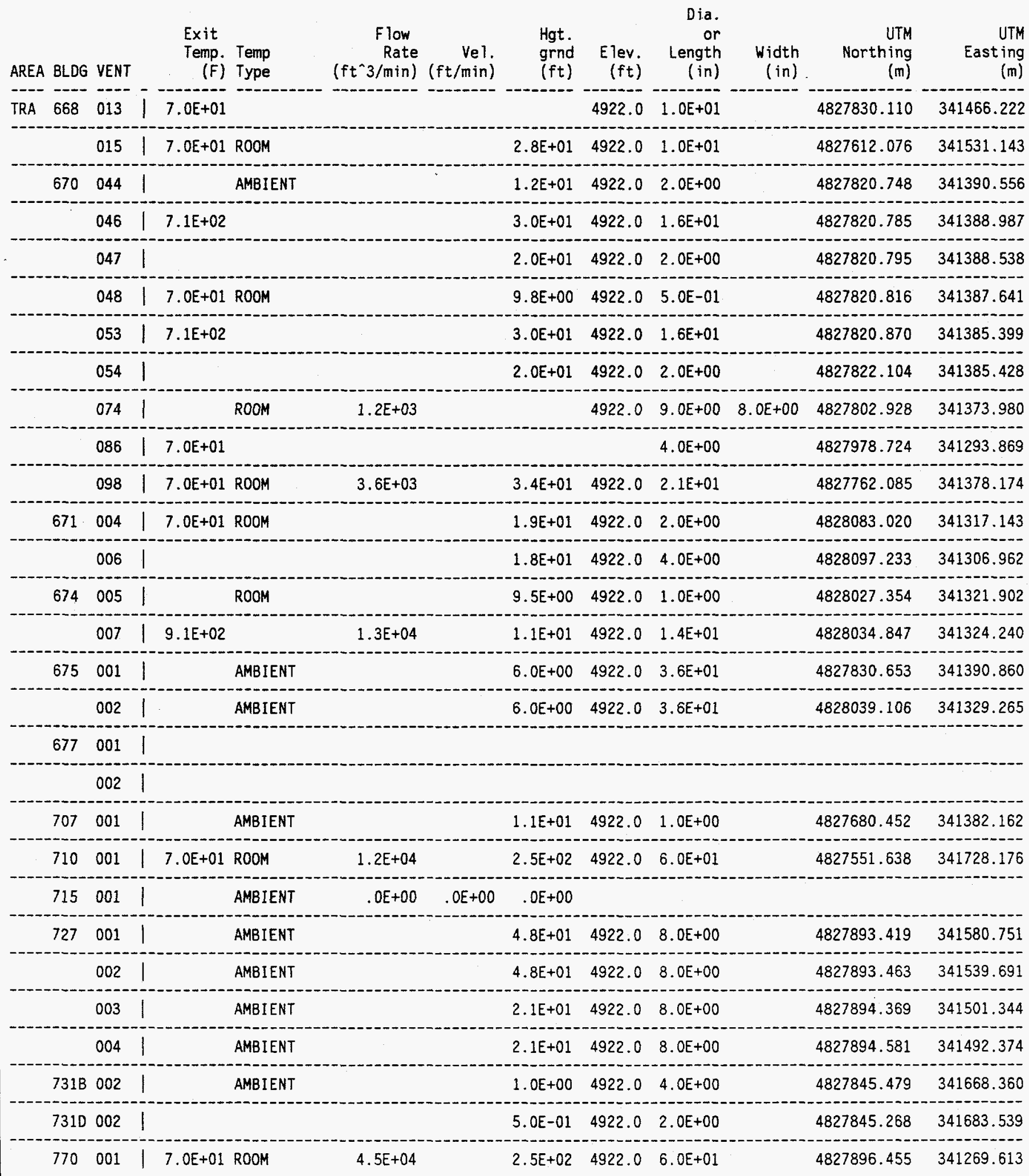




\begin{tabular}{|c|c|c|c|c|c|c|c|c|c|c|c|c|}
\hline AREA & BLDG & VENT & $\begin{array}{l}\text { Exit } \\
\text { Temp. } \\
\text { (F) }\end{array}$ & $\begin{array}{l}\text { Temp } \\
\text { Type }\end{array}$ & $\begin{array}{r}\text { Flow } \\
\text { Rate } \\
\text { (ft^3/min) }\end{array}$ & $\begin{array}{r}\text { Vel. } \\
(\mathrm{ft} / \mathrm{min})\end{array}$ & $\begin{array}{l}\text { Hgt. } \\
\text { grnd } \\
\text { (ft) }\end{array}$ & $\begin{array}{l}\text { Elev. } \\
(\mathrm{ft})\end{array}$ & $\begin{array}{r}\text { Dia. } \\
\text { or } \\
\text { Length } \\
\text { (in) }\end{array}$ & $\begin{array}{l}\text { Width } \\
\text { (in) }\end{array}$ & $\begin{array}{r}\text { UTM } \\
\text { Northing } \\
(\mathrm{m})\end{array}$ & $\begin{array}{r}\text { UTM } \\
\text { East ing } \\
(m)\end{array}$ \\
\hline TRA & 771 & 001 & & & & $\because$ & $2.0 E+01$ & 4922.0 & & & 4828118.629 & 341325.734 \\
\hline & 775 & 001 & & AMBIENT & & & $2.1 E+01$ & 4922.0 & $8.0 E+00$ & & 4827894.157 & 341510.314 \\
\hline
\end{tabular}




\begin{tabular}{|c|c|c|c|c|c|c|c|c|c|c|c|c|}
\hline AREA & BLDG & VENT & $\begin{array}{l}\text { Exit } \\
\text { Temp. } \\
\text { (F) }\end{array}$ & $\begin{array}{l}\text { Temp } \\
\text { Type }\end{array}$ & $\begin{array}{r}\text { Flow } \\
\text { Rate } \\
\left(\mathrm{ft}^{\wedge} 3 / \mathrm{min}\right)\end{array}$ & $\begin{array}{r}\text { Vel. } \\
(\mathrm{ft} / \mathrm{min})\end{array}$ & $\begin{array}{l}\text { Hgt. } \\
\text { grnd } \\
\text { (ft) }\end{array}$ & $\begin{array}{l}\text { Elev. } \\
(\mathrm{ft})\end{array}$ & $\begin{array}{r}\text { Dia. } \\
\text { or } \\
\text { Length } \\
\text { (in) }\end{array}$ & $\begin{array}{c}\text { Width } \\
\text { (in) }\end{array}$ & $\begin{array}{r}\text { UTM } \\
\text { Northing } \\
(\mathrm{m})\end{array}$ & $\begin{array}{r}\text { UTM } \\
\text { East ing } \\
(\mathrm{m})\end{array}$ \\
\hline WMF & 601 & 009 & & ROOM & 1. $3 E+02$ & $1.0 E+02$ & 2. $3 \mathrm{E}+01$ & 5005.0 & $1.2 E+01$ & & 4818209.142 & 335208.980 \\
\hline & 603 & 001 & & & & & $1.3 \mathrm{E}+01$ & 5005.0 & $6.0 E+00$ & & .4818238 .486 & 335293.992 \\
\hline & & 002 & & AMBIENT & & & $1.8 E+01$ & 5005.0 & $1.5 E+00$ & & 4818242.795 & 335293.448 \\
\hline & & 005 & & & & & $1.5 E+01$ & 5005.0 & $6.0 E+00$ & & 4818231.774 & 335296.441 \\
\hline & & 008 & & & & & $5.0 E+00$ & 5005.0 & $4.0 E+00$ & & 4818227.148 & 335303.425 \\
\hline & 610 & 003 & & & & & $2.5 E+01$ & 5005.0 & $3.0 E+00$ & & 4818036.135 & 335304.274 \\
\hline & & 004 & & & & & $2.6 \mathrm{E}+01$ & 5005.0 & $1.6 E+01$ & & 4818033.174 & 335304.155 \\
\hline & 612 & 001 & & & & & $4.0 E+00$ & 5005.0 & $2.5 E+00$ & & 4818270.977 & 335307.962 \\
\hline & & 004 & & & & & $1.5 E+01$ & 5005.0 & $1.0 E+01$ & $1.0 E+01$ & 4818270.429 & 335308.906 \\
\hline & 615 & 001 & & AMBIENT & $4.9 E+03$ & $2.6 E+03$ & $1.5 E+01$ & 5005.0 & $1.4 \mathrm{E}+01$ & $2.0 E+01$ & 4818097.521 & 335298.751 \\
\hline & 640 & 001 & & & $5.0 E+02$ & & $2.5 E+01$ & 4915.0 & $4.0 E+00$ & & 4818025.313 & 334733.266 \\
\hline & 700 & 002 & & & $4.0 \mathrm{E}+03$ & & $1.0 E+\infty 0$ & 5005.0 & $4.8 E+01$ & $3.6 E+01$ & 4818225.181 & 334696.125 \\
\hline & 711 & 001 & & & & & $7.0 E+00$ & 5005.0 & $2.0 E+00$ & & 4818262.318 & 335211.974 \\
\hline & & 004 & & & & & $1.3 E+01$ & 5005.0 & $1.0 E+01$ & $1.0 E+01$ & 4818058.479 & 335267.209 \\
\hline
\end{tabular}




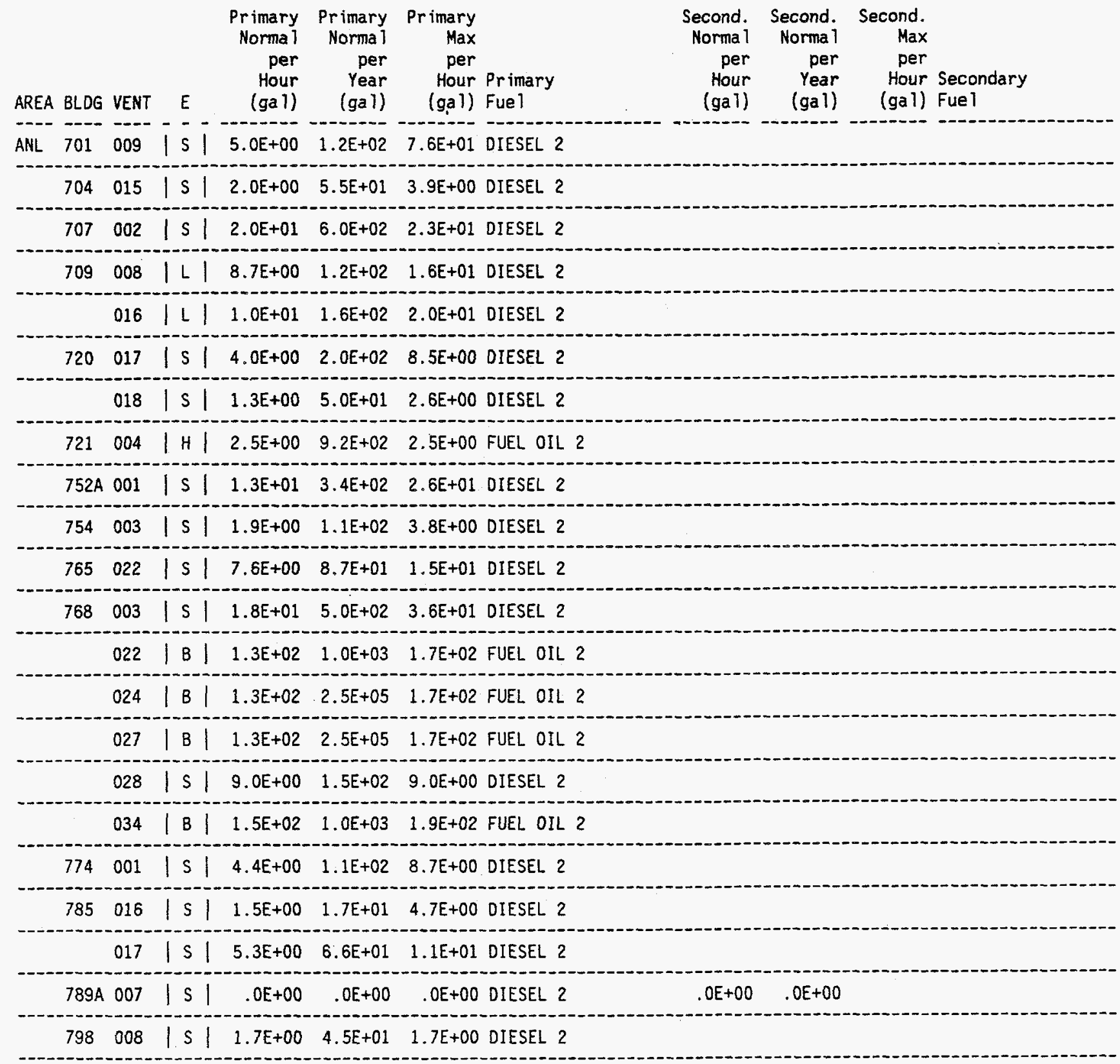




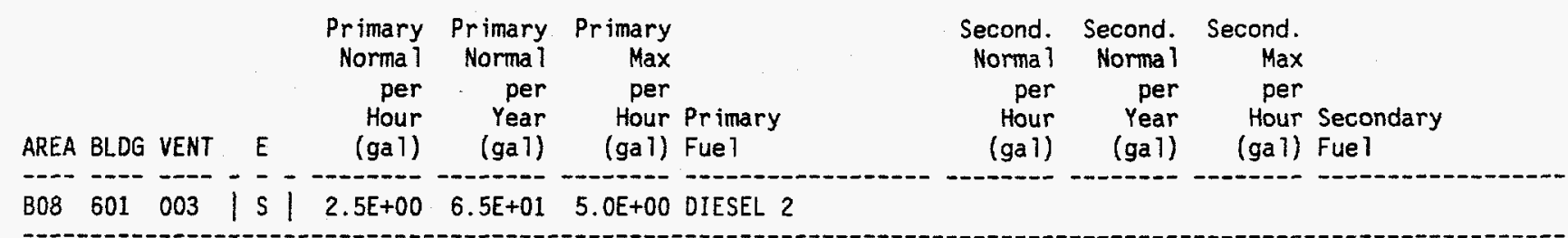

Update Survey for AIR EMISSIONS INVENTORY FUEL BURNING EQUIPMENT - $1993 \quad$ Page: 3 PART I

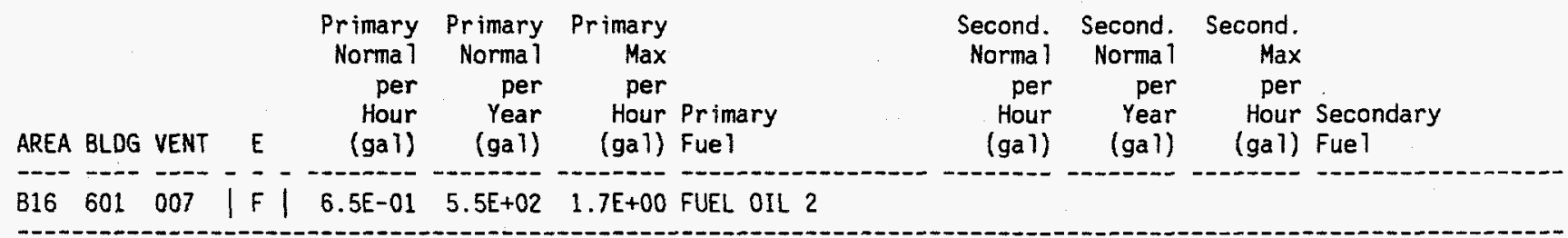

Update Survey for AIR EMISSIONS INVENTORY FUEL BURNING EQUIPMENT - $1993 \quad$ Page: 4 PART I

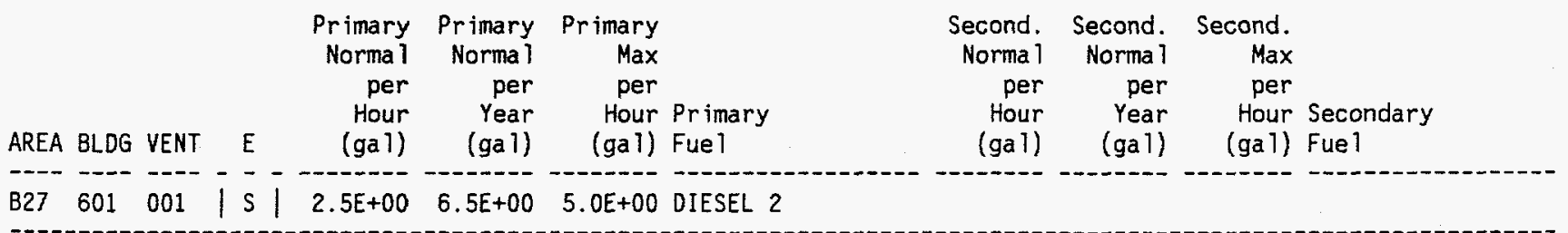


Update Survey for AIR EMISSIONS INVENTORY FUEL BURNING EQUIPMENT - 1993 PART I

Page: 5

\begin{tabular}{|c|c|c|c|c|c|c|c|c|c|c|c|}
\hline AREA & BLDG & VENT & $E$ & $\begin{array}{r}\text { Primary } \\
\text { Norma } 1 \\
\text { per } \\
\text { Hour } \\
\text { (ga 1) }\end{array}$ & $\begin{array}{r}\text { Primary } \\
\text { Norma I } \\
\text { per } \\
\text { Year } \\
\text { (ga } 1)\end{array}$ & $\begin{array}{r}\text { Primary } \\
\text { Max } \\
\text { per } \\
\text { Hour } \\
\text { (gal) }\end{array}$ & $\begin{array}{l} \\
\text { Primary } \\
\text { Fue 1 }\end{array}$ & $\begin{array}{c}\text { Second. } \\
\text { Normal } \\
\text { per } \\
\text { Hour } \\
\text { (gal) }\end{array}$ & $\begin{array}{r}\text { Second. } \\
\text { Norma } 1 \\
\text { per } \\
\text { Year } \\
(\text { ga } 1)\end{array}$ & $\begin{array}{c}\text { Second. } \\
\text { Max } \\
\text { per } \\
\text { Hour } \\
(\text { ga } 1)\end{array}$ & $\begin{array}{l}\text { Secondary } \\
\text { Fuel }\end{array}$ \\
\hline \multirow{27}{*}{ CFA } & 604 & 001 & $|s|$ & $2.0 E+00$ & $6.0 E+01$ & $1.0 E+01$ & DIESEL 2 & & & & \\
\hline & 607 & 004 & $|F|$ & $1.3 E-04$ & $8.6 E+02$ & $4.8 E+00$ & FUEL OIL 2 & & & & \\
\hline & 608 & 001 & | B | & $1.1 E+00$ & $1.1 E+04$ & $1.1 E+01$ & FUEL OIL 2 & & & & \\
\hline & 609 & 001 & $|s|$ & $5.7 E+00$ & $9.0 E+01$ & $1.5 E+01$ & DIESEL 2 & & & & \\
\hline & & 005 & $|B|$ & $1.1 E+00$ & $1.1 E+04$ & $1.5 E+01$ & FUEL OIL 2 & & & & \\
\hline & 613 & 003 & $|B|$ & $2.6 \mathrm{E}-01$ & $1.5 E+03$ & $2.4 E+00$ & FUEL OIL 2 & & & & \\
\hline & 617 & 024 & $|\mathrm{~B}|$ & $1.5 E+01$ & $1.2 E+04$ & $3.4 E+01$ & PROPANE E & & & & \\
\hline & 633 & 091 & $|s|$ & $4.1 \mathrm{E}+00$ & $2.1 E+02$ & $5.7 E+00$ & DIESEL 2 & & & & \\
\hline & 650 & 007 & $|B|$ & $2.1 E+00$ & $1.2 E+04$ & $3.5 \mathrm{E}+01$ & FUEL OIL 2 & & & & \\
\hline & 662 & 011 & $|B|$ & $3.3 E+00$ & $1.6 E+04$ & $2.4 E+01$ & FUEL OIL 2 & & & & PROPANE E \\
\hline & & 027 & $|B|$ & $4.2 E+00$ & $4.7 E+04$ & $3.6 \mathrm{E}+01$ & FUEL OIL 2 & & & & PROPANE E \\
\hline & 664 & 034 & $|H|$ & $2.5 \mathrm{E}+00$ & $6.0 E+02$ & $2.5 E+00$ & PROPANE E & & & & \\
\hline & & 035 & $|\mathrm{H}|$ & $2.5 E+00$ & $6.0 E+02$ & $2.5 E+00$ & PROPANE E & & & & \\
\hline & 665 & 028 & $|B|$ & $.0 E+00$ & $.0 E+\infty 0$ & $3.6 E+01$ & FUEL OIL 2 & $.0 E+00$ & $.0 E+00$ & & \\
\hline & & 029 & $|B|$ & 1. $4 E+01$ & $1.0 E+05$ & 8. $4 E+01$ & FUEL OIL 2 & & & & PROPANE E \\
\hline & & 030 & $|B|$ & $.0 E+0 O$ & $.0 E+00$ & $3.6 \mathrm{E}+01$ & FUEL OIL 2 & $.0 E+00$ & $.0 E+00$ & & PROPANE E \\
\hline & 668 & 006 & $|s|$ & $.0 E+00$ & $.0 E+00$ & $2.3 E+01$ & DIESEL 2 & $.0 E+00$ & $.0 E+00$ & & \\
\hline & & 023 & $|\mathrm{~B}|$ & 7.5E-01 & $6.6 E+03$ & $4.9 E+00$ & FUEL OIL 2 & & & & \\
\hline & 671 & 007 & $|B|$ & $9.9 E-01$ & 3. $6 E+04$ & $5.6 E+01$ & FUEL OIL 2 & & & & PROPANE E \\
\hline & & 008 & $|B|$ & $1.1 E+\infty 0$ & $3.6 E+04$ & $5.6 E+01$ & FUEL OIL 2 & & & & \\
\hline & 675 & 002 & $|s|$ & $7.5 E+00$ & $6.0 E+01$ & $9.8 E+00$ & FUEL OIL 2 & & & & \\
\hline & 679 & 007 & $|\mathrm{P}|$ & $5.7 E+00$ & $1.9 E+02$ & 7. $6 E+00$ & PROPANE E & & & & \\
\hline & 682 & 002 & $|s|$ & $1.1 E+01$ & $5.1 E+02$ & $2.1 E+01$ & DIESEL 2 & & & & \\
\hline & 688 & 043 & $|B|$ & $5.1 E+00$ & $5.1 E+04$ & $8.1 E+01$ & DIESEL 2 & & & & PROPANE E \\
\hline & & 044 & $|B|$ & $6.2 E+01$ & $2.6 E+04$ & $3.5 E+01$ & DIESEL 2 & & & & PROPANE E \\
\hline & & 047 & $|s|$ & $7.5 E+00$ & $9.0 E+01$ & $1.5 E+01$ & DIESEL 2 & & & & \\
\hline & 751 & 004 & $|\mathrm{H}|$ & $.0 E+00$ & $.0 E+00$ & $.0 E+\infty 0$ & PROPANE E & & & & \\
\hline
\end{tabular}




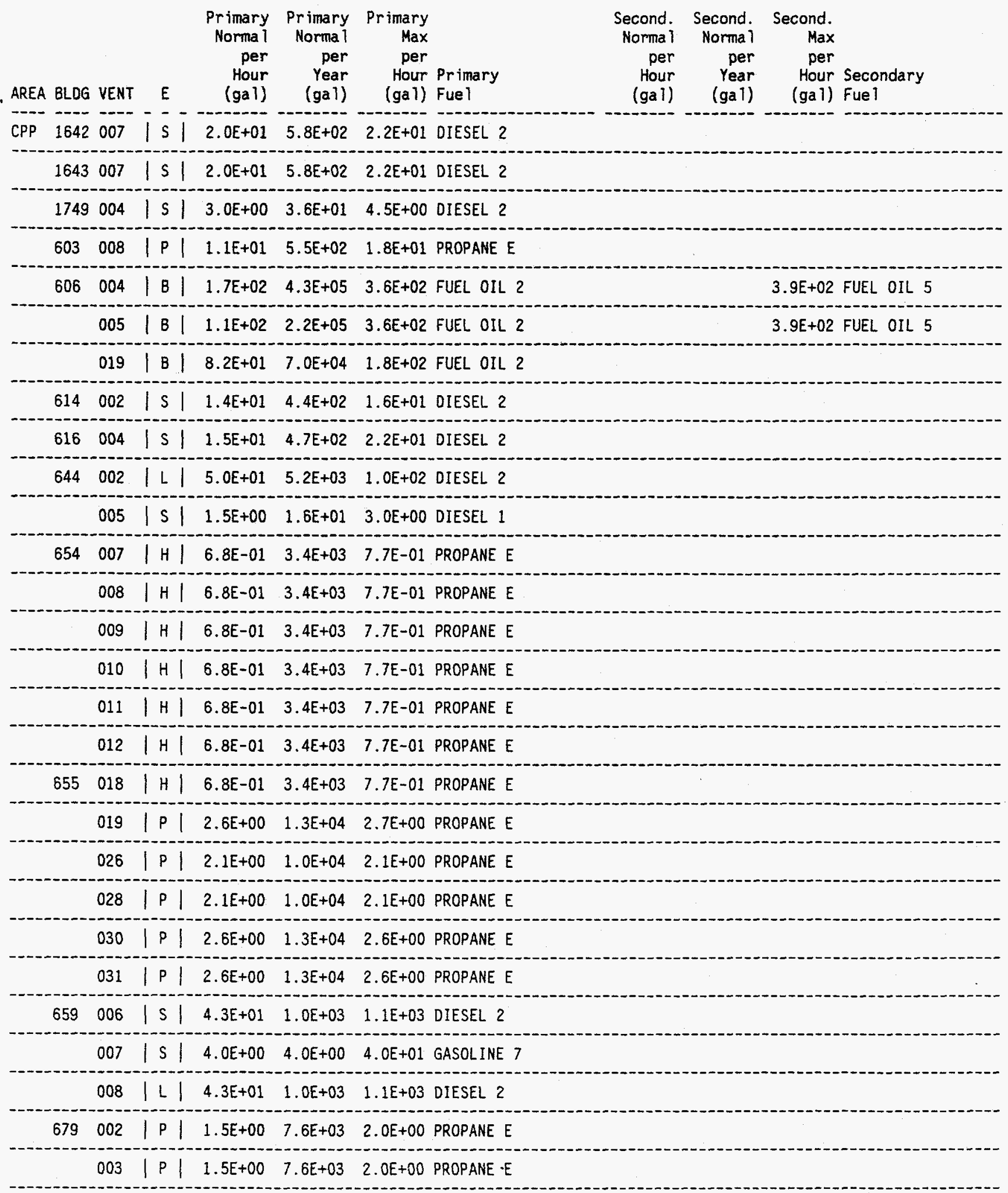




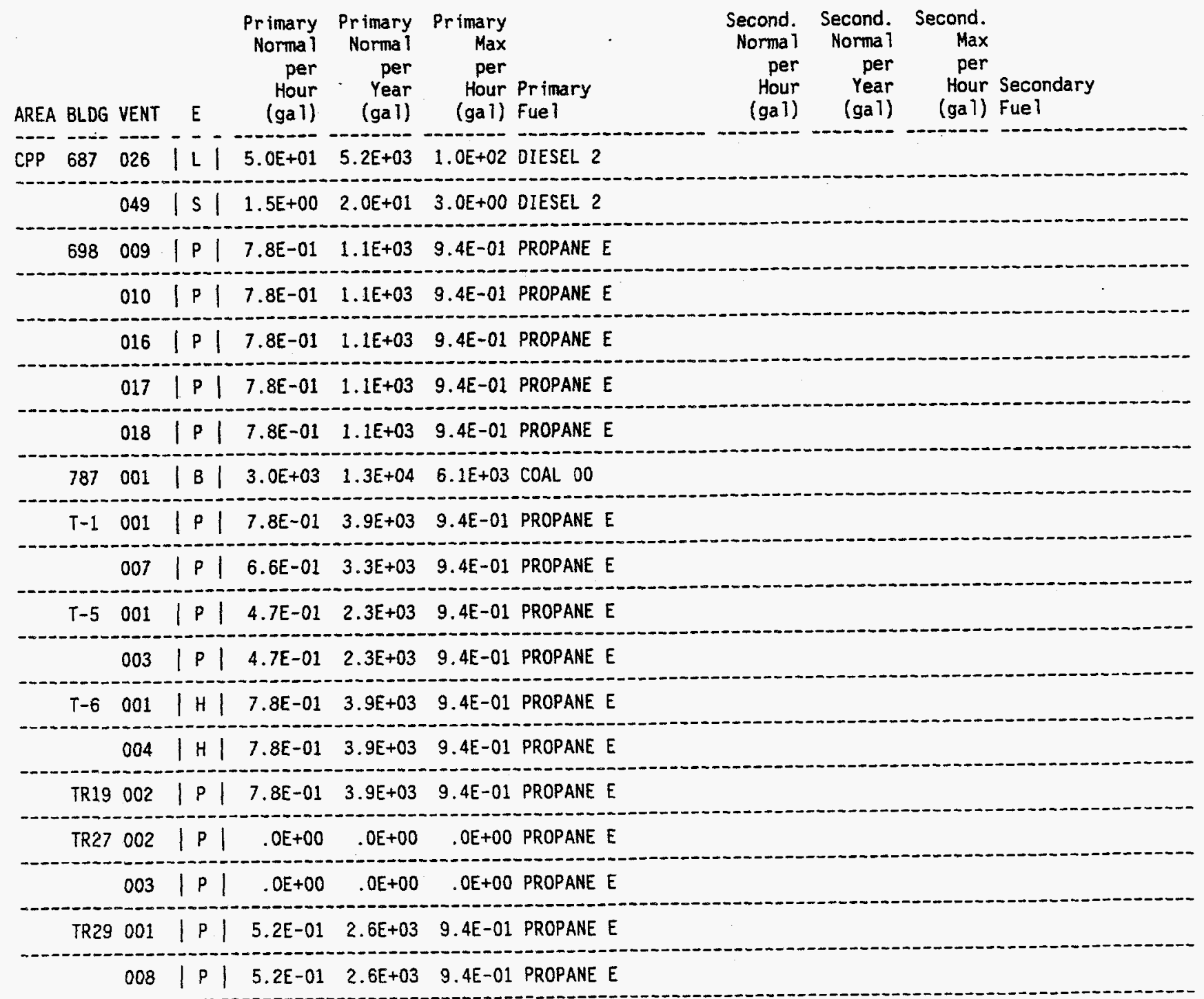


Update Survey for AIR EMISSIONS INVENTORY FUEL BURNING EQUIPMENT - 1993 PART I
Primary Primary Primary Norma I Normal Max per per per
Hour Year Hour Primary (gal) (gal) (gal) Fuel

AREA BLDG VENT E HPTF $601001|P| 3.5 E+01 \quad 1.5 E+02$

\author{
Second. Second. Second. \\ Norma 1 Norma 1 Max \\ per per per \\ Hour Year Hour Secondary \\ (gal) (gal) (gal) Fuel
}




\begin{tabular}{|c|c|c|c|c|c|c|c|c|c|c|}
\hline AREA & BLDG & VENT & $E$ & $\begin{array}{r}\text { Primary } \\
\text { Normal } \\
\text { per } \\
\text { Hour } \\
\text { (gal) }\end{array}$ & $\begin{array}{r}\text { Primary } \\
\text { Norma } 1 \\
\text { per } \\
\text { Year } \\
\text { (gal) }\end{array}$ & $\begin{array}{l}\text { Primary } \\
\text { Max } \\
\text { per } \\
\text { Hour Primary } \\
\text { (gal) Fuel }\end{array}$ & $\begin{array}{r}\text { Second. } \\
\text { Norma } 1 \\
\text { per } \\
\text { Hour } \\
(\text { gal) }\end{array}$ & $\begin{array}{r}\text { Second. } \\
\text { Norma } 1 \\
\text { per } \\
\text { Year } \\
\text { (ga 1) }\end{array}$ & $\begin{array}{r}\text { Second. } \\
\text { Max } \\
\text { per } \\
\text { Hour } \\
\text { (gal) }\end{array}$ & $\begin{array}{l}\text { Secondary } \\
\text { Fue } 1\end{array}$ \\
\hline NRF & 602 & 005 & 51 & $1.2 E+01$ & $1.2 E+03$ & 1.2E+01 DIESEL 2 & & & & OIESEL 1 \\
\hline & $617 \mathrm{C}$ & 001 & $L$ & $5.0 E+01$ & 1. $3 E+04$ & 7. OE+01 DIESEL 2 & & & & DIESEL 1 \\
\hline & & 002 & $|L|$ & $5.0 E+01$ & $1.1 E+04$ & 7. OE+01 DIESEL 2 & & & & OIESEL 1 \\
\hline & 620 & 012 & B 1 & $1.6 E+02$ & $2.2 E+05$ & 4.5E+02 FUEL OIL 5 & $1.7 E+02$ & $7.9 E+03$ & $4.8 E+02$ & DIESEL 2 \\
\hline & & 013 & 18 & 1. $6 \mathrm{E}+02$ & $2.2 E+05$ & $4.5 E+02$ FUEL OIL 5 & $1.7 E+02$ & $7.9 E+03$ & $4.8 E+02$ & DIESEL 2 \\
\hline & & 014 & B 1 & $1.6 \mathrm{E}+02$ & $2.2 E+05$ & 4.5E+02 FUEL OIL 5 & $1.7 E+02$ & $7.9 E+03$ & $4.8 E+02$ & DIESEL 2 \\
\hline & 622 & 001 & $|s|$ & $1.2 E+01$ & $1.9 \mathrm{E}+02$ & 1. $2 E+01$ DIESEL 2 & & & & DIESEL 1 \\
\hline & $633 A$ & 078 & L & $3.8 \mathrm{E}+01$ & $4.0 E+03$ & 4.3E+01 DIESEL 2 & & & & DIESEL 1 \\
\hline & 635 & 006 & $s$ & $7.7 E+00$ & $4.0 E+02$ & $1.3 E+01$ DIESEL 2 & & & & DIESEL 1 \\
\hline & & 007 & $|s|$ & $7.7 E+00$ & $4.0 E+02$ & $1.3 \mathrm{E}+01$ DIESEL 2 & & & & DIESEL 1 \\
\hline & 686 & 016 & $L \mid$ & $7.0 E+01$ & $3.9 E+03$ & $9.0 E+01$ DIESEL 2 & & & & DIESEL 1 \\
\hline & & 017 & $|\mathrm{~L}|$ & $7.0 E+01$ & $3.9 E+03$ & $9.0 E+01$ DIESEL 2 & & & & DIESEL 1 \\
\hline & & 018 & $|L|$ & 7. $.0 E+01$ & $3.9 E+03$ & $9.0 E+01$ DIESEL 2 & & & & DIESEL 1 \\
\hline & & 019 & $|\mathrm{~L}|$ & $7.0 E+01$ & $3.9 E+03$ & 9.0E+01 DIESEL 2 & & & & DIESEL 1 \\
\hline
\end{tabular}




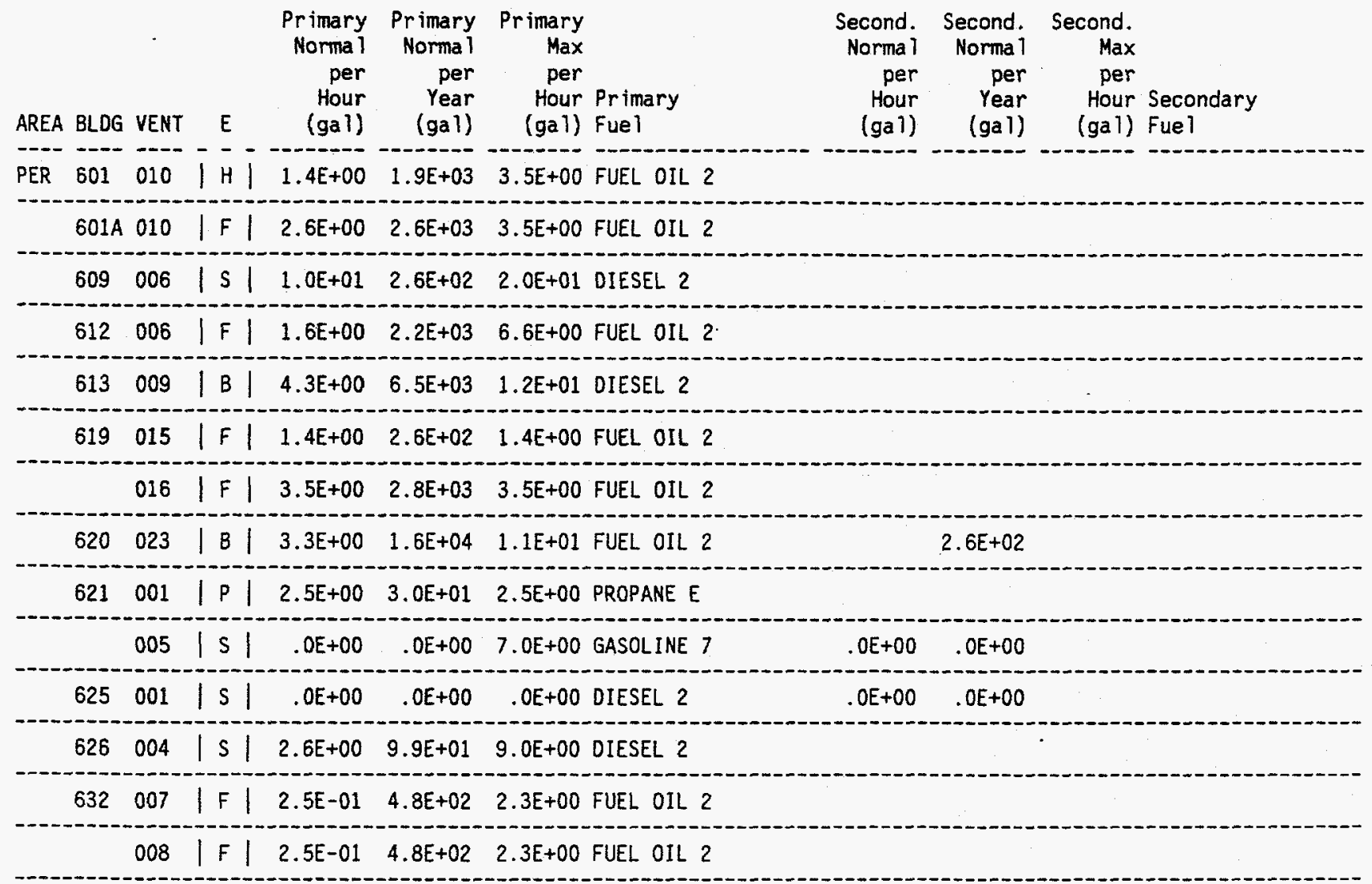




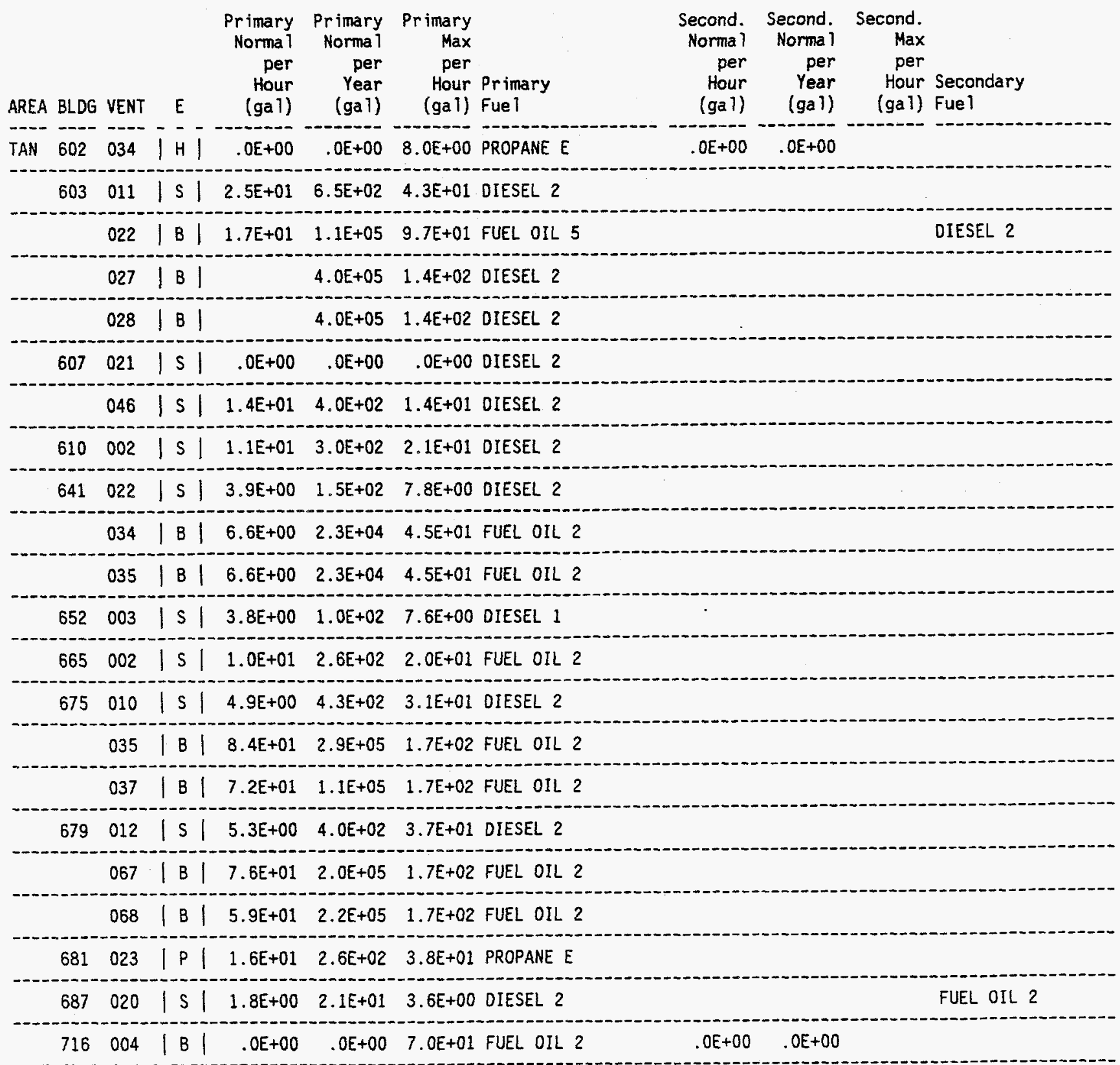


Update Survey for AIR EMISSIONS INVENTORY FUEL BURNING EQUIPMENT - 1993 PART I

\begin{tabular}{|c|c|c|c|c|c|c|c|c|c|c|}
\hline AREA & BLDG & VENT & $E$ & $\begin{array}{r}\text { Primary } \\
\text { Norma } 1 \\
\text { per } \\
\text { Hour } \\
\text { (gal) }\end{array}$ & $\begin{array}{r}\text { Primary } \\
\text { Norma } 1 \\
\text { per } \\
\text { Year } \\
\text { (gal) }\end{array}$ & $\begin{array}{r}\text { Primary } \\
\text { Max } \\
\text { per } \\
\text { Hour } \\
\text { (gal) }\end{array}$ & $\begin{array}{l}\text { Primary } \\
\text { Fuel }\end{array}$ & $\begin{array}{r}\text { Second. } \\
\text { Normal } \\
\text { per } \\
\text { Hour } \\
\text { (gal) }\end{array}$ & $\begin{array}{r}\text { Second. } \\
\text { Norma } 1 \\
\text { per } \\
\text { Year } \\
\text { (ga l) }\end{array}$ & $\begin{array}{l}\text { Second. } \\
\text { Max } \\
\text { per } \\
\text { Hour Secondary } \\
\text { (ga 1) Fue I }\end{array}$ \\
\hline \multirow[t]{7}{*}{ TRA } & 619 & 008 & $|s|$ & $1.0 \mathrm{E}+01$ & 5. $2 E+02$ & $1.0 E+01$ & DIESEL 1 & & & \\
\hline & & 009 & $|s|$ & $1.0 E+01$ & $5.2 E+02$ & $1.0 E+01$ & DIESEL 1 & & & \\
\hline & 633 & 003 & |s | & $1.0 E+01$ & $5.2 E+02$ & $1.0 E+01$ & DIESEL 1 & & & \\
\hline & & 004 & $|s|$ & $1.0 E+01$ & $5.2 E+02$ & $1.0 E+01$ & DIESEL 1 & & & \\
\hline & 670 & 046 & $|L|$ & $4.8 \mathrm{E}+01$ & $2.1 E+05$ & $6.0 E+01$ & DIESEL 2 & & & \\
\hline & & 053 & $|L|$ & $4.8 E+01$ & $2.1 E+05$ & $6.0 E+01$ & DIESEL 2 & & & \\
\hline & 674 & 007 & $|s|$ & $5.4 E+01$ & 1. $4 \mathrm{E}+03$ & $1.1 \mathrm{E}+02$ & DIESEL 2 & & & \\
\hline
\end{tabular}




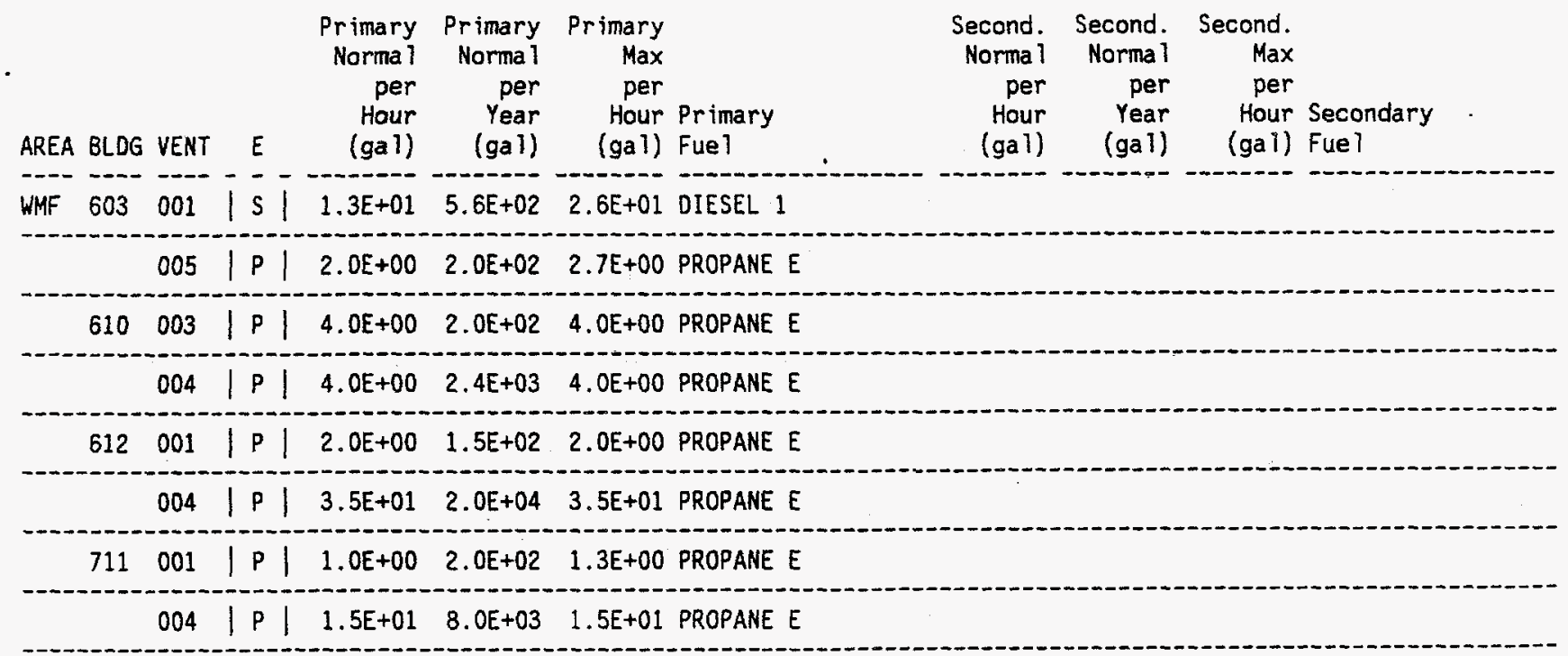


Update Survey for AIR EMISSIONS INVENTORY FUEL BURNING EQUIPMENT - 1993 Page: 1 PART II

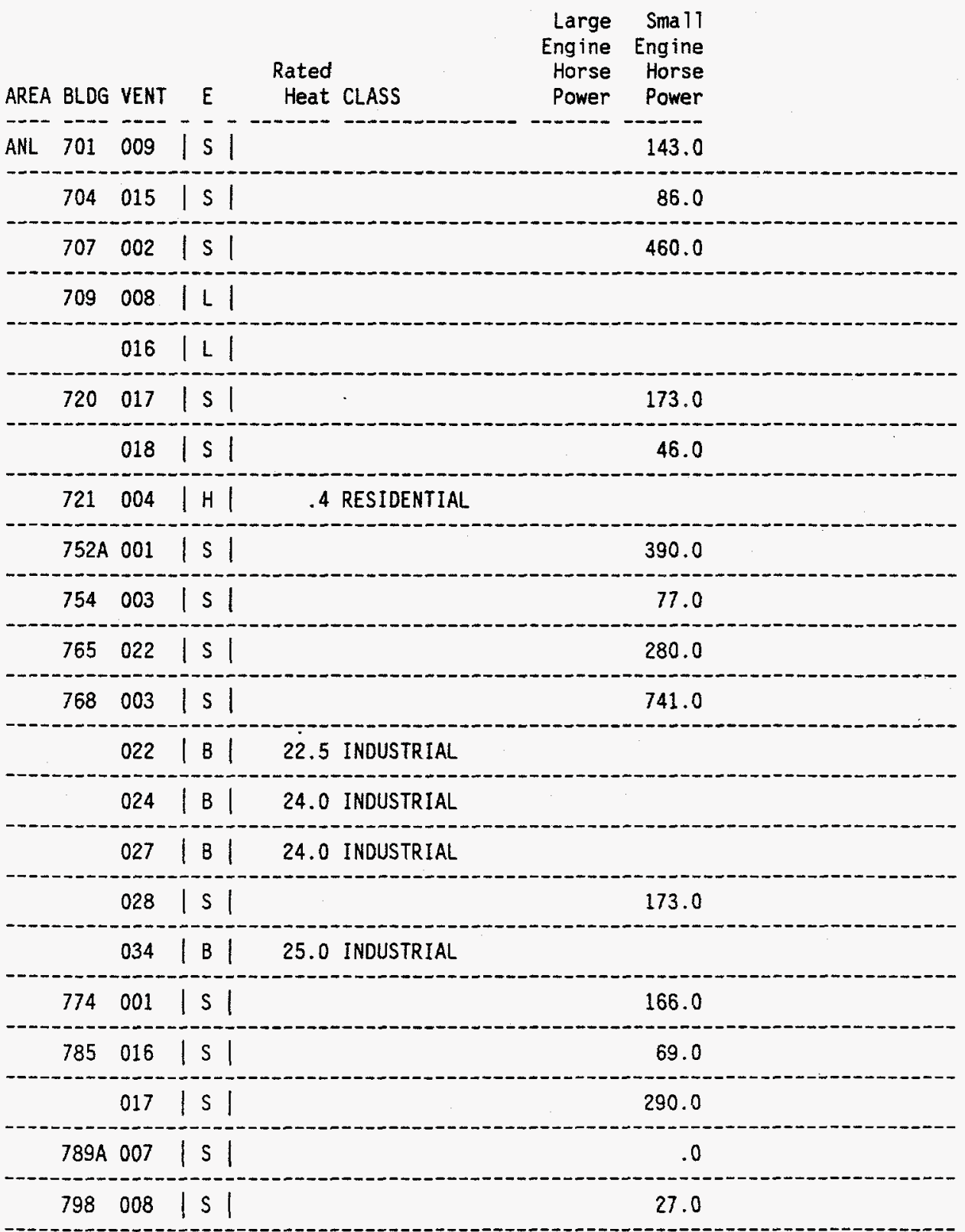


Update Survey for AIR EMISSIONS INVENTORY FUEL BURNING EQUIPMENT - 1993 Page: 2 PART II

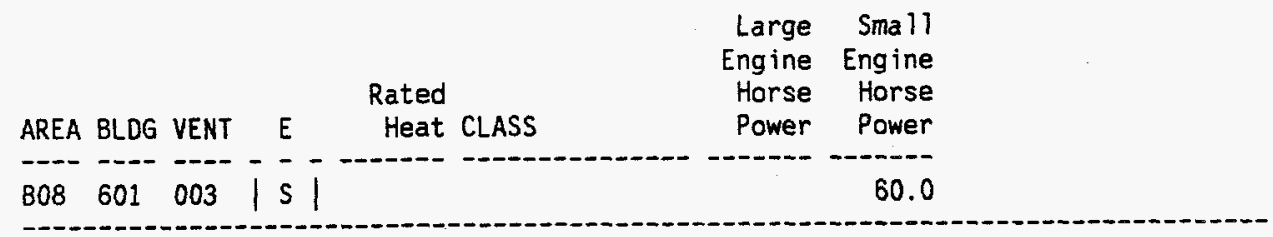

Update Survey for AIR EMISSIONS INVENTORY FUEL BURNING EQUIPMENT - 1993 Page: 3 PART II

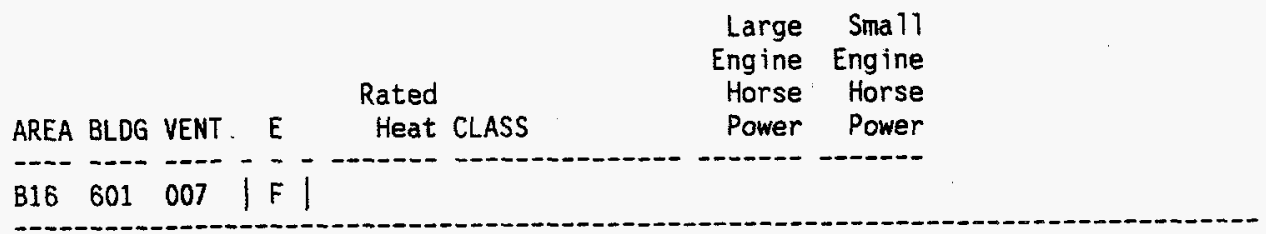

Update Survey for AIR EMISSIONS INVENTORY FUEL BURNING EQUIPMENT - 1993 Page: 4 PART II

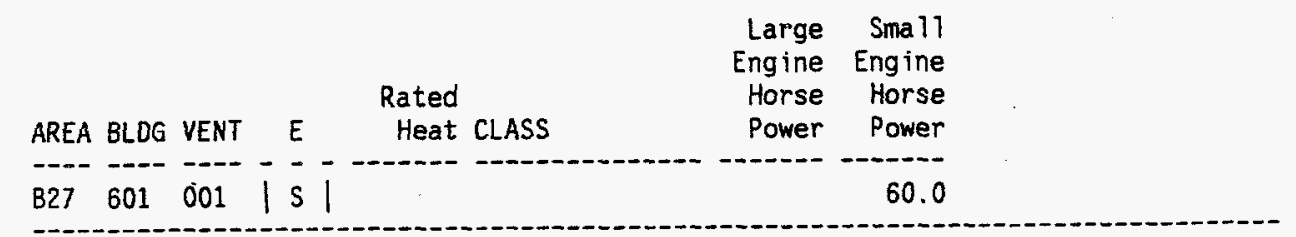


Update Survey for AIR EMISSIONS INVENTORY FUEL BURNING EQUIPMENT - 1993 Page: 5 PART II

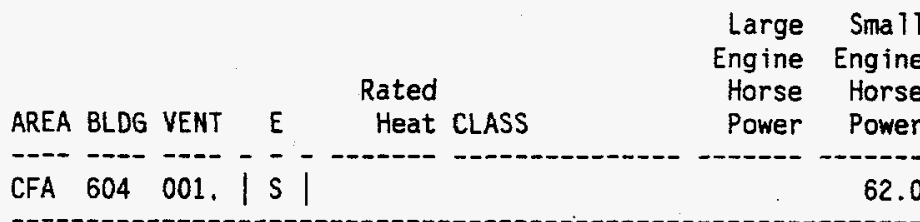

\begin{tabular}{|c|c|c|c|c|}
\hline 607 & 004 & $|F|$ & RESIDENTIAL & \\
\hline 608 & 001 & B $\mid$ & 1.5 COMMERCIAL & \\
\hline 609 & 001 & $|s|$ & & 166.0 \\
\hline & 005 & $|B|$ & 2.1 COMMERCIAL & \\
\hline 613 & 003 & $|\mathrm{~B}|$ & RESIDENTIAL & \\
\hline 617 & 024 & $|B|$ & 2.5 COMMERCIAL & \\
\hline 633 & 091 & $|s|$ & & 110.0 \\
\hline 650 & 007 & $B$ & 5.2 COMMERCIAL & \\
\hline 662 & 011 & $|B|$ & COMMERCIAL & \\
\hline & 027 & $|B|$ & 5.0 COMMERCIAL & \\
\hline 664 & 034 & $|H|$ & 1.0 RESIDENTIAL & \\
\hline & 035 & $|H|$ & 1.0 RESIDENTIAL & \\
\hline 665 & 028 & $|B|$ & 4.2 COMMERCIAL & \\
\hline & 029 & $|B|$ & 12.6 INDUSTRIAL & \\
\hline & 030 & $|B|$ & 4.2 COMMERCIAL & \\
\hline 668 & 006 & $|s|$ & & 350.0 \\
\hline & 023 & $|B|$ & .6 COMMERCIAL & \\
\hline 671 & 007 & B & 8.4 COMMERCIAL & \\
\hline & 008 & $|8|$ & 8.4 COMMERCIAL & \\
\hline 675 & 002 & $|s|$ & & 150.0 \\
\hline 679 & 007 & $P \mid$ & & \\
\hline 682 & 002 & 51 & & 310.0 \\
\hline 688 & 043 & B 1 & 14.7 INDUSTRIAL & \\
\hline & 0.44 & B 1 & 5.0 COMMERCIAL & \\
\hline & 047 & s 1 & & 100.0 \\
\hline 751 & 004 & $|H|$ & .0 RESIDENTIAL & \\
\hline
\end{tabular}


Update Survey for AIR EMISSIONS INVENTORY FUEL BURNING EQUIPMENT - 1993 Page: 6 PART II

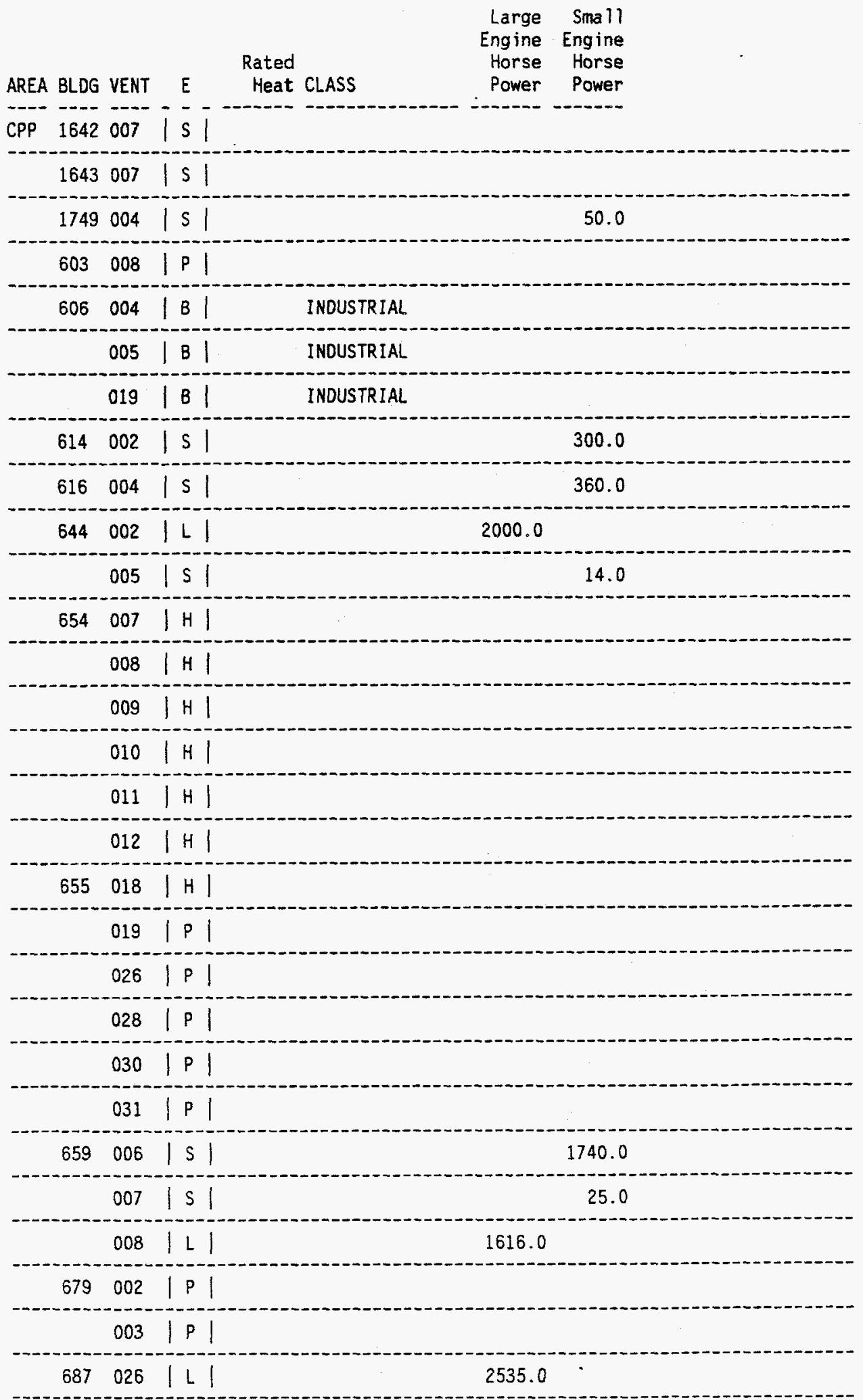


Update Survey for AIR EMISSIONS INVENTORY FUEL BURNING EQUIPMENT - 1993 : Page: 7 PART II

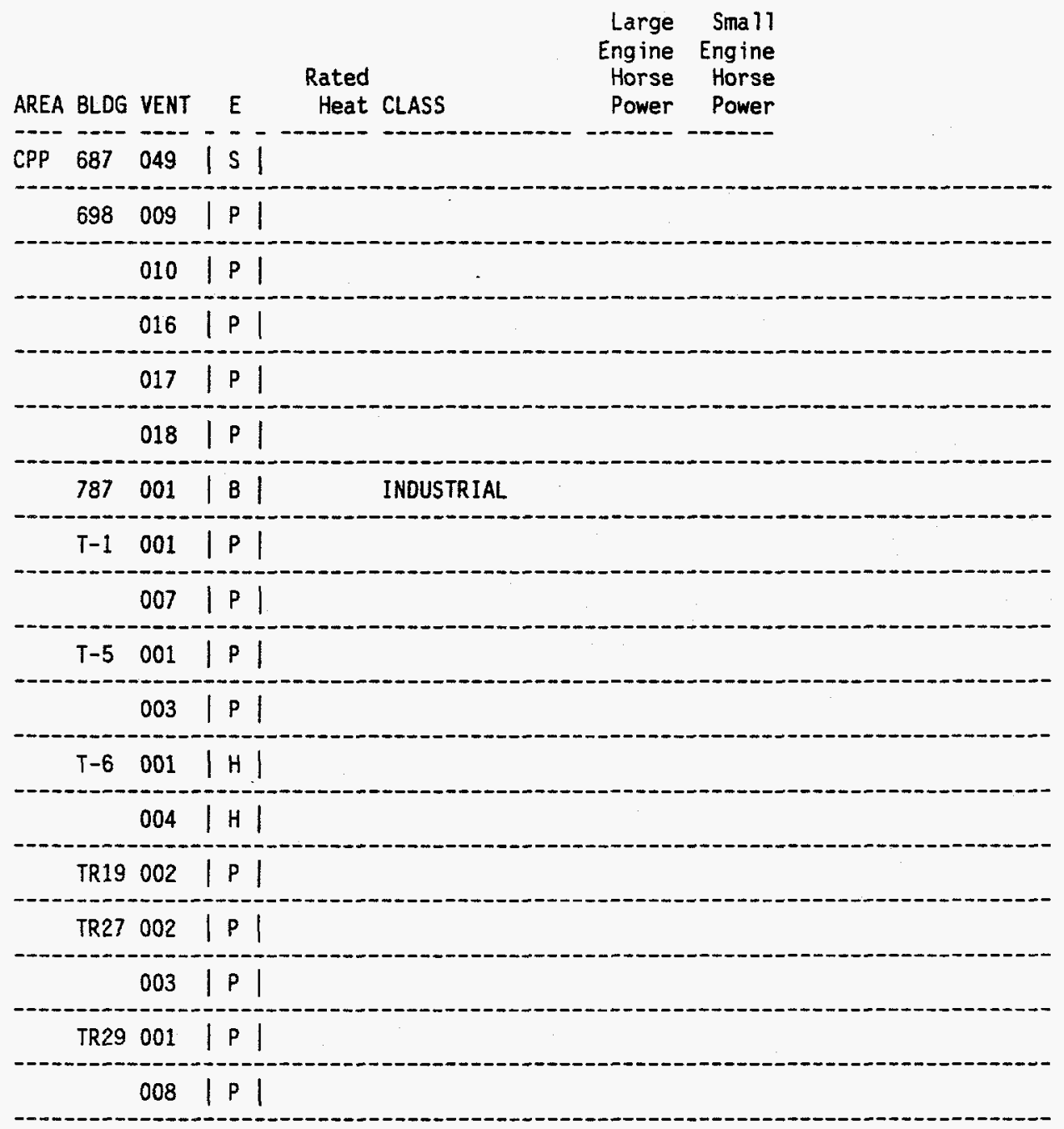


Update SUrvey for AIR EMISSIONS INVENTORY FUEL BURNING EQUIPMENT - 1993 Page: 8 PART II

Large Sma 11

Engine Engine

Horse Horse

AREA BLOG VENT

HPTF $601001|\mathrm{P}|$ 
Update Survey for AIR EMISSIONS INVENTORY FUEL. BURNING EQUIPMENT - 1993 Page: 9 PART II

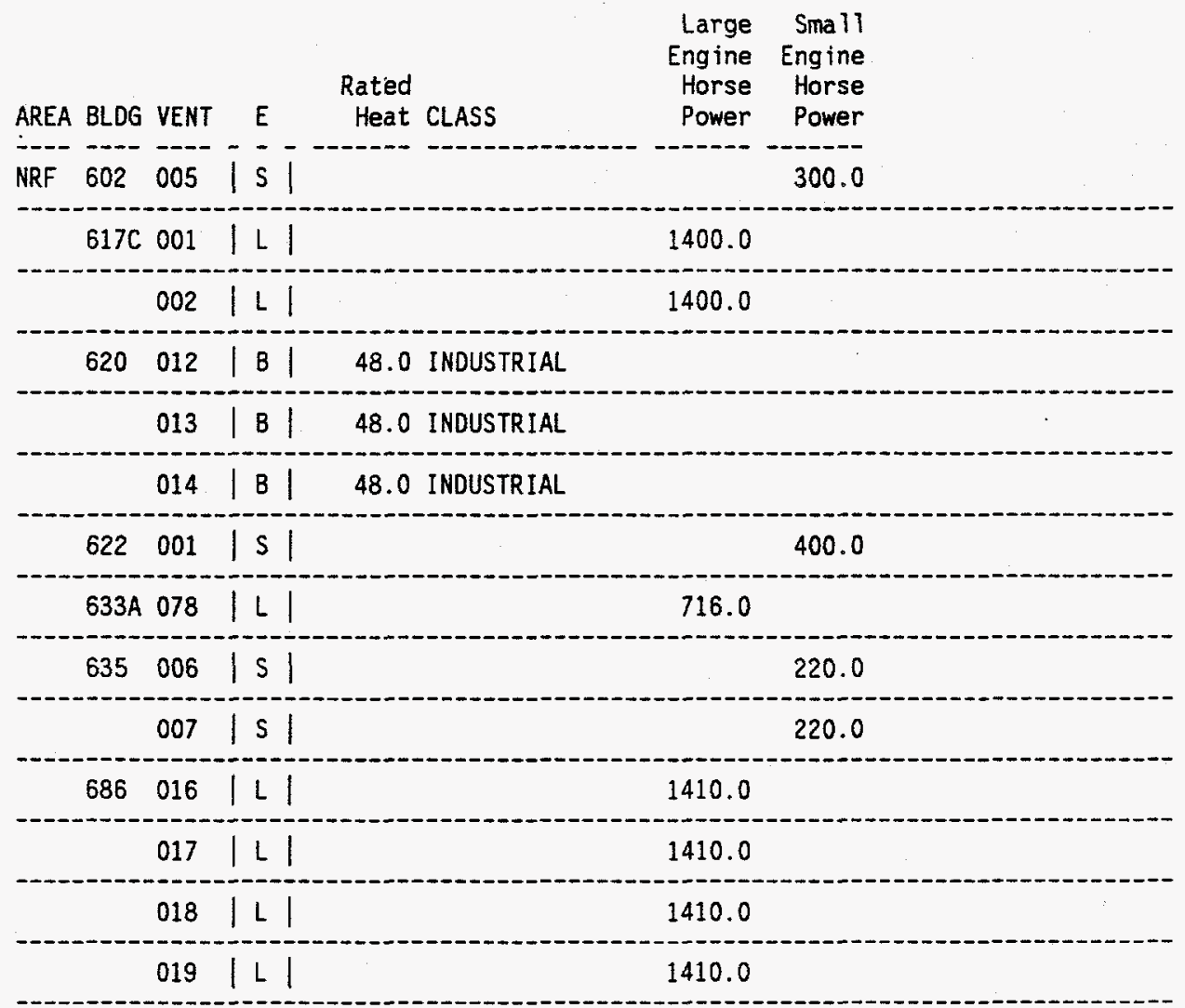


Update Survey for AIR EMISSIONS INVENTORY FUEL BURNING EQUIPMENT - 1993 Page: 10 PART II

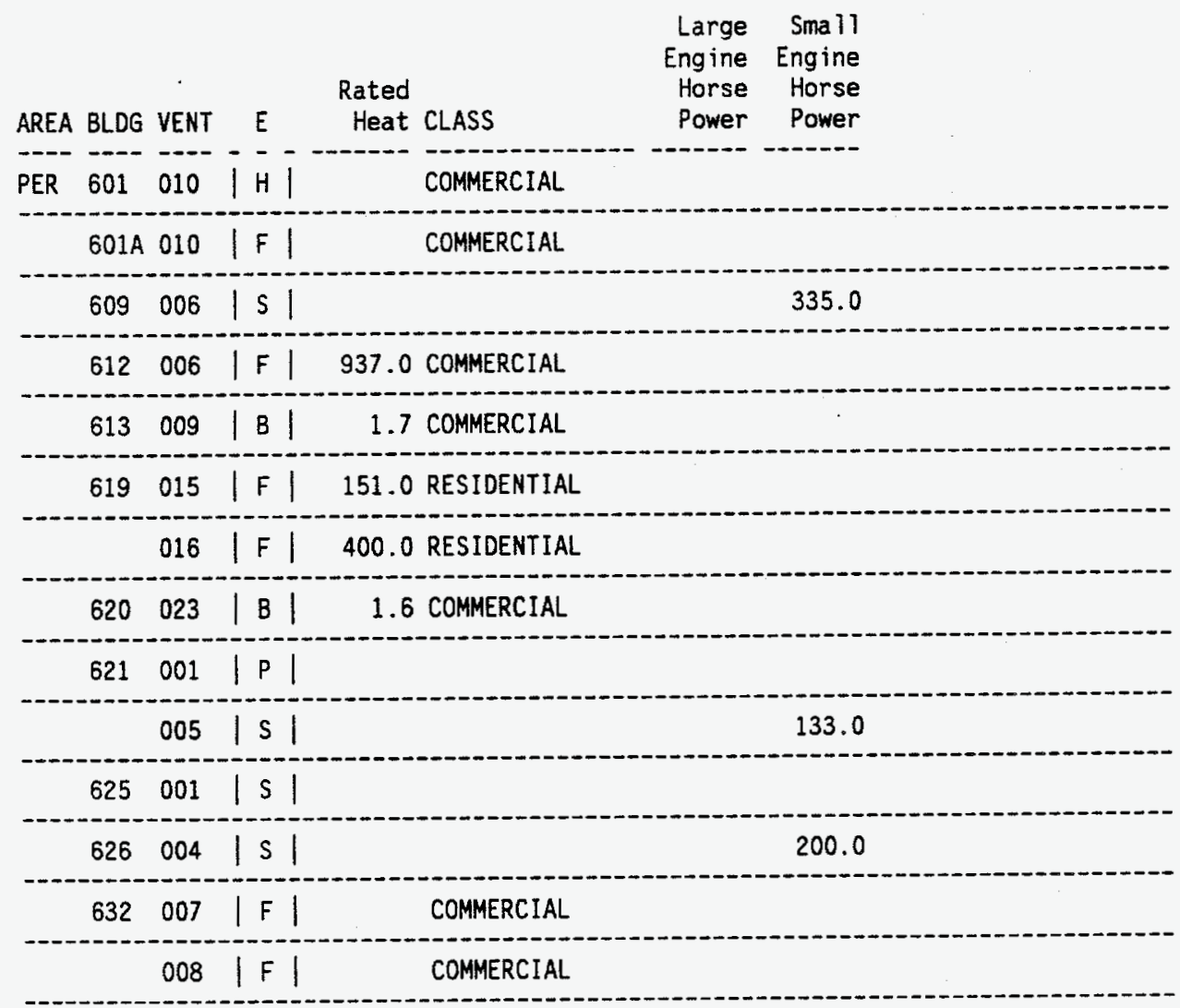


Update Survey for AIR EMISSIONS INVENTORY FUEL BURNING EQUIPMENT - 1993 Page: 11 PART II

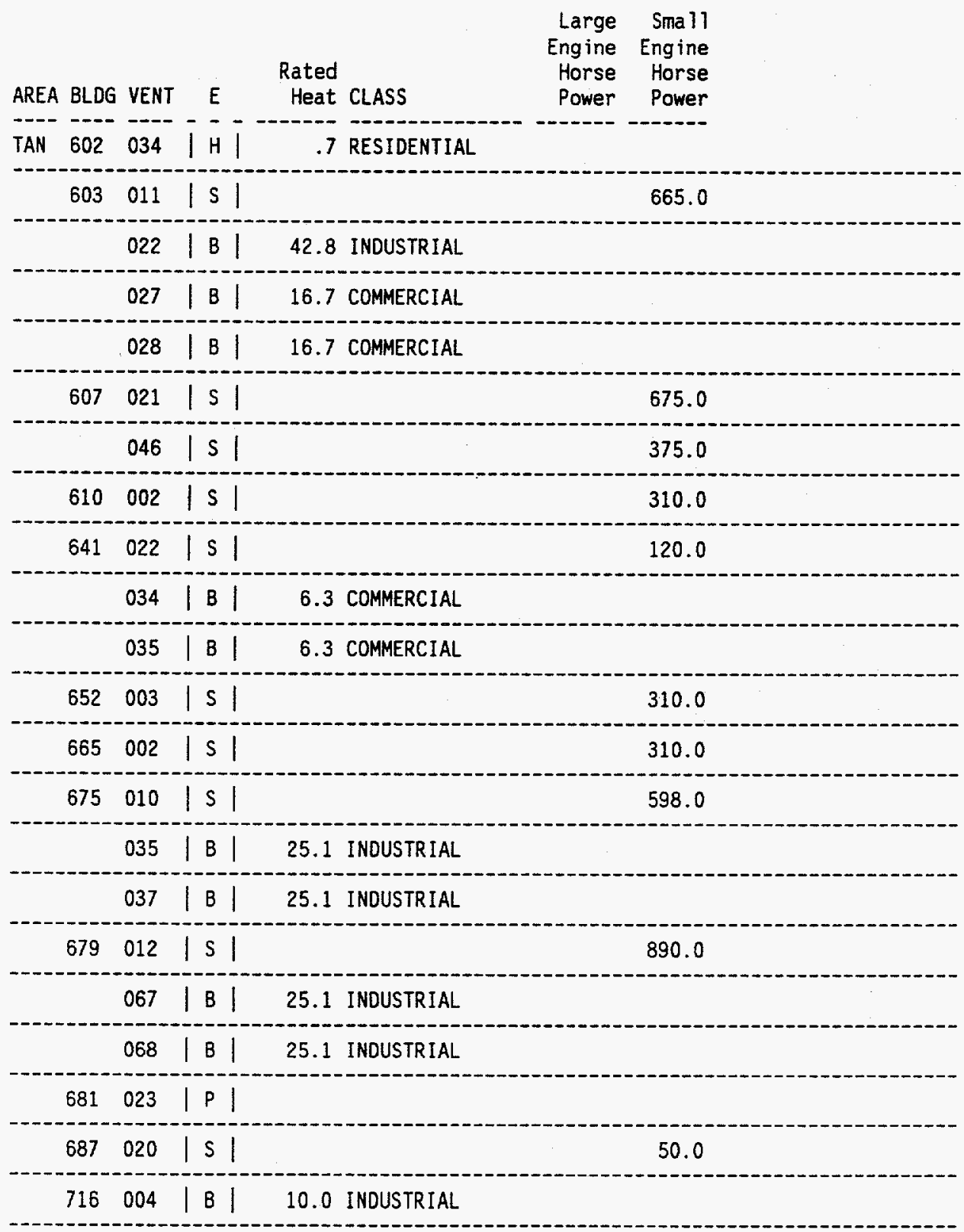


Update Survey for AIR EMISSIONS INVENTORY FUEL BURNING EQUIPMENT - 1993 Page: 12 PART II

\begin{tabular}{|c|c|c|c|c|c|}
\hline AREA BLDG & VENT & E & $\begin{array}{l}\text { Rated } \\
\text { Heat CLASS }\end{array}$ & $\begin{array}{c}\text { Large } \\
\text { Engine } \\
\text { Horse } \\
\text { Power }\end{array}$ & $\begin{array}{r}\text { Sma ll } \\
\text { Eng ine } \\
\text { Horse } \\
\text { Power }\end{array}$ \\
\hline TRA 619 & 008 & $|s|$ & & & 525.0 \\
\hline & 009 & $|s|$ & & & 525.0 \\
\hline 633 & 003 & $|s|$ & & & 525.0 \\
\hline & 004 & $|s|$ & & & 525.0 \\
\hline 670 & 046 & | L | & & 2118.0 & \\
\hline & 053 & $|L|$ & & 2118.0 & \\
\hline 674 & 007 & $|\mathrm{~s}|$ & & & \\
\hline
\end{tabular}


Update Survey for AIR EMISSIONS INVENTORY FUEL BURNING EQUIPMENT - 1993 Page: 13 PART II

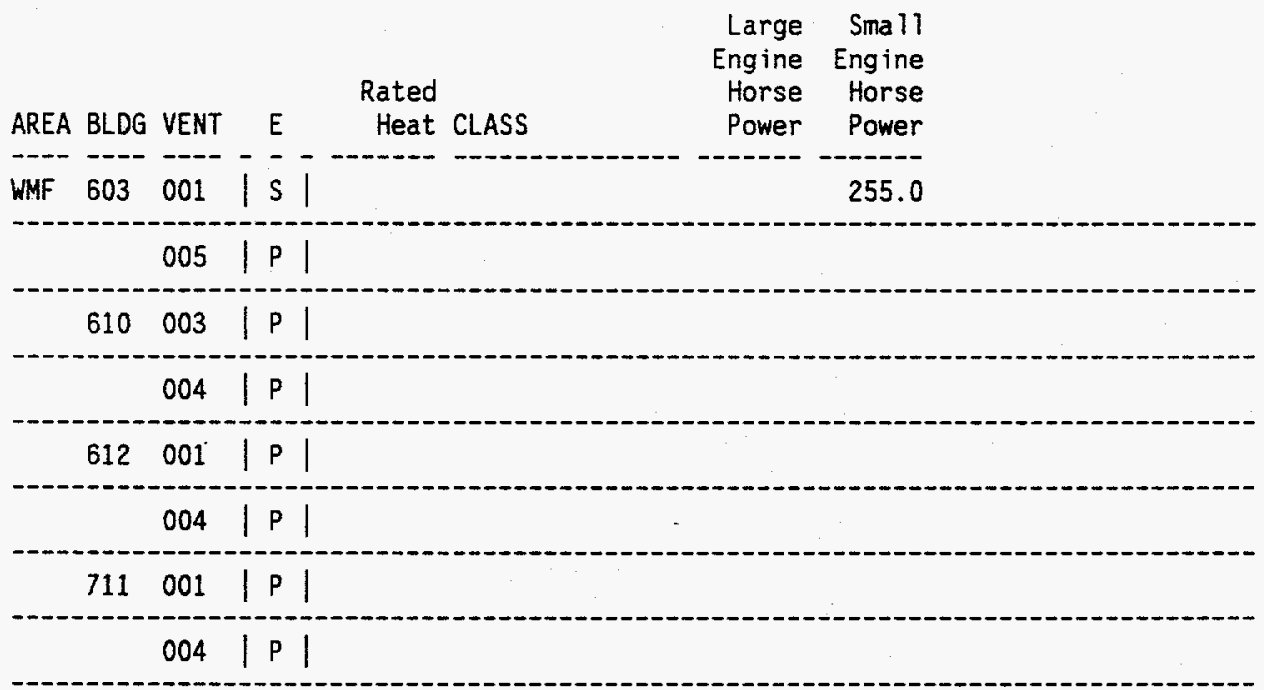


Update Survey for AIR EMISSIONS INVENTORY ORGANIC STORAGE TANKS - 1993 PART I

Page:

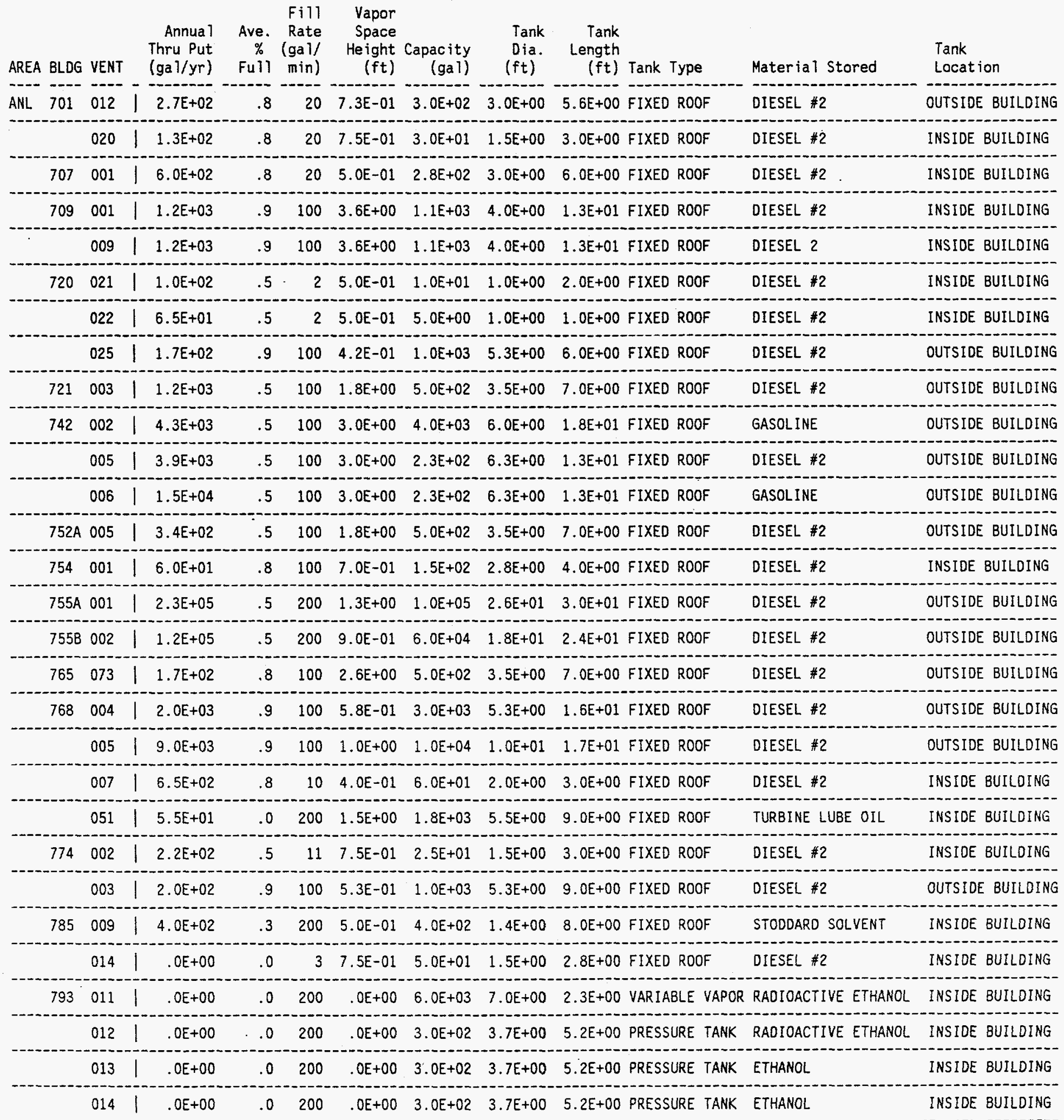


Update Survey for AIR EMISSIONS INVENTORY ORGANIC STORAGE TANKS - 1993

Page: 2 PART I

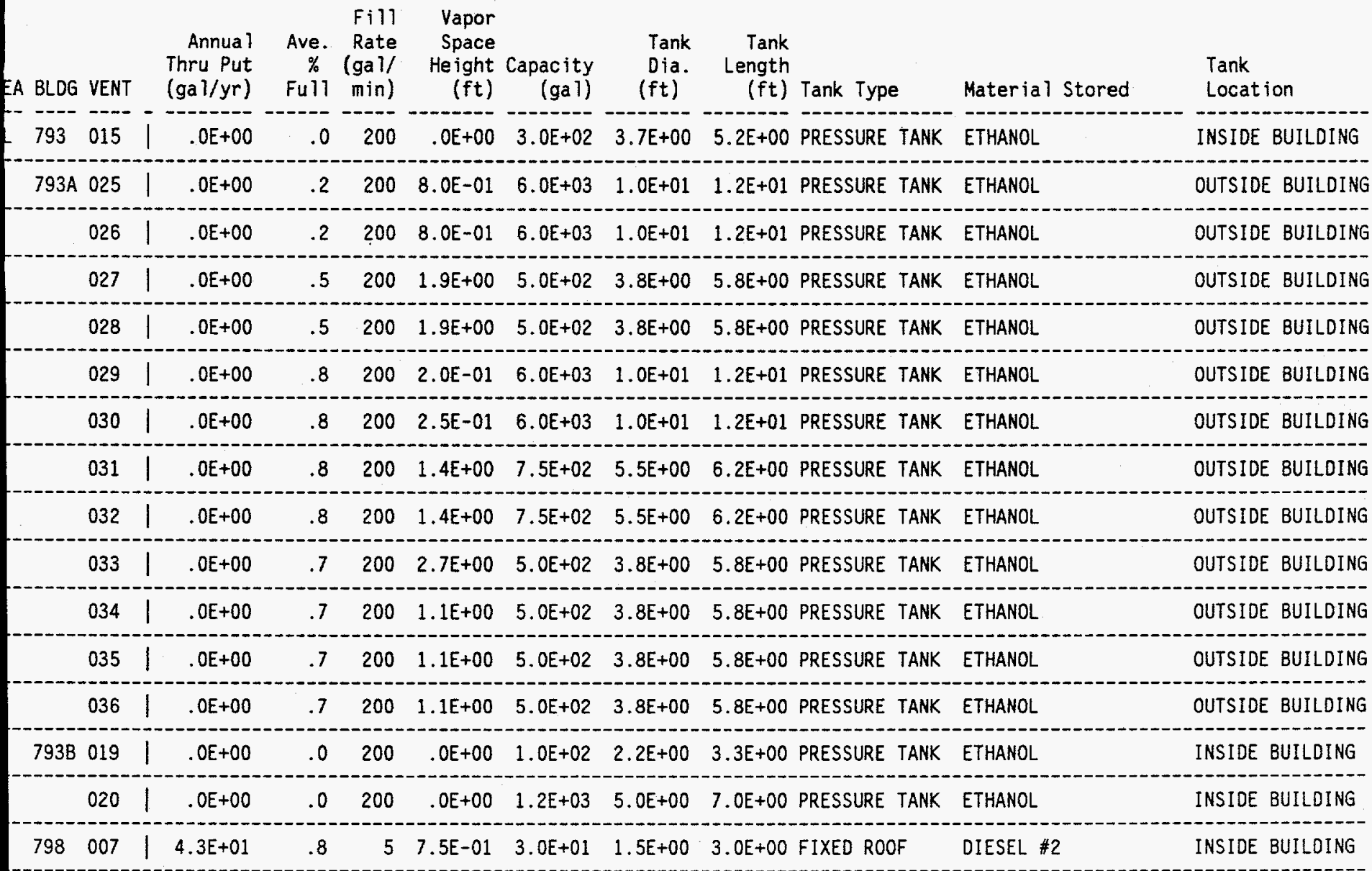




\begin{tabular}{|c|c|c|c|c|c|c|c|c|c|c|c|c|}
\hline REA & BLDG & VENT & $\begin{array}{l}\text { Annual } \\
\text { Thru Put } \\
\text { (gal/yr) }\end{array}$ & $\begin{array}{c}\text { Ave. } \\
\% \\
\text { Ful1 }\end{array}$ & $\begin{array}{r}\text { Fil1 } \\
\text { Rate } \\
\text { (gal/ } \\
\text { min) }\end{array}$ & $\begin{array}{r}\text { Vapor } \\
\text { Space } \\
\text { He ight } \\
\text { (ft) }\end{array}$ & $\begin{array}{r}\text { Capacity } \\
\text { (gal) }\end{array}$ & $\begin{array}{l}\text { Tank } \\
\text { Dia. } \\
\text { (ft) }\end{array}$ & $\begin{array}{r}\text { Tank } \\
\text { Length } \\
(\mathrm{ft})\end{array}$ & Tank Type & Material Stored & $\begin{array}{l}\text { Tank } \\
\text { Locat ion }\end{array}$ \\
\hline 08 & 601 & 001 & $6.5 E+01$ & .8 & 200 & $3.4 E-01$ & $6.0 E+01$ & $2.0 E+00$ & $2.0 E+00$ & FIXED ROOF & DIESEL \#2 & INSIDE BUILDING \\
\hline
\end{tabular}

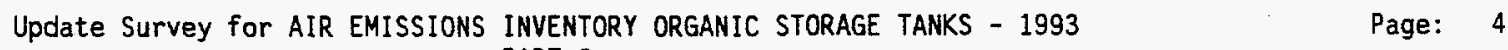
PART I

\begin{tabular}{|c|c|c|c|c|c|c|c|c|c|c|c|c|}
\hline AREA & BLDG & VENT & $\begin{array}{r}\text { Annual } \\
\text { Thru Put } \\
\text { (gal/yr) }\end{array}$ & $\begin{array}{c}\text { Ave. } \\
\% \\
\text { Fu11 }\end{array}$ & $\begin{array}{r}\text { Fill } \\
\text { Rate } \\
\text { (gal/ } \\
\text { min) }\end{array}$ & $\begin{array}{r}\text { Vapor } \\
\text { Space } \\
\text { Height } \\
(\mathrm{ft})\end{array}$ & $\begin{array}{r}\text { Capacity } \\
\text { (gal) }\end{array}$ & $\begin{array}{l}\text { Tank } \\
\text { Dia. } \\
\text { (ft) }\end{array}$ & $\begin{array}{r}\text { Tank } \\
\text { Length } \\
(\mathrm{ft})\end{array}$ & Tank Type & Material Stored & $\begin{array}{l}\text { Tank } \\
\text { Location }\end{array}$ \\
\hline 816 & 601 & 008 & $5.5 E+02$ & .9 & 100 & $5.8 E-01$ & 1. $0 E+03$ & $5.3 E+00$ & $6.0 E+\infty 0$ & FIXED ROOF & DIESEL \#2 & OUTSIDE BUILDING \\
\hline & 703 & 001 & $1.1 E+03$ & .8 & 100 & $8.8 E-01$ & $5.0 E+02$ & $1.2 E+01$ & $4.4 E+00$ & FIXED ROOF & GAS/DIESEL MIX & OUTSIDE BUILDING \\
\hline
\end{tabular}

Update Survey for AIR EMISSIONS INVENTORY ORGANIC STORAGE TANKS - 1993

Page: 5 PART I

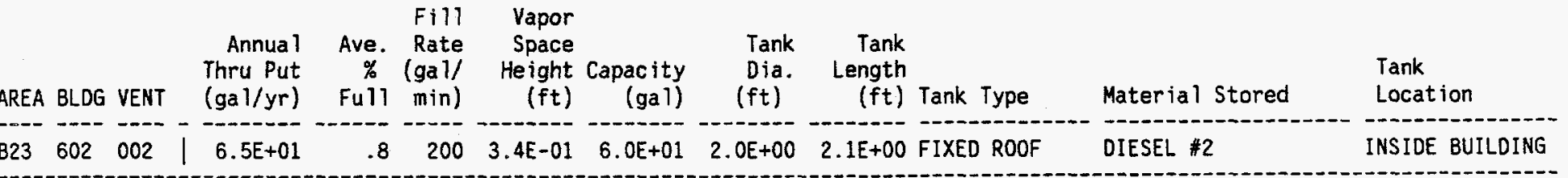

Update Survey for AIR EMISSIONS INVENTORY ORGANIC STORAGE TANKS - 1993

Page: 6 PART I

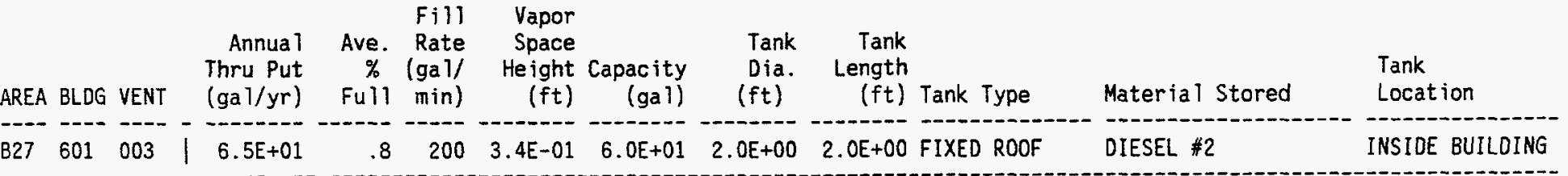


Update Survey for AIR EMISSIONS INVENTORY ORGANIC STORAGE TANKS - 1993

Page: 7 PART I

\begin{tabular}{|c|c|c|c|c|c|c|c|c|c|c|}
\hline BLDG & VENT & $\begin{array}{l}\text { Annual } \\
\text { Thru Put } \\
\text { (ga }] / y r)\end{array}$ & $\begin{array}{c}\text { Ave. } \\
\% \\
\text { Ful1 }\end{array}$ & $\begin{array}{l}\text { Fill } \\
\text { Rate } \\
\text { (gal/ } \\
\text { min) }\end{array}$ & $\begin{array}{r}\text { Vapor } \\
\text { Space } \\
\text { Height } \\
(\mathrm{ft})\end{array}$ & $\begin{array}{r}\text { Capacity } \\
\text { (gal) }\end{array}$ & $\begin{array}{l}\text { Tank } \\
\text { Dia. } \\
\text { (ft) }\end{array}$ & $\begin{array}{l}\text { Tank } \\
\text { Length } \\
\text { (ft) Tank Type }\end{array}$ & Material Stored & $\begin{array}{l}\text { Tank } \\
\text { Location }\end{array}$ \\
\hline 609 & 002 & $.0 E+00$ & .5 & 10 & $7.5 E-01$ & $5.0 E+01$ & $1.5 E+00$ & 3. $8 E+00$ FIXED ROOF & DIESEL \#2 & INSIDE BUILDING \\
\hline 668 & 001 & $.0 E+00$ & .0 & 100 & $.0 E+00$ & $1.0 \mathrm{E}+03$ & $8.0 E+00$ & 2.7E+OI FIXED ROOF & DIESEL \#2 & OUTSIDE BUILDING \\
\hline & 010 & $.0 E+00$ & .0 & 100 & $.0 E+00$ & $1.0 E+04$ & $8.0 E+00$ & 2.7E+O1 FIXED ROOF & GASOL INE & OUTSIDE BUILDING \\
\hline 684 & 002 & $5.0 E+02$ & .5 & 200 & $1.8 \mathrm{E}+00$ & $5.0 E+02$ & $3.5 E+00$ & 7. OE+OO FIXED ROOF & GASOLINE & OUTSIDE BUILDING \\
\hline 688 & 003 & $.0 E+00$ & .5 & 100 & $1.0 E-02$ & $2.0 E+03$ & $5.0 E+00$ & 1. $3 E+01$ FIXED ROOF & DIESEL \#2 & OUTSIDE BUILDING \\
\hline & 048 & $.0 E+00$ & .0 & 100 & $.0 E+00$ & $5.0 E+02$ & $3.5 E+00$ & 7. OE+OO FIXED ROOF & DIESEL \#2 & OUTSIDE BUILDING \\
\hline 708 & 001 & $5.8 E+04$ & .8 & 200 & $4.5 E+00$ & $4.2 E+04$ & $2.0 E+01$ & $1,8 E+01$ FIXED ROOF & DIESEL \#2 & OUTSIDE BUILDING \\
\hline 713 & 001 & $3.5 E+04$ & .5 & 100 & $4.0 E-01$ & $1.0 E+04$ & $8.0 E+00$ & 2.7E+01 FIXED ROOF & GASOLINE & OUTSIDE BUILDING \\
\hline & 002 & $3.5 E+04$ & .5 & 100 & $4.0 E-01$ & $8.0 E+03$ & $8.0 E+00$ & 2.1E+01 FIXED ROOF & GASOLINE & OUTSIDE BUILDING \\
\hline 721 & 001 & $6.2 E+04$ & .8 & 100 & $1.3 E+00$ & $5.0 E+03$ & $6.0 E+00$ & 2. $4 E+01$ FIXED ROOF & DIESEL \#2 & OUTSIDE BUILDING \\
\hline 729 & 001 & $6.7 E+03$ & .9 & 100 & $6.9 E-01$ & $1.0 E+03$ & $5.3 E+00$ & $6.0 E+00$ FIXED ROOF & DIESEL \#2 & OUTSIDE BUILDING \\
\hline 730 & 001 & $1.6 \mathrm{E}+03$ & .9 & 100 & $3.2 \mathrm{E}-01$ & $5.0 E+02$ & $3.5 E+00$ & 7. OE+00 FIXED ROOF & DIESEL \#2 & OUTSIDE BUILDING \\
\hline 731 & 001 & $1.0 E+05$ & .7 & 100 & $2.7 E+00$ & $1.2 E+04$ & $8.0 E+00$ & $3.2 E+01$ FIXED ROOF & $J P-4$ & UTSIDE BUILDING \\
\hline 732 & 001 & $2.1 E+04$ & .5 & 100 & 4.0E-01 & $1.2 E+04$ & $8.0 E+00$ & $3.2 E+01$ FIXED ROOF & DIESEL \#2 & OUTSIDE BUILDING \\
\hline 734 & 001 & $8.7 E+02$ & .5 & 100 & 1. $8 \mathrm{E}-01$ & $5.0 E+02$ & $3.5 E+00$ & 7. OE +00 FIXED ROOF & DIESEL \#2 & SIDE BUILDING \\
\hline 735 & 001 & $7.9 E+01$ & .8 & 100 & $5.6 E-01$ & $5.0 E+02$ & $3.5 E+00$ & 7.OE+OO FIXED ROOF & DIESEL \#2 & OUTSIDE BUILOING \\
\hline 738 & 001 & $6.0 E+03$ & .8 & 100 & $1.2 E+00$ & $2.5 E+03$ & $5.3 E+00$ & 1.1E+01 FIXED ROOF & DIESEL \#2 & OUTSIDE BUILDING \\
\hline 739 & 001 & $6.0 \mathrm{E}+03$ & .8 & 100 & $1.2 E+00$ & $2.5 E+03$ & $5.3 E+00$ & 1.1E+01 FIXED ROOF & DIESEL \#2 & OUTSIDE BUILDING \\
\hline 741 & 001 & $1.7 E+05$ & .9 & 100 & $5.6 \mathrm{E}-01$ & $1.0 E+04$ & $8.0 E+00$ & $2.7 \mathrm{E}+01$ FIXED ROOF & DIESEL \#2 & OUTSIDE BUILDING \\
\hline & 002 & $1.7 E+05$ & .9 & 100 & $5.6 \mathrm{E}-01$ & $1.0 E+04$ & $8.0 E+00$ & $2.7 \mathrm{E}+01$ FIXED ROOF & IESEL \#2 & OUTSIDE BUILDING \\
\hline 748 & 001 & $.0 E+00$ & .7 & 100 & $1.6 \mathrm{E}+00$ & $1.0 E+03$ & $5.3 E+00$ & $6.0 \mathrm{E}+00$ FIXED ROOF & IESEL \#2 & OUTSIDE BUILDING \\
\hline 749 & 001 & $2.0 E+04$ & .4 & 200 & $5.2 E+00$ & $1.0 E+04$ & $9.0 E+00$ & 2. $4 E+01$ FIXED ROOF & IESEL \#2 & OUTSIDE BUILDING \\
\hline 754 & 001 & $1.8 E+05$ & .5 & 90 & $9.0 E+00$ & $3.0 E+04$ & $1.7 E+01$ & 1.8E+01 FIXED ROOF & IESEL \#2 & OUTSIDE BUILDING \\
\hline & 002 & $3.1 E+04$ & .5 & 90 & $4.3 E+00$ & $2.1 E+04$ & $1.5 \mathrm{E}+01$ & 2.0E+01 FIXED ROOF & DIESEL \#2 & OUTSIDE BUILDING \\
\hline & 003 & $3.3 E+05$ & .5 & 90 & $4.3 E+\infty 0$ & $2.1 E+04$ & $1.5 E+01$ & 1.7E+01 FIXED ROOF & UNLEADED GA & OUTSIDE BUILDING \\
\hline & 004 & $3.8 \mathrm{E}+03$ & .5 & 90 & $3.4 E+00$ & $5.0 E+03$ & $8.5 E+00$ & 1.2E+01 FIXED ROOF & DIESEL \#1 & OUTSIDE BUILDING \\
\hline & 005 & $3.8 E+03$ & .5 & 90 & $3.4 E+00$ & $5.0 E+03$ & $8.5 E+00$ & 1.2E+01 FIXED ROOF & DIESEL \#1 & OUTSIDE BUILDING \\
\hline & 006 & $1.7 E+05$ & .5 & 90 & $4.0 E+00$ & $4.6 E+04$ & $2.2 E+01$ & 1.6E+01 FIXED ROOF & DIESEL \#2 & OUTSIDE BUILDING \\
\hline & 007 & $3.3 E+05$ & .5 & 90 & $2.5 E+00$ & $1.6 \mathrm{E}+04$ & $9.5 E+00$ & 2.1E+01 FIXED ROOF & UNLEADED GASOLINE & OUTSIDE BUILDING \\
\hline
\end{tabular}


Update Survey for AIR EMISSIONS INVENTORY ORGANIC STORAGE TANKS - 1993

Page: 8 PART I

\begin{tabular}{|c|c|c|c|c|c|c|c|c|c|c|c|}
\hline REA BLDG & VENT & $\begin{array}{r}\text { Annual } \\
\text { Thru Put } \\
\text { (gal/yr) }\end{array}$ & $\begin{array}{c}\text { Ave. } \\
\% \\
\text { Full }\end{array}$ & $\begin{array}{r}\text { Fill } \\
\text { Rate } \\
\text { (gal/ } \\
\text { min) }\end{array}$ & $\begin{array}{r}\text { Vapor } \\
\text { Space } \\
\text { Height } \\
\text { (ft) }\end{array}$ & $\begin{array}{r}\text { Capacity } \\
\text { (gal) }\end{array}$ & $\begin{array}{l}\text { Tank } \\
\text { Dia. } \\
\text { (ft) }\end{array}$ & $\begin{array}{r}\text { Tank } \\
\text { Length } \\
(f t)\end{array}$ & Tank Type & Material Stored & $\begin{array}{l}\text { Tank } \\
\text { Location }\end{array}$ \\
\hline FA 757 & 001 & $1.0 E+05$ & .9 & 100 & $9.6 E-01$ & $1.2 \mathrm{E}+04$ & $8.0 E+00$ & $3.2 E+01$ & FIXED ROOF & DIESEL \#2 & OUTSIDE BUILOING \\
\hline 759 & 001 & $7.0 E+04$ & .9 & 100 & $1.3 E+00$ & $1.7 E+04$ & $1.1 E+01$ & $2.6 E+01$ & FIXED ROOF & DIESEL \#2 & OUTSIDE BUILDING \\
\hline
\end{tabular}


Update Survey for AIR EMISSIONS INVENTORY ORGANIC STORAGE TANKS - 1993

Page: 9 PART I

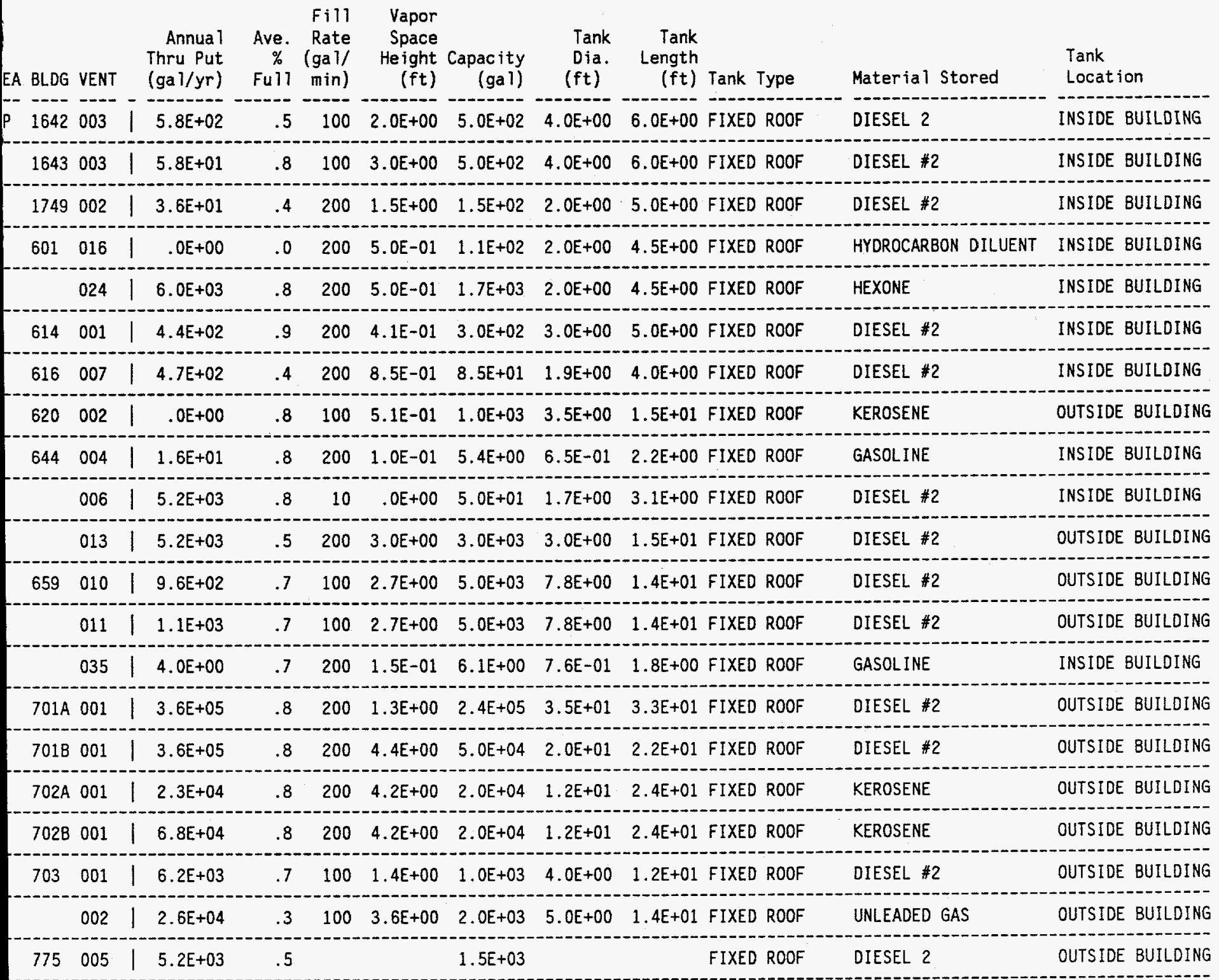


Update Survey for AIR EMISSIONS INVENTORY ORGANIC STORAGE TANKS - 1993

Page: 10 PART I

\begin{tabular}{|c|c|c|c|c|c|c|c|c|c|c|c|}
\hline AREA & BLDG & VENT & $\begin{array}{r}\text { Annual } \\
\text { Thru Put } \\
\text { (ga 1/yr) }\end{array}$ & $\begin{array}{l}\text { Ave. } \\
\% \\
\text { Full }\end{array}$ & $\begin{array}{l}\text { Fill } \\
\text { Rate } \\
\text { (gal/ } \\
\text { min) }\end{array}$ & $\begin{array}{r}\text { Vapor } \\
\text { Space } \\
\text { Height } \\
\text { (ft) }\end{array}$ & $\begin{array}{r}\text { Capacity } \\
\text { (gal) }\end{array}$ & $\begin{array}{l}\text { Tank } \\
\text { Dia. } \\
\text { (ft) }\end{array}$ & $\begin{array}{l}\text { Tank } \\
\text { Length } \\
\text { (ft) Tank Type }\end{array}$ & Material Stored & $\begin{array}{l}\text { Tank } \\
\text { Location }\end{array}$ \\
\hline NRF & 602 & 044 & $1.2 \mathrm{E}+03$ & .8 & 200 & $9.9 E-01$ & $5.0 E+02$ & $3.9 E+00$ & $6.1 E+00$ FIXED ROOF & DIESEL \#2 & OUTSIDE BUILDING \\
\hline & $617 \mathrm{C}$ & 003 & $2.4 E+04$ & .8 & 200 & $9.4 E-01$ & $1.6 E+03$ & $6.0 E+00$ & 1. $4 E+01$ FIXED ROOF & DIESEL \#2 & INSIDE BUILDING \\
\hline & 618 & 200 & $.0 E+00$ & .0 & 100 & $.0 E+00$ & $1.5 E+03$ & $4.0 E+00$ & $9.5 E+00$ FIXED ROOF & DIESEL \#2 & OUTSIDE BUILDING \\
\hline & 622 & 007 & $3.8 E+02$ & .8 & 200 & $1.6 E+00$ & $3.0 E+03$ & $6.3 E+00$ & 1.3E+01 FIXED ROOF & DIESEL \#2 & OUTSIDE BUILDING \\
\hline & $633 \mathrm{~A}$ & 004 & $3.6 E+03$ & .9 & 200 & $5.0 E-01$ & $6.4 E+03$ & $8.0 E+00$ & 1. $6 E+01$ FIXED ROOF & DIESEL \#2 & OUTSIDE BUILOING \\
\hline & & 031 & $.0 E+00$ & .0 & 200 & $.0 E+00$ & $1.0 E+04$ & $8.5 E+00$ & $2.5 E+01$ FIXED ROOF & DIESEL \#2 & OUTSIDE BUILDING \\
\hline & 635 & 008 & $8.9 E+02$ & .8 & 200 & $8.4 E-01$ & $2.8 E+02$ & $3.5 \mathrm{E}+00$ & 4. OE +00 FIXED ROOF & DIESEL \#2 & OUTSIDE BUILDING \\
\hline & 686 & 001 & $3.9 E+03$ & .9 & 200 & $3.2 E-01$ & $2.2 E+02$ & 4. $0 E+00$ & 2.3E+00 FIXED ROOF & DIESEL \#2 & INSIOE BUILDING \\
\hline & & 002 & $3.9 E+03$ & .9 & 200 & $3.2 E-01$ & $2.2 E+02$ & $4.0 E+00$ & 2.3E+OO FIXED ROOF & DIESEL \#2 & INSIDE BUILDING \\
\hline & & 003 & $3.9 E+03$ & .9 & 200 & $3.2 E-01$ & $2.2 E+02$ & $4.0 E+00$ & 2.3E+00 FIXED ROOF & DIESEL \#2 & INSIDE BUILDING \\
\hline & & 004 & $3.9 E+03$ & .9 & 200 & $3.2 E-01$ & $2.2 E+02$ & $4.0 E+00$ & $2.3 E+00$ FIXED ROOF & DIESEL \#2 & INSIDE BUILDING \\
\hline & 709 & 001 & 2. $4 \mathrm{E}+04$ & .7 & 200 & $1.5 E+00$ & $3.0 E+03$ & $5.0 E+00$ & $1.8 E+01$ FIXED ROOF & OIESEL \#2 & OUTSIDE BUILDING \\
\hline & 711 & 001 & $2.3 E+05$ & .8 & 200 & $4.0 E+00$ & $2.5 E+04$ & $1.7 E+01$ & 1. $6 E+01$ FIXED ROOF & FUEL OIL \#5 & OUTSIDE BUILDING \\
\hline & & 002 & $2.3 E+0.5$ & .8 & 200 & $4.0 E+00$ & $2.5 E+04$ & $1.7 E+01$ & 1. $6 E+01$ FIXED ROOF & FUEL OIL \#5 & OUTSIDE BUILDING \\
\hline & & 003 & $2.3 E+05$ & .8 & 200 & $4.0 E+00$ & $2.5 E+04$ & $1.7 E+01$ & 1. $6 E+01$ FIXED ROOF & FUEL OIL \#5 & OUTSIDE BUILDING \\
\hline & 739 & 001 & $.0 E+00$ & .9 & 200 & $5.0 E-01$ & $1.2 E+04$ & $1.0 E+01$ & 2. OE+OI FIXED ROOF & DIESEL \#2 & OUTSIDE BUILDING \\
\hline & & 002 & $.0 E+00$ & .9 & 200 & $5.0 \mathrm{E}-01$ & $1.2 E+04$ & $1.0 E+01$ & 2. OE+01 FIXED ROOF & DIESEL \#2 & OUTSIDE BUILDING \\
\hline & 747 & 001 & $9.0 E+03$ & .5 & 200 & $7.5 E+00$ & $1.0 \mathrm{E}+04$ & $1.0 E+01$ & $1.5 E+01$ FIXED ROOF & FUEL OIL \#5 & OUTSIDE BUILDING \\
\hline & & 002 & $9.0 E+03$ & .5 & 200 & $7.5 E+00$ & $1.0 E+04$ & 1. $0 E+01$ & 1.5E+01 FIXED ROOF & FUEL OIL \#5 & OUTSIDE BUILDING \\
\hline & $759 A$ & 001 & $7.7 E+03$ & 1.0 & 200 & $4.0 E-01$ & $2.5 E+04$ & $1.0 E+01$ & 4. OE+01 FIXED ROOF & DIESEL \#2 & OUTSIDE BUILDING \\
\hline & $759 B$ & 001 & $7.7 E+03$ & 1.0 & 200 & 4. $0 E-01$ & $2.5 E+04$ & $1.0 E+01$ & 4. OE+01 FIXED ROOF & DIESEL \#2 & OUTSIDE BUILOING \\
\hline
\end{tabular}


Update Survey for AIR EMISSIONS INVENTORY ORGANIC STORAGE TANKS - 1993

Page: 11 PART I

\begin{tabular}{|c|c|c|c|c|c|c|c|c|c|c|c|}
\hline BLDG & VENT & $\begin{array}{l}\text { Annual } \\
\text { Thru Put } \\
\text { (gal/yr) }\end{array}$ & $\begin{array}{c}\text { Ave. } \\
\% \\
\text { Ful1 }\end{array}$ & $\begin{array}{r}\text { Fill } \\
\text { Rate } \\
\text { (gal/ } \\
\text { min) }\end{array}$ & $\begin{array}{r}\text { Vapor } \\
\text { Space } \\
\text { Height } \\
(f t)\end{array}$ & $\begin{array}{r}\text { Capacity } \\
(\text { gal) }\end{array}$ & $\begin{array}{l}\text { Tank } \\
\text { Dia. } \\
\text { (ft) }\end{array}$ & $\begin{array}{r}\text { Tank } \\
\text { Length } \\
(\mathrm{ft})\end{array}$ & Tank Type & Material Stored & $\begin{array}{l}\text { Tank } \\
\text { Location }\end{array}$ \\
\hline 609 & 010 & $2.6 E+02$ & .9 & 10 & $.0 E+00$ & $8.0 E+01$ & $1.8 \mathrm{E}+01$ & $3.6 E+00$ & FIXED ROOF & DIESEL \#2 & INSIDE BUILDING \\
\hline 625 & 002 & $.0 E+00$ & .0 & 5 & $.0 E+00$ & $2.0 E+01$ & $3.5 E+00$ & $2.0 E+00$ & FIXED ROOF & DIESEL \#2 & INSIDE BUILDING \\
\hline & 004 & $.0 E+00$ & .0 & 200 & $.0 E+00$ & $1.5 E+01$ & $1.0 E+00$ & $1.3 E+00$ & FIXED ROOF & LUBE OIL & INSIDE BUILDING \\
\hline 626 & 005 & $6.8 \mathrm{E}+01$ & .8 & 2 & $2.5 E-01$ & $1.1 E+02$ & $2.0 E+00$ & $6.0 E+00$ & FIXED ROOF & DIESEL \#2 & INSIDE BUILDING \\
\hline 705 & 001 & $4.0 E+03$ & .8 & 200 & $6.2 E+00$ & $4.0 E+03$ & $8.0 E+00$ & $1.3 E+01$ & FIXED ROOF & MIXED \#1 \& & OUTSIDE BUILDING \\
\hline 711 & 001 & $1.0 E+03$ & .8 & & & $5.0 E+03$ & $3.2 E+00$ & $5.2 E+\infty 0$ & FIXED ROOF & DIESEL 2 & OUTSIDE BUILDING \\
\hline 716 & 001 & $4.8 E+03$ & .9 & 100 & $4.9 E+00$ & $3.0 E+03$ & $5.0 E+00$ & $2.0 E+01$ & FIXED ROOF & DIESEL \#2 & OUTSIDE BUILDING \\
\hline 722 & 001 & $2.4 E+04$ & .9 & 100 & $7.5 \mathrm{E}+00$ & $1.0 E+04$ & $8.0 E+00$ & $2.7 E+01$ & FIXED ROOF & DIESEL \#2 & OUTSIDE BUILOING \\
\hline 737 & 001 & $4.2 E+03$ & .9 & 100 & $4.9 E+00$ & $2.0 E+03$ & $5.3 E+00$ & $1.2 E+01$ & FIXED ROOF & DIESEL \#2 & OUTSIDE BUILDING \\
\hline 740 & 001 & $2.9 E+03$ & .9 & 100 & $4.9 E+00$ & $2.0 E+03$ & $5.0 E+00$ & $1.4 E+01$ & FIXED ROOF & DIESEL \#2 & OUTSIDE BUILDING \\
\hline 742 & 001 & $1.5 E+03$ & .9 & 100 & $4.9 E+00$ & $1.0 \mathrm{E}+03$ & $4.0 E+00$ & $1.1 E+01$ & FIXED ROOF & DIESEL \#2 & OUTSIDE BUILDING \\
\hline 743 & 001 & $4.9 E+02$ & .9 & 100 & $5.0 E+\infty 0$ & $2.0 \mathrm{E}+03$ & $5.0 \mathrm{E}+00$ & $1.4 E+01$ & FIXED ROOF & DIESEL \#2 & OUTSIDE BUILDING \\
\hline 749 & 001 & $.0 E+00$ & .0 & 100 & $.0 E+00$ & $5.0 E+03$ & $6.0 E+00$ & $2.4 E+01$ & FIXED ROOF & DIESEL \#2 & OUTSIDE BUILDING \\
\hline 752 & 001 & $1.8 \mathrm{E}+03$ & .9 & 100 & $4.9 E+\infty 0$ & $2.0 E+03$ & $5.0 E+00$ & $1.4 \mathrm{E}+01$ & FIXED ROOF & DIESEL \#2 & OUTSIDE BUILDING \\
\hline
\end{tabular}


Update Survey for AIR EMISSIONS INVENTORY ORGANIC STORAGE TANKS - 1993

Page: 12 PART I

\begin{tabular}{|c|c|c|c|c|c|c|c|c|c|c|c|c|}
\hline AREA & BLDG & VENT & $\begin{array}{r}\text { Annua } 7 \\
\text { Thru Put } \\
\text { (gal/yr) }\end{array}$ & $\begin{array}{c}\text { Ave. } \\
\% \\
\text { Full }\end{array}$ & $\begin{array}{r}\text { Fill } \\
\text { Rate } \\
\text { (gal/ } \\
\text { min) }\end{array}$ & $\begin{array}{r}\text { Vapor } \\
\text { Space } \\
\text { Height } \\
(\mathrm{ft})\end{array}$ & $\begin{array}{r}\text { Capacity } \\
\text { (ga } 1)\end{array}$ & $\begin{array}{l}\text { Tank } \\
\text { Dia. } \\
(\mathrm{ft})\end{array}$ & $\begin{array}{r}\text { Tank } \\
\text { Length } \\
(\mathrm{ft})\end{array}$ & Tank Type & Material Stored & $\begin{array}{l}\text { Tank } \\
\text { Locat ion }\end{array}$ \\
\hline AN & 607 & 047 & $4.0 E+02$ & .5 & 100 & $1.8 E+00$ & $1.0 E+03$ & $3.5 E+\infty 0$ & $7.0 E+00$ & FIXED ROOF & OIESEL \#2 & OUTSIDE BUILDING \\
\hline & 610 & 001 & $3.0 E+02$ & .5 & 200 & $1.1 \mathrm{E}+00$ & $3.0 E+02$ & $2.0 E+00$ & $5.0 E+00$ & FIXED ROOF & DIESEL \#2 & INSIDE BUILDING \\
\hline & 652 & 002 & $.0 E+00$ & .0 & 200 & $.0 E+00$ & $1.9 E+02$ & & & FIXED ROOF & DIESEL \#2 & INSIDE BUILDING \\
\hline & 665 & 001 & $2.6 E+02$ & .5 & 200 & $1.5 E+00$ & $3.0 E+02$ & $2.9 E+00$ & $6.0 E+00$ & FIXED ROOF & DIESEL \#2 & INSIDE BUILDING \\
\hline & \multirow[t]{5}{*}{675} & 011 & I $4.6 E+00$ & .7 & 100 & $6.4 E+00$ & $8.0 E+03$ & $8.0 E+00$ & $2.6 E+01$ & FIXED ROOF & DIESEL \#2 & OUTSIDE BUILDING \\
\hline & & 012 & I $4.6 E+00$ & .6 & 21 & $1.0 E+00$ & $1.0 E+02$ & $2.0 E+00$ & $4.5 E+00$ & FIXED ROOF & DIESEL \#2 & INSIDE BUILDING \\
\hline & & 013 & I $4.0 \mathrm{E}+02$ & .6 & 21 & $1.8 E+00$ & $4.0 \mathrm{E}+02$ & $3.5 E+00$ & $5.6 E+00$ & FIXED ROOF & DIESEL \#2 & INSIDE BUILDING \\
\hline & & 021 & I $3.4 E+02$ & .9 & 100 & $2.5 E+00$ & $4.8 E+04$ & $1.2 E+01$ & $6.3 E+01$ & FIXED ROOF & DIESEL \#2 & OUTSIDE BUILDING \\
\hline & & 024 & | $1.6 E+05$ & .7 & 100 & $1.8 \mathrm{E}+00$ & $4.8 E+04$ & $1.2 E+01$ & $6.3 E+01$ & FIXED ROOF & DIESEL \#2 & OUTSIDE BUILDING \\
\hline \multirow{3}{*}{\multicolumn{2}{|c|}{679}} & 013 & | $5.8 E+02$ & .7 & 100 & $6.8 E+00$ & 1. $2 E+04$ & $8.5 E+00$ & $3.5 E+01$ & FIXED ROOF & DIESEL \#2 & OUTSIDE BUILDING \\
\hline & & 069 & I $4.2 E+06$ & .5 & 21 & $1.8 \mathrm{E}+00$ & 4. $0 E+02$ & $3.5 E+00$ & $5.8 E+00$ & FIXED ROOF & OIESEL \#2 & INSIDE BUILDING \\
\hline & & 084 & I $1.9 E+02$ & .4 & 21 & $1.3 E+00$ & $2.0 E+02$ & $2.5 E+00$ & $6.0 E+00$ & FIXED ROOF & DIESEL \#2 & INSIDE BUILDING \\
\hline & 681 & 004 & I $4.2 E+05$ & .7 & 100 & $2.5 E+00$ & $9.6 E+04$ & $1.2 E+01$ & $6.3 E+01$ & FIXED ROOF & DIESEL \#2 & OUTSIDE BUILDING \\
\hline & 687 & 008 & 11 & .5 & 200 & $1.1 \mathrm{E}+00$ & $1.5 E+02$ & $2.5 E+00$ & $E+\infty$ & FIXED ROOF & DIESEL \#2 & OUTSIDE BUILDING \\
\hline \multirow{2}{*}{\multicolumn{2}{|c|}{702}} & 001 & 1 $2.0 E+05$ & .5 & 100 & $1.5 E+00$ & $1.0 E+05$ & $2.2 E+01$ & $3.0 E+01$ & FIXED ROOF & DIESEL \#2 & OUTSIDE BUILDING \\
\hline & & 002 & $.0 E+00$ & .0 & 90 & $.0 E+00$ & $1.0 E+05$ & $2.2 E+01$ & $3.0 E+01$ & FIXED ROOF & FUEL OIL \#5 & OUTSIDE BUILDING \\
\hline & 704 & 001 & I $2.0 E+05$ & .5 & 90 & $4.3 E+00$ & $1.9 E+05$ & $2.8 E+01$ & $3.6 E+01$ & FIXED ROOF & DIESEL \#2 & OUTSIDE BUILDING \\
\hline \multirow{2}{*}{\multicolumn{2}{|c|}{724}} & 001 & $.0 E+00$ & .0 & 90 & $.0 E+00$ & $1.9 E+00$ & $2.8 E+01$ & $3.6 \mathrm{E}+01$ & FIXED ROOF & FUEL OIL \#5 & OUTSIDE BUILDING \\
\hline & & 002 & | $6.6 E+03$ & .5 & 90 & $1.1 E+00$ & $1.9 E+05$ & $2.8 E+01$ & $3.6 \mathrm{E}+01$ & FIXED ROOF & FUEL OIL \#5 & OUTSIDE BUILDING \\
\hline & 738 & 001 & $. v e+b u$ & .0 & 100 & $.0 E+00$ & $1.0 E+04$ & $8.0 E+00$ & $2.7 E+01$ & FIXED ROOF & FUEL OIL \#2 & OUTSIDE BUILOING \\
\hline & 753 & 001 & $.0 E+\infty 0$ & .0 & 00 & $.0 E+00$ & $5.5 E+04$ & $1.2 E+01$ & $6.0 \mathrm{E}+01$ & FIXED ROOF & IEL OIL \#5 & UTSIDE BUILDING \\
\hline & 759 & 001 & $14.5 E+04$ & .5 & 200 & 5. $0 \mathrm{E}-01$ & $1.9 E+02$ & $2.5 E+00$ & $4.0 E+00$ & FIXED ROOF & DIESEL \#1 & INSIDE BUILDING \\
\hline \multirow{2}{*}{\multicolumn{2}{|c|}{766}} & 001 & $.0 E+\infty 0$ & .0 & 100 & $6.0 E+00$ & $5.0 E+04$ & $1.2 E+01$ & $6.0 E+01$ & FIXED ROOF & DIESEL \#2 & OUTSIDE BUILDING \\
\hline & & 002 & $. W E+\infty u$ & .0 & & $.0 E+\infty 0$ & & & & & & \\
\hline & $767 \mathrm{~A}$ & 001 & I $3.2 E+04$ & .5 & 100 & $6.0 E+00$ & $3.5 E+04$ & $1.2 E+01$ & $3.6 E+01$ & FIXED ROOF & DIESEL \#2 & OUTSIDE BUILDING \\
\hline & $767 \mathrm{~B}$ & 001 & I $3.2 E+04$ & .5 & 100 & $6.0 E+00$ & $3.5 E+04$ & $1.2 E+01$ & $3.6 \mathrm{E}+01$ & FIXED ROOF & DIESEL \#2 & OUTSIDE BUILDING \\
\hline & 783 & 001 & | $5.7 E+04$ & .6 & 100 & $4.8 E+00$ & $1.2 E+04$ & $8.0 E+00$ & $3.2 E+01$ & FIXED ROOF & GASOLINE & OUTSIDE BUILDING \\
\hline & 787 & 001 & $.0 E+00$ & .0 & 100 & $.0 E+00$ & $1.0 E+04$ & $8.0 E+00$ & $2.7 E+01$ & FIXED ROOF & DIESEL \#2 & OUTSIDE BUILDINE \\
\hline & 792 & 001 & $17.5 E+04$ & .6 & 100 & $5.0 E+00$ & $1.0 E+04$ & $8.0 E+00$ & $2.7 E+01$ & FIXED ROOF & DIESEL \#1 & OUTSIDE BUILDING \\
\hline
\end{tabular}


Update Survey for AIR EMISSIONS INVENTORY ORGANIC STORAGE TANKS - 1993

$$
\text { PART I }
$$

\begin{tabular}{|c|c|c|c|c|c|c|c|c|c|c|c|}
\hline BLDG & VENT & $\begin{array}{l}\text { Annual } \\
\text { Thru Put } \\
\text { (ga } 1 / \text { yr) }\end{array}$ & $\begin{array}{c}\text { Ave. } \\
\% \\
\text { Ful1 }\end{array}$ & $\begin{array}{r}\text { Fill } \\
\text { Rate } \\
\text { (gall } \\
\text { min) }\end{array}$ & $\begin{array}{r}\text { Vapor } \\
\text { Space } \\
\text { Height } \\
(\mathrm{ft})\end{array}$ & $\begin{array}{r}\text { Capacity } \\
\text { (gal) }\end{array}$ & $\begin{array}{l}\text { Tank } \\
\text { Dia. } \\
(\mathrm{ft})\end{array}$ & $\begin{array}{r}\text { Tank } \\
\text { Length } \\
(\mathrm{ft})\end{array}$ & Tank Type & Material Stored & $\begin{array}{l}\text { Tank } \\
\text { Location }\end{array}$ \\
\hline 794 & 001 & $6.0 \mathrm{E}+02$ & .5 & 100 & $2.7 E+00$ & $1.0 \mathrm{E}+03$ & $5.3 \mathrm{E}+00$ & $6.0 E+00$ & FIXED ROOF & DIESEL \#2 & OUTSIDE BUILDING \\
\hline 797 & 001 & $6.5 E+02$ & .5 & 100 & $2.7 E+00$ & $1.0 E+03$ & $5.3 E+00$ & $6.0 E+00$ & FIXED ROOF & DIESEL \#2 & OUTSIDE BUILDING \\
\hline
\end{tabular}


Update Survey for AIR EMISSIONS INVENTORY ORGANIC STORAGE TANKS - 1993

Page: 14 PART I

\begin{tabular}{|c|c|c|c|c|c|c|c|c|c|c|c|c|}
\hline AREA & BLDG & VENT & $\begin{array}{r}\text { Annua } 1 \\
\text { Thru Put } \\
\text { (ga1/yr) }\end{array}$ & $\begin{array}{c}\text { Ave. } \\
\% \\
\text { Fu11 }\end{array}$ & $\begin{array}{r}\text { Fill } \\
\text { Rate } \\
\text { (gal/ } \\
\text { min) }\end{array}$ & $\begin{array}{r}\text { Vapor } \\
\text { Space } \\
\text { Height } \\
(\mathrm{ft})\end{array}$ & $\begin{array}{r}\text { Capacity } \\
\text { (gal) }\end{array}$ & $\begin{array}{l}\text { Tank } \\
\text { Dia. } \\
\text { (ft) }\end{array}$ & $\begin{array}{r}\text { Tank } \\
\text { Length } \\
(\mathrm{ft})\end{array}$ & Tank Type & Material Stored & $\begin{array}{l}\text { Tank } \\
\text { Location }\end{array}$ \\
\hline \multirow[t]{16}{*}{ TRA } & 619 & 006 & $7.8 E+02$ & .8 & 200 & $8.5 E-01$ & $3.0 E+02$ & $3.4 E+00$ & $4.0 E+00$ & FIXED ROOF & DIESEL \#2 & INSIDE BUILDING \\
\hline & 633 & 002 & | $7.8 \mathrm{E}+02$ & .8 & 200 & $9.4 \mathrm{E}-01$ & $6.6 E+02$ & $3.8 E+00$ & $8.0 E+00$ & FIXED ROOF & DIESEL \#2 & INSIDE BUILDING \\
\hline & 640 & 004 & $.0 E+\infty$ & .5 & 200 & $9.4 \mathrm{E}-01$ & $5.5 E+01$ & $2.3 E+01$ & $3.3 E+01$ & FIXED ROOF & LUBE OIL & INSIDE BUILDING \\
\hline & 670 & 044 & I $4.2 E+05$ & .9 & 100 & $6.8 E-01$ & $1.5 E+03$ & $5.4 E+00$ & $9.4 E+00$ & FIXED ROOF & DIESEL \#2 & \\
\hline & & 047 & | $1.5 E+03$ & 1.0 & 200 & 2. $9 E-01$ & $5.5 E+02$ & $4.9 E+00$ & $5.8 E+00$ & FIXED ROOF & LUBE OIL & INSIDE BUILDING \\
\hline & & 048 & | $9.6 \mathrm{E}+01$ & 1.0 & 2 & $5.0 E-01$ & $1.0 E+01$ & $8.3 E-01$ & $2.0 E+00$ & FIXED ROOF & DIESEL \#2 & INSIDE BUILOING \\
\hline & & 054 & $1.5 E+0$ & 1.0 & 200 & $2.9 E-01$ & $5.5 E+02$ & $4.9 E+00$ & $5.8 E+00$ & FIXEO ROOF & LUBE OIL & INSIDE BUILDING \\
\hline & 674 & 005 & $.0 \mathrm{E}+00$ & .0 & 20 & $.0 E+00$ & $2.8 \mathrm{E}+02$ & $3.9 E+00$ & $5.0 E+00$ & FIXED ROOF & DIESEL \#2 & INSIDE BUILDING \\
\hline & 675 & 001 & | $9.5 E+02$ & .5 & 200 & $1.8 E+\infty 0$ & $5.5 E+02$ & $3.6 \mathrm{E}+00$ & $7.3 E+00$ & FIXED ROOF & LUBE OIL (ATTACHED M & INSIDE BUILDING \\
\hline & & 002 & $19.5 E+02$ & .5 & 200 & $1.8 E+00$ & $5.5 E+02$ & $3.6 E+00$ & $7.3 E+00$ & FIXED ROOF & LUBE OIL (AT & INSIDE BUILDING \\
\hline & 707 & 001 & $1.6 E+C$ & .9 & 100 & $7.0 E-01$ & $3.5 E+03$ & $6.0 E+00$ & $1.7 E+01$ & FIXED ROOF & UNLEADED GAS & \\
\hline & 727 & 001 & $.0 E+00$ & .0 & 200 & $.0 E+00$ & $2.2 E+05$ & $3.0 E+01$ & 4. $2 E+01$ & FIXED ROOF & DIESEL \#2 & OUTSIDE BUILDING \\
\hline & & 002 & $.0 E+00$ & .0 & 200 & $.0 E+00$ & $2.2 E+05$ & $3.0 E+01$ & $4.2 E+01$ & FIXED ROOF & OIESEL \#2 & OUTSIDE BUILDING \\
\hline & & 003 & $1.3 \mathrm{E}+05$ & .8 & 150 & $2.0 E+00$ & $3.0 E+04$ & $1.6 E+01$ & $2.1 E+01$ & FIXED ROOF & DIESEL \#2 & OUTSIDE BUILDING \\
\hline & & 004 & $1.3 E+05$ & $\cdot .8$ & 150 & $2.0 E+\infty 0$ & $9.2 E+04$ & $2.0 E+01$ & $2.1 E+01$ & FIXED ROOF & OIESEL \#2 & OUTSIDE BUILDING \\
\hline & 775 & 001 & $1.3 E+05$ & .8 & 150 & $2.0 E+00$ & $3.7 E+04$ & $1.8 E+01$ & $2.1 E+01$ & FIXED ROOF & DIESEL \#2 & OUTSIDE BUILDING \\
\hline
\end{tabular}


Update Survey for AIR EMISSIONS INVENTORY ORGANIC STORAGE TANKS - 1993

Page: 15 PART I

\begin{tabular}{|c|c|c|c|c|c|c|c|c|c|c|c|}
\hline BLDG & VENT & $\begin{array}{l}\text { Annual } \\
\text { Thru Put } \\
\text { (ga } 7 / y r)\end{array}$ & $\begin{array}{l}\text { Ave. } \\
\% \\
\text { Full }\end{array}$ & $\begin{array}{r}\mathrm{Fill1} \\
\text { Rate } \\
\text { (ga } 1 / \\
\text { min) }\end{array}$ & $\begin{array}{r}\text { Vapor } \\
\text { Space } \\
\text { Height } \\
(\mathrm{ft})\end{array}$ & $\begin{array}{r}\text { Capacity } \\
\text { (gal) }\end{array}$ & $\begin{array}{l}\text { Tank } \\
\text { Dia. } \\
\text { (ft) }\end{array}$ & $\begin{array}{r}\text { Tank } \\
\text { Length } \\
(\mathrm{ft})\end{array}$ & Tank Type & Material Stored & $\begin{array}{l}\text { Tank } \\
\text { Location }\end{array}$ \\
\hline 603 & 002 & $5.6 E+02$ & .6 & 200 & $2.0 E+00$ & $2.5 E+02$ & $3.0 E+00$ & $5.0 E+00$ & FIXED ROOF & DIESEL \#2 & INSIDE BUILDING \\
\hline
\end{tabular}




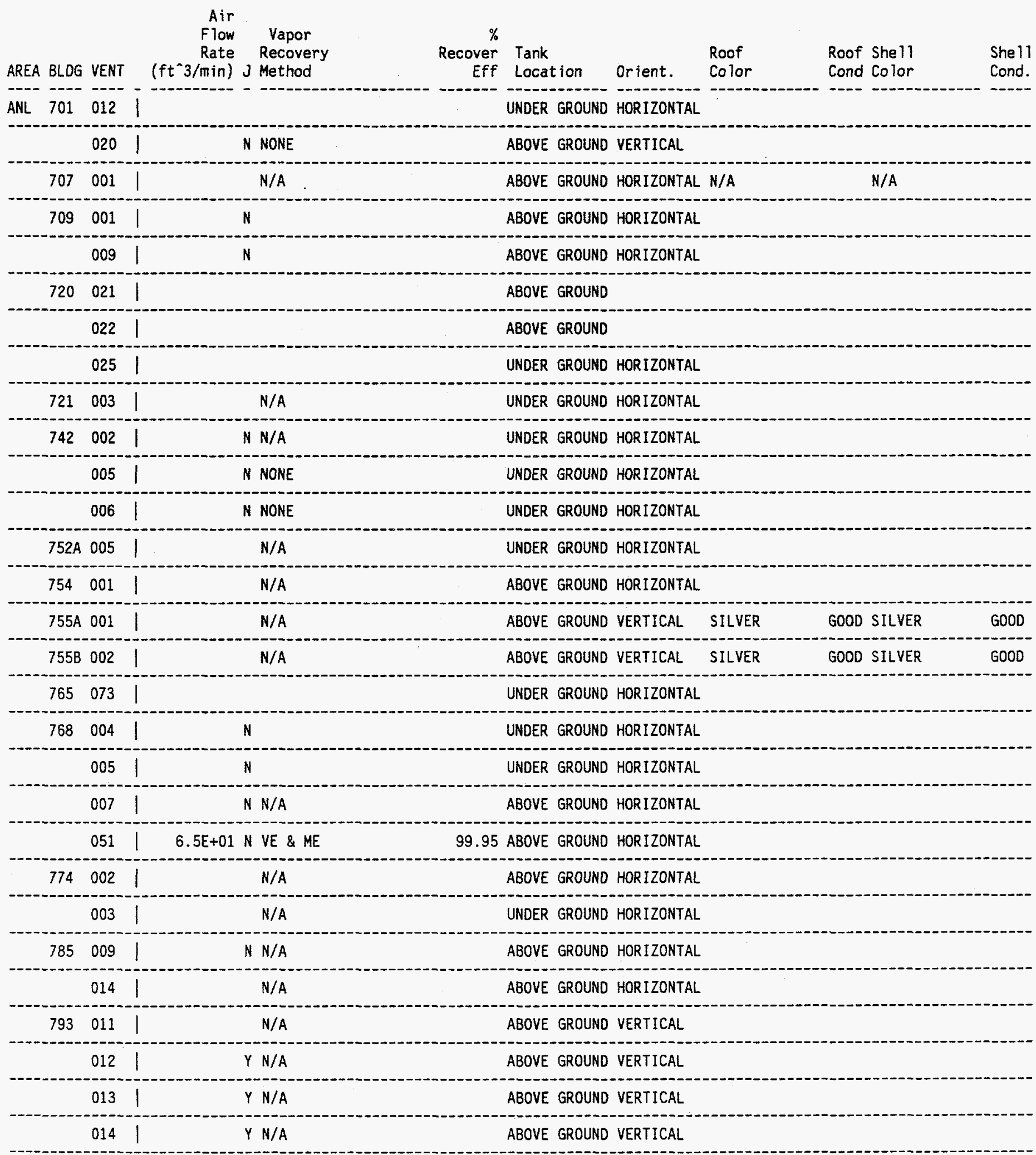




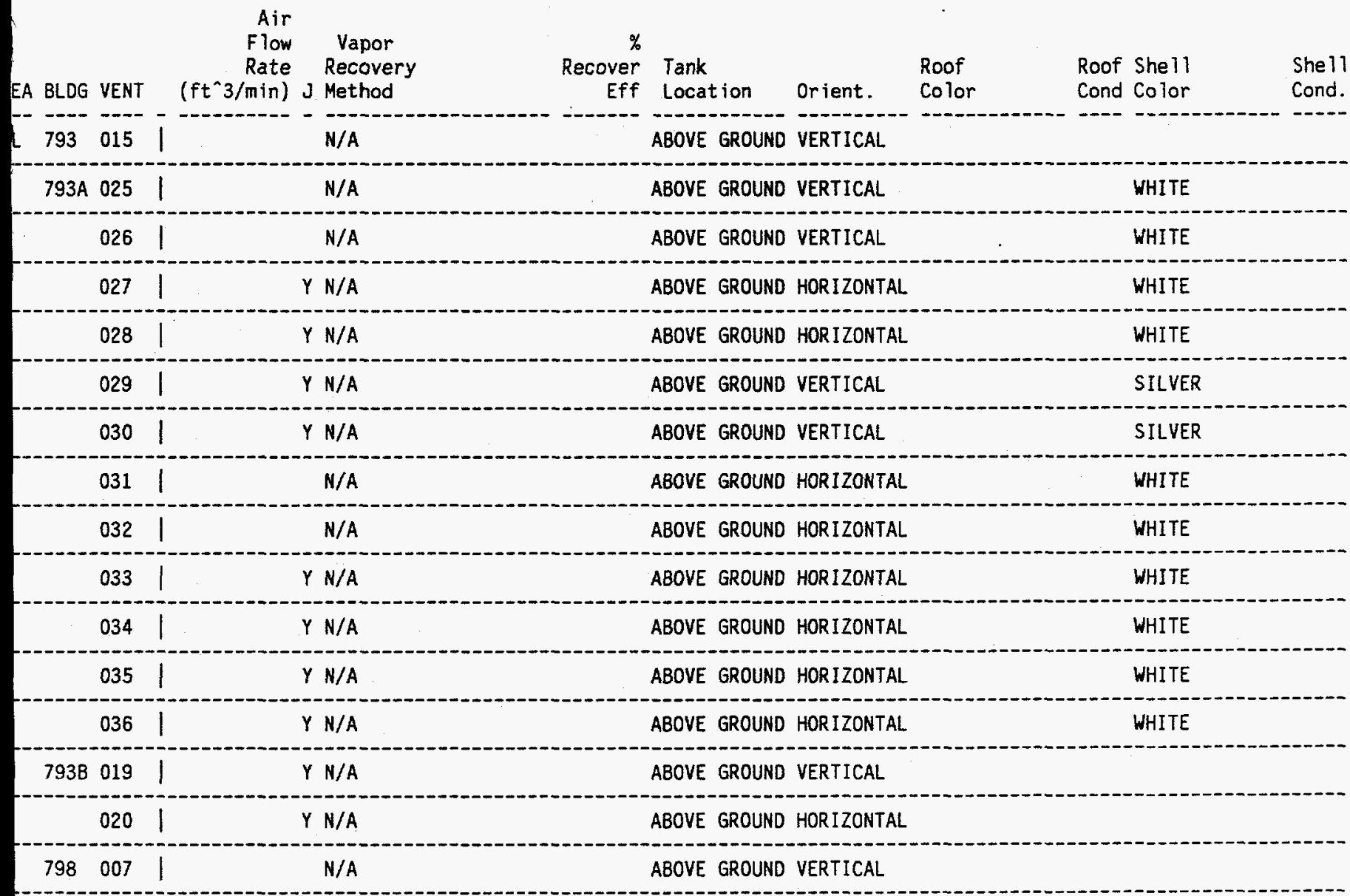


Update Survey for ORGANIC STORAGE TANKS - 1993

Page: 4 PART II

\begin{tabular}{|c|c|c|c|c|c|c|c|c|c|c|}
\hline AREA & BLDG & VENT & $\begin{array}{r}\text { Air } \\
\text { Flow } \\
\text { Rate } \\
\left(\mathrm{ft}^{\wedge} 3 / \mathrm{min}\right)\end{array}$ & $\begin{array}{l}\text { Vapor } \\
\text { Recovery } \\
\text { Method }\end{array}$ & $\begin{array}{r}\% \\
\text { Recover } \\
\text { Eff }\end{array}$ & $\begin{array}{l}\text { Tank } \\
\text { Locat ion }\end{array}$ & Orient. & $\begin{array}{l}\text { Roof } \\
\text { Color }\end{array}$ & $\begin{array}{l}\text { Roof Shell } \\
\text { Cond Color }\end{array}$ & $\begin{array}{l}\text { She } 11 \\
\text { Cond. }\end{array}$ \\
\hline B16 & 601 & 008 & & & & UNDER GROUI & HORIZONTAL & & & \\
\hline & 703 & 001 & & NONE & & UNDER GROUI & HOR IZONTAL & & & \\
\hline
\end{tabular}

Update Survey for ORGANIC STORAGE TANKS - 1993

Page: 5 PART II

\begin{tabular}{|c|c|c|c|c|c|c|c|c|c|c|}
\hline AREA & BLDG & VENT & $\begin{array}{r}\text { Air } \\
\text { Flow } \\
\text { Rate } \\
\left(\mathrm{ft}^{\wedge} 3 / \text { min }\right)\end{array}$ & $\begin{array}{l}\text { Vapor } \\
\text { Recovery } \\
\text { J Method }\end{array}$ & $\begin{array}{r}\% \\
\text { Recover } \\
\text { Eff }\end{array}$ & $\begin{array}{l}\text { Tank } \\
\text { Location }\end{array}$ & Orient. & $\begin{array}{l}\text { Roof } \\
\text { Color }\end{array}$ & $\begin{array}{l}\text { Roof She } 11 \\
\text { Cond Color }\end{array}$ & $\begin{array}{l}\text { She } 11 \\
\text { Cond. }\end{array}$ \\
\hline$B 23$ & 602 & 002 & & & & ABOVE GROL & HORIZON & & & \\
\hline
\end{tabular}

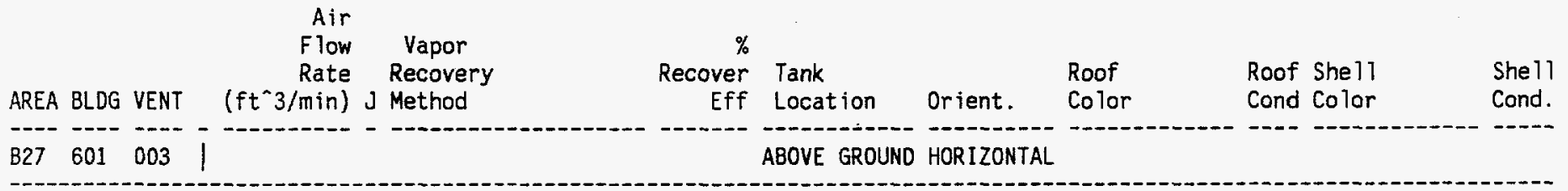




\begin{tabular}{|c|c|c|c|c|c|c|c|c|}
\hline BLDG & $\begin{array}{r}\text { Air } \\
\text { Flow } \\
\text { Rate } \\
\text { VENT } \quad\left(\mathrm{ft}^{\wedge} 3 / \mathrm{min}\right)\end{array}$ & $\begin{array}{l}\text { Vapor } \\
\text { Recovery } \\
\text { Method }\end{array}$ & $\begin{array}{r}\% \\
\text { Recover } \\
\text { Eff }\end{array}$ & $\begin{array}{l}\text { Tank } \\
\text { Locat ion }\end{array}$ & Orient. & $\begin{array}{l}\text { Roof } \\
\text { Color }\end{array}$ & $\begin{array}{l}\text { Roof Shell } \\
\text { Cond Color }\end{array}$ & $\begin{array}{l}\text { She } 11 \\
\text { Cond. }\end{array}$ \\
\hline 609 & 0021 & & & ABOVE GROUND & VERTICAL & & & \\
\hline 668 & 0011 & & & UNDER GROUND & HOR IZONTAL & & & \\
\hline & 0101 & & & UNDER GROUND & HOR IZONTAL & & & \\
\hline 684 & 0021 & & & ABOVE GROUND & HOR IZONTAL & FLAT SILVER & POOR FLAT SILVER & POOR \\
\hline 688 & 0031 & $N / A$ & & UNDER GROUND & HORIZONTAL & & & \\
\hline & $048 \quad 1$ & & & UNDER GROUND & HORIZONTAL & & & \\
\hline 708 & 0011 & & & ABOVE GROUND & VERTICAL & WHITE & GOOD WHITE & GOOD \\
\hline 713 & 0011 & & & UNDER GROUND & HORIZONTAL & & & \\
\hline & 0021 & & & UNDER GROUND & HOR IZONTAL & & & \\
\hline 721 & 0011 & & & UNDER GROUND & HOR IZONTAL & & & \\
\hline 729 & 0011 & & & UNDER GROUND & HOR IZONTAL & & & \\
\hline 730 & $001 \quad 1$ & & & UNOER GROUND & HORIZONTAL & & & \\
\hline 731 & 0011 & & & UNDER GROUND & HORIZONTAL & & & \\
\hline 732 & 0011 & & & UNDER GROUND & HORIZONTAL & & & \\
\hline 734 & 0011 & & & UNDER GROUND & HORIZONTAL & & & \\
\hline 735 & 0011 & & & UNDER GROUND & HORIZONTAL & & & \\
\hline 738 & 0011 & & & UNDER GROUND & HORIZONTAL & & & \\
\hline 739 & 0011 & & & UNDER GROUND & HOR IZONTAL & & & \\
\hline 741 & 0011 & & & UNDER GROUND & HOR IZONTAL & & & \\
\hline & 0021 & & & UNOER GROUND & HORIZONTAL & & & \\
\hline 748 & 0011 & & & UNDER GROUND & HOR IZONTAL & & & \\
\hline 749 & 0011 & & & ABOVE GROUND & HORIZONTAL & WHITE & GOOD WHITE & GOOD \\
\hline 754 & 0011 & & & ABOVE GROUND & VERTICAL & SILVER, DULL & GOOD SILVER, DULL & GOOD \\
\hline & 0021 & & & ABOVE GROUND & VERTICAL & SILVER, DULL & GOOD SILVER, DULL & GOOD \\
\hline & 0031 & & & ABOVE GROUND & VERTICAL & SILVER, DULL & GOOD SILVER, DULL & \\
\hline & 0041 & & & ABOVE GROUND & VERTICAL & SILVER, OULL & GOOD SILVER, DULL & \\
\hline & 0051 & & & ABOVE GROUND & VERTICAL & SILVER, DULL & GOOD & \\
\hline & 0061 & & & ABOVE GROUND & VERTICAL & SILVER, OULL & & \\
\hline & $007 \quad$ & & & ABOVE GROUND & VERTICAL & SILVER, DULL & & \\
\hline
\end{tabular}


Update Survey for ORGANIC STORAGE TANKS - 1993

Page: 8 PART II

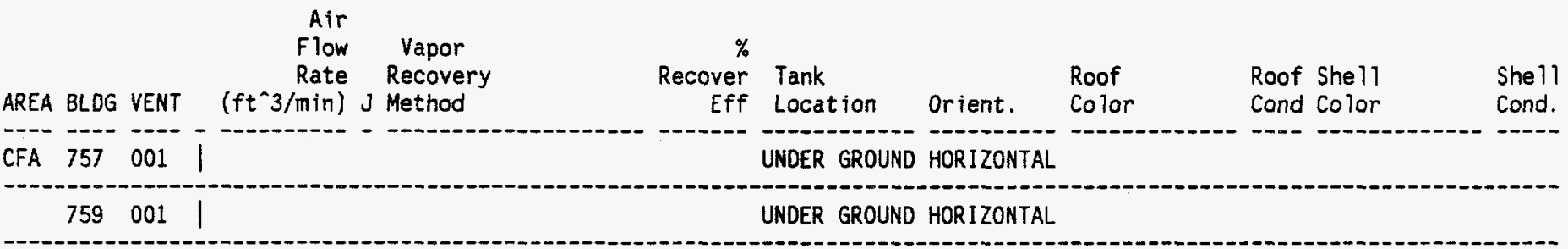




\begin{tabular}{|c|c|c|c|c|c|c|c|c|c|c|}
\hline BLDG & VENT & $\begin{array}{r}\text { Air } \\
\text { Flow } \\
\text { Rate } \\
\left(\mathrm{ft}^{\wedge} 3 / \mathrm{min}\right) \mathrm{J}\end{array}$ & $\begin{array}{l}\text { Vapor } \\
\text { Recovery } \\
\text { Method }\end{array}$ & $\begin{array}{r}\% \\
\text { Recover } \\
\text { Eff }\end{array}$ & $\begin{array}{l}\text { Tank } \\
\text { Locat ion }\end{array}$ & Orient. & $\begin{array}{l}\text { Roof } \\
\text { Color }\end{array}$ & $\begin{array}{l}\text { Roof } \\
\text { Cond }\end{array}$ & $\begin{array}{l}\text { Shell } \\
\text { Color }\end{array}$ & $\begin{array}{l}\text { She } 11 \\
\text { Cond. }\end{array}$ \\
\hline 1642 & 003 & 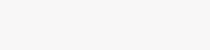 & & & ABOVE GROUND & HORIZONTAL & & & & \\
\hline 1643 & 003 & | & & & ABOVE GROUND & HORIZONTAL & & & & \\
\hline 1749 & 002 & 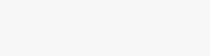 & & & ABOVE GROUND & HOR IZONTAL & RED & GOOD & RED & GOOD \\
\hline 601 & 016 & 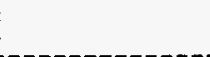 & N/A & & ABOVE GROUND & VERTICAL & SILVER & N/A & SILVER & N/A \\
\hline & 024 & 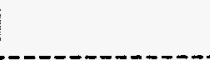 & & & & & & & & \\
\hline 614 & 001 & | & & & ABOVE GROUND & HORIZONTAL & YELLOW & GOOD & & \\
\hline 616 & 007 & 1 & & & ABOVE GROUND & HORIZONTAL & DULL RED & & DULL RED & \\
\hline 620 & 002 & 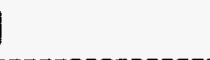 & & & UNDER GROUND & HORIZONTAL & & & & \\
\hline 644 & 004 & ! & N/A & & ABOVE GROUND & HOR IZONTAL & SILVER, DULL & & SILVER, DULL & \\
\hline & 006 & ! & & & ABOVE GROUND & VERTICAL & BLUE & GOOD & & GOOD \\
\hline & 013 & | & & & ABOVE GROUND & HOR I ZONTAL & SILVER & GOOD & SILVER & GOOD \\
\hline 659 & 010 & ! & & & UNDER GROUND & HORIZONTAL & & & & \\
\hline & 011 & 1 & & & UNDER GROUND & HOR IZONTAL & & & & \\
\hline & 035 & 1 & N/A & & ABOVE GROUND & HOR I ZONTAL & MEDIUM GREY & & MEDIUM GREY & \\
\hline $701 \mathrm{~A}$ & 001 & $1.4 E+05$ & & & ABOVE GROUND & VERTICAL & SHINY SILVER & GOOD & SILVER, DULL & GOOD \\
\hline $701 B$ & 001 & N & & & ABOVE GROUND & VERTICAL & SHINY SILVER & TIN & SILVER, DULL & TIN \\
\hline $702 \mathrm{~A}$ & 001 & $7.5 E+03$ & & & ABOVE GROUND & VERTICAL & FLAT SILVER & BAD & FLAT SILVER & BAD \\
\hline $702 B$ & 001 & $1.4 E+03$ & & & ABOVE GROUND & VERTICAL & FLAT SILVER & BAD & FLAT SILVER & BAD \\
\hline 703 & 001 & $2.6 E+03$ & & & UNDER GROUND & HOR IZONTAL & & & & \\
\hline & 002 & - $\quad 3.5 E+04$ & & & UNDER GROUND & HOR IZONTAL & & & & \\
\hline 775 & 005 & 1 & & & ABOVE GROUND & HORIZONTAL & GRAY & GOOD & GRAY & GOOD \\
\hline
\end{tabular}


Update Survey for ORGANIC STORAGE TANKS - 1993

Page: 10

PART II

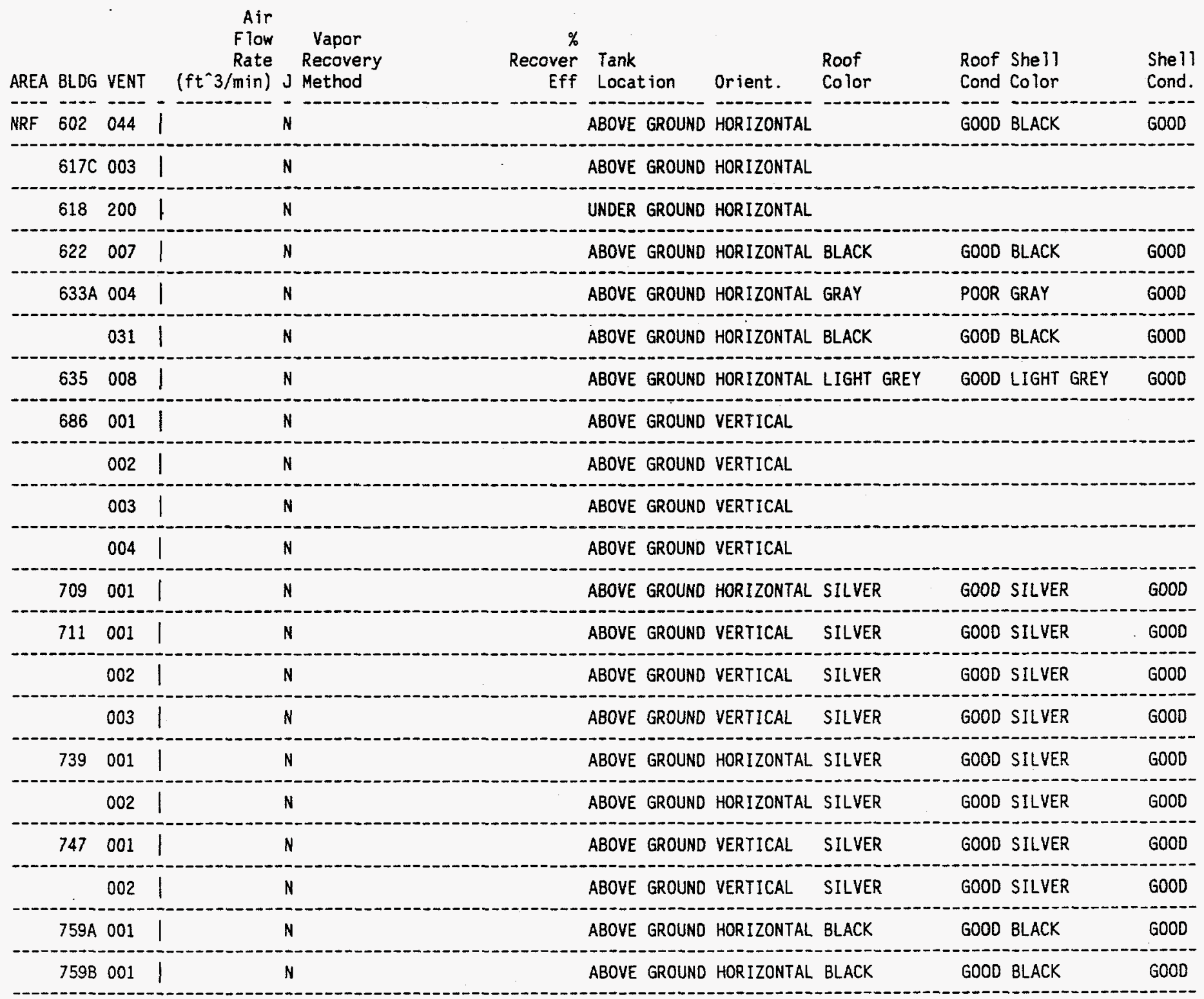




\begin{tabular}{|c|c|c|c|c|c|c|c|c|c|c|}
\hline BLDG & VENT & $\begin{array}{r}\text { Air } \\
\text { Flow } \\
\text { Rate } \\
\left(\mathrm{ft}^{\wedge} 3 / \mathrm{min}\right)\end{array}$ & $\begin{array}{l}\text { Vapor } \\
\text { Recovery } \\
\text { J Method }\end{array}$ & $\begin{array}{r}\% \\
\text { Recover } \\
\text { Eff }\end{array}$ & $\begin{array}{l}\text { Tank } \\
\text { Location }\end{array}$ & Orient. & $\begin{array}{l}\text { Roof } \\
\text { Color }\end{array}$ & $\begin{array}{l}\text { Roof } \\
\text { Cond }\end{array}$ & $\begin{array}{l}\text { Shell } \\
\text { Color }\end{array}$ & $\begin{array}{l}\text { She } 11 \\
\text { Cond. }\end{array}$ \\
\hline 609 & 010 & | & NONE & & ABOVE GROUND & VERTICAL & GREEN & G000 & GREEN & GOOD \\
\hline 625 & 002 & | & NONE & & ABOVE GROUND & HORIZONTAL & & & SILVER, DULL & EXCEL \\
\hline & 004 & & NONE & & ABOVE GROUND & VERTICAL & & & SILVER, DULL & POOR \\
\hline 626 & 005 & & NONE & & ABOVE GROUND & HORIZONTAL & BLACK & G000 & BLACK & GOOD \\
\hline 705 & 001 & 1 & MONE & & ABOVE GROUND & VERTICAL & WHITE & 6000 & WHITE & GOOD \\
\hline 711 & 001 & | & $N N / A$ & & ABOVE GROUND & HORIZONTAL & WHITE & GOOD & WHITE & GOOD \\
\hline 716 & 001 & | & NONE & & UNDER GROUNO & HORIZONTAL & & & & \\
\hline 722 & 001 & $.0 E+00$ & NONE & & UNDER GROUND & HORIZONTAL & & & & \\
\hline 737 & 001 & | & NONE & & UNDER GROUND & HORIZONTAL & & & & \\
\hline 740 & 001 & | & NONE & & UNDER GROUND & HORIZONTAL & & & & \\
\hline 742 & 001 & | & NONE & & UNDER GROUND & HORIZONTAL & & & & \\
\hline 743 & 001 & | & NONE & & UNDER GROUND & HORIZONTAL & & & & \\
\hline 749 & 001 & | & NONE & & UNDER GROUND & HORIZONTAL & & & & \\
\hline 752 & 001 & | & NONE & & UNDER GROUND & HOR IZONTAL & & & & \\
\hline
\end{tabular}




\begin{tabular}{|c|c|c|c|c|c|c|c|c|c|c|c|}
\hline AREA & BLDG & VENT & $\begin{array}{r}\text { Air } \\
\text { Flow } \\
\text { Rate } \\
\left(\mathrm{ft}^{\wedge} 3 / \mathrm{min}\right)\end{array}$ & $\begin{array}{l}\text { Vapor } \\
\text { Recovery } \\
\text { Method }\end{array}$ & $\begin{array}{r}\% \\
\text { Recover } \\
\text { Eff }\end{array}$ & $\begin{array}{l}\text { Tank } \\
\text { Location }\end{array}$ & Orient. & $\begin{array}{l}\text { Roof } \\
\text { Color }\end{array}$ & $\begin{array}{l}\text { Roof } \\
\text { Cond }\end{array}$ & $\begin{array}{l}\text { Shell } \\
\text { Color }\end{array}$ & $\begin{array}{l}\text { She } 11 \\
\text { Cond. }\end{array}$ \\
\hline TAN & 607 & $047 \mid$ & | & NONE & & UNDER GROUND & HOR IZONTAL & & & & \\
\hline & 610 & 0011 & | & NONE & & ABOVE GROUND & HOR IZONTAL & & & YELLOW & \\
\hline & 652 & 0021 & | & & & ABOVE GROUND & HORIZONTAL & & & & \\
\hline & 665 & 001 & I & NONE & & ABOVE GROUND & HORIZONTAL & YELLOW & & & \\
\hline & 675 & 0111 & I & N/A & & UNDER GROUNO & HORIZONTAL & & & & \\
\hline & & 0121 & | & $\mathrm{N} / \mathrm{A}$ & & ABOVE GROUND & HORIZONTAL & & & WHITE & GOOD \\
\hline & & 0131 & | & $N \mathrm{~N} / \mathrm{A}$ & & ABOVE GROUND & HOR IZONTAL & & & WHITE & GOOD \\
\hline & & 0211 & | & $N / A$ & & UNDER GROUND & HORIZONTAL & & & & \\
\hline & & 0241 & & N/A & & UNDER GROUND & HORIZONTAL & & & & \\
\hline & 679 & $013 \mid$ & | & $N / A$ & & UNDER GROUND & HORIZONTAL & & & & \\
\hline & & $069 \quad$ & & $N N / A$ & & ABOVE GROUND & HOR IZONTAL & & & WHITE & GOOD \\
\hline & & $084 \mid$ & I & & & ABOVE GROUND & HOR IZONTAL & & & WHITE & GOOD \\
\hline & 681 & 0041 & & N/A & & UNDER GROUND & HOR IZONTAL & & & & \\
\hline & 687 & $008 \quad 1$ & & NONE & & ABOVE GROUND & HORIZONTAL & & & & \\
\hline & 702 & 0011 & I & & & ABOVE GROUND & VERTICAL & WHITE & G00D & LIGHT GREY & Go00 \\
\hline & & 0021 & & & & ABOVE GROUND & VERTICAL & WHITE & GOOD & LIGHT GREY & GOOD \\
\hline & 704 & 0011 & & & & ABOVE GROUND & VERTICAL & FLAT SILVER & GOOD & FLAT SILVER & GOOD \\
\hline & 724 & 0011 & & & & ABOVE GROUND & VERTICAL & WHITE & GOOD & LIGHT GREY & G000 \\
\hline & & 0021 & & $N / A$ & & ABOVE GROUND & VERTICAL & WHITE & GO0D & LIGHT GREY & G00D \\
\hline & 738 & 0011 & I & & & UNDER GROUND & HORIZONTAL & & & & \\
\hline & 753 & $001 \quad 1$ & | & & & UNDER GROUND & HOR IZONTAL & & & & \\
\hline & 759 & 0011 & & & & ABOVE GROUND & HOR IZONTAL & LT. BLUE & FAIR & LT. BLUE & POOR \\
\hline & 766 & 0011 & | & NONE & & UNDER GROUND & HOR IZONTAL & & & & \\
\hline & & 0021 & & & & & & & & & \\
\hline & $767 \mathrm{~A}$ & 001 & | & NONE & & UNDER GROUND & HORIZONTAL & & & & \\
\hline & $767 \mathrm{~B}$ & 001 & & NONE & & UNDER GROUND & HOR IZONTAL & & & & \\
\hline & 783 & 0011 & | & & & UNDER GROUND & HORIZONTAL & & & & \\
\hline & 787 & 001 & I & & & UNDER GROUND & HOR IZONTAL & & & & \\
\hline & 792 & 0011 & & & & UNOER GROUND & HOR IZONTAL & & & & \\
\hline
\end{tabular}


Update Survey for ORGANIC STORAGE TANKS - 1993

Page: 13

PART II

Air

Flow

Recovery

( $\left.\mathrm{ft}^{\wedge} 3 / \mathrm{min}\right) \mathrm{J}$ Method

A BLDG VENT

N

N

797001
$\%$

Recover Tank Roof Roof Shell

Eff Location Orient. Color Cond Color

She 11

Cond.

UNDER GROUND HORIZONTAL

UNDER GROUNO HORIZONTAL 


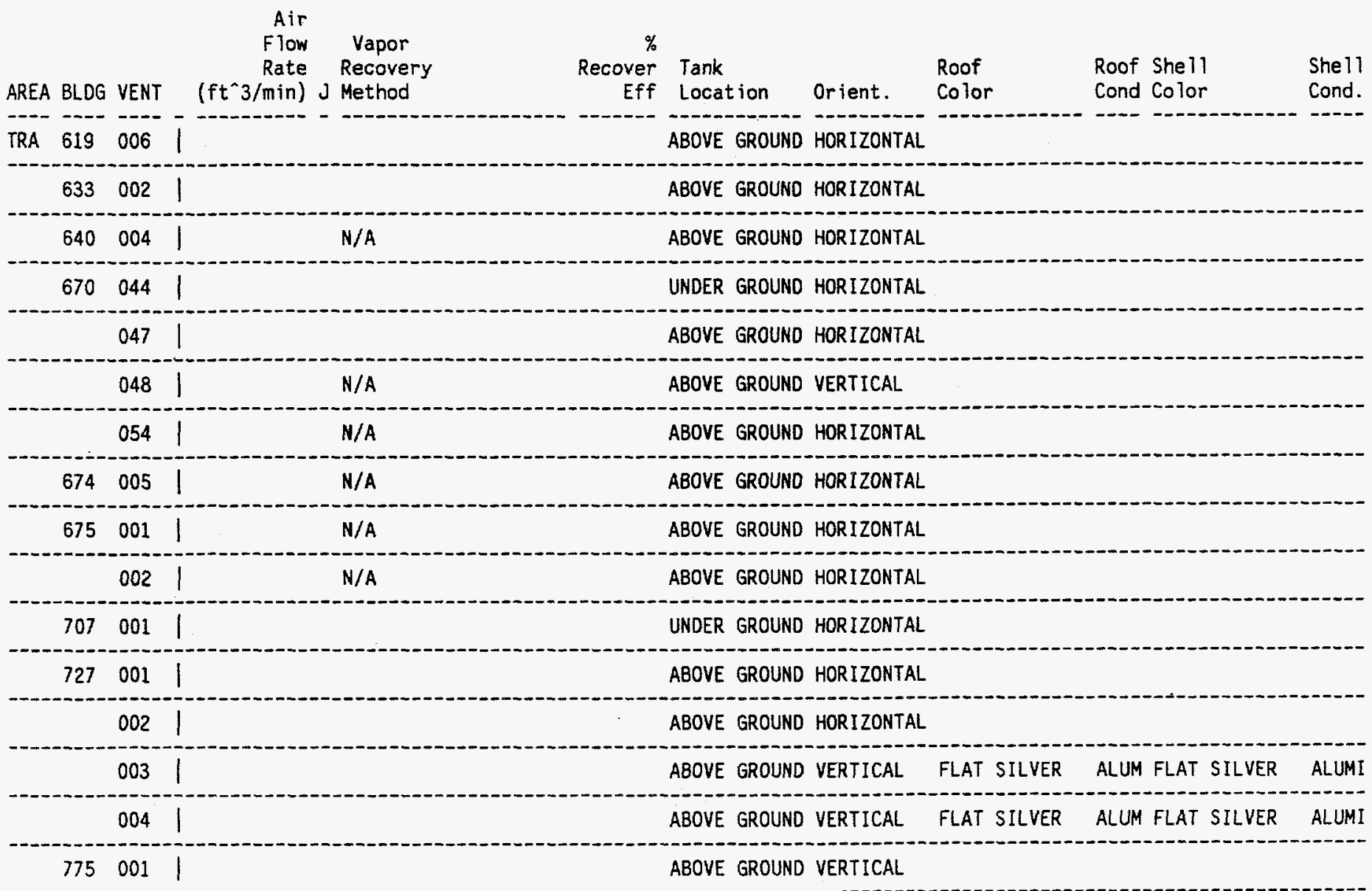


Air

Flow Vapor

Rate Recovery

A BLDG VENT ( $\left.\mathrm{ft}^{\wedge} 3 / \mathrm{min}\right) \mathrm{J}$ Method N/A

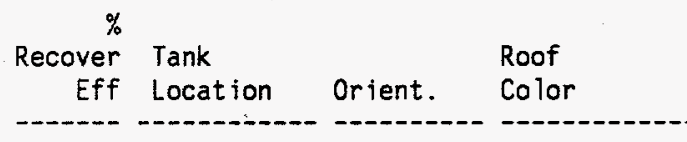

Roof She 11 Cond Color

She 11 Cond. ABOVE GROUND HORIZONTAL 
Update Survey for AIR EMISSIONS INVENTORY INORGANIC STORAGE TANKS - 1993

Page: 1 PART I

\begin{tabular}{|c|c|c|c|c|c|c|c|c|c|c|c|}
\hline$A \quad B L D G$ & VENT & $\begin{array}{r}\text { Annual } \\
\text { Thru Put } \\
\text { (gal/yr) }\end{array}$ & $\begin{array}{c}\text { Ave. } \\
\% \\
\text { Fuil }\end{array}$ & $\begin{array}{r}\text { Fill } \\
\text { Rate } \\
\text { (gal/ } \\
\text { min) }\end{array}$ & $\begin{array}{r}\text { Vapor } \\
\text { Space } \\
\text { Height } \\
(\mathrm{ft})\end{array}$ & $\begin{array}{r}\text { Capacity } \\
\text { (gal) }\end{array}$ & $\begin{array}{l}\text { Tank } \\
\text { oia. } \\
(f t)\end{array}$ & $\begin{array}{r}\text { Tank } \\
\text { Length } \\
(\mathrm{ft})\end{array}$ & Tank Type & Material Stored & $\begin{array}{l}\text { Tank } \\
\text { Location }\end{array}$ \\
\hline $757 \mathrm{~A}$ & 002 & $6.0 \mathrm{E}+03$ & .5 & & $3.5 \mathrm{E}+00$ & $4.0 E+03$ & $7.0 E+00$ & $1.6 \mathrm{E}+01$ & FIXED ROOF & $93 \%$ SULFURIC ACID & OUTSIDE BUILDI \\
\hline 768 & 097 & $2.1 E+03$ & .5 & 20 & $2.0 E+00$ & $2.0 E+03$ & $5.0 E+00$ & $1.5 E+01$ & FIXED ROOF & $93 \%$ SULFURIC ACID & DUT \\
\hline & 134 & $7.5 E+02$ & .5 & & $2.5 E+00$ & $2.0 E+03$ & $5.0 E+00$ & $1.2 E+01$ & FIXED ROOF & - POTASSIUM HYDROXIDE & 20 \\
\hline
\end{tabular}


Update Survey for AIR EMISSIONS INVENTORY INORGANIC STORAGE TANKS - 1993

Page: 2 PART I

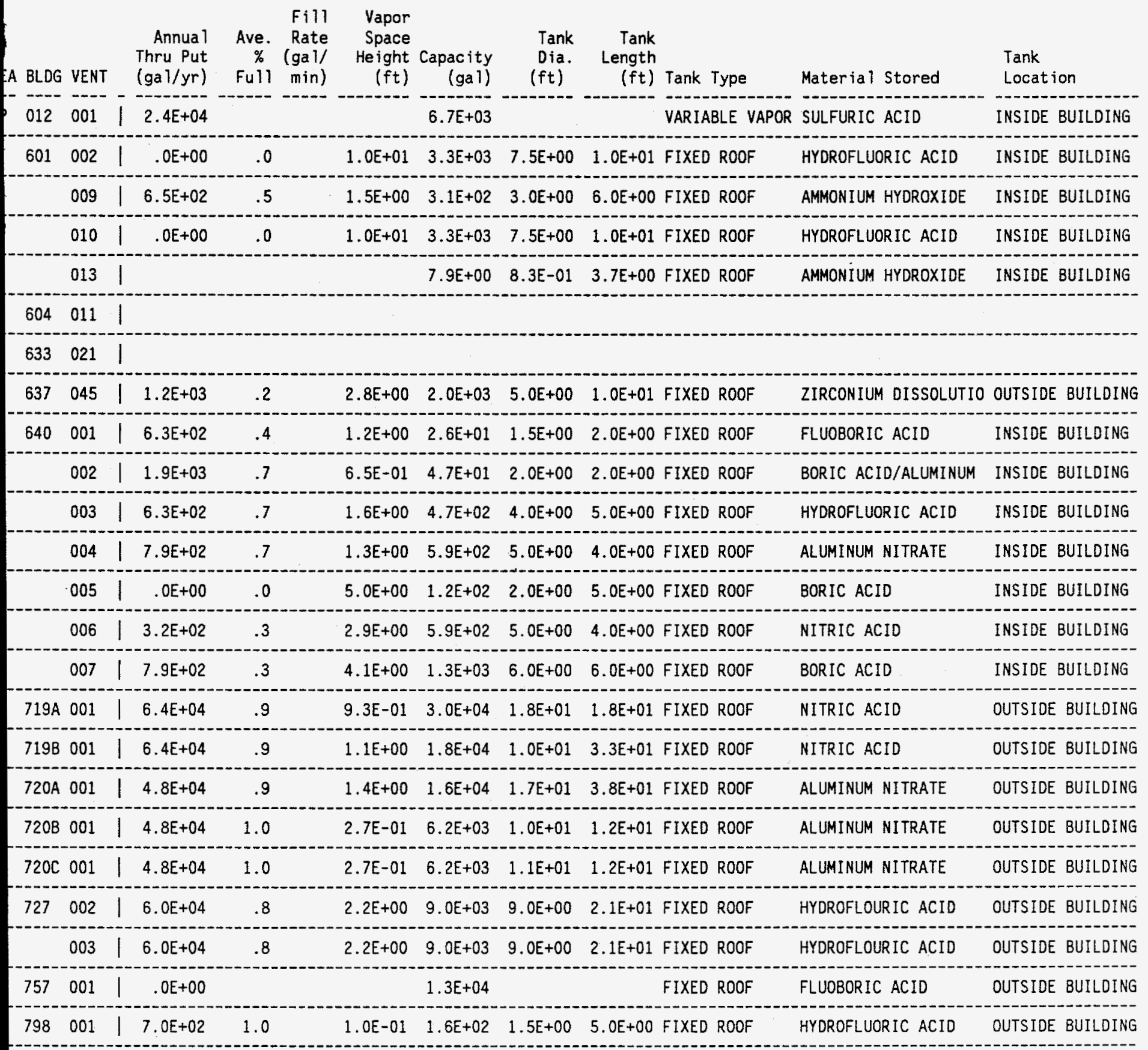


Update Survey for AIR EMISSIONS INVENTORY INORGANIC STORAGE TANKS - 1993

Page: $\quad 3$ PART I

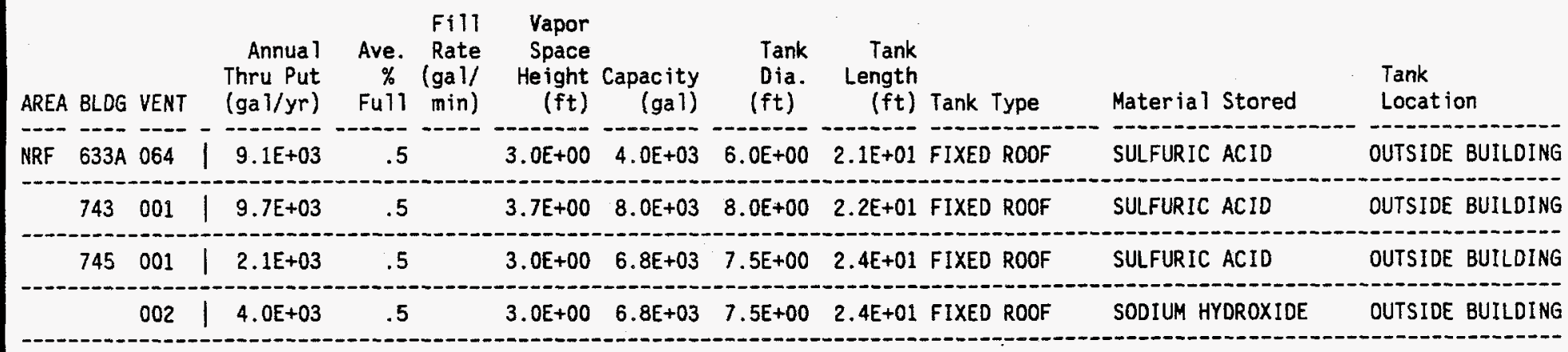



PART I

\begin{tabular}{|c|c|c|c|c|c|c|c|c|c|c|c|}
\hline BLDG & VENT & $\begin{array}{r}\text { Annual } \\
\text { Thru Put } \\
\text { (gal/yr) }\end{array}$ & $\begin{array}{c}\text { Ave. } \\
\% \\
\text { Full }\end{array}$ & $\begin{array}{r}\text { Fill } \\
\text { Rate } \\
\text { (gall/ } \\
\text { min) }\end{array}$ & $\begin{array}{r}\text { Vapor } \\
\text { Space } \\
\text { Height } \\
\text { (ft) }\end{array}$ & $\begin{array}{r}\text { Capacity } \\
\text { (gai) }\end{array}$ & $\begin{array}{l}\text { Tank } \\
\text { Dia. } \\
\text { (ft) }\end{array}$ & $\begin{array}{r}\text { Tank } \\
\text { Length } \\
(\mathrm{ft})\end{array}$ & Tank Type & Material Stored & $\begin{array}{l}\text { Tank } \\
\text { Location }\end{array}$ \\
\hline 620 & 001 & $.0 E+00$ & .5 & & $1.8 E+00$ & $2.5 E+02$ & $3.5 E+00$ & 8. $0 E+00$ & FIXED ROOF & SULFURIC ACID & OUTSIDE BUILDING \\
\hline 624 & 005 & $1.5 \mathrm{E}+02$ & .5 & & $1.5 E+00$ & $4.0 E+02$ & $3.0 E+00$ & $7.0 E+00$ & FIXED ROOF & SULFURIC ACID & OUTSIDE BUILDING \\
\hline
\end{tabular}


Update Survey for AIR EMISSIONS INVENTORY INORGANIC STORAGE TANKS - 1993

Page: 5

$$
\text { PART I }
$$

Fi11 Vapor

Annual Ave. Rate Space Tank Tank

Thru Put \% (gal/ Height Capacity Dia. Length

AREA BLDG VENT (gal/yr)

Full min) (ft) (gal) (ft) (ft)

Tank

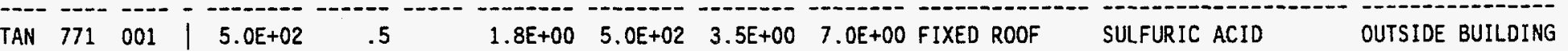

TAM 771 001 1 $5.0 E+02$. 50


Update Survey for AIR EMISSIONS INVENTORY INORGANIC STORAGE TANKS - 1993

Page: 6 PART I

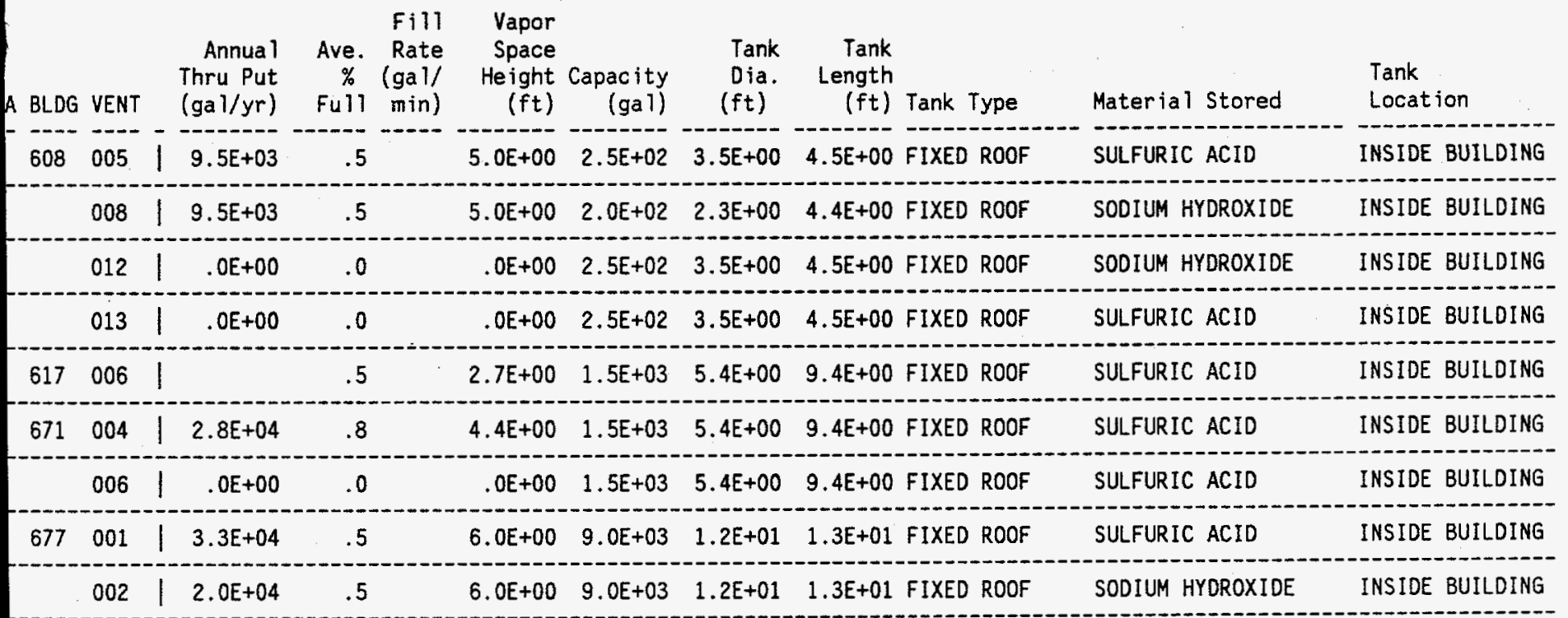


Update Survey for INORGANIC STORAGE TANKS - 1993

Page: 1

PART II

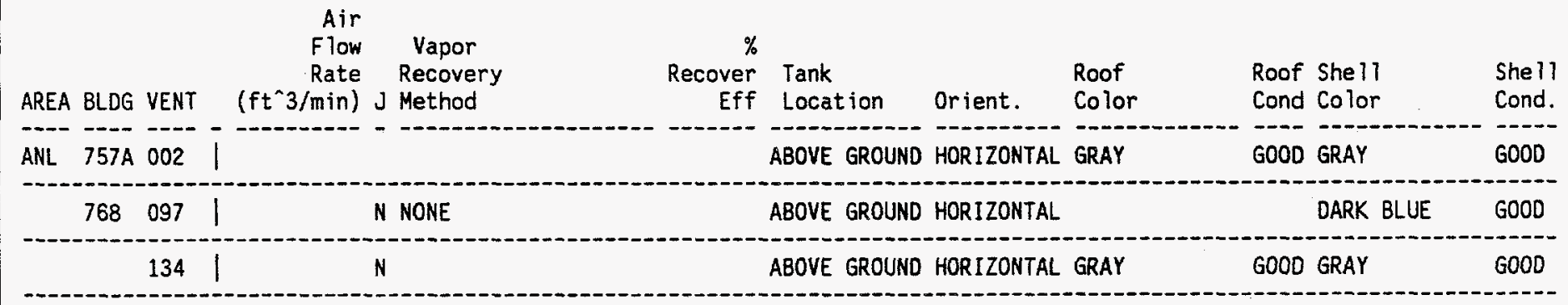




\begin{tabular}{|c|c|c|c|c|c|c|c|c|c|c|}
\hline BLDG & VENT & $\begin{array}{r}\text { Air } \\
\text { Flow } \\
\text { Rate } \\
\left(\mathrm{ft}^{\wedge} 3 / \mathrm{min}\right)\end{array}$ & $\begin{array}{l}\text { Vapor } \\
\text { Recovery } \\
\text { Method }\end{array}$ & $\begin{array}{r}\% \\
\text { Recover } \\
\text { Eff }\end{array}$ & $\begin{array}{l}\text { Tank } \\
\text { Locat ion }\end{array}$ & Orient. & $\begin{array}{l}\text { Roof } \\
\text { Color }\end{array}$ & $\begin{array}{l}\text { Roof } \\
\text { Cond }\end{array}$ & $\begin{array}{l}\text { Shell } \\
\text { Color }\end{array}$ & $\begin{array}{l}\text { She } 11 \\
\text { Cond. }\end{array}$ \\
\hline 012 & 001 & & GROTH SILICA GEL FIL & 80.00 & ABOVE GROUND & HORIZONTAL & & & & \\
\hline 601 & 002 & & $N / A$ & & ABOVE GROUND & VERTICAL & WHITE & GOOD & WHITE & GOOD \\
\hline & 009 & & $N / A$ & & ABOVE GROUND & HORIZONTAL & SILVER & & SILVER & \\
\hline & 010 & & $\mathrm{~N} / \mathrm{A}$ & & ABOVE GROUND & VERTICAL & WHITE & 6000 & WHITE & G000 \\
\hline & 013 & & $\mathrm{~N} / \mathrm{A}$ & & ABOVE GROUND & VERTICAL & SILVER & $\mathrm{N} / \mathrm{A}$ & SILVER & N/A \\
\hline 604 & 011 & & & & & & & & & \\
\hline 633 & 021 & & & & & & & & & \\
\hline 637 & 045 & & & & ABOVE GROUND & HORIZONTAL & SILVER & GOOD & SILVER & GOOD \\
\hline 640 & 001 & & $N / A$ & & ABOVE GROUND & VERTICAL & SILVER & $N / A$ & SILVER & N/A \\
\hline & 002 & & N/A & & ABOVE GROUND & VERTICAL & WHITE & G000 & WHITE & GOOD \\
\hline & 003 & & $N / A$ & & ABOVE GROUND & VERTICAL & SILVER & $N / A$ & WHITE & GOOD \\
\hline & 004 & & $\mathrm{~N} / \mathrm{A}$ & & ABOVE GROUND & VERTICAL & SILVER & & WHITE & GOOD \\
\hline & 005 & & N/A & & ABOVE GROUND & VERTICAL & SILVER & $N / A$ & SILVER & $N / A$ \\
\hline & 006 & & N/A & & ABOVE GROUND & VERTICAL & SILVER & $\mathrm{N} / \mathrm{A}$ & WHITE & GOOD \\
\hline & 007 & & N/A & & ABOVE GROUND & VERTICAL & SILVER & & WHITE & GOOD \\
\hline $719 \mathrm{~A}$ & 001 & & $N / A$ & & ABOVE GROUND & VERTICAL & SILVER, DULL & $B A D$ & SILVER, DULL & BAD \\
\hline $719 B$ & 001 & & N/A & & ABOVE GROUND & HOR IZONTAL & SILVER, DULL & $B A D$ & SILVER, DULL & BAD \\
\hline $720 \mathrm{~A}$ & 001 & & $N / A$ & & ABOVE GROUND & VERTICAL & SILVER & GOOD & SILVER & GOOD \\
\hline $720 B$ & 001 & & $N / A$ & & ABOVE GROUND & VERTICAL & SILVER & G000 & SILVER & GOOD \\
\hline $720 \mathrm{C}$ & 001 & & N/A & & ABOVE GROUND & VERTICAL & SILVER & GOOD & SILVER & GOOD \\
\hline 727 & 002 & & & & ABOVE GROUND & HORIZONTAL & WHITE & BAD & WHITE & BAD \\
\hline & 003 & & & & ABOVE GROUND & HORIZONTAL & WHITE & BAD & WHITE & BAD \\
\hline 757 & 001 & & & & ABOVE GROUND & HOR I ZONTAL & & & & \\
\hline 798 & 001 & & $N / A$ & & ABOVE GROUND & VERTICAL & GRAY & GOOD & GRAY & GOOD \\
\hline
\end{tabular}



PART II

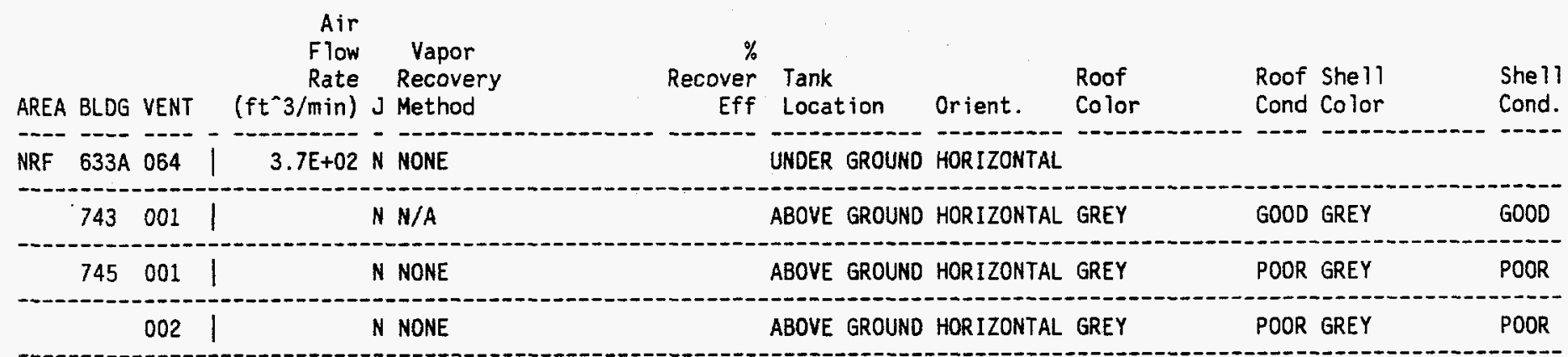


Update Survey for INORGANIC STORAGE TANKS - 1993

Page: 4

PART II

Air

Flow Vapor

Rate Recovery

EA BLDG VENT (ft` $3 / \mathrm{min}$ ) J Method

\begin{tabular}{rrrr}
$\begin{array}{r}\text { Recover } \\
\text { Eff Lank Location }\end{array}$ Orient. & $\begin{array}{l}\text { Roof } \\
\text { Color }\end{array}$ & $\begin{array}{l}\text { Roof She } 11 \\
\text { Cond Color }\end{array}$ & $\begin{array}{l}\text { She } 11 \\
\text { Cond. }\end{array}$ \\
\hline ABOVE GROUND HORIZONTAL YELLOW & YELLOW & EXCEL \\
\hline ABOVE GROUND HORIZONTAL & YELLOW & GOOD
\end{tabular}

NONE

ABOVE GROUND HORIZONTAL 
Update Survey for INORGANIC STORAGE TANKS - 1993

Page: 5 PART II

$\begin{array}{ll}\text { Air } & \\ \text { Flow } & \text { Vapor } \\ \text { Rate Recovery }\end{array}$

AREA BLDG VENT (ft^3/min) J Method

TAN 771 001
$\%$

Recover Tank Roof Roof She 11

Eff Location

Orient.

Color

ABOVE GROUND HORIZONTAL SILVER
Cond Color

She 11

Cond. 


\begin{tabular}{|c|c|c|c|c|c|c|c|c|c|}
\hline BLDG & VENT & $\begin{array}{r}\text { Air } \\
\text { Flow } \\
\text { Rate } \\
\left(\mathrm{ft}^{\wedge} 3 / \mathrm{min}\right)\end{array}$ & $\begin{array}{l}\text { Vapor } \\
\text { Recovery } \\
\text { J Method }\end{array}$ & $\begin{array}{r}\% \\
\text { Recover } \\
\text { Eff }\end{array}$ & $\begin{array}{l}\text { Tank } \\
\text { Locat ion }\end{array}$ & Orient. & $\begin{array}{l}\text { Roof } \\
\text { Color }\end{array}$ & $\begin{array}{l}\text { Roof Shell } \\
\text { Cond Color }\end{array}$ & $\begin{array}{l}\text { She } 11 \\
\text { Cond. }\end{array}$ \\
\hline 608 & 005 & & & & ABOVE GROUND & VERTICAL & & & \\
\hline & 008 & & & & ABOVE GROUND & VERTICAL & & & \\
\hline & 012 & & & & ABOVE GROUND & VERTICAL & & & \\
\hline & 013 & & & & ABOVE GROUND & VERTICAL & & & \\
\hline 617 & 006 & & $N / A$ & & ABOVE GROUND & HORIZONTAL & & & \\
\hline 671 & 004 & 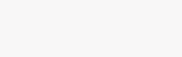 & $N / A$ & & ABOVE GROUND & HORIZONTAL & & & \\
\hline & 006 & 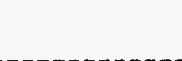 & N/A & & ABOVE GROUND & HORIZONTAL & & & \\
\hline 677 & 001 & 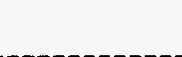 & N N/A & & ABOVE GROUND & VERTICAL & & & \\
\hline & 002 & | & N N/A & & ABOVE GROUND & VERTICAL & & & \\
\hline
\end{tabular}


Update Survey for AIR EMISSIONS INVENTORY CONTROL EQUIPMENT - 1993 Page: 1

\begin{tabular}{|c|c|c|c|c|c|}
\hline AREA & $B L D G$ & VENT & $\begin{array}{l}\text { Control } \\
\text { Type }\end{array}$ & Pollutant & $\begin{array}{r}\% \\
\text { Eff. }\end{array}$ \\
\hline ANL & 704 & 008 & HEPA FILTERS-2 BANKS & PARTICULATE & 99.97 \\
\hline & 720 & 027 & HEPA FILTER & PARTICULATE & 99.97 \\
\hline & 752 & 004 & HEPA FILTERS & PARTICULATE & 99.97 \\
\hline & & 005 & HEPA FILTER BANKS & PARTICULATE & 99.97 \\
\hline & 753 & 006 & $620^{\prime \prime} \times 20^{\prime \prime} \times 1 "$ FILTERS & PARTICULATE & 90.00 \\
\hline & & 029 & FILTER & PARTICULATE & 87.00 \\
\hline & 764 & 001 & HEPA FILTERS & PARTICULATE & 99.97 \\
\hline & 768 & 105 & HEPA FILTER & PARTICULATE & 99.97 \\
\hline & & 108 & HEPA FILTER & PARTICULATE & 99.97 \\
\hline & & & & & \\
\hline & $768 \mathrm{~B}$ & 121 & HEPA FILTER & PARTICULATE & 99.97 \\
\hline & 774 & 008 & HEPA BANK & PARTICULATE & 99.97 \\
\hline & & & & & $-2-1$ \\
\hline & & 025 & HEPA FILTER & PARTICULATE & 99.97 \\
\hline & 777 & 002 & HEPA FILTER & PARTICULATE & 99.97 \\
\hline & & 002 & HEPA FILTER & PARTICULATE & 99.70 \\
\hline & & 002 & SAND/GRAVEL & & \\
\hline & 785 & 011 & HEPA FILTER & PARTICULATE & 99.97 \\
\hline & & & HEPA FILTER & PARTICULATE & 99.97 \\
\hline & 787 & 001 & HEPA FILTER & PARTICULATE & 99.97 \\
\hline & 788 & 014 & FILTER & PARTICULATE & 90.00 \\
\hline & 793 & 001 & HEPA FILTER & PARTICULATE & 99.97 \\
\hline & & & HEPA FILTERS & PARTICULATE & 99.97 \\
\hline & 798 & 017 & 6 BAGOUT TYPE HEPA BANKS & PARTICULATE & 99.97 \\
\hline & 799 & 003 & HEPA FILTER & PARTICULATE & 99.97 \\
\hline & & 010 & HEPA FILTER & PARTICULATE & 99.97 \\
\hline
\end{tabular}


Update Survey for AIR EMISSIONS INVENTORY CONTROL EQUIPMENT - 1993 Page: 2

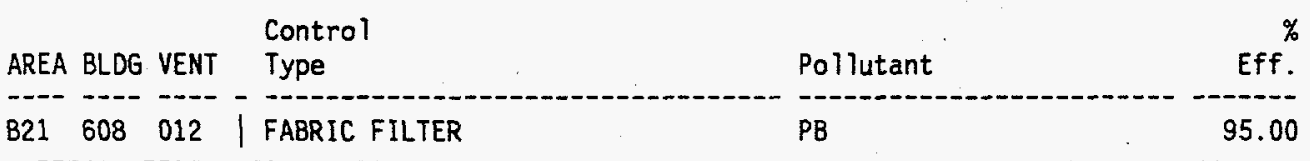


Update Survey for AIR EMISSIONS INVENTORY CONTROL EQUIPMENT - 1993 Page: 3

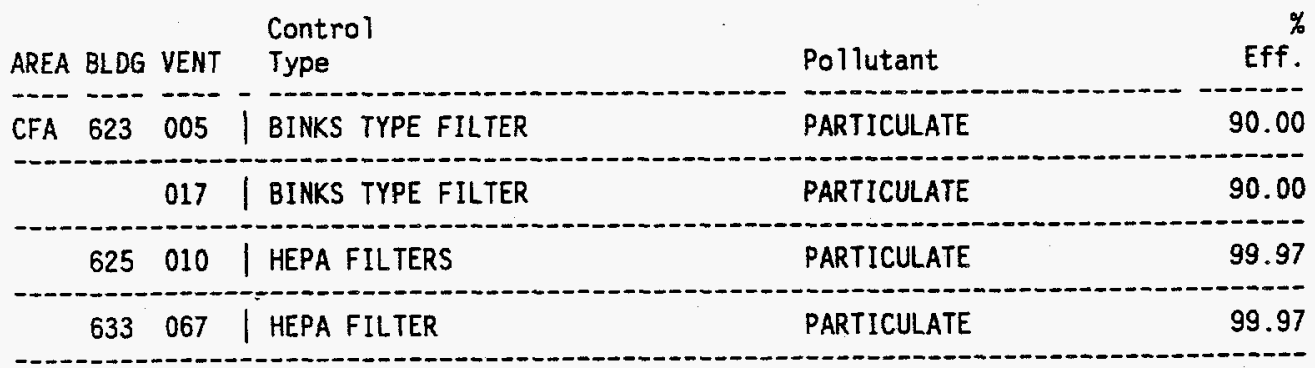


Update Survey for AIR EMISSIONS INVENTORY CONTROL EQUIPMENT - 1993 Page: 4

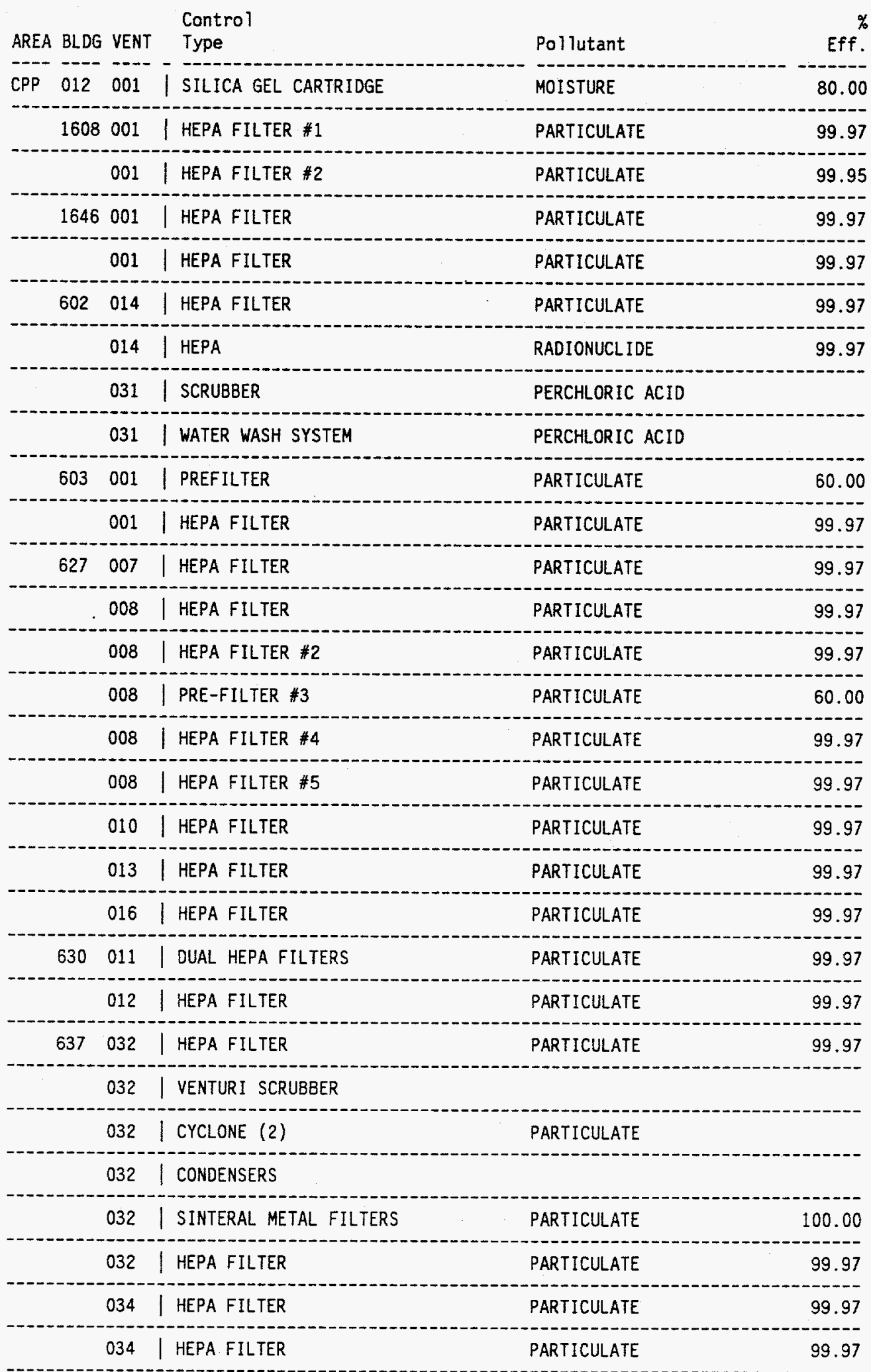


Update Survey for AIR EMISSIONS INVENTORY CONTROL EQUIPMENT - 1993 Page: 5

\begin{tabular}{|c|c|c|c|c|}
\hline AREA BLDG & VENT & $\begin{array}{l}\text { Control } \\
\text { Type }\end{array}$ & Pollutant & $\begin{array}{r}\% \\
\text { Eff. }\end{array}$ \\
\hline CPP 637 & 034 & SCRUBBER (ALUMINUM NITRATE) & URANIUM & 99.99 \\
\hline & 034 & SCRUBBER (ALUMINUM NITRATE) & HYDROFLUORIC ACID & 90.00 \\
\hline & 034 & CONDENSER & URANIUM & 99.97 \\
\hline & 035 & HEPA FILTER & PARTICULATE & 99.97 \\
\hline & 035 & SINTERED METAL FILTER & PARTICULATE & 100.00 \\
\hline & 036 & ALUMINUM NITRATE SCRUBBER & HYDROFLUORIC ACID & 40.00 \\
\hline & 042 & HEPA FILTER & PARTICULATE & 99.97 \\
\hline & 042 & SINTERED METAL FILTER & PARTICULATE & 100.00 \\
\hline & 052 & HEPA FILTER & PARTICULATE & 99.97 \\
\hline & 053 & HEPA FILTER & PARTICULATE & 99.97 \\
\hline & 058 & HEPA FILTER & PARTICULATE & 99.97 \\
\hline 648 & 002 & HEPA FILTER & PARTICULATE & 99.97 \\
\hline 659 & 033 & HEPA FILTERS & PARTICULATE & 99.97 \\
\hline & 033 & DEMISTER & VOC VAPORS & 90.00 \\
\hline 663 & 002 & HEPA FILTERS & NOTE \#1 & 99.97 \\
\hline 684 & 001 & HEPA FILTERS & PARTICULATE & 99.97 \\
\hline 687 & 010 & PULSE JET BAGHOUSE & PARTICULATE & 99.80 \\
\hline & 011 & PULSE JET BAGHOUSE & PARTICULATE & 99.80 \\
\hline & & PULSE JET BAGHOUSE & PARTICULATE & 99.80 \\
\hline & 034 & PULSE JET BAGHOUSE & PARTICULATE & 99.80 \\
\hline 694 & 007 & HEPA FILTER & PARTICULATE & 99.97 \\
\hline & 008 & HEPA FILTER & PARTICULATE & 99.97 \\
\hline & & HEPA FILTER & PARTICULATE & 99.97 \\
\hline & 010 & HEPA FILTER & PARTICULATE & 99.97 \\
\hline 708 & 001 & HEPA FILTER (FROM SOG) & PARTICULATE & 99.97 \\
\hline & 001 & HEPA FILTER (FROM 604,633,SOG) & PARTICULATE & 99.97 \\
\hline & 001 & DEEP BED FIBERGLASS PREFILTER & PARTICULATE & 90.00 \\
\hline & 001 & SCRUBBER (FROM 601, E-DOG) & & \\
\hline & 001 & DEMISTER (FROM 604, E-DOG) & ACIDS, LIQUIOS & \\
\hline & 001 & HEPA FILTER (FROM 601, E-DOG) & PARTICULATE & 99.97 \\
\hline
\end{tabular}


Update Survey for AIR EMISSIONS INVENTORY CONTROL EQUIPMENT - 1993 Page: 6

\begin{tabular}{|c|c|c|c|c|}
\hline AREA BLDG & VENT & $\begin{array}{l}\text { Control } \\
\text { Type }\end{array}$ & Pollutant & Eff. \\
\hline P 708 & 001 & FIBERGLASS PACKED PREFILTER & PARTICULATE & 90.00 \\
\hline & 001 & DEMISTER (FROM 604, VOG) & ACIDS, LIQUIDS & \\
\hline & 001 & HEPA FILTER (FROM 601, E-DOG) & PARTICULATE & 99.95 \\
\hline & 001 & HEPA FILTER & PARTICULATE & 99.97 \\
\hline & 001 & DEMISTER ( FROM 604, E-DOG) & & \\
\hline & 001 & SUPER HEATER (FROM 601, E-DOG) & & \\
\hline & 001 & SUPER HEATER (FROM 604, VO6) & & \\
\hline & 001 & HEPA FILTER (FROM 604, V06) & PARTICULATE & 99.97 \\
\hline & 001 & RARE GAS PLANT (FROM DOG, 604) & & \\
\hline & 001 & DEMISTER (FROM 604, DOG, CPM) & & \\
\hline & 001 & SUPER HEATER (FROM 604, DOG, CPM) & & \\
\hline & 001 & HEPA FILTER (FROM 604, CPM, DOG) & PARTICULATE & 99.97 \\
\hline & 001 & CYCLONES (FROM WCF-POG) & & \\
\hline & 001 & SCRUBBERS (FROM WCF-POG) & & \\
\hline & 001 & ADSORBERS (FROM WCF-POG) & & \\
\hline & 001 & HEPA FILTER (FROM WCF-POG-633) & PARTICULATE & 99.97 \\
\hline & 001 & CONDENSER/OEMISTER (FROM VOG, DOG, & & \\
\hline & 001 & SUPERHEATER/FIBERGLASS PACKED PREF & PARTICULATE & 90.00 \\
\hline & 001 & FINAL HEPA FILTER (VOG, DOG, CPM,L & PARTICULATE & 99.97 \\
\hline 727 & 002 & CAUSTIC SCRUBBER & HYDROFLUORIC ACID & 99.00 \\
\hline 765 & 003 & HEPA FILTER & PARTICULATE & 99.97 \\
\hline & 003 & HEPA FILTER & PARTICULATE & 99.97 \\
\hline & 003 & OFF GAS PREFILTER & PARTICULATE & \\
\hline & 003 & OFF GAS FILTER & PARTICULATE & \\
\hline 787 & 001 & REVERSE AIR CLEANING BAGHOUSE & PARTICULATE & 99.80 \\
\hline 791 & 004 & OFF GAS PREFILTER & PARTICULATE & 1 \\
\hline & 004 & OFF GAS HEPA & PARTICULATE & 99.97 \\
\hline & 004 & OFF GAS HEPA & PARTICULATE & 99.95 \\
\hline & 005 & HEPA FILTER & PART ICULATE & 99.97 \\
\hline & 005 & OFF GAS PREFILTER & PARTICULATE & \\
\hline
\end{tabular}


Update Survey for AIR EMISSIONS INVENTORY CONTROL EQUIPMENT - 1993 Page: 7

\begin{tabular}{|c|c|c|c|c|}
\hline AREA BLDG & VENT & $\begin{array}{l}\text { Control } \\
\text { Type }\end{array}$ & Pollutant & Eff. \\
\hline CPP 791 & 005 & OFF GAS HEPA & PARTICULATE & 99.95 \\
\hline & 005 & HEPA FILTER & PARTICULATE & 99.97 \\
\hline & 005 & OFF GAS HEPA FILTER & PARTICULATE & 99.97 \\
\hline & 006 & HEPA FILTER & PARTICULATE & 99.97 \\
\hline & 006 & OFF GAS PREFILTER & PARTICULATE & \\
\hline & 006 & OFF GAS HEPA & PARTICULATE & 99.95 \\
\hline & 006 & HEPA FILTER & PARTICULATE & 99.97 \\
\hline & 006 & OFF GAS HEPA & PARTICULATE & 99.97 \\
\hline 792 & 001 & PULSE JET DUST COLLECTOR & PARTICULATE & 99.80 \\
\hline & 002 & CYCLONE & PARTICULATE & 99.00 \\
\hline & 002 & CYCLONE & PARTICULATE & 99.00 \\
\hline & 002 & BAG FILTER & PARTICULATE & 99.50 \\
\hline & 003 & CYCLONE & PARTICULATE & 99.00 \\
\hline & 003 & CYCLONE & PARTICULATE & 99.00 \\
\hline & 003 & BAG FILTER & PARTICULATE & 99.50 \\
\hline 793 & 002 & PULSE JET DUST COLLECTOR & PARTICULATE & 99.80 \\
\hline 794 & 001 & FABRIC FILTER DUST COLLECTOR & PARTICULATE & 99.80 \\
\hline & 001 & FABRIC FILTER DUST COLLECTOR & PARTICULATE & 99.80 \\
\hline
\end{tabular}


Update Survey for AIR EMISSIONS INVENTORY CONTROL EQUIPMENT - 1993 Page: 8

\begin{tabular}{|c|c|c|c|c|c|}
\hline AREA & BLDG & VENT & $\begin{array}{l}\text { Control } \\
\text { Type }\end{array}$ & Pollutant & $\begin{array}{c}\% \\
\text { Eff. }\end{array}$ \\
\hline NRF & 601 & 023 & PREFILTER & PARTICULATE & 80.00 \\
\hline & & & 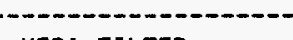 & & 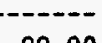 \\
\hline & & 023 & HEPA FILTER & PARTICULATE & 99.90 \\
\hline & & 023 & MIST EXTRACTOR & MIST - WATER & 100.00 \\
\hline & $601 A$ & 019 & HEPA & PARTICULATE & 99.95 \\
\hline & $601 C$ & 019 & HEPA & PARTICULATE & 99.95 \\
\hline & $601 F$ & 019 & HEPA & PARTICULATE & 99.95 \\
\hline & 602 & 008 & FURNACE FILTER & PARTICULATE & 80.00 \\
\hline & & 023 & FILTER & PARTICULATE & 80.00 \\
\hline & 616 & 039 & HEPA FILTER & PARTICULATE & 99.90 \\
\hline & 6164 & $\log 2$ & HEPA EUTFD & PARTICII ATF & 99.97 \\
\hline & -..... & -..... & - & - & -.-- \\
\hline & 617 & 013 & PREF ILTER & PARTICULATE & 80.00 \\
\hline & & 013 & HEPA FILTER & PARTICULATE & 99.90 \\
\hline & 618 & 099 & CARBON & VOC-NONMETHANE & 99.90 \\
\hline & & 099 & PREFILTER & PARTICULATE & 80.00 \\
\hline & & 099 & HEPA & PARTICULATE & 99.95 \\
\hline & & 103 & CARBON & VOC-NONMETHANE & 99.90 \\
\hline & & & HEPA & PARTICULATE & 99.95 \\
\hline & & 103 & PREF ILTER & PARTICULATE & 80.00 \\
\hline & $628 \mathrm{~A}$ & 006 & HEPA FILTER & PARTICULATE & 99.97 \\
\hline & 631 & 101 & HEPA FILTER & PARTICULATE & 99.97 \\
\hline & $633 \mathrm{~A}$ & 057 & HEPA FILTER & PARTICULATE & 99.95 \\
\hline & $759 A$ & & CONSERVATION VENT & VOC VAPORS & 75.00 \\
\hline & 7598 & 001 & CONSERVATION VENT & VOC VAPORS & 75.00 \\
\hline
\end{tabular}


Update Survey for AIR EMISSIONS INVENTORY CONTROL EQUIPMENT - 1993 Page: 9

\begin{tabular}{|c|c|c|c|c|}
\hline AREA BLDG & VENT & $\begin{array}{l}\text { Control } \\
\text { Type }\end{array}$ & Pollutant & $\begin{array}{r}\% \\
\text { Eff. }\end{array}$ \\
\hline PER 620 & 016 & HEPA FILTER & PARTICULATE & 99.97 \\
\hline & 041 & HEPA FILTER & PARTICULATE & 99.97 \\
\hline 622 & 003 & HEPA FILTER & PARTICULATE & 99.97 \\
\hline 755 & 001 & BAGHOUSE & PARTICULATE & 90.00 \\
\hline & 001 & HEPA FILTER & & \\
\hline 756 & 001 & HEPA FILTER & & \\
\hline 765 & 001 & BAGHOUSE & PARTICULATE & 90.00 \\
\hline & 001 & BAGHOUSE & PARTICULATE & 90.00 \\
\hline & 001 & HEPA FILTER & & \\
\hline
\end{tabular}


Update Survey for AIR EMISSIONS INVENTORY CONTROL EQUIPMENT - 1993 Page: 10.

\begin{tabular}{|c|c|c|c|c|c|}
\hline AREA & $B L D G$ & VENT & $\begin{array}{l}\text { Control } \\
\text { Type }\end{array}$ & Pollutant & Eff. \\
\hline TAN & 606 & 005 & CYCLONE DUST COLLECTOR & SAWDUST & 84.00 \\
\hline & 607 & 039 & HEPA FILTERS & PARTICULATE & 99.97 \\
\hline & & 059 & HEPA FILTER & PARTICULATE & 99.97 \\
\hline & & 066 & HEPA FILTER & PARTICULATE & 99.97 \\
\hline & & 107 & HEPA FILTERS & PARTICULATE & 99.97 \\
\hline & & 119 & HEPA FILTERS & PARTICULATE & 99.97 \\
\hline & & 136 & HEPA FILTERS & PARTICULATE & 99.97 \\
\hline & 610 & 002 & AIR CLEANER & & \\
\hline & 629 & 012 & HEPA FILTER & PARTICULATE & 99.97 \\
\hline & & 012 & DUST COLLECTOR & PARTICULATE & 99.00 \\
\hline & & 012 & ORY FILTERS & PARTICULATE & 75.00 \\
\hline & & 012 & HEPA & RADIONUCLIDE & 99.97 \\
\hline & & 012 & DUST COLLECTOR & PARTICULATE & 99.00 \\
\hline & & 013 & HEPA FILTERS & PARTICULATE & 99.97 \\
\hline & & 014 & HEPA FILTERS & PARTICULATE & 99.97 \\
\hline & & 014 & DUST COLLECTOR & PARTICULATE & 99.00 \\
\hline & & 014 & ORY FILTERS & PARTICULATE & 75.00 \\
\hline & & 014 & HEPA & RADIONUCLIDE & 99.97 \\
\hline & & 014 & DUST COLLECTOR & PARTICULATE & 99.00 \\
\hline & 636 & 002 & FURNACE FILTER & PARTICULATE & 80.00 \\
\hline & 650 & 007 & HEPA FILTER & PARTICULATE & 99.97 \\
\hline & & 010 & HEPA FILTER & PARTICULATE & 99.97 \\
\hline & 675 & 035 & OXYGEN TRIM & NITROGEN OXIDES & 11.00 \\
\hline & & 037 & OXYGEN TRIM & NITROGEN OXIDES & 11.00 \\
\hline & 679 & 022 & HEPA FILTERS & PARTICULATE & 99.97 \\
\hline & & 023 & HEPA FILTER & PARTICULATE & 99.97 \\
\hline & & 024 & HEPA FILTERS & PARTICULATE & 99.97 \\
\hline & & 025 & HEPA FILTER & PARTICULATE & 99.97 \\
\hline & & 026 & HEPA FILTERS & PARTICULATE & 99.97 \\
\hline & & 027 & HEPA FILTERS & PARTICULATE & 99.97 \\
\hline
\end{tabular}


Update Survey for AIR EMISSIONS INVENTORY CONTROL EQUIPMENT - 1993 Page: 1

\begin{tabular}{|c|c|c|c|c|c|}
\hline AREA & BLDG & VENT & $\begin{array}{l}\text { Control } \\
\text { Type }\end{array}$ & Pollutant & Eff. \\
\hline TAN & 679 & 067 & OXYGEN TRIM & NITROGEN OXIDES & 11.00 \\
\hline & & 068 & OXYGEN TRIM & NITROGEN OXIDES & 11.00 \\
\hline & 681 & 012 & SCRUBBER & NITROGEN OXIDES & 50.00 \\
\hline & & 012 & HEPA FILTERS & PARTICULATE & 99.97 \\
\hline & & 018 & HEPA FILTERS & PARTICULATE & 99.97 \\
\hline & & 020 & HEPA FILTERS & PARTICULATE & 99.97 \\
\hline
\end{tabular}


Update Survey for AIR EMISSIONS INVENTORY CONTROL EQUIPMENT - 1993 Page: 12

\begin{tabular}{|c|c|c|c|c|c|}
\hline AREA & BLDG & VENT & $\begin{array}{l}\text { Control } \\
\text { Type }\end{array}$ & Pollutant & $\begin{array}{r}\% \\
\text { Eff. }\end{array}$ \\
\hline TRA & 604 & 035 & HEPA FILTER & PARTICULATE & 99.97 \\
\hline & 632 & 019 & HEPA FILTER & PARTICULATE & 99.97 \\
\hline & & 019 & PREFILTER & PARTICULATE & 60.00 \\
\hline & & 019 & AGX ABSORBER & IODINE & \\
\hline & & 030 & HEPA FILTER & PARTICULATE & 99.97 \\
\hline & & 030 & PREFILTER & PARTICULATE & 60.00 \\
\hline & & 030 & AGX ABSORBER & IODINE & \\
\hline & & 041 & PREFILTER & PARTICULATE & 60.00 \\
\hline & & 041 & HEPA FILTER \#1 & PARTICULATE & 99.97 \\
\hline & & 041 & CHARCOAL FILTER & IODINE & \\
\hline & & 041 & HEPA FILTER \#2 & PARTICULATE & 99.97 \\
\hline & 660 & 004 & HEPA FILTER & PARTICULATE & 99.97 \\
\hline & 661 & 008 & HEPA FILTER & PARTICULATE & 99.97 \\
\hline & & 008 & PRE-FILTER & PARTICULATE & \\
\hline & 670 & 074 & HEPA FILTER & PARTICULATE & 99.97 \\
\hline & & 086 & HEPA & PARTICULATE & 99.97 \\
\hline & & 086 & FURNACE FILTER & PARTICULATE & 80.00 \\
\hline & & 098 & HEPA FILTER & PARTICULATE & 99.97 \\
\hline
\end{tabular}


Update Survey for AIR EMISSIONS INVENTORY CONTROL EQUIPMENT - 1993 Page: 13

\begin{tabular}{|c|c|c|c|c|c|}
\hline AREA & BLDG & VENT & $\begin{array}{l}\text { Control } \\
\text { Type }\end{array}$ & Pollutant & $\begin{array}{r}\% \\
\text { Eff. }\end{array}$ \\
\hline WMF & 601 & 009 & HEPA FILTERS & PARTICULATE & 99.97 \\
\hline & 615 & 001 & HEPA FILTER & PARTICULATE & 99.97 \\
\hline & 640 & 001 & HEPA FILTER & PARTICULATE & 99.97 \\
\hline & 700 & 002 & HEPA FILTER & PARTICULATE & 99.97 \\
\hline
\end{tabular}


AREA BLDG VENT Manufacturer

ANL 704 008 | HOMEMADE

752004 | RMS EBERLINE

764001 | EBERLINE

$774025 \quad \mid \mathrm{N} / \mathrm{A}$

793001 | HOMEMADE

001 | NONE

\begin{tabular}{ll|l}
798 & 017 & $\mathrm{~N} / \mathrm{A}$
\end{tabular}

017 EBERLINE
Mode 1 NONE

N/A

SPING

N/A

NONE

NONE

N/A

SPING
Pollutant

C Freq. RADIONUCLIDE

RADIONUCLIDE

CS -137

RADIONUCLIOE

RADIONUCLIDE

CS-137

RADIONUCLIDE
$Y$

y

$y$


AREA BLDG VENT Manufacturer

CFA 617031 | HOMEMADE
Mode 1

NONE
Pollutant

RADIONUCLIDE
C Freq. - 


\begin{tabular}{|c|c|c|c|c|c|c|}
\hline AREA & BLDG & VENT & Manufacturer & Mode 1 & Pollutant & C Freq \\
\hline $\mathrm{CPP}$ & 603 & 001 & I NONE & NONE & RADIONUCLIOE & Y \\
\hline & 627 & 010 & | EBERLINE & NONE & RADIONUCLIDE & Y \\
\hline & & 013 & I N/A & $N / A$ & CS-137 & Y \\
\hline & 659 & 033 & I N/A & $N / A$ & CS-137 & Y \\
\hline & & 033 & I N/A & $N / A$ & & \\
\hline & 765 & 003 & $\mathrm{~N} / \mathrm{A}$ & CAM-WS5-02 & RADIONUCLIDE & Y \\
\hline & 767 & 001 & I HOMEMADE & NONE & RADIONUCLIDE & N \\
\hline & 791 & 004 & I N/A & R-WSG-791-1 & RADIONUCLIDE & $Y$ \\
\hline
\end{tabular}




\begin{tabular}{|c|c|c|c|c|c|}
\hline AREA & BLDG VENT & Manufacturer & Model & Pollutant & C Freq. \\
\hline NRF & $601 \quad 023$ & RADECO & $H D-28$ A/B & & $Y$ \\
\hline & $601 C 019$ & RADECO & $H D-28 \quad A / B$ & RADIONUCLIDE & $Y$ \\
\hline & $601 F 019$ & RADECO & $\mathrm{HD}-28 \mathrm{~A} / \mathrm{B}$ & RADIONUCLIDE & $Y$ \\
\hline & $\begin{array}{ll}616 & 039\end{array}$ & RADECO & $H D-28 A / B$ & & $Y$ \\
\hline & $616 A 002$ & RADECO & $H D-28 \quad A / B$ & PARTICULATE & $\gamma$ \\
\hline & $616 B \quad 006$ & RADECO & $\mathrm{HD}-28 \mathrm{~A} / \mathrm{B}$ & RADIONUCLIDE & Y \\
\hline & $\begin{array}{ll}617 & 013\end{array}$ & RADECO & $H D-28 \quad A / B$ & & Y \\
\hline & 013 & & & TRITIUM & \\
\hline & $\begin{array}{ll}618 & 027\end{array}$ & RADECO & $\mathrm{HD}-28 \mathrm{~A} / \mathrm{B}$ & & $\begin{array}{l}Y \\
-\cdots\end{array}$ \\
\hline & 035 & RADECO & $\mathrm{HD}-28 \mathrm{~A} / \mathrm{B}$ & & $Y$ \\
\hline & 039 & RADECO & $H D-28 \quad A / B$ & & $Y$ \\
\hline & 099 & NUCLEAR MEAS & $B A M-22 \quad B A$ & RADIONUCLIDE & $Y$ \\
\hline & 103 & NRF/ECF & $N / A$ & & $Y$ \\
\hline & $620 \quad 012$ & ENERGY EFFICIENCY SYSTEMS & 2000 & & $\mathrm{~N} \quad 1.00$ \\
\hline & 013 & ENERGY EFFICIENCY SYSTEMS & 2000 & & $\mathrm{~N} \quad 1.00$ \\
\hline & 014 & ENERGY EFFICIENT SYSTEMS & 2000 & & $\mathrm{~N} \quad 1.00$ \\
\hline & $628 \mathrm{~A} 003$ & & & TRITIUM & \\
\hline & 003 & RADECO & $\mathrm{HB}-28 \mathrm{~A} / \mathrm{B}$ & & $\gamma$ \\
\hline & 006 & RADECO & $H D-28 \mathrm{~A} / \mathrm{B}$ & & $\begin{array}{r}-1 \\
--\end{array}$ \\
\hline & 006 & & & TRITIUM & \\
\hline & 631101 & RADECO & $\mathrm{HB}-28 \mathrm{~A} / \mathrm{B}$ & & Y \\
\hline & $633 \mathrm{~A} 057$ & RADECO & $\mathrm{HD}-28 \mathrm{~A} / \mathrm{B}$ & & Y \\
\hline
\end{tabular}


AREA BLDG VENT Manufacturer

PER 755 001 | EBERLINE

756001 | EBERLINE

\begin{tabular}{ll|l}
765001 & EBERLINE
\end{tabular}
Mode 1

AMS -3

AMS-3A

AMS-3A
Pollutant

RADIONUCLIDE

RADIONUCLIDE

RADIONUCLIDE
C Freq. 


\begin{tabular}{|c|c|c|c|c|c|c|}
\hline AREA & BLDG & VENT & Manufacturer & Mode 1 & Pollutant & $C$ \\
\hline TAN & 607 & 039 & EBERLINE & AMS-3 (BETA) & RADIONUCLIDE & $Y$ \\
\hline & & 119 & EBERLINE & AMS -3 & RADIONUCLIOE & Y \\
\hline & 609 & 014 & HOMEMADE & NONE & RADIONUCLIDE & N \\
\hline & 629 & 012 & EBERLINE & AMS-3 (BETA) & RAOIONUCLIOE & $Y$ \\
\hline & & 013 & EBERLINE & AMS -3 & RADIONUCLIDE & $Y$ \\
\hline & & 014 & EBERL INE & AMS -3 & RADIONUCLIDE & $Y$ \\
\hline & 679 & 022 & EBERLINE & AMS-3 (BETA) & RADIONUCLIDE & $Y$ \\
\hline & & 023 & EBERLINE & AMS-3 (BETA) & RADIONUCLIDE & $Y$ \\
\hline & & 024 & EBERL INE & AMS-3 (BETA) & RADIONUCLIDE & $Y$ \\
\hline & & 025 & EBERLINE & AMS-3 (BETA) & RADIONUCLIDE & \\
\hline & & 026 & EBERLINE & AMS-3 (BETA) & RADIONUCLIDE & $Y$ \\
\hline & & 027 & EBERL INE & AMS-3 (BETA) & RADIONUCLIDE & $Y$ \\
\hline & 681 & 012 & EBERL INE & AMS-3 (BETA) & RADIONUCLIDE & \\
\hline & & 018 & EBERLINE & AMS-3 (BETA) & RADIONUCLIDE & $Y$ \\
\hline & & 020 & EBERLINE & AMS-3 (BETA) & RADIONUCLIDE & $Y$ \\
\hline
\end{tabular}




\begin{tabular}{|c|c|c|c|c|c|c|}
\hline AREA & BLDG & VENT & Manufacturer & Mode 1 & Pollutant & C \\
\hline TRA & 632 & 019 & EBERL INE & PING II & RADIONUCLIDE & $Y$ \\
\hline & & 030 & EBERLINE & PING II & RADIONUCLIDE & $Y$ \\
\hline & & 041 & EBERLINE & PING II & RADIONUCLIDE & $Y$ \\
\hline & 661 & 008 & HOMEMADE & NONE & RADIONUCLIDE & $N$ \\
\hline & 710 & 001 & EBERLINE & PING II & RADIONUCLIDE & $Y$ \\
\hline & 770 & 001 & EBERLINE & PING II & RADIONUCLIDE & $\gamma$ \\
\hline
\end{tabular}


AREA BLDG VENT Manufacturer

WMF 615 001 | EBERLINE
Mode 1 AMS -3 (BETA)
Pollutant RADIONUCLIDE
C Freq.

Y 